\author{
Universidade de São Paulo \\ Faculdade de Filosofia, Letras e Ciências Humanas \\ Departamento de Lingüística \\ Programa de Pós-Graduação em Semiótica e Lingüística Geral
}

\title{
O ethos do enunciador dos romances de Machado de Assis: uma abordagem semiótica
}

Dilson Ferreira da Cruz Júnior

Tese apresentada ao Departamento de Lingüística da Faculdade de Filosofia, Letras e Ciências Humanas da Universidade de São Paulo, para obtenção do título de doutor em Semiótica e Lingüística Geral.

Orientador: Prof. Dr. Izidoro Blikstein

São Paulo, outono de 2006. 
Para minha mãe, que me ensinou as primeiras letras e todos os significados importantes.

Para meu querido amigo André, que descobre os sentidos e os sentidos e dá a tudo um novo sentido. 


\section{Agradecimentos}

Prof. Dr. Izidoro Blikstein (FFLCH-USP), pela forma segura e serena com que conduziu a orientação deste doutorado, pelo diálogo sempre aberto, pelos inúmeros conselhos e, acima de tudo, pelo respeito que sempre demonstrou por minhas idéias e opiniões.

Professeur Denis Bertrand (Université de Paris 8). Sua supervisão sempre diligente de meu estágio na França foi fundamental para a redefinição do quadro teórico que passei a adotar e, conseqüentemente, para todo o doutorado.

Prof. Dr. José Luiz Fiorin (FFLCH-USP), que de forma atenciosa por diversas vezes se prontificou a me ouvir e a fazer generosas contribuições para a elaboração desta tese.

Profa. Dra. Diana Luz Pessoa de Barros (FFLCH-USP), pelos valiosos conselhos para o doutorado e por outros ainda mais valiosos.

Profa. Dra. Elizabeth Hargot-de-la-Taille (PUC-SP), pelas conversas e discussões sempre enriquecedoras, especialmente para a conclusão deste trabalho.

Profa. Dra. Norma Discini (FFLCH-USP), que me salvou de vários erros que eu ia cometendo e espero não ter cometido.

Prof. Dr. Valentin Facioli, pelas várias sugestões bibliográficas e conversas machadianas.

Prof. Jean Briant (Aliança Francesa), por tudo que me tem ensinado e, em especial, pela elaboração do résumé.

Márcia S. Camargo Bueno, cuja amizade tem-se feito presente em muitos momentos e de maneira especial durante minha estada na França.

Marcos Vicente A. Sanches (TCMSP), que me ensinou que engenheiros podem fazer contribuições valiosas para teses de semiótica. Esta deve muito a seus conselhos, seu apoio, seu incentivo. Enfim, à sua solidariedade. 
Profa. Dra. Fabiana Komesu (UNESP), parceira de várias traduções e companheira de angústias doutorandas.

Profa. Dra. Maria José Guerra, pelas palavras encorajadoras, sempre tão necessárias.

Subsecretário de fiscalização e controle do Tribunal de Contas do Município de S. Paulo, Livio Mário Fornazieri, e aos colegas Smara Gonsaga Silva e Valmir Leôncio da Silva, que compreenderam as dificuldades para conciliar a elaboração de uma tese de semiótica com a fiscalização contábil e financeira do Município de São Paulo.

Capes, pela concessão da bolsa-sanduíche na França.

Tribunal de Contas do Município de São Paulo (TCMSP), pela concessão da licença sem vencimentos, graças à qual pude realizar meu estágio no exterior.

Departamento de Lingüistica da FFLCH-USP, pelo apoio em diversos momentos deste doutorado e, especialmente, para a realização do estágio no exterior.

Grupo de Estudos Semióticos da USP (GESUSP), pela oportunidade de expor minhas idéias e pelos debates sempre profícuos.

$\cos \cos 20$

E, claro, de maneira muito especial, à Emília e ao Pedro. Sem eles esta tese simplesmente não teria razão de ser. 
E o Verbo se fez carne, e habitou entre nós, cheio de graça e de verdade...

João 1.14 


\section{Sumário}

Resumo

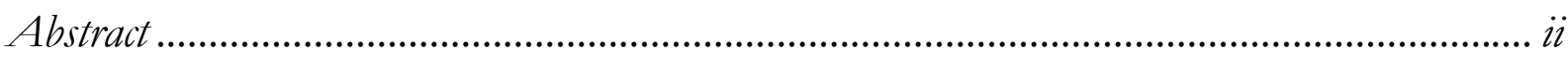

Résumé

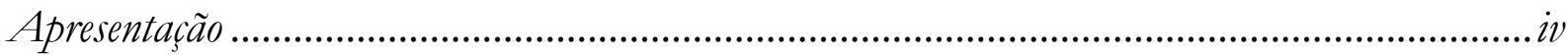

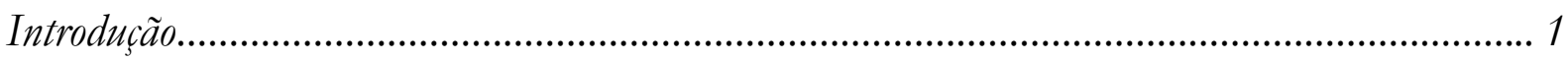

Um pouco de retórica................................................................................................ 5

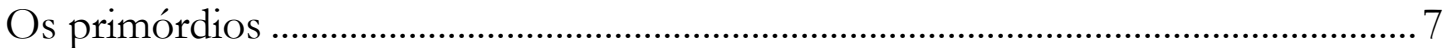

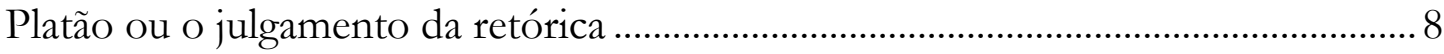

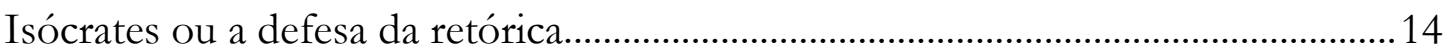

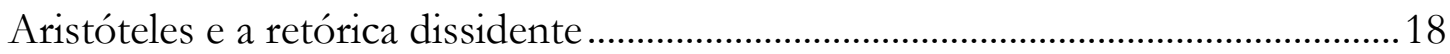

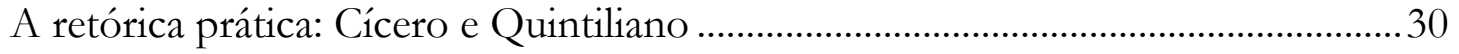

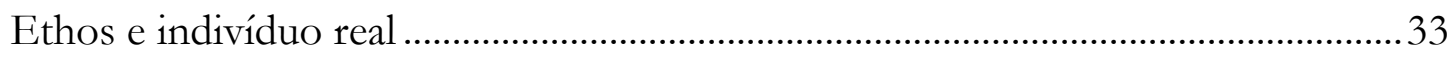

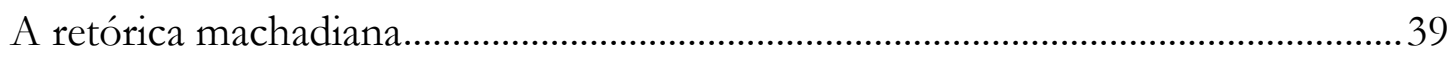

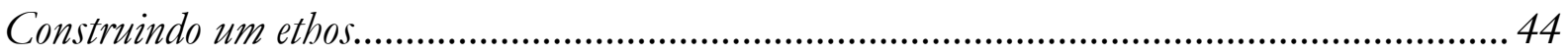

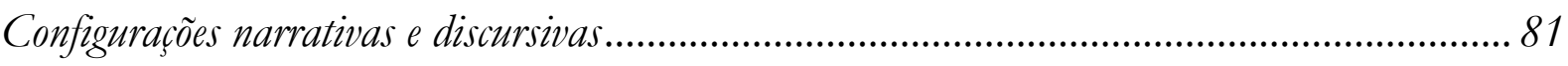

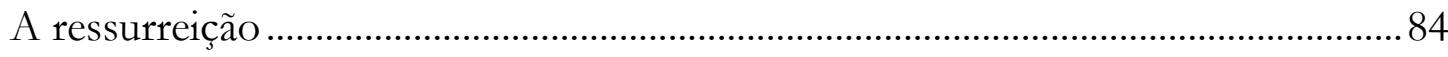

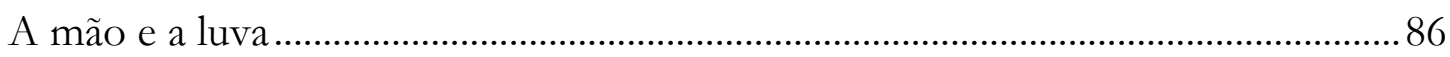

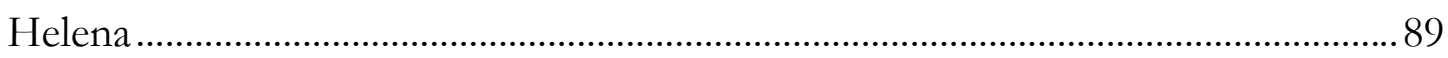

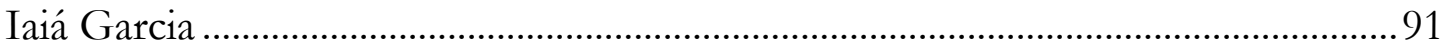

Memórias póstumas de Brás Cubas....................................................................... 94

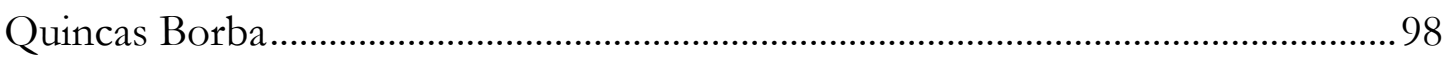

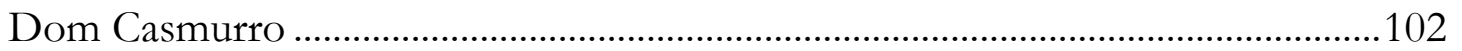

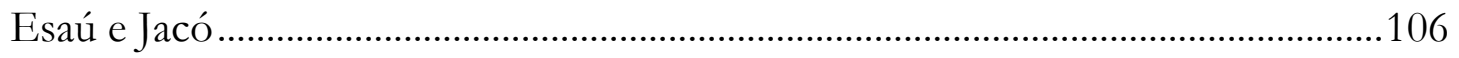

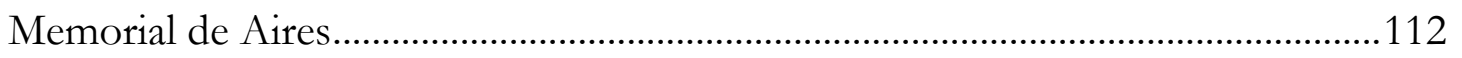

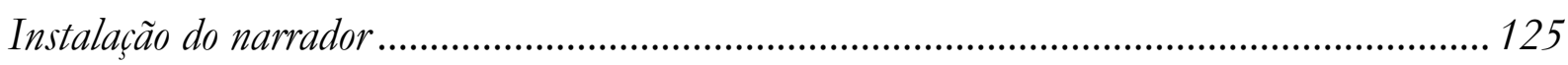

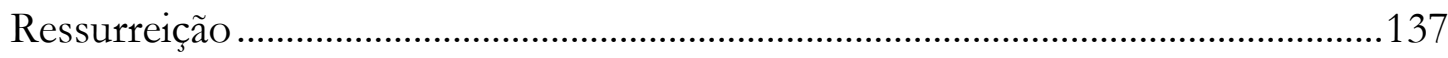

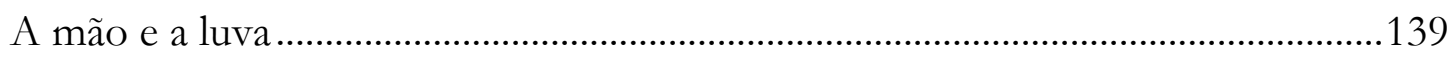

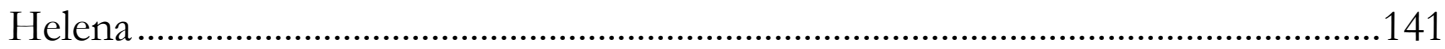

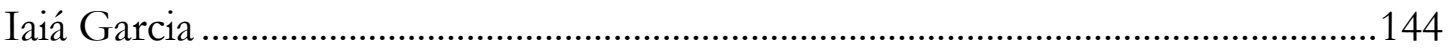

Memórias póstumas de Brás Cubas..............................................................................146

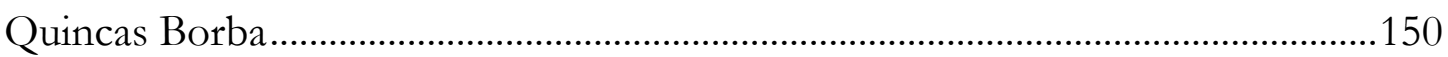

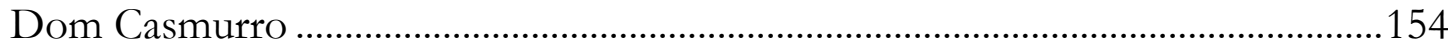

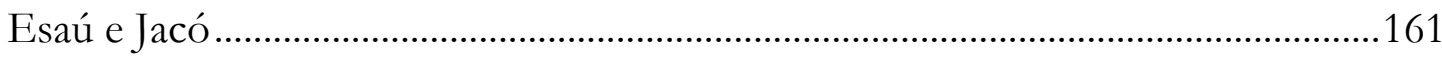

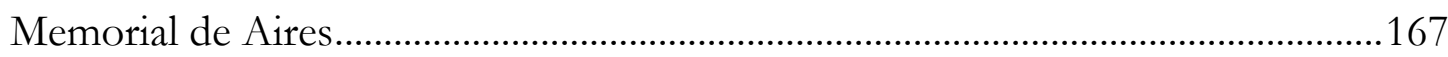


Delegação do saber.

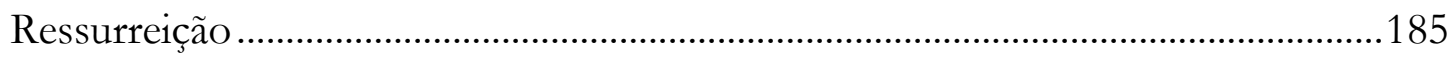

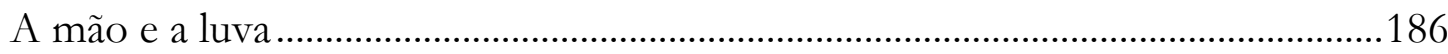

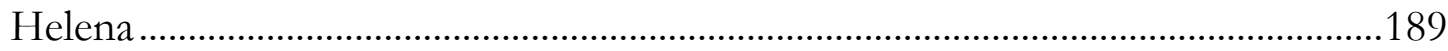

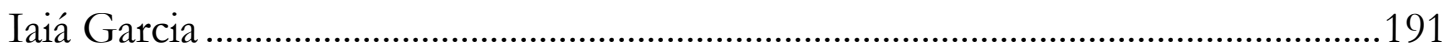

Memórias póstumas de Brás Cubas........................................................................193

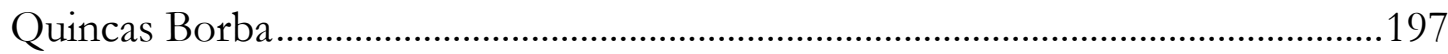

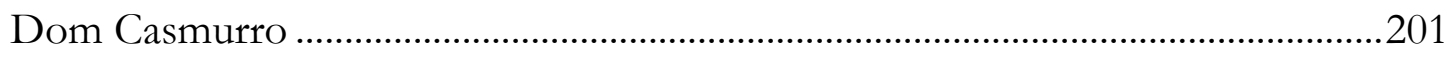

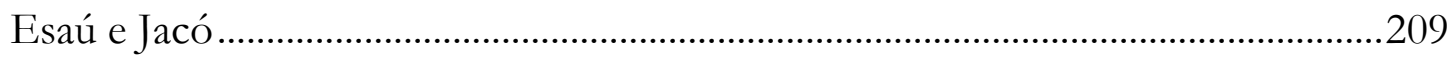

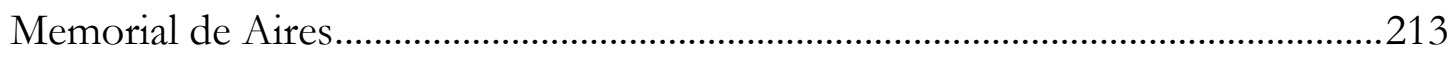

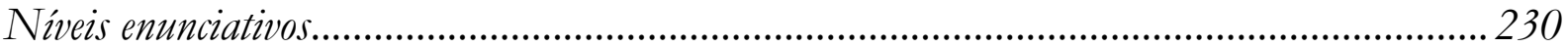

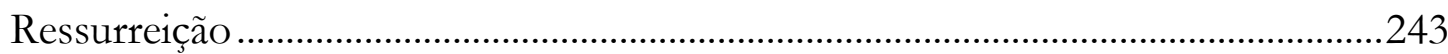

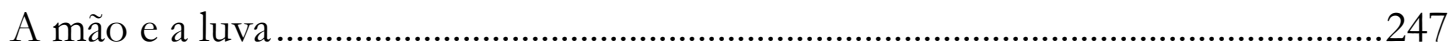

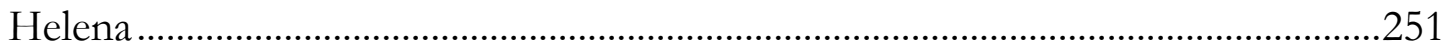

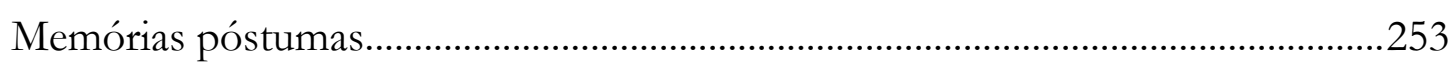

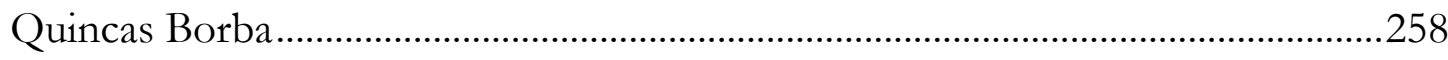

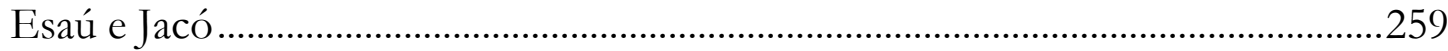

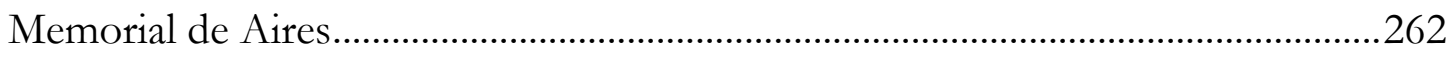

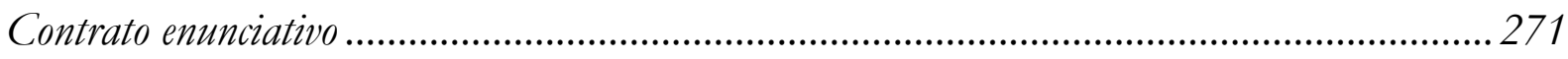

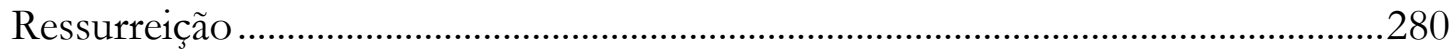

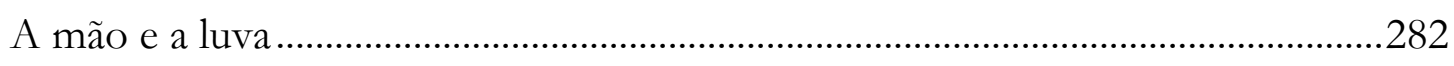

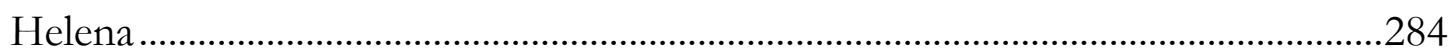

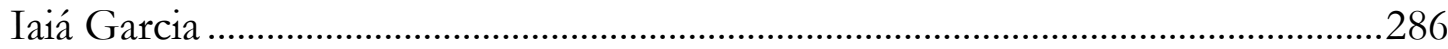

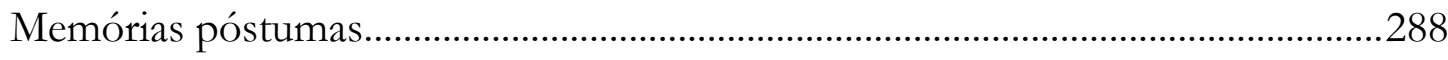

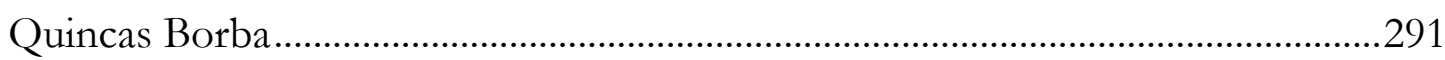

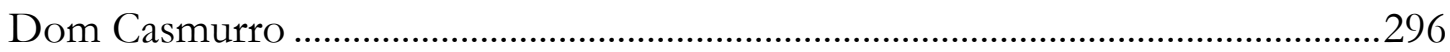

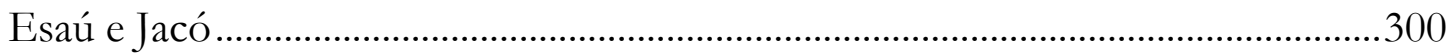

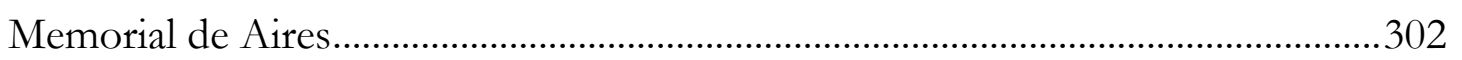

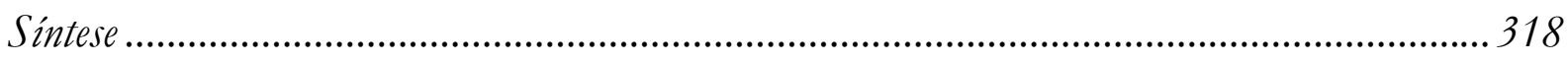

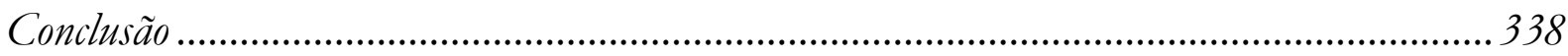

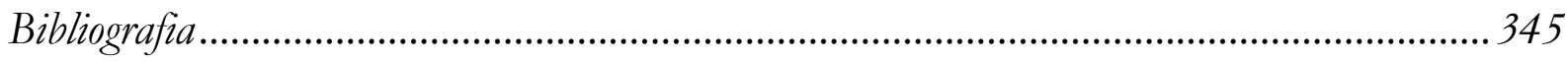

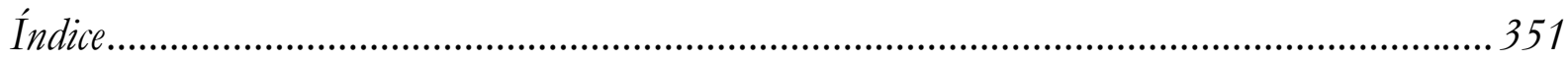


Definido por Aristóteles como o caráter ou a imagem que o orador constrói de si para ganhar a adesão de seus ouvintes, o ethos constituiu ao longo da história um dos principais núcleos de estudos retóricos. Nas últimas décadas, a partir, principalmente, dos trabalhos de Ducrot e de Barthes, o conceito passou a ser estudado também pelas demais ciências da linguagem, que passaram a utilizá-lo para explicar os mecanismos implicados no fazer persuasivo. É nessa linha de investigação que se insere este trabalho, porém com a diferença de que se busca analisar o ethos não mais em discursos puramente persuasivos, como o político ou o publicitário, mas em textos poéticos. Em termos mais específicos, procura-se determinar o ethos do enunciador da obra romanesca de Machado de Assis.

O ethos analisado não é, portanto, o do narrador, isto é da instância que afirma eu no interior dos romances, nem, tampouco, o do cidadão Joaquim Maria Machado de Assis. O objeto deste estudo é o enunciador pressuposto ou, como afirma Greimas, com o ator da enunciação. $\mathrm{O}$ trabalho articula-se em três momentos. No primeiro, procura-se construir uma reflexão sobre o tema alicerçada na retórica antiga, na semiótica e na análise do discurso. No segundo, investiga-se o comportamento das cinco variáveis que foram eleitas para determinação do ethos do enunciador: configurações narrativas e discursivas, instalação do narrador, delegação do saber, níveis narrativos e contrato enunciativo. Finalmente, na ultima parte, é apresentada a síntese dos achados e as conclusões que a partir daí puderam ser obtidas.

Palavras-chave: ethos, Machado de Assis, literatura, retórica, semiótica 
Defined by Aristotle as the character or the image that the speaker builds of himself to call his listeners attention, the ethos have been, along the history, the main nucleus of rhetoric studies. However, in the last decades, mainly from the works of Ducrot and Bathes, the ethos has been also studied by other sciences which study the language, seeing in this concept an important instrument to explain the mechanisms implied in the "persuasive making". It is in this line of investigation that this work is inserted, with the difference that it searches analyzing not only the persuasive speeches anymore, like the political or the publicity, but also the poetic texts. More specifically, this thesis aims determining the enunciator's ethos of the romanesque work of Machado de Assis.

Focus on the fact that the searched ethos is not narrator's, of the instance that claims the "I" in the inner part of the novels, that conducts the narrative, makes comments and descriptions, not either of the citizen Joaquim Maria Machado de Assis, object of several literary analysis and uncountable biographic studies. Our worry is with the presupposed enunciator or, as Greimas says, with the author of the enunciations. The work articulates in three moments. In the first one, tries to know a little more about the concept of the ethos, such as it was studied by the old rethoric ones, and builds a reflection about the theme based in the semiotic theory and the analysis of the speech. The second part of the work, it investigates the behavior of five variables that were elected to determine the enunciator's ethos: narrative and discursive configurations, the narrator's installation, delegation of knowledge, narrative levels and enunciatively contract. Finally, the third part shows the synthesis of the findings and the conclusions that from that part can be obtained.

Keywords: ethos, Machado de Assis, literature, rhetoric, semiotic 


\section{Résumé}

Défini par Aristote comme le caractère ou l'image de soi que l'orateur construit pour obtenir l'adhésion de ses auditeurs, l'ethos, à côté du pathos et du logos, constitue, tout au long de l'histoire, le principal noyau des études rhétoriques. Néanmoins, au cours de ces dernières décennies, à partir surtout des travaux de O.Ducrot et de R.Barthes, les autres sciences s'intéressant au langage se sont également mises à étudier l'ethos, voyant dans ce concept un important instrument d'analyse des mécanismes du «faire persuasif ». C'est dans cette ligne de recherche que s'inscrit ce travail, avec la différence toutefois que nous cherchons à analyser non plus des discours purement persuasifs, comme le sont les discours politique et publicitaire, mais des textes poétiques. Plus spécifiquement, cette thèse se propose de déterminer l'ethos de l'énonciateur dans l'œuvre romanesque de Machado de Assis.

Il convient d'observer que l'ethos recherché n'est pas celui du narrateur, c'est-à-dire de

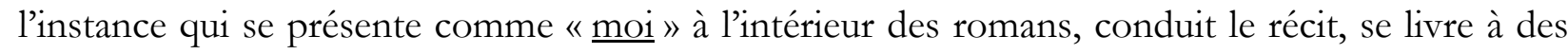
commentaires et à des descriptions, ni davantage le citoyen Joaquim Maria Machado de Assis, objet d'innombrables analyses littéraires et de non moins nombreuses études biographiques. Nous nous préoccupons ici de l'énonciateur présumé ou, comme l'affirme Greimas, de l'acteur de l'énonciation. Le travail s'articule autour de trois moments. Le premier, comportant l'introduction et les deux chapitres qui la suivent, cherche à mieux cerner le concept de l'ethos, tel qu'il a été étudié par les anciens rhéteurs et à construire une réflexion sur le thème, fondée sur les théories de la sémiotique et de l'analyse du discours. La seconde partie du travail analyse le comportement des cinq variables choisies pour définir l'ethos de l'énonciateur : configurations narratives et discursives, installation du narrateur, délégation du savoir, niveaux narratifs et contrat fiduciaire. On a, dans chaque cas, recherché des récurrences susceptibles de définir un mode d'énonciation et donc un mode d'être de l'énonciateur et, en conséquence, une image de lui, son ethos. Enfin, dans la troisième partie, nous présentons la synthèse de nos observations et les conclusions que nous avons pu en tirer.

Mots-clé: ethos, Machado de Assis, littérature, rhétorique, sémiotique 


\section{Apresentação}

Méfiez-vous des mots.

anônimo

Concordo contigo, leitor. Chego mesmo a pensar que, neste exato momento, estás a te lembrar do ilustre homem de letras, autor de uma percuciente biografia do Padre Luís Gonçalves dos Santos e de uma alentada historia dos subúrbios do Rio de Janeiro, que nos estertores do século XIX dizia que nada há mais feio que dar pernas longuíssimas a idéias curtíssimas*. Sei que tu, leitor do século XXI, cioso do teu tempo e das tuas tecnologias, depois de constatar que as pernas que tens sob os olhos parecem vir do país de Brobdingnag, pergunta-te se as idéias por elas carregadas não seriam liliputianas.

Quisera eu afugentar teus temores, mas que posso diante de tuas indagações?

Contudo... contudo, se me deres uma ou duas dúzias de linhas da tua paciência, posso te contar como e porque este volume alcançou esse volume. Bem sei que há mistérios mais interessantes a que tua curiosidade e tua ciência podem se dedicar, mas, ao fim, tudo é descoberta, e não existiriam as grandes sem as pequenas.

Repara: sendo o objetivo desta tese determinar o ethos do enunciador dos romances de Machado de Assis, entendeu-se que o melhor seria ir conhecer o conceito em seu nascedouro: a retórica antiga. É disso que cuida o primeiro capítulo. Já o seguinte, busca olhar o ethos com os olhos de uma ciência de mais viço, a semiótica, adequando-o ao material em questão: não mais os discursos da ágora, mas um texto ficcional. Por aí também se explica porque a tarefa requer a análise dos nove romances de Machado e que ela seja feita sob cinco enfoques diferentes: configurações narrativas e discursivas, instalação do narrador, delegação do saber, níveis narrativos e contrato enunciativo. Ao final, o resultado da análise realizada em cada capítulo foi

\footnotetext{
* Santiago, Bento. Dom Casmurro. Paris-Rio de Janeiro: Garnier Frères, 1899. Edição Princeps.
} 
convertido em uma descrição do ethos do enunciador, de maneira que na conclusão pudessem ser apresentadas as descobertas realizadas ao longo do percurso que agora se inicia.

Aí está, leitor da minha ignorância, a causa das pernas longuíssimas: as análises necessárias para definir, com a precisão permitida pela bisonhice deste escrevente, o ethos do enunciador.

Mas, se continuas a torcer o nariz e a julgar que tudo podia ser escrito com menos e melhores palavras, permita que eu te diga uma coisa mais, antes de concordar contigo: a culpa de tudo é dessa tua ciência, eterna desconfiada que não partilha da condescendência da tua curiosidade. É ela que exige que cada asserção seja precedida de demonstrações, e ambas, acompanhadas de exemplos e citações, preferencialmente aos pares, tudo muito bem explicado e identificado. Enfim, uma miríade de provas que pedem linhas e tomam tempo - dieu sinistre, effrayant, impassible... joueur avide qui gagne sans tricher, como diz o poeta*.

Eis a explicação do mistério; a causa dos significantes copiosos e dos significados escassos. Se ela te agradar, fino leitor, pago-me da tarefa. Senão...

\footnotetext{
* Baudelaire, Charles. L'Horloge. In: Les Fleurs du mal. Ouvres Complètes, p. 81. Paris : Gallimard / Bibliothèque de la Pléiade, 1975.
} 


\section{Introdução}

Entre Iaiá Garcia e as Memórias póstumas de Brás Cubas, entre o romancista medíocre e o grande romancista, existiu apenas isso: seis meses de doença, de outubro de 1878 a março de 1879 , três dos quais passados na roça.

Lúcia Miguel Pereira In Machado de Assis, p. 168.

U

m consenso entre a crítica é justamente este: Machado teria conhecido duas fases; uma, dita romântica, e outra, chamada realista, dizem uns; a da inexperiência, dos modelos seguidos à risca, e a da maturidade, em que desponta o gênio, preferem outros. Citando outro ponto de concordância — o de que Memórias póstumas é um divisor de águas na obra de Machado —, Bosi (1999, p. 83) lembra Otto-Maria Carpeaux, para quem Machado é um desses escritores que nascem duas vezes, como Pascal ou Santo Agostinho. É também de Bosi (1994, p. 177) a afirmação segundo a qual a revolução estética e ideológica empreendida por Memórias póstumas cavou um fosso entre as duas épocas do artista. Facioli (2002, p. 33-4) chama de verdadeiro terremoto a transformação pela qual passou Machado, tamanha a diferença entre os dois ciclos de sua obra. $\mathrm{O}$ autor aponta as explicações de alguns críticos para a reviravolta: a ascensão social do artista, uma crise pessoal, seus problemas de visão e a conseqüente necessidade de ditar sua obra para a mulher, Carolina, o medo da morte e a profunda desilusão com a sociedade de sua época.

Bosi observa ainda que alguns abalos sísmicos, já presentes nos contos da década dos 70, teriam prenunciado o terremoto que estaria por vir, ao mostrarem, por exemplo, que na obra do autor a "aparência funciona universalmente como essência, não só na vida pública, mas no segredo da alma" (1999: 84). A crítica não é unânime apenas quanto à existência das duas fases. Também o é (ou quase) quanto à demarcação da fronteira entre elas e à classificação dos romances, a qual, diga-se de passagem, é também quase simétrica. Dessa maneira, pertenceriam a primeira e considerada menor fase: Ressurreição (1872), A mão e a Luva (1874), Helena (1876), e Iaiá Garcia (1878); e fariam parte da segunda: Memórias póstumas de Brás Cubas 
(1881), Quincas Borba (1891), Dom Casmurro (1899), Esaú e Jacó (1904) e Memorial de Aires (1908). Quanto aos contos, o divisor de águas seria a coletânea Papéis avulsos, de 1882.

Contudo, não é objetivo deste trabalho buscar os motivos que teriam levado o escritor a mudar seus escritos — se é que houve mudança — pois não é do autor, Joaquim Maria Machado de Assis, que nos ocupamos, mas do enunciador, do eu pressuposto no texto, ou, como diz a semiótica, do ator da enunciação. E é justamente por isso que as observações da crítica são importantes. Comentários como o de que Machado seria um escritor nascido duas vezes convidam a uma investigação acerca da identidade do enunciador e a um exame dos aspectos que possam apontar para a unidade ou dualidade da obra. A produção do escritor seria tão variada que permitiria falar em dois Machados, como propõe Carpeaux, ou revelaria um único enunciador, um único eu, que teria a mesma visão de mundo, as mesmas preocupações e que sempre se valeria de procedimentos semelhantes. Será que, apesar da tão semeada diferença, essas obras não revelariam um único caráter? Para responder a essa questão - e considerando que (não custa repetir) o objetivo deste trabalho não é investigar o indivíduo de carne e osso, mas a imagem do enunciador implicada no texto - é preciso, antes de qualquer coisa, esquecer a biografia e passar a abordar o texto por ele mesmo, eterna bóia sem a qual (parece que alguém já o disse) não há salvação.

Desse modo, as análises não se ocuparão de Machado de Assis cidadão, mas do ator da enunciação, que, conforme afirmam Greimas \& Courtés (1993: p. 8), é definido pela totalidade de seus discursos. A partir da perspectiva que adota não é o "escritor" com sua biografia que auxilia na compreensão da obra, mas é o texto, o enunciado, que define o sujeito da enunciação e seu ator. É por isso que apenas o exame dos textos poderá definir se existem ou não dois atores distintos da enunciação ou duas fases. Quem sabe se, por trás de um narrador aparentemente ingênuo e de obras que soam em um primeiro momento pueris; e sob outro narrador, que parece mais maduro e realista que o primeiro, não haveria um único e mesmo enunciador, um ator da enunciação? Veja, não se nega a diferença entre os narradores machadianos - afinal, que semelhança poderia haver, por exemplo, entre Aires, Brás Cubas, o narrador de Iaiá Garcia e o de Ressurreição ? - , mas ocorre também não é o narrador o objeto desta pesquisa, mas sim o enunciador.

Mais precisamente, busca-se determinar as principais características do ethos do enunciador, o qual é entendido de forma bastante próxima à que era utilizada pelos antigos 
retóricos, isto é, como imagem ou caráter que o discurso constrói de seu enunciador para com isso ganhar a adesão de seus ouvintes. Para tanto, a proposta é examinar todos os romances de Machado, a partir de diversos enfoques, a fim de verificar qual o ethos (ou os ethê) que tais textos constroem. A decisão de trabalhar com todas as obras se justifica pelo fato de que somente assim poderiam ser observadas (ou não) na obra do autor recorrências que justificassem sua divisão. Embora os critérios de análise venham a ser especificados mais adiante, é preciso esclarecer desde já que entre eles não se encontram os de natureza estética e que se evitou-se, dentro do possível, realizar qualquer juízo de valor sobre os romances. Desse modo, é importante esclarecer que não será discutida a qualidade de nenhuma das obras analisadas, em síntese, não se propõe a análise crítica da obra de Machado; primeiro, porque foge aos objetivos desta tese; depois, porque essa crítica pode ser realizada (como tem sido) com mais propriedade pelos estudiosos da literatura.

O objetivo é, portanto, modesto: fazer um levantamento dos procedimentos adotados pelo enunciador nos níveis fundamental, narrativo e discursivo do percurso gerativo do sentido para instalar no enunciado sujeitos, objetos e programas narrativos que compõem os seus romances. Naturalmente, não seria viável esgotar a análise de cada um dos níveis gerativos do sentido e, por isso, a investigação em cada romance será limitada ao comportamento de cinco variáveis que perpassam os diferentes níveis: (a) as configurações narrativas de cada romance; (b) o processo empregado na instalação do narrador; (c) a forma como o enunciador delega o saber aos actantes; (d) os níveis enunciativos existentes em cada obra; e, (e) o contrato enunciativo estabelecido entre enunciador e enunciatário. O processo é relativamente simples: em cada um dos nove romances do autor, será examinado o comportamento das cinco variáveis citadas, objetivando, assim, verificar a recorrência de determinados procedimentos e, em caso positivo, o que tal recorrência permite concluir acerca do ethos do enunciador. Como se vê, o entendimento é o de que o ethos, a imagem que o enunciador constrói de si no discurso se constrói pelos procedimentos adotados na discursivização das estruturas fundamentais e narrativas.

No entanto, antes de colocar em prática tal proposta, convém investigar em detalhes o que vem a ser exatamente o ethos, esse conceito, nascido da retórica, que hoje ganha autonomia e vôo próprios e adquire um poder de explicação cada vez maior frente aos desafios enfrentados pelas ciências que lidam com a linguagem e com a significação. Essa investigação será realizada em dois capítulos. No primeiro, será abordada brevemente a 
concepção de ethos a partir da perspectiva dos retóricos antigos: Platão, Isócrates, Aristóteles e Cícero. No segundo, busca-se uma leitura desse conceito à luz das contribuições da semiótica e da análise do discurso. A partir daí, seguem-se as análises de cada um dos tópicos acima, os quais são reunidos em um capítulo que tem por objetivo sintetizar as principais descobertas e associá-las a um ou mais traços de caráter. A aposta é que, se o comportamento das variáveis for o mesmo em todos os romances ou em parcela significativa deles, poder-se-á falar em um único ethos do enunciador. Caso contrário, os ethos serão múltiplos, ou seja, aparecerão em número correspondente aos diferentes comportamentos apresentados pelas variáveis. Como não poderia deixar de ser, o trabalho se encerra com a conclusão, que deverá apresentar a descrição do ethos ou ethé desse enunciador. 


\section{Um pouco de retórica}

$S$

iracusa, 467 a.C.. A cidade fundada pelos Coríntios, três séculos antes, agora estende sua hegemonia por toda a Sićlia. O tirano Hierão I, que, juntamente com Gelão, expropriara terras para expandir o domínio da cidade e recompensar os mercenários que lhe serviram, acabou de ser derrubado por um levante popular. Faz-se necessário restituir os bens aos seus antigos proprietários; mas como? Já não existem títulos ou outros documentos que atestem a propriedade. $\mathrm{Na}$ falta de melhor alternativa, tudo tem de ser resolvido em assembléias populares, por meio das quais, depois de ouvidas as partes em longas audiências, o júri decide quem é o legítimo dono da terra. Como se pode imaginar, a palavra, em tais circunstâncias, torna-se instrumento fundamental: aquele que é eloqüente, isto é, desenvolto para falar, tem muito mais possibilidades de reaver o que é seu... ou mesmo o que não é. Diante da escassez de provas materiais, todos se vêem envolvidos com a mesma questão: saber-fazer-crer ou, se preferirmos, fazer-parecer-verdadeiro.

É nesse momento que surge Empédocles, considerado o primeiro retórico da história, para ensinar os interessados a falar em público para obter a adesão dos ouvintes às teses defendidas. Seguindo o pensamento de Ricoeur (1975, p.15), Empédocles é, ao mesmo tempo, o mais antigo aliado da Retórica e seu maior inimigo, pois a arte do "bem dizer" ensinada por ele pode facilmente abandonar o "dizer verdadeiro" e fornecer a munição por meio da qual vários dos inimigos da retórica, a começar por Platão, procurarão atingi-la. Dois alunos de Empédocles, Córax e Tísias, logo percebem a possibilidade de ganho e se propõem a criar uma escola em que os alunos paguem para aprender a arte de convencer e, assim, aumentar suas chances de reaver seus bens. Córax, considerado por Aristóteles o inventor da Retórica do verossímil, (Retórica II, XXIV, XI), ensina que o mais importante é que a tese defendida seja provável, pois, quanto mais verossímil, maior a probabilidade de ser aceita.

Os negócios prosperam; todos percebem que a novidade é excelente e que aquele que a domina pode não apenas recuperar suas terras, mas também exercer grande influência sobre seus semelhantes: com a propriedade, a autoridade. É nesse ambiente tão familiar, de 
disputa pela posse da terra e de lutas pelo poder; de discussão acerca da propriedade privada, que nasce a retórica, definida, por Córax, como a arte da persuasão e, por Tísias, como a arte oratória, propícia aos debates, à resolução de litígios. Arte que não é propriamente marcial, mas bem beligerante e apropriada à disputa, ao embate. Arte sem propósitos estéticos, mas com objetivos práticos e concretos: defender a própria propriedade ou, quem sabe, apoderarse da alheia. Enfim, retóricos não são artistas, são técnicos; não confeccionam adornos, mas instrumentos do dia-a-dia; não ensinam estética, mas o combate; mostram como construir e manejar uma arma temível: a palavra.

Paris, 1885. A Terceira República francesa (1870-1914) parece, finalmente, consolidada. Jules Ferry, ex-ministro da instrução pública e presidente do conselho, acaba de concluir a reforma do ensino público. Os objetivos: eliminar a influência da Igreja Católica sobre a educação e edificar uma escola que promova a liberdade de pensamento; desenvolva nos alunos o sentimento de cidadania; incentive a ciência, o desenvolvimento; ensine os estudantes a raciocinar e a se expressar com lógica e clareza; faça a Ciência triunfar; enfim, que traga, diríamos deste lado do Atlântico e do Equador, Ordem e Progresso. Entre as várias medidas adotadas está a exclusão do ensino da retórica nas escolas públicas. Sim, da retórica, esse ofício de ociosos que nada mais fazem senão criar discursos edulcorados, vazios de sentido e sem qualquer finalidade prática. Diante dos desafios enfrentados pela República, frente à necessidade de construir um Estado moderno que conclua a obra de recuperação da França após a dura derrota para os alemães em 1870 e cure as chagas da Comuna de Paris, de 1871, a escola deve se ocupar de coisas mais importantes que listas intermináveis de figuras da linguagem — sobre as quais, aliás, os retóricos jamais estão de acordo.

Paris, primavera de 2000. A conceituada revista Langages — fundada em 1966 por Greimas, Barthes e outros pais da Semiótica; reconhecida por seu rigor científico e por apontar os rumos das ciências da linguagem - acaba de publicar um número intitulado Sémiotique et rhétoriques tensives, todo ele dedicado às relações entre a retórica (!) e a semiótica, ciência que, apesar da idade (ou talvez por causa dela), causa não poucas controvérsias... Mas... mas o que faz essa moça de 40 anos ao lado da senhora de 2.500 que todos julgavam morta e já sepulta? E o que dizer do adjetivo "tensivas", que parece não recomendar a velha senhora às melhores casas... O que se passa? De que se ocupa a retórica, afinal: de guerras ou de adereços? E, então, quer dizer que está viva? É moribunda ou ressuscitou? E por falar nisso, por que o Império Retórico, que viu nascer e morrer tantos de seus pares, como os de 
Alexandre, o Romano, o de Carlos Magno, o Britânico, o Francês..., por que esse império, que declarou tantas guerras e celebrou a paz algumas vezes, (quase) extinguiu-se? Por que a retórica, que assistiu ao nascimento do cristianismo - a quem serviu em várias ocasiões e combateu em outras - , por que essa ciência, predecessora de tantas, agoniza, mas, como diria o sambista, não morre?

Questão prenhe de questões, diria um retórico conhecido. É provável que durante o percurso que ora se inicia venha-se a resvalar nessas questões, mas, como se sabe, o objetivo é outro: estudar o ethos do enunciador de textos literários. Trata-se de conhecer o percurso da retórica em seus primeiros anos para entender um pouco mais a polêmica citada e compreender como, no interior dessa disputa, nasceu o conceito de ethos, que adquiriu vida própria e hoje transita não só entre as ciências da linguagem, mas invade o conjunto das ciências humanas, como atesta, por exemplo, a sociologia de Pierre Bordieu. Apesar de muitas vezes parecer longa e os caminhos, tortuosos, espera-se que a viagem seja útil para melhor fundamentar o trabalho.

\section{Os primórdios}

Como se dizia há pouco, a escola de Córax e Tísias prosperou; suas idéias ganharam todo o mundo grego e, com elas, chegaram novos mestres. Protágoras e Górgias, por exemplo, logo se dedicaram a criar embasamento teórico para a então jovem disciplina.

Por volta de 430 a.C., Górgias fundou em Atenas uma nova escola. Suas aulas inovaram não apenas pela técnica, baseada na análise de episódios da Odisséia, mas, principalmente, pelas idéias. As disputas de Siracusa envolvendo a posse da terra eram, então, um fato distante e as preocupações dos atenienses, sempre notáveis pelo manejo da palavra, passaram a ser de outra ordem. Trata-se agora de influenciar o destino da Polis. Em seus ensinamentos, Górgias se vale do famoso episódio da Guerra de Tróia para expor sua doutrina; mais especificamente, da passagem em que Helena é seduzida por Paris. Tomando para si a defesa da princesa, o mestre pergunta: que culpa tem ela de ter sido seduzida, se estava como enfeitiçada, agindo sob o domínio de um poder superior? Sim, continua o retórico, o discurso age sobre o espírito humano da mesma maneira que certas drogas atuam sobre o corpo: subtraem-lhe a vontade e o deixam à mercê daquele que exerce a persuasão. Helena não era mais senhora de suas ações: o discurso a dominava e a fazia-fazer, o que não 
aconteceria se não estivesse sob tal jugo. Assim, conclui Górgias, a justiça deve absolver a esposa de Menelau, a qual sob tais condições era inimputável, e condenar aquele que exerceu tal persuasão, que produziu e inoculou na pobre senhora o terrível entorpecente: o discurso. $\mathrm{E}$, de fato, finaliza o retórico, o discurso, quando bem manejado, tem desses poderes miraculosos: é capaz de por fim ao medo, acalmar a dor, levar ao regozijo, produzir a piedade ${ }^{1}$.

Para os fins deste trabalho, o interesse maior dos ensinamentos de Górgias advém do fato de sua abordagem da Guerra de Tróia mostrar que a verdade repousa sobre um acordo tácito entre os interlocutores, o qual é, ao mesmo tempo, resultado da discussão e condição para sua realização, pois, sem um entendimento mínimo sobre os valores em jogo, a discussão nem mesmo poderia nascer. Assim, para uns, Helena será culpada, algoz do destino de seu povo; para outros, inocente, vítima do invasor. Alguém poderia objetar que a retórica serve a duas senhoras: à justiça e à injustiça; seria, portanto, ciência (ciência?) de moral dúbia. Sim, a objeção foi feita; e por ninguém menos que Sócrates e Platão.

\section{Platão ou o julgamento da retórica}

Para Platão, a derrocada de Atenas e sua submissão, primeiramente, a Esparta e, depois, a Tebas eram decorrentes, ao menos em parte, da atuação dos sofistas, por ele associados aos retóricos ${ }^{2}$. O filósofo acusa Péricles, entre outros, de ter tornado os atenienses preguiçosos, covardes, falastrões e ávidos por dinheiro (Górgias 515b-515e). Segundo o discípulo de Sócrates, os retóricos e seus aliados, "negligenciam o interesse público para cuidar de seus interesses pessoais, conduð̨em-se com relação ao povo como crianças, procurando somente agradá-lo, sem se preocupar minimamente se com suas atitudes o tornam melhor ou pior” (Górgias, 502c-503b). Platão entendia que existiam duas "retóricas": a dos sofistas, que tinham por finalidade apenas fazer o público aderir às idéias daquele que fala, independentemente da sabedoria de suas palavras;

\footnotetext{
1 Tal visão da linguagem não era, naturalmente, exclusiva de Górgias. Encontramo-la, ainda que em formulações bastante distintas, na Índia e na Pérsia. A título de exemplo, vejam-se para algumas das deliciosas fábulas de Calila e Dimna, extraídas do Pantchatantri, Mahabarata e do Vischno Sarna. Nelas são encontradas inúmeras narrativas cujo tema é esse poder mágico - ilocutório, dirão os pragmáticos - da linguagem.

${ }^{2}$ É o que Sócrates afirma em Górgias (519b-520b): "Sofística e retórica, meu bem aventurado amigo, são a mesma coisa ou são vizinhas e se parecem, como eu dizia a Pólos. Mas tu, em tua ignorância, crês que uma, a retórica, é uma perfeitamente bela e tu desprezas a outra." Isócrates dedicará um dos seus mais famosos discursos, intitulado Contra os sofistas, de cerca de 390 a. C. a essa mesma questão. .
} 
e a retórica praticada por Sócrates, que visava não à persuasão pura e simples, mas a faz̧er nascer a justiça na alma de seus concidadãos, banir a injustiça, fazer germinar a temperança e afastar a incontinência; enfim, introduz̧ir as virtudes e excluir os vicios. (Górgias, 504c - 505b). Em relação à retórica, a preocupação de Platão é de duas naturezas: de um lado, expurgar aquela praticada pelos sofistas - e, nesse ponto, ele e Isócrates estão de acordo; de outro, fazer nascer uma nova retórica, cujo objetivo último fosse a obtenção da Verdade absoluta, não influenciada por interesses particulares ou pelo contexto. Essa retórica, a verdadeira, deveria, portanto, afastar da linguagem, especialmente a rebuscada, elaborada pelos retóricos — para Platão, uma casa de traições — me aproximar-se da dialética ou da lógica.

Em três dos diálogos de Platão — Protágoras, Górgias e Fedro —, a retórica ocupa uma posição de destaque ${ }^{3}$; porém, no banco dos réus; não como ciência ou arte, como acontecia até então, mas como engodo, charlatanismo, pois todos os mestres dessa disciplina seriam, para utilizar as palavras de Isócrates em Contra os sofistas, pessoas ininteligentes que apostam na ininteligência de seus seguidores, a começar, como comprova Sócrates, pela dificuldade que demonstram para explicar do que tratava a retórica. Por exemplo, em Protágoras, Sócrates interroga a personagem que dá nome ao diálogo sobre o ofício do sofista e da possibilidade de a virtude poder ser ensinada. Não obtendo resposta satisfatória, acaba por demonstrar a superioridade da dialética sobre a retórica e mostrar que essa ciência (que ele recusa a chamar como tal) estaria a serviço de interesses particulares e escusos. Um exemplo da retórica socrática está em Górgias, mais precisamente na discussão entre Sócrates Górgias, Pólos e Cálicles sobre se o pior infortúnio é sofrer ou cometer uma injustiça, e sobre a identidade e a diferença do bom e do belo. Estes se valem da retórica e produzem discursos para defender seus pontos de vista; Sócrates procura traçar relações lógicas entre os termos em discussão. Ao final, faz seus interlocutores aderirem a seu ponto de vista e, mais importante que isso, mostra a superioridade de seu método. Finalmente, em Fedro, a discussão de Sócrates com Fedro gira em torno das idéias de Lísias e do seguinte tema: é melhor ceder seus favores a

\footnotetext{
${ }^{3}$ Há uma imprecisão nessa afirmação, pois em Crátilo Platão também discute questões que concernem à retórica, porém não o faz como nos diálogos citados. Como se sabe, na obra em questão, o tema discutido interessa muito de perto às ciências que lidam com a linguagem e a significação: trata-se de saber se os nomes espelham a essência das coisas, como propõe Crátilo, ou se são resultado de uma convenção social, como defende Hermógenes. Segundo os estudiosos, o diálogo teria relação com a retórica não apenas por esse aspecto, mas pelo fato de a origem dos nomes e da linguagem interessar aos retóricos por verem aí subsídios para melhorar suas técnicas de persuasão. Além disso, o diálogo contém inúmeras etimologias propositadamente falsas, cujo objetivo não é outro senão provocar os velhos desafetos de Platão, os mesmos retóricos que, não raro, entregavam-se a tal questão.
} 
quem se ama ou a quem não se ama? Embora as questões sejam distintas, há um problema que perpassa todas as discussões: descobrir a verdade acerca desses temas e avaliar a contribuição que a retórica poderia oferecer em cada uma das situações. Em todos os casos, a conclusão de Sócrates, à qual seus interlocutores são constrangidos a aderir, é que a palavra nada faz senão dar uma aparência de verdade ao que não é verdadeiro e, assim, iludir os ouvintes. Faz-se necessário, portanto, substituí-la pela lógica que, livre das artimanhas da linguagem, dedica-se a desvendar (quase diríamos, em um nível profundo) as relações que mantém as categorias e as classes em jogo.

É preciso observar que, a despeito de seu discurso anti-retórico, Platão realiza, em seus diálogos, um percurso bastante familiar aos retóricos: partindo do que seus interlocutores consideram provável ou verdadeiro - mas que ele próprio rejeita -, o filósofo os leva a reconhecer como sendo verdade o que, em um primeiro momento, poderia parecerlhes improvável. Mas há também um uso mais comezinho da retórica; aliás, bem familiar aos políticos: em Protágoras, por exemplo, embora Sócrates acuse seu interlocutor de se valer de respostas longas para confundi-lo, ele próprio confessa a seu amigo e discípulo que, diante da habilidade de Protágoras, chega a se valer de expedientes como ganhar tempo, para encontrar um argumento à altura de seu oponente ${ }^{4}$. E, claro, para ganhar tempo, vale-se da retórica, que se mostra assim como que incontornável, como dizem os franceses. Mas, se Platão se utiliza da retórica para levar seu público à verdade, por que ele a considera, como em Górgias, um engodo, um simulacro, uma aparência de ciência, uma simples cosmética (463c-464a)? O problema é que, para Platão, existem dois tipos de persuasão: uma fundada na ciência, outra alicerçada na crença; ou, se preferirmos, uma fundada no saber e outra, no crer ${ }^{5}$. A retórica, como Górgias acaba reconhecendo (Górgias, 454d-455b), ocupar-se-ia da persuasão fundada na verossimilhança, naquilo que tem a aparência de verdade, em uma ilusão no crer e não no saber, que, segundo Sócrates, seria o único caminho capaz de conduzir à verdade:

[Sócrates] A retórica é, portanto, ao que parece, artífice da persuasão que faz crer, e não da que faz saber o que é justo e injusto.

\footnotetext{
4 "Quanto a mim, em um primeiro momento, fiquei surpreso e um tanto zonzo sob o impacto de suas palavras [de Protágoras] e das aclamações, como se eu tivesse sido atingido por um hábil lutador. Em seguida, para te falar francamente, eu procurei ganhar tempo para refletir sobre o raciocínio do poeta e foi por isso que me dirigi a Pródicos e o interpelei..."(Protágoras, 339b-340a). Veja que nesse diálogo a atividade retórica é claramente marcada como um duelo .

${ }^{5}$ A semiótica retomará essa discussão em Du sens II (p. 115-134), onde Greimas estuda dois universos cognitivos, cada qual fundado em uma dessas modalidades. No entanto, a conclusão final, como indica o título do capítulo, é que existe apenas um universo cognitivo que articula as duas modalidades.
} 
[Górgias] Sim.

Como a retórica dos sofistas é fundada no crer e não no saber verdadeiro, seria uma imitação de justiça, uma justiça falsificada, da mesma forma que a sofística seria uma legislação adulterada, e a culinária, um arremedo da medicina. Nenhuma delas seria arte. No lugar dos adornos, adulações e condescendência da retórica, Platão propõe uma linguagem simples e direta, mesmo rude, que despreza o discurso, que não faz concessões e que não aceita meios-termos. Mediante perguntas e respostas, Sócrates procura estabelecer relações de identidade ou de diferença, de superioridade ou inferioridade, de pertinência ou de exclusão etc. entre categorias fundamentais (diria a semiótica): assim, ele procede, por exemplo, com o bom e o belo, ou com o justo e o injusto, ou, ainda, com a felicidade e a infelicidade. $\mathrm{Na}$ verdade, parte significativa dos discursos de Platão é constituída de exercícios lógicos, e o próprio filósofo insiste, em diversas passagens, sobre o fato de que se vale de tal método para fugir das armadilhas dos discursos longos, que poderiam iludir o ouvinte e impedi-lo de alcançar a verdade. Partindo de um termo, Sócrates o divide em duas espécies, segundo suas articulações naturais. Os dois termos dão origem, cada um, a dois outros, até que se chegue a uma unidade indivisível, que é, então, confrontada com a proposição inicial, a fim de saber se o termo obtido pertence ou não à categoria proposta inicialmente ${ }^{6}$. A linguagem não teria lugar nesse exercício de lógica, ou melhor, seu papel seria somente ocultar o que se passa de fato. Assim, (o fazer-crer da retórica estaria, na visão de Platão, além de não conduzir ao saber, implicaria um fazer-não-saber).

Para Platão, o retórico não pode transmitir a ninguém o saber, pois não o possui. Não pode ensinar a fazer navios, a construir pontes ou a curar doenças, porque desconbece a verdadeira natureza das coisas (Górgias, 464a - 465b). E uma das críticas mais freqüentes que faz à retórica é em relação a seu caráter genérico; ao fato de não ter um objeto específico, a não ser a persuasão. Por isso, a retórica não pode ensinar a virtude; o máximo que pode fazer o retórico é transmitir, aos que o escutam, sua crença, que, nas mais das vezes, não é geral, nem verdadeira, como a ciência, mas particular e sujeita aos interesses pessoais do orador, os quais não serão necessariamente, os da comunidade. Por esse motivo, Sócrates, porta-voz de Platão, considera a retórica uma adulação ou mesmo um engodo. Chega-se aqui à primeira

\footnotetext{
${ }^{6}$ Para um exemplo bem mais interessante e rico a respeito do método, ver a discussão que Platão mantém com Pólos, acerca da seguinte questão: o que é pior: sofrer ou praticar uma injustiça? (Górgias, 465b481b.)
} 
divisão da retórica: ela não mais se ocupará do saber, mas do crer e, desse modo, conforme Sócrates afirma em Fedro (259b-260a), o orador não precisaria conhecer o que é verdadeiramente bom ou justo, mas apenas o que pareceria a ele próprio, ou aos olhos do público a que se dirige, o bom e o justo ${ }^{7}$. O retórico não se preocupará com a verdade, mas com o que parece ser verdadeiro, segundo seu pensamento ou o de seus interlocutores, ou mesmo segundo os seus objetivos, muitas vezes ilícitos. Sua meta e método não seriam, portanto, a busca da verdade, mas sim a obediência à verossimilhança. A verdadeira retórica, ou a dialética, não se fundaria na verossimilhança, mas na verdade. Conforme o filósofo explica a Fedro (Fedro, 266a-266d), aquele que busca a verdade deveria se valer da dialética, a qual, por meio de definições, divisões e sínteses, poderia ensinar o homem a pensar e a conhecer as coisas em sua unidade e em sua multiplicidade, permitindo-lhe chegar, assim, ao verdadeiro conhecimento.

A retórica dos sofistas - que não estaria preocupada com a verdade, mas com o consenso ou com a redução da dissensão - serviria, como ficou dito, a suas senhoras, tanto à justiça, quanto à injustiça; poderia devolver a terra ao seu legítimo proprietário ou expropriar o camponês indefeso; poderia conduzir o público ao acerto, e também ao erro; levar Atenas à paz e ao progresso ou conduzir os atenienses a uma guerra fratricida e ao opróbrio; e, por essas razões, ela seria um simulacro da política. O retórico, na visão de Platão, seria uma espécie de ignorante, que, valendo-se de engodos, teria mais habilidade para convencer outros ignorantes do que os verdadeiros sábios caso se propusessem a tal (Górgias, 459a-459c). O retórico não precisaria, portanto, conhecer a verdade; bastar-lhe-ia a verossimilhança. Aliás, Sócrates acusa os retóricos de considerarem esta preferível àquela (Fedro, 272d-273c) e condena Tísias e Górgias por terem descoberto que a verossimilhança é superior à verdade, que, pela força de suas palavras, faz̧em parecer grande o que é pequeno e pequeno o que é grande, que dão às coisas novas um ar de antiguidade, às coisas antigas um ar de novidade, e que inventaram discursos condensados ou amplificados ao infinito sobre qualquer assunto. (Fedro, 266e-267c). O poder da verossimilhança é decorrente do fato de ela assemelhar-se à verdade; de ter a aparência de verdade (idem, 273c-274a), embora não o seja. A importância de discursos condensados ou amplificados seria conseqüência dessa necessidade de causar um efeito de sentido de verdade e

\footnotetext{
${ }^{7}$ Em Górgias (518b-519b), por exemplo, uma das críticas que Sócrates dirige aos políticos é justamente o fato de terem dito aos cidadãos de Atenas o que eles queriam ouvir, e não o que lhes seria bom ou justo.
} 
de, a partir de tal ilusão, impor-se à multidão, que, ignorante, deixa-se iludir pelos sofistas, os quais trabalhariam no modo do parecer, e não do ser.

Além de não conduzir à verdade, a retórica inibiria a atuação da justiça, já que os ímpios dela se valeriam dela para ocultar sua culpa e, com o auxílio dos discursos dos advogados e de falsas testemunhas, iludir o júri e fugir à punição (Górgias, 471d - 472c). Se a justiça é prejudicada pela retórica, os justos não podem ser seus beneficiários, pois, se cometessem alguma falta, melhor lhes seria denunciarem a si próprios, pois é preferível, ao menos segundo Sócrates, sofrer a justa punição a permanecer impune e com alma doente (idem, 481b-482a). Assim, em qualquer meio em que se insira, a retórica afastará a verdade e a substituirá pela verossimilhança; seu fruto, a persuasão, não será, portanto, a vitória da primeira, mas a prevalência da segunda. Fato que ocorreria em todos os locais, especialmente nos tribunais:

De fato, nos tribunais não se busca de forma alguma dizer a verdade, mas persuadir, e a persuasão pertence à verossimilhança; é a verossimilhança que devemos utilizar se desejamos falar com arte. Há mesmo situações em que é preciso se guardar de expor os fatos tal como se passaram: é quando eles são contrários à verossimilhança; é preciso, então, reduzi-los ao verossímil [...]. Enfim, em geral, o orador deve ater-se ao verossímil e esquecer o verdadeiro. Verossimilhança sustentada do início ao fim do discurso, eis no que consiste toda a arte oratória.(Fedro, 272d-273c)

E um pouco mais adiante:

[...] essa verossimilhança se impõe à multidão precisamente por sua semelhança à verdade, $\mathrm{e}$ fazíamos ver há pouco que é quando se possui a verdade que se sabe melhor descobrir todas as semelhanças em todas as circunstâncias.(Fedro, 273c-274a)

As citações acima demonstram claramente que, para Platão, a verdade e a verossimilhança encontram-se freqüentemente em campos opostos, o mesmo ocorrendo entre aqueles que trabalham com a primeira (os filósofos) e que buscam o conhecimento (o saber-ser) e aqueles que lidam com a verossimilhança (os retóricos), cuja ambição é a persuasão ou o fazer-fazer. Platão provoca, desse modo, talvez o maior cisma epistemológico da história. A partir daí as ciências da linguagem saberão, com maior ou menor clareza, que seu objeto não é mais a "realidade", isto é, "a verdade", mas apenas um simulacro dela construído pela linguagem. Tudo até estaria bem, se a demarcação fosse assim nítida, estável. Mas o que a modernidade ensina é que a linguagem invade territórios e faz com que, mesmo aquele discurso que se quer científico, objetivo, isento, seja uma construção linguageira. A diferença é que, em alguns casos, as evidências empíricas seriam maiores, e noutros, menores, mas sempre estarão subordinadas ao discurso; aliás, como Aristóteles ira afirmar. A discussão 
não está restrita a gregos; cariocas também a realizam, porém em outra chave. Um deles, lá Cosme Velho, ira divertir-se mostrando que as tais evidências empíricas são bem pouca coisa diante da linguagem. Mas aguardemos.

\section{Isócrates ou a defesa da retórica}

As grandes escolas de retórica da Antiguidade não foram apenas as de Górgias e Protágoras. Isócrates, que tomou aulas com Pródicos, Górgias e Sócrates, também abriu seu estabelecimento; um dos mais conceituados de toda a Antiguidade. De uma longevidade espantosa para a época - morreu aos 98 anos, tendo publicado, pelo menos, até os 82 -, Isócrates era, antes de mais nada, um prático, um advogado, se assim podemos dizer, que ensinava seu ofício aos interessados. Por conta de seu temperamento e da riqueza que obteve, envolveu-se em um sem-número de polêmicas e disputas com muitos que o acusaram de ter feito da retórica um comércio; crítica, aliás, que ele próprio faz a outros, em vários de seus discursos. Tímido, de voz estridente e desagradável, evitava manifestações públicas e procurava escrever todos os seus discursos e registrar seus pensamentos, fato que permitiu que boa parte de sua obra chegasse até nossos dias, apesar de um tanto considerável ter se perdido.

Em função de sua longevidade (436 - 342 a.C.), Isócrates foi contemporâneo de Platão, que talvez tenha conhecido nos seminários de Sócrates, e de Aristóteles. Suas relações com o primeiro são ainda hoje objeto de controvérsia. Platão cita-o em Fedro (278 D), atribuindo-lhe certo "espírito filosófico", expressão que não se sabe ao certo se foi ou não lisonjeira. Seja como for, tinham vários pontos em comum: repudiavam o uso meramente utilitário da retórica e defendiam a moralização tanto de seu ensino quanto de sua prática; conferiam especial atenção ao aspecto estético de seus textos; e, muitas vezes, combatiam e defendiam as mesmas causas, como se pode ver, por exemplo, em Contra os sofistas, de 360 a.C., discurso em que, como sugere o título, Isócrates — à semelhança de Platão — faz várias acusações graves aos sofistas. Por outro lado, havia pelo menos um ponto de discordância decisivo: ao contrário de Platão, Isócrates não acreditava que fosse possível chegar ao conhecimento real, à verdade absoluta. Para ele, era possível, apenas, verificar o conteúdo de verdade de algumas (e não de todas, convém frisar) proposições, confrontando-as com a realidade. Ele pretendia partir da realidade observada para melhorá-la, valendo-se, para tanto, 
da retórica. Daí resulta um segundo ponto de discordância: Isócrates, ao contrário de Platão, rejeita uma linguagem fria, desprovida de emoção, e busca uma linguagem elaborada elevada, que distinga o orador. Isócrates rejeita, portanto, uma retórica "logicizada".

Embora, em seus textos, Isócrates faça um uso muito comedido das figuras de linguagem (a metáfora é bastante rara em sua obra), para o professor de Atenas a retórica estará sempre associada à criatividade, ao suspense, ao uso de uma linguagem elevada, bem cuidada, que crie uma expectativa positiva no auditório e o seduza.. Essa concepção do discurso leva Isócrates a condenar os sofistas por utilizarem formas fixas, lugares comuns (certo cronista do Rio de Janeiro diria chapas) cujo sentido já se teria esvaído. Para o retórico, a linguagem deve identificar o orador, quase como uma digital, desde que ele não se repita, mas inove sempre. Como se vê, a acusação de que retóricos se valem de formas vazias é antiga e começa com um dos pais da retórica. Veja-se o trecho a seguir:

Espanto-me ao ver que indivíduos que utilizam, sem perceber, exemplos fixos em uma arte criativa são considerados dignos de ter discípulos. De fato, exceto eles, quem ignora que as cartas [comerciais] não se alteram e guardam o mesmo valor, de forma que são empregadas sempre as mesmas fórmulas para os mesmos objetos, ao passo que se passa algo totalmente diferente com as palavras? O que um homem diz não tem a mesma utilidade para o que vem depois dele e o mais hábil nessa arte é o que exprime como pede a matéria, mas com o poder de encontrar expressões absolutamente diferentes das empregadas pelos outros. (Contra os sofistas, §12)

Entretanto, em Elogio a Helena (\$2), Isócrates faz a ressalva: a novidade do discurso não é um valor em si mesma e não pode ser dissociada da harmonia entre os períodos, da sintaxe clara bem articulada aos elementos acessórios. O discurso que unir elegância, originalidade e clareza distinguirá seu enunciador. Para o retórico, a linguagem é o ponto capital que diferencia os homens dos animais, distinguindo, por sua vez, os cidadãos de estilo mais elevado dos que se contentam com o falar cotidiano. É por isso que a retórica não poderá se conformar com uma linguagem matemática, ocupada apenas com relações lógicas, impessoal, fria, como a utilizada por Sócrates nos diálogos de Platão, mas deve ambicionar a criação de um logos que conduza à verdade, sem esquecer a beleza. Para ser beligerante, o discurso deve antes ser belo, agradável aos ouvidos, harmonioso. Observe-se que essa diferença em relação a Platão é capital e não se limita, simplesmente, às preferências estilísticas de um e de outro, mas decorre de uma visão oposta do que é persuasão. Viu-se que em Platão não havia lugar para o ethos, pois a Verdade é universal e não depende do contexto ou do indivíduo que enuncia. Já Isócrates tem outro entendimento e vê na 
linguagem bem cuidada não um instrumento para alcançar a verdade, mas para permitir ao orador tornar-se distinto (em todos os sentidos) em relação aos seus pares.

Por ter adotado esse posicionamento, considera-se que Isócrates, involuntariamente, teria dado o primeiro passo - mas não o decisivo - para que a retórica fosse amputada (como afirma Ricœur em La métaphore vive) de seu lado argumentativo e se restringisse a ornamento. Todavia, a estética não é a única preocupação de Isócrates; para o retórico, o orador não deve jamais abandonar a ética, que o guiará na elaboração de seu discurso e na busca da verdade. Daí porque o retórico sempre dedicará bastante atenção à reputação do orador, à importância de ele ser um cidadão distinto e distinguir-se pelo uso que faz da linguagem. Sua preocupação com a ética e o repúdio a uma retórica meramente formal fica evidente em vários pontos de sua obra, como nesta exortação que faz parte de Elogio a Helena, um dos mais famosos discursos do autor:

Que eles [os que pretendem ser retóricos] busquem a verdade, que formem seus discípulos na prática de nossa vida política, se esforcem para dar-lhes experiência para essa lide com a convicção sincera de que vale mais trazer na alma temas úteis e opiniões razoáveis do que futilidades sobre conhecimentos exatos; que mais vale ter uma vantagem discreta sobre um grande tema do que uma superioridade arrasadora perante os medíocres e sem utilidade para a vida humana. (Elogio a Helena, § 5)

Veja que Isócrates busca um conhecimento genérico, experiência para essa lide, sem se importar (como era o caso de Platão) com que o retórico tenha um conhecimento específico sobre um assunto ou outro. Por outro lado, há uma grande preocupação com a prática da vida política, conseqüentemente, com a reputação que o orador tem perante a Polis. Por esse motivo, alguns estudiosos, como Ruth Amossy (2004, p. 220), consideram que Isócrates foi o primeiro a tratar da questão do ethos do orador, a partir de uma perspectiva que, embora bastante distinta da de Aristóteles, foi seguida pela retórica latina, especialmente Quintiliano. Para Isócrates, além da qualidade estilística do discurso, objeto de vários de seus ensinamentos, o elemento central na persuasão do ouvinte é o ethos do orador, entendido como a reputação deste perante o seu grupo social. Na sua visão, os dois fatores — qualidade do discurso e estatura moral do orador — andam juntos: os bons oradores, isto é, os que têm um ethos que os torna dignos de confiança, são também os que mais cuidam de seu discurso, que falam de forma original, clara e elegante. Dessa forma, o autor é o primeiro a propor uma nexo causal entre caráter e discurso, ainda que no sentido inverso do que será proposto por 
Aristóteles mais tarde. É o que se pode verificar — se o leitor perdoar tantas citações — em um dos seus últimos e mais famosos discursos - Sobre a troca:

[...] entre os políticos contemporâneos e os que morreram há pouco, aqueles que dispensam mais cuidados a seus discursos são também os mais honestos que já subiram à tribuna [...]

Aquele que deseja persuadir não pode também deixar de se preocupar com a virtude e terá que depreender os maiores esforços para conseguir a melhor reputação entre seus concidadãos. De fato, quem ignora que um discurso parecerá mais verdadeiro se provier de alguém bem considerado do que se for proferido por um individuo menosprezado, e que a demonstração fornecida pela vida de um homem tem mais força do que o conteúdo do discurso?

[...] além disso, os filósofos sabem que os apelos à verossimilhança, os argumentos e todos os meios de prova, se aplicam apenas à circunstância em questão, enquanto a reputação de honesto não somente dá mais confiança ao discurso, mas também confere lustro a todos os atos daquele que goza de tal conceito, o qual deve ser buscado por todos os homens inteligentes (Sobre a troca, $\S 278$ e $\S 280)$.

Nos três parágrafos acima, fica claro que é a reputação do orador que garante a eficácia do discurso. A eloqüência seria apenas um índice de distinção, da probidade daquele que toma a palavra. O ethos, na visão de Isócrates, não é, portanto, construído pelo discurso, mas pela vida em sociedade. Como se vê na passagem acima, a verossimilhança tem seu poder esvaziado, limitado a determinada circunstância, e sua eficiência passa a estar condicionada à imagem pública do orador: parecerá verdadeiro o discurso que provier do homem que é probo aos olhos de seus concidadãos.

De Platão a Isócrates, observou-se um movimento importante: apesar das críticas realizadas pelo primeiro à retórica e aos retóricos, o segundo resgata a legitimidade de ambos, mas a condiciona ao logos e, sobretudo, ao ethos do orador. Onde antes se viam apenas relações lógicas, passa agora a existir uma preocupação estética e ética que apresentará desdobramentos importantes em Aristóteles e em todo o edifício retórico, pois, as teorias de Isócrates, adotadas pelos retóricos romanos, darão origem a um conceito que será dominante em toda a Idade Média e se manterá vivo até hoje. Nessa acepção, o ethos não é uma construção discursiva, mas fruto da reputação do sujeito no meio social em que vive. O que está em jogo, na verdade, são relações intertextuais, pois a reputação nada mais é que um conjunto de discursos sobre o enunciador, os quais podem contribuir ou não para o discurso mantido por ele. Assim, na visão de Isócrates, o ethos é uma espécie de sanção positiva ou de prova qualificante que a um só tempo sanciona as performances anteriores do orador e atesta a sua competência para a produção de novos discursos. 
Embora as relações pessoais entre Isócrates e Aristóteles fossem francamente hostis ${ }^{8}$ e as divergências teóricas, profundas, havia também alguns pontos de convergência importantes entre suas idéias. Por exemplo, Aristóteles concorda com Isócrates ao afirmar que as provas resultam não apenas das demonstrações realizadas, mas principalmente das qualidades morais que se supõe que o orador deva ter (Retórica, I, VIII, VI). Assim, influenciado ou não por Isócrates, Aristóteles também dedicará especial atenção ao ethos, muito embora (e agora se chega à divergência) o entenda em uma concepção bastante distinta da de Isócrates: o ethos não será mais fruto da imagem pública do orador, exterior ao discurso, mas construído por ele. Não será decorrente dos discursos sobre o enunciador, mas do efeito produzido por sua enunciação. A diferença é sutil: viu-se que para Isócrates os atributos morais do orador e a qualidade do discurso andam juntos, sendo que os primeiros o habilitam a construir o segundo. Em Aristóteles, de certa forma, as qualidades do orador e do discurso também andam juntas, mas há uma inversão importante: aquelas são construídas por este. É o bom discurso que constrói o bom orador e não o contrário.

\section{Aristóteles e a retórica dissidente}

Não é possível afirmar categoricamente que Isócrates tenha influenciado Aristóteles; é fato, porém, que algumas de suas idéias são retomadas pelo estagirita, para quem a persuasão também não podia ser obtida apenas mediante relações lógicas frias, mas era resultado de uma linguagem elaborada de forma a seduzir o publico. Uma vez voltada para o ouvinte, a retórica de Aristóteles não pode deixar de considerar suas emoções, costumes, paixões... Em Entre a Retórica e a poética: Aristóteles, Ricoeur (1975, p.43) mostra que o argumento retórico, na visão de Aristóteles, reúne a verossimilhança inerente à matéria discutida, com a qualidade persuasiva do orador, ambas erigidas sobre os atributos do público. Logo, por envolver toda uma dimensão intersubjetiva da linguagem, a retórica aristotélica (que, nesse aspecto, aproxima-se da de Isócrates) não pode se contentar em ser

\footnotetext{
${ }^{8}$ As ofensas mútuas teriam origem em uma questão bem pouco acadêmica: Isócrates acusa Aristóteles de ter-lhe roubado um aluno bastante especial; ninguém menos que Alexandre, o grande...
} 
puramente formal e argumentativa; deve preocupar-se com a especificidade da relação intersubjetiva que estabelece com o ouvinte?

Por outro lado, como se sabe, não restam dúvidas quanto à influência de Platão sobre Aristóteles, seu mais famoso discípulo. O aluno não renega os ensinamentos recebidos, mas vale-se do material rejeitado por Platão para construir sua retórica; não discute que a nova ciência tenha os vícios apontados, mas talvez se possa afirmar que ela o interessa justamente por causa deles. ${ }^{10}$ Aliás, encontra-se em Fedro uma passagem que poderia ser uma notável síntese da retórica que viria a ser a de Aristóteles:

Uma vez que é próprio do discurso conduzir as almas, para ser um orador hábil é preciso conhecer quantas espécies de almas existem; ora, há certo número delas com tais e tais qualidades, há em seguida tais e tais homens. A essas distinções correspondem tantas espécies de discursos. E assim é fácil persuadir homens de tais coisas por tais discursos e por determinada causa, enquanto outros resistem aos mesmos meios de persuasão. [...] quando dominamos tais meios, quando soubermos o momento de falar ou de se calar, de ser conciso, emotivo, veemente [...], então teremos atingido a plena perfeição da arte, não antes. (Fedro: 271b-272d)

Na passagem acima não está em discussão a verdade, mas a persuasão, e esta depende dos valores em jogo: aquele persuade um grupo de indivíduos pode não provocar o mesmo efeito em outros. E, de fato, a preocupação central de Aristóteles na Retórica não é descobrir a verdade, e sim o que pode conduzir à persuasão; ele e Platão concordam quanto aos mecanismos que a regem; entretanto, enquanto o mestre os despreza, por considerar que não conduzem à verdade, mas à verossimilhança, o discípulo os acolhe pela mesma razão. Talvez, se a conhecesse, Platão afirmaria que a retórica de seu mais famoso aluno é também

\footnotetext{
${ }^{9}$ Nesse estudo, Ricoeur apresenta uma síntese bastante clara dos princípios que regem a retórica aristotélica, como se pode ver neste pequeno trecho:

[...] a retórica não pode ser absorvida por uma disciplina puramente argumentativa, pois está voltada para o ouvinte; ela não pode, portanto, não considerar o caráter do locutor e a disposição da audiência; em sintese, ela se liga à dimensão intersubjetiva e dialogal do uso público do discurso, dai resulta que a consideração das emoções, das paixões, dos hábitos, das crenças permanece da competência da retórica, mesmo que tal consideração não deva ter mais prioridade que o argumento verossimil; o argumento propriamente retórico leva em conta ao mesmo tempo o grau de verossimilhança inerente à matéria discutida e o valor persuasivo que resulta da qualidade do locutor e do auditor. (1975, p.43)

${ }^{10}$ Em um primeiro momento, Aristóteles teria seguido as opiniões do mestre, chegando mesmo, segundo Meyer, a defender a mesma posição em um texto que se perdeu, denominado Gryllos. No entanto, a partir daí, o estagirita vai se dedicar cada vez mais a um estudo da retórica que o afastara de Platão. Os conhecimentos retóricos de Aristóteles seriam notáveis. Em De oratore (II, 38), Cícero conta que ele teria elaborado uma história da retórica que contemplaria os ensinamentos de todas as grandes escolas, desde a de Tísias. Segundo Cícero, a elegância, a precisão, o cuidado dessa obra seriam tais que ninguém mais recorria, naqueles dias, aos textos originais. Todos procuravam as lições de Aristóteles, mais claro e mais fácil de ser compreendido. Para maiores detalhes, ver "Aristote ou la pluralité de l'être comme base de la Rhétorique” In Histoire de la Rhétorique des grecs à nos jours p. 39-40.
} 
uma retórica "degenerada", justamente a que ele rejeitava, pois ao invés de buscar a verdade, preocupa-se com o que pode parecer verdadeiro aos olhos e ouvidos dos ouvintes. A retórica de Aristóteles está, portanto, mais próxima da de Isócrates, pois, como o ateniense, preocupa-se menos com o objeto de sua discussão e mais com a opinião do público; assim, a verdade não está mais no objeto, ela é construída pelo discurso.

Barthes (1985: 94) argumenta que só é possível compreender satisfatoriamente a retórica aristotélica se, além de confrontá-la com as idéias de Platão, forem consideradas outras teorias do próprio Aristóteles. Como se sabe, além do Technè rhétoriké, em que trata tanto da comunicação cotidiana quanto da oratória e onde discute o encadeamento das idéias que deverão compor a tese defendida, Aristóteles escreveu também o Technè poiétikè, no qual são apresentados os princípios que devem reger a composição das imagens que farão a imitação da realidade; ou seja, a mímesis. As duas obras reunidas formam a visão de Aristóteles sobre o discurso e em ambas a verossimilhança é o conceito central; na Retórica, como condição para ganhar a adesão do público às teses defendidas e criar a impressão de verdade; na Poética, por ser um indicador de que a realidade foi bem imitada e que a imitação não é imitação, mas realidade. A poesia, objeto da Poética, não quer - ao contrário do discurso — convencer ninguém de coisa alguma; quer "apenas" purificar as almas ao provocar o terror e a piedade. A Retórica pode ser entendida como um manual (bastante prático, por sinal) sobre como produzir provas para convencer o outro de que se está falando a verdade. De certa forma, a Poética também ensina como dizer a verdade, mas uma verdade mais séria - pois, como afirma o estagirita, a poesia é algo mais sério do que história — , e o faz por meio da ficção, da fábula, do enredamento, diria Jó Joaquim, talvez colocando a fábula em ata. ${ }^{11}$

Apesar de esses dois tratados cuidarem não apenas de diferentes usos da palavra, mas de situações discursivas também distintas, ambos foram sendo aproximados ao longo do tempo, fato que se reflete na crescente preocupação da retórica com o estilo. Por exemplo, na Idade Média, as artes poéticas passaram a ser conhecidas como artes retóricas e os poetas,

\footnotetext{
${ }^{11}$ Jó Joaquim leva, incorrigivelmente, ao genial e ingênuo prefácio de Tutaméia, o famigerado "Aletria e hermenêutica" em que Rosa trata de assuntos vizinhos aos da poética e da retórica:

A estória não quer ser história. A estória, em rigor deve ser contra a História. A estória, às vezes, quer-se um pouco parecida à anedota.

E mais adiante:
}

Não é o chiste rasa coisa ordinária; tanto seja porque escancha os planos da lógica, propondo-nos realidade superior e dimensões para mágicos novos sistemas de pensamento In Tutameia, p. 3. 
chamados de retóricos. O convívio com a Poética parece não ter feito bem à Retórica, pois a preocupação com o falar bem, já presente em germe em Empédocles e defendida por Isócrates, passou cada vez mais a sobrepujar a argumentação. A retórica começa, então, a ser decupada: desaparecem a inventio, responsável pela elaboração dos argumentos e provas, e a dispositio, que cuidava da ordenação do discurso. Permanece apenas a elocutio, que discute o estilo e o uso das figuras e que já era considerada de menor importância por Aristóteles.

Uma das principais características da Retórica de Aristóteles é a preocupação com situações concretas, fato demonstrado pela estrutura da obra: o livro primeiro será dedicado àquele que produz o discurso; quais argumentos usar, como construí-los, que efeitos causam etc.... O livro segundo pertence àquele que vai receber a palavra; nele, o autor procura examinar as paixões e as emoções do auditório para descobrir como interagir com elas, como utilizá-las para alcançar os fins desejados. Finalmente, o terceiro livro vai cuidar do que une enunciador e enunciatário: o discurso. São discutidos, por exemplo, a ordem dos argumentos visando à boa elocução, a dicção, e quais figuras devem ser utilizadas de acordo com o gênero empregado. Essa preocupação se reflete também nos três gêneros de retórica: o deliberativo, a ser empregado nas reuniões públicas onde se discute os destinos dos participantes; o judiciário, próprio dos tribunais; e o epidêutico, concebido para as ocasiões em que se quer enaltecer alguém ou um fato. Mais uma vez vê-se que para Aristóteles, a retórica não pode contentar-se em estabelecer relações lógicas; ela precisa estar atenta a todos os elementos que, de alguma forma, interferirão na transmissão da mensagem: são as paixões do orador e do auditório e as crenças e costumes de cada um, além, claro, do próprio discurso. Assim entende-se bem a afirmação de Barthes segundo a qual a Retórica de Aristóteles é apropriada à cultura de massas, pois busca o que é próprio para convencer cada indivíduo em cada situação; algo bem familiar aos marqueteiros de nossos dias. O que Platão excluía, ou mesmo bania, de sua retórica, Aristóteles considerava o cerne da discussão: onde Platão procurava a verdade e rejeitava a verossimilhança, Aristóteles busca esta e despreza aquela, talvez por considerá-la inacessível.

Ao contrário de Platão, Aristóteles não ensina o que é a essência das coisas, mas o que poderia ser diferente, ser de outro modo, ou mesmo não ser; sua retórica atua no que é discutível, no que comporta múltiplas soluções; age quando há divergências ou quando ela pode ser instaurada (Retórica, Livro I, cap. II, XII). Sua ação se produz quando a ciência se mostra impotente ou insuficiente para resolver uma questão, quando, na falta de evidências 
materiais (e na impossibilidade do recurso à violência), tudo deve ser resolvido pelo debate. Em outras palavras, mais semióticas, dir-se-ia que a retórica trabalha com modalidades epistêmicas, mais precisamente com o crer-ser. Por ser inerente à atividade humana, a retórica não está circunscrita a ciência alguma; participa das discussões do dia a dia, tanto das sérias quanto das ordinárias, essas mesmas que a ciência não consegue suportar. Ora, se a retórica, na versão de Aristóteles, busca o que é próprio para persuadir ou como levar alguém a aceitar como verdadeira a tese defendida, então deve partir do que é provável, ou mesmo improvável, para chegar àquilo que, em função da atuação do orador, passa a ser considerado certo. Deve partir do parecer, da manifestação (parecer ou não-parecer), para atingir a essência (ser ou não-ser) — mas, claro, a essência na visão do enunciador, e, por isso, as pretensões da dessa retórica são bem mais modestas do que as do modelo platônico. Agora, a verdade buscada não é mais a absoluta, a única, a soberana, mas a que é construída pelo discurso, que é considerada como tal pelo orador. Conforme lembram Greimas \& Courtés, o fazer persuasivo do enunciador consiste na construção de simulacros de verdade, os quais estão relacionados tanto a seu próprio universo axiológico quanto ao do enunciatário e, sobretudo, à representação que este último faz do universo do enunciador (1993: p. 418). O papel da retórica será, então, fornecer as ferramentas necessárias ao fazer-crer do orador, para que as teses apresentadas sejam consideradas corretas e para que o enunciatário alcance o crer-ser, independentemente do ramo de conhecimento em questão. Por aí se compreende bem porque Sócrates acusava Górgias, Protágoras e Lísias de discorrerem sobre assuntos que não dominavam, assim como a dificuldade encontrada por esses retóricos para explicar a Sócrates qual era, afinal, o objeto da ciência que ensinavam. Talvez por conhecer o rigor de seu antigo mestre no trato dessa questão, Aristóteles tenha se adiantado e esclarecido logo no início de sua obra: a retórica é a faculdade de considerar para cada questão o que é próprio a persuadir (Retórica, Livro I, cap. II, I).

Aristóteles ensina que, para alcançar tal objetivo, devem-se trilhar, simultaneamente, dois caminhos complementares: o da razão e o da emoção; ambos constituídos de provas ou argumentos que podem ser externos ou internos ao discurso. Os testemunhos, as convenções e leis, as informações obtidas pela tortura, os juramentos são exemplos de argumentos do primeiro grupo, embora o discurso não permaneça indiferente a eles, uma vez que cabe ao orador manipulá-los em seu proveito. Trata-se não apenas de obter provas, mas de construí- 
las, (re)inventá-las no processo da enunciação ${ }^{12}$. Aristóteles explica, por exemplo, que os testemunhos mais úteis são os de indivíduos que não estão diretamente relacionados ao caso em discussão ou os testemunhos dos antigos ou, ainda, aqueles proferidos por pessoas tidas por incorruptíveis (Livro I, cap. XV, XVII). No entanto, aquele que não dispõe de testemunhos a seu favor deve esquecer essas considerações, que de nada lhe valerão, e alegar que o juiz deve julgar de acordo com o que lhe parece mais verossímil e segundo sua própria consciência. Todavia, se o adversário não dispõe de testemunhos, então é preciso fazer o raciocínio inverso e alegar que apenas a verossimilhança não basta e que os testemunhos são fundamentais (id., $i b)$. Raciocínio análogo vale para tortura: se é favorável ao orador, argumenta-se que a informação obtida por esse meio é a mais confiável, posto que foi preciso recorrer à força para obtê-la; mas se favorece ao adversário, deve-se alegar que sob tortura confessa-se qualquer coisa, tanto os fatos quantos os delírios; logo, tal informação não é digna de crédito (Livro I, cap. XV, XXVI). É nesse jogo de dois pesos e duas medidas, em que tudo é relativo, em que o ser se curva ao parecer, que reina a retórica de Aristóteles. $\mathrm{Na}$ verdade, o testemunho, a tortura ou qualquer outra prova ou demonstração "exterior" ao discurso valem não pelo que são, mas por aquilo que o discurso os faz parecer, pois cabe ao orador lapidá-los, dar-lhes a roupagem mais adequada a seus interesses, ocultar a face hostil aos seus propósitos e ostentar a que lhe é favorável.

Atente-se para a diferença fundamental em relação a Platão: em Górgias, Sócrates afirma que os advogados recorrem a testemunhos falsos para iludir o juiz e fazê-lo descrer da verdade. No entanto, mesmo os depoimentos legítimos são desprezados por Platão, que considera que apenas a filosofia pode descobrir a verdade. Quando instado a apresentar testemunhas que corroborem suas teses, Sócrates afirma que a única necessária é seu oponente, Pólos. A partir desse momento, o filósofo passa a submetê-lo a uma série de perguntas cujas respostas implicam o estabelecimento de relações de equivalência e de hierarquia entre os termos que estão discutindo até ficar evidente para seu interlocutor e ouvintes as contradições nas quais caíram e constrangê-los a aceitar as teses defendidas por Sócrates. Para Platão, a verdade não se curva a considerações de outra ordem que a da investigação da realidade mediante o uso da lógica, sendo que só o filósofo está habilitado a

\footnotetext{
${ }^{12}$ Bordron e Fontanille lembram que "Não se trata somente, nos termos de Aristóteles, de "aceitar" a prova, mas frequentemente de inventá-la (ou crer tê-la inventado) no próprio momento da enunciação em ato." Langages, n. 137, p. 4.
} 
empreendê-la. Por isso, também, Platão considera os retóricos farsantes, pois, como não são filósofos, não estão habilitados a fazer emprego da lógica; conseqüentemente, tudo o que podem é produzir discursos que cuidam da aparência e esquecem a essência. Por outro lado, Aristóteles não discute se os testemunhos desviam ou aproximam da verdade; sua preocupação é outra: como usa-los (ou evita-los) para obter a persuasão.

Além das provas ou argumentos exteriores ao discurso, o orador deve, segundo Aristóteles, apresentar os que lhe são internos:

Os argumentos inerentes ao discurso são de três espécies: alguns residem no caráter moral [ethos] do orador; outros na disposição do auditório [pathos] e outros, enfim, no discurso propriamente dito [logos], quando este é demonstrativo ou aparenta sê-lo. (Retórica, I, cap. II, IV - grifo nosso)

Além de suas fontes externas, o orador tem a seu dispor o ethos - o caráter por ele construído com seu discurso - o pathos - o sentimento para o qual o público se inclina e que o orador deve saber manipular em seu proveito - , e o logos — o discurso propriamente dito, discutido no Livro III, no qual Aristóteles explica que o orador pode conduzir sua argumentação de quatro modos: o científico, que, alicerçado no silogismo demonstrativo, parte de premissas dadas como verdadeiras e primeiras (é o recurso empregado por Platão); o dialético, de acordo com o qual o silogismo (nesse caso, também chamado de epiquerema) baseia-se em premissas prováveis, originadas no senso comum; o heurístico ou sofístico, que apresenta como prováveis premissas que, na verdade, não o são, ou que simula conclusões não decorrentes das premissas apresentadas (recurso muito utilizado por delegados de certo bruxo do Cosme Velho da segunda metade do século XIX); e, finalmente, o propriamente retórico, que se constrói com dois procedimentos, a saber, os entimemas ${ }^{13}$ e os exemplos, (que) podem ser históricos ou inventados.

Os entimemas são um tipo de silogismo do qual foi suprimida uma das premissas ou a conclusão. Por exemplo, em lugar de afirmar: "Todos os homens são mortais. Pedro é homem. Logo, Pedro é mortal", que, convenhamos, é um tanto maçante, afirma-se, simplesmente: "Pedro é homem; logo, mortal" ou, em dado contexto, bastaria afirmar que Pedro é homem para que o enunciatário deduzisse a primeira premissa e, a partir dela, chegasse à conclusão. A brevidade do entimema - que Quintiliano considera sua

\footnotetext{
${ }^{13}$ Para uma excelente abordagem da questão do entimema em uma perspectiva semiótica ver o estudo de Denis Bertrand, Enthymème et textualisation. In Langages n. 137, p. 29 - 45 março de 2000
} 
característica fundamental — permite, segundo os gramáticos de Port Royal, a construção de um raciocínio mais extenso do que o expresso pelo discurso, já que uma parte do pensamento deixou de ser expressa e deve ser reconstituída pelo enunciatário. Naturalmente, o entimema só produzirá o efeito desejado se o enunciatário souber reconstituir o raciocínio original, o que torna necessário que seu entendimento acerca da parte ausente seja concorde com o do enunciador e, conseqüentemente, que ambos partilhem do mesmo universo de valores. Uma das principais características do entimema é proporcionar ao ouvinte o prazer da reconstrução do raciocínio do orador, de comungar a mesma linha de pensamento. Claro, valer-se do entimema implica apostar que o enunciatário será capaz de interpretá-lo e, nessa medida, representa um risco em relação ao silogismo; e é esse risco mesmo que o torna atraente. À medida que a operação obtiver êxito e a premissa ou a conclusão ausente for restabelecida, o entimema transforma o ouvinte em co-responsável pelo discurso e cúmplice do orador, revestindo, assim, a relação entre ambos de um componente afetivo, que extrapola a dimensão cognitiva, tônica da doutrina de Platão. O leitor atual poderá argumentar, sentindo-se um pouco na pele do Monsieur Jourdan de Le bourgeois gentilhomme, de Molière: mas se é essa a definição de entimema, então falei por entimemas por toda a vida e nunca o soube. Oui, monsieur, de fato, valemo-nos de entimemas a cada instante, mas aí é preciso pensar, primeiramente, que Aristóteles tinha em mente uma teoria que abrangia, além da oratória stricto sensu, a conversação cotidiana, pois a retórica está em todo lugar. Depois - e esse é o ponto principal -, deve-se ter como parâmetro a argumentação binária de Platão que, se, por um lado, exigia a máxima concisão, por outro, determinava igualmente a explicitação de todo o raciocínio e a supressão de tudo o que fosse da ordem do afetivo ${ }^{14}$. Acontece que a hipertrofia da razão causava a atrofia do afeto, que é outra das provas ou demonstrações inerentes ao discurso; aliás, fato que os diálogos de Platão demonstram bem: Sócrates vence seus adversários, mas estes saem mais derrotados que convencidos; a razão prevalece, mas o preço é alto: instaura-se a antipatia mútua. O entimema, por sua vez, não é tão evidente, e pode ser mais doce - ou mais ácido. Finalmente, a eventual observação do leitor abre espaço para uma última consideração, que nos leva um pouco longe. Conforme visto, o entimema torna o discurso mais intenso, devido a sua carga afetiva, e menos extenso, uma vez que

\footnotetext{
${ }^{14}$ É preciso que se faça uma ressalva. É fato que a retórica dá especial atenção à interação verbal e, de forma alguma, ela exclui o afeto. Todavia, o afeto é pré-condição para o diálogo e não fruto dele. Mestre e discípulo devem ser unidos pelo amor inspirado que os leva, juntos, a procurarem a verdade. Assim, Barthes tem plena razão quando considera a retórica platônica erotizada (1985: 93), como um diálogo de amor.
} 
suprime a expressão de determinadas idéias. Ou seja - e aí está o ponto que leva para longe —, é possível pensar a retórica aristotélica nos termos propostos pela retórica tensiva, isto é, como um gradiente entre intensidade e extensidade. Esse é o pensamento de Bordron e Fontanille, no artigo da revista Langages já citado e que será novamente discutido ao final deste trabalho. Na visão dos autores, a retórica é uma "cultura da ausência" e a dinâmica que impulsiona a retórica reside justamente na tensão suscitada entre o elemento ausente, ou potencial, e aquele que está presente.

Conforme ficou dito, o Livro II da Retórica é destinado ao enunciatário. O título do capitulo primeiro indica explicitamente que o objetivo é discutir como fazer para agir sobre o espirito dos juizes. Partindo do pressuposto de que o objetivo de toda retórica é obter um julgamento favorável ao ponto de vista apresentado, Aristóteles afirma que não basta zelar pelo discurso nos termos vistos anteriormente; é preciso também se apresentar perante o auditório de tal forma que este se coloque numa disposição favorável ao orador. Naturalmente, isso envolve o ethos do enunciador, mas não é sobre esse conceito que se dá ênfase nessa parte da Retórica, e sim em como fazer para pré-dispor o ouvinte a aderir às idéias que receberá. A justificativa de Aristóteles é clara: não se vêem as coisas com o mesmo olhar quando se ama e quando se é movido pelo ódio, nem quando se está encolerizado e quando se está calmo; mas tudo se mostra de outra forma ou recebe uma importância bastante diferente.(Retórica, II, cap. I, IV). Aristóteles procede então a um dos primeiros estudos sobre as paixões de que se tem notícia, e, fiel a seus princípios, mantém um enfoque bastante prático. Para o retórico, as paixões interessam na medida em que produzem diferenças nos julgamentos; portanto, provocam uma redefinição das estratégias a serem empregadas com vistas á persuasão: os meios não serão os mesmos quando o discurso é voltado para a alguém indignado ou envergonhado. Dessa maneira, o mesmo logos, produzido pelo mesmo ethos, apresentará resultados diferentes de acordo com a disposição passional do enunciatário o seu pathos. Por exemplo, no caso da cólera é preciso ver em qual estado de espírito se encontram os que são tomados por tal sentimento, contra o quê normalmente se dirige sua cólera e por qual motivo ela se instaura. Aristóteles discute também outras paixões: a calma, o amor, o medo, a vergonha, a gratidão, a piedade, a indignação, a inveja, o amor-próprio e as paixões da juventude, da velhice, e da idade adulta. Não se trata apenas de o que fazer quando alguém está... mas também de como fazer alguém ficar..., tendo sempre em vista a persuasão. Logo, a provocação de determinada emoção não é um fim em si mesma, mas um meio, um programa de uso, para se realizar o 
programa de base: persuadir o destinatário. O que resulta desse exercício, entre outras coisas, é que a verdade se torna, mais do que nunca, relativa.

$\cos 20$

$\mathrm{Na}$ Poética, tudo é visto por um ângulo diferente do adotado na retórica. Seu objetivo não é persuadir, mas provocar paixões, mais especificamente o terror e a piedade. Não é importante discutir se algo é ou não é, pois a poética não se ocupa dessas questões; seu foco está naquilo que poderia ser, poderia ter acontecido, justamente porque é verossímil. Por isso, imitar uma corça com galhada é menos grave do que imitá-la de forma não artística (Poética, $\mathbb{S}$ 165), pois o que está em jogo não é a verdade, se corças têm ou não galhada, mas o caráter artístico da imitação. Se a Retórica cuida do que é próprio para persuadir, a Poética busca o que constitui a boa imitação. Aristóteles ensina ainda (\$161) que o poeta pode imitar as coisas de três maneiras diferentes: tal como elas eram ou são, tal como os outros dizem que são ${ }^{15}$, tal como poderiam ser. Não se discute, portanto, a veracidade do fato, pois ninguém se preocupa com isso; trata-se, sim, da verossimilhança. Se, para Platão, a categoria mais importante é a verdade, intrínseca ao objeto em discussão, na poética ela é uma referencia, mas não uma obrigatoriedade: é irrelevante se o narrado pelo poeta aconteceu de fato ainda que todos saibam que não ocorreu —; importa se é verossímil, se os fatos são encadeados segundo certa lógica, que é a que preside a realidade. É por isso que se lhe desculpa (na verdade, talvez se agradeça) a imitação do impossível se o objetivo da poesia foi alcançado e "se tornou mais vívida a impressão causada por essa ou outra parte do poema" (\$164). O filósofo lembra também - e o Conselheiro Aires o cita quase literalmente - que "Quanto à poesia, o impossivel convincente tem preferência ao possivel que não convence” (\$176). Vê-se, assim, que enquanto a retórica trabalha em um contínuo entre o provável e o improvável, a poética articula dois estados que não admitem gradação: o possível e o impossível.

Como se sabe, Platão desprezava os retóricos e propunha que os poetas fossem banidos da República; já Aristóteles, corteja tanto uns quanto outros e elege a verossimilhança como preceptora de todos. É a ela que devem consultar na hora de elaborar seu discurso ou de imitar o mundo. E é razoável que seja assim, pois Aristóteles está

\footnotetext{
${ }^{15}$ A discussão sobre a obra de Machado deixará claro que essa modalidade de imitação é a preferida por esse enunciador, ainda que nem sempre isso seja evidente.
} 
interessado apenas no discurso, em que esse produza emoções em um caso e adesões, no outro. Os fins são diferentes, mas os recursos a serem empregados têm lá seus pontos em comum, de forma que há muita argumentação na ficção e não pouca fabulação na retórica, como, aliás, demonstra cabalmente um poeta-retórico que habitava o Catumbi em fins do século XIX no Brasil... Viu-se há pouco que para Aristóteles o impossível convincente tem prevalência sobre o possível que não convence. Ora, se convencer e persuadir são praticamente sinônimos (e os dicionários pensam dessa forma), qual a diferença entre os objetos da Retórica e da Poética? Certamente, essa é uma discussão que extrapola este trabalho, mas assinalemos apenas um ponto fundamental: enquanto para a retórica há o pressuposto de que o retórico considera seu discurso como verdadeiro, para o poeta não existe tal preocupação, pois, nesse caso, a adesão buscada não é quanto ao conteúdo de verdade do seu discurso, mas quanto à verossimilhança, que se tornou um fim em si mesmo. Por outro lado, na retórica, o verossímil só se justifica se, ao final, o destinatário entender que a mensagem recebida (e que tem a aparência de verdade) é verdadeira.

Mas... afinal, o que é a verossimilhança, que está na base tanto da poética quanto da retórica, mas é execrada por Platão, justamente por sua aparência de verdade? Greimas e Courtés a relacionam, no Dicionário de Semiótica, a uma concepção do discurso que corresponde mais ou menos à realidade sócio-cultural e que se relaciona ao encadeamento dos estereótipos esperados pelo enunciatário:

Trata-se da atitude que uma cultura adota em relação a seus próprios signos [...]. No interior de tal concepção, o verossímil serve de critério veridictório para avaliar os discursos narrativos de caractere figurativo [...],científicos e, de maneira geral, discursos predominantemente não figurativos e abstratos [...] nessa perspectiva, o discurso verossímil não é somente uma representação correta da realidade sociocultural, mas também um simulacro montado para fazer parecer verdadeiro e que pertence, assim, à classe dos discursos persuasivos (Greimas \& Courtés, 1993, p. 422-3)

Nesse trecho, fica claro que a verossimilhança (como já havia afirmado Platão em outros termos) é uma atitude sócio-cultural que indica como determinado grupo lida com os signos que produz. Nessa medida, será verossímil o discurso que apresentar as marcas do que o grupo "decidiu” considerar verossímil. Tal concepção explica por que a verossimilhança permite avaliar tanto discursos narrativos quanto poéticos e por que Platão a rejeita enquanto Aristóteles a acolhe: ela é um dispositivo para fazer parecer verdadeiro, a ser manejado de diferentes maneiras na Retórica e na Poética, mas com o mesmo objetivo, pois os dois tipos de discursos se enquadram na categoria de discursos persuasivos. Mais adiante, ao estudar a obra 
de Machado de Assis, será visto que a discussão sobre o que é considerado verossímil ou não ocupa parte importante da obra do autor, pois o narrador, valendo-se de estratégias variadas, está a todo o momento julgando o próprio discurso e provocando o questionamento de sua veracidade. Ao agir desse modo, lembra que a verossimilhança é uma espécie de julgamento que o discurso faz de si mesmo considerando determinada concepção de realidade, exatamente como propõe Greimas (1981, p. 106).

Para concluir este tópico, observe-se que retórica aristotélica não é mais a retórica selvagem, nascida em Siracusa; nem a mal-humorada, de Sócrates; nem, tampouco, uma botânica de figuras, mero ornamento, para lembrar as palavras de Ricoeur, segundo o qual, o grande feito de Aristóteles foi ter estabelecido uma retórica que une a persuasão, como todos os recursos convocados por ela, à lógica e, assim, construir uma retórica filosófica, na qual o entimema exerce papel fundamental. A obra de Aristóteles encontra-se, desse modo, no meio do caminho, entra a selva e o jardim, mas já apresenta os sintomas do mal que a destruirá. Ricoeur argumenta (1975, p.46-45) que, como se ligava às idéias aceitas pela maioria, a retórica via-se constrangida a recorrer aos lugares comuns, isto é, aos argumentos e imagens mais aceitos pelo público e que funcionam como uma espécie de receita e roteiro para que o orador alcance seus objetivos — é a velha crítica de Isócrates, conforme vimos. Nasce, assim, a associação da Retórica com a Tópica e a busca por metáforas, parábolas, imagens comparações etc.... adequadas à persuasão. Todavia, como o pai de Janjão demonstra com maestria em Teoria do Medalhão, os meios se transformaram, aos poucos, em fins, e a persuasão deixou de se preocupar com a argumentação e a lógica para ambicionar apenas impressionar os demais; o uso de uma linguagem pretensamente elevada transforma-se, então, em um fim em si mesmo. Ao longo dos anos, a cristalização de figuras e seus usos, e a associação delas a situações-tipo, problema que já era apontado por Isócrates, foram fazendo com que passassem a receber primazia em relação ao discurso a que deviam servir. Desse modo, a retórica arruinou-se em um exercício formal: de um lado, uma lista de argumentos, figuras, comparações etc.; de outro, situação-tipo. O retórico, à maneira de um experto em etiquetas, contentava-se em ensinar quando usar o que. ${ }^{16}$

\footnotetext{
${ }^{16}$ Em O declínio da retórica: a tropologia, Ricoeur acrescenta ainda outra causa para o declínio da retórica. $\mathrm{O}$ autor critica aqueles que atribuem sua derrocada à amputação de suas partes principais - as teorias da argumentação e da composição _ e mostra como tal amputação já é, ela própria, decorrente da primazia dada a palavra, ao tropos em detrimento do discurso como um todo:
} 


\section{A retórica prática: Cícero e Quintiliano}

A contribuição dos romanos, especialmente Cícero e Quintiliano, para o edifício retórico foi, como se sabe, imensa, e de muitas implicações. Não sendo possível discuti-las (e nos faltaria competência para tanto) no espaço disponível neste trabalho, decidiu-se examinar muito rapidamente o que elas têm de mais peculiar e, naturalmente, o que mais diretamente se relaciona ao objeto desta tese, o ethos.

Cícero não se conformava com a posição reservada por Platão à retórica. Tal sentimento fez com que toda sua obra apresentasse uma preocupação central: mostrar que a retórica nada ficava a dever à filosofia, que as duas disciplinas eram complementares e que aquele que desejasse persuadir deveria ser hábil para manejar tanto uma quanto outra. Talvez se possa afirmar, se for perdoado o exagero, que Cícero não se importa com a filosofia; como cidadão romano, advogado de renome que defendeu as causas mais diversas e político que viveu altos e baixos (foi questor e cônsul da República antes de ser exilado), Cícero está interessado em descobrir o que habilita o homem público a ganhar adeptos para sua causa. Observador arguto da vida cívica, Cícero sabe que nesse terreno não cabe falar em verdadeiro ou falso, certo ou errado, mas convencer os demais da viabilidade de um projeto. Sua retórica, a exemplo da de Aristóteles, mas de forma, digamos, mais explícita, não se preocupa com o que é certo ou necessário, pois sabe, por experiência própria, o quanto a verdade é instável; procura, porém, descobrir como tornar algo provável ou, ao menos, possível. Não se trata, portanto, de uma retórica que busca convencer da verdade, embora em muitas de suas obras Cícero demonstre uma preocupação com uma retórica ética, mas apenas da probabilidade de algo. A desconfiança de Cícero em relação à existência da verdade é bem exemplificada por uma afirmação que, de acordo com Meyer (1999, p. 65), constaria dos Acadêmicos, tratado que versa sobre filosofia, publicado em 45 a.C., dois anos antes de ser executado. Nessa obra, Cícero afirma que a diferença entre ele - que não busca a verdade, mas a persuasão - e aqueles que supõem conhecer a verdade é apenas uma: estes não desconfiam do próprio saber e o têm por certo, enquanto Cícero e os seus o sabem apenas provável e não cobiçam mais. No mesmo texto, Cícero demonstra certo ceticismo e estabelece uma relação direta entre conhecimento e incerteza que não é estranha ao

"O declínio da retórica resulta de um erro inicial que afeta a própria teoria dos tropos independentemente do lugar concedido à tropologia no campo retórico. Esse erro inicial se deve à ditadura da palavra na teoria da significação. Desse erro só se percebeu os efeitos muito tempo depois: a redução da metáfora a um simples ornamento". $(1975, p .63)$ 
enunciador com que lidamos, o qual, como se sabe, é um eterno desconfiado e cuja desconfiança começa sempre pelo próprio saber.

Barthes (1975, p. 97-8), afirma que a retórica de Cícero seria uma versão para o grande público da retórica de Aristóteles, e que o orador romano procura simplificar e tornar mais práticos os ensinamentos do retórico grego. A proximidade entre ambos é novamente sugerida pelo fato de sua retórica, tal como a do estagirita, ser caracterizada pela tríade formada pelo orador (ethos), auditório (pathos) e discurso (logos). Tal como acontece com Aristóteles, o ethos continua a ser considerado o elemento mais importante, porém é como se perdesse parte de sua independência, já que se busca a persuasão e não a verdade, portanto, para lembrar os termos da semiótica, busca-se o crer e não o saber. Também para Cícero, o caráter mostrado pelo orador em seu discurso é fundamental para a obtenção da persuasão, porém o ethos passa como que a estar, de certa forma, subordinado ao pathos: mais do que revelar a probidade daquele que usa da palavra, o ethos deve atuar de forma a emocionar o auditório. Para Cícero, a eloqüência apresenta duas dimensões: uma ética, naturalmente relacionada à conduta pública do orador; e outra patética, destinada a ganhar os corações pela emoção. O ethos deve traduzir a emoção pela qual o orador se encontra possuído e que é decorrente das teses abraçadas e de suas implicações práticas. Por sua vez, essa emoção contagiante do orador deve, juntamente com sua eloqüência, contaminar o auditório, que, emocionado, adere às teses defendidas. ${ }^{17}$ Se a preocupação com a demonstração lógica e racional da verdade arrefeceu, faz-se necessário ganhar os ouvintes pelo coração, sem, contudo, descuidar da articulação entre as idéias defendidas e as emoções suscitadas. Dessa maneira, tanto o ethos quanto o logos devem atuar para comover (no sentido etimológico do verbo) o auditório. Não se trata da lógica fria de Platão que, ao ser imposta ao enunciatário, constrange-o a aceitá-la, mas da manifestação da verdade por meio da encenação discursiva apresentada pelo orador, para que a paixão que o move passe a comover o auditório. Meyer (1999, p. 68) definiu bem o processo de persuasão da retórica ciceriana:

Ela não é, em suma, senão a teatralização de uma paixão sinceramente sentida e cujo espetáculo faz nascer verdadeiros arrebatamentos. Superando as distinções tradicionais entre o natural e o artificial, entre a realidade e a ilusão, o ser e o parecer a eloqüência ciceriana nos

\footnotetext{
17 A teoria semiótica elaborada por Eric Landowski baseia-se justamente na noção de contágio. Nesse caso, segundo o autor, não cabe falar em manipulação, mas interação intersomática em que "corpossujeitos" interagem diretamente e assim promovem mudanças de estado. Para uma síntese das idéias do autor ver En deçà ou delà des stratégies: la présence contagieuse. In Oliveira (Org.) et al. VII Caderno de discussão do centro de pesquisas sociossemióticas.. São Paulo: Editora CPS, 2001
} 
introduz em um universo de representação sensível onde as simulações do corpo e do discurso tem a sinceridade por condição e a emoção real por efeito.

$\mathrm{Na}$ visão de Cícero, o ethos é menos verbal e mais corporal e cinestésico, pois as convicções pessoais do orador deve ter como contrapartida determinada manifestação somática - entendida enquanto gestualidade, tom e intensidade da voz, expressões faciais etc. — que atestaria sua sinceridade. A adesão do orador a determinado sistema de valores o levaria a determinada disposição tímica, a qual, diante de determinado fato da realidade (objeto do discurso), o levaria a determinada expressão corporal. O ethos continua a ser, de certo modo, uma construção discursiva, à medida que deve ser encenado pelo corpo, que funcionaria como testemunho de que a emoção do orador é genuína e de que ele realmente adere aos valores professados ${ }^{18}$. Naturalmente, não se deve esquecer de que tudo é, afinal, uma teatralização.

\section{$\cos \cos 20$}

Quintiliano foi, digamos, o primeiro retórico oficial.. Professor pago pelo Estado, ele promoveu a recuperação da obra de Cícero, porém sem segui-la integralmente. O ethos continua a ocupar uma posição de destaque, porém não mais relacionada à demonstração das emoções que movem o orador, mas ao conjunto de atributos morais (integridade, coragem), intelectuais (conhecimento, capacidade de raciocínio) e verbais (eloqüência) que deve possuir aquele que toma a palavra. Volta-se, portanto, a uma concepção mais próxima da de Isócrates, especialmente pelo fato de a retórica deixar de ser a arte da persuasão para ser a arte do bem falar. Concordando uma vez mais com o retórico grego, Quintiliano entende que não é possível falar bem sem ser um homem de bem; em outras palavras, não é o ethos construído pelo discurso que convence, mas a reputação do homem público. Sem deixar de estar ligada à veridicção, a retórica de Quintiliano caracteriza-se por sua preocupação moral, pois como observa Barthes (1975, p. 98), sua obra é bastante moralizadora, o que talvez explique o esplendor que seu nome conquistou após sua morte. Lutero, Erasmo, La Fontaine, Racine, dentre outros, o tinham na mais alta conta e durante e após o renascimento sua retórica talvez tenha sido mais influente que a de seus predecessores.

\footnotetext{
${ }^{18}$ Uma análise bastante instigante sobre as relações entre a adesão a um determinado universo de valores e disposição tímica pode ser encontrado em Componentes tímicos e predicativos do crer. In Geninasca, Jacques, La parole littéraire. Paris: Presse Universitaire de France, 1997.
} 
. Destaque-se, ainda, que, mais uma vez, observa-se o embate entre duas posições a respeito do ethos: uma que o associa ao discurso e outra que o relaciona ao indivíduo. No item seguinte, serão examinados alguns breves momentos desse debate, que se prolongou ao longo da história.

\section{Ethos e individuo real}

A noção de ethos que prevaleceu ao longo da história não foi a de Aristóteles ou Cícero, mas a de Isócrates e Quintiliano, se é que os rótulos procedem. De fato, nas mais das vezes, o ethos foi relacionado não a uma construção discursiva, mas à reputação, à imagem pública daquele que toma a palavra. Viu-se que, seguindo a concepção de Isócrates, Quintiliano entendia que o ethos é produzido não pelo discurso, mas pela vida pública do orador, por sua posição pessoal e sua inserção junto às instituições sociais que sustentam seu discurso. O ethos equivaleria à fama do orador, como dizemos hoje em dia. Quintiliano também privilegiava aspectos morais e sociais do ethos, considerando que a imagem pública é o melhor argumento de que pode dispor o orador para imprimir autoridade a seu discurso. $\mathrm{O}$ ethos seria, assim, resultado da conjugação de atributos morais, como coragem, integridade e honra, e "discursivos", como eloqüência e saber, entre outros.

As idéias dos retóricos da antiguidade, lastreadas, como se sabe, em Isócrates, ainda serão aceitas no século XVI, quando nada mais resta do Império Romano e o Império Retórico vive seus derradeiros dias de esplendor. É a partir desse momento que começa seu declínio, provocado, talvez, como sugere Perelman, pela ascensão da burguesia. São tempos de guerras devastadoras: enquanto François I, na França, e Carlos V, na Espanha, lutam pelas terras da Europa, católicos e protestantes disputam o coração dos homens. Embora não estivesse ausente das trincheiras, será no púlpito que a retórica se fará mais presente e que o ethos será objeto das discussões mais calorosas. ${ }^{19}$ Lutero, por exemplo, talvez tendo por alvo o comportamento dos sacerdotes católicos que tanto criticara, prega que a mensagem seja autêntica, fruto da experiência pessoal do pregador, a qual deve estar à altura da vocação e do

\footnotetext{
${ }^{19} \mathrm{Na}$ mesma época, o Império Retórico também se viu dividido entre duas correntes: de um lado, havia os que defendiam uma retórica fundada na ética e que tinha no ethos a sua coluna de sustentação. De outro, havia os que eram partidários de uma retórica estética, que se alicerçava no pathos. Trata-se de uma discussão bastante interessante, mas que foge às nossas possibilidades. Maiores informações podem ser encontradas em Meyer (1999), em especial nos capítulos 4 e 5.
} 
ministério. A mensagem não se limita, contudo, ao sacerdote, mas alcança também todos os fiéis, conclamados a manter uma atitude, uma héxis diríamos nós, adequada à fé que dizem professar. $\mathrm{Na}$ verdade, Lutero retoma a idéia da vocação do cristão, expressa de forma clara na carta de Paulo aos Efésios (4: 1-4):

Rogo-vos, pois, eu, o prisioneiro no Senhor, que andeis de modo digno da vocação a que fostes chamados, com toda a humildade e mansidão, com longanimidade, suportando-vos uns aos outros em amor, esforçando-vos diligentemente por preservar a unidade do Espírito no vínculo da paz; há somente um corpo e um Espírito, como fostes chamados numa só esperança da vossa vocação[...](Trad. de João Ferreira de Almeida, revista e corrigida - grifo meu)

Uma das definições do dicionário de Houaiss para vocação é disposição natural $e$ espontânea que orienta uma pessoa no sentido de uma atividade, uma função ou profissão. Uma definição que se aproxima, portanto, do ethos, exceto pelo adjetivo espontâneo, que, se por um lado, não cabe na definição de Aristóteles, por outro, coaduna-se à de Isócrates, uma vez que, para esse filósofo, o ethos correspondia à reputação do indivíduo. Voltemos ao texto bíblico. Segundo a passagem acima, o comportamento, a reputação, enfim, o ethos do cristão deve ser caracterizado pela mansidão e humildade, dentre outras paixões, as quais, séculos mais tarde, Lutero voltará a chamar de vocação ${ }^{20}$. Vê-se que a conduta do cristão, na concepção paulina, que será a dos reformadores, deverá ser marcada por um ethos que ateste a verdade - no sentido que Platão emprega o termo - da sua mensagem. O texto bíblico define, portanto, qual deve ser o ethos condizente com a conduta do cristão e que pode ou não conferir autoridade ao discurso e torná-lo eficaz para a conversão das almas. A conversão do gentio não será, portanto, resultado da eloqüência do pregador, mas dependerá da sua conduta. Ele deve se apresentar aos que o ouvem em conformidade com o que diz o texto bíblico, e dessa correspondência dependerá em grande medida a eficácia de sua palavra. O ethos não é, nessa concepção, construído pelo discurso, mas exterior a ele. No modelo dos reformadores, tendo Lutero à frente, o discurso eficaz, portanto capaz de converter o gentio, será aquele produzido por um orador que apresentar um ethos compatível com o texto bíblico e, desse modo, passa a ter sua eficácia alienada a fatores que lhe são exteriores.

Um pouco mais ao sul, em Genebra, Calvino acompanha o entendimento de Lutero, conferindo, porém, menor peso ao pregador. Sem renunciar à importância da ascese, Calvino

\footnotetext{
${ }^{20}$ Para uma discussão mais detalhada, consultar o grande trabalho de Max Weber, A ética protestante e o espirito capitalista, especialmente os capítulos 3 "A concepção da vocação em Lutero", e 4, "A ética vocacional do protestantismo ascético".
} 
entende que o pregador deve, antes de qualquer coisa, deixar falar a voz original das escrituras, o ethos daquele que está no púlpito deve ser o da voz bíblica, cuja obediência é confirmada pela vida do ministro. Calvino irá buscar a palavra bruta, dura, sem ornamentos, e recusará discursos elaborados ou refinados que, tal como os dos sofistas criticados por Sócrates, afastariam o auditório da verdade e atenuariam a contundência da palavra divina, por si só apta a trazer o discernimento e o arrependimento. A força da pregação não estaria na lógica, na dialética ou na retórica do pregador, mas nas próprias Escrituras, que seriam por si só de grande eficácia ${ }^{21}$. Calvino não nega a força da retórica, mas entende que ela deve se submeter ao texto, ao verbo, bíblico, pois ele, e não o estilo do pregador, convenceriam o pecador do pecado e do juízo.

Entre alguns teólogos católicos, encontram-se idéias não totalmente dissonantes. Por exemplo, as críticas de Erasmo de Roterdã à Igreja começaram em 1504, antes, portanto, do cisma provocado por Lutero em 1517. Após terem defendido as mesmas idéias, os dois homens passaram a se opor em função de questões tanto religiosas quanto políticas ${ }^{22}$. No entanto, na questão retórica, seus pensamentos eram semelhantes: ambos, em especial Erasmo, defendiam uma retórica do "bom" e do "verdadeiro" que prevalecesse sobre o "belo", e um ethos interior, legítimo, não preocupado com o impacto a ser causado no destinatário, resultado do caráter "real" do orador. A posição de Erasmo é ambígua: seguindo Agostinho, ele compreendia que o exterior do homem revelava seu interior. Assim, era preciso que a aparência do discurso fosse tal que se adequasse a seu conteúdo, de modo que o parecer fosse controlado tanto para ser adequado ao público a que se dirigia, quanto para demonstrar as qualidades morais daquele que fala.

A reforma protestante levou ainda os teólogos católicos a uma maior preocupação com a doutrina, como demonstra a realização do Concílio de Trento que, em suas diversas seções (1545-1549; 1551-1552 e 1562-1563), impôs um maior controle ao clero e aos seminários e buscou recuperar a fé na autenticidade e nos símbolos católicos (aí incluída a palavra do sacerdote), seriamente abalados desde as denúncias protestantes. Esse cuidado

\footnotetext{
${ }^{21}$ Evidentemente, simplifica-se aqui a doutrina de Calvino, que, antes de mais nada, atribui a conversão do pecador à vontade divina: seriam salvos os predestinados para a salvação. No entanto, segundo Calvino, a atuação divina não exime o pregador da pregação e esta deve, por princípio, deixar falar a palavra divina.

${ }^{22}$ Lutero pregava que, em função do pecado original, o homem perdera seu livre-arbítrio e que o único meio de encontrar a salvação era mediante a graça e a misericórdia divinas, enquanto Erasmo entendia que o homem preservara seu livre arbítrio para escolher seu caminho, cabendo a ele a responsabilidade de buscar a salvação.
} 
adquire matizes bem diferenciados no meio católico: de um lado, os jesuítas, preocupados em deter a reforma e ocupados em fazer prosperar a contra-reforma, perseguirão o discurso eficaz, capaz de converter as almas. Por outro, as novas ordens fundadas nos anos que se seguiram ao encerramento do Concílio de Trento, e que também buscavam um retorno às origens do pensamento cristão, como as de Michel de Bay, Cornelius Jansenius (conhecida como Jansenismo), Philippe Néri e Pierre Bérulle, pregarão, em oposição ao pensamento de Calvino, que não é a palavra que conduz ao convencimento do pecado e ao arrependimento, mas a alma piedosa e sincera: convence-se não pelas palavras, mas pelas obras ${ }^{23}$. Como se vê, é o ethos associado ao indivíduo que volta a ocupar o centro da cena. A associação entre o homem, ontologicamente considerado, e o discurso não está ausente nos Jesuítas; Vieira, em seu célebre sermão da sexagésima, acerca da parábola do semeador, afirmará em 1655:

"Sabem, padres e pregadores, por que fazem pouco abalo os nossos sermões? Porque não pregamos aos olhos, pregamos só aos ouvidos. Por que convertia o Batista tantos pecadores? Porque assim como as suas palavras pregavam aos ouvidos, seus exemplos pregavam aos olhos. As palavras do Batista pregavam penitência Agite poenitentiam [Rom. X: 16]. Homens: fazei penitência; e o exemplo clamava; Ecce homo: eis aqui está o homem que é o retrato da penitência e da aspereza.’In Sermões, Porto 1959, Tomo I. p. 16

$\mathrm{Na}$ visão de Vieira, similar à de Lutero nesse aspecto, o discurso de João Batista era eficaz não por sua retórica - aliás, o profeta era notório por um discurso duro, tal como preconizado por Calvino -, mas pelo seu testemunho ou, como dizemos, pelo seu ethos, que se aproximaria da areté que, tal como proposta por Aristóteles, corresponde um falar duro sem meias palavras. Quando Vieira afirma que o exemplo de vida de João Batista pregava aos olhos, pode-se entender que seu comportamento, ou ao menos sua fama, era compatível com o que os discursos de sua época consideravam sobre o homem virtuoso. Da mesma forma, a vocação a que se refere Lutero em seus sermões estaria ligada ao que o discurso bíblico define como o ethos do cristão; por exemplo, apresentar os atributos citados no texto de Efésios.

Em resumo, o que se observa em todos esses exemplos é que a palavra perde sua autonomia e vê seu poder condicionado a algo que lhe é exterior: pode ser a sociedade onde ocorre o discurso, a instituição que o cauciona ou mesmo a conduta do orador. $\mathrm{Na}$ verdade,

\footnotetext{
${ }^{23}$ Enquanto os protestantes calvinistas pendem mais para a doutrina paulina, o pensamento dos católicos se dirige mais para Tiago. Veja-se, por exemplo, Tiago 2: 14 e 18:

Meus irmãos, qual é o proveito, se alguém disser que tem fé, mas não tiver obras? Pode semelhante fé salva-lo? [...] Mas alguém dirá: Tu tens fé, e eu tenho obras; mostra-me essa fé sem as obras, e eu, com as obras, te mostrarei a minha fé.
} 
pouco importa a natureza desse algo exterior. O relevante é que o discurso passa a ter que recorrer a um poder exterior a ele para se tornar plenamente eficaz. Tais entendimentos ecoarão na sociologia de Bourdieu, especialmente em $A$ economia das trocas lingüísticas, em que o autor argumenta que a eficácia do discurso não se relaciona com sua substância lingüística, mas resulta da adequação entre a posição social do enunciador e seu discurso. Para o sociólogo, mais do que um fenômeno lingüístico, o ethos é empírico e está diretamente relacionado às instituições sociais em cuja jurisdição o discurso é produzido. Discordando do pensamento de Austin em Quando dizer é fažer, Bourdieu nega que a força ilocutória de algumas expressões esteja nas palavras, as quais apenas representariam, na melhor das hipóteses, o verdadeiro poder. Para o autor, o "poder das palavras é apenas o poder delegado do porta-voz $[\ldots]$ cujas palavras constituem, no máximo, um testemunho, entre outros, da garantia de delegação de que o enunciador está investido". (Bourdieu, 1996: p. 87). A diferença entre as posições de Bourdieu e de Aristóteles é clara: agora a principal fonte da eficácia do discurso não reside mais nas palavras, que não mais constroem o ethos do orador, mas nas instituições que caucionam suas palavras e nas relações entre o discurso proferido e o discurso institucional. Amossy (2005) associa a posição de Aristóteles à dos pragmáticos e a de Bourdieu à dos sociólogos, mostrando que, para os primeiros, o ethos liga-se ao discurso, e, para os últimos, sua origem está nos mecanismos sociais:

Assim o ethos dos pragmáticos, na linha de Aristóteles, se constrói na interação verbal e é puramente interno ao discurso, enquanto o dos sociólogos se inscreve em uma troca simbólica regida por mecanismos sociais e posições institucionais exteriores. (Amossy, 2005: p. 122)

No entanto, em que pesem tais diferenças, deve-se observar que as duas posições não são irreconciliáveis e podem mesmo se complementar. Aristóteles não nega que a reputação do orador contribui para o convencimento do destinatário, mas lhe atribui uma importância menor que a do discurso. Por outro lado, a não ser em algumas situações (a leitura de um texto totalmente desconhecido, por exemplo), o destinatário sempre dispõe de uma imagem preliminar, um pré-conceito fornecido pela biografia do orador, pela instituição que lhe concede a palavra ou, ainda, pelo gênero ao qual o discurso se filia. A relação de complementaridade entre o ethos discursivo e o institucional é defendida também por Eggs (2005), para quem o ethos, ligado aos valores pessoais do orador, é indissociável do que é construído no discurso. Essa é também a posição de Amossy, para quem considera a eficácia do discurso não é nem exclusivamente institucional nem unicamente discursiva; é, na 
verdade, resultado da interação dessas duas instâncias em vários níveis. Assim, a imagem preliminar do orador será confirmada ou negada no discurso proferido, pois aquele que usa a palavra se valerá da tensão existente entre sua imagem prévia e a criada por seu discurso para convencer o auditório: quem busca chocar o público poderá construir um discurso que colocará em oposição o ethos institucional e o discursivo; quem não desejar fazê-lo procurará confirmar em seu discurso o pré-conceito que se tem dele.

Não se pode esquecer, contudo, que a fama e a reputação nada mais são do que discursos sobre o sujeito, que o sancionam positiva ou negativamente; aliás, o dicionário de Aurélio Buarque de Hollanda ensina que reputação é o ato ou efeito de reputar, considerado pelo autor como sinônimo de julgar. Assim, em termos semióticos, a reputação nada mais é que a sanção do sujeito constituída discursivamente. Retome-se o texto de Paulo. Em Efésios, o autor define o ethos cristão caracterizado por determinadas paixões como humildade, amor, longanimidade e mansidão, cujas definições são apresentadas ao longo do Novo Testamento. Gozará, portanto, de "boa reputação", em termos cristãos, o indivíduo que exibir tais valores em seu discurso, aquele cujo "andar", demonstre sua filiação a tal universo de valores. Dessa forma, vai se construindo um emaranhado de discursos que, de um lado, elaboram sóciohistoricamente o "bom" ethos para dado grupo social e, de outro, constroem uma imagem do indivíduo perante o seu grupo social que será tanto mais positiva na medida em que se aproximar do conceito de boa reputação. Por exemplo, a reputação do político é construída não apenas a partir de um artigo de jornal, das notícias da TV e de discursos de outros políticos, mas também pelos próprios discursos por ele produzidos ${ }^{24}$. Tanto em um caso quanto em outro, é irrelevante se as afirmações e impressões causadas por esses discursos são verdadeiras ou não. Vejam-se reportagens do tipo "fulano de tal na intimidade". Tais textos apresentam-se como especiais porque não se baseariam em outros discursos do indivíduo sobre ele, e nem mesmo nos dele próprio, mais no acesso à sua dita vida privada, que, evidentemente, deixa de sê-lo ao se tornar pública. Em geral, essas matérias tentam traçar paralelos entre a imagem pública do indivíduo e como ele seria na "vida real", expressão bastante curiosa, por sinal. Não é raro que os dois discursos - o da intimidade e o da vida em sociedade - sejam antagônicos, sem que isso implique necessariamente o descrédito de um ou de outro.

\footnotetext{
${ }^{24}$ Para uma discussão acerca da construção do ethos no meio político ver Charaudeau, Patrick. Discurso Político. . Trad. Dilson Ferreira da Cruz e Fabiana Komesu. São Paulo: Contexto, 2006, p.111-84
} 
Enfim, a conclusão a que se chega é que a abordagem que procura associar o ethos ao “indivíduo real” aponta não propriamente para o sujeito tomado ontologicamente, mas para o sujeito construído por outros discursos. Ou seja, o ethos seria construído discursivamente também nesse caso, mas com a diferença de que tal construção é exógena; isto é, resultante dos discursos com os quais sujeito se relaciona; é o caso da passagem do Sermão da Sexagésima que citamos ainda há pouco: o discurso de João Batista seria eficaz porque se coadunaria ao discurso sobre João Batista. De igual modo, o discurso do cristão seria convincente se fosse compatível com o discurso bíblico sobre o cristão. Nesse caso, o ethos corresponderia à sansão, positiva ou negativa, feita ao enunciador por outros discursos.

Por outro lado, há o ethos construído endogenamente, isto é, pela instância da enunciação no ato de comunicação. Observe-se que, no primeiro caso, são as performances anteriores do sujeito que são objeto de julgamento; no segundo, trata-se da competência exibida pelo sujeito no momento em que ele toma a palavra.

\section{A retórica machadiana}

Encerrada essa volta às origens, é preciso abandonar os gregos da Antiguidade para acompanhar os cariocas do século XIX, e ver como discípulos de Isócrates, Aristóteles e Cícero aplicam os ensinamentos recebidos. O diálogo com esses senhores permitirá compreender um pouco melhor o quanto a Retórica e a Poética podem se misturar e dará mostras do combate entre a verdade e a verossimilhança e de sua importância tanto para persuasão quanto para a mimesis. Caminhando pela Rua do Ouvidor ou pela Praia de Botafogo, depararemos com alguns alunos aplicados. Vários deles. Quer tenham escrito romances, crônicas ou contos, todos aprenderam - e ensinam - que o verossímil vale mais que o verdadeiro e não hesitam em abandonar o último, caso ele imponha dificuldades para o convencimento de seu auditório. Claro, as águas sempre ficam turvas na companhia desses senhores: categorias bem definidas, estáveis, sólidas começam a se desmanchar, não no ar, é verdade, mas no papel. Esse mesmo, confidente do Conselheiro Aires, talvez o mais experiente de toda a gente, Assis, para usar uma expressão do agrado do velho diplomata. Tanto Esaú e Jacó quanto Memorial de Aires são ficção e, como tais, obedecem à verossimilhança. No entanto, o narrador, Aires, nos dois casos, finge desprezar sua senhora para cuidar das vontades de outra dama, que, em princípio, não lhe diz respeito. Constrói-se, 
então, uma narrativa que, para se mostrar verossímil, esnoba, ou aparenta esnobar, a verossimilhança. O raciocínio do narrador é sofisticado: afirma que não se preocupa com a verossimilhança, dado que não é poeta (o diário seria puro registro de fatos), nem retórico (seu único interlocutor é o papel), mas apenas alguém que registra o caminhar dos dias, quase um amanuense. No entanto, é o próprio narrador que, por inúmeras vezes, levanta a questão para depois desqualificá-la. Não se trata de tarefa ociosa: as constantes afirmações de Aires sobre a verossimilhança de sua narrativa têm um papel fundamental na constituição do seu ethos, como se sabe, a maior prova de que dispõe o orador para convencer seu público. Vejase, por exemplo, um trecho do seu memorial:

\section{0 de setembro}

Se eu tivesse a escrever uma novela, riscaria as páginas do dia 12 e do dia 22 deste mês. Uma novela não permitiria aquela paridade de sucessos. Em ambos esses dias - que então chamaria de capítulos -, encontrei a viúva Noronha, trocamos algumas palavras, vi-a entrar no bonde ou no carro e partir logo; dei com dois sujeitos que pareciam admirá-la. Riscaria os dois capítulos, ou os faria mui diversos um do outro; em todo caso diminuiria a verdade exata, que aqui me parece mais útil que na obra de imaginação. (p.1.154, grifos nossos)

O conselheiro explica que a ocorrência que acabara de registrar em seu diário, duas seqüências de fatos idênticos, ocorridas em um intervalo de 10 dias, ambos terminados com o número 2, pareceria inverossímil conquanto fosse verdade. Afirma que, se fosse romancista, alteraria os fatos em defesa da verossimilhança, mas não o fez porque tem compromisso com a verdade. Se esse é o comportamento de Aires, então, em vez de seguir as lições dos sofistas, ele é discípulo de Platão e busca apenas o que é verdadeiro, pouco se importando com a verossimilhança: mesmo sabendo que seu discurso poderia soar inverossímil e que isso poderia prejudicar a adesão de seu auditório, ele se mantém fiel à verdade! Atente-se para as astúcias do enunciador: em um primeiro momento, a coincidência de fatos poderia parecer inverossímil aos olhos do público; no entanto, o enunciador pressuposto a Aires, que chamaremos de M. de A., utiliza essa "deficiência" do texto como argumento para convencer o enunciatário de que, primeiro, o texto não é ficção, mas pura realidade, portanto, não é sua culpa se os fatos se lhe apresentam dessa forma; depois, não se preocupa em convencer quem quer que seja, pois tem em mãos um diário íntimo sobre cujo conteúdo não tem domínio fato comprovado pela manutenção de um texto que sabia de antemão parecer inverossímil —, o que seria inaceitável em um bom ficcionista. Perceba-se agora a transmutação, digna de um bom alquimista, como, aliás, o são todos os bruxos: o que era inverossímil transforma-se em efeito de verdade; a verossimilhança perdida em um primeiro momento é agora recuperada 
com lucro: ainda que a sucessão de fatos pudesse parecer inverossímil, é a própria inverossimilhança que garante a adesão do público, pois atestaria a sinceridade do enunciador que — ao contrário dos sofistas — não se mostraria preocupado com adesão do seu público, mas com a verdade pura dos fatos, tal como os filósofos de Platão. Ainda que a narrativa de Aires fosse pouco convincente, graças ao comentário que ele faz dos fatos narrados, constrói o ethos de um homem confiável e transmite ao público a certeza de que fala a verdade, doa a quem doer, como se diz hoje em dia. Desse modo, agora ele confirma a proposição de Isócrates segundo a qual o discurso proveniente de um enunciador com boa reputação tem maior poder de persuasão do que o que é pronunciado por alguém menosprezado. Enfim, a inverossimilhança de Aires converte-se em verossimilhança, contribuindo para a adesão de seu público. Nesse aspecto, Aires segue as lições de Aristóteles na poética, quando este ensina que "o impossivel tem preferência ao possivel que não convence", e que o "irracional justifica-se pela opinião comum, bem como algumas vezes parece irracional aquilo que não o é, pois é verossimil que acontecam coisas que aparentem verossimilhança" (Poética, 177). Recorde-se ainda a lição de Roberto Schwarz. Em Um mestre na periferia do capitalismo, o autor demonstra como alguns dos princípios do liberalismo econômico, ao serem transportados para o Brasil, passaram a ter um comportamento oposto ao que tinham em sua terra natal, por se transformarem em princípios mantenedores da ordem escravocrata. O autor mostra, ainda, como essa subversão está inscrita nas memórias de Brás Cubas, sendo um elemento estruturador da narrativa. Ora, o que se tem aqui, conquanto seja de ordem muitíssimo distinta, apresenta pontos de convergência: acabou-se de ver que um elemento de inverossimilhança é convertido em argumento para a verossimilhança da narrativa de Aires. Como será visto lá na frente, essa subversão é um traço do caráter do enunciador dos romances de Machado de Assis e já estava presente suas primeiras obras.

Examine-se, agora, outra passagem, em que novamente é narrado um fato que é considerado inverossímil, não pela pouca probabilidade de ocorrer, mas por fugir à lógica dos fatos. Está naquela passagem de Esaú e Jacó em que o Conselheiro Aires explica que existem contradições explicáveis:

Não me peças a causa de tanto encolhimento no anúncio e na missa, e tanta publicidade na carruagem, lacaio e libré. Há contradições explicáveis. Um bom autor, que inventasse a sua história ou prezasse a lógica aparente dos acontecimentos, levaria o casal Santos a pé ou em caleça de praça ou de aluguel; mas eu, amigo, eu sei como as coisas se passaram e refiro-as tais quais [...].(p. 955, grifo meu) 
Mais uma vez, o enunciador opõe a verdade à verossimilhança e do embate entre ambas, extrai os recursos para ganhar seu público. O narrador que prezasse a lógica dos fatos narraria de outro modo, do modo que a sociedade considera mais verossímil, isto é, com menos pompa e mais descrição. Se o narrador age de outro modo, é porque ele, mais uma vez, se limita a registrar o que ocorreu. Algumas linhas abaixo, explica a aparente contradição: Santos (que havia encomendado a missa) age dessa forma porque assim impressionaria os moradores da redondeza e poderia gozar o assombro local com a extensão de suas posses. O que poderia parecer irracional revela-se ao final racional, e Aires ganha a confiança do leitor ao contar-lhe um segredo, a saber, o que se passava na mente de Santos. O diplomata, a um só tempo, persuade seu leitor e lhe ensina a ler o próprio romance; de quebra, reafirma que não escreve ficção, que sabe como as coisas se passaram e as relatas tais quais. Mais uma vez, acontecimentos aparentemente inverossímeis atestam a veracidade do que é narrado. Observe, porém, que, nesse exemplo e no anterior, os fatos tidos por inverossímeis são de importância mínima para a trama: no primeiro caso, pouco importava se tudo se passara nos dias e na forma relatados, assim como as condições da missa não alteram a narrativa de Aires como um todo. Contudo, os fatos secundários adquirem importância capital quando o diplomata deles se vale para reforçar seu ethos e, por essa via, sedimentar a confiança do seu público em sua narrativa e nele próprio. Em outras palavras, o que está em jogo não é verdade factual, mas a inscrição do enunciador em um determinado quadro de valores que lhe dá credibilidade.

Esquecendo o diplomata e subindo um nível enunciativo, pode-se perguntar a causa de tanta insistência em episódios inverossímeis; ou melhor, em episódios que Aires considera inverossímeis. Afinal, na verdade, não são resultado do "destino", mas das criações do enunciador, M. de A.; portanto, não há explicação para tanta inverossimilhança a não ser o desejo do enunciador de se valer de uma narrativa aparentemente inverossímil para, por meio dela, discutir os mecanismos que, em sua cultura, fazem um texto parecer verdadeiro, tema que parece ser dos mais freqüentes em Machado (a tentação de dizer o tema é grande...). Vejase, agora, o outro lado da equação: o narratário e o enunciatário. Aires tem em mente um narratário (o papel, no caso do Memorial, ou o leitor inscrito, no caso de Esaú e Jacô) que se preocupa com detalhes da superfície do texto, tais como semelhanças de datas e de episódios, mas que, ao mesmo tempo, dá-se por satisfeito se determinadas convenções - que talvez não consiga enxergar enquanto tais - forem respeitadas. Já o enunciador, M. de A., tem em mente 
um leitor que se compraz com a análise desses processos; que enxerga nas entrelinhas das anedotas contadas por Aires uma reflexão sobre os processos de criação da verdade, sendo que esta, reduzida a um simples efeito de sentido, tem seu estatuto questionado. Se Aires tenta persuadir seu leitor, M. de A. apenas mostra, do avesso, os mecanismos da engrenagem. Justamente por conhecê-los bem, o enunciatário percebe que o que está em jogo não são apenas datas, mas justamente a discussão acerca dos processos de criação das marcas de veracidade do texto. Como Penélope, o enunciador desfia a trama construída por Aires e por outros narradores delegados seus e constrói a imagem de alguém lúcido, arguto, perspicaz, que não se deixa iludir pelas artimanhas de seus narradores, apesar de boa parte de seus leitores caírem nas armadilhas.

Nas páginas seguintes, buscar-se-á entender um pouco mais o que vem a ser ethos na concepção de Aristóteles e como o conceito tem sido tratado pelas ciências da linguagem. O passo seguinte será tentar aplicá-lo à obra de Machado para que se defina, se possível, o ethos desse enunciador. 


\section{Construindo um ethos}

$\varepsilon$

mbora existam concepções anteriores, especialmente em Isócrates, viu-se que a noção de ethos praticamente nasce com a Retórica de Aristóteles, e que, desde então, o conceito tem ocupado lugar central não apenas nas retóricas que se seguiram, mas também, mais recentemente, no conjunto das ciências da linguagem. ${ }^{25}$ A posição de destaque que o conceito ocupa neste trabalho talvez justifique a citação na íntegra de sua certidão de nascimento:

Os argumentos inerentes ao discurso são de três espécies: alguns residem no caráter moral [ethos] do orador; outros na disposição do auditório [pathos] e outros, enfim, no discurso propriamente dito [logos], quando este é demonstrativo ou parece sê-lo.

É o caráter moral (do orador) que conduz à persuasão, quando o discurso é construído de tal maneira que inspira confiança no orador [...]. É preciso, aliás, que tal resultado seja obtido pela força do discurso e não apenas por uma predisposição do auditório favorável ao orador. Não é exato dizer que $[\ldots]$ a probidade do orador não contribui em nada para conduzir à persuasão, mas, [ao contrário], é ao caráter moral que o discurso deve seu maior poder de persuasão.

\section{$[\ldots]$}

Enfim, é pelo próprio discurso que persuadimos quando demonstramos a verdade ou o que parece sê-lo, segundo as provas apresentadas, deduzidas uma a uma.

(Retórica, I, cap. II, IV-VI — grifos nossos)

À primeira vista, o conceito parece não apresentar dificuldades: o ethos é a imagem que o enunciador constrói de si no discurso para impressionar o enunciatário e, assim, ganhar sua confiança. $\mathrm{Na}$ visão de Aristóteles, o ethos é o grande responsável pela persuasão, pois o caráter daquele que fala é fundamental para ganhar a confiança do ouvinte... ou perdê-la. No capítulo primeiro do livro segundo (onde discute como agir sobre o espírito dos juízes), o filósofo explica que há três coisas que inspiram confiança no orador [...] independentemente das demonstraçôes produ₹ida. São o bom senso (phrónesis), a virtude (areté) e a benevolência (eúnoia) ${ }^{26}$. $\mathrm{O}$ orador parecerá fidedigno se seus argumentos forem sábios, ponderados, razoáveis; se, em sua argumentação ele se mostrar honesto, virtuoso; e se suas palavras indicarem que ele é

\footnotetext{
${ }^{25}$ Em Imagens de si no discurso - a construção do ethos (São Paulo, Contexto, 2005, p.9-27), Ruth Amossy mostra que o ethos se encontra no ponto de intersecção de várias disciplinas, como a retórica, a sociologia $\mathrm{e}$ a pragmática.

${ }^{26}$ Retórica, II, cap. I, V
} 
solidário, amável, interessado no bem daqueles que o ouvem. Embora se possa entender que a phrónesis está ligada ao logos; a areté, ao ethos; e a eúnoia, ao pathos, a tendência dos estudiosos é considerar que o ethos, o caráter do orador, deve mostrar os três predicados ${ }^{27}$. Não se trata, como no caso de Isócrates, de atributos de que disporia o indivíduo real, que permanece fora da linguagem, mas das características de uma personagem (aliás, ethos em grego, $\eta \theta$ os, significa personagem) criada pelo discurso e que coincide com o enunciador. Para o estagirita, a persuasão não é obtida, necessariamente, quando se diz a verdade, mas quando se afirma o que parece sê-lo segundo as provas apresentadas. Por sua vez, essas provas não são, ou não são fundamentalmente, de natureza material, nem são evidências "extralingüísticas"; trata-se, como se viu, de provas construídas na cena enunciativa, pelo próprio discurso. Por esse motivo, Barthes (1985, p. 146) afirma que pouco importa a sinceridade daquele que fala; primeiro, porque ela não pode ser averiguada pelo discurso (e Aristóteles está tratando do discurso), e, depois, porque basta que o enunciador pareşa sincero. Enfim, o ethos não está relacionado ao indivíduo real, com sua história, CPF e RG, e sim ao criado pelo discurso, ao ator da enunciação.

O ethos seria, enfim, a imagem que a instância da enunciação projeta de si própria no discurso. Naturalmente, isso não significa que, nos textos em que não ocorra uma debreagem enunciativa $^{28}$ — isto é, em que não há uma projeção da enunciação no enunciado —, não exista um ethos, pois, a rigor, a enunciação é sempre enunciada, o que muda é a forma como ela se faz presente no texto. Há textos em que a projeção das categorias de pessoa, espaço e tempo que remetem a essa instância é visível; em outros, essa presença será mitigada, tendendo — mas apenas tendendo - ao desaparecimento. Por exemplo, espera-se de um texto científico que as marcas da enunciação sejam todas apagadas, pois a ciência se quer objetiva, e não fruto dos juízos de valor de um indivíduo - muito embora eles sempre existam. Contudo, também aí estará inscrito um ethos; no caso, o do enunciador competente para produzir um discurso dito objetivo, impessoal, que dá a ilusão de que os fatos se enunciam a si próprios. É por isso também que Barthes, ao discutir a noção de ethos, afirma que, ao enunciar, além do conteúdo de sua afirmação, o enunciador estará, invariavelmente, conotando a si próprio e afirmando que é ou não isso ou aquilo (1985: 146). Quando alguém

\footnotetext{
${ }^{27}$ Ver Eggs, O ethos aristotélico, convicção e pragmática moderna Trad. Dilson Ferreira da Cruz. In Amossy, Ruth. Imagens de si no discurso - a construcão do ethos, p. 29-46.

${ }^{28}$ Para detalhes ver Fiorin (1996), p. 27-58.
} 
relata uma partida de futebol, além de informar o placar, a destreza de um ou outro jogador, as táticas empregadas pelos adversários etc., estará, também, indicando se gosta ou não desse esporte, se conhece as regras e técnicas do jogo, o time pelo qual tem mais simpatia, seu posicionamento diante da importância da vitória e da obediência às regras e, até mesmo, eventualmente, seu estado de espírito. Nunca é demais lembrar que esses são os conhecimentos e competências do discurso, e não os "reais": nada impede, por exemplo, que alguém dê a entender que gosta de futebol, apesar de não apreciá-lo, apenas para ser (ou parecer) agradável ao seu interlocutor.

Uma vez estabelecido que o ethos expressa a identidade do ator da enunciação, o passo seguinte é lembrar que, na verdade, isso nada tem de extraordinário e que seria espantoso se não fosse assim. É impossível à linguagem deixar de manifestar uma subjetividade e, mais que isso, talvez a linguagem (em qualquer semiótica) seja o único meio de constituir uma identidade e de estabelecer a alteridade. Ou seja, além de o ethos ser o caráter mostrado no discurso, seria impossível ao discurso não conferir um caráter à instância da enunciação, porque, até mesmo discursos como o jurídico ou o científico, que se querem anônimos, terão seu ethos. Conforme afirma Benveniste (1995: 287), uma linguagem que não exprimisse a subjetividade, talvez não pudesse receber esse nome. A discussão leva à problemática da identidade, a qual só pode ser definida em oposição à alteridade, pelo confronto do conjunto de semas de um indivíduo em oposição aos de outros (Greimas \& Courtés, 1993: p. 178) ${ }^{29}$. Tal constatação é valida, inclusive, para textos, como as leis, que não podem apresentar qualquer sema que remeta a um único indivíduo, nem mesmo àquele que as elaborou ou promulgou (e isso apesar de serem assinadas), pois um dos princípios fundamentais dos direitos constitucional e administrativo é justamente o da impessoalidade. Assim, embora seja evidente que a lei tenha um enunciador e que, provavelmente, atenda aos interesses de apenas uma parcela dos indivíduos que deverão segui-la, a imagem da enunciação criada por ela, sua subjetividade, é a de uma coletividade absolutamente homogênea, na qual não se identificam indivíduos. Por exemplo, a Constituição da República Federativa do Brasil, de 1988, pretende ser, evidentemente, um texto perene, despido de qualquer

\footnotetext{
${ }^{29}$ Em Soi-même comme un autre, Paul Ricoeur propõe, grosso modo, duas vias para a discussão da identidade do indivíduo: uma, semântica, fundada na ipseidade ou nos atributos que distinguem um indivíduo dos demais. Outra, que tem inspiração na pragmática, busca investigar o que faz com que um indivíduo sempre seja igual a ele próprio. É o que o autor chama de mesmidade (mêmeté, em francês). Embora as idéias de Ricoeur tenham implicações interessantes para este estudo, entendeu-se que sua investigação extrapolaria os limites definidos para esta tese.
} 
individualidade. Com esse objetivo, é debreado de forma enunciva; o sujeito, quando expresso, é sempre um coletivo: a República, o cidadão, a União, o povo etc. Contudo, isso não impede que a versão original seja datada e assinada pelos indivíduos que a outorgaram. Após o Artigo 250 e antes do Título X, que trata das disposições transitórias, podem-se ver seus nomes: Ulysses Guimarães, Presidente- Mauro Benevides, $10^{\circ}$ Vice-Presidente - Jorge Arbage, 2. ${ }^{\circ}$ Vice-Presidente - Marcelo Cordeiro... Ou seja, nesse caso, o ethos criado pelo texto produz o efeito de uma não-individualidade, e não pretende, de forma alguma, refletir o ethos dos indivíduos ontológicos que produziram o texto. Clara está a dissociação entre o sujeito que produziu o discurso e o ethos a ele correspondente. Esse fato está de certa forma explicado no preâmbulo da carta, que afirma: Nós, representantes do povo brasileiro, reunidos em Assembléia Nacional Constituinte para instituir um Estado Democrático... Veja que o que torna o nós acima competente para redigir a Carta é sua qualidade de representante do povo brasileiro, logo, de uma coletividade que se quer homogênea. Quer dizer, quem assina o texto não o faz em nome de sua individualidade, mas em nome da posição de representante de um actante coletivo e é a imagem desse actante que se reflete na Constituição Federal. Como se vê, o eu construído pelo discurso será sempre único, mesmo quando coletivo, e, ao mesmo tempo, perene e efêmero. É perene porque dura enquanto durar o discurso. No caso das leis, por exemplo, esse $e u$ vive por séculos, mesmo quando não há mais qualquer identidade entre a sociedade que a elaborou a lei e a os indivíduos que se submetem a ela, como no caso do Código Civil Brasileiro, que, elaborado em 1850, vigorou até bem pouco tempo. Mas o en pode ter uma existência fugaz, quando se tratar, por exemplo, de um diálogo em que a reversão entre o en e o $t u$ faça com que cada um desses actantes viva por apenas alguns segundos. Enfim, o eu não pode ser identificado senão no interior de um determinado discurso; vive, portanto, enquanto viver aquele que lhe serve de morada.

Se é inevitável que a linguagem implique uma subjetividade e, portanto, que a enunciação construa um caráter, uma identidade, então, o ethos, antes de ser um ato intencional do enunciador, uma prova engendrada para ganhar a confiança do enunciatário, seria uma realidade inevitável: não é possível enunciar sem produzir um ethos; pode-se controlá-lo, mas não evitá-lo. Por outro lado, se o fundamento da subjetividade está na língua e se esta é inconcebível sem aquela, qual a especificidade, o poder de explicação do ethos? Não seria este um termo ocioso? Não, porque graças a esse conceito é possível, digamos, monitorar o processo de construção de uma identidade - e parte substancial da Retórica não 
se dedica a outra coisa. O eu nascido do discurso não é fruto apenas das referências que o discurso faz ao sujeito da enunciação, nem do que esse sujeito diz de si próprio; é, principalmente, resultado do que o enunciado como um todo dá a entender da enunciação, mesmo quando ela parece não estar enunciada no texto. Ou seja, o ator da enunciação terá seu caráter, seu ethos, definido em função do percurso que executa, da estratégia adotada para dizer, e não do que diz efetivamente. O candidato a um posto de uma empresa não conquistará seu emprego simplesmente enunciando suas qualificações técnicas, morais e intelectuais. É preciso que demonstre possuí-las, e isso dependerá do vocabulário e da sintaxe empregados, de seu tom de voz, dos conhecimentos mobilizados, da forma como se veste, da estratégia que emprega para mostrar o que sabe e o que ignora. Enfim, são as diversas semióticas por ele mobilizadas que estarão conotando-o de forma positiva ou negativa e afirmando que o candidato, além da formação profissional e acadêmica que possui, é, ou não, isso ou aquilo, como diria Barthes. Ao responder às perguntas que lhe forem feitas, ao expressar seu ponto de vista sobre qualquer assunto, o postulante construirá um ator da enunciação, pouco importando se tal ator existe ou não. Mediante o ethos, o dizer confirma, ou não, o dito. Trata-se não apenas de dar uma identidade à enunciação até então pressuposta, mas também de construir uma identidade que faça o discurso parecer verdadeiro. Isócrates dizia que o homem de prestígio convence com mais facilidade do que o desconhecido. Aristóteles não pensa, em relação a esse aspecto, de forma diferente, a diferença surge na origem do prestígio; para Isócrates ele é construído por outros discursos; para o estagirita, nasce do discurso em ato, se assim podemos dizer. Se a enunciação é um enunciado quem tem a intencionalidade como predicado e o discurso como objeto, então, talvez se possa afirmar que o ethos é também um enunciado cujo objeto também é o discurso, e o predicado é, especificamente, o fazer-crer. Se é importante observar que o ethos se refere ao sujeito do discurso, não é menos relevante atentar para o fato de que Aristóteles o define como prova argumentativa, tornando-o, assim, operacional; aliás, operacionalidade possível somente porque o ethos remete à enunciação, e não ao indivíduo real, podendo, portanto, ser construído pela linguagem. O ethos revela ainda que a enunciação, embora pressuposta, muda, ausente do texto, pode manifestar-se de forma a contribuir ou não para a persuasão, ao endossar ou negar o conteúdo do enunciado. Fiorin \& Savioli (1995: 11-2) lembram um exemplo curioso. Ao defender-se de uma acusação de corrupção, determinado homem público fez a seguinte afirmação: “Como São Pedro, nego, nego, nego”. Ora, sabe-se que a 
negação citada refere-se à passagem em que Pedro, mentindo, negou, por três vezes, conhecer Cristo. Nesse caso, de forma involuntária, a enunciação contradiz o enunciado, não porque tivesse afirmado que este era mentiroso, mas porque se valeu de uma comparação absolutamente infeliz, com alguém que, confrontado com fatos que lhe eram contrários, mentiu. Segundo a leitura que o enunciatário fez da afirmação - e as revistas da época o comprovam — , o enunciador, tal como Pedro, mentiu. Essa foi a imagem — de mentirosa - que a instância da enunciação construiu para si, ainda, que, eventualmente, falasse a verdade.

O ethos não pode ser afirmado diretamente: é absolutamente impossível construir para si uma imagem de modesto simplesmente afirmando que se é modesto, por maior que seja a boa vontade do enunciatário para com o enunciador. Assim que começa a discutir o próprio caráter, o sujeito inicia a construção de um novo ethos para si, mudando o sentido do discurso inicial sobre seu caráter e, constituindo, dessa maneira, um outro ethos. Qualquer comentário sobre esse ethos mais recente desencadearia novamente o mesmo processo, e, assim, infinitamente. Em nosso exemplo, o sujeito que afirmasse que é modesto criaria um ethos oposto, por exemplo, o de pedante. Se tentasse se explicar, talvez produzisse um outro, o de alguém pouco hábil, e assim sucessivamente, até o infinito. Ora, nada impede que o sujeito discorra sobre sua própria competência; o problema é que o ethos não decorre - ao menos não de forma direta — de tais afirmações, mas do que o interlocutor puder deduzir delas, do julgamento epistêmico que fizer dessas afirmações. O ethos constituiria, desse modo, uma espécie de "indizível", pois qualquer tentativa de afirmá-lo faria com que se deslocasse para uma nova posição. É algo semelhante às técnicas utilizadas para o estudo das estruturas subatômicas: qualquer feixe de luz projetado sobre elas faz com que sua composição se altere, impedindo a observação. Por isso, o exame dessas partículas deve ser feito de forma indireta, mediante a utilização de meios mais sofisticados. É assim também com o ethos: o sujeito não pode (ou não somente) construí-lo com afirmações sobre si próprio; deve fazê-lo de forma indireta, criando, pela forma como elabora seu discurso, indícios de que possui ou não essa ou aquela qualidade, sem afirmá-las diretamente. É isso que faz Bento Santiago.

Ao final de Dom Casmurro, o narrador conclui que sua primeira amiga e seu maior amigo, tão extremosos ambos e tão queridos também ${ }^{30}$, acabaram juntando-se e traindo-o. Contudo, como

\footnotetext{
${ }^{30}$ Obra Completa, vol. I, p.944.
} 
não há prova material do adultério, o narrador, tal como na velha Siracusa, tem de recorrer à linguagem para convencer seus leitores. Nesse momento, é fundamental criar um ethos compatível com seus argumentos. Obediente a tal estratégia, divide sua narrativa em duas partes. Na primeira e maior delas, relata principalmente sua infância e os primeiros tempos de casado; na segunda, conta como nasceram suas desconfianças, como estas se transformaram em certezas e quais as conseqüências daí advindas. A divisão é explícita:

Tudo acaba, leitor; é um velho truísmo, a que se pode acrescentar que nem tudo o que dura, dura muito tempo. Esta segunda parte não acha crentes fáceis, ao contrário, a idéia de que um castelo de vento dura mais que o mesmo vento de que é feito, dificilmente se despegará da cabeça, e é bom que seja assim, para que se não perca o costume daquelas construções quase eternas. (Obra Completa, vol. I, p.923)

Qual a razão dessa divisão e por que o narrador utilizou quase três quartos do texto para narrar sua infância e adolescência com Capitu, além de outros fatos que não guardam, aparentemente, relação direta com a matéria da segunda parte da narrativa? Tendo em mente que o ethos não pode ser afirmado diretamente, mas mostrado pelo discurso, fica fácil perceber que a primeira parte é fundamental, pois é nela que Bento Santiago constrói seu próprio ethos: ele jamais afirma que é ingênuo, palavra que sequer aparece no romance, mas é assim que se mostra, em oposição à pretensa capacidade de Capitu de dissimular seus sentimentos. $\mathrm{Na}$ segunda parte do romance, a credulidade de Bentinho será usada como prova de que, por um lado, fala a verdade, já que é incapaz de fabular; por outro, de que a alegada dissimulação da mulher a capacitaria a enganá-lo. A título de exemplo, recorde-se aquela passagem em que ele e Capitu estão quase se beijando quando ouvem os passos do pai dela no corredor:

Quando Pádua, vindo pelo interior, entrou na sala de visitas, Capitu, em pé, de costas para mim, inclinada sobre a costura, como a recolhê-la, perguntava em voz alta:

-Mas, Bentinho, que é protonotário apostólico?

-Ora, vivam! exclamou o pai.

— Que susto, meu Deus!

Agora é que o lance é o mesmo; mas se conto aqui, tais quais, ou dous lances de há quarenta anos, é para mostrar que Capitu não se dominava só em presença da mãe, o pai não lhe meteu mais medo. No meio de uma situação que me atava a língua, usava da palavra com a maior ingenuidade deste mundo. A minha persuasão é que coração não lhe batia mais nem menos. Alegou susto, e deu à cara um ar meio enfiado; mas eu, que sabia tudo, vi que era mentira e fiquei com inveja. Foi logo falar ao pai, que apertou a minha mão, e quis saber por que a filha falava em protonotário apostólico. Capitu repetiu-lhe o que ouvira de mim, e opinou logo que o pai devia ir cumprimentar o padre em casa dele; ela iria à minha. E coligindo os petrechos da costura, enfiou pelo corredor, bradando infantilmente: (...) (Obra Completa, vol. I, p. 850 - grifo meu) 
Bentinho praticamente afirma que, se não soubesse o que se passara antes, seria capaz de crer que de fato nada houvera entre eles, tal o autocontrole de Capitu e sua capacidade de dissimulação na presença de quem quer que fosse. Enquanto ele ficava de língua atada, ela usava da palavra com a maior ingenuidade do mundo. Nessa e em inúmeras outras passagens, Bentinho constrói o ethos de alguém inocente, ingênuo, frágil, incapaz de compreender corretamente o que se passa, em oposição a Capitu, sempre maquiavélica, hábil para diversas urdiduras - a maior delas, o adultério. Em outras palavras, Capitu é modalizada como sujeito do saber/poder dissimular e Bentinho do não-saber/não-poder. Ora, poderia ser o raciocínio do narratário: se Bento não foi capaz de mentir para o Pádua, também não o faria em relação a mim. Por outro lado, continuaria o mesmo narratário, se Capitu mentia ao pai e à mãe, poderia perfeitamente tê-lo feito para o marido. Logo, seria sua conclusão final, simplificando um pouco as coisas, tudo quanto o narrador afirmou é verdade. Assim, se, por um lado, o episódio não apresenta nenhuma prova material do adultério, por outro, coloca o auditório numa disposição favorável a Bentinho; primeiro porque mostra que sua tese é verossímil; segundo, porque o apresenta como vítima, tocando, desse modo, o pathos dos que o lêem. Enfim, o episódio constrói o ethos do narrador, dotando-o, assim, da capacidade de poder-fazer-crer ou, ainda, tornando-o competente para persuadir.

\section{$\cos \cos 20$}

Greimas e Courtés definem o fazer-crer, ou a persuasão, como a convocação, pelo enunciador, de toda sorte de modalidades a fim de levar o enunciatário a aceitar o contrato enunciativo que lhe é proposto e, assim, tornar a comunicação possível e - acrescentamos - eficaz. (1993: 274). Apesar de ser uma performance fundamentalmente cognitiva, a persuasão pode envolver também aspectos pragmáticos se, por exemplo, o enunciador se valer de seu poder para impor ao enunciatário um objeto de valor negativo, caso este se recuse a executar o que lhe é determinado, ou para oferecer-lhe um objeto positivo, caso aceite fazê-lo. Naturalmente, a persuasão também pode implicar apenas uma dimensão cognitiva, hipótese em que o enunciador irá utilizar seu saber para fazer julgamentos positivos ou negativos do enunciatário, constrangendo-o a aceitar o contrato que lhe é proposto - é o caso do desafio, conforme estudado por Greimas (1983: 213-27). Finalmente, a persuasão pode se limitar à transferência de um saber-fazer, como no caso de um discurso 
programador, em que o sujeito da enunciação subsume dois actantes: um programador, assumido pelo narrador, e um sujeito-realizador. Os três casos citados têm em comum: (a) o fato de a persuasão implicar a transmissão de um saber; e (b) a expectativa de um fazer compatível com o saber recebido. Por isso, a persuasão pode ser entendida como um fazerfazer de natureza predominantemente cognitiva ou, mais precisamente, um fazer comunicativo, cujo objetivo é colocar o enunciatário em conjunção com um objeto de saber para que ele faça aquilo que lhe é determinado, de maneira mais ou menos sutil, pelo enunciador. Como toda modalidade factiva, a persuasão tem dois predicados idênticos, dois fazeres, porém com sujeitos diferentes. O esquema abaixo, inspirado no proposto por Greimas (1983: 214), talvez ajude a compreender como as coisas funcionam e qual o papel do ethos no processo:

$$
\mathrm{S}_{1} \rightarrow \mathrm{S}_{2} \cap \mathrm{O}_{0}, \mathrm{O}_{1}\left[\mathrm{O}_{2}\left(\mathrm{O}_{3}\right)\right]
$$

onde:

$\mathrm{S}_{1}=$ sujeito do fazer persuasivo

$\mathrm{S}_{2}=$ sujeito do fazer interpretativo

$\mathrm{O}_{0}=\mathrm{S}_{2} \cap \Sigma \mathrm{M}$ (conjunto de modalidades de que $\mathrm{S}_{1}$ se encontraria investido e que seria transmitida a $S_{2}$ junto com o saber)

$\mathrm{O}_{1}=$ objeto cognitivo: o saber que é $\mathrm{S}_{1}$ transmite a $\mathrm{S}_{2}$

$\mathrm{O}_{2}=$ o querer de $\mathrm{S}_{1}$ no tocante à realização de um programa narrativo.

$\mathrm{O}_{3}=$ programa narrativo que deve ser executado por $\mathrm{S}_{2}$ de acordo com a estratégia de $\mathrm{S}_{1}$

Examine-se cada um dos componentes do esquema. O primeiro fazer, executado pelo enunciador $\left(\mathrm{S}_{1}\right)$, consiste na transferência de um saber $\left(\mathrm{O}_{1}\right)$ para que o enunciatário $\left(\mathrm{S}_{2}\right)$ realize o programa narrativo $\left(\mathrm{O}_{3}\right)$ desejado $\left(\mathrm{O}_{2}\right)$ por $\mathrm{S}_{1}$. O esquema mostra ainda que o saber $\left(\mathrm{O}_{1}\right)$ é parte importante da competência necessária para que $\mathrm{S}_{2}$ aja. Parte necessária, mas não suficiente. $\mathrm{Na}$ verdade, é preciso investigar uma etapa anterior, o fazer interpretativo do enunciatário, que o leva a aceitar ou não a manipulação. E aí se percebe a importância do que se denominou $\mathrm{O}_{\circ}$, a somatória de modalidades de que $\mathrm{S}_{1}$ estaria investido e que, ao ser comunicada a $\mathrm{S}_{2}$, conferiria credibilidade ao seu discurso e conduziria à persuasão. Ora, uma vez que a persuasão, como qualquer ato, também pode ser vista como um fazer-ser, e que a competência é aquilo que faz ser, ou a condição prévia para realização do ato, então o ethos seria essa condição, na forma de um conjunto de modalidades que modalizariam o enunciador como alguém que pode atuar de forma compatível com o conteúdo do enunciado, influenciando de forma decisiva o julgamento epistêmico realizado pelo 
enunciatário no momento da proposição do contrato (na notação acima, $\mathrm{O}_{0}$.). Por exemplo, supondo que a persuasão envolva uma dimensão pragmática, isto é, que esteja associada à colocação de $\mathrm{S}_{2}$ em conjunção com um objeto de valor positivo ou negativo, é preciso, primeiro, que o enunciatário creia que o enunciador de fato possa ou queira colocá-lo em conjunção com tal objeto. Por outro lado, se a persuasão envolver apenas a transferência de um saber, sem nenhuma contrapartida pragmática, é preciso que o enunciatário creia que o enunciador disponha do saber que deseja transmitir; caso contrário não o levará a sério. Em outras palavras, nos dois casos, é preciso que o enunciatário confie na capacidade / vontade do enunciador em cumprir o contrato. Por sua vez, tal confiança apresenta duas implicações: primeira, a crença, por parte do enunciatário, de que o enunciador partilha do mesmo universo de valores que ele, de modo que o valor do objeto de saber em questão seja o mesmo para os dois envolvidos. Segunda, que os valores do enunciador sejam compatíveis os valores envolvidos no contrato proposto. Por outro lado, se não houver uma comunhão de valores entre enunciador e enunciatário e se tais valores não forem compatíveis com os inscritos no discurso, não se estabelecerá uma relação fiduciária, nem um ethos positivo e, conseqüentemente, a manipulação fracassará, não ocorrendo persuasão. O conto Noite de almirante (Histórias sem data, 1884) oferece uma boa oportunidade de observar esse mecanismo em funcionamento.

Deolindo Venta-Grande é o marujo que, após uma longa ausência no mar, volta à terra ansioso para ter uma noite de almirante junto a seu grande amor, Genoveva. Juro por Deus que está no céu; a luz me falte na hora da morte foram as palavras dela, jurando fidelidade eterna ao marinheiro, no momento em que se despediram. Crente no juramento, pois supôs que ambos partilhavam os mesmos valores, Deolindo sofre um grande abalo ao descobrir que a amada agora vive com José Diogo, um mascate. Encontram-se, e o narrador conta a reação do namorado ao saber que fora abandonado:

Deolindo declarou, com um gesto de desespero, que queria matá-lo [a José Diogo]. Genoveva olhou para ele com desprezo, sorriu de leve e deu um muxoxo; e como ele the falasse de ingratidão e perjúrio, não pode disfarçar o pasmo. Que perjúrio? Que ingratidão? Já lhe tinha dito e repetia que quando jurou era verdade. (Obra Completa, vol. II, p.449-50)

Na primeira vez, Deolindo tenta manipular Genoveva usando seu poder: ameaça matar o amante. A persuasão fracassa, não porque a vida de Diogo não fosse um valor importante para Genoveva, mas porque ela não crê que o marinheiro possa ou queira 
cumprir a promessa, ou seja, não crê que ele esteja investido das modalidades que o capacitariam a cumprir o contrato $\left(\mathrm{O}_{0}\right.$, no esquema mais acima). Em seguida, ele tenta manipulá-la pelo saber, fazendo um julgamento negativo da moça. Novo fracasso, pois ela não considera que tenha havido ingratidão ou perjúrio em seus atos. Agora, os valores assumidos pelos dois sujeitos é que são diferentes. $O$ final do conto oferece outra oportunidade de ver o mesmo processo em funcionamento, com a diferença de que, dessa vez, a manipulação é bem-sucedida:

No dia seguinte, alguns dos companheiros bateram-lhe no ombro [de Deolindo], cumprimentando-o pela noite de almirante, e pediram-lhe notícias de Genoveva, se estava mais bonita, se chorava na ausência, etc. Ele respondia a tudo com um sorriso satisfeito e discreto, um sorriso de pessoa que viveu uma grande noite. Parece que teve vergonha da realidade e preferiu mentir. (Obra Completa, vol. II, p. 451)

Segundo o cruel narrador, Deolindo teve vergonha da realidade, isto é, do julgamento dos amigos, e preferiu mentir. Fez isso valendo-se não de uma descrição detalhada dos momentos que teria passado junto a Genoveva, mas de um sorriso satisfeito e discreto, um sorriso de pessoa que viveu uma grande noite. Apesar de não convencer a amada em nenhuma das ocasiões, Deolindo logra fazê-lo com seus amigos, e a prova de que se vale é apenas o caráter que constrói em seu discurso, a héxeis elaborada por meio de manifestações somáticas que não seriam planejadas: um reflexo, supostamente inconsciente, decorrente da menção à noite que teria tido. Isso mostra que, muitas vezes, o ethos deve parecer inconsciente, muito embora esteja a serviço de uma estratégia bem definida. Os amigos viram no sorriso discreto de Deolindo uma reação inconsciente de quem viveu uma grande noite, e isso os persuadiu de que o marinheiro falava a verdade. A diferença nas três manipulações realizadas por Deolindo está principalmente no ethos elaborado; se, nas duas primeiras, ele mostrou-se falho, justamente por que não inspirou confiança no enunciatário de que o contrato será cumprido, por outro lado, na última tentativa, Deolindo conseguiu ganhar a confiança dos ouvintes e os persuadiu.

O conto ensina que não é suficiente parecer modesto, honesto, bem-intencionado etc.; é necessário, em muitas situações, que essas qualidades adquiram o status de valores que o enunciador realmente assume, que sejam vistas como a comprovação de que o enunciador estaria em conjunção com as modalidades implicadas pelo fazer persuasivo em questão. Elas não podem ser vistas como o resultado de um programa narrativo executado pelo enunciador, em função do qual adquire valores modais que lhe propiciam uma ascendência sobre o enunciatário - muito embora, seja exatamente esse o caso. Tudo deve se passar como se o 
enunciador estivesse investido de apenas uma modalidade: o não-poder agir de outra forma; ele não deve parecer modesto porque deva, saiba ou queira ser modesto com a finalidade de convencer seu público, mas porque não pode, não sabe, não consegue agir de outra forma em função dos valores que assume. Deolindo não teria sorrido porque isso seria importante para persuadir, mas porque quem viveu uma grande noite não poderia não-sorrir. Quanto ao ethos, o enunciador deve parecer que age como um robô programado para se comportar dessa ou daquela maneira e que não poderia fugir à sua programação inicial. Seus enunciados devem ser mostrados como a "enunciação" de seu modo de ser. O ethos estabeleceria assim uma imbricação entre a enunciação, o discurso e o corpo que enuncia, conferindo, dessa forma, verossimilhança ao que é dito. É como se o orador se dividisse: ele é o sujeito realizado que quer, sabe e pode proferir o discurso, e, ao mesmo tempo, é, lembrando os termos de Coquet, o não-sujeito, aquele que ainda não adquiriu capacidade de julgamento e que, como o lobo da fábula de La Fontaine, age seguindo seus instintos, sem ter domínio sobre eles ${ }^{31}$. O ethos revelaria, enfim, uma dimensão do sujeito aparentemente desprovida de intencionalidade, e seria um comportamento espontâneo, sem premeditação, como a relação perene, estável, entre o ser e o dizer.

$\cos 80 \cos 20$

A experiência de Deolindo lembra a posição de Dominique Maingueneau (2005, p. 70) para quem o ethos se manifesta como um "corpo enunciante" historicamente especificado e inscrito em uma situação, que sua enunciação ao mesmo tempo pressupõe e valida progressivamente. É bem o caso do exemplo citado: o sorriso faz supor que, de fato, Deolindo tivera uma grande noite, validando, assim, sua afirmação. É o caso também de Capitu que, ao simular o susto com a chegada do pai, dá a entender que estava totalmente concentrada na discussão sobre o protonotário, portanto, não praticara nenhum ato que pudesse ser condenável. Em todos esses exemplos, observa-se algo que já havia sido proposto por Cícero: o corpo testemunha os valores assumidos pelo sujeito. Partindo das idéias de Ducrot, Maingueneau entende que o ethos permite personificar, corporificar, a origem enunciativa do texto, como se a enunciação encarnasse e assumisse de forma pessoal sua função de fiador do texto. Para Maingueneau, o ethos deve ser considerado de forma mais ampla, não apenas como resultado das escolhas

\footnotetext{
${ }^{31}$ Ver Instances d'énonciation et modalités. In: Coquet, Jean-Claude. La quête du sens. Paris, Presse Universitaire de France, 1997, p. 147-58.
} 
pessoais daquele que toma a palavra, mas também - e, talvez, principalmente - como fruto de coerções originadas na cena enunciativa, a qual deve considerar, por exemplo, o tipo de discurso (literário, religioso...), o gênero (poesia, sermão...) e as condições específicas do momento. O enunciador não seria, portanto, a origem da enunciação, estável, sólida, autônoma, que disporia de infinitas alternativas para compor seu discurso, mas ele próprio estaria inscrito em uma rede de coerções que implicariam a adoção de determinados papéis e que restringiria, sensivelmente, as escolhas possíveis. Lembrando um exemplo de Bordieu, a classe social a que o indivíduo pertence estará, assim, associada a determinada gestualidade, a uma fisionomia, a uma forma de ocupar o espaço social. A posição social é, pois, indissociável de determinada atitude discursiva, de uma béxeis. Cada sociedade e cada discurso teriam, além do temperamento ou caráter específicos, um corpo pressuposto pelo discurso e por ele validado: o discurso pressupõe determinadas condições que, ao mesmo tempo, são validadas pela própria enunciação.

Observe-se que a implicação entre cena enunciativa e ethos é a origem do poder de persuasão deste, pois o enunciatário sempre acreditará que determinado comportamento é decorrente de coerções de diversas ordens, que variam conforme a sociedade e a cultura. Por isso, como adiantou Greimas, a verossimilhança é uma questão que depende do gênero e da cultura. Segundo Maingueneau, o olhar doce do humanismo devoto não seria uma escolha do enunciador tendo em vista o proselitismo, mas resultado da disposição moral a que foi conduzido o adepto dessa doutrina, de forma, digamos, inconsciente. Evidentemente, nada impede que alguém simule certa docilidade para fazer supor sua adesão a determinada forma de pensamento quando isso, na verdade, não ocorre. Mas aí já não se está mais no campo das ciências da linguagem, pois não lhes cabe decidir o que é ou deixa de ser, mas apenas o que parece ser. Talvez a Marcela de Memórias póstumas possa ajudar a entender um pouco melhor como tudo se passa:

[...] como eu [Brás Cubas] lhe não pudesse dar [a Marcela] certo colar, que ela vira num joalheiro, retorquiu-me que era um simples gracejo, que o nosso amor não precisava de tão vulgar estímulo. dedo.

— Não lhe perdôo, se você fizer de mim essa triste idéia, concluiu ameaçando-me com o

[...] Depois, reclinada na marquesa, continuou a falar daquilo, com simplicidade e franqueza. Jamais consentiria que lhe comprassem os afetos. [...] Duarte, por exemplo, o alferes Duarte, que ela amara deveras, dois anos antes, só a custo conseguia dar-lhe alguma coisa de valor, como me acontecia a mim; ela só lhe aceitava sem relutância os mimos de escasso preço, como a cruz de ouro, que lhe deu, uma vez, de festas.

- Esta cruz... 
Dizia isto, metendo a mão no seio e tirando uma cruz fina, de ouro, presa a uma fita azul e pendurada ao colo.

- Mas essa cruz, observei eu, não me disseste que era teu pai que...

Marcela abanou a cabeça com um ar de lástima:

- Não percebeste que era mentira, que eu dizia isso para te não molestar? Vem cá, chiquito, não sejas assim desconfiado comigo... Amei a outro; que importa, se acabou? Um dia, quando nos separarmos...

— Não digas isso! bradei eu.

— Tudo cessa! Um dia... Não pôde acabar; um soluço estrangulou-lhe a voz; estendeu as mãos, tomou das minhas, conchegou-me ao seio, e sussurrou-me baixo ao ouvido:

- Nunca, nunca, meu amor! Eu agradeci-lho com os olhos úmidos. No dia seguinte leveilhe o colar que havia recusado.

- Para te lembrares de mim, quando nos separarmos, disse eu.

Marcela teve primeiro um silêncio indignado, depois fez um gesto magnífico: tentou atirar o colar à rua. Eu retive-lhe o braço; pedi-lhe muito que não me fizesse tal desfeita, que ficasse com a jóia. Sorriu e ficou. (Obra Completa, vol. I, p. 535-6)

A exemplo de Deolindo, Marcela simula uma série de comportamentos aos quais se veria constrangida a adotar em virtude dos sentimentos que teria: usar de gracejos, falar com franqueza e simplicidade, sussurrar, ter soluços, voz estrangulada, um olhar indignado... Além disso ela simula tentar atirar longe o colar como se tal ato fosse uma reação quase instantânea, provocada pelas palavras de Brás Cubas. Como se sabe, ela mentia, mas é justamente a existência de uma cena enunciativa pré-estabelecida e cristalizada em determinadas culturas, segundo a qual mulheres apaixonadas agem como ela agiu, que dá credibilidade a seu comportamento: as manifestações somáticas apresentadas por Marcela corroboram o seu dizer e assim indicam, ao menos para Brás, que ela dizia a verdade. Retorne-se a Aristóteles. O filósofo ensinava que dentre as provas inerentes aos discursos estava o ethos. Agora se vê o porquê: a prova, eficientíssima, apresentada por Marcela é o seu caráter apaixonado; a testemunha, é seu corpo: abonar a cabeça, sussurrar, soluçar ter a voz estrangulada. E qual a importância de o testemunho ser forjado? Nenhuma, diria Barthes.

Para este trabalho, o exemplo citado tem interesse ainda maior. Como se viu, Marcela afirma explicitamente que não quer o colar, que o amor de ambos não precisava de tão vulgar estímulo e que ela não consentia que lhe comprassem os afetos. Ora, se, como foi dito, o fato de ela mentir é irrelevante, então é preciso explicar porque ela não conseguiu manipular Brás a ponto de demovê-lo da compra do colar. Claro, sabe-se que Marcela queria, sim, o colar e que manipulou Brás para dar-lho. Mas, então, como explicar uma argumentação em sentido contrário? Recorde-se a célebre a passagem em que Ducrot discute o ethos:

[...] Na minha terminologia direi que o ethos está ligado a L, o locutor enquanto tal: é enquanto fonte da enunciação que ele se vê dotado [affoublé] de certos caracteres que, por 
contraponto, tornam esta enunciação aceitável ou desagradável. O que o orador poderia dizer de si enquanto objeto da enunciação, diz, em contrapartida, respeito a $\lambda$, o ser do mundo, e não é este que está em questão na parte da retórica de que falo (a distância entre esses dois aspectos do locutor é particularmente sensível quando L ganha a benevolência de seu público pelo próprio modo como humilha $\lambda$ : virtude da autocrítica) (Ducrot: 1987, p. 188- 189).

A estratégia de Marcela é análoga. Marcela-fonte-da-enunciação, L, recusa o colar enquanto $\lambda$, isto é, a Marcela-ser-do-mundo, emite sinais de que não só ficaria contente com o presente (a lembrança de outros mimos que teria recebido dos antecessores de Brás), como também o merecia como retribuição pelo amor desinteressado que nutriria por Brás Cubas. Criam-se, então, dois programas de persuasão, cada qual executado por um actante, embora ambos estejam sincretizados no ator Marcela. O primeiro opera na dêixis da persuasão (comprar o colar), o segundo, concebido para fracassar, opera na dêixis da dissuasão (não comprar o colar). A atitude de Marcela poderia se enquadrar no que Greimas (1983: 215) chama de "persuasão antifrástica: o enunciado persuasivo é mostrado como uma persuasão a recusar com a intenção oculta de que seja lido, no fazer interpretativo do sujeito manipulado, como uma dissuasão a recusar". Pede-se o que não se quer para se obter o que é desejado. A razão desse anti-programa destinado ao fracasso é clara: agindo assim, Marcela consegue construir um ethos de mulher apaixonada e desinteressada — que não seria obtido se afirmasse que queria o colar — , que valoriza os sentimentos mais do que os bens materiais e que ama perdidamente Brás Cubas. Desse modo, aumenta seu merecimento e seu valor aos olhos de Brás, tornando-se, ao mesmo tempo, ainda mais digna do presente. É difícil pensar em argumentos mais poderosos...

Maingueneau mostra ainda que, mesmo textos escritos, de qualquer natureza, apresentam um ethos que implica uma vocalização e uma corporificação daquele que fala; uma maneira de vestir, de falar, de se locomover, enfim, uma presença e uma forma de habitar o espaço social construído pelo discurso - e isso, até em discursos que simulam não ter marcas de corporalidade. Maingueneau mostra como os discursos humanista devoto e jansenista fazem supor uma determinada compleição física, uma forma de se vestir e um tom de voz, que constroem os seus ethé, os quais passam a estar intimamente relacionados às doutrinas de cada escola. A austeridade do jansenismo se articularia a um enunciador magro, de expressão mais dura, enquanto o humanismo devoto pressuporia um olhar mais sereno, 
formas antes cheias que magras, e gestos mais flexíveis ${ }^{32}$. O ethos funcionaria, enfim, como um articulador entre o texto e o corpo ou, nas palavras de Maingueneau (1995: 143), uma articulação entre o mundo representado e a enunciação que o carrega: a qualidade do ethos remete a um fiador que através desse ethos se proporciona uma identidade à medida do mundo que supostamente deve fazer surgir.

Outro exemplo, citado por Fiorin (2004, p. 130-4), é o dos diferentes ethé dos poetas românticos no Brasil. De acordo com o autor, a primeira geração pode ser caracterizada pelo jovem pálido, magro, tísico e de aspecto frágil. É essa a imagem que nos vem à mente quando lemos, por exemplo, Lembrança de morrer, de Álvares de Azevedo. Já a terceira geração, chamada condoreira, por Machado de Assis, pode ser caracterizada pelo poeta de voz firme, de maior compleição física e de gestos mais arrebatados. É nessa "corporificação" que se pensa quando se lê Vozeses d'África, de Castro Alves. Algo semelhante se passa com o próprio Machado de Assis. Comparem-se os versos abaixo, extraídos de três poemas distintos ${ }^{33}$ :

\section{Versos a Corina - II}

A minha alma, talvez, não é pura, Como era pura nos primeiros dias; Eu sei; tive choradas agonias De que conservo alguma nódoa escura, (...)

\section{O Sofá}

Um sofá! Mais belo símbolo Da preguiça não há...

Ai, que belas entrevistas Não se dão sobre um sofá, E que de beijos ardentes Muita boca aí não dá!

\section{A Carolina}

Querida, ao pé do leito derradeiro Em que descansas dessa longa vida, Aqui venho e virei, pobre querida, Trazer-te o coração do companheiro.

Nas três segmentos acima, há um único enunciador que assina "Machado de Assis", mas três ethé claramente distintos e três "corporificações" também diferentes. ${ }^{34}$ Da leitura integral de Versos a Corina, (Crisálidas, 1864), pode-se depreender a imagem de um jovem que lembra o eu de Álvares de Azevedo, com seu aspecto mais frágil, talvez esquálido, a voz mais aguda que grave e o olhar ansioso, gestos compatíveis com quem afirma ter tido agonias que o levaram ao choro. Em O sofá (A marmota, 1858), a figura sugerida é também a de alguém ainda jovem, mas não tanto, dotado de maior compleição física, de olhar vivo, de voz firme e de modos expansivos e estouvados, que teriam redundado em beijos ardentes. No célebre

\footnotetext{
${ }^{32}$ Para maiores informações ver Genèses du discours, também de Maingueneau, obra em que o autor faz uma análise, bastante interessante, dos dois discursos.

33 Obra Completa, vol. III, p. 28, 287 e 318, respectivamente.

${ }^{34} \mathrm{O}$ fato, aliás, aponta para a importância de a definição do ethos do enunciador não considerar apenas uma obra isolada, mas um conjunto da produção literária de um enunciador.
} 
soneto A Carolina (Relíquias da casa velha, 1906), não se pensa mais num jovem, mas em alguém maduro, embora de idade indefinida, de olhar sereno, voz pausada e modos contidos. Pode-se argumentar que há muito de cultural e de particular nas imagens apresentadas e que nada garante que sejam essas as corporificações imaginadas em outras culturas, épocas ou mesmo por outros leitores. É verdade, mas isso não altera o fato de que uma imagem, uma corporificação, é sempre pressuposta ao texto e que ela remete ao sujeito que a enuncia, seja ele real ou não. Veja-se agora uma imagem do enunciador construída de maneira completamente diferente; é a que se depreende da leitura das Cartas portuguesas:

E, no entanto, não me arrependo de te haver adorado e sinto-me bem feliz por me teres seduzido! A tua ausência rigorosa, e talvez eterna, em nada diminui a veemência do meu amor,. Quero que todos o saibam, e disso não faço mistério, que estou encantada por ter feito por ti tudo quanto fiz contra toda a espécie de decoro. A minha religião e a minha honra, faço-as consistir unicamente em te amar loucamente por toda a minha vida, já que a amar-te comecei. (Alcoforado, Maria. Cartas portuguesas. Porto Alegre, L\&PM Editores, 2000. p. 25 - grifo meu)

A imagem construída no texto é clara: trata-se de uma mulher jovem, religiosa, (outros trechos deixam claro tratar-se de uma freira), de tom de voz mais elevado, modos arrebatados e, claro, temperamento passional. Claro, nada disso pode ser aplicado ao autor ontológico, aquele que efetivamente produziu esse texto, pois não se sabe nem mesmo se as cartas de fato existiram, se foram escritas por uma freira, por seu amante - o conde de Chamilly —, por Cuillevaraque, que se apresenta como "tradutor" da versão francesa do texto, ou por alguém que se valeu de uma boa estratégia de marketing para promover um romance epistolar. Aliás, segundo os estudiosos não haveria nem mesmo a certeza se o texto original teria sido escrito em francês ou português. Na verdade, nada disso importa, pois o ethos do ator da enunciação pressuposto pelo texto é compatível com uma jovem freira, e um enunciador com essas características dá credibilidade à obra: o fato de a "autoria" das cartas corresponder a uma freira as faz verossímeis, e o conteúdo delas torna verossímil que seu enunciador seja uma noviça.

$\cos \cos 20$

A delimitação dos discursos de um enunciador é uma das primeiras tarefas que se impõe quando se busca determinar seu ethos. Evidentemente, há registros históricos de Machado de Assis, obras que levam o seu nome e uma vastíssima fortuna crítica que deveriam dispensar tal atividade ao traçarem um perfil do caráter de "Machado de Assis". De 
fato, tal trabalho existe, mas não resolve o problema, pois se busca o ethos do ator da enunciação desses textos, do enunciador pressuposto a eles, e não do autor ontológico, do homem que assina essas obras. Levantamentos bibliográficos e estudos biográficos poderiam até oferecer informações sobre o escritor, mas nada diriam sobre o caráter construído pelos romances. Cabe, portanto, aos próprios romances indicar seu "autor implícito", o ator da enunciação construído por eles, para, a partir daí, chegar a seu ethos, assim como citado a respeito das Cartas Portuguesas.

Um caminho é o proposto por Lotman, que pensa a cultura e o material nela produzido "sob o ponto de vista de uma determinada informação de conteúdo e sob o ponto de vista do sistema de códigos sociais, os quais permitem expressar essa informação por meio de determinados signos e torná-la patrimônio destas ou daquelas coletividades bumanas". (1979: 32-3). De acordo com tal enfoque, a cultura pode ser pensada como uma hierarquia de códigos historicamente formada (id. ib. $)^{35}$, na qual cada código histórico-cultural corresponde a um único sistema de características tipológicas. Sendo a cultura um sistema hierarquizado, é possível fazer sucessivos cortes do código cultural em níveis hierárquicos distintos, delimitando-o conforme o enfoque adotado. Seguindo o exemplo de Lotman, pode-se pensar, por exemplo, o comportamento do santo e do cavaleiro medievais ora como dois códigos distintos, ora, subindo um nível na hierarquia, como invariantes pertencentes a um mesmo código cultural, o do comportamento do indivíduo na Idade Média. Vai depender, então, da perspectiva adotada na análise dos discursos, se esses comportamentos devem ser vistos como grandezas distintas ou como membros pertencentes a um único modelo, do qual seriam subdivisões. Esse enfoque é próximo do conceito de episteme, que, segundo Greimas \& Courtés (1993: 128), seria uma "organização hierárquica de vários sistemas semióticos suscetivel de gerar, com a ajuda de uma combinatória e de regras restritivas de incompatibilidade, o conjunto de manifestações recobertas por esses sistemas no interior de uma dada cultura”. De posse dessas regras, é possível, além de reconhecer os textos pertencentes a dada cultura ou escola literária, recriá-los fora de seu contexto. Grosso modo, bastaria que se aplicasse a combinatória e as regras citadas por Greimas \& Courtés, ou os códigos sociais, na visão de Lotman. Não é diferente o procedimento de Manuel Bandeira em

35 É preciso observar que Lotman considera, ainda, como elemento primordial na classificação das culturas, portanto, do pensamento de uma sociedade, "sua vinculação com o problema do signo" ou, em outras palavras, o modo como essa sociedade se relaciona com os sistemas simbólicos que produz e que acabam por definir sua identidade. Para uma boa discussão a esse respeito, inviável neste espaço, ver "Sobre o problema da tipologia da cultura" Trad. Lucy Seki. In: Schnaiderman, Boris (org.). Semiótica Russa. São Paulo: Perspectiva, 1979. 
vários dos textos que compõem a coletânea Mafuá do Malungo, de 1948. Nos poemas intitulados " $\grave{A}$ maneira de...", o poeta faz versos fazendo-se passar por Alberto de Oliveira, Olegário Mariano, Augusto Frederico Schmidt, e.-e. cummings. Na mesma obra, encontramse ainda a Oitava camoniana para Fernanda e o Soneto parnasiano e acróstico em louvor de Helena Oliveira, em que Bandeira escreve imitando Camões e a escola parnasiana. Não fosse pela assinatura, talvez esses textos pudessem ser aceitos como de autoria dos autores imitados, pois, de fato, apresentam a organização e a estrutura utilizada por aqueles poetas. Para produzir esse efeito de sentido, pois é disso que se trata em última instância essa identidade, Bandeira aplica a norma - entendida no sentido estatístico, de ocorrência verificada com dada freqüência em um conjunto de elementos — seguida por aqueles autores e escolas. Ao fazê-lo, Bandeira dá vida novamente a esses enunciadores. O texto, materialmente falando, é de autoria de Manuel Bandeira, mas o enunciador se apresenta como Alberto de Oliveira, e.e. cummings, Camões e outros. O fato faz supor que, do conjunto da obra desses autores, como de quaisquer outros, é possível depreender determinados conteúdos de informação e um sistema de códigos sociais, que os identificam como pertencentes a determinadas escolas e a enunciadores específicos. Tais recorrências constroem, portanto, um ator da enunciação que, depois, é recriado por Bandeira ao reempregá-las. Possivelmente, não fosse pelo título, os poemas intitulados "à maneira de..." não seriam atribuídos a Bandeira nem mesmo por um leitor que conhecesse a obra do poeta pernambucano, pois tal leitor veria nos textos não o enunciador a que estava habituado, mas outro. Os poemas de Bandeira encerram ainda outras lições, talvez mais relevantes para os fins deste trabalho: a "autoria" de um texto é um efeito de sentido; o ator da enunciação é construído pelo texto e não guarda nenhuma relação com o indivíduo que o redigiu; é possível que um mesmo produtor de texto se faça passar por vários atores da enunciação, como fez Fernando Pessoa, ou que se passe por outro, a exemplo de Bandeira.

A questão conduz à discussão sobre a noção de estilo, entendida por Discini (2003, p. 31) como a recorrência de determinados traços delimitadores de um conjunto de textos que pode, então, ser atribuído a um ator da enunciação. Ora, o ethos também se define pela recorrência de traços que, olhados em perspectiva, permitem configurar um caráter ao qual se soma, conforme se viu anteriormente, um caráter, um temperamento, determinadas competências e um corpo, todos associados a um sujeito da enunciação. No decorrer deste trabalho, os romances de Machado serão utilizados para, independentemente de fatores 
externos a eles, como a assinatura, comentários da crítica ou referências biográficas, definir um determinado ator da enunciação. Em um primeiro momento, pode-se considerar todos os textos literários como código (para lembrar os termos de Lotman) que se opõe a outros códigos, estes, definidores de textos não-literários. Em um nível inferior a esse, pode-se pensar as diversas escolas literárias como códigos culturais ou, nas palavras de Lotman, como línguas distintas que se opõem umas às outras. Faz-se, então, o mesmo raciocínio para cada autor no interior de cada escola. Finalmente, é possível considerar a obra de um escritor como um todo ou, então, segmentá-la seguindo critérios convenientes para a análise. Fazendo esses cortes sucessivos, chega-se a Machado de Assis. O passo seguinte é verificar se, dessa totalidade, é possível depreender outras subdivisões, como as fases que, segundo a crítica, comporiam a obra do escritor, ou se não haveria divisões possíveis e, nesse caso, a produção romanesca desse ator seria uma única totalidade. Nas páginas anteriores, concluiu-se que o ethos do enunciador pode ser construído de maneira endógena, pelo próprio discurso, mediante manifestações relativas à sua competência e às suas modalidades, tais como o crer e o saber, ou pode ser construído de forma exógena, "de fora para dentro", pelos discursos com os quais dialoga. (é a posição de Isócrates). A questão agora é semelhante: um autor ou uma escola pode ser definido internamente, pelo caráter mostrado no discurso ou pelos demais discursos com os quais se relaciona. Por exemplo, um romance pode ser considerado romântico por outros textos ou por sua organização interna ao apresentar os traços daquilo que a comunidade considera Romantismo. Essa tem sido, grosseiramente falando, a tarefa da crítica literária: de um lado, utilizando o método que lhe é próprio, define escolas e gêneros; de outro, faz a correspondência entre as manifestações literárias e as escolas e gêneros definidos.

Naturalmente, tanto o critério chamado de exógeno quanto o endógeno são válidos. Ocorre, porém, que não faria sentido para um trabalho que se pretende elaborado segundo uma orientação metodológica da semiótica discutir, por exemplo, o que é Romantismo ou Realismo ou em qual dessas escolas se enquadra a obra de Machado de Assis. É tarefa que já está feita e que pode nos ser útil para as reflexões aqui presentes. Todavia, obedecendo à perspectiva da semiótica e tendo em vista o objetivo deste trabalho, entende-se que, para definir o ethos do enunciador da obra machadiana, não basta adotar o entendimento da crítica literária, dividindo a produção do autor em duas fases; é preciso determinar, no interior do texto machadiano, se existem dois ethos, que corresponderiam às diferentes etapas de sua 
produção, ou se há um ethos único, que caracterizaria toda a obra do escritor. Discini (2003, p. 39) propõe que o enunciador de um estilo - e entende-se que isso vale para uma escola literária - pode ser constituído a partir de uma dada perspectiva sobre o mundo, por um conjunto de crenças e de valores tematizados e figurativizados no discurso. Assim, é preciso buscar reconstruir a perspectiva do mundo, o conjunto de crenças e valores e, em um nível mais profundo, a sintaxe e a semântica presentes nesses textos para, então, por meios dessas descobertas, determinar um ethos e, com ele, uma identidade para o ator da enunciação que se convencionou chamar de Machado de Assis.

$\cos \cos 20$

Em seu alentado Formação da literatura brasileira, Antonio Candido mostra que o Romantismo no Brasil foi regido, para lembrar as palavras de Machado, por certo instinto de nacionalidade fruto do desejo e da necessidade documentar e descrever o país e suas gentes. $\mathrm{O}$ tema da identidade nacional, que inaugura nossa literatura, praticamente nascido com o Estado Brasileiro e figurativizado de inúmeras formas pelos autores românticos, perpassa todas as obras do período e acaba por dar origem a esquemas narrativos muito distintos. Segundo Candido, os romancistas do século 19, de diversas estaturas, viam-se imbuídos de um senso de missão que os levava a buscar na literatura antes um instrumental para a interpretação da realidade brasileira e a afirmação da identidade nacional que uma forma de realização artística de nível. Esse senso de missão corresponderia a uma determinada perspectiva do mundo, a um conjunto de valores, nas palavras de Discini, ou a uma informação de conteúdo atrelada a um sistema de códigos, na visão de Lotman. Tanto em um caso quanto em outro, a recorrência conteúdos e códigos leva à definição de um ethos; no caso brasileiro, o do Romantismo; no mais, caracterizado por certo fazer, por um quadro de valores que é subjacente a essa produção literária. O resultado foi, segundo Antonio Candido, a produção de um conjunto de textos que explicavam ou descreviam de maneira satisfatória a realidade nacional, mas não logravam produzir obras de maior envergadura. Define-se, desse modo, em um primeiro nível, um ator da enunciação coletivo, que prioriza a questão sóciohistórica em detrimento da estética, pois, nas mais das vezes, é com um saber relativo à primeira que ele coloca o enunciatário em conjunção. 
Um dos fatores para o insucesso da literatura nacional em suas origens teria sido a contradição à qual se viu presa, pois seu ardor realista entrava em choque com os ideais e sonhos próprios da escola romântica em que tal produção nascia: o Romantismo brasileiro recorria a um molde europeu que pressupunha uma organização social e relações de produção absolutamente inexistentes deste lado do Atlântico e do Equador. Além disso, o romantismo desses escritores, demasiado românticos no dizer de Candido, não cessava de se insurgir a cada linha da descrição realista. Produzia-se, assim, um Romantismo realista que só não soava incongruente porque se veria acompanhado, anos mais tarde, por um Naturalismo... romântico! É como se nosso sujeito romântico se visse duplamente manipulado: ora por um destinador "nacional" que lhe propusesse reprodução da "cor local", ora por outro, espécie de anti-destinador, que lhe incumbia de reproduzir o molde europeu. Daí as contradições de toda espécie que prejudicavam o resultado final. Percursos incompatíveis, ao menos para esse sujeito, que se via premido diante dessas duas imposições que, no entanto, enquanto conjunto de valores e de crenças, caracterizam a produção do período, configurando, pois, seu ethos.

Ao contrário do que talvez se possa pensar, Machado não era estranho a esse ambiente - e nem poderia ser, a menos que se supusesse que a manipulação referida não surtiu efeito no seu caso, o que, por sua vez, levaria a pensar em um quadro de valores distinto do dos demais autores. Como será visto em breve, as duas questões apontadas - a sócio-histórica, ligada ao realismo e à realidade nacional, e a estética, que remete ao Romantismo e ao molde europeu — se mostram e se enfrentam de maneira explícita na obra machadiana. Mais: esse enfrentamento, não raro se transforma em elemento articulador de suas obras, revelando a absoluta e espantosa consciência que esse enunciador tinha da sua condição. Conforme lembra Candido, Machado não descartou a produção nacional que o antecedeu - desde o Uraguai (1769), poema épico de Basílio da Gama que ele tanto admirava, até os romances de Macedo e Alencar, praticamente contemporâneos dos seus -, mas saciou-se dela e, literalmente, re-produziu-a de formas muitíssimo variadas no decorrer dos seus romances. Tome-se um exemplo, escolhido mais ou menos ao acaso: a divertida cena em que o pai de Brás Cubas oferece um jantar para comemorar a queda de Napoleão. Conta o narrador que lá estava o Vilaça, glosador insigne que havia jurado aos céus não mais parar de glosar. Diante da admiração dos presentes, ele responde pernosticamente: 
- A senhora diz isso, retorquia modestamente o Vilaça, porque nunca ouviu o Bocage, como eu ouvi, no fim do século, em Lisboa. Aquilo sim! que facilidade! e que versos! Tivemos lutas de uma e duas horas, no botequim do Nicola, a glosarmos, no meio de palmas e bravos. Imenso talento o do Bocage! Era o que me dizia, há dias, a Senhora duquesa de Cadaval...

E estas três palavras últimas, expressas com muita ênfase, produziram em toda a assembléia um frêmito de admiração e pasmo. Pois esse homem tão dado, tão simples, além de pleitear com poetas, discreteava com duquesas! Um Bocage e uma Cadaval! Ao contato de tal homem, as damas sentiam-se superfinas; os varões olhavam-no com respeito, alguns com inveja, não raros com incredulidade. (Obra Completa, vol. I, p. 529-30)

De fato, era assim que acontecia a literatura no Brasil: em meio a saraus literários que davam ao ouvinte o direito de sentir-se leitor de Bocage, só por ter tido contato com ele por vias para lá de indiretas, como esse Dr. Vilaça. Candido explica que os escritores brasileiros produziam tendo em vista esse tipo de recepção: os textos eram feitos antes para serem ouvidos que lidos, para serem consumidos em salão ou em família, predominantemente por mulheres, mais como marca de distinção do que qualquer outra coisa. Como quer que fosse, era esse o leitor ideal, e a ele os escritores deveriam se subordinar ${ }^{36}$. Novamente, Machado soube tirar partido dessa situação e transformar todo esse ambiente em material literário: não só os saraus literários e os Vilaças da vida, mas também a multidão de leitores e leitoras anônimos que ele transforma em narratários de suas obras. Afinal, quem não se lembra das inúmeras referências à cara leitora ou à leitora minha que pululam na obra de Machado? Claro, o bruxo não escrevia para esse tipo de leitor, ingênuo, de saraus, interessado em obras romanescas, que está sempre em busca de clichês — embora tivesse plena consciência de que não esperavam dele outra coisa $^{37}$ - , mas para um outro leitor, certamente mais sofisticado. A instalação de tais leitores não é, portanto, mero exercício metalingüístico ou uma demonstração de virtuosismo: revela bem o dilema do escritor constrangido a seguir um molde europeu, como lhe pediria seu público, e a necessidade de imitar bem a realidade nacional, constituída por destinos sem qualquer

\footnotetext{
${ }^{36}$ A cena descrita por Machado se coaduna de tal forma à explicação de Candido, que dá a impressão de que os dois autores teriam escrito em parceria. Recorde-se um breve trecho de Literatura e sociedade:

A ação dos pregadores, dos conferencistas de academia, dos glosadores de mote, dos oradores nas comemorações, dos recitadores de toda hora, correspondia a uma sociedade de iletrados, analfabetos ou pouco afeitos à leitura. Deste modo, formou-se, dispensando o intermédio da página impressa, um público de auditores, muito maior do que se dependesse dela e favorecendo, ou mesmo requerendo no escritor certas características de facilidade e ênfase, certo ritmo oratório que passou a timbre de boa literatura e prejudicou entre nós a formação de um estilo realmente escrito para ser lido. A grande maioria dos nossos escritores, em prosa e verso, fala de pena em punho e prefigura um leitor que ouve o som da sua voz. brotar a cada passo por entre as linhas. (Mello e Souza: 2000, p. 73-4)

${ }^{37}$ Para ter uma idéia do que isso significava na prática, ver o excelente trabalho de Hélio Guimarães, $O$ romance machadiano e o público de literatura no século 19. São Paulo, Nankin / Edusp, 2004.
} 
grandeza, como bem notou Alfredo Bosi. Onde os demais procuravam uma solução de compromisso, que contentasse a uns e outros, Machado resolve explicitar o problema e transformá-lo em matéria literária. Ao instaurar o leitor como narratário do texto, o bruxo transforma o fazer literário em tema de sua narrativa, ao mesmo tempo em que cava um fosso entre o enunciador e enunciatário construídos por sua obra, e o narrador e o narratário, nela instalados. Como se verá a seguir, os dois pares estarão sempre em franca oposição. Tudo isso sem perder de vista a questão social, que Machado abordou com precisão e profundidade, apesar de ter sido acusado de não se ocupar da realidade do Brasil.

$\cos \cos 20$

Um dos maiores desafios que se apresenta a este trabalho decorre do fato de que se busca o ethos do enunciador - actante que, como se sabe, está apenas pressuposto no texto, e nunca presente nele. Se fosse buscado o ethos do narrador, a tarefa seria mais simples, pois é com o narrador que o leitor interage, é ele quem conduz a narrativa, faz comentários e apreciações sobre os acontecimentos, descreve cenas, explica o que se passou, delega a voz aos actantes do enunciado etc. Não é difícil reconhecer Brás Cubas, Bento Santiago, José da Costa Marcondes Aires ou outros narradores machadianos não nominados, pois cada um desses senhores tem seu jeito de falar, sua maneira de conduzir o leitor por entre as linhas de sua trama, seu modo peculiar de fazer julgamentos sobre um ou outro fato. Por exemplo, pode-se arriscar dizer que Brás Cubas é extrovertido e debochado, enquanto Bento Santiago é, para usar o termo que o consagrou, casmurro, e Aires, um cidadão acima de qualquer suspeita. Já o narrador de Quincas Borba é cínico, atrevido, de Ressurreição e de $A$ mão e a luva também, mas não tanto, enquanto o de Iaiá Garcia um modelo de compostura e o de Helena, um cavalheiro. Mas mesmo que seus falares sejam familiares; ainda que se possam definir seus temperamentos e, quem sabe, tentar uma descrição física desses senhores; apesar de todos se esforçarem por construir uma imagem de si em seus discursos, de tal modo que o ethos de cada um resulte consideravelmente diferente; e, reconhecendo que a cada linha atestam que são, sim, os enunciadores de seus textos; não são eles o objeto deste trabalho. E com uma agravante: se nos detivermos nos falares desses senhores, acabaremos enredados nas malhas dos seus discursos e o ethos do enunciador jamais será alcançado. 
Tampouco este trabalho se interessa pelo ethos de um personagem — certamente mais ilustre e conhecido, genitor, se permitem a expressão, desses senhores. Sim, sabe-se que Joaquim Maria Machado de Assis é o produtor das obras que aqui serão analisadas, que era mulato, que nasceu na corte do Império Brasileiro a 21 de junho de 1839 e morreu na capital da República Federativa do Brasil a 29 de setembro de 1908, que usava barba e óculos, sofria de epilepsia, mas não de miopia intelectual; que era, ao contrário de Aires e Brás Cubas, abolicionista ferrenho e, segundo alguns, monarquista, que era conhecido do Imperador e amigo de Joaquim Nabuco, José de Alencar, Vitor Meireles, José Veríssimo e Carlos Gomes — aliás, que era profundo conhecedor da música nacional e via em Nepomuceno um grande talento quando ninguém o conhecia -, que lutou pela preservação da obra do Pe. José Maurício, que sabia de tudo que se passava no Brasil e no mundo, mas era partidário de quase nada, que era capaz de citar teóricos socialistas que sequer eram conhecidos na Europa, que na adolescência foi tipógrafo, na juventude, jornalista e censor de teatro, e que já adulto tornou-se funcionário público de segundo escalão, autor de pareceres impecáveis, e que durante todo esse tempo foi cronista de mão cheia e pena afiada; que por muitos anos teve um cãozinho de estimação, era casado com D. Carolina, apaixonado pelo Rio de Janeiro e que tinha um caso com a Rua do Ouvidor, em cujos cafés sempre encontrava os amigos para falar de tudo e de nada; que se interessava por política, apesar de desiludir-se dela; que amava a natureza brasileira, mas entendia que o país tinha outras riquezas; que era admirador de Gonçalves Dias, Wagner, Sarah Bernardt, Vitor Hugo, Renan, Edgar Allan Poe, de quem foi tradutor, de Eça de Queiroz, apesar das duras crítica que dirigiu ao último; que festejou a vinda de Luísa Michel ao Rio de Janeiro quando poucos conheciam a história da Comuna de Paris e quase ninguém sabia da sua musa; que lia, ao menos, inglês, francês, e alemão e escrevia um português de dar inveja a Vieira; que, apesar de ter um estilo impecável, detestava os puristas da língua que, que, que ... Sim, se desejássemos traçar o ethos de Machado de Assis, tal como propõe Isócrates, não faltaria material, pois não foram poucos os que se dedicaram a estudar esse brasileiro, mas, hélas!, não é esse senhor o objeto dos cuidados deste texto. Por mais fascinante que seja o homem, não é o seu ethos que se busca aqui.

Mas, afinal, procura-se pelo ethos de quem?

Pelo ethos do enunciador, como ficou dito acima, leitor impaciente. Sim, o enunciador, que, como se sabe, é mudo, e a quem só se tem acesso de forma indireta, pois nunca está dentro do texto, e sim, fora dele; como ensina Bakhtin, o eu que fala no papel 
jamais pode ser confundido com o en que existe fora dele. Seria como tentar erguer-se a si próprio pelos cabelos, diz o filósofo russo. O enunciador permanece assim em sua posição lógica, em sua condição de ser cuja existência é, ao mesmo tempo, certa, uma vez que o enunciado a atesta, mas inacessível, posto que ausente do texto.

A empreitada é tão mais arriscada na medida em que a todo o momento corre-se o risco cair no precipício da ontologia e enveredar por sendas que não são as da semiótica. Daí a preocupação de Greimas, na Semântica Estrutural, em mostrar que a análise semiótica, fiel à velha dicotomia saussuriana langue / parole, deve eliminar do texto toda manifestação de subjetividade. Além disso, o semioticista lista as principais categorias a serem excluídas da análise: as categorias de pessoa, de tempo e de espaço, a dêixis e todos os elementos fáticos em geral (p. 153-4). Em outras palavras, a análise semiótica deveria excluir toda atividade enunciativa, portanto, deveria se restringir ao enunciado já debreado, ignorando o processo de debreagem. Como, então, estudar o ethos do enunciador se ele já não pertence ao escopo da semiótica? Se a atividade que o define - a enunciação — não pertence ao escopo dessa ciência? É que a posição de Greimas mudou e são justamente os termos em que o autor expressa a mudança que fornecem a primeira indicação para a possibilidade — e importância — de um estudo sobre o ethos do enunciador. Vale a pena citar o trecho. Está em Pour une théorie du discuous poétique, ensaio que abre a coletânea Essais de sémiotique poétique:

[...] Ou bem a enunciação é um ato performático não lingüístico e como tal escapa à competência do semioticista, ou ela está presente de uma maneira e de outra — como um pressuposto implícito no texto, por exemplo - e então a enunciação pode ser formulada como um enunciado de tipo particular, isto é, como um "enunciado dito enunciação", uma vez que comporta outro enunciado ao título de actante-objeto, e nesse momento se encontra integrada à reflexão semiótica, que procurará definir o estatuto semântico e gramatical de seu sujeito. (Greimas: 1972, p. 20)

Assim, se o enunciador é apenas uma instância teórica, uma posição lógica, um ser cuja existência não se confunde com a do narrador ou a do produtor físico do texto; se sua existência é apenas pressuposta, na verdade, imposta pela lógica, pela necessidade de rigor formal do modelo; ele também é sujeito de um predicado, a enunciação, cujo objeto é o enunciado, podendo, desse modo, integrar-se à reflexão semiótica, que deverá definir seu estatuto semântico - , portanto, seu ethos, dizemos forçando um pouco o ponto de vista aqui defendido. E à medida que se examina o produto do seu fazer, o enunciado, pouco a pouco se começa a vislumbrar algo sobre o sujeito. Aliás, uma outra lição fundamental da semiótica é que a identidade do sujeito não é apenas semântica, ou seja, decorrente de um conjunto de 
semas que caracterizam o sujeito e o opõem a um indivíduo que não os possui, mas também sintática, isto é, decorrente das condições que garantem sua unidade com o objeto que o define. Em outras palavras, o sujeito é sempre sujeito de alguma coisa, de um objeto descritivo ou modal, sendo essa a base, segundo Greimas \& Courtés (1993: 370), da definição de sujeito da enunciação. O que se quer dizer, enfim, é que o ethos do enunciador pode ser estabelecido mediante a análise dos procedimentos adotados pelo sujeito da enunciação na constituição de seu objeto, o enunciado. Recordando o que foi dito há pouco, as estratégias utilizadas e as escolhas feitas pelo sujeito em seu fazer persuasivo deverão definir seu caráter, portanto, seu ethos. Assim, sua imagem pode ganhar contornos mais nítidos, sua identidade pode adquirir alguma consistência e é possível que até mesmo um corpo se delineie em nossa mente. A partir da análise do enunciado, pode-se, portanto, reconstituir a enunciação e seu sujeito, e, nesse ponto, é secundário se a enunciação é enunciada ou não, se o eu encontra-se explícito no texto ou se, como ocorre com as leis jurídicas, parece surgir do nada, uma vez que a enunciação e seu sujeito sempre estarão pressupostos. Caberá à semiótica explicitar esse sujeito e definir seu estatuto semântico e gramatical. E nesse momento, o conceito de ethos, inaugurado pela retórica, e reformado pela semiótica, poderá ser de grande valia.

Acompanhando o pensamento de Bertrand (2000: 52), entende-se que a atividade do enunciador deve ser apreendida a partir dos actantes da enunciação instalados no texto. São os delegados da enunciação enunciada, narrador, narratário, observador etc., que permitem conhecer a face daquele que os gerou. Têm igual importância os valores colocados em jogo, os percursos e programas narrativos instalados no discurso, as modalidades de debreagem e embreagem utilizadas; enfim, toda a performance do enunciador deverá permitir que se infira sua competência e, a partir dela, que se chegue ao seu ethos. Nunca é demais insistir que o produtor físico do enunciado, no caso, Joaquim Maria Machado de Assis, permanece fora dessa investigação; respeitosamente, afirmamos que ele não nos concerne, deixamo-lo aos (bons) cuidados dos biógrafos e críticos literários para cuidar do ator da enunciação; daquele que é o lugar de convergência e investimento de componentes sintáticos e semânticos (Greimas \& Courtés, 1993: p. 8), o portador do papel actancial de sujeito do discurso e do papel temático de escritor e que, desse modo, constitui o sujeito da enunciação - que aqui chamaremos apenas de Machado de Assis, para distingui-lo do cidadão Joaquim Maria —, o qual não se define por sua biografia, mas pela totalidade dos discursos que produz. Se o ator é o lugar de convergência de investimentos sintáticos e semânticos, se é portador de um papel temático e 
ao menos de um papel actancial, a definição do ethos do enunciador determinará os componentes semânticos com os quais o sujeito se relaciona e que definem sua individualidade.

Contudo, se um dos lados da equação, o enunciador, parece momentaneamente solucionado, o outro, o ethos, começa a apresentar problemas. É que mesmo sendo possível reconstruir o ator da enunciação por meio de seu discurso, é preciso que se atente para o fato de que essa empreitada implica uma mudança importante no conceito, não só em relação à sua definição pela retórica, mas também em relação ao modo como tem sido trabalhado mais recentemente pelas ciências da linguagem. Diz Aristóteles — e teóricos da análise do discurso como Maingueneau concordam — que o ethos é decorrente da imagem criada pelo orador em seu discurso para convencer o seu auditório. Ora, o enunciador não produz, no sentido retórico do termo, discurso algum, na medida em que aquele que diz eu no texto é sempre o narrador; logo, uma análise pura e simples do discurso desse sujeito nos levaria à definição do ethos do narrador, como ficou dito acima, e não ao enunciador. Aliás, foi por esse motivo que se optou por uma via, digamos, indireta para o estudo do ethos do enunciador: não mais o discurso, mas os procedimentos utilizados para debrear o discurso. Desse modo, itens de análise caros à retórica, como as figuras de linguagem, o léxico, a prosódia ou a sintaxe empregados, seriam de pouca valia, pois conduziriam, uma vez mais, ao narrador. É preciso, portanto, que fique claro que o conceito passa por uma mudança importante que é, ao mesmo tempo, um alargamento do sentido original: em vez de ser apreendido apenas no nível discursivo, o ethos passa a ser buscado também nos níveis narrativo e fundamental, pois é principalmente nesses níveis, prévios à discursivização das estruturas narrativas, que se pode ter acesso ao fazer do enunciador e entender esse fazer como definidor da identidade do sujeito da enunciação.

Todavia, essa não é a única alteração no conceito; há ainda outra, de certa forma correlata. Segundo os estudos retóricos, a função do ethos é conferir credibilidade ao discurso, fazer com que suas palavras pareçam verdadeiras, conquistando, assim, a adesão do ouvinte. No entanto, não se pode usar das mesmas medidas quando se lida com um texto literário. È verdade que o discurso poético é também um discurso persuasivo, mas, obviamente, não se busca convencer ninguém que algo realmente ocorreu, mas que poderia ter ocorrido ou poderá acontecer. É a questão do embate entre verdade e verossimilhança discutido lá atrás. Não é possível afirmar que o enunciador de textos literários deseje ganhar a adesão do leitor, 
no sentido adotado pela retórica; trata-se, antes, de proporcionar-lhe um prazer, principalmente estético, que implica suspensão de toda dúvida em relação ao conteúdo de verdade daquilo que lhe é oferecido. É o que afirma Genette, com a clareza que lhe é peculiar, em Fiction et diction:

Entrar na ficção é sair do campo ordinário do exercício da linguagem, marcada pelas preocupações de verdade ou de persuasão que comandam as regras da comunicação e da deontologia do discurso. Como vários filósofos têm repetido desde Frege, o enunciado de ficção não é nem verdadeiro nem falso (mas somente, diria Aristóteles, "possível") ou é ao mesmo tempo verdadeiro e falso: ele está além ou aquém do verdadeiro e do falso, e o contrato paradoxal de irresponsabilidade recíproca que ele firma com seu receptor é um emblema perfeito do desinteresse estético. (p. 99).

Ora, se, como diz Genette, entrar na ficção é abandonar as preocupações de verdade ou de persuasão, e se nela, enunciador e enunciatário partilham de uma irresponsabilidade recíproca, no tocante à falsidade do que é lido, qual o sentido de se falar em ethos, já que sua função é justamente contribuir para a persuasão do enunciatário - e, nesse caso, a persuasão é de outra natureza?

O interesse pelo ethos, no caso dos textos ficcionais, não reside no papel desempenhado na persuasão, tal como na retórica, mas no fato de ele constituir uma porta de entrada para o exame da identidade do enunciador. Tanto um texto ficcional quanto outro não-ficcional projetam uma imagem da enunciação que não corresponde ao indivíduo real, pois se trata de uma imagem construída, um simulacro, que, nas mais das vezes, quer se passar pelo sujeito "real". A diferença é que, no discurso ficcional, o enunciador, em virtude da suspensão de uma das cláusulas do contrato enunciativo (que será estudado mais à frente), está desobrigado de falar a verdade, e o enunciatário de procurar por ela. Em bom português, o leitor sabe que o autor não fala "a sério"; assim, a imagem que se depreende da leitura não pode mais ser atribuída a nenhum individuo "real", ou, ainda que seja, esse indivíduo real não pode mais ser responsabilizado pelo que foi dito. Assim, não se pode mais imputar ao enunciador as idéias defendidas por aquele que fala no romance, isto é, que diz eu. Pensar de modo diferente seria atribuir ao enunciador, ao autor implícito, como diz a teoria literária, idéias que são de seus narradores. Em L'art de convaincre, Halsall (1988: 239-40) apresenta um exemplo que ilustra bem o problema. Em 1984, o jornalista Peter Reading publicou em uma revista literária um poema que abordava o conflito entre israelenses e palestinos sob a ótica dos últimos. Durante meses, o autor e a publicação foram acusados de anti-semitismo, sob a alegação de que seu ponto de vista seria o mesmo dos terroristas palestinos. Halsall comenta 
que a procedência da acusação depende da natureza das relações entre o narrador e o autor do poema ou, pode-se dizer, entre o enunciador e o narrador. Se não houvesse distinção entre os dois níveis e o eu do texto remetesse de fato ao autor ontológico, então o jornalista poderia ser acusado de anti-semitismo. Por outro lado, se for considerado que se trata de instâncias distintas, que o ponto de vista do jornalista não pode ser assimilado ao do narrador, então cai por terra tal alegação.

Como as palavras do eu que fala no texto ficcional não podem ser atribuídas ao enunciador, mas ao narrador, é preciso contar com uma amostra de textos suficientemente grande para permitir a constatação de que determinada prática constitui um comportamento do enunciador, portanto seu ethos. Seguindo o raciocínio de Bertrand, procura-se detectar o ethos do enunciador pelo modo como ele instala no enunciado os actantes da enunciação e do enunciado. Espera-se, assim, fazer com que a enunciação deixe de estar apenas pressuposta e passe a ganhar também um revestimento semântico, de modo que seja possível mostrá-la como uma criação ${ }^{38}$ ou, para usar os termos de Greimas, como um enunciado dito enunciação. Em outras palavras, pretende-se chegar ao indivíduo não tanto pelo dito, mas, principalmente, pelo dizer. Ao discutir a individualização, Greimas \& Courtés afirmam que, apesar das transformações sofridas e realizadas pelo sujeito, sua identidade permanece constante quando enfocada como um conjunto de traços pertinentes que distinguem seu fazer e/ ou seu ser do de outros atores: consideraremos então a individualização como um efeito de sentido, que reflete uma estrutura discriminatória subjacente (1993: 187 - grifo meu). A individualização que se busca não é aquela produzida pelas biografias ou mesmo pela crítica literária, mas a que é fruto de um fazer, da construção de um dado objeto. O que se quer determinar é o conjunto de semas que se depreendem desse fazer e cujo efeito de sentido é a constituição de uma individualização, portanto, de uma identidade da enunciação e de seu ator que os distinga da dos demais sujeitos na mesma posição.

$\cos \cos \cos \cos 20$

\footnotetext{
${ }^{38}$ Entende-se que esta foi talvez uma das mais geniais criações de Fernando Pessoa: a construção poética - de atores da enunciação (Alberto Caieiro, Álvaro de Campos, Ricardo Reis, Fernando Pessoa, ele mesmo, dentre outros), dotados de personalidades e biografias próprias que eram confirmadas pelo ethos construído nos poemas que produziram.
} 
A questão é mais complexa — ou ao menos assim parece — do que a levada a cabo pela retórica, pois agora é preciso lidar com várias debreagens que dificultam a definição do caráter do enunciador, já que ele está oculto pelo narrador, especialmente nos casos em que este assume explicitamente a condução da narrativa. Por isso, no caso da literatura, não é possível fazê-lo com base em apenas uma obra, uma vez que cada romance tem sua identidade própria, com seu narrador e os actantes do enunciado que realizam percursos também distintos. É preciso, então, partir de uma amostra representativa das enunciações do enunciador e, da diversidade, obter a constância que remete ao ator da enunciação, o qual constrói o mundo e si mesmo quando enuncia (Greimas \& Courtés 1993: 127). A inspiração vem das contribuições de Bertrand, já citado, e de Fiorin (1996: 32), que propõe que as marcas da enunciação presentes no enunciado permitem reconstituir o ato enunciativo, possibilitando, portanto, conhecer o enunciador no tocante a três aspectos: o das competências para a produção de um enunciado, o da ética da informação e o do acordo fiduciário entre enunciador e enunciatário. Posteriormente, (2004: 125) Fiorin propõe que, na totalidade das obras do autor, sejam buscadas recorrências em quaisquer elementos composicionais do discurso on texto que permitam identificar o ethos do enunciador.

Considerando as contribuições dos dois autores, propõe-se que a determinação do ethos do enunciador dos romances de Machado de Assis avalie cinco aspectos:

1. Configurações narrativas e discursivas. Como não é possível utilizar as palavras e o ponto de vista do narrador para definir o ethos do enunciador, e como o enunciador é, pode-se dizer, mudo, optou-se por analisar as configurações narrativas e discursivas de cada romance para verificar se há recorrências e, em caso positivo, o que elas poderiam indicar em relação ao objeto deste trabalho, o ethos. Greimas \& Courtés (1993: 58-60) definem configurações discursivas como um conjunto de micro-narrativas que possuem uma organização sintática e semântica autônomas e que podem ser acolhidas por unidades maiores, que as englobam. Como toda narrativa, a micro-narrativa apresenta um percurso narrativo, composto de um ou mais programas narrativos que recebem, em um nível discursivo, um revestimento figurativo também recorrente. Elas gozam de certa autonomia, mas, naturalmente, assumem valores e funções diferentes conforme ocorre sua incorporação por discursos englobantes. A hipótese deste trabalho é que na medida em que ethos do enunciador caracteriza-se pela constância do saber com o qual o enunciador coloca o enunciatário em conjunção, tal comportamento deve se refletir em 
uma predileção por uma determinada configuração discursiva, ou seja, pela repetição de determinados programas e pela instalação recorrente de sujeitos que buscam valores semelhantes. Finalmente, a relação tímica do enunciador com os sujeitos, programas e valores instalados no enunciado deve ser de mesma natureza.

É verdade, a recorrência de um dado programa narrativo, por exemplo, de apropriação, não é suficiente para determinar uma configuração discursiva; é preciso que o revestimento figurativo desse programa também seja constante. Ou seja, buscam-se constantes sintagmáticas e paradigmáticas: os mesmos sintagmas narrativos sendo preenchidos por elementos de uma mesma classe paradigmática. Assim, o programa narrativo de apropriação deve ser figurativizado sempre da mesma forma, por exemplo, por meio de um casamento. Lembrando ainda que a configuração é um enunciado autônomo, capaz de aderir a discursos mais complexos, entende-se que sua análise revelará um modo de ser do enunciador que não seria apreensível em discursos maiores, uma vez que aí haveria a interferência do discurso englobante. Talvez um exemplo rápido torne essas idéias mais claras. Veja-se o caso de Julio Verne: em vários de seus romances - Viagem ao centro da terra (1864), Da terra à lua (1865), Vinte mil léguas submarinas, (1870); A volta ao mundo em 80 dias (1876), Cinco semanas em um balão (1893), para ficar nos casos mais conhecidos —, é instalado um sujeito já modalizado pelo saber, e que é manipulado (ou auto-manipulado) para querer saber mais ou para comprovar o que sabe. Esses sujeitos empreendem, então, com sucesso, um percurso não possível, ou pouco provável, para a época, demonstrando, ao final, que seu saber é superior ao dos demais, ainda que não restem provas materiais de seus feitos. A reincidência de tal configuração mostra um enunciador que privilegia a fantasia em detrimento da realidade, e que, ao mesmo tempo, valoriza a ciência e a busca pelo saber.

2. Instalação do narrador. Três questões serão examinadas nesse item: a opção do enunciador por um tipo de debreagem (enunciva ou enunciativa), o sincretismo ou não do narrador com os actantes do enunciado, e, em menor grau, a autoridade do narrador, assunto que ocupa também a discussão sobre delegação do saber e contrato enunciativo. A hipótese é que a forma como o narrador é instalado traz revelações sobre o ethos do enunciador. Por exemplo, a debreagem enunciativa da enunciação já é um primeiro indicador de subjetividade, na medida em que haverá um eu instalado no enunciado que narrará fatos que lhe concernem de alguma maneira. Observe-se que a presença explícita do narrador 
não implica, necessariamente, sua participação nos fatos narrados. É o que acontece quanto o narrador conta fatos que ouviu ou aos quais teve acesso por meio de anotações que encontrou. Nesses casos, o narrador não estará em sincretismo com os actantes do enunciado, pois não participou dos fatos narrados. Isso não o impede, porém, de apresentar-se explicitamente como narrador que se empenha como fiel portador das informações recebidas, transformando-se, assim, em sujeito de outro programa narrativo: a construção da narrativa primeira. Por exemplo, a coletânea Dentro das marés, de Joseph Conrad $^{39}$, é formada por contos cujos narradores primeiros não participaram dos fatos que relatam, mas tiveram acesso à matéria narrada por meio de escritos encontrados ou de relatos de um narrador segundo. Um segundo grau de subjetividade decorre da instalação de um narrador intradiegético, isto é, que participou dos fatos narrados. Nesse caso, a subjetividade é ainda maior, uma vez que o narrador é, digamos, parte interessada na matéria narrada, não só porque, enquanto actante do enunciado, executou os percursos narrativos, mas também porque, como actante da enunciação enunciada, empenha-se na transmissão dos fatos. Nesses casos, o leitor sempre poderá se perguntar se os acontecimentos realmente aconteceram conforme relatado pelo narrador e se a apreciação feita por ele desses fatos é correta. É o caso dos contos de Edgar Allan Poe, freqüentemente narrados em primeira pessoa pelo sujeito que os viveu. Em muitas das narrativas, o leitor nunca sabe onde acaba a "realidade" e onde começa o delírio do narrador, nem mesmo sabe se este não age dessa forma para ocultar ou justificar seu crime.

3. Delegação do saber. Como todo ato de comunicação, o romance nasce do desejo da instância de enunciação de transmitir um saber sobre algo a outra instância de enunciação. Visando a tal objetivo, são instalados no enunciado diversos actantes cognitivos, observadores, narradores etc., encarregados de manipular o saber. A recepsão desse saber pelo enunciatário dependerá da atuação desses actantes e, principalmente do saber a eles delegado pelo enunciador. Alguns aspectos são importantes para este trabalho. Primeiro, o observador, ou observadores, desses romances têm foco total ou parcial? Isto é, o enunciador delega a eles um saber irrestrito ou um saber limitado de alguma forma? Segundo, o foco é interior ou exterior aos personagens? Quer dizer, o actante cognitivo adota a perspectiva de um dos actantes do enunciado ou é exterior a todos? Por fim, e mais importante, percebe-se

\footnotetext{
${ }^{39}$ Dentro das Marés. Tradução de Julieta Cupertino. Rio de Janeiro, Editora Revan, 2004.
} 
alguma defasagem entre o saber desses actantes e o do enunciador? Essa questão liga-se à da autoridade dos narradores que se equivocam ou que são pouco confiáveis: nos casos em que se observa uma defasagem entre o saber do enunciador e o do narrador, é comum acontecer de o primeiro não sancionar de forma positiva o saber do segundo, dados os equívocos que comete. Finalmente, a autoridade do narrador pode ainda ser mitigada ou ampliada conforme ele seja intra ou extra diagético. Albert W. Halsall afirma que há dois aspectos implicados na autoridade do narrador: o primeiro decorre da ausência de contradições entre os atos e os dizeres dos narradores / personagens e também entre as visões que eles dão dos incidentes intradiagéticos (1995: p. 350); o segundo seria oriundo do julgamento que o narrador faz de fatos históricos. Se ele apresentar um ponto de vista errado ou absurdo, indicará, provavelmente que o enunciador não partilha dos mesmos valores.

Um caso bem freqüente na obra de Machado é a escravidão: em geral seus narradores não se importam com ela e mesmo a defendem. Contudo, apesar da indiferença do narrador em relação ao tema, é imensa a lista de obras em que a questão é abordada. Dentre muitos casos, veja-se o do conto $O$ caso da vara (Páginas recolhidas, 1899). Nele, não há uma só palavra do narrador contra a escravidão; no entanto, toda a ignomínia dessa instituição está claramente identificada nos abusos cometidos por Sinhá Rita, protetora do protagonista Damião, contra uma escrava adolescente. É também o caso do narrador das crônicas de Machado de Assis, especialmente nas colunas Balas de estalo, Bons dias! e A semana. Nesses textos, via de regra, o cronista assume o papel de escravocrata ferrenho, que tem idéias inadmissíveis acerca da escravidão, de modo a tornar-se não confiável aos olhos do leitor ${ }^{40}$; Nesses casos, contudo, é claro que o enunciador afasta-se do narrador, uma vez que suas opiniões absurdas não seriam defendidas nem mesmo pelo mais ferrenho escravocrata, pelo menos, não em público. No caso da escravidão, está claro que a enunciação não poderia assumir as idéias defendidas pelo cronista, pois as sabe absurdas. Há, portanto, um desnível entre o saber dessa instância e o do narrador. Sobressai, assim, sua competência epistêmica: o enunciador, por meio de artifícios variados, demonstra sua discordância em relação ao ponto de vista do narrador e

\footnotetext{
${ }^{40} \mathrm{~A}$ esse respeito, vale lembrar, dentre muitas, as crônicas 19.5 e 26.6 de 1888, nas quais Machado discute práticas comuns nos dias que sucederam a escravidão. Na primeira, o cronista conta, orgulhoso, que, apesar da abolição, continuava e espancar seu ex-escravo, Pancrácio, pois isso era um impulso natural e tais impulsos não haviam sido abolidos. Na segunda, mostra prática comum na época: após a abolição comerciantes compravam escravos já libertos de seus ex-proprietários para depois reivindicar uma indenização do governo. Ver Gledson, John. Bons dias! São Paulo: Hucitec, 1992.
} 
evidencia sua capacidade para julgar os fatos narrados. Mais uma vez, aposta-se no modo como o enunciador delega o saber aos actantes instalados no discurso para a constituição de seu ethos.

4. Niveis enunciativos. Ao contrário do que será discutido no item que trata do narrador, aqui não é a natureza da debreagem que será examinada, mas sim sua quantidade. Como ensina As mil e uma noites, o processo de debreagem é infinito: o enunciador delega a palavra a um narrador que a delega a Sherazade que a delega a outro interlocutor que a delega a outro, e assim de forma quase infinita. Cada interlocutor passa, então, a ser considerado o narrador do relato que narra até que delegue a palavra a seu sucessor, que, de interlocutor, é promovido a narrador, enquanto o narrador que o instalou seria elevado à categoria de enunciador. Cria-se, desse modo, uma outra polifonia que não é decorrente das várias vozes existentes em mesmo enunciado, mas da presença explícita de vários narradores que, eventualmente, podem ter visões distintas do narrado. As vozes pertencerão a níveis enunciativos distintos: uma voz será oriunda da primeira debreagem; outra, da segunda; e outra, ainda, da terceira ou de quantas houver. Pois bem, o que se quer verificar é se o enunciador Machado de Assis opta, nas mais das vezes, pela instalação de um único narrador ou se, em geral, instala no texto um narrador primeiro que delega a voz a um narrador segundo. Supondo que exista uma maior freqüência num caso ou noutro, procurar-se-á, como já se tornou costume, verificar o que se pode inferir do ethos do narrador. Imagina-se que um enunciador que instale mais vozes no texto privilegie o debate e a discussão. O texto seria assim um ponto de encontro de vozes convergentes ou divergentes. O passo seguinte será verificar, considerando os achados dos demais capítulos, quais são as causas da convergência e da divergência, e, a partir daí, tentar verificar se é possível depreender o posicionamento do enunciador acerca do que está em jogo. Como se vê mais uma vez, na definição do ethos do sujeito da enunciação, será utilizado o seu fazer, o método por ele adotado para construir seu enunciado, e não seu discurso propriamente dito.

5. Contrato enunciativo. Toda enunciação implica o estabelecimento de um contrato entre enunciador e enunciatário visando a estabelecer o efeito de sentido buscado pelo enunciador em seus enunciados: verdade, mentira, segredo ou falsidade. Assim, há romances que procuram causar efeitos de verdade, de que os fatos narrados realmente teriam ocorrido, e há aqueles que procuram causar o efeito contrário, de que tudo é 
mesmo ficção. Entende-se que é possível definir o ethos de um enunciador de acordo com o tipo de contrato que ele oferece a seu enunciatário: o enunciador dissimulado, por exemplo, optaria por um discurso em que o ser e o parecer estão em oposição; já o enunciador franco optaria pela concordância entre essas duas modalidades. O fato de, nos romances de Machado, a narração ocupar tanto espaço quanto a narrativa, obriga que a investigação do contrato enunciativo considere os dois planos. Assim, será investigado o contrato implícito no narrado e na narração e, a partir dele, será verificado se enunciação e o enunciado estão em acordo ou desacordo e, principalmente, se o ator da enunciação desses romances tem um jeito de ser que o definiria como otimista, crente na capacidade do indivíduo de representar de forma isenta a realidade, ou cético em relação a tal possibilidade.

\section{$\cos \cos 20 \cos$}

É importante notar que os cinco enfoques listados são, na verdade, o desdobramento do que se afirmou a respeito da constituição do ethos. Mais acima ficou dito que o ethos é elemento importante na persuasão e que esta consiste na convocação de toda sorte de modalidades para fazer o enunciatário crer que aquilo que recebe é verdade. $\mathrm{Na}$ ocasião, foi afirmado que a persuasão envolvia a transmissão de dois saberes, dentre outros: o saber propriamente dito, que o enunciador deseja transmitir ao enunciatário (na nossa notação, $\left.\mathrm{O}_{1}\right)$, e o saber relativo à competência modal do enunciador ( $\mathrm{O}_{0}$ na notação adotada). Como se viu, o segundo tem a função de comprovar a adesão do enunciador às teses que ele próprio defende e, por esse caminho, influi de forma decisiva na adesão ou não do enunciatário. Com a análise dos aspectos citados, pretende-se determinar a natureza desses dois saberes. Cada um dos pontos que serão investigados diz respeito tanto ao saber transmitido pelo enunciador quanto à competência modal do enunciador, ainda que com ênfases diferenciadas. Por exemplo, ao investigar a forma como o narrador é instalado nos romances, descobre-se não só o conteúdo do saber com o qual o enunciador deseja colocar o enunciatário em conjunção - um saber relativo ao sujeito que constrói sua própria narrativa —, mas também é possível ficar conhecendo a competência do enunciador para narrar (portanto, sua autoridade para discorrer sobre o que discorre) e sua visão de mundo sobre essa atividade. $\mathrm{O}$ mesmo raciocínio pode ser feito em relação às configurações narrativas ou qualquer outro dos pontos enfocados. 
$\mathrm{Na}$ relação acima, talvez se sinta a falta de um dos elementos mais freqüentes nos estudos literários, mais ainda naqueles sobre Machado de Assis: o leitor. Antes de qualquer coisa, é preciso definir inicialmente a qual instância se faz referência. Se com o termo leitor quer-se designar o leitor inscrito, isto é, o narratário, então se deve observar que a questão será tratada, ainda que de forma lateral, na discussão da instalação do narrador, pois ambos pertencem ao mesmo nível enunciativo e ambos são instalados no enunciado pelo enunciador. Já o leitor pressuposto pelo romance, isto é, o enunciatário, será definido à medida que o ethos do enunciador for delimitado, pois ambos, enunciador e enunciatário, constituem o sujeito da enunciação. Finalmente, se leitor referir-se ao leitor empírico desses romances, isto é, aos indivíduos que adquiriram os livros e os leram, então tal análise estará fora deste trabalho, pois, como se sabe, não pertence ao escopo da semiótica ${ }^{41}$.

Finalmente, é preciso considerar que se os itens elencados parecem afastar o conceito de ethos da definição que lhe foi atribuída pela retórica, eles confirmam o que o ethos não é determinado pelo que o sujeito diz de si mesmo, mas pelo modo como produz o seu discurso. Aliás, deve-se lembrar que a enunciação é o lugar de exercício da competência semiótica do sujeito, como, aliás, explicam Greimas \& Courtés:

[...] se a enunciação é o lugar de exercício da competência semiótica, ela é, ao mesmo tempo, a instância da instauração do sujeito (da enunciação). [...] O conjunto dos procedimentos suscetíveis de instituir o discurso como um espaço e um tempo, povoado de sujeitos outros além do enunciador, constituem assim para nós a competência discursiva no sentido estrito. Se juntarmos a esta competência o depósito de figuras do mundo e de configurações discursivas, que permitem ao sujeito da enunciação exercer seu saber-fazer cognitivo, os conteúdos da competência discursiva - no sentido amplo desse termo - encontram-se provisoriamente traçados (1993: 127 - grifo meu).

Nas páginas seguintes, procura-se colocar em prática as propostas de Greimas \& Courtés. Partindo dos procedimentos utilizados pelo enunciador para instituir o discurso (os cinco pontos listados mais acima) como um espaço e um tempo povoados de sujeitos, buscar-se-á determinar o depósito de figuras que abastece o sujeito da enunciação para definir o conteúdo de sua competência, e, a partir dela, inferir o ethos do ator da enunciação, a imagem que ele constrói no seu discurso e que se torna fiadora de seu texto. Trata-se, é bom ressaltar, do ethos do ator da enunciação denominado Machado de Assis, que não se confunde com o cidadão Joaquim Maria Machado de Assis.

\footnotetext{
${ }^{41}$ Para um excelente estudo sobre os leitores de Machado, tanto inscritos quanto pressupostos, ver o livro de Hélio de Seixas Guimarães: Os leitores de Machado de Assis: o romance machadiano e o público de literatura no século 19. São Paulo, Nankin / Edusp, 2005.
} 


\section{Configurações narrativas e discursivas}

realização do fazer persuasivo do enunciador implica, basicamente, dois tipos de
estratégias: as estratégias narrativas e as discursivas. As primeiras relacionam-se à construção e ao encadeamento dos programas narrativos realizados pelos sujeitos instalados no enunciado e à manipulação que será exercida entre eles (Greimas \& Courtés, 1993: 359.). Já as estratégias discursivas estão relacionadas aos procedimentos adotados pelo sujeito da enunciação para discursivizar as estruturas narrativas; portanto, dizem respeito aos procedimentos de debreagem e embreagem utilizados. A adoção dessas estratégias pelo enunciador implica ainda o uso de determinadas configurações narrativas ou micro-narrativas, as quais gozam de organização sintática e semântica autônomas e podem se encaixar em unidades maiores, ditas englobantes, onde funcionam como variáveis que assumem valores distintos, de acordo com o contexto no qual se enquadram Greimas \& Courtés (1993: p. 5860). Duas questões, então, apresentam-se: a primeira diz respeito à organização interna de uma configuração: o tipo de programa narrativo, os papéis actanciais e temáticos, os valores em jogo etc. A segunda diz respeito à forma como se dá a integração de uma micro narrativa à narrativa maior que a engloba e que, ao final, irá definir o efeito de sentido do todo. Nos romances de Machado de Assis, por exemplo, uma configuração narrativa recorrente é a constituída por programas narrativos de aquisição de prestígio social., que se encaixa em outra maior em relação à qual funciona como um programa narrativo de uso. Essa mesma configuração recebe ainda três tipos de figurativizações: o casamento (A mão e a luva, Iaiá Garcia, Dom Casmurro, Memorial de Aires), o recebimento de uma herança (Ressurreição, Helena e Quincas Borba) e a extorsão (Procópio, em Iaiá Garcia, o Casal Palha em Quincas Borba, Santos em Esaú e Jacô). Por usa vez, a figura do casamento como meio de ascensão social adquire conotações distintas conforme a narrativa maior que a acolhe, o que, aliás, garante a identidade da narrativa. Por exemplo, o casamento não é abordado da mesma forma em Ressurreição, A mão e a luva e Dom Casmurro, pois cada caso envolve articulações com um contexto mais amplo, especifico e diversificado, embora os valores envolvidos se repitam. 
A reincidência de determinadas configurações discursivas acaba por caracterizar o tipo de estratégia empregada pelo enunciador para manipular seu enunciatário, e a repetição desta permite falar em um determinado proceder do enunciador, em uma maneira de ser, a qual remete, naturalmente, a um ethos. A adoção de determinadas estratégias discursivas indica não apenas a competência do enunciador, mas também sua preferência pela discussão de determinados valores e temas e por determinada figurativização. Trata-se de escolhas que não são neutras do ponto de vista ideológico, mas reveladoras da ideologia do sujeito da enunciação. O tema do sujeito que busca o /poder/ poderia dar origem a vários percursos; mas nos romances de Machado de Assis, por exemplo, relacionam-se, nas mais das vezes, com a questão da ascensão social. Nem sempre é assim, nem mesmo em Machado. é o caso dos contos Um homem célebre (Várias histórias, 1896)e Cantiga de Esponsais (Histórias sem data, 1884), onde o poder-fazer relaciona-se ao /saber-fazer/, e é figurativizado, nos dois casos, por meio de compositores que não conseguem produzir a obra que desejariam. Tampouco a figurativização é neutra, pois a escolha de uma ou de outra figura do mundo para construção do sentido é reveladora da ideologia do sujeito da enunciação. Guardadas as devidas proporções, da mesma forma que, segundo Aristóteles (Retórica, II, I, VI), o orador mostra que é sábio (phrónesis), virtuoso (aretê) ou benevolente (eúnoia), pelo modo como emprega as figuras de linguagem e constrói o seu discurso, pode-se, por homologação ${ }^{42}$, concluir que as estratégias discursiva e narrativa, e tudo o que elas implicam, são reveladoras do caráter do sujeito da enunciação. Portanto, do seu ethos.

A partir desse momento, a tarefa que se impõe consiste em um levantamento das configurações discursivas dos romances de Machado de Assis - isto é, dos programas narrativos; da forma como são figurativizados sujeitos e objetos, os valores buscados, a instalação dos actantes da enunciação enunciada etc. Em seguida, deve-se verificar se há recorrências e se estas permitem, ao lado dos demais pontos, determinar o caráter do enunciador desses romances. Evidentemente, não seria viável analisar amiúde o percurso narrativo de todos os nove romances de Machado de Assis; por esse motivo, optou-se por realizar uma análise mais breve, que, focada nas linhas mestras de cada romance, possa

\footnotetext{
${ }^{42}$ Pretende-se empregar o termo homologação tal como o definem Greimas \& Courtés (1993: 174). Todavia, cabe questionar se se trata realmente de homologação, pois a relação do orador com o discurso não difere da relação do enunciador com a narrativa. A diferença, se existe, é que a relação pretendida por Aristóteles era circunscrita ao nível discursivo, enquanto entendemos que a definição do caráter implica também a determinação das estratégias narrativas.
} 
ressaltar os aspectos julgados mais produtivos para os fins deste trabalho. O que se buscará são as invariantes, tanto temáticas quanto figurativas, que, pela sua recorrência, permitem a construção do caráter do enunciador, de sua ideologia, dos valores com os quais se preocupa e dos objetos de saber com os quais se pretende colocar o enunciatário em conjunção. Em linhas gerais, serão observadas as modalidades de que estão investidos os sujeitos instalados nesses discursos, os valores por eles perseguidos, as sanções sofridas e a maneira eufórica ou disfórica como os valores são reconhecidos pela instância da enunciação.

Para tanto, o conceito de isotopia talvez seja útil. Sabe-se que a isotopia está relacionada à recorrência de temas e figuras que garantem a coesão e a coerência de determinado discurso. Em geral, o conceito é aplicado a um texto específico, isto é, procurase, em dado discurso, a recorrência de traços temáticos e figurativos que permitam entendêlo. É assim que nascem comentários como "este livro fala de...". Pois bem, neste trabalho, serão buscadas isotopias que perpassam não um texto em particular, mas um conjunto deles. Entende-se que a adoção de tal procedimento é justificada pela natureza do objeto pesquisado, o ethos do enunciador, que, como foi visto, não pode ser depreendido por um único discurso, mas apenas por vários deles. Assim, a manutenção de uma mesma isotopia ao longo de vários romances será reveladora de um estoque muito mais amplo de figuras e de temas do enunciador e das regras de que se vale para empregá-los. Considerando que temas e figuras são reveladores do universo de valores do sujeito, e que este compõe o ethos do sujeito, o levantamento das invariantes citadas permitirá um primeiro passo em direção à tarefa proposta.

Conforme já foi dito, predominam nos romances de Machado de Assis percursos de obtenção de prestígio social por meio da realização de casamentos ou do recebimento de heranças. Essa micro-narrativa, ou programa narrativo condensado, combina-se com outros e, assim, constituem a especificidade de cada romance. Como será visto a seguir, a questão não é abordada da mesma forma em todos os romances; e em Ressurreição ela é mais sutil do que nos demais, mas mesmo aí se faz presente. Nas páginas seguintes, cada romance será examinado sob essa ótica para, ao final, verificar-se o que ela tem a ensinar sobre o ethos desse enunciador. 


\section{$A$ ressurreição}

No romance de estréia de Machado de Assis, o narrador apresenta Félix, que entrava em seus trinta e seis anos e era apenas um rapaz vadio e despretensioso $0^{43} \mathrm{ou}$, em outros termos, sujeito do não-querer, já que ser despretensioso é ser desprovido de um sentimento que incite a conseguir algo e a ter desejos e aspirações. $\mathrm{O}$ adjetivo vadio não deixa dúvidas de que a sanção é negativa e que ele é o sujeito do não-fazer, que não exerceu nem exercerá uma performance relacionada ao percurso da narrativa. De fato, ao longo do romance, Félix será, em vão, manipulado para querer constituir família, objeto no qual estão investidos, de forma implícita, valores como status social, estabilidade, felicidade etc. Sabe-se que o moço pode, sabe e está consciente de que deve casar, mas falta-lhe o querer. Como este não se efetiva, ele termina o romance sem atender à manipulação a que fora exposto: acaba solteiro, como começou, não operando aquela que seria sua principal transformação.

Lívia é uma viúva, de extrema beleza, como convém, que, ao contrário de Felix, quer casar, porém não pode fazê-lo, pois depende do herói que, conforme visto, não cede às manipulações a que é submetido, inclusive por ela. O resultado é que também Lívia chega ao final do romance no mesmo estado em que estava no seu início, viúva, mas com a diferença de que opera duas transformações importantes, como indica o título do romance: primeiro, sucumbe ao ser abandonada por Félix no altar; depois, lentamente, ressurge para a vida.

Como já se desconfia, e como acontecerá em outros romances de Machado, o programa constituir família é central na trama e importante para a realização de um programa de base que pode ser denominado obter status social. No entanto, ao contrário do que ocorre, por exemplo, em $A$ mão e a luva ou em Dom Casmurro, o casamento não é visado pelos pretendentes apenas como solução para uma situação social incômoda (como o seria para Guiomar e Capitu). Uma vez que Félix e Lívia gozam de boa situação social, o casamento é, antes de tudo, solução para uma questão amorosa e ato de obediência a uma imposição da sociedade. O narrador conta, no início do romance, que Félix fora tirado da pobreza por uma herança inesperada, adquirindo meios de não pensar no dia seguinte ${ }^{44}$, isto é, de não precisar mais trabalhar até o fim de seus dias. O narrador pouco conta da situação social de Lívia, mas, considerando-se que planejava viagens à Europa, supõe que pertencia à mesma classe

\footnotetext{
${ }^{43}$ Obra Completa, p. 117.

${ }^{44}$ Idem, p. 117
} 
que Félix. Além disso, a moça é beneficiária de, ao menos, duas heranças: a do marido e a da mãe.

Contudo, a posição social dos protagonistas e paixão mútua não ofusca o fato de que o casamento é visto como uma obrigação da sociedade, estando, portanto, ligado ao status social do indivíduo. Veja-se a passagem em que Félix tem remorsos por ter desistido, na véspera da realização da cerimônia, de casar-se:

[...] A consciência padecia também, porque a sociedade, que ele não vira no primeiro instante, agora lhe parecia como um juiz inflexível, a pedir-lhe contas de uma injúria sem explicação. (Obra Completa, vol. I p. 188 - grifos meus).

A consciência de Félix lhe dói não pelo sofrimento infringido a Lívia, praticamente abandonada no altar, mas porque agora ele percebe que a sociedade é juiz implacável, idéia que voltará com mais ênfase algumas páginas adiante. Aí está um dos elos importantes desse romance com os demais romances de Machado: o papel da sociedade como destinador do sujeito e a constituição da família como performance essencial daquele que almeja uma posição nessa sociedade. Como nenhum dos sujeitos executa os programas que lhe foram propostos pelo destinador (casar-se), e nem adquirem as modalidades que se esperava que adquirissem (o querer, no caso de Félix; o poder, para Lívia), ambos terminam com menos do que possuíam originariamente, o que, em síntese, poderia qualificar esse romance como uma seqüência de programas narrativos que culminam na privação de valores. A sanção final não será a mesma para os dois personagens. É a Lívia que se refere o título do romance; é ela quem, depois de morrer socialmente, ressurge, passando da disjunção total, representada pela morte, para vida. Embora seja sancionada negativamente, ao tornar-se solitária, ela é também sancionada positivamente: preserva seu encanto e permanece a mesma feiticeira amável de outro tempo, tendo como consolo o filho do primeiro casamento, companhia de sua velhice ${ }^{45}$. Ou seja, a parcela positiva da sanção decorre do fato de ela ter já uma vez realizado o percurso que lhe era devido: casar-se. Já Felix, que dispunha de todos os meios que o podiam fazer venturoso, segundo a sociedade, [... é essencialmente infeliz. ${ }^{46}$. Repare que a posição da sociedade, quem o narrador é fiel preposto, como destinador judicador é novamente explicitada. Fora a sociedade que dera a Felix todas as modalidades para que ele realizasse o fazer que era sua obrigação: ele possuía dinheiro, profissão, aparência e tudo o mais para executar o programa

\footnotetext{
${ }^{45}$ Obra completa, p. 195.

${ }^{46} \mathrm{Id}$. Ib.
} 
a ele proposto. Como não cumpre a sua parte, recebe o devido castigo: torna-se essencialmente infeliz: Ao final, para que não restem dúvidas, o narrador explica o crime e o castigo de Félix:

Não se contentando com a felicidade exterior que o rodeia, quer haver essa outras das afeições íntimas, duráveis e consoladoras. Não a há de alcançar nunca, porque o seu coração, se ressurgiu por alguns dias, se esqueceu na sepultura o sentimento da confiança e a memória das ilusões. (Obra Completa, p. 195 - grifo meu).

O que se recrimina, afinal, no médico, não é exatamente, ou não apenas, ter abandonado a noiva às vésperas do casamento, mas não se ter contentado com a felicidade exterior, aquela mesma oferecida pela sociedade via casamento, e ter ido buscar afeições intimas duráveis e consoladoras. A sedução do casamento não funcionou, pois os valores buscados pelo sujeito eram diferentes dos propostos pelo destinador.

Em síntese, no romance de estréia de Machado, vislumbram-se alguns temas que acompanharão o enunciador em todos os demais: a preocupação com a posição do indivíduo na sociedade, a importância da família ${ }^{47}$ - em razão do casamento e/ou do recebimento de heranças - como elemento fundamental para obtenção uma boa colocação social, e, finalmente, uma visão nada romântica das relações pessoais. Além disso, a figurativização não será alterada de forma significativa nas demais obras: sempre haverá homens jovens e aparvalhados (Estácio, Jorge, Brás Cubas, Bentinho...), manipulados com mais ou menos sucesso por moças sagazes (Guiomar, Helena, Iaiá, Vigília, Marcela, Sofia, Capitu...). O que afasta Ressurreição dos romances que o sucederão é o fato de o componente amoroso apresentar mais força do que a habitual. Todavia, a distância volta a diminuir quando se observa que Félix é sancionado negativamente, justamente por privilegiar as afeições íntimas. Como será visto a seguir, esse foi o primeiro e o último dentre os protagonistas dos romances de Machado a cometer tal falha.

\section{A mão e a luva}

No segundo romance de Machado, os dois atores principais poderiam ser vistos como um ator dual, correspondente, em um nível mais profundo, a um único actante — fato, aliás, já sugerido pelo título. Guiomar e Luis, os protagonistas, estão em busca de um mesmo

\footnotetext{
${ }^{47}$ A esse respeito, recorde-se a insistência com que Sabina propõe a Brás Cubas que se case. Está entre os capítulos LXXXI e CCXX de Memórias póstumas.
} 
objeto de valor —- a ascensão social —- e são caracterizados pelas mesmas modalidades. Os dois são descritos como ambiciosos, o que significa, adotando-se a definição do Houaiss, que são caracterizados por um forte desejo de poder ou riquezas, honras on glória. O oposto, portanto, de Félix. Os dois querem, devem, sabem e podem conseguir o objeto, restando-lhes apenas colocar em prática os programas narrativos imaginados para esse fim. Para Luís, a ascensão acontecerá via trabalho, mas deve contar, como Cristiano Palha explicará em detalhes mais tarde, com a força moral da mulher. Para Guiomar, a ascensão se fará via casamento, mas para que este conduza ao fim desejado, é preciso que o escolhido goze de uma posição ou venha a obtê-la de um jeito ou de outro. Os parágrafos abaixo relatam os percursos imaginados e os valores buscados pelos dois sujeitos:

Guiomar amava [Luís Alves] deveras. Mas até que ponto era involuntário aquele sentimento? Era-o até o ponto de lhe não desbotar à nossa heroína a castidade do coração, de lhe não diminuirmos a força de suas faculdades afetivas. Até aí só; daí por diante entrava a fria eleição do espírito. Eu não a quero dar como uma alma que a paixão desatina e cega, nem fazê-la morrer de um amor silencioso e tímido. Nada disso era, nem faria. Sua natureza exigia e amava essas flores do coração, mas não havia esperar que as fosse colher em sítios agrestes e nus, nem nos ramos do arbusto modesto plantado em frente de janela rústica. Ela queria-as belas e viçosas, mas em vaso de Sèvres, posto sobre móvel raro, entre duas janelas urbanas, flanqueado o dito vaso e as ditas flores pelas cortinas de caxemira, que deviam arrastar as pontas na alcatifa do chão.

Podia dar-lhe Luís Alves este gênero de amor? Podia; ela sentiu que podia. As duas ambições tinham-se adivinhado, desde que a intimidade as reuniu. O proceder de Luís Alves, sóbrio, direto, resoluto, sem desfalecimentos, nem demasias ociosas, fazia perceber à moça que ele nascera para vencer, e que a sua ambição tinha verdadeiramente asas, ao mesmo tempo que as tinha ou parecia têlas o coração. Demais, o primeiro passo do homem público estava dado; ele ia entrar em cheio na estrada que leva os fortes à glória. Em torno dele ia fazer-se aquela luz, que era a ambição da moça, a atmosfera que ela almejava respirar. Estêvão dera-lhe a vida sentimental, — Jorge a vida vegetativa; em Luís Alves via ela combinadas as afeições domésticas com o ruído exterior (Obra Completa, p. 253-4 - grifos meus)

O texto fala por si e dispensa maiores comentários; confirma a ambição de ambos e o domínio do cálculo — próprio do espírito capitalista — sobre a paixão. No momento em que Guiomar tece essas considerações, Luís Alves já é deputado - é o tal primeiro passo do homem público - e a moça tem a certeza de que ele poderá livrá-la da situação incômoda de agregada, sem que, com isso, precise se sujeitar a mais um favor, como poderia ocorrer se aceitasse a mão de Jorge, sobrinho de sua benfeitora. Ao escolher Luis Alves, Guiomar cumpre uma etapa do percurso que estabeleceu para si e em nada conflita com os valores desejados. Embora haja sentimentos nessa escolha, o que predomina é a fría eleição do espirito, que elege Luís visando a um fim claro: a ascensão social. Como se sabe, o casal se une ao final, constitui família, e, assim, cumpre cabalmente o programa que lhes havia sido proposto pelo mesmo destinador . Naturalmente, são sancionados positivamente (isso o narrador não 
conta, mas dá a entender). A passagem é, de fato, longa, mas é importante lê-la toda para que se observem os valores em jogo nesse romance — os mesmos que se faziam presentes em Ressurreição:

[...] Os anos passaram depois, e à medida que vinham, ia-se Estêvão afundando no mar vasto e escuro da multidão anônima. O nome, que não passara da lembrança dos amigos, aí mesmo morreu, quando a fortuna o distanciou deles. Se ele ainda vegeta em algum recanto da capital, ou se acabou em alguma vila do interior, ignora-se.

O destino não devia mentir nem mentiu à ambição de Luís Alves.

Guiomar acertara; era aquele o homem forte. [...]

— Vi que você era homem resoluto, disse a moça a Luís Alves, que, assentado, a escutava. outra coisa.

- Resoluto e ambicioso, ampliou Luís Alves sorrindo; você deve ter percebido que sou uma e

- A ambição não é defeito.

- Pelo contrario, é virtude; eu sinto que a tenho, e que hei de fazê-la vingar. Não me fio só na mocidade e na força moral; fio-me também em você, que há de ser para mim uma força nova.

— Oh! sim! exclamou Guiomar.

E com um modo gracioso continuou:

- Mas que me dá você em paga? um lugar na câmara? uma pasta de ministro?

- O lustre do meu nome, respondeu ele.

Guiomar, que estava de pé defronte dele, com as mãos presas nas suas, deixou-se cair lentamente sobre os joelhos do marido, e as duas ambições trocaram o ósculo fraternal. Ajustavam-se ambas, como se aquela luva tivesse sido feita para aquela mão. (Obra Completa, p. 269-70 - grifos meus).

Na mesma página em que narra a felicidade dos recém-casados, o narrador relata a sanção negativa recebida por Estevão, amigo de Luís, e explica sua causa. Tal como Félix, ele é reprovado por sua falta de ambição. Agora, descobre-se que a sanção negativa consiste em afundar-se no mar vasto e escuro da multidão anônima... e acabar em alguma vila do interior, quer dizer, não sobressair-se de forma alguma e, ainda por cima, afastar-se do convívio com a (subentende-se) boa sociedade da época. No extremo oposto, estão Guiomar e Luís, cuja ambição - explicitada cinco vezes no trecho citado - funciona como patrocinadora das relações comerciais que ambos estabelecerão e das quais cada qual será mercadoria, administrador e cliente do outro, de uma forma que será aprimorada e explicitada mais tarde pelo casal Palha. A natureza da relação entre Luís e Guiomar está claramente colocada: Guiomar é, na verdade, um objeto qualificante para Luís: uma força nova. Mas Luís deve pagar por ela com lustro de seu nome. Tudo isso será recolocado na relação de Palha e Sofia, com uma diferença: aqui não há a ironia que caracteriza o narrador de Quincas Borba, que mostra a oposição entre enunciação e enunciado. Por enquanto, cumpre destacar que essa ambição ou, em termos modais, um querer intenso - é valorizada euforicamente pelo narrador, ao ser chamada de virtude, da mesma forma que a não ambição de Félix e Estevão, (que o narrador 
chama de frouxidão), é valorizada disforicamente. Ora, a disforia está ligada aos valores do percurso em jogo; nos dois casos, esse querer é necessário para que se cumpra a ascensão social para a qual são manipulados todos os sujeitos. Uma última observação: essa questão estará presente em toda a obra de Machado, porém com sinal trocado.

\section{Helena}

Helena apresenta questões bastante semelhantes às observadas nos dois romances anteriores. Como se sabe, o amante da mãe de Helena, Conselheiro Vale, a reconhecera postumamente como sua filha legítima e lhe legara parte da herança. O pai verdadeiro de Helena concorda com a farsa, que ela aceita relutante, apesar das implicações existentes todas explicitadas no texto. E é o verdadeiro pai de Helena que as recorda, quando explica a Estácio e ao Padre Melchior os argumentos que usara para convencer a filha:

[...] Sabendo a verdade, [Helena] não queria escondê-la ao mundo. Aceitando o reconhecimento, entendia que prejudicava direitos de terceiro, além de repudiar-me solenemente, o que não queria fazer desde que adquiria a liberdade de ação. Entre a herança e o dever, dizia ela, escolho o que é honesto, justo e natural. [...] Tê-la comigo era a minha ventura, o meu sonho, a minha ambição; era a realidade que eu chegara a tocar com as mãos. Mas, podia atá-la ao carro decrépito da minha fortuna, dar-lhe o pão amargo de todos os dias? A família do conselheiro ia afiançar-lhe futuro, respeito, prestígio; a lei ia ampará-la. [...] Adverti que, cedendo à vontade do morto, cavaria um abismo entre mim e Helena, e que não mais, ou só raramente e a ocultas, podia desfrutar a felicidade de lhe dizer que a amava, de ouvir a mesma palavra de seu coração [...] Não a convenci. [...]. A nobre alma repudiava a cumplicidade e o lucro de uma usurpação. Eu não via usurpação, porque a meus olhos nem os interesses da família do conselheiro, nem as noções da simples moral prevaleciam; eu via minha filha e seu futuro: nada mais. [...] Enfim, meu coração, egoísta e ulcerado, entendia que o reconhecimento daquela pobre criança era o simples retorno das carícias de que eu havia sido defraudado; tais foram os motivos da minha consciência. Helena resistiu até à última; cedeu somente à necessidade da obediência, à imagem de sua mãe que eu invoquei, como um supremo esforço, à fiança que lhe dei de que a acompanharia sempre, de que iria viver perto dela, onde quer que o destino a levasse; cedeu exausta, sem convicção nem fervor. [...] Seu erro foi não ter a prudência necessária para não transpor o abismo que nos separava. (Obra Completa, p. 379-80 grifos meus)

De longe, Helena, a quem repudiava o lucro de uma usurpação, parece muito diferente de Guiomar, esta bastante movida por interesses materiais. Porém, olhando mais de perto, percebe-se que os valores da protagonista e de seu pai (que, curiosamente, chama Salvador) não são assim tão distintos. Como Félix, também Helena tem de optar entre as afeições intimas, duráveis e consoladoras de seu pai — o que significava ter de comer com ele o pão amargo da fortuna paterna - e o respeito, prestígio e o amparo da lei que podiam proporcionar-lhe a família do Conselheiro Vale. Apesar de, em um primeiro momento, optar pelo que é justo, honesto e natural, Helena, diferentemente de Félix, acaba aceitando a manipulação por tentação 
e fica com as benesses da usurpação, mesmo sabendo que com isso cavaria um abismo entre ela e o pai. Observe-se que os cálculos de Guiomar também não são de todo estranhos a Salvador e Helena. O pai ama a filha, mas não pode colocar esse amor à frente do futuro dela. Por outro lado, embora Helena ame o pai, como Guiomar amava as flores, ela não poderia colher os frutos desse amor em sítios agrestes e nem acompanhá-lo no carro decrépito da fortuna dele, aliás, o mesmo de Estevão de Ressurreição. O reconhecimento da família Vale, com todas as benesses daí decorrentes, equivalia às carícias paternas de que Salvador havia sido defraudado. Convém se deter um instante no uso da metáfora. Os dicionários dão o verbo defraudar como sinônimo de espoliar, expropriar, esbulhar e outros semelhantes, mais comumente empregados quando se trata de bens materiais e relações próprias ao comércio. No entanto, o narrador, pela boca de Salvador, utiliza-o para falar de sentimentos. É como se uma fraude própria da esfera jurídica e econômica — uma herança e um reconhecimento falsos suprisse a falta, no sentido semiótico do termo, causada pela privação a que se viu forçado Salvador. Enfim, afeições familiares e bens materiais são colocados na mais absoluta igualdade. Helena é manipulada por dois conjuntos de valores: de um lado, o amor paterno; de outro, os bens materiais. Fica com o segundo, claro. O que pode haver de romântico ou de idealista em uma decisão como essa? Nada, certamente. Prevalece, uma vez mais, a fria eleição do espírito, ainda que com uma camadinha de bons sentimentos.

Antes de avançar, é preciso ressaltar que, nos três romances, a mercantilização das relações, a ambição e a acumulação são todos valorizados euforicamente, e, em relação a esse fato, não há diferença nos percursos apresentados ou na posição do narrador. Há, contudo, uma aparente discordância entre as dois romances anteriores e Helena. No primeiro, Félix não atende ao chamado de seu destinador e é sancionado negativamente, o mesmo acontecendo com Estevão em $A$ mão e a luva. Já Guiomar e Luís o obedecem e são sancionados positivamente. Helena ouve o mesmo chamamento e, ainda que com relutância, atende,-o mas... ao contrário do que se esperaria nesse quadro de valores, foi sancionada negativamente, já que morre sem poder usufruir da condição social que conquistara. Por quê? Quem explica é Salvador, quando afirma que o erro de Helena foi não ter a prudência necessária para não transpor o abismo que os separava. Em bom português, o erro de Helena foi não ter rompido totalmente com os laços paternos, tendo desejado manter as tais afeições íntimas a que se referia o narrador de Ressurreição. Observe que, como última tentativa de preservar o status que a filha havia obtido, Salvador desaparece — no que, aliás, obtém a concordância 
tácita de todos. Contudo, pode-se argumentar que, mesmo depois de descoberta a fraude, a família Vale, abençoada pelo Padre Melchior, desejava manter a situação de Helena. Mas aí já é tarde. Há ainda a explicação dada pela própria personagem quando conta que a descoberta da farsa poderia fazer com que a considerassem uma aventureira, ou seja, pessoa que obtém proveitos indevidos - no caso, receber uma herança a que não tinha direito. Confirma-se, também aqui, o papel fundamental e praticamente exclusivo da família como caminho quase único de ascensão social. A via preferencial é, sabe-se, o casamento. Na sua ausência, serve a herança; mas a de Helena atentava justamente contra direitos de terceiro a que se referia Salvador, no trecho citado. Em termos mais diretos: a herança de Helena espoliava os legais direitos de outrem e atentava contra a ordem social estabelecida. Por isso, revelada a fraude, ela não pode ser mantida. Veja-se o caso de Rubião de Quincas Borba, cuja herança não era mais legítima do que a de Helena. Embora se possa afirmar que ela foi, ao menos em parte, resultado de sua ruína, isso não se deveu a questões legais ou éticas, e a razão é clara: ninguém nunca a descobriu.

\section{Iaiá Garcia}

Desencanto, desapego, desilusão. Esses são alguns dos adjetivos que Roberto Schwarz (1992) emprega com freqüência para definir Iaiá Garcia. São também eles — todos indicando uma avaliação disfórica dos acontecimentos envolvidos — que dão o tom da diferença desse romance em relação aos anteriores. Sim, também nesse o leitor se vê às voltas com uma heroína nascida com a alma acima do destino ${ }^{48}$, a quem, tal como ocorrido com Guiomar e Helena, cabia corrigir o equívoco da natureza. Também em Iaiá, o paternalismo, o arbítrio e as relações de favor que pontuavam $A$ Mão e a luva e Helena se fazem presentes, mostrando-se agora de maneira explícita; e o narrador tem plena consciência deles, o que não ocorria anteriormente. Por outro lado, ao contrário de Guiomar, Estela recusa a ascensão via casamento, caminho, contudo, percorrido por Iaiá, que dá nome ao livro. Estela rejeita Jorge, pois, ao contrário de Helena, sabe que não é possível misturar afetos e negócios. O consórcio dos desiguais é descartado, tal como fora em Helena, mas aqui, com todas as cores. O narrador conta que Valéria jamais permitiria a união de Estela com Jorge, apesar da afeição que dizia nutrir pela protegida. Sua máxima inflexivel era - lé com lé, cré com cré. O contrário não

\footnotetext{
${ }^{48}$ Obra completa, p. 411
} 
passava de absurdo ou romance ${ }^{49}$. Como ocorrerá em Ressurreição, A mão e a luva e Helena, os sentimentos não podem se sobrepor a questões de ordem prática e social: fazê-lo seria absurdo ou romance, os, quais aparecem como sinônimos, e esse narrador parece ter ojeriza a absurdos. A recusa de Valéria em aceitar uma união desigual desencadeia a trama e dá origem a um comentário do narrador que revela sua clara percepção da diferença entre o ser e o parecer. Para evitar que Jorge se aproxime de Estela, Valéria o envia para a Guerra do Paraguai, atitude que, ao contrário do que poderia parecer, não era uma ação patriótica. O que guerra poderia fazer parecer uma ação patriótica, não é, conforme mostra sucintamente o narrador quando afirma que de um caso doméstico saía uma ação patriótica ${ }^{50}$. Se a afirmação não tem a mordacidade característica dos narradores seguintes de Machado, também não tem a ingenuidade dos primeiros e explicita a presença de outros valores, o que, até então, não ocorria. A afirmação é reveladora ainda da confusão de interesses públicos — vencer a guerra — e domésticos — afastar o filho de más influências dos dominados. Como se vê, a mistura entre o público e o privado, aparentemente distintos, passará, mais e mais, a integrar a paisagem das obras de Machado até se tornar dominante em Esaú e Jacó.

Feitas essas observações, é preciso refletir, em termos mais semióticos, em que medida o percurso narrativo dos sujeitos e os valores em jogo se assemelham aos dos romances anteriores; afinal, procuram-se as recorrências no fazer do enunciador. Já foi dito que o programa da ascensão social via casamento será realizado por Iaiá. No entanto, o mesmo não ocorrerá com Estela, que não ascende, não recebe herança e recusa o casamento com alguém de outra classe social, pois isso significaria uma outra troca de favores, e sua taça de gratidão já estava cheia, conforme conta o narrador ${ }^{51}$. O destinador manipulador continua a ser figurativizado, tal como ocorreu nos dois romances anteriores, na família detentora do capital, mas agora surge a possibilidade do rompimento, ao menos parcial, do contrato, uma vez que Estela recusa a união com Jorge. Antes de qualquer coisa, reconheça-se que a ruptura já fora esboçada em $A$ mão e a luva, quando Guiomar recusa o sobrinho da baronesa, sem deixar de optar pelo casamento como forma de ascensão. Em Helena, a sugestão do suicídio de personagem, não concretizado, segue na mesma direção, mas a morte termina por confirmar as regras do jogo. Em todos os casos, a ruptura é apenas sugerida; nunca

\footnotetext{
${ }^{49}$ Obra Completa, vol. I p. 415

${ }^{50} \mathrm{Id}$. Ib.

${ }^{51}$ Idem, p. 411.
} 
implementada. Examine-se, agora, Iaiá Garcia: o destino final de Estela, fora do casamento e da ascensão, é também a solidão, a exemplo de Felix e de Estevão; ou seja, o rompimento de Estela com o jogo vigente lhe acarreta uma sanção também negativa, ainda que o narrador seja mais recatado. Todavia, o final do romance, quando Estela insiste em ser madrinha do casamento de Jorge e de Iaiá, apesar da oposição deles, acaba por reforçar a busca da protagonista por uma superioridade qualquer, como acontece desde o início do romance, porém agora a um preço ainda mais elevado:

[...] Mas Estela não se deu por entendida. O papel de acólita, que a si mesma distribuíra, tinhao desempenhado com lealdade e dignidade. Quis ir até o fim. Era o melhor modo de se mostrar isenta e superior. Jorge sentia-se vexado e transportado ao mesmo tempo, ao observar a simplicidade e o desvelo que a viúva punha naquele ato. Iaiá sentia só admiração e gratidão. (Obra Completa, vol. I, p. 507 grifos meus)

Um último exame do parágrafo acima mostrará que a questão da superioridade também se encontra presente nesse romance, porém, investida em outro objeto. Se é verdade, como afirma Schwarz, que depois de Estela não haverá no romance de Machado outro personagem com igual estatura moral, também é fato que ela não é exceção na busca por uma superioridade qualquer, que parece ser o motor desses personagens. Durante todo seu percurso, também Estela procurou a superioridade - de modo que não se distinguia de Helena ou de Guiomar - , no entanto, não a buscou em objetos descritivos como o casamento ou a ascensão social, mas numa superioridade moral. Como revela o texto acima, seu desejo de tornar-se madrinha de Jorge e Iaiá embute um programa para adquirir alguma superioridade última sobre aquele que sempre lhe fora superior e sobre aquela que passaria a sê-lo. Todavia, a superioridade de Estela, que faz Jorge sentir vexado (portanto, humilhado, inferior), não compensa a não situação social, pois não há possibilidade de realização fora dos quadros da ascensão social. Veja que Estela tenta manipular o pai para que ele busque também essa tal superioridade, mas fracassa. Ao despedir-se, Estela descobre - como Helena o fizera por outras vias - que não teria o amparo do pai, que já lhe diz que ela não fazia nada bem e a repreende, em outras palavras, por também buscar afeições íntimas, que só atrapalham. A considerar-se o desfecho do romance, não levam mesmo a nada.

Estela fechou os olhos para não ver o pai. Nem esse amparo lhe ficava na solidão. Compreendeu que devia contar só consigo, e encarou serenamente o futuro. Partiu. (Obra Completa, vol. I p. 507) 
Partiu para o norte de São Paulo. Ainda que por escolha própria, Estela, como Estevão, acaba em uma obscura vila do interior (o norte de São Paulo não podia ser outra coisa na época) e, como Lívia e Félix, terá por companhia apenas a solidão. Mas não há qualquer idealismo na sua atitude: ela é apenas resultado do cálculo, como, aliás, fora seu casamento com Luís Garcia, como a própria personagem explica a Iaiá: Não nos casamos por amor; foi escolha da razão, e por isso acertada. Não tínhamos ilusões; pudemos ser felizes sem desencanto.(P.504 - grifo meu). Como se vê, também Estela é movida pela fria eleição do espirito, ainda que use de outras estratégias. Por outro lado, Iaiá, que Roberto Schwarz considera uma Guiomar mais domesticada, encontrará no casamento uma felicidade sem contraste. A sociedade não lhe negou carinhos e respeitos... e ela depressa aprendeu a prosódia e a sintaxe; afez-se a todos os requintes da urbanidade ${ }^{52}$.

Enfim, em Iaiá Garcia, observam-se os mesmos percursos e o mesmo quadro de valores encontrados nos romances anteriores: Iaiá empreende o percurso central de ascensão social e é sancionada positivamente; Estela não o faz e, como Estevão ou Félix, recebe a devida punição. Família e sociedade formam o par de destinadores que sancionam uns e outros, conforme o quadro de valores vigentes: para Iaiá, carinhos e respeitos; para Estela, solidão em uma obscura vila do interior. ${ }^{53}$.

\section{Memórias póstumas de Brás Cubas.}

O percurso narrativo central desse romance é diferente (mas muito pouco) do encontrado nos três anteriores, pois, graças ao costumeiro recebimento de uma herança, objeto de disputas com e a irmã e o cunhado, Brás Cubas não teria necessidade de ascender socialmente já que nasceu na classe dominante. Contudo, apesar de sua posição social, ao longo da narrativa o sujeito tenta realizar algumas performances, todas malogradas, com o intuito de se promover socialmente e obter algum lustro para o seu nome, como diria Luís Alves, além do recebido de berço. Comparando Brás Cubas com os personagens dos três romances que o antecederam, percebe-se que a ascensão social que ele tinha em mente era,

\footnotetext{
${ }^{52} \mathrm{Id} \mathrm{Ib}$

${ }^{53}$ Essa discussão pode causar a impressão de que aspectos diferenciadores do romance são negligenciados. Caso ocorra, isso se deve à segmentação de cada obra segundo recortes propostos. Como se verá em breve, quando for abordada a questão do narrador, Iaiá distancia-se e diferencia-se de todos os demais romances de Machado.
} 
proporcionalmente, análoga à desejada por Guiomar, Helena e Iaiá. A diferença é que ele parte do patamar onde elas esperavam chegar; mas, em compensação, almeja um salto bem maior. É assim com as fracassadas tentativas de casamento com Virgília e Nhã-ló-ló; sua curta carreira de deputado; a não obtenção de um ministério; e, especialmente, a venda do emplastro Brás Cubas, que acaba por levá-lo para a campa. Ao contrário do que acontecia nos romances anteriores, em que os sujeitos, ou melhor, as mulheres, agiam com firmeza, a Brás Cubas falta determinação, e seus programas, todos carentes de coesão, terminam por não suprir a falta que os engendrou. Cada fracasso desencadeia um programa de liquidação da falta, que, ao soçobrar, provoca outro programa e assim por diante. A sucessão de fracassos de Brás Cubas o configura como sujeito virtual - fato cabalmente confirmado pelo fato de ser um defunto-autor - que sempre está em conjunção com o querer ou o dever, mas nunca com o poder e o saber. Manipulado pelo destinador família/sociedade, o sujeito sempre acaba fracassando e, por isso, é sempre sancionado negativamente. O programa final de liquidação da falta coincide com o derradeiro capítulo do livro (o que mostra como o ato de narrar e o conteúdo da narrativa são indissociáveis), em que Brás Cubas procura liquidar suas faltas minimizando seus fracassos e realçando seus supostos sucessos:

Este último capítulo é todo de negativas. Não alcancei a celebridade do emplasto, não fui $\underline{\text { ministro, }}$ não fui califa, não conheci o casamento. Verdade é que, ao lado dessas faltas, coube-me a boa fortuna de não comprar o pão com o suor do meu rosto. Mais; não padeci a morte de Dona Plácida, nem a semidemência do Quincas Borba. Somadas umas coisas e outras, qualquer pessoa imaginará que não houve míngua nem sobra, e, conseguintemente que saí quite com a vida. E imaginará mal; porque ao chegar a este outro lado do mistério, achei-me com um pequeno saldo, que é a derradeira negativa deste capítulo de negativas: - Não tive filhos, não transmiti a nenhuma criatura o legado da nossa miséria. (Obra completa, p. 639 - grifos nossos)

Brás Cubas apresenta-se como o enunciador do romance, sanciona o próprio fazer, e, ao mesmo tempo, manipula o enunciatário (na verdade, o narratário) para que este passe a ver seus inúmeros fracassos de forma eufórica. Trata-se de uma sanção cognitiva, e não pragmática, que o sujeito faz de si mesmo: ao concluir que não obteve nenhum dos objetos de valor desejados, ele procura compensar a sua a falta lembrando os objetos de valor negativos com os quais não entrou em conjunção. Observe que todas as faltas são relacionadas à não ascensão social ou à não obtenção de prestígio social: Brás Cubas não se tornou um célebre capitalista empreendedor, como esperava com a invenção do emplastro; não se tornou funcionário público de destaque: não foi califa e... talvez a maior das faltas, não se casou; aliás como Félix, que fora sancionado negativamente pelo narrador de forma explícita. Veja que, ao lado da preservação da razão, os únicos aspectos positivos lembrados 
por Brás Cubas são relacionados ao fato de não ter descendido socialmente, ou seja, ter tido $a$ boa fortuna de não comprar o pão com o suor do seu rosto - pão ao qual Salvador, pai de Helena, acrescentou o adjetivo amargo — e não ter padecido a morte de D. Plácida.

Como se vê, o programa central executado pelo sujeito é rigorosamente o mesmo dos romances anteriores. Ele fracassa e é sancionado negativamente como Félix. Mas, como negativamente, se o próprio narrador que afirma achou-se com um pequeno saldo? Talvez a maior das sanções esteja no fato de o narrador não ter qualquer crédito, pois, certamente, não pode ser considerado eufórico o fato de ele não ter tido filhos, e isso não em função de qualquer juízo de valor acerca da paternidade, mas sim porque o próprio Brás Cubas afirmou que desejava um baby, para usar sua expressão ${ }^{54}$. Ou seja, o que ele afirma ser um pequeno saldo na verdade não o é, segundo seus próprios valores. Desse modo, mais uma vez Brás Cubas se diminui perante os olhos do leitor, que o sanciona negativamente. Repare que sanção negativa de Félix podia ser feita sem maiores dificuldades, pois ele não estava encarregado da narração, porém como proceder em relação a Brás Cubas se é ele quem detém a narração? O reconhecimento de que é um completo idiota soaria completamente inverossímil e seria incompatível com o restante do romance. Assim, a sanção negativa de Brás não deve ser dita, mas, digamos, mostrada e consiste em ele ser como é; sua sanção não ocorre no plano do enunciado, mas da enunciação que se afasta dele e, conseqüentemente de seu mundo.

Veja-se ainda uma segunda passagem em que fica mais evidente o fato de os percursos e os valores em jogo em Memórias póstumas serem bastante próximos dos romances anteriores. É a passagem em que Virgília e Lobo Neves trocam juras de amor, se é que cabe a expressão:

\footnotetext{
Uma semana depois, Virgília perguntou ao Lobo Neves, a sorrir, quando seria ele ministro.

- Pela minha vontade, já; pela dos outros, daqui a um ano.

Virgília replicou:

— Promete que algum dia me fará baronesa?
}

\footnotetext{
${ }^{54}$ Recorde-se parte do capitulo XC em que Brás Cubas sonha com o filho que Virgília estaria esperando dele. Na passagem, não restam dúvidas da importância que ele atribuía à paternidade:

Lá me escapou a decifração do mistério, esse doce mistério de algumas semanas antes, quando Virgília me pareceu um pouco diferente do que era. Um filho! Um ser tirado do meu ser! Esta era a minha preocupação exclusiva daquele tempo. Olhos do mundo, zelos do marido, morte do Viegas, nada me interessava por então, nem conflitos politicos, nem revoluções, nem terremotos, nem nada. Eu só pensava naquele embrião anônimo, de obscura paternidade, e uma voz secreta me dizia: é teu filho. Meu filho! E repetia estas duas palavras, com certa voluptuosidade indefinivel, e não sei que assomos de orgulho. Sentia-me homem. (Obra Completa, vol. I p. 598)
} 
— Marquesa, porque eu serei marquês.

Desde então fiquei perdido. Virgília comparou a águia e o pavão, e elegeu a águia, deixando o pavão com o seu espanto, o seu despeito, e três ou quatro beijos que lhe dera. Talvez cinco beijos; mas dez que fossem não queria dizer coisa nenhuma. $\mathrm{O}$ lábio do homem não é como a pata do cavalo de Átila, que esterilizava o solo em que batia; é justamente o contrário. (Obra Completa, vol. I p. 561 - grifo meu)

Isso mesmo, a passagem é muito parecida com aquela, já citada, em que Guiomar e Luís Alves fazem planos para o futuro. As duas mulheres vêem no seu eleito uma escada para sua ascensão. Agindo como Guiomar, Virgília não pergunta a Lobo Neves se ele a fará feliz, será fiel etc., questões absolutamente estranhas à obra de Machado. A discussão é de ordem mais prática; se o escolhido fará ascender socialmente, pois, como sempre, o casamento é um programa de uso em relação a outro de base: a ascensão social. Aliás, observe-se que Guiomar é mais direta que Virgília. Esta pergunta quando Lobo Neves será ministro enquanto aquela pede uma pasta de ministro em pagamento pela força moral (que Sofia explicará direitinho no que consiste) que dará a Luís Alves. Não há diferença entre o procedimento dos dois casais. Se algo muda é a forma como o narrador os vê; ou melhor, a autoridade do narrador num caso e noutro, já que os dois narradores — o de $A$ mão e a luva e o de Memórias póstumas — apóiam a conduta narrada: Brás Cubas não reprova a conduta de Virgília, pois reconhece que seu sentimento não passa de despeito (segundo o Houaiss, desgosto motivado pela preferência dada a outrem ou por decepção; raiva, indignação, inveja, ciúme).

Recorde-se agora o julgamento que o narrador faz do sobrinho da baronesa, em $A$ mão e a luva; de Estácio, em Helena e de Jorge, em Iaiá Garcia. Todos gozaram a boa fortuna de não comprar o pão com o suor deles; eram todos vadios como Brás Cubas, mas nenhum é apresentado desse modo pelo narrador que parece de vê-los com bons olhos. Portanto, a posição do narrador de Memórias póstumas em relação a vadiagem de Brás Cubas não difere, em essência, da de seus antecessores ${ }^{55}$. O problema é que agora os elogios vêm de um narrador de tal forma desprestigiado e de tal forma jactancioso que os elogios se transformam

\footnotetext{
${ }^{55}$ A descrição que o narrador faz de Jorge, em Iaiá Garcia, revela-o, aliás, mais semelhante a Brás Cubas do que poderíamos imaginar em um primeiro momento. A distância que parece haver entre eles, decorre muito mais do retrato que o narrador faz de ambos do que de seus próprios atributos. Recordemos:

[...] Elegante, ocupava Jorge um dos primeiros lugares entre os dandies da Rua do Ouvidor; ali podia ter nascido, ali poderia talvez morrer.

$V$ aléria acertava quando dizia não achar no filho nenbum amor à profissão de advogado. Jorge sabia muita cousa do que aprendera; tinha inteligência pronta, rápida compreensão e memória vivíssima. Não era profundo; abrangia mais do que penetrava. Sobretudo, era uma inteligência teórica; para ele, o praxista representava o bárbaro. Possuindo muitos bens, que Ihe davam para viver à farta, empregava uma particula do tempo em advogar o menos que podia - apenas o bastante para ter o nome no portal do escritório e no almanaque de Laemmert. (Obra Completa, vol. I p. 402)
} 
em insultos, mais ou menos como ele próprio faz em relação a Cotrim. Em outras palavras, o que muda não é a índole das personagens, seu fazer, ou mesmo a forma com a narração lida com os valores em jogo, mas tão somente a autoridade do narrador. Antes eram enfocados apenas os aspectos positivos (ou, que seja, os negativos eram deixados de lado); o elogio era discreto e feito por um narrador competente; agora, a exaltação é feita de forma acintosa e por alguém cujos elogios só podem diminuir o elogiado. Conforme será visto mais adiante, quando forem discutidos os níveis enunciativos, esses romances sequer se diferenciam pelas relações entre o enunciador e o narrador, pois elas sempre foram conflituosas; na verdade, as diferenças são bem mais superficiais, no sentido semiótico do termo, do que se pode pensar em um primeiro momento.

\section{Quincas Borba}

O programa narrativo central de Quincas Borba é o de espoliação de um sujeito; no caso, de Rubião pelo casal Palha. Naturalmente, invertendo-se o enfoque, pode-se pensar que se trata de um programa aquisição de valores pelo casal Palha, que ascende socialmente ao esbulhar Rubião. Embora essa leitura seja absolutamente possível e não exclua a anterior, uma vez que as narrativas são sempre polêmicas, não é essa a perspectiva da instância da enunciação que privilegia o primeiro enfoque. Recorde-se que em Helena essa leitura também poderia ser feita, já que se tratava também de um programa de espoliação parcial dos herdeiros do comendador Vale, os quais perderam parte da herança para Helena. Essa possibilidade é aventada inclusive pela narrativa, mas negada de imediato pela instância da enunciação, que, por meio do narrador, jamais caracteriza a heroína desse modo. Aliás, a questão da herança é outro ponto de contato entre os dois romances. Tal como Helena, Rubião enriquece a custa de uma herança cuja legitimidade é questionável e, novamente, à semelhança dela, oculta de todos as circunstâncias em que a herança foi concedida (o real estado mental de Quincas Borba), com receio de que o conhecimento desse fato invalide o testamento. Verifica-se, portanto, que o percurso narrativo e também o investimento figurativo do fazer dos sujeitos aproximam os dois romances, que no mais, distanciam-se tanto pelo restante do percurso narrativo quanto pela valorização tímica dos valores em jogo.

Voltemos ao casal Palha. Cristiano e Sofia ajustam-se como a mão à luva, da mesma forma que Guiomar e Luís Alves, e a relação que os cônjuges mantêm entre si em cada caso é 
marcada pelo interesse, assemelhando-se, em alguns aspectos, a uma relação comercial. Se o leitor tem uma imagem mais positiva do segundo casal e mais negativa do primeiro, isso se deve menos a uma diferença de caracteres e mais à posição adotada pelo narrador em cada caso. O relacionamento de Guiomar e Luís Alves era narrado sem ironia, portanto, sem oposição entre enunciação e enunciado; Guiomar e Luís Alves eram sancionados positivamente enquanto o casal Palha, não. Veja-se, por exemplo, o episódio em que Sofia conta ao marido que Rubião a assediara insistentemente e lhe pede providências. Cristiano tergiversa, pois um afastamento, ainda que justificável em função da conduta de Rubião, prejudicaria seus interesses, e esses — como ensina Guiomar — não devem ser contrariados. Por isso, Palha não sabia como responder à mulher. Trava-se, então, um diálogo que expõe a natureza das relações entre o marido, a mulher e o herdeiro de Quincas Borba:

Sofia, disse-lhe o marido, sentando-se ao pé dela. Não quero entrar em minudências; digo só que não permito que alguém te falte ao respeito...

Houve uma pequena pausa: Sofia olhava para ele, esperando.

- Não permito, e ai daquele que o fizesse, assim como ai de ti se o consentires; sabes que sou de ferro, a este respeito, e que a certeza da tua amizade, — ou, vá logo tudo, — do amor que me tens é que me tranqüiliza. Pois bem, nada me abala relativamente ao Rubião. Crê que o Rubião é nosso amigo, devo-lhe obrigações.

- Alguns presentes, algumas jóias, camarotes no teatro, não são motivos para que eu fite o Cruzeiro com ele.

— Prouvera a Deus que fosse só isso! suspirou o zangão.

- Que mais?

— Não entremos em minudências... Há outras coisas... Falaremos depois... Mas fica certa que nada me faria recuar, se visse no que contaste alguma gravidade. Não há nenhuma. O homem é um simplório.

- Não.

- Não?

Sofia levantou-se; também não queria entrar em minudências. [...] - Bem, tornou o Palha depois de breve silêncio; escrevo-lhe amanhã que não ponha aqui os pés. Olhou para a mulher esperando alguma recusa. Sofia coçava as sobrancelhas, e não respondeu nada. Palha repetiu a solução; e pode ser que desta vez com sinceridade. A mulher então com ar de tédio:

- Ora, Cristiano... Quem é que te pede cartas? Já estou arrependida de haver falado nisto. Contei-te um ato de desrespeito, e disse que era melhor cortar as relações, — aos poucos ou de uma vez.

- Mas como se hão de cortar as relações de uma vez?

- Fechar-lhe a porta, mas não digo tanto; basta, se queres, aos poucos.

Era uma concessão; Palha aceitou-a; mas imediatamente ficou sombrio, soltou a mão da mulher, com um gesto de desespero. Depois, agarrando-a pela cintura, disse em voz mais alta do que até então:

— Mas, meu amor, eu devo-lhe muito dinheiro. (Obra completa, vol. I p. 684-5 - grifos meus)

Observem-se as reticências de Palha, os gestos de Sofia, as minudências que cada um tenta ocultar do outro: os argumentos de Palha, ditos e não ditos, que não convencem Sofia ingenuidade de Rubião, mas demonstram a inconveniência, para ambos, do afastamento. É 
que o relacionamento entre Palha e Sofia - aliás, tal como o de Guiomar e Luís Alves - está subordinado ao interesse; ao que ambos, em conúbio, podem extrair de Rubião. Sofia usa o herdeiro de Quincas Borba para conseguir o que quer ao mesmo tempo em que se deixa usar por Palha para que este atinja seus objetivos e lhe dê, em seguida, sua parte em jóias e roupas, as quais the renderão mais admiradores a serem explorados, de um jeito ou de outro, por ambos, em um ciclo virtuoso (?). É a força moral de Guiomar e o lustro do nome de Luís Alves em uma nova roupagem, diga-se, menos vistosa, mas mais eficiente para usar um termo caro ao sistema econômico em questão. E Palha, jeitoso, ativo, e com faro dos negócios e situações ${ }^{56}$, administra a mulher como uma propriedade que ele usa para adquirir outras propriedades e assim, realizar sua função social. E aí está reproduzido, na esfera doméstica, o processo de acumulação de capital no interior do qual a família exerce função primordial, como se sabe, mas que até então não era explicitada com essas cores nos romances de Machado. Sim, também isso é mostrado em $A$ mão e a luva, e, no trecho citado mais acima, as declarações de amor trocadas entre Guiomar e Luís Alves são a demonstração cabal da mais pura ganância, mas o narrador não as assume enquanto tais. Em todos os romances, com exceção de Ressurreição, apesar de a família ser proprietária e guardiã da ordem estabelecida, não é essa a qualidade enfatizada pelo narrador, mas sim a de depositária de valores outros, vistos como fins em si mesmos. Agora não, pois o narrador permite que esse processo seja visto por dentro, como se fosse um mergulho mais a fundo nas intenções de Guiomar e Luís Alves ou uma visão do que seriam os dias seguintes, após o casamento de ambos. É verdade que a santidade familiar começa a desbotar já em Iaiá, quando o narrador mostra que de um caso

\footnotetext{
${ }^{56}$ Está na página 669 da obra completa. Na seqüência, o narrador conta um pouco mais da natureza dos sentimentos de Palha por Sofia e da natureza da relação entre eles.:

O pior é que ele despendia todo o ganbo e mais. Era dado à boa xira; reuniōes freqüentes, vestidos caros e jóias para a mulher, adornos de casa, mormente se eram de invenção ou adoção recente, — levavam-lhe os lucros presentes e futuros. [...]. I a muita vez ao teatro sem gostar dele, e a bailes, em que se divertia um pouco, — mas ia menos por si que para aparecer com os olhos da mulher, os olhos e os seios. Tinha essa vaidade singular; decotava a mulher sempre que podia, e até onde não podia, para mostrar aos outros as suas venturas particulares. Era assim um rei Candaules, mais restrito por um lado, e, por outro, mais público.

Um pouco mais adiante, no episódio em que Sofia cai do cavalo e, constrangida, deixa à mostra o bico da bota que usava, o narrador conta as reflexões de Palha. O texto por si só é eloqüente ao mostrar os sentimentos do homem:

Aquele pudor medroso e incrédulo de Sofia fazia-lhe bem. Mostrava que ela era sua, totalmente sua; mas, por isso mesmo que ele a possuía, considerava que era de grande senhor não se afligir com a vista casual e instantânea de um pedaço oculto do seu reino. E lastimava que o casual tivesse parado na ponta da bota. Era apenas a fronteira; as primeiras vilas do território, antes da cidade machucada pela queda, dariam idéia de uma civilização sublime e perfeita (Obra completa, $p$. 765)
} 
doméstico saía uma ação patriótica - a ida de Jorge para a Guerra do Paraguai. No entanto, embora a ação de Valéria fosse motivada pelo temor de misturar lé com cré, faltava ao narrador (e não a enunciado, ressalve-se) a percepção de que sua ação se incluía em um contexto mais amplo. Além disso, se a análise já era perspicaz, o tom era bem mais respeitoso. Não havia esse jeito de farsa que agora predomina. Em outras palavras, o lugar da família na sociedade não estava tematizado dessa forma: a conivência entre vícios familiares e benefícios públicos não era forte o suficiente para garantir a estrutura da narrativa, como ocorre em Quincas Borba em relação ao casal Palha.

A verdadeira natureza das relações entre Palha e Sofia não é denunciada pelo narrador, que, em momento algum, faz qualquer juízo de valor, mas pela instauração de um discurso polifônico, que faz com que a cada frase de Palha ou Sofia ouça-se uma outra voz que os denuncia. É o caso do texto citado acima em que o diálogo entre o casal é ironizado mediante o uso do discurso indireto livre. Quando Sofia pergunta a Palha o que ele devia a Rubião, este responde: Não entremos em minudências... O uso das reticências indica que havia algo mais a ser dito, que foi suprimido pela instância da enunciação, no caso Palha, porque não convinha ser dizê-lo. Ao lado da voz do marido de Sofia, ouve-se outra explicando que Palha devia muito mais a Rubião do que jóias ou camarotes no teatro, como mostra o restante da narrativa. Daí porque a separação entre ambos seria catastrófica. Um pouco mais abaixo, quando Palha se espanta diante da afirmação de Sofia, segundo a qual Rubião não era um simplório, o narrador conta que Sofia apenas se levanta e diz que também ela não queria entrar em minudências. A palavra minudências tem agora confirmado o sentido que Palha lhe recusara momentos antes, em discurso direto: não mais de coisas sem importância, mas de fatos que não devem ser ditos porque não são convenientes e porque já são, ao menos parcialmente, sabidos. Também Sofia não tem interesse em dizer a Palha que, diversas vezes, seduzira e tentara Rubião, pois, eventualmente, o marido poderia vir a concordar com a necessidade do afastamento, o que também não lhe interessava. Assim, com o uso do discurso indireto livre, o narrador simula ocultar a natureza das relações entre Palha e Sofia, quando, na verdade, as está revelando.

O diálogo acima confirma o que se observa desde Ressurreição: a instauração de sujeitos que têm um programa narrativo único e muito claro: ascender socialmente. Em Quincas Borba, existem, na verdade, dois percursos dessa natureza: um, realizado por Rubião, que muda de classe ao receber um herança cuja legitimidade é questionável; outro, o do casal 
Palha, que ascende ao esbulhar o herdeiro. Enquanto, ao final, Rubião, já louco, é recolhido a um asilo, o casal Palha inaugura um novo palacete no Botafogo. Um fracassa por voltar a buscar as tais afeições que já haviam causado a desgraça de Félix e Helena; outros triunfam porque, como Guiomar e Luís, souberam conciliar seus objetivos com a fria eleição do espírito. Mais uma vez, revela-se o ethos de um enunciador lúcido, frio e, acima de tudo, consciente da questão central que se impõe à modernidade: a acumulação de capital.

\section{Dom Casmurro}

As configurações narrativas de Dom Casmurro são semelhantes às de obras anteriores de Machado. Capitu realiza a ascensão social desejada por Helena, vedada a (e rejeitada por) Estela, mas efetivada por Iaiá e Guiomar. Todas o fazem por meio do casamento. Em Dom Casmurro, também se encontra o papel temático do filho-único-mimado-e-ocioso, que se apaixona pela moça de alto valor ${ }^{57}$, mas baixo poder aquisitivo, que já fora vivido por Jorge e Estácio em Iaiá e Helena, respectivamente, além, claro, do próprio Brás Cubas. D. Glória, mãe de Bentinho é viúva e matriarca, tal como a Valéria de Iaiá e a Baronesa de A mão e a luva, e guarda lá suas semelhanças com D. Úrsula, que era solteira, é verdade, mas que vivera sempre com o irmão, cuja casa dirigia desde o falecimento da cunhada ${ }^{58}$. E, claro, como não podiam faltar, os parasitas e agregados, talvez a classe social mais bem representada na obra de Machado. O primeiro exemplo é o Viana, de Ressurreição, parasita da consideração e da amizade, o intruso polido e alegre que à força de arte e obstinação conseguia tornar-se aceitável e querido ${ }^{59}$, seguido pela Ms. Oswald, mulher inteligente e sagaz, dotada de boa indole e serviçal que, antes da chegada de Guiomar, era a dama de companhia na casa da baronesa e a alma da casa ${ }^{60}$. E não se esqueça que Guiomar e Estela não eram senão agregadas nas casas em que viviam, sendo o pai da última, o Sr. Antunes, também parasita de nomeada. Chega-se assim ao mais famoso membro da classe, o José Dias, que tinha certa autoridade na familia, não abusava, e sabia opinar obedecendo e cujas

\footnotetext{
${ }^{57}$ Certo, o "valor" de Capitu é questionável, mas não custa lembrar que é questionado por sua pretensa vítima, Bentinho.

${ }^{58}$ Obra Completa, vol I, p. 273.

${ }^{59}$ Idem, p.120.

${ }^{60}$ Idem, p. 212.
} 
cortesias vinham antes do cálculo (sempre ele) que da indole ${ }^{61}$. Assim, os revestimentos figurativos de Dom Casmurro caminham na mesma direção dos outros romances.

Não se trata apenas do revestimento figurativo. Em termos sintagmáticos, o velho programa narrativo de ascensão social, observado nos demais romances, ocupa a posição central, com a diferença - de várias implicações, como se verá adiante — de que agora é narrado pela parte interessada no episódio, o que dá ao leitor pleno direito de questionar se a interpretação do narrador, perguntando-se se ela corresponde à realidade ou se seria fabulação. Na verdade, para o momento, tanto faz se Bentinho distorce ou não os fatos, a verdade é que, no entendimento do narrador, Capitu usou o casamento para ascender socialmente, embora isso nunca seja dito com todas as letras, como muita coisa não o é. Por exemplo, logo no início do livro, o narrador enfatiza a condição social de Capitu ao afirmar que a despeito de alguns ofícios rudes ela trazia as mãos curadas com amor, não cheiravam a sabões finos nem águas de toucador, mas com água do poço e sabão comum trazia-as sem mácula e ao acrescentar que ela Calçava sapatos de duraque, rasos e velhos, a que ela mesma dera alguns pontos. ${ }^{62} \mathrm{Um}$ pouco mais tarde, José Dias afirma a Bentinho que não era conveniente que ele andasse com o Pádua, pai de Capitu e explica:

Quando era mais jovem; em criança, era natural, ele [Pádua] podia passar por criado. Mas você está ficando moço e ele vai tomando confiança. D. Glória, afinal, não pode gostar disso. A gente Pádua não é de todo má. Capitu, apesar daqueles olhos que o Diabo lhe deu... Você já reparou nos olhos dela? São assim de cigana oblíqua e dissimulada. Pois, apesar deles, poderia passar, se não fosse a vaidade e a adulação. Oh! a adulação! D. Fortunata merece estima, e ele não nego que seja honesto, tem um bom emprego, possui a casa em que mora, mas honestidade e estima não bastam, e as outras qualidades perdem muito de valor com as más companhias em que ele anda. Pádua tem uma tendência para gente reles. Em lhe cheirando a homem chulo é com ele. Não digo isto por ódio, nem porque ele fale mal de mim e se ria, como se riu, há dias, dos meus sapatos acalcanhados... (Obra Completa, vol. I p. 834)

Segundo o José Dias, havia o risco de era Pádua, que passava por criado de Bentinho, ganhar confiança e os desiguais aproximarem-se. D. Glória, como Valéria, não podia gostar disso, claro. Valores em jogo: Pádua é honesto e, mais importante, tem bom emprego, mas isso não basta, pois ele é chulo, isto é, não elevado socialmente e nem mesmo sua maior qualidade, possuir a casa própria, é suficiente para permitir o convívio entre ele e Bentinho, e muito menos para unir as duas famílias. Ah sim, há também a adulação de Capitu, característica que, segundo os dicionários, consiste em agradar alguém por interesse e com

\footnotetext{
${ }^{61}$ Obra Completa, vol. I, p.814

${ }^{62}$ Idem, p. 823
} 
exagero. Logo, Capitu teria se aproximado de Bentinho em razão do cálculo, visando ao que ela poderia auferir no futuro, e não por razões sentimentais. Certo, Bento Santiago jamais endossa as palavras do agregado, mas também nunca as nega, e de, forma insidiosa, ao longo da narrativa, vai retratando Capitu como uma arrivista, maquiavélica, de forma a tornar verossímil a hipótese de José Dias. Recorde-se agora que a diferença de classes já estava presente em $A$ mão e a luva, nas relações entre, de um lado, Guiomar e Mrs Oswald e, de outro, a Baronesa e o Sobrinho, e que a máxima inflexivel de Valéria, de Iaiá Garcia, era lé com lé, cré com cré e que o contrário não passava de absurdo ou romance. ${ }^{63}$. Na ocasião, a frase ficou sem justificativa, apresentada como puro preconceito; agora, a tese é retomada por José Dias e defendida por Bento Santiago que, por experiência própria, demonstra porque a máxima de Valéria - que se revela também a sua - era verdadeira. Em situação oposta, a recusa de Estela em aceitar a união com Jorge, então julgada apenas fruto de orgulho, encontra agora sua razão de ser, pois ela se tornaria vítima, tal qual Capitu, e sempre teria a legitimidade de sua união questionada. Veja-se, ainda, que Brás Cubas julgava prestar um favor a Eugênia pelo simples fato de manter-se próximo a ela, dadas as diferenças de classe que havia entre eles — e isso apesar de usá-la como mero instrumento. Observe-se, finalmente, que a desigualdade de classe não é superada pelo casamento, nem mesmo quando a distância entre os cônjuges é menor do que a existente entre Bentinho e Capitu. Basta que se volte a Quincas Borba e se recorde o relacionamento entre Maria Benedita, prima de Sofia que veio da roça, e seu marido rico e esnobe, o Carlos Maria. Depois de casados ele, lhe pergunta, como já haviam feito Luís Alves e Lobo Neves a suas respectivas noivas, se ela gostaria de vê-lo ministro.

— Que hei de responder? pensou ela, escrutando o rosto do marido. Ele, rindo:

- Confessa que me adorarias, ainda que eu fosse uma simples ordenança de ministro.

- Justamente! exclamou a moça, lançando-lhe os braços aos ombros. Carlos Maria afagou-lhe os cabelos, e murmurou sério: - Bernadotte foi rei, e Bonaparte imperador. Você queria ser a rainhamãe da Suécia?

Maria Benedita não entendeu a pergunta nem ele a explicou. Para explicá-la seria mister dizer que possivelmente trazia ela no seio um Bernadotte; mas esta suposição significava um desejo, e o desejo uma confissão de inferioridade. Carlos Maria espalmou outra vez as mãos sobre a cabeça da mulher, com um gesto que parecia dizer: "Maria, tu escolheste a melhor parte..." E ela pareceu entender o sentido daquele gesto.

\section{— Sim! sim!}

O marido sorriu e tornou à revista inglesa. Ela, encostada à poltrona, passava-lhe os dedos pelos cabelos, muito ao de leve e caladinha para não perturbá-lo. Ele ia lendo, lendo, lendo. Maria Benedita foi atenuando a carícia, retirando os dedos aos poucos, até que saiu da sala, onde Carlos

\footnotetext{
${ }^{63}$ Não custa recordar que, segundo o Houaiss, uma máxima é um preceito, sentença que exprime uma regra moral, um princípio de conduta
} 
Maria continuou a ler um estudo de Sir Charles Little, M. P., sobre a famosa estatueta de Narciso, do Museu de Nápoles. (Obra Completa, vol. I, p. 787-8 - grifos meus)

Como se vê, a desigualdade das relações, fruto de diferenças sociais não atenuadas, mas reproduzidas no casamento, não é um tema isolado de Dom Casmurro, mas perpassa toda a obra de Machado. Todavia, o percurso da moça que ascende socialmente é agora relativizado, pois não é mais afirmado explicitamente por um narrador alheio aos fatos narrados, mas por alguém que é parte interessada e cujo objetivo não é contar uma história qualquer, mas provar que sua mulher casara-se para apoderar-se de seus bens — aliás, em um procedimento não tão diferente do adotado por Helena — e, assim, ascender socialmente. Depois, não contente — continuaria o narrador — , passou a traí-lo com o melhor amigo, que não seria menos ganancioso que Capitu e veria na família Santiago apenas uma forma de obter lucros. ${ }^{64}$ Desse modo, o percurso dos actantes do enunciado é emoldurado pela narração desse percurso, que atende aos fins de Bento Santiago. Daí decorrem dois fatos: a situação de narração torna-se a trama principal do romance, à qual as demais se subordinam; e a ideologia do narrador — sempre apresentando como enunciador — é mostrada em todas as suas cores. Sim, isso já havia ocorrido em Memórias póstumas e em Quincas Borba, mas, no primeiro caso, ela era satirizada, pois o narrador não tinha qualquer credibilidade, o que não ocorre aqui. Já em Quincas Borba, o narrador não estava sincretizado com um actante do enunciado, fato que, de certa forma, separava sua ideologia daquela implicada nos fatos narrados.

Em que pesem as diferenças (e não poderia ser de outro modo, pois cada romance tem sua identidade), as semelhanças entre Dom Casmurro e as demais obras de Machado configuram determinadas regularidades paradigmáticas e sintagmáticas, definidas por Greimas \& Courtés (1993: p. 245) como iterações entre estruturas e conteúdos as quais acabam por permitir a delimitação de um esquema narrativo e de um padrão de comportamento do enunciador, portanto, de um ethos. A desigualdade, o caráter imperioso da ascensão social, o arbítrio, o favor... tudo já estava presente na obra de Machado desde Ressurreição. O que

\footnotetext{
${ }^{64}$ Veja-se a passagem em que Bentinho conta que Santiago sabia de cor a renda dos aluguéis que a família tinha e critica D. Glória por não fazer maiores investimentos:

[...] Era opinião de prima Justina que ele [Escobar] afagara a idéia de convidar minha mãe a segundas núpcias; mas, se tal idéia houve, cumpre não esquecer a grande diferença de idade. Talvez ele não pensasse em mais que associá-la aos seus primeiros tentâmens comerciais, e de fato, a pedido meu, minha mãe adiantou-lhe alguns dinheiros, que ele the restituiu, logo que pôde, não sem este remoque: "D. Glória é medrosa e não tem ambição." (Obra Completa, vol. I p. 905)
} 
acontece a partir de Brás Cubas é a transformação desse conteúdo em forma, na medida em que a desigualdade e a arbitrariedade vigentes entre os actantes do enunciado são transpostas para a narração, na relação entre narrador e narratário, havendo, assim, uma vez mais, a neutralização entre a narração e a narrativa, já que ambas passam a estar diretamente ligadas. A desigualdade e suas implicações não são apenas narradas; passam a ser, também, mostradas. Chega-se, assim, ao padrão de comportamento, ao ethos desse enunciador, já tantas vezes citado: frio, cético, desiludido e, naturalmente, detentor de um grande poder de análise que não deixa nenhuma pedra sob as pedras.

\section{Esaú e Jacó}

Em Esaú e Jacó, não há mais mocinhas bem ou mal intencionadas à procura de um casamento que lhes permita ascender socialmente. Apesar disso, e de a maioria dos personagens já pertencer à classe dominante, o programa de ascensão permanece latente em todo o romance. Por exemplo, Santos, pai dos dois gêmeos, cujo percurso lembra o de Cristiano Palha, chegou ao Rio de Janeiro por ocasião da febre das ações (1855), e logo revelou grandes qualidades para ganhar dinheiro depressa. Ganhou logo muito, e fê-lo perder a outros ${ }^{65}$, não só nessa época, mas, provavelmente, também durante o encilhamento.. ${ }^{66}$ Segundo Aires, Santos também não teria lá muitos escrúpulos, além de não ajudar os parentes menos favorecidos, tal como João de Melo, para quem fez rezar um missa que causou espécie, não pela cerimônia, que foi simples, mas pela presença do coupé com lacaio e libré ${ }^{67}$. Há também a história do Nóbrega que, no início do romance, apropria-se da esmola de Natividade e, ao final, reaparece como um capitalista de sucesso que, como todos os personagens machadianos, procura racionalizar e justificar sua atitude. Há também o caso de Batista, pai de Flora, político corrupto, pródigo em sonhos e nulo de idéias, que serve aos conservadores, depois aos liberais, sobrevive à queda do Império ${ }^{68}$ e não deixa de encontrar seu lugar junto ao governo de Floriano. E não se pode esquecer sua mulher, D. Cláudia, mentora da carreira do marido e detentora de um masoquismo que talvez só seja comparável ao sadismo de Fortunato de $A$ causa secreta (Várias histórias, 1896) ${ }^{69}$.

\footnotetext{
${ }^{65}$ Obra Completa, p. 953.

${ }^{66}$ Encilhamento foi o nome pelo qual ficou conhecida a política econômica conduzida por Rui Barbosa, ministro da economia de Deodoro. Em síntese, consistia em estimular a economia mediante a utilização
} 
A ascensão social não está presente apenas em narrativas periféricas; aparece também, e principalmente, no eixo central do romance, os dois gêmeos, Pedro e Paulo, que são ociosos, como de costume, vivem do amor da mãe e da bolsa do pai, inesgotáveis ambos ${ }^{70} \mathrm{e}$ disputam tudo entre si. A busca de ambos pelo prestígio social começa antes mesmo do nascimento, quando Natividade consulta a cabocla do castelo para conhecer o destino dos seus filhos. Observe no trecho abaixo a presença explícita do verbo subir referindose,justamente à ascensão social que será realizada pelos dois gêmeos. Repare: Natividade primeiro pergunta se serão felizes; depois, se serão famosos, poderosos, e o narrador explica que bastou que ela soubesse que os filhos seriam grandes e gloriosos para ficar alegre. Quer dizer, mais uma vez, o que interessa mesmo, ao menos no plano do enunciado, é a posição social, ou a alma exterior, como diria Jacobina, de O espelho (Papéis avulsos, 1882). Recorde-se a passagem:

Natividade instou pela resposta, que lhe dissesse tudo, sem falta...

— Coisas futuras! murmurou finalmente a cabocla.

- Mas, coisas feias?

— Oh! não! não! Coisas bonitas, coisas futuras!

- Mas isso não basta; diga-me o resto. Esta senhora é minha irmã e de segredo, mas se é preciso sair, ela sai; eu fico, diga-me a mim só... Serão felizes?

- Sim.

- Serão grandes?

— Serão grandes, oh! grandes! Deus há de dar-lhes muitos benefícios. Eles hão de subir, subir, subir...

de títulos públicos (e não mais do ouro) como lastro das emissões monetárias. A meio circulante aumentou instantaneamente, trazendo inflação e inúmeras sociedade por ações que fizeram muitos perder tudo e poucos (dentre eles Batista) ganhar muito. A política do encilhamento fez ainda as delícias do cronista Machado de Assis que, dominicalmente, escrevia crônicas, no mínimo, tremendamente divertidas, na coluna $A$ semana. O leitor interessado encontrará em Gledson (1996) uma edição crítica desses textos de grande qualidade com comentários, nas mais vezes, muito pertinentes.

${ }^{67}$ Ver o capítulo IV, A missa do coupé.

${ }^{68}$ É imperdível a crítica que Machado faz aos políticos, pela boca do próprio Batista:

- Não sei o que ele queria que eu fizesse mais, dizia Batista falando do ministro. Cerquei igrejas, nenhum amigo pediu polícia que eu não mandasse; processei umas vinte pessoas, outras foram para a cadeia sem processo. (Obra Completa. P. 984)

${ }^{69}$ A descrição dos sentimentos da mãe de Flora ao ler as críticas que a oposição fazia ao marido não permite outra conclusão:

A folha da oposição era a primeira que D. Cláudia lia em palácio. Sentia-se vergastada também e tinha nisso uma grande volúpia, como se fosse na própria pele, almoçava melhor. Onde iam os látegos daquele tempo?(Obra Completa, p. 985).

Mais para o fim do romance, quando Batista volta ao poder, mas, devido à censura da época, sem receber as críticas da imprensa, D. Cláudia sente falta dos látegos de muitas pontas, que lhe rasgavam as carnes e a excitavam ao mesmo tempo, esse prazer não lhe dava a comissão reservada. (Obra Completa, p. 1.039)

${ }^{70}$ Obra Completa, p..1.046 
$[\ldots]$

Todos os oráculos têm o falar dobrado, mas entendem-se. Natividade acabou entendendo a cabocla, apesar de lhe não ouvir mais nada; bastou saber que as coisas futuras seriam bonitas, e os filhos grandes e gloriosos para ficar alegre e tirar da bolsa uma nota de cinqüenta mil-réis. (Obra Completa, vol. I, p. 949-50 - grifos meus).

Contudo, um outro percurso é constituído ao longo do romance pela menção ostensiva a fatos da história brasileira, como não ocorre em nenhuma outra obra de Machado, à exceção das crônicas, ${ }^{71}$ fazendo com que o próprio país acabe se constituindo em sujeito. E, de fato, aspectos da vida nacional até então só abordados nas colunas que Machado mantinha nos jornais estão todos presentes em Esaú e Jacó ${ }^{72}$ a crise de $1855^{73}$, Abolição da Escravatura ${ }^{74}$; o célebre baile da Ilha Fiscal, derradeiro do Império, descrito em primeira pessoa por Aires nos capítulos XLVIII e XLIX; a Proclamação da República, que ocupa nove capítulos praticamente inteiros ${ }^{75}$; vários fatos que se seguiram a ela, como a Constituição de 24.02.1891 ${ }^{76}$; a política do Encilhamento ${ }^{77}$, do qual Santos teria sido um dos protagonistas; o golpe de Estado de Deodoro e o contragolpe de Floriano, que derruba de novo a carreira de Batista $^{78}$; a Revolta da Armada e a Revolução Federalista ${ }^{79}$; além do fato de o próprio marechal

\footnotetext{
${ }^{71}$ A situação política do Brasil sempre freqüentou as crônicas de Machado, mas passa a ganhar um espaço maior a partir da coluna Bons Dias (1888-1889) e cresce em A Semana (1892-1897), ambas publicadas no Jornal Gazeta de Notícias. Por outro lado, está quase completamente ausente dos demais romances. Por exemplo, Dom Casmurro foi publicado em 1899, sendo, portanto, mais próximo dos episódios narrados em Esaú e Jacó, que data de 1901. Todavia, apesar dos fatos narrados serem contemporâneos à publicação, a única menção a acontecimentos do momento é relativa à guerra entre Espanha e Estados Unidos pela posse das Filipinas, iniciada em abril de 1898 e terminada em dezembro do mesmo ano, quando o Tratado de Paris cedeu o arquipélago aos norte-americanos. A referência está na página. 876 da Obra Completa. Recordemo-la:
}

Era uma alusão às Filipinas. Pois que não amo a política, e ainda menos a política internacional, fechei a janela e vim acabar este capitulo para ir dormir.

${ }^{72}$ Nada custa lembrar a observação de Lúcia Miguel Pereira que considera que o verdadeiro "autor" das crônicas de A Semana é Aires e não Machado de Assis:

Esse conselho dado logo no início das colaborações semanais na Gazeta de Notícias, cheira a Aires. Desse momento em diante não é mais possivel separar os dois sósias. Machado adota o criado, o gosto, a polidez e a indiferensa de Aires. Esse vai se deixando dominar por ele. (1988: 245).

${ }^{73}$ Obra Completa, vol. I, p. 954

${ }^{74}$ Idem, p. 992

${ }^{75}$ Capítulos LX a LXVIII

${ }^{76}$ Idem, p. 1.056

${ }^{77}$ Ver capítulo LXXIII, cujo título é Um Eldorado e LXXXVII

${ }^{78}$ Ver capítulo LXXII

${ }^{79}$ Idem, p. 1.085 
Floriano, surgir como personagem e título do capítulo LXVII, Visita ao Marecha ${ }^{\beta}$. Note-se que estas não são simples referências, mas constituem mesmo o arcabouço do livro, pois a oposição dos dois irmãos se pauta em boa medida pela forma como sancionam o fazer do sujeito Brasil, com natural destaque para oposição entre a Monarquia e a República.

Mas afinal, qual a razão para tantas menções a fatos da história brasileira em um romance cuja trama poderia ser resumida, exagerando, a um velho e banal triângulo amoroso, envolvendo dois irmãos? Um exame um pouco mais detalhado revelará a íntima ligação entre os episódios da história nacional e os acontecimentos envolvendo os dois irmãos e que, por sua vez, extrapola fatores ligados ao chamado romance histórico. Veja-se, por exemplo, a explicação dada pelo conselheiro para a rivalidade dos gêmeos. Após a morte de Flora, os irmãos trocam de posição: Paulo passa atacar a República, que até então defendera, e Pedro se aproxima do governo que até esse momento combatera. Natividade pergunta por que os irmãos nunca estavam de acordo e D. Cláudia sugere que as desavenças eram decorrentes dos propósitos de um e de outro. Aires discorda e oferece a seguinte explicação:

— Não, baronesa, disse ele, não creia em propósitos.

- Mas que pode ser então?

$[\cdots]$

- A razão parece-me ser que o espírito de inquietação reside em Paulo, e o de conservação em Pedro. Um já se contenta do que está, outro acha que é pouco e pouquíssimo, e quisera ir ao ponto a que não foram homens. Em suma, não lhes importam formas de governo, contanto que a sociedade fique firme ou se atire para diante. Se não concorda comigo, concorde com D. Cláudia.

[...] Aires fez um gesto afirmativo, e chamou a atenção de Natividade para a cor do céu, que era a mesma, antes e depois da chuva. Supondo que havia nisto algo simbólico, ela entrou a procurálo, e o mesmo farias tu, leitor, se lá estivesses; mas não havia nada.

- Tenha confiança, baronesa, prosseguiu ele pouco depois. [...] Suponha um déspota, uma corte, uma mensagem. A corte discute a mensagem, a mensagem canoniza o déspota. Cada cortesão toma a si definir uma das virtudes do déspota, a mansidão, a piedade, a justiça, a modéstia... Chega a vez da grandeza da alma; chega também a notícia de que o déspota morreu de apoplexia, que um cidadão assumiu o poder e a liberdade foi proclamada do alto do trono. A mensagem é aprovada e copiada. Um amanuense basta para trocar as mãos à História; tudo é que o nome do novo chefe seja conhecido, e o contrário é impossível; ninguém trepa ao sólio sem isso, nem a senhora sabe o que é memória de amanuense. Como nas missas fúnebres, só se troca o nome do encomendado - Petrus, Paulus... (Obra Completa, p. 1.086-7 - grifos meus)

De acordo com Aires, a rivalidade dos dois irmãos se traduz na oposição entre a conservação e a mudança, ou entre o estado e a transformação, ou, em termos modais, entre as modalidades epistemológicas (relativas ao ser) e as factivas (referentes ao fazer): Pedro

\footnotetext{
${ }^{80}$ Em 1911, dez anos depois da publicação de Esaú e Jacó, Lima Barreto narra, em um registro muitíssimo diferente, a visita feita ao Marechal Floriano por outro personagem ilustre: Policarpo Quaresma. Ver O triste fim de Policarpo Quaresma. São Paulo: Ática, 1995, 14 ed. p. 128-133.
} 
queria que a sociedade continuasse sendo o que era; Paulo, que ela se transformasse, mudasse de estado. Observe agora a descrença de Aires em propósitos, seu comentário sobre a permanência da cor do céu e sua observação sobre o fato de um amanuense bastar para trocar mãos à história e ninguém subir ao sólio sem ele. Ao que parece, a única crença de Aires é na linguagem como instrumento para mudar a aparência; mas não a essência, que permanece na ordem do inefável. Recorde-se agora o divertido episódio envolvendo o vizinho de Aires, Custodio (capítulos XLIX, LXII e LXIII), que diante da Proclamação da República fica sem saber qual nome colocar em seu estabelecimento, até então chamado Confeitaria do Império. No diálogo, a indiferença de Aires para com as duas formas de governo fica patente quando ele propõe ao vizinho que mude o nome para Confeitaria do Governo. O narrador (o próprio Aires) atribui a calma do conselheiro à sua incredulidade diante da notícia, mas é provável que a incredulidade fosse relativa às mudanças que poderiam ser decorrentes desse fato. É o que se deduz do diálogo que, em seguida, Aires mantém com Santos para tranqüilizá-lo em relação às transformações que poderiam ocorrem com a mudança de regime.

Aires quis aquietar-lhe o coração. Nada se mudaria; o regímen, sim, era possível, mas também se muda de roupa sem trocar de pele. Comércio é preciso. Os bancos são indispensáveis. No sábado, ou quando muito na segunda-feira, tudo voltaria ao que era na véspera, menos a constituição. (Obra Completa p. 1.031 - grifos meus)

Parece que, para Aires, a mudança para a República era apenas uma mudança de roupa; transformação e permanência ao mesmo tempo: quer dizer, era uma falsa mudança, pois parecia ser e não era; em segredo, era a permanência de tudo. $\mathrm{Na}$ seqüência, Aires afirma que tudo voltaria ao que era na véspera, menos a Constituição. É curioso que tudo possa a continuar ser o que era, com exceção, justamente, da Constituição, que é conjunto de leis que rege o Estado. A única possibilidade para a assertiva ser verdadeira é a Constituição não ter influência no dia a dia dos cidadãos, o que significa que ela seria uma Constituição apenas no modo da aparência; uma falsa constituição, portanto. Os anos nos quais se passam os fatos narrados por Aires foram, talvez, os mais tumultuados de toda a história do Brasil. A Abolição da Escravatura e a Proclamação da República poderiam desencadear mudanças estruturais em todo o país. Todavia, na visão de Aires, pode-se mudar de roupa sem mudar de pele; pode-se mudar a aparência sem mudar a essência. Assim, a questão que opunha os dois irmãos, o fazer e o ser, é também a mesma que se coloca para o país: conservar sua estrutura política e econômica ou realizar mudanças verdadeiras. Daí a importância de serem gêmeos, de funcionarem como um ator dual. Observe que, exceto pela preferência de um, Pedro, pela 
conservação e de outro, Paulo, pela mudança, os dois poderiam ser vistos como um único actante figurativizado em dois atores com investimentos modais distintos, e é essa divisão no plano actorial que permite sua existência. A morte de Flora não está desconectada desse fato. Em vários momentos, ela é apresentada como o termo complexo que reunia conservação e mudança; seu desejo de ver os dois irmãos em um é mostrado em suas alucinações que, cada vez mais freqüentes e intensas, causam sua morte, dado que o convívio de categorias opostas em um único ser é exclusividade dos mitos. A morte de Flora não afirma nem nega a possibilidade de mudanças, a despeito da descrença do narrador, mas assinala a impossibilidade do convívio de ambas, aliás já sugerida pela rivalidade dos gêmeos.

Os aspectos comentados — e que certamente não excluem outros — aproximam e afastam Esaú e Jacó dos demais romances de Machado. Aproximam, quando mostram que a estrutura central da trama liga-se à problemática da ascensão social; afastam, quando evidenciam que essa discussão está colada a outra, que reflete não apenas a questão nacional, mas a própria possibilidade da mudança, qualquer que seja. As duas discussões voltam a se misturar quando se observa que a ascensão social (portanto, uma transformação) não muda a essência do sujeito ou, melhor, que as mudanças só o são na aparência ou no que não é relevante. Isso fica explicito nas frases finais do romance, as quais, como de costume, não deixam lugar para esperanças. Um amigo pergunta a Aires o que teria feito com que os dois irmãos brigassem um com o outro:

- O senhor que se dá com eles diga-me o que é que os fez mudar, concluiu o amigo.

— Mudar? Não mudaram nada; são os mesmos.

— Os mesmos?

- Sim, são os mesmos.

— Não é possível.

$[\ldots]$

— Ora, espere, não será... Quem sabe se não será a herança da mãe que os mudou? Pode ter sido a herança, questões de inventário...

Aires sabia que não era a herança, mas não quis repetir que eles eram os mesmos, desde o útero. Preferiu aceitar a hipótese, para evitar debate, e saiu apalpando a botoeira, onde viçava a mesma flor eterna. (Obra Completa, vol. I p. 1.093)

Ainda que a herança, um dos elementos mais freqüentes em Machado, volte a figurar no trecho acima, o que se destaca é a descrença de Aires no que quer que seja. De fato, os irmãos ascenderam ainda mais, mas isso não alterou sua essência: eram os mesmos. Por outro lado, em que possam pesar as diferenças apontadas entre esse romance e os demais, não se altera o ethos do enunciador: ele continua a ser um indivíduo cético que, como o conselheiro, 
não acredita em propósitos, não mantém ilusões de quaisquer espécies e sabe que a fria eleição do espírito sempre prevalece.

\section{Memorial de Aires}

Para começar, pode-se perguntar onde estão os indivíduos pouco escrupulosos que habitam os romances de Machado. Onde está o Brás, o Cotrim, o Palha, o Bentinho, o Batista? Onde está a infinita coleção de tipos pouco nobres que povoam todos os contos do autor? Parece não haver vilões no mundo memorial escrito por Aires. Todos são gente respeitável, honesta, bem intencionada, inclusive o narrador, apesar de uns pequenos deslizes aqui e ali. Não há problemas sociais. No império brasileiro da felicidade, os conflitos (nenhum muito grave) limitam-se à esfera familiar e terminam quase todos com um final feliz: Aires parece viver bem consigo e com a irmã; Fidélia fora feliz no primeiro casamento e parece que o será no segundo. É moça prendada que toca piano, pinta e borda como ninguém, que nos dizeres do conselheiro é deliciosa e, claro, rica, conseguindo, até mesmo, reconciliar-se com o pai (um santo escravocrata!) antes da morte deste. Mesmo que a carreira de Tristão seja uma demonstração prática do jeito medalhão de ser, no melhor estilo Janjão, é preciso reconhecer que o moço conseguiu tudo o que queria sem abrir mão de nada (prova cabal de que a teoria do medalhão funciona). O moço é mesmo bem sucedido: rico; bacharel (médico); consegue a esposa bonita, prendada e mais rica; e ingressa em uma promissora carreira política, não na ex-colônia, como sonhava Brás Cubas, mas na metrópole. Aguiar e a esposa, exemplo de felicidade conjugal perpétua, têm também uma posição financeira estável, a qual lhes permite viajar à Europa; mobiliar uma casa para Tristão e Fidélia, sem que isso represente qualquer dificuldade no orçamento; e, ainda, receber semanalmente dúzias de amigos que suprem a falta dos filhos. Sim, é verdade que para o casal o final não será assim tão feliz, mas isso será investigado mais tarde. Enfim, todos são movidos pelas melhores intenções, ou principalmente por elas, e mesmo Santa-Pia - em cujo nome se inscreve uma devoção tal que só encontra paralelo na brancura de Candido das Neves, de Pai contra mãe (Relíquias de casa velha, 1906) - nunca deixou de ser um homem exemplar para os mais próximos - talvez, até mesmo para Aires. Realmente, nesse plano, o Memorial estaria mais próximo de Macedo de $A$ moreninha do que de Machado. Mas será que é só isso? 
E os outros ausentes? Os tipos pouco nobres não são a única ausência a se fazer presente no Memorial. Onde estão a escravidão, as relações de favor, o arrivismo, e tantas outras tradicionais instituições brasileiras? Conforme afirma Nabuco em Minha formação, bastava uma página de qualquer publicação nacional para fazer a escravidão saltar aos olhos do leitor. Mas, salvo poucas anotações de Aires e a alforria promovida por Santa-Pia, não há escravidão no Brasil. Aliás, parece que ser escravo do Barão não deve ser dos maiores infortúnios, já que todos se mantém trabalhando apenas pelos olhos de Fidélia. Mas e as relações de favor, de dependência, tão bem marcadas em Memórias póstumas, em Quincas Borba, em Dom Casmurro e em Iaiá Garcia, A mão e a luva, Ressurreição, Helena... ? Não há dependentes no mundo de Aires: todos trabalham, casam, vivem do próprio trabalho ou da própria propriedade, sem precisar mendigar favores de ninguém e sem lesar quem quer que seja (salvo os escravos, mas esses não contam), de modo que tipos como o Palha, o José Dias, a Mrs Oswald ou o Viana parecem não ter lugar no mundo de Aires.

Enfim, o Brasil do conselheiro mais parece uma peça promocional do Governo de Sua Majestade, ao estilo das realizadas para convencer o mundo de que a escravidão havia sido abolida. Assim, vivendo em um país idílico, não é de se estranhar que Teócrito, poeta das cenas bucólicas, e observador dos costumes, dos ambientes urbanos e requintados, seja citado três vezes no romance: em uma delas para referir-se ao amor de Tristão e Fidélia e outras duas para comentar o relacionamento do casal Aguiar. Em nenhuma das citações, a ironia está descartada ${ }^{81}$. Certo, o conselheiro nunca cessa de espalhar pelo texto indícios de que desconfia desse admirável mundo velho, mas, ao mesmo tempo em que denuncia, defende, como se quisesse ou conciliar ou... como se temesse as próprias descobertas e preferisse ocultar certos fatos a macular seu diário com verdades - aliás, como um contemporâneo seu, Teixeira de Feiras, faria com o código civil, conforme será visto mais adiante.

A desconfiança sobre a imparcialidade de Aires começa logo no início do romance, quando o conselheiro duvida desse mundo de fantasias em que tudo é alegria e bondade. É o que se depreende de seu comentário às observações de Rita sobre a felicidade conjugal de Fidélia e do primeiro marido:

\footnotetext{
${ }^{81}$ Uma está nas anotações do dia 29 de fevereiro e duas na do dia 13 de fevereiro.
} 
- Pelo que ouço, enquanto eu andava lá fora, a representar o Brasil, o Brasil fazia-se o seio de Abraão. Você, o casal Aguiar, o casal Noronha, todos os casais, em suma, faziam-se modelos de felicidade perpétua. (Obra Completa, vol. I p. 1.105)

Aires não rebate a observação de Rita e limita-se à ironia: todos faz̧iam-se modelos de felicidade perpétua. Ele não explicita seus julgamentos, como seria esperado, já que escreve em um diário íntimo. Seus pensamentos são abafados, para lembrar a feliz expressão de José Paulo Paes; tudo o que se sabe é que as visões dele e da irmã sobre o país são incompatíveis. O narrador descreve uma situação idílica, mas deixa entrever nas entrelinhas do seu texto que ele próprio duvida do que escreve. As estratégias são diferentes das empregadas em Dom Casmurro, mas o efeito é o mesmo: ao lado da voz do narrador surge uma outra que o nega ou, pelo menos, o questiona. Ele afirma que se o Brasil era como Rita o descrevia, ele estivera representando ${ }^{82}$ o país errado. No entanto, o mesmo conselheiro irá traçar um retrato de seus amigos que não soará mais verossímil que o de Rita.

Um exame um pouco mais cauteloso mostrará que toda essa felicidade resulta, na verdade, do olhar que Aires lança sobre o seu mundo, podendo sua opinião estar equivocada. Essa questão será discutida no capítulo seguinte. No momento importa apenas assinalar que a problemática do interesse e da ascensão social não está ausente nesse romance, apenas é camuflada por Aires, ainda que ela esteja bem debaixo dos olhos dele. Daí a importância de D. Cesária, pois a velha senhora seria uma espécie de embaixadora (já que o narrador é um diplomata) a representar o velho mundo de Machado, onde todos desconfiam de todos e todos os atos ocultam intenções outras. O fato de D. Cesária ser constantemente desqualificada por Aires não a impede de transmitir uma versão diferente do mesmo mundo que o conselheiro descreve em seu diário. Veja-se, por exemplo, a relação entre Tristão e Fidélia, elemento central da trama. Em dado momento, D. Cesária diz a Aires que Tristão gosta da Fidélia, mas é claro que lhe prefere a política ${ }^{83}$ e depois que Tristão se demoraria no Rio. O conselheiro entende que ela se referia à afeição do moço pelos pais de estimação, mas ela explica que a razão era outra:

\footnotetext{
${ }^{82}$ Nesse momento vale a pena lembrar algumas das definições que o dicionário de Aurélio Buarque de Hollanda dá para o verbo representar:

1. Ser a imagem ou a reprodução de; 2.Tornar presente; patentear, significar; 3. Participar de espetáculo teatral, de filme, etc., desempenhando papel, interpretar: 4. Levar à cena; exibir, encenar (em teatro); 5. Chefiar missão junto a (governo, organismo internacional, congresso, etc.): 6. Estar em lugar de; substituir; 7. Ser procurador ou mandatário de; 8. Figurar, aparentar.

${ }^{83}$ Obra Completa, vol. I p. 1,170
} 
- Sim, concordei, parece que the custa [a Tristão] muito deixar os padrinhos.

— Os padrinhos? redargüiu Cesária rindo. Ora, conselheiro! Certamente chama assim aos dous olhos da viúva, que são bem ruins padrinhos. Mas lá tem consigo a água benta para o batizado.

Não entendendo, perguntei-lhe que água benta era, e que batizado. O marido [de D. Cesária], com a sua rabugem do costume, respondeu que a água benta era o dinheiro, e esfregou o polegar e o índice; ela riu apoiando, e eu compreendi que atribuíam ao moço uma afeição de interesse.

Quis ponderar à dama que isto que me dizia agora estava em contradição com o que uma vez lhe ouvi. Ouvi-lhe então (e creio que o escrevi neste Memorial) que Tristão preferia a política à viúva, e por isso a deixava. [...] A contradição é aparente; está toda no ódio que ela tem a Fidélia, e este sentimento é a causa íntima e única das duas opiniões opostas. Preterida pela política ou preferida pelo dinheiro, tudo é diminuir a outra dama. [...] Há ocasiões em que a graça de D. Cesária é tanta que a gente tem pena de que não seja verdade o que ela diz, e facilmente lho perdoa. (Obra Completa, vol. I p. 1.177-8)

E aí está novamente o casamento como programa de uso para a realização de um programa de base de ascensão social. E também a preponderância de interesses materiais sobre as afeições íntimas, como diria o narrador de Ressurreição. Pode até ser que Aires desconsiderasse totalmente a opinião de D. Cesária, mas não se pode afirmar o mesmo do enunciador, que, por meio dela, instaura uma outra visão dos fatos narrados, permitindo, tal como ocorria em Dom Casmurro, a construção de uma nova interpretação para os mesmos fatos apontados por Aires. O narrador pode até não partilhar da leitura de D. Cesária, da mesma forma que o narrador de Helena não via os atos das personagens como Brás Cubas veria, mas essa possibilidade está claramente colocada pelo enunciador. A hipótese ganha força quando se observa, ao final do romance, a desilusão de Aires e Campos com o comportamento de Tristão e Fidélia, que abandonaram os dois velhos sem ao menos dizerlhes que sua partida para Portugal era definitiva. Quer dizer, se a imagem que D. Cesária fazia de ambos era equivocada, a de Aires não é mais acertada. Recordemos brevemente o momento em que Campos conta ao conselheiro que o casal não mais voltaria ao Brasil:

Em particular, a um canto, [Campos] disse-me que Tristão lhe escrevera dizendo achar-se eleito deputado quando desembarcou em Lisboa, e pedindo-lhe que desse a notícia à gente Aguiar como entendesse melhor; não lhes escrevia a eles sobre isso para evitar o sobressalto. Que me parecia?

- Sempre se lhes há de dizer tudo, respondi; o melhor é que seja logo, e aqui estamos para dizer as cousas cautelosamente.

- Também me parece.

- Eu engenharei uma fábula...

Engenhei o que pude. Falei do golpe que o moço recebeu quando desembarcou deputado, e viu misturadas as alegrias dos pais com as dos amigos políticos; devia dizer também que a primeira idéia de Tristão foi rejeitar o diploma e vir para Santa-Pia; mas que o partido, os chefes, os pais... Não fui tão longe; seria mentir demais. Ao cabo, não teria tempo. Os dous velhos ficaram fulminados, a mulher verteu algumas lágrimas silenciosas, e o marido cuidou de lhas enxugar. 

meus)

Assim correram as cousas, a mentira e os efeitos. (Obra Completa, vol. I p. 1,199-grifos

Como já é rico, Tristão, assim como Pedro e Paulo, persegue a glória e o poder via deputação, porém, não mais na ex-colônia, mas na ex-metrópole. Para alcançar esse objetivo, não hesita em abandonar seus pais de estimação, e assim não só quebra a promessa que lhes havia feito, de permanecer junto deles ${ }^{84}$, mas leva consigo Fidélia que lhes havia feito igual juramento. É o mesmo dilema já vivido por Helena, mas agora sem lugar para considerações de qualquer ordem. O Memorial de Aires mostra que, além dos relacionamentos amorosos, como os de Guiomar ou Iaiá, as relações entre pais e filhos, como em Helena, não podem se sobrepor às necessidades ${ }^{85}$. Diferentemente de Helena, de Guiomar e de Estela, dentre outros, Tristão teve a boa fortuna de não comprar o pão com o suor do meu rosto, mas isso não vem ao caso: para obter a glória, também sonhada por Natividade para seus filhos, ele não hesita em desfazer-se daqueles que poderiam representar alguma dificuldade. Agora já não se poderia dizer, em hipótese alguma, que o Memorial de Aires se pareça com A moreninha. A palavra mentira aparece duas vezes na pena do diarista, que não hesita em assim qualificar as justificativas que tentou apresentar para o ato de Tristão e Fidélia. Aires começa mentindo e depois reconhece: seria mentir demais. Os dois velhos ficam a olhar para longe, para onde se perde a

${ }^{84} \mathrm{O}$ percurso de Tristão já está, de certa forma, condensado no próprio nome, que remete, inevitavelmente, à lenda de Tristão e Isolda, que se tornou famosa principalmente na versão musical de Richard Wagner (Munique, 1865). Marcos, rei da Cornualha, incumbe seu sobrinho, Tristão, de buscar sua esposa, Isolda. No entanto, em vez de levá-la ao tio que o comissionou, Tristão apaixona-se por ela e é correspondido. A partir daí, há várias versões do drama. Em algumas, ambos fogem juntos e são perseguidos por Marcos; em outras, afastam-se para não prejudicar o rei que amam. No entanto, a união do casal jamais se consuma, pois Tristão morre sem conseguir unir-se definitivamente a Isolda, confirmando o tema da paixão fatal e da morte como única forma de união.

Claramente as coisas se passam de forma diferente com o Tristão machadiano. Há, porém, pontos de contato: o casal Aguiar procura estimular a união Tristão e Fidélia para que ambos permaneçam ao seu lado, mas acontece justamente o contrário; com o casamento, que acontece sem qualquer impedimento.Tristão não somente afasta-se dos velhos, como também os priva da companhia de Fidélia, a exemplo do Tristão da tragédia, que acabou por afastar Isolda de Marcos. A pungente descrição final dos dois velhos, quando Aires vai visitá-los algum tempo depois da partida do casal, dá a medida da sanção a que foram submetidos por acreditarem nos dois jovens. Vale a pena relembrá-la:

Ao transpor a porta para a tua, vi-lhes no rosto e na atitude uma expressão a que não acho nome certo ou claro; digo o que me pareceu. Queriam ser risonhos e mal se podiam consolar. Consolava-os a saudade de si mesmos. (Obra Completa, vol. I, p.1200)

${ }^{85}$ Aires considera que Fidélia e Tristão são, de fato, filhos do casal Aguiar. Veja-se, por exemplo, sua notação de 21 de junho de 1888, quando da morte de Santa-Pia, pai de Fidélia:

O pior é não serem [Tristão e Fidélia] filhos [do casal Aguiar] de verdade, mas só de afeição; é certo que, em falta de outros, consolam-se com estes, e muita vez. os de verdade são menos verdadeiros.(Obra Completa, vol. I, p. 1126) 
vida presente e tudo se esvai depressa ${ }^{86}$, em uma atitude que lembra a de Estela, quando percebe que o futuro não the seria coisa nenbuma. Nos dois casos, como no de Félix, não há lugar para afeições genuínas que não conduzem a nada. A diferença — grande — no Memorial de Aires é que, nos momentos finais, narrador e enunciador passam a concordar, não porque o segundo mude de posição, mas porque o primeiro une-se a ele, na sanção negativa aos demais actantes do enunciado. De Ressurreição a Dom Casmurro, o enunciador instalou sujeitos que buscavam a ascensão social e um narrador que se mantinha neutro ou, em graus e formas variadas, concordava com os percursos dos actantes do enunciado. Já em Esaú e Jacó, o narrador mantém-se cético em relação aos propósitos desses actantes, enquanto no Memorial, ele narrador é conivente durante parte da narrativa — ou não se dá conta de suas implicações para, ao final, perceber toda a vilania que havia neles e nos valores vigentes.

A posição oscilante de Aires talvez faça do Memorial de Aires um romance mais complexo do que os que o antecederam, pois tudo nele é mais sutil, mais delicado, e, acima de tudo, dotado de uma aversão a qualquer posição maniqueísta como a que nossas palavras podem ter sugerido. A questão da ascensão se faz presente, porém, com muito mais sutileza, mostrando-se mesclada a considerações de toda ordem e sob um olhar que não é condescendente, e tampouco implacável, como o de outros narradores. Se, para o narrador de Quincas Borba, tudo já era nebuloso, para Aires, então, nada pode ser definido; nada é, mas tudo parece ser. Confirma-se, assim, por uma outra via, o ceticismo do enunciador, que opta por instalar um narrador crédulo, ou melhor, que tenta ser crédulo, mas que termina o romance desenganado.

$\cos \cos 20$

A análise dos nove romances de Machado indicou a reiteração de uma configuração discursiva constituída por um programa narrativo central de aquisição de valores descritivos. O objeto é sempre figurativizado como ascensão social ou obtenção de prestígio social e o sujeito que o busca é jovem e solteiro, com exceção do casal Palha. A execução desse programa de base demanda a realização de outro, de uso: o casamento ou o recebimento de uma herança, sendo que este pode ser explícito, como no caso de Helena e Quincas Borba, ou

\footnotetext{
${ }^{86}$ Obra Completa, vol. I p. 1.199
} 
implícito, como no caso de Ressurreição, Memórias póstumas e Esaú e Jacó. Em todos os casos, a família desempenha papel central na realização do programa de uso.

No plano do enunciado, a ascensão é sempre vista como um valor positivo; portanto, eufórico: todos os actantes desse nível desejam ascender socialmente, de um modo ou de outro, mesmo que pertençam ao grupo dos dominantes. No entanto, como se verá nos capítulos seguintes, quando se atenta para o nível da enunciação, o quadro é diferente, pois essa instância não lança o mesmo olhar para essas condutas, o que acaba por opor, por meio de estratégias muito diversas, a enunciação e o enunciado. O que é visto de forma neutra ou positiva pelo narrador é sancionado negativamente pelo enunciador.

A repetição de uma mesma configuração discursiva, tanto em termos sintagmáticos quanto paradigmáticos, permite determinar um modo padrão de agir do enunciador. Tal recorrência não é percebida apenas no nível discursivo - afinal, o que há de comum, à primeira vista, entre Dom Casmurro e Helena? Em termos paradigmáticos, observa-se a reiteração dos mesmos elementos: o espaço tópico não se altera; é sempre urbano e sempre a cidade do Rio de Janeiro, ou a corte, como prefere o enunciador. A única exceção, se é que se pode chamá-la assim, é Esaú e Jacó, em que o espaço tópico se alarga para, de certa forma, abranger o país inteiro. A cronotopia é rigorosamente a mesma: a última metade do século XIX, época em que o Brasil firmava sua independência e identidade políticas. Essas considerações levam a pensar em um enunciador urbano e da modernidade, para quem a questão da ascensão social, presente em todos os romances, está colocada, e em um enunciatário para quem esse tema representa, ao mesmo tempo, um aspecto relevante da existência e/ou uma falta a ser suprida. Ora, se é a ascensão social que está em jogo, então, supõe-se que as categorias fundamentais em discussão devem estar relacionadas ao mesmo fazer. Assim, em nível um fundamental, pode-se dizer que o enunciador trabalha em todos os romances com a categoria superioridade $\mathrm{x}$ inferioridade e que, no plano do narrado, a dêixis positiva será sempre superioridade, enquanto, no plano da narração, conforme será visto, ocorre uma inversão. Para não fugir à regra convém expor essas categorias no quadrado semiótico, onde se tem:

Superioridade

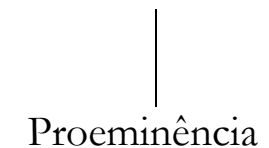

Inferioridade

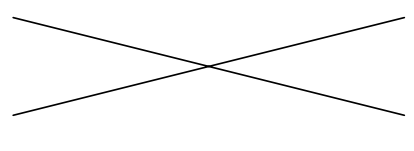

Mediocridade 
Sendo sempre essas as categorias em jogo, observa-se nos nove romances uma sintaxe fundamental variada, que envolve percursos também diferentes. Assim temos:

- Guiomar (A mão e a luva), Helena (Helena), Iaiá (Iaiá Garcia), o Casal Palha (Quincas Borba) e Capitu (Dom Casmurro) realizam o percurso canônico: negam a inferioridade em que se encontram, afirmam a proeminência como um valor positivo e atingem a superioridade.

- Rubião (Quincas Borba) realiza o percurso inteiro: confirma a mediocridade e, assim, afirma a inferioridade em suas relações com Quincas Borba (o filósofo), para, em seguida, negála, atingir a proeminência com o recebimento da herança, e depois a superioridade graças à fama adquirida. Em seguida, volta à mediocridade e, enfim, a inferioridade, quando enlouquece.

- Pedro e Paulo (Esaú e Jacó) e Tristão (Memorial de Aires) realizam apenas parte do percurso: confirmam a proeminência para manter a superioridade.

- Brás Cubas (Memórias póstumas) oscila todo o romance entre a proeminência e a mediocridade, sem jamais tornar-se inferior nem superior.

- Bentinho (Dom Casmurro), Felix (Ressurreição) e Estela (Iaiá Garcia) não realizam nenhuma transformação em termos sociais: os primeiros permanecem na dêixis da superioridade (ainda que, em termos morais, ocorra uma descensão), e a segunda, na dêixis da inferioridade (ainda que, em termos morais, ocorra uma ascensão).

Em todos os romances, estabelecem-se programas de aquisição de valores descritivos para os quais, conforme ficou dito, são executados programas de uso: em geral, casar-se (Félix. Guiomar, Helena, para legitimar a ascensão, Iaiá, Capitu, Tristão etc.) ou receber uma herança (Helena, Rubião, Brás Cubas, Pedro e Paulo). Em segundo plano, há quase sempre alguém executando um programa de esbulho (Procópio, Cotrim, Casal Palha, Santos, Nóbrega). Como quer que seja, no plano do narrador, ocorre, geralmente, a passagem da inferioridade (valorizada disforicamente) para a superioridade (valorizada euforicamente), com exceção de Dom Casmurro, em que a ascensão de Capitu ou de Escobar é sempre vista com desconfiança.

Em termos figurativos, a constância não é pequena. Em $A$ mão e a luva, Iaiá Garcia e Dom Casmurro, há um sujeito, figurativizado em uma mulher jovem, branca, e de baixa condição social, que busca ascender socialmente via casamento. Em Helena e Quincas Borba, o 
mesmo percurso é realizado, com a diferença que programa de uso é o recebimento de uma herança cuja legitimidade, nos dois casos, é questionável; além disso, no caso de Quincas Borba, o sujeito é figurativizado em um ator do sexo masculino. Em Ressurreição (Félix), Memórias póstumas (Brás Cubas), Esaú e Jacó (Pedro e Paulo) e Memorial de Aires (Tristão), o sujeito já ascendeu socialmente (por meio de uma herança), mas almeja ainda mais prestígio e grandeza, como diria a cabocla do Castelo. O resultado final do percurso realizado pelo sujeito se equilibra: Guiomar, Iaiá, o casal Palha, Tristão, Pedro e Paulo têm sucesso e são sancionados positivamente. Já Félix, Brás Cubas, Rubião, Helena e Capitu (supondo que o casamento tenha sido realizado com essa intenção) fracassam, recebendo, portanto, a sanção negativa. Não terminam aí as semelhanças. Em oito desses romances, o sujeito não se deixa levar por razões de natureza sentimental, mas dão razão à fria eleição do espírito, tendo suas atitudes norteadas pelo cálculo e não pelas emoções. São sujeitos que não crêem em propósitos, como dizia o Conselheiro Aires, e que julgam romances uma coisa absurda, como explica Valéria. A exceção fica por conta de Félix, que não se contenta com a felicidade exterior e procura afeições mais íntimas. Observe-se, porém, que a regra não se altera na medida em que ele é sancionado negativamente por ter feito a escolha errada, e não porque o destinador o enganou nem porque tenham mudado o quadro de valores.

Recorde-se agora que o objeto de valor, em vez de ser adquirido, pode ser construído pelo sujeito que nele investirá os valores de que tem necessidade. É assim com a sopa de legumes e assim é com a narrativa; também ela é construída para ser depositária de valores dos quais o sujeito tem necessidade. Viu-se que, nessas narrativas, o valor predominante é a ascensão social, a qual deve se sobrepor a qualquer sentimento. Daí porque a primeira visão que vem à mente do ethos desse enunciador é alguém cético, distante e frio. Para entender exatamente o que isso significa, o melhor é recorrer às definições do Houaiss, que, por sinal, contribuem para a construção de um corpo para esse enunciador. Diz o dicionário que alguém frio é alguém

8. que sabe conservar a calma, que controla sentimentos;

9. sob controle, que não se manifesta (diz-se de sentimento);

10. que denota reserva, que é pouco acolhedor, que não é caloroso;

11. que carece de calor comunicativo;

12. lânguido, frouxo, sem vigor; inerte;

13. de temperamento fleumático, que não é dado a expansões de sentimentos, que se mostra impassível; insensível;

14. seco, duro, desprovido de afeto, de calor humano (diz-se de atitude, gesto etc.);

15. indiferente e/ou insensível ao prazer sexual; 
16. que denota crueldade, ruindade; cruel;

17. falso, forjado, fictício;

18. não apimentado.

Evidentemente, nem todas as acepções listadas se aplicam ao ethos desse enunciador, mas algumas delas, sim, e por razões que ainda falta especificar. Por ora, basta lembrar as inúmeras vezes em que, na obra de Machado, os sentimentos foram opostos, em uma posição desfavorável, à razão. Assim, e tomando por base as definições 8 e 9 acima, percebese que, em todos os romances, o enunciatário está diante de um ator da enunciação que não é um romântico, não acredita em paixões ou ideais, tem seus sentimentos sob controle e não crê em amores possíveis ou impossíveis, mas tem um temperamento fleumático (definição 13), regido pelo cálculo e pela razão. Isso o coloca, portanto, muito distante do poeta romântico sonhador e de físico frágil. Esse enunciador não é idealista; enxerga as coisas como de fato são. Também é grande a distância em relação ao enunciador que brada contra as injustiças sociais e se propõe a lutar contra elas, como o de $O$ navio negreiro. Esse narrador se assemelha antes ao analista que apenas observa e perscruta sem tecer juízos de valor; ou que o faz com mais ou menos ironia. Não brada, nem sussurra, apenas fala, sem manifestar sentimentos, de forma não apimentada (definição 18). Trata-se, portanto, de um enunciador que privilegia o dever e o saber e não o querer e o poder, e é nessa linha que atua. Segundo ainda as definições do dicionário, pensa-se em alguém dissimulado, o que se aproxima da definição 17. Quanto ao corpo, trata-se de alguém dotado de gestos comedidos (definições 13 e 14), pouco expansivo,não necessariamente frágil, mas, provavelmente, não corpulento.

Em outra chave, é Antonio Candido que, com a argúcia que lhe é peculiar, observa que Machado diz as coisas mais terríveis da forma mais cândida. (1995: 27) Quais? O sentimento de absurdo que permeia a vida humana, com um defunto que se compara a Moisés para narrar suas desventuras e se gaba de não ter tido filhos, portanto, de não haver transmitido a ninguém o legado de nossa miséria. O horror de colocar em cena um narrador que não vacila ao confessar, impávido, que por pouco não assassinou o próprio filho e que, ao saber de sua morte, janta bem e vai ao teatro. Ou, ainda, de apresentar um narrador que resvala nas perversões humanas ao narrar os sonhos eróticos de D. Cláudia, que gozava ao sentir látegos sublimados em críticas ao marido. É também o enunciador terrível que desvela o que se encontra de verdade por trás de bom casamento burguês, ao expor o modus operandi do casal Palha, exemplo cabal da instrumentalização do homem pelo próprio homem. Horror 
que também pode ser visto na atitude de Valéria, que prefere um filho morto na Guerra do Paraguai que casado com agregada; afinal, não se mistura lé com crê. Invertendo os papéis, há o Salvador e Helena que preferem trocar sua relação, negando-a, por outra, espúria, para receber uma herança e, assim, ascender socialmente. Há também o espetáculo não muito edificante de Guiomar, para quem a as relações pessoais podem ser transpostas para um livro-caixa. Vê-se que a lista é grande e não autoriza a divisão da obra do autor em duas metades, por exemplo, uma otimista ou romântica e a outra pessimista ou realista; mostra , ao contrário, que, para esse enunciador, realmente não há grandes destinos a serem cumpridos. A observação de Candido se relaciona também à oposição entre ser (a coisa terrível) e o parecer (a forma cândida, que apresenta Helena e Aires, por exemplo, com traços bem diferentes dos que ele seriam na realidade), que constituem o arcabouço que estrutura toda a obra e que pressupõe um enunciatário também sofisticado, não apenas por que é capaz de dominar uma norma culta ou desvendar os mecanismos de funcionamento da linguagem, mas também por saber apreciar esse jogo entre aparência e essência, nem sempre fácil ou agradável.

A forma cândida, a imagem de alguém instruído, refinado, mas que não se furta a tocar os pontos mais obscuros da alma, é construída também pelo fato de esse enunciador, além de ser um usuário da norma culta da língua, ter se tornado o grande responsável pela definição do que é e o que não é norma culta no português do Brasil ${ }^{87}$, graças à autoridade que adquiriu no correr dos anos. Como observa Discini (2003: 130), o uso da norma culta insere o sujeito em determinado lugar enunciativo e dependendo do contexto de comunicação qualifica ou desqualifica o discurso. No caso desses romances, a norma qualifica o discurso, pois seu enunciador é alguém culto, que se dirige a um enunciatário em situação próxima, conforme poderá ser observado mais adiante, nas discussões sobre os níveis enunciativos. Assim, pelo viés do idioma, afirmase, mais uma vez, o ethos de alguém de hábitos refinados, discretos e, no que diz respeito à língua, corretos. Será que tratar-se de alguém que respeita ao extremo a norma e, por meio

\footnotetext{
${ }^{87}$ É ocioso discorrer sobre a influência de Machado no idioma, todavia, talvez a eloqüência dos números dê uma idéia do que isso significa. Um levantamento superficial da autoria das abonações no dicionário de Aurélio Buarque de Hollanda apresentou o seguinte resultado: Machado de Assis: 849 ocorrências; Eça de Queirós, 498; Coelho Neto, 450; José de Alencar, 389; Olavo Bilac 265; Graciliano Ramos, 202; Luís de Camões, 180; Euclides da Cunha, 170. Além disso, Machado de Assis é o autor mais citado pelas gramáticas de Celso Cunha e de Evanildo Bechara (embora não se possa quantificar), para exemplificar os usos da língua considerados gramaticalmente corretos por esses autores. Mas não é apenas na gramática que isso ocorre. José Luis Fiorin (1996), por exemplo, vale-se grandemente de Machado de Assis para exemplificar o quanto a enunciação pode ser astuta.
} 
dela, as convenções? Afinal, os romances examinados poderiam se enquadrar na categoria dos destinados às boas famílias ${ }^{88}$, aqueles que podem ser lidos, sem susto, por todas as almas católicas (como gosta de dizer certo cronista), sem medo de encontrar algo que venha a perturbar-lhes o sono. Assim, estaria configurado o ethos do enunciador absolutamente respeitador das convenções, sejam as de natureza lingüística, sejam as relativas à moral e aos bons costumes...

Mas será que é mesmo assim?

$\mathrm{Na}$ verdade, não, muito pelo contrário. Os textos lidos parecem respeitar os cânones da língua e da moral, mas o fazem apenas no modo da aparência. Em segredo - e em um nível mais profundo - , subvertem tanto um quanto outro. Veja-se o caso das instâncias narrativas, discutido mais detalhadamente a seguir. Diz a teoria que o enunciador, pressuposto e exterior ao texto, instaura, por debreagem, o narrador, o qual, por sua vez, instaura o interlocutor e assim sucessivamente. No entanto, Machado subverte essa ordem com narradores que se apresentam como enunciadores, como faz inúmeras vezes Brás Cubas; ou então com narrativas que se fingem na chamada terceira pessoa quando, na verdade, são na primeira, como é o caso de Esaú e Jacó; e, ainda, com o diálogo constante com o leitor que não deveria estar dentro do texto, mas fora dele. Sim, a teoria explica esse processo, e é justamente a explicação que permite a Machado subvertê-lo, produzindo um texto que foge aos cânones da escola realista que é onde, segundo os críticos, o autor se enquadra. Assim, embora pareça sujeitar-se à norma sob vários aspectos, esse enunciador, na verdade, lança desafios a ela.

Compare-se, agora, o simulacro de realidade construído e figurativizado pelos enunciadores "naturalistas". Aluísio Azevedo, ator da enunciação de romances contemporâneos aos de Machado, como O mulato (1881), O cortiço (1884) ou Casa de pensão (1890), apresenta a seu destinatário um objeto de saber diferente do oferecido pelo enunciador da obra aqui examinada. Embora ambos se proponham a produzir obras realistas (fiquemos com essa etiqueta, para facilitar as coisas), o simulacro de realidade produzido por eles é claramente distinto. No caso do Aluísio Azevedo, o simulacro da realidade era constituído primeiramente pela descrição viva, e quase sem rodeios, das necessidades

\footnotetext{
${ }^{88}$ É o que afirma explicitamente o crítico Auraucários que a respeito do lançamento de $A$ mão e a lwva escreve nO Novo Mundo de Nova York de 22.2.1875: "Pelo que respeita à moralidade, [Machado] pertence à classe dos que como os de Tchackerey podem os pais darem às sem prévia leitura”. In: Guimarães (2001: 320).
} 
primeiras do corpo, frutos da herança biológica, da educação ou , ainda, nascidas do meio social em que vive o sujeito. Esse falar sem rodeios, às claras, traz à imaginação um corpo que também afirma em vez de sugerir, que fala alto, ou, pelo menos, não fala baixo; um enunciador menos sutil, mais direto, sem preocupação de dissimular o que diz; e um enunciatário que, em contrapartida, também não está muito disposto a jogar o jogo do ser e do parecer, porque ele, simplesmente, não é jogado. É bem diferente o caso do enunciador Machado de Assis; não porque seus sujeitos sejam moralmente mais sãos dos que os dos enunciadores naturalistas, mas sim porque a narração recobre o que o narrado desvela, de modo a mostrar um sujeito da enunciação mais sutil ou dissimilado: de um lado, à primeira vista, o pleno respeito a todas as normas sociais vigentes; de outro, mas ao fundo o escárnio a todas as convenções. É, portanto, outro o corpo que vem agora à mente, não necessariamente de compleição mais frágil que o anterior, mas, certamente, mais discreto, dotado de um falar menos forte.

Para encerrar, é preciso que fique claro que o percurso narrativo relativo à ascensão social não é o único a dominar a cena. Talvez não seja nem mesmo o principal, uma vez que estaria subordinado a outro, a ser estudado no capítulo seguinte: o percurso realizado por um sujeito cujo programa narrativo de base consiste na construção de uma narrativa no interior da qual estaria inserida a busca por prestígio social. Nesse caso, o saber mobilizado pelo enunciador é de outra natureza: não se trata mais de questões sociais, mas daquelas ligadas ao fazer literário, à construção de efeitos de verdade e de mentira ou, simplesmente do papel e do funcionamento da linguagem nas relações humanas. Na outra ponta, há um enunciatário que não está à procura de uma história romanesca, cheia de peripécias e reviravoltas; que se compraz justamente com a discussão sobre a própria narração, e que tem no jogo entre ficção e realidade seu interesse último. Claro, as duas questões não são estanques; estão articuladas para construir o sentido global da obra. Todavia, para a análise desses fenômenos, é preciso examinar a enunciação e seus delegados: narrador e observador. É o que será feito nos dois capítulos seguintes. 


\section{Instalação do narrador}

$P$

ara realizar sua performance, isto é, enunciar, o enunciador precisa instalar no discurso enunciado duas categorias de sujeitos: os que executam os programas narrativos inscritos no enunciado e os dotados de uma competência específica para transmitir o fazer dos demais sujeitos instaurados ao enunciatário. No item anterior, analisou-se a instalação dos actantes do enunciado e dos programas narrativos realizados por eles. Agora se trata de analisar as estratégias utilizadas para instalar os actantes da enunciação enunciada, isto é, os sujeitos cuja missão é relatar o fazer dos outros sujeitos. Mais uma vez, espera-se encontrar, no modo de instalar tais actantes, uma constância que permita definir o ethos do enunciador. Observe-se que, no caso do ator da enunciação Machado de Assis, essa questão se torna ainda mais relevante, pois, como aponta Fiorin (1996:.105), na obra do escritor os comentários do narrador e não o narrado constituem o elemento central de composição.

A semiótica tem dois entendimentos acerca do narrador. Ele pode ser considerado como a manifestação da enunciação e, nesse caso, sua não existência (por exemplo, narração em terceira pessoa) seria um tipo de narrador. Ou então, pode-se considerar que existe narrador apenas quando o papel temático da narração é explicitado. Nesse caso, o narrador deve ser entendido tanto como um ator que exerce tanto o papel actancial de sujeito do discurso quanto como aquele que desempenha o papel de destinador, pois ele é o destinador do discurso explicitamente instalado no enunciado (Greimas \& Courtés 1993: 242). Para o exame da obra de Machado de Assis, as duas posições se equivalem, pois a função temática da narrativa é sempre explicitada em todos os romances, mesmo naqueles que a crítica considera narrativas em terceira pessoa.

Conforme se sabe, o enunciador pode optar por instalar o narrador por meio de uma debreagem enunciva ou enunciativa. No primeiro caso, o narrador não se manifestará de forma explícita, havendo um efeito de sentido de objetividade, embora nem sempre isso se verifique. No segundo caso, o narrador será um eu, havendo uma simulação da própria enunciação e um maior efeito de sentido de subjetividade. O enunciador poderá ainda dotar 
um mesmo ator de dois papeis actanciais distintos: ele é actante do enunciado, na medida em que desempenha um fazer pragmático de executar os programas narrativos que lhe são apresentados; e é, também, actante da enunciação enunciada, na medida em que conduz a narrativa e exerce o fazer cognitivo, de transmitir os fatos que sabe. Nesses casos, um mesmo ator subsume um actante narrativo, que executa determinados programas narrativos, e um actante discursivo, encarregado de transmitir um saber relativo aos programas executados. Naturalmente, em tal situação, cria-se um efeito ainda maior de subjetividade, pois relata-se aquilo que se viveu. É isso que acontece no belíssimo Missa do galo (Páginas recolhidas, 1899), em que, passado muito tempo, o narrador relata o colóquio, repleto de sensualidade, que teve com Conceição, jovem senhora em cuja casa estava hospedado. Recorde-se o primeiro parágrafo do conto:

Nunca pude entender a conversação que tive com uma senhora há muitos anos, contava eu com dezessete anos, ela trinta. Era noite de Natal. Havendo ajustado com um vizinho irmos à missa do galo, preferi não dormir; combinei que eu iria acordá-lo à meia noite. (Obra Completa, vol. II, p. 605)

O narrador diz eu, enunciando, desse modo, a enunciação. A subjetividade é clara e não se sabe, ao final do conto, se Conceição tentou ou não seduzi-lo, nem mesmo o real significado dos seus gestos e olhares, dado que tudo pode ter sido fruto da imaginação do adolescente, ainda turvada pela passagem dos anos. A subjetividade é também a característica do enigmático conto $O$ enfermeiro (Várias histórias, 1896), em que o narrador confessa que quando jovem matara por acidente o homem de quem cuidava. A situação é um pouco mais complexa, pois, na verdade, o narrador faz sua narrativa no interior de um diálogo em que apenas um dos protagonistas usa da palavra. Assim, pode-se pensar que há um narrador primeiro, implícito, que instala os dois interlocutores, um dos quais assume a narrativa. Ao final da narrativa, esse narrador segundo, que relata os fatos que viveu a seu ouvinte, se despede de seu interlocutor:

Adeus, meu caro senhor. Se achar que esses apontamentos valem alguma coisa., pague-me também com um túmulo de mármore., no qual data por epitáfio esta emenda que faço aqui ao divino sermão da montanha: "Bem-aventurados os que possuem, porque eles serão consolados." (Obra Completa, vol. II p. 535)

Dois efeitos se misturam no conto: inicialmente, o de objetividade, já que o narrador primeiro, que permanece oculto, apenas reproduziria um diálogo, sem emitir qualquer comentário; em seguida, porém, sobrevém o efeito oposto, de subjetividade, dado que o 
relato do narrador segundo, o enfermeiro, não se mostra confiável, pois está em jogo um possível assassinato perpetrado por ele.

Pode-se citar também o divertido e sarcástico O segredo do bonz̧o (Papéis avulsos, 1882), em que o narrador — supostamente o navegador Fernão Mendes Pinto — conta as aventuras que viveu na cidade de Funchéu, capital do reino do Bonzo. Observe-se que, na medida em que o título do conto é precedido da frase "Capítulo inédito de Fernão Mendes Pinto", podese supor um narrador primeiro - que não diz eu — que instaura um narrador segundo, o próprio Mendes Pinto, que narra em primeira pessoa: Atrás deixei narrado o que se passou nesta cidade Funchéu, capital do reino de Bungo, com o Padre-mestre ... ${ }^{89}$ diz Nesse caso, também há dois narradores: um que cita o capítulo inédito de Fernão Mendes Pinto e assim instala o narrador dessa obra, que, a partir dá, narra em primeira pessoa. Contudo, isso em nada afeta a conclusão de que o que prevalece no conto é um narrador que diz eu, portanto, uma debreagem enunciativa da enunciação Em todos esses casos, a identidade do narrador parece contaminar o material narrado. Em $A$ missa do galo, não se sabe exatamente o que de fato aconteceu e o que é apenas um julgamento do narrador. Raciocínio semelhante é valido para O enfermeiro: será que os fatos se passaram como narrado, ou o narrador os modifica visando à expiação de sua falta? Finalmente, a história registra que o narrador de $O$ segredo do Bonzo era um mentiroso contumaz, o que retira toda credibilidade do narrador e faz pairar a dúvida sobre os fatos narrados.

Pode acontecer também de, apesar de haver um sincretismo de actantes narrativos e actantes discursivos, o narrador não dizer $e$. Nesse caso, ocorre uma neutralização da primeira e da terceira pessoas e o narrador refere-se a si próprio como ele. É o que acontece com o romance $A$ peste, de Albert Camus, em que o narrador revela apenas na última página ser o doutor Rieux, médico que cuidara dos doentes durante a epidemia que teria assolado Oruan na década de 40. Observe-se a passagem:

O Velho tinha razão, os o homens eram sempre os mesmos. Mas essa era a sua força e a sua inocência, e era aqui que Rieux, acima de toda a dor, sentia que se juntava a eles. Em meio aos gritos que redobravam de força e de duração, que repercutiam longamente junto do terraço, à medida que as chuvas multicores se elevavam mais numerosas no céu, o doutor Rieux decidiu, então, redigir esta narrativa, que termina aqui, para não ser daqueles que se calam, para depois a favor dessas vítimas da peste, para deixar ao menos uma lembrança da injustiça e da violência que lhes tinham sido feitas e para dizer simplesmente o que se aprende no meio dos flagelos: que há nos homens mais coisas a admirar que coisas a desprezar." (Rio de janeiro: Record, s/d Trad. de Valery Rumjanek, p. 213 - Grifos meus).

\footnotetext{
${ }^{89}$ Obra Completa, vol. II, p. 323
} 
Até esse parágrafo, o antepenúltimo do livro, supunha-se que o romance era narrado em terceira pessoa, pois acreditava-se que o narrador não participava dos fatos narrados. Com a revelação acima, descobre-se que o narrador teve participação importante na narrativa, pois era o médico que cuidava dos doentes. Contudo, não se perde o efeito de objetividade, pois nos dois parágrafos seguintes o narrador continua a referir-se ao doutor Rieux como ele e não como $e$, de modo a manter a ilusão de objetividade (agora já apresentada como ilusão) criada ao longo do romance. Nesse caso, um en continua a se passar por ele, como se o narrador e o actante do enunciado não estivessem sincretizados no mesmo ator.

O enunciador pode ainda optar por não atribuir ao ator responsável pela narração nenhum papel actancial relativo ao enunciado, ou, pelo menos, nenhum papel relevante, explicitando, ainda assim, o papel de condução da narração. É o que se passa em Macunaíma. No romance de Mário de Andrade, a identidade do narrador também é revelada apenas nos parágrafos finais, com a diferença de que o narrador não teve qualquer participação nos fatos narrados, No entanto, ainda assim a da condução da narrativa é explicitada. Recordemos:

Uma feita um homem foi lá. Era madrugadinha e Vei mandara as filhas visar o passe das estrelas. $[\ldots]$ Falou:

Então o homem descobriu na ramaria um papagaio verde de bico dourado espiando pra ele.

— Dá pé, papagaio.

O papagaio veio pousar na cabeça do homem e os dois se acompanheiraram. Então o pássaro principiou falando numa fala mansa, muito nova, muito! [...]

Tudo ele [o papagaio] contou pro homem e depois abriu asa rumo de Lisboa. E o homem sou eu, minha gente, e eu fiquei pra vos contar a história. Por isso que vim aqui. Me acocorei em riba destas folhas, catei meus carrapatos, ponteei a violinha e em toque rasgado botei a boca no mundo cantando na fala impura as frases e os casos de Macunaíma, herói de nossa gente,

Tem mais não.

(Paris: Association Archives de la Littérature latino-américaine, des Caraibes et africaine du XXe siècle / Brasília : CNPq, 1988 - grifos meus)

Ao contrário do que ocorria em $A$ peste, a partir do momento em que revela sua identidade, o narrador passa a usar o pronome de primeira pessoa, criando um efeito de subjetividade, reforçado, em seguida, pelo possessivo nossa, que sugere ainda a identidade com o enunciatário. Quase nada se sabe do narrador, apenas que é um homem, que não participou dos fatos narrados, e que seu único fazer pragmático o chamar o papagaio e ouvir a história, relativa aos feitos de Macunaíma, para, em seguida, narrá-los para o narratário (identificado como minha gente). Observe-se que todas as apreciações e observações sobre Macunaíma são 
do narrador segundo, o papagaio. Cabe ao homem apenas transmitir o saber recebido, explicando as condições em que o recebeu.

A condução da narração também pode ser explicitada ao longo do texto, e não apenas em um momento, sem que isso implique a participação do narrador nos eventos narrados. Um exemplo famoso talvez ajude a compreender melhor o que se passa. Recordese o final da primeira parte do Dom Quixote. O herói havia detido uma procissão que carregava uma imagem da Virgem Imaculada, pensando tratar-se uma formosa senhora que ia sendo levada contra sua vontade. Os participantes percebem que o Quixote é louco e põemse a rir, acendendo ainda mais a fúria do cavalheiro, que investe contra eles. O rápido embate termina com D. Quixote mortalmente ferido. Seu fiel escudeiro, Sancho Pança, leva-o para sua casa, onde o cavalheiro se restabelece sob os cuidados de sua ama e de sua sobrinha. (p. 942-9). Nesse momento, intervém o narrador com a seguinte explicação:

Mas o autor desta história, embora tenha posto toda a curiosidade e diligência em buscar os feitos de Don Quixote na sua terceira saída, não pôde achar notícia deles, pelo menos em escritas autênticas; só a tradição guardou nas memórias da Mancha, que Dom Quixote, saindo pela terceira vez de sua casa foi Saragosa, onde tomou parte numas famosas justas que naquela cidade se fizeram; e ali se passaram coisas dignas de seu valor e bom entendimento. Nem do seu fim e acabamento alcançaria ou saberia coisa alguma, se a boa sorte não lhe houvesse deparado um antigo médico que tinha em seu poder uma caixa de chumbo, que, segundo declarou fora achada entre os alicerces em ruínas de uma velha ermida, que se renovava; nessa caixa se encontraram uns pergaminhos escritos com letras góticas, mas em versos castelhanos, que continham muitas de suas façanhas [...] Os que se puderam e tirar a limpo foram os que aqui mostra o fidedigno autor desta nova e nunca vista história. $\mathrm{O}$ qual autor não pôde aos que a lerem, em prêmio do imenso que lhe custou inquirir e buscar todos os arquivos manchegos para tirá-la à luz, senão que lhe dêem o mesmo crédito que soem dar os discretos aos livros de cavalaria, que tão boa cotação têm no mundo [...] (Cervantes, 1954, V. III, p. 949-50)

Observe que esse narrador não diz eu, como em Macunaíma, mas isso não o impede de relatar os feitos do autor, que, assim, também se torna sujeito de um percurso específico; não a busca por aventuras, mas a própria escritura do livro. O narrador dá, então, testemunho do empenho do autor na elaboração da primeira parte da obra e de como, apesar das dificuldades, ele teria obtido informações fidedignas sobre a terceira incursão do Quixote. Curiosamente, o narrador continua a narrar como se estivesse fora da narrativa, muito embora o assunto tenha mudado radicalmente e passe a referir-se a seu próprio fazer. A quebra na seqüência da narrativa continua na segunda parte uma vez que essa é precedida por um Prólogo ao leitor em que o narrador volta a fazer considerações sobre a redação do romance e não sobre as aventuras de Dom Quixote. Segundo os comentaristas, tal prólogo teria sido motivado pelo fato de que, entre a publicação da primeira (1605) e da segunda 
(1615) partes, teria surgido o Quixote de Avellaneda, que narrava justamente as aventuras do herói nas justas citadas no trecho acima, fato que muito teria aborrecido a Cervantes. Veja-se o prólogo:

Valha-me Deus, com que gana deves estar esperando agora, leitor ilustre, ou mesmo plebeu, este prólogo, crendo achar nele vinganças, ataques e vitupérios contra o autor do segundo Dom Quixote, isto é, daquele que dizem se gerou em Tordesílias e nasceu Tarragona! Em verdade, porém, não te hei de dar tal alegria; pois, se bem que os agravos despertam a cólera nos humildes peitos, no meu tal regra há de sofrer exceção. Quererias o chamasse asno, mentecapto e atrevido, mas não me passa coisa semelhante pelo pensamento; castigue-o seu pecado, com seu pão o coma e bem se avenha [...](Cervantes, 1954, V. III, p. 973 - grifos meus)

Não interessa a este trabalho saber se Cervantes ficou ou não irado com a obra homônima ou se o parágrafo acima tem relação com o fato citado anteriormente, mas ver que, ao lado das aventuras do cavaleiro, surge uma outra história, agora narrada em primeira pessoa: a de outro sujeito que se envolve em torneios, armado, não mais de lanças, como seu personagem, mas da palavra. Sua aventura consiste em narrar e publicar um romance e é esse o feito que é narrado. Observe que esse percurso também é explicitado nos títulos dos capítulos. Tomem-se dois exemplos, escolhidos a esmo. O título do capítulo IV da segunda parte é: Onde Sancho satisfaz. o bacharel carrasco sobre suas dúvidas e perguntas, com outros sucessos dignos de saber-se e contar-se. Já o do capítulo VI é: Do que se passou a Dom Quixote com a sobrinha e a ama, um dos importantes capitulos de toda a bistória. ${ }^{90}$ Veja que os nomes dos capítulos referem-se tanto aos fatos narrados quanto ao ato de narrá-los, mostrando o equilíbrio entre uns e outros em um processo que não passou desapercebido a Machado (não, nos esquecemos dele), como mostra o narrador de Quincas Borba quando se lamenta por não ter o mesmo talento que Cervantes para nomes aos capítulos.

Como se sabe, a preocupação com a narração não é exclusiva do narrador de Quincas Borba, uma vez que ela ocupa um lugar de destaque em toda a obra de Machado; não apenas nos romances, mas também nos contos. É o que ocorre no Cantiga de Esponsais (Histórias sem data, 1884), que conta a história do mestre Romão, músico de prestígio em sua paróquia, que morre sem conseguir compor um cântico esponsálico, projeto acalentado por toda a vida. $\mathrm{O}$ narrador, que não participa dos fatos narrados, inicia o conto dessa maneira:

Imagine a leitora que está em 1813, na igreja do Carmo, ouvindo uma daquelas boas festas antigas que eram todo o recreio público e toda a arte musical. [...]. Não lhe chamo a atenção para os padres e sacristães nem para o sermão, nem para os olhos das moças cariocas, que já eram bonitos nesse tempo, nem para asa mantilhas das senhoras graves, os calções as cabeleiras, as

\footnotetext{
${ }^{90}$ Cervantes: 1954 , p. 1.019 e 1,035, respectivamente - grifo meu.
} 
sanefas, as luzes, os incensos, nada. Não falo sequer da orquestra, que é excelente; limito-me a mostrar lhe uma cabeça branca desse velho que rege a orquestra, com alma e devoção. (Obra completa, vol. II. P. 386)

Uma leitura mais superficial desse trecho poderia levar à conclusão de que se está diante de uma debreagem enunciva do enunciado, isto é, de que a enunciação se projeta em um lá (a Igreja do Carmo), um então (1813) e um ele (o velho que rege a orquestra). Poder-se-ia pensar há apenas um observador que nada mais faz além de exercer seu fazer receptivo, sem conduzir a narrativa, que vai por si só. No entanto, um exame mais acurado revela que o papel temático da narrativa está marcado tanto pela instauração do narratário - que, evidentemente, acarreta a instauração do narrador - quanto pelo fato de o narrador conduzir o olhar do leitor para a cena. Não se trata apenas de verbalizar o que o ocorre, mas também de enfatizar que se está diante da uma narrativa e de conduzir o olhar do leitor, como se este visse um quadro ou estivesse presente na cena. Aliás, o narrador acaba mostrando para o enunciatário que existem padres em cena justamente ao afirmar que não chama a atenção da leitora para os fatos narrados e para o sermão. Um olhar mais atento revela, portanto, uma debreagem enunciativa da enunciação, como indicam os verbos (imagine, chamo, limito-me). No entanto, ao contrário do que se observou nos demais contos de Machado analisados neste capítulo, esse narrador não participa dos fatos narrados, ele é actante da enunciação enunciada, mas não do enunciado enunciado.

O trecho acima permite, ainda, distinguir os fazeres do observador e do narrador, ainda que os dois actantes estejam sincronizados em um único ator. O primeiro mostra a cena; o segundo orienta o leitor para que não se deixe levar pela beleza dela e se concentre no essencial: o regente. Observe-se ainda a presença clara do narratário figurativizado em uma leitora, para quem, provavelmente, as festas como a mostrada são familiares. Sabe-se que o narratário não se confunde com o enunciatário e que o enunciador não escrevia para "leitoras"; no entanto, ao explicitar um narratário que sabidamente não corresponde ao enunciatário, o enunciador instaura um narrador que cria um clima de proximidade e de familiaridade com o narratário, ao mesmo tempo em que parece afastar o enunciador da cena, posto que ele praticamente se apaga.

Outro exemplo é o do conto O cônego on a metafísica do estilo (Várias histórias, 1896), que narra as dificuldades de Matias, cônego honorário e pregador efetivo para compor um sermão. $\mathrm{O}$ 
narrador parece ausente até no nono parágrafo, quando instaura o narratário, portanto a si próprio, e explicita o papel temático da narrativa, ao orientar o leitor na leitura do texto:

Upa! Cá estamos. Custou-te, não, leitor amigo? É para que não acredites nas pessoas que vão ao corcovado e dizem que ali a impressão da altura é tal, que o homem fica sendo cousa nenhuma. [...] Não creias tu nisso, leitor amado. Nem Corcovado nem Himalaias valem muita cousa ao pé da tua cabeça que os mede. Cá estamos. Olha bem que é a cabeça do cônego. Temos à escolha um ou outro dos hemisférios cerebrais; mas vamos por este, que é onde nascem os substantivos. Os adjetivos nascem no da esquerda. Descoberta minha, que, ainda assim não é a principal, mas a base dela, como se vai ver. (Obra Completa, vol. II p. 571 - grifos meus)

Os advérbios, verbos e pronomes grifados não deixam dúvidas: trata-se de uma debreagem enunciativa da enunciação, porém sem que o narrador seja actante do enunciado, pois ele permanece como se estivesse "recolhido" à enunciação. Instaura-se um narrador e um narratário impossíveis; dessa vez, liliputianos, já que são capazes de ir até o topo da cabeça do cônego, o qual, em virtude da visita do narrador e do narratário, passa do nível do narrado para o nível da narração, e dessa forma deixa o enunciado para pertencer à enunciação. Pode-se pensar também que se opera uma neutralização das instâncias da enunciação e do enunciado, pois narrador e narratário, apresentados como enunciador e enunciatário, passam a fazer parte do narrado na medida em que sobem à cabeça do actante do enunciado, de onde passam a comentar tanto o narrado quanto a narração. Pode-se, portanto, entender igualmente que a narrativa não é sobre o cônego, mas sobre as explorações "científicas" feitas pelo narrador e narratário para descobrir o funcionamento da linguagem (sempre ela!). Se essa for a "verdadeira" narrativa do conto, então o narrador é também actante do enunciado enunciado. $\mathrm{Na}$ verdade, as duas alternativas são possíveis, pois uma das características desse enunciador é justamente o embaralhamento das fronteiras entre as instâncias enunciativas. Como quer que seja, cria-se um efeito de distanciamento do enunciador, que tem seu lugar usurpado pelo narrador, este, desejoso de fazer crer que é de fato o enunciador.

Veja-se agora o belo e amargo $A$ letra vencida (publicado em $A$ estação, em novembro de 1882), conto que narra a história de dois jovens, Beatriz e Eduardo, que se amam apesar da oposição dos pais. Contrariando as narrativas românticas nas quais o amor impossível jamais se concretiza, os dois apaixonados conseguem unir-se 17 anos depois de trocarem as primeiras juras. Contudo, a união ocorre apenas no modo da aparência, pois não traz a felicidade conjugal esperada. Os fatos parecem narrar-se a si mesmos, sem a explicitação da 
presença do narrador, até que a função narrativa é tematizada por uma breve intervenção do narrador no início do segundo capítulo:

Para que hei de dizer que Beatriz deixou de dormir o resto da noite? Subentende-se que as últimas horas dessa triste noite 23 de abril forma para ela de vigília de desespero. Direi somente que também foram de devoção [...]. (Obra Completa, vol. II, p. 903 - grifo meu)

Mais uma vez os verbos delatam a presença da enunciação no enunciado, apesar de o narrador não ter um papel nesse nível. Ao final do conto, depois que os dois personagens finalmente se casam, surge a frase "—Enfim”, indicando a presença de um interlocutor não identificado que se refere à conclusão da narrativa contada até aquele momento pelo narrador. Segue-se, então, a narrativa dos dias que seguiram ao casamento e, depois, o seguinte diálogo:

— São felizes? Perguntei a um amigo íntimo deles em 1879.

— Eu lhe digo, respondeu esse amigo observador. Não são felizes nem infelizes [...]

—Então, infelizes?

- Também não. Vivem, respeitam-se; não são infelizes, nem podemos dizer que são felizes. Vivem, respeitam-se vão ao teatro... (Obra Completa, vol. II, p. 903. — grifos meus)

O diálogo entre o narrador e seu interlocutor revela que a narração, até esse ponto, era, na verdade fruto do diálogo entre dois interlocutores, portanto, actantes do enunciado. Desse modo, é preciso rever as observações anteriores. Na verdade, a afirmação "direi somente que..." não se tratava dos comentários de um narrador, actante da enunciação enunciada, mas referia-se ao interlocutor, actante do enunciado, que explicava os fatos a seu interlocutário. Considerando, porém, a obra de Machado, nada impede que o sujeito daqueles verbos seja de fato o narrador, que, uma vez mais, posa de enunciador. Nesse entendimento, o amigo que conta os fatos narrados a seu interlocutor seria o observador que transmitiu ao narrador tudo o que ocorreu e os diferentes actantes da enunciação estão figurativizados em atores diferentes e seus fazeres são também bem demarcados: o narrador só narra aquilo que sabe por meio do observador, conforme é explicitado no trecho acima, quando o narrador se refere ao seu interlocutor como o amigo observador de quem recebeu as informações que relata. Chega-se, assim, novamente, a uma neutralização entre enunciação e enunciado, que parece ser uma característica desse enunciador.

No conto A forma da espada (Artifícios), de Júlio Borges, o narrador, apresentado como o próprio Borges, narra o relato que ouvira de um homem que lhe contara a origem de 
uma cicatriz que trazia no rosto. Durante quase toda a narrativa, pensa-se que o narrador segundo era também o observador da narrativa que narra, mas, curiosamente, há uma inversão nessa narrativa segunda, pois o ponto de vista não é o do narrador, e sim o do homem que ele matara. Nesse caso, claramente o papel de narrador e de observador são exercidos por atores distintos. No último parágrafo do texto, descobre-se que ainda o narrador não era o herói, como se pensava até então, mas o traidor. No entanto, ele contara os fatos do ponto de vista daquele que ele traíra, para obter a atenção do narrador primeiro, Borges:

— Você não me acredita - balbuciou. - Não vê que levo escrita no rosto a marca da minha infâmia? Narrei-lhe a história dessa forma para que você a ouvisse até o fim. Denunciei o homem que me amparou: eu sou Vincent Moon. Despreze-me agora. (Obra Completa, Vol. I. p. 551. Trad. Carlos Nejar).

Como se vê, nesse caso, o narrador segundo, Vicent Monn, é também actante do enunciado segundo (a história da traição), e o narrador primeiro, Borges, actante do enunciado da narrativa primeira e interlocutor de Monn.

Naturalmente, pode ocorrer de o narrador estar completamente ausente ou implícito; isto é, de ninguém assumir explicitamente a condução da narrativa. É o caso do conto $O$ anel de Policrates (Papéis avulsos, 1882), inteiramente constituído por um diálogo entre $A$ e $Z$ sobre Xavier, nababo e pródigo que termina na miséria. Também é assim com o famoso Teoria do medalhão (Papéis avulsos, 1882), constituído de um diálogo entre Janjão e seu pai, que ensina ao filho, por ocasião de seu aniversário de 21 anos, como subir na vida. Contudo, não é necessário ir aos extremos dos contos constituídos de diálogos para perceber a ausência do narrador. Esse é o recurso empregado por Borges em no conto O Atroz redentor Lazarus Morell (História universal da Infâmia), em que são relatadas as atividades de Lazarus Morell, criminoso que ajudava escravos a fugirem no sul dos Estados Unidos para depois (re)vendê-los como escravos. Nesse caso, a narrativa é conduzida de forma a causar a impressão de que seria uma seqüência de notícias publicadas em um jornal,

Em Pai contra mãe (Relíquias de casa velha, 1906), é narrada a história de Candido das Neves, que ganhava a vida capturando escravos fugidos e que salva o próprio filho da roda dos enjeitados ao conseguir uma recompensa pela captura de uma escrava que acabara de dar à luz. Em nenhum momento, o narrador diz "eu" ou emite sua opinião sobre o que narra. Os fatos narram-se a si mesmos, gerando um efeito de sentido de grande objetividade. Veja-se o seguinte trecho: 
Há meio século, os escravos fugiam com freqüência. Eram muitos e nem todos gostavam da escravidão. Sucedia ocasionalmente apanharem pancada, e nem todos gostavam de apanhar pancada. Grande parte era apenas repreendida; havia alguém de casa que seria de padrinho, e o mesmo dono não era mau; além disso, o sentimento da propriedade moderava a ação, porque dinheiro também dói. A fuga repetia-se entretanto. Casos houve, ainda que raros, em que o escravo de contrabando, apenas comprado no Valongo, deitava a correr, sem conhecer as ruas da cidade. Dos que seguiam para a casa, não raro, apenas ladinos, pediam ao senhor que lhes marcasse aluguel e iam ganha-lo fora, quitandando. (Obra Completa, vol. II p. 659).

O tempo, marcado pelo pretérito imperfeito, é do então (Há meio século os escravos fugiam). O espaço é o lá, tenuemente marcado; apenas na segunda metade do parágrafo, sabe-se que parte dos fatos narrados ocorriam no Valongo, nas ruas da cidade ou na casa do senhor. Os atores são os escravos (eles). Ninguém diz eu. Ninguém diz tu. A enunciação é pressuposta. Parece haver apenas uma testemunha ocular que observa, sem se explicitar no texto, sem emitir seus pontos de vista. O tom é quase de um historiador que busca transmitir seu saber com a isenção requerida pela ciência. É diferente dos contos discutidos há pouco, nos quais o narrador assume a condução do texto, relatando, inclusive, como obteve as informações que transmite ao leitor.

Mas em que essa discussão sobre o narrador em suas diversas modalidades contribui para a determinação do ethos do enunciador nos romances de Machado de Assis? Afinal, até o momento, discutiu-se o narrador e não o enunciador. Além disso, qual a finalidade, de se evocar tantos autores tão distintos? Inicialmente, lembremos que o enunciador só pode ser apreendido a partir de uma totalidade, ao passo que o narrador pertence à esfera da unidade, pois ele é exclusivo de uma única obra, de um único texto. O exame dos procedimentos adotados para a instalação do narrador, tal como realizado até o momento, envolvendo Machado e outros autores, foi importante para mostrar a existência muitas possibilidades, e que, nos contos, Machado de Assis se utiliza de várias delas. Por outro lado, as práticas de Machado não são, obviamente, exclusivas dele, mas são de uso freqüente por outros atores. Desse modo, considerando-se apenas o parâmetro instalação do narrador não seria possível definir um ethos do enunciador desses contos. No entanto, como será visto a seguir, o processo de instalação do narrador nos romances não apresenta a variedade a verificada nos contos; ao contrário, esse procedimento obedece sempre a um padrão muito semelhante, ainda que um exame feito na superfície possa levar à conclusão contrária..

Em todos os nove romances de Machado — isto é, em 100\% das ocorrências — ,o papel temático da narrativa é explicitado; há sempre um narrador explícito, que, de forma 
mais gentil, como o de Helena, ou menos, como o de Quincas Borba, com mais ou menos solicitude, conduz seu narratário na leitura do texto. Sim, há lugar para a variedade nessa uniformidade; ela é decorrente do fato de que nem sempre os actantes da enunciação e do enunciado são sincretizados em único ator. Como se sabe, cabe ao narrador o fazer pragmático de relatar o que sabe sobre os programas narrativos executados pelos actantes do enunciado. Em Ressurreição, A mão e a luva, Helena, Iaiá Garcia e Quincas Borba, a função de condução da narrativa é exercida por um ator distinto daquele que executa os programas narrativos. Já em Memórias póstumas, Dom Casmurro e Memorial de Aires, há um sincretismo, na medida em que Brás Cubas, Bento Santiago e José da Costa Marcondes Aires são actantes tanto da enunciação enunciada, pois são narradores, quanto do enunciado, uma vez que executam os programas narrativos dessa instância. ${ }^{91}$ Finalmente Esaú e Jacó representa um caso especial, pois ambos pode ser incluídos tanto no primeiro quanto no segundo grupo, conforme se verá mais à frente.

Observe-se, ainda, que o não sincretismo do narrador com os actantes do enunciado tem levado a crítica literária a afirmar que os primeiros romances de Machado seriam narrativas em terceira pessoa, o que parece pouco apropriado, pois, conforme citado, o narrador e o papel temático da narrativa são explicitados também nesses romances e, também neles, os comentários do narrador se fazem tão importantes quanto o conteúdo narrado. $\mathrm{O}$ narrador está todo o tempo presente na narrativa, interferindo nela e mesmo atuando, não enquanto actante do enunciado, mas enquanto actante da enunciação, o qual explicita seu papel de destinador do discurso. Em outras palavras, o que se observa em todos os romances de Machado é a debreagem enunciativa da enunciação, na medida em os actantes dessa instância são projetados pelo enunciador no enunciado, procedimento cuja constância diz muito a respeito do modo de ser e da competência do ator da enunciação e será útil na busca de um ethos que o defina. Em todos eles, enfim, o narrador diz eu. Mas, talvez, o mais conveniente seja ir diretamente aos textos, já que, segundo dizem, fora deles estamos todos danados, como dizem os franceses...

${ }^{91}$ Essa afirmação deve ser nuançada. Bento Santiago e José da Costa Marcondes são, conforme citado, actantes da enunciação e do enunciado, porém o enunciador os diferencia de acordo com a instância em que atuam. Enquanto actante do enunciado, o primeiro é chamado de Bentinho e o segundo, de Conselheiro Aires. 


\section{Ressurreição}

Em Ressurreição, o fazer do narrador, a narração, é explicitado ao longo da narrativa, como acontecerá em absolutamente todos os romances de Machado (mas não em todos os contos). E o processo começa já no início do romance, no encerramento da descrição sobre Félix:

Do seu caráter e espírito melhor se conhecerá lendo estas páginas e acompanhando o herói por entre as peripécias da singelíssima ação que empreendo narrar. (Obra Completa vol. I, p.118 一. grifos meus)

Não contente em se fazer presente no texto, orientando a leitura e explicando ao narratário o que ele encontrará nas páginas seguintes, o narrador apresenta-se como o próprio enunciador (e assim faz o narratário se assimilar ao enunciatário). Ele se incumbe ainda (um pouco à maneira de José Dias, é verdade) de avaliar a narrativa que, de fato, está em vias de começar. Cria-se, assim, um espelhamento entre o narrado e a narração, já que esta narra a leitura que está sendo realizada. A essa intervenção do narrador (que não é a primeira) seguirse-ão inúmeras outras, como esta, já na segunda metade do livro, que novamente discute não só a narrativa, mas a narração:

Aqui podia acabar o romance muito natural e sacramentalmente casando-se esses dois pares de corações e indo desfrutar a sua lua-de-mel em algum canto ignorado dos homens, mas para isto, leitor impaciente, era necessário que a filha do coronel e o Dr. Meneses se amassem, e eles não se amavam, nem se dispunham a isso. (Obra Completa vol. I, p.159 - grifos meus)

Sim, o estilo lembra o de Diderot em Jacques le fataliste, que faz do ato de narrar uma narrativa, e do narrador, um herói. $\mathrm{O}$ ato de narrar torna-se, então, a trama primeira. A passagem mostra que algumas das características do que se convencionou chamar a segunda fase de Machado já estavam bem presentes no seu primeiro romance. É o caso, visto no item anterior, da recusa ao drama romântico, aos finais felizes, e da primazia do cálculo sobre o sentimento. É também o caso da ironia e do trato para com leitor. Veja, o narratário construído por esse texto é o leitor de obras românticas, desejoso de finais felizes com casais que se amam para todo sempre; mas esse não é o caso do enunciatário, que recusa justamente esse tipo de narrativa e sente prazer em ver seu próprio fazer interpretativo tornar-se objeto de imitação.

Dois outros aspectos estão em jogo: a dicotomia entre verdade e verossimilhança, em torno da qual tanto debateram os filósofos e retóricos da antiguidade; e o processo de 
imitação da realidade. Na passagem acima, o narrador explicita seu poder e o seu dever: ele poderia casar as personagens, tem poder para tanto, mas ele não deve fazê-lo, pois isso não corresponderia à verdade dos fatos; e esse narrador, conforme se viu na primeira parte deste trabalho sempre diz ter um compromisso com a realidade, com a verdade, e não com a verossimilhança. Daí surge a pergunta: qual é, de fato, o percurso central do romance? $\mathrm{O}$ drama amoroso de Félix e Lívia ou fazer do narrador? Entende-se que ambos são importantes, mas não são hierarquicamente iguais, pois o drama de Félix subordina-se ao do narrador. Pode-se dizer que a construção de uma narração qualquer (nesse caso, a de Félix) é um programa de uso para realização de um programa de base: mostrar o drama do narrador na construção da narrativa. Volte-se um passo atrás: o sujeito da enunciação construiu um objeto de valor - o romance - e investiu nele seus valores, figurativizados pela história de um sujeito - o narrador - que constrói um objeto de saber - a narrativa desse nível — no qual instala os valores relativos à ascensão social. Desse modo, os percursos deste nível subordinam-se aos daquele e a debreagem da enunciação é duplamente enunciativa, se assim se pode dizer; não só porque o sujeito da enunciação se projeta no enunciado, mas também porque ele o faz explicitando seu papel temático de enunciador.

$\mathrm{Na}$ antepenúltima página do romance, encontra-se outro diálogo (que não é o último) entre narrador e leitor, no qual o primeiro reafirma sua autoridade, originária, justamente, do fato de ele ser o narrador:

\footnotetext{
Entendamo-nos, leitor; eu, que te estou contando esta história posso afirmar-te que a carta era efetivamente de Luís Batista. A convicção, porém, do médico — sincera, decerto — era menos sólida e pausada do que convinha. (Obra Completa vol. I, p.191 - grifo meu)
}

O narrador travestido de enunciador intervém na narrativa, atestando sua onisciência ao revelar que Luís Batista era o autor da carta anônima que difamava Lívia, e eliminando qualquer dúvida a respeito da veracidade do seu conteúdo. Observe que, nesse momento, são executados dois movimentos de sentidos opostos: de um lado, o narrador afirma-se como enunciador, quando diz eu, que te estou contando esta história...; porém, simultaneamente, considerando-se que está sendo narrado o processo de narração, ele se torna, também, actante do enunciado ao atuar como testemunha da ocorrência de um fato que se deu nesse nível. Com tais procedimentos, que com o tempo, irão se tornar quase sua digital, esse enunciador subverte a ortodoxia das instâncias narrativas e desestabiliza as certezas. Não é apenas a moral das personagens que é dúbia; a própria enunciação se torna nebulosa, com 
actantes passando de um nível a outro e embaralhando as fronteiras: onde, exatamente, acaba a narração e começa a narrativa?. Qual o estatuto dessa voz que dialoga com o leitor? As passagens citadas (antes e depois delas há várias outras) destacam não apenas a tematização da narrativa, mas também o predomínio da narração sobre o narrado e a instauração de actantes de um nível como se fossem de outro; é o caso do narrador que se apresenta como enunciador, realizando uma embreagem actancial, na medida em que são neutralizadas as diferenças entre as instâncias enunciativas.

Há, contudo, outro efeito, decorrente dessa engenharia, importante para conclusões futuras: a hipertrofia dos actantes da enunciação enunciada causa a hipotrofia dos demais actantes; tanto o da enunciação pressuposta quanto o do enunciado. Explique-se. Foi citado inúmeras vezes que em Machado a narração prevalece sobre o narrado, o que, naturalmente faz com que os actantes do enunciado tenham menos importância. Esse processo atinge o ápice no Memorial de Aires, em que a redação do diário ocupa tanto ou mais espaço que os fatos neles inscritos. A hegemonia do narrador causa ainda outro efeito: o esmaecimento do enunciador, que tende a desaparecer, pois seu lugar foi também usurpado pelo narrador que, não contente com a comissão recebida, quer ser também o comitente, pois se interpõe entre o enunciador e o enunciatário e se apresenta mesmo como produtor efetivo do texto. Certo, isso não ocorre de fato, pois o enunciador está fora do texto e a salvo da sanha do seu delegado, sem esquecer, claro, que foi o próprio enunciador quem instaurou o narrador no texto à sua imagem e semelhança. No entanto, no modo do parecer, é isso que ocorre: um falso enfraquecimento do enunciador que se vê ofuscado pelo narrador delegado. $\mathrm{Na}$ verdade, em segredo, ocorre algo muito diferente: o engrandecimento do enunciador cuja força e habilidade são tais que ele se permite mesmo obscurecer, sem que isso apague as marcas de seu ethos presentes no enunciado.

\section{A mão e a luva}

Seria inviável reproduzir as inúmeras vezes em que o narrador de $A$ mão e a luva intervém na narrativa e evidencia a narração, como acabou de fazer o narrador de Ressurreição. Citem-se, então, dois exemplos que atestam o fato de esse romance, como o anterior, ser constituído, em linhas gerais, por uma macro-debreagem enunciativa da enunciação, de modo que se pode dizer que é inadequada sua classificação como narrativa em terceira pessoa. $\mathrm{O}$ 
fato de o narrador, que não é actante do enunciado, intervir constantemente na narrativa, comentando a narração, faz com que o assunto do romance não seja apenas os percursos realizados por Guiomar, mas também — talvez principalmente - os realizados pelo narrador: Veja-se o exemplo a seguir:

Guiomar disse isto com tanta graça e singeleza, que a madrinha não pôde deixar de rir, e a melancolia acabou de todo. A sineta do almoço chamou-as a outros cuidados, e a nós também, amigo leitor. Enquanto as três almoçam, relanceemos os olhos ao passado, e vejamos quem era esta Guiomar, tão gentil, tão buscada e tão singular, como dizia Mrs. Oswald. (Obra Completa, vol. I, p. 215 - grifos meus).

É início do romance e a trama começa a ser fiada; mas essa não é a primeira vez que o narrador se dirige ao leitor. O trecho acima apresenta uma peculiaridade: além da instauração do narratário como se este fosse o enunciatário (leitor), há também a genial fusão das instâncias da enunciação e do enunciado: a sineta do almoço, actante do enunciado, manipula Guiomar e a baronesa, também actantes do enunciado, transmitindo-lhes um saber (o almoço está pronto) e um dever (realizar outros cuidados). No entanto, esse mesmo actante do enunciado migra para o nível da enunciação enunciada onde lembra o narradorenunciador e o narratário-enunciatário que também eles têm seus cuidados: relancear os olhos ao passado e ver quem era Guiomar, ou seja, continuar a narração, agora mediante uma debreagem enunciva, pois o parágrafo e o capítulo seguintes tratam de um lá e de um então a história da Guiomar a partir da morte do pai. Passam a existir, então, dois fazeres pragmáticos: o dos actantes do enunciado, que executam seus programas narrativos (almoçar); e dos actantes da enunciação, que exercem também não só um fazer pragmático, uma vez que a narração é exibida em sua característica de fazer (pesquisar o passado de Guiomar), mas também cognitivo, pois trata da transferência de um saber do narrador para o narratário. A enunciação deixa, desse modo, de estar pressuposta e se mostra como de fato é: uma manipulação de enunciatário-destinatário por um enunciador-destinador para que aquele entre em conjunção com um dado saber. Nesse trajeto, o enunciador é apresentado como aquele que constrói seu objeto de valor, tanto para satisfação das suas necessidades (é evidente, em inúmeras passagens, o prazer que sente em construir a narrativa) quanto das do enunciatário que usufruir do objeto que lhe é proposto. Veja-se um segundo exemplo:

Guiomar havia já alguns minutos que não atendia à interlocutora; tinha o ouvido afiado e assestado sobre o grupo da madrinha. Ninguém a observava; mas é privilégio do romancista e do leitor ver no rosto de uma personagem aquilo que as outras não vêem ou não podem ver. No rosto de Guiomar podemos nós ler, não só o tédio que lhe causava aquela opinião unânime contra o projeto da 
baronesa, mas ainda a expressão de um gênio imperioso e voluntário. (Obra Completa vol. I, p. 244 grifos meus).

Pode-se pensar que há, nessa passagem, uma neutralização de instâncias, já que os actantes da enunciação enunciada são projetados no enunciado. Todavia, as fronteira entre os dois níveis é claramente marcada: Guiomar é actante do enunciado; narrador e narratário são actantes da enunciação enunciada. Não são iguais, pois a enunciação é hierarquicamente superior ao enunciado, e os actantes desse nível foram projetados pelos actantes daquela, que mantém todos os fios e os manipulam a seu bel prazer. Claro, qualquer leitor sabe disso, sabe que é o "autor" quem manda, mas agora esse fazer é explicitado e, ao mesmo tempo, atenuado, pois surge uma cumplicidade entre o romancista e o leitor, os quais são, na verdade, narrador e narratário, ambos usurpando uma posição que não lhes pertence. O privilégio é, todavia, verdadeiro. Romancista e leitor podem, sim, ver o que actantes do enunciado não podem, pois seu saber é outro: ambos constituem outro percurso, paralelo e hierarquicamente superior ao enunciado: o da leitura. A passagem acima revela, ainda, que ambos constituem o sujeito da enunciação e que esta é, ao final, um trabalho a quatro mãos. Todavia, na medida em que o narrador se apresenta como romancista, ele afasta o enunciador.

Enfim, essas duas passagens — e há inúmeras outras — mostram que, como em Ressurreição, são narrados simultaneamente dois percursos: o de Guiomar e dos demais actantes desse nível; e o do narrador e do narratário. Embora as fronteiras entre as duas instâncias sejam claramente demarcadas, como indica a passagem acima, o fato de o narrador ser apresentado como sujeito de um fazer, de um percurso narrativo, iguala-o aos actantes do enunciado e, de certa forma, transforma-o em personagem como os demais. Claro, o seu percurso é muito distinto: não busca prestígio social, mas construir seu objeto, a narrativa.

\section{Helena}

Talvez Helena seja a obra de Machado que mais tem sido considerada romanesca, tecida com revelações bombásticas sobre paternidades, chantagens veladas, amores ameaçados pelo incesto que não se concretiza e gestos arrebatados a cada instante, tudo cercado pelas melhores intenções. Nessa atmosfera de excelentes, o narrador machadiano parece não se sentir muito à vontade, pois ele pouco aparece — ou melhor, aparece pouco se 
comparado aos demais romances do autor. Mesmo assim, aqui e ali, ele dá as caras para auxiliar o leitor ou para fazer apreciações acerca do que narra. Veja-se um caso desses:

Eugênia era uma das mais brilhantes estrelas entre as menores do céu fluminense. Agora mesmo, se o leitor lhe descobrir o perfil em camarote de teatro, ou se a vir entrar em alguma sala de baile, compreenderá, - através de um quarto de século, — que os contemporâneos de sua mocidade lhe tivessem louvado, sem contraste, as graças que então alvoreciam com o frescor e a pureza das primeiras. (Obra Completa vol. I, p. 289 - grifo meu)

O enunciador, mais uma vez, provoca a neutralização das instâncias da enunciação e do enunciado: o leitor e Eugênia poderão se encontrar em um baile, pois não há fronteiras entre eles. Como o narratário seria também o leitor, e Eugênia, um actante do enunciado, são três os níveis enunciativos que são neutralizados ao encontrarem-se no dito camarote: o da enunciação, onde está o enunciador e o enunciatário; o da enunciação enunciada, onde estão o narrador e o narratário; e o do enunciado, onde está Eugênia. Tudo se funde e se condensa: não se pode determinar onde acaba a narração e onde começa o narrado, os quais acabam também por se imiscuírem mutuamente. Veja que o "leitor" também acaba se tornando, sob essa ótica, um actante do enunciado caso encontre Eugênia em um teatro...

No mesmo capítulo, o narrador explica ao leitor que omite certos aspectos da narrativa por considerá-los desinteressantes, e assim apresenta-se como senhor da narração e único detentor do saber em jogo:

\footnotetext{
Eugênia desfiou uma historiazinha de toucador, que omito em suas particularidades por não interessar ao nosso caso, bastando saber que a razão capital da divergência entre as duas amigas fora uma opinião de Cecília acerca da escolha de um chapéu. (Obra Completa vol. I, p. 290)
}

Inicialmente, registre-se que o narrador, não sincretizado com nenhum actante do enunciado, diz en e, assim, projeta-se na narrativa e se torna, também ele, sujeito de um fazer: narrar o romance Helena. Veja que esse fazer é explicitado no trecho acima quando o narrador conta que sua narração omite um fato. Evidentemente, se ele não contasse que não narrou a historiazinha de toucador de Eugênia, ninguém ficaria sabendo que ela a contara às amigas. No entanto, ao revelar sua omissão, o narrador cria uma defasagem entre o seu saber e o saber que ele transmite ao narratário: ele sabe mais do que narra e, assim, volta a explicitar o seu fazer, que não é outro senão o de contar o que se passou. Veja que, na verdade, o narrador não tem o poder discricionário para decidir o que deve narrar ou não; como se sabe, tal decisão é da competência exclusiva do enunciador. Se tem, ou diz ter, conclui-se que ele está querendo se passar uma vez mais por enunciador, tematizando, nesse processo, uma vez 
mais a narração e as astúcias do... enunciador, o qual poderia simplesmente omitir o fato sem revelar a omissão. Se a revela, é para mostrar o seu domínio total sobre o texto (como farão os demais narradores,) e imitar a própria narração. Em outras palavras, se a omissão leva em conta apenas o narrador, conclui-se que ele não narra tudo o que sabe; se considera também o enunciador, percebe-se uma defasagem entre seu saber e o de seu delegado, assunto que será objeto do capítulo seguinte. Outro aspecto importante do exemplo acima, é que ele evidencia que a narração não é mais uma imitação da realidade (pois se fosse a omissão não teria cabimento), mas sua reconstrução pela linguagem — e aí os critérios utilizados nessa reprodução são de interesse secundário.

Um terceiro exemplo, extraído do momento em que Camargo recebe a carta de Estácio pedindo a mão de Eugênia, pode mostrar a dissociação entre o narrador e o observador — assunto do próximo capítulo — , ainda que eles estejam sincretizados em um único ator:

\footnotetext{
Daquele sonho foi despertada [Eugênia] pelo pai, que lhe imprimiu na testa o seu segundo beijo. O primeiro, como o leitor se há de lembrar, foi dado na noite da morte do conselheiro. O terceiro seria provavelmente no dia em que ela casasse. (Obra Completa vol. I, p. 327)
}

O narrador mais uma vez instaura o leitor e o orienta, lembrando-lhe do primeiro beijo dado por Camargo a Eugênia e chamando sua atenção para o terceiro, No entanto, ao contrário do que ele prevê, esse beijos não será dado no casamento da filha com Estácio, mas após a morte de Helena. Ora, obviamente, o enunciador conhece toda a história e sabe exatamente como as coisas se passarão, sabe, portanto, exatamente quando será o terceiro beijo; além disso, o narrador não está sincretizado com nenhum actante do enunciado, que o obrigaria a prender-se a seu ponto de vista saber. Desse modo, nada impediria o enunciador de dar a informação correta, precisa — ainda mais dispondo de um narrador sempre tão prestativo e educado, como o de Helena. Contudo, ao não fazê-lo ele revela uma defasagem entre o seu saber e o que ele delega ao narrador, procedimento que, a partir de Memórias póstumas, torna-se mais e mais intenso.

Em síntese, em Helena vigoram os mesmos procedimentos adotados em Ressurreição e A mão e a luva; de modo que a ausência de sincretismo entre narrador e actantes do enunciado não impede que o narrador seja projetado no texto como eu. Por outro lado, esse fato faz com que passem a existir duas narrativas: a inscrita no romance e o percurso do narrador que tenta construir sua narrativa. 


\section{Iaiá Garcia}

Tal como os romances anteriores, Iaiá Garcia é constituído por uma debreagem enunciativa da enunciação. Por outro lado, o narrador, que não é actante do enunciado, mostra-se muito mais reservado que seus antecessores, e poucas são as vezes em que comenta os fatos que narra, a ponto mesmo de, em termos quantitativos, a debreagem enunciva da enunciação predominar em toda a narrativa. Para que se tenha uma idéia de como as coisas se passam, as palavras leitor ou leitora, referindo-se ao narratário, não aparecem uma vez sequer no romance.

Apesar desse comedimento, algumas poucas intervenções do narrador explicitam sua condição de actante da enunciação enunciada e destacam a condução da narrativa de forma significativa, na medida em que abrem e fecham o romance, indicando que o que o acontece entre elas é resultado da atividade do narrador. A primeira intervenção acontece logo no sexto parágrafo do romance, quando o narrador afirma que No momento em que começa esta narrativa, tinha Luis Garcia quarenta e um anos ${ }^{92}$. Primeiramente, observe-se o correr da enunciação e do enunciado: não era apenas a narrativa que se iniciava naquele momento, mas também a narração, pois a leitura está de fato começando. Porém, ao mesmo tempo, enunciação e enunciado se separam. Repare nos tempos: o verbo começar, referindo-se à enunciação, no presente do indicativo cria de efeito de sentido de que a enunciação é concomitante à leitura.; em seguida, surge o verbo ter no pretérito imperfeito, pois a ação não diz mais respeito à enunciação e sim ao enunciado. Assim, se é verdade que no romance predomina, em termos quantitativos, a debreagem enunciva da enunciação, não o é menos que ela não apaga a debreagem enunciativa, a qual corre em paralelo, fazendo com que os dois sistemas convivam, de modo que o primeiro se submeta ao segundo. Surgem, assim, os dois percursos referidos no decorrer deste trabalho: o dos actantes do enunciado (Estela, Jorge Luís, Iaiá e outros) e o dos actantes da enunciação enunciada (o narrador).

Existem duas outras breves aparições do narrador, bastante semelhantes, que orientam o leitor na leitura da obra. A primeira está no terceiro capítulo, quando Jorge, de partida para a Guerra do Paraguai, vai à casa de Estela. Ao relatar o diálogo entre eles, o

\footnotetext{
${ }^{92}$ Obra Completa, vol. I, p. 393 - grifos meus.
} 
narrador afirma: Antes de lá entrar, vejamos quem eram os moradores ${ }^{93}$. Se, no exemplo anterior, o tempo da enunciação e do enunciado se separavam, agora é a vez de o mesmo acontecer com o espaço. Observe-se que o uso do advérbio lá só se justifica se o narrador estiver distante da cena e próximo do narratário, uma vez que o verbo ver está na primeira pessoa do plural do presente do indicativo, sugerindo que narrador e narratário estão juntos. Mais uma vez, observam-se atores, tempos e espaços da enunciação e do enunciado correndo em pistas paralelas. Os fazeres cognitivos de narrar e de ler, atribuições da enunciação enunciada, misturam-se ao fazer pragmático, no nível do enunciado, de dirigir-se à casa de Estela e conhecer os moradores. Segue-se um longo flashback em que o narrador narra como Estela passou a morar na casa de Valéria e porque saiu de lá..

A terceira intervenção do narrador acontece no início do capítulo VI, quando Jorge volta da Guerra do Paraguai. Antes de narrar os fatos que sucederam, o narrador faz outro retrocesso, iniciado com a seguinte frase: Antes de irmos direito ao centro da ação, vejamos por que evolução do destino se operon o casamento de Estela. ${ }^{94}$ Mais uma vez, narrador e narratário, apresentados como enunciador e enunciatário, estão juntos, descobrindo e conhecendo os fatos passados, ao mesmo tempo, o narrador sugere o apagamento do enunciador. Finalmente, o narrador volta nos momentos finais do livro, quando Estela se despede do pai e lhe explica o que a levou a recusar o amor de Jorge:

\footnotetext{
Depois contou-lhe a paixão de Jorge e todo o episódio da Tijuca, causa originária dos acontecimentos narrados neste livro; mostrou-lhe com calor, com eloqüência, que, recusando ceder à paixão de Jorge, sacrificara algumas vantagens ao seu próprio decoro; sacrifício tanto mais digno de respeito, quanto que ela amava naquele tempo o filho de Valéria.(Obra Completa vol. I, p. 508 - grifo meu.)
}

Dessa vez, é o demonstrativo neste que propõe que o narrador é o enunciador. O livro em questão, em princípio um actante do enunciado, torna-se, actante da enunciação, uma vez que o exemplar que o leitor "real' tem em mãos contém os mesmo fatos que são narrados pelo narrador de Iaiá Garcia. Dois percursos surgem ainda: os executados no interior do livro e os realizados do lado de fora; isto é, a própria escritura / leitura do livro.

Essas poucas e breves passagens parecem suficientes para marcar a debreagem enunciativa da enunciação, portanto, a presença explícita do narrador, e marcar seu papel

\footnotetext{
${ }^{93}$ Obra Completa vol. I, p. 407 - grifos meus.

${ }^{94}$ Idem, p. 424 - grifos meus.
} 
temático de narrar e de orientar o narrador, eliminando a idéia de que o narrador intruso seja um privilégio dos romances da chamada segunda fase de Machado de Assis.

\section{Memórias póstumas de Brás Cubas}

Memórias póstumas inaugura um novo procedimento na obra de Machado: a sincretização do narrador com os actantes do enunciado. Viu-se que nos quatro romances anteriores o narrador não participava da trama, muito embora interviesse na narrativa com freqüência, sempre dizendo $e u$. Agora isso muda, pois Brás é, ao mesmo tempo, actante da enunciação enunciada e do enunciado; conduz a narrativa e dela participa. Além disso, o texto é de tal forma pontuado por seus comentários que, conforme observado diversas vezes, a narração sobrepuja a narrativa. Não sendo viável fazer um levantamento exaustivo das inúmeras ocorrências, apontam-se, a seguir, aquelas julgadas mais significativas e ilustrativas do espírito geral do livro. Trata-se do celebérrimo (é o convívio com o José Dias) capítulo IX, em que o narrador se vangloria da habilidade para conduzir a narrativa:

$$
\text { Capítulo IX - Transição }
$$

E vejam agora com que destreza, com que arte faço eu a maior transição deste livro. Vejam: o meu delírio começou em presença de Virgília; Virgília foi o meu grão pecado da juventude; não há juventude sem meninice; meninice supõe nascimento; e eis aqui como chegamos nós, sem esforço, ao dia 20 de outubro de 1805, em que nasci. Viram? Nenhuma juntura aparente, nada que divirta a atenção pausada do leitor: nada. De modo que o livro fica assim com todas as vantagens do método, sem a rigidez do método. Na verdade, era tempo. Que isto de método, sendo, como é, uma coisa indispensável, todavia é melhor tê-lo sem gravata nem suspensórios, mas um pouco à fresca e à solta, como quem não se lhe dá da vizinha fronteira, nem do inspetor de quarteirão. É como a eloqüência, que há uma genuína e vibrante, de uma arte natural e feiticeira, e outra tesa, engomada e chocha. Vamos ao dia 20 de outubro. (Obra Completa, vol. I, p. 525)

Veja, o título do capítulo refere-se à narração, e não à narrativa como seria esperado. A transição não diz respeito ao percurso narrativo de Brás Cubas, actante do enunciado, isto é, ao narrado, mas à própria narração, portanto, à enunciação enunciada. No capítulo VIII, era narrado o delírio de Brás Cubas, e, no X, o nascimento. O foco do capítulo IX não é nenhum programa narrativo realizado por Brás Cubas, mas sim o fazer do narrador, que teria passado da narração da própria morte para a do nascimento sem Nenbuma juntura aparente, nada que divirta a atenção pausada do leitor. O narrador apresenta-se como o próprio enunciador na medida em que se refere ao livro que o enunciatário está lendo e comenta a transição que está se operando no exato momento da leitura. O único assunto do capítulo é a auto-louvada destreza do narrador em conduzir sua narrativa e em redigir o próprio capítulo que está 
narrando. No entanto, apesar de apresentar-se como actante da enunciação, Brás Cubas é, na verdade, duplamente actante do enunciado: enquanto sujeito que vivencia os percursos citados (delirar, amar Virgília, nascer, morrer etc.) e enquanto sujeito que executa o percurso escrever o livro e realizar a transição brutal da narração da morte para a narração do nascimento, tema central do capítulo. É que conforme foi dito, a elaboração do romance se torna uma trama tão ou mais importante que os fatos narrados. Contudo, o narrador engana o narratário - como se tornará prática habitual ao longo do romance —, pois não é verdade que a transição saia sem Nenbuma juntura aparente, nada que divirta a atenção pausada do leitor; pois é exatamente o contrário que faz o capítulo: divertir a atenção do leitor, quebrando a seqüência da narrativa que ele seguia até o momento. A juntura não é apenas aparente; é explícita, reluzente; há todo um capítulo dedicado a ela, com direito a títulos e tudo o mais. Em seguida, a juntura evidente é cinicamente negada; como se o simples fato de negar sua existência fizesse com que ela desaparecesse. Observe, ainda, que a emenda aparece mais na medida em que o narrador procura ocultá-la, já que o pretenso encadeamento lógico citado pelo narrador, entre o delírio e a meninice, nada tem de natural ou de lógico: é arbitrário e poderia ser tecido de inúmeras outras maneiras; aliás, o leitor só consegue reconstituir o percurso e a pretensa lógica subjacente depois de ela ser afirmada pelo narrador. Em síntese, o narratário é triplamente ludibriado: primeiro, ao ter diante de si um narrador que finge ser o enunciador; depois, por que o narrador, além de impostor é também mentiroso, pois não cumprir o que promete (um texto sem emendas) e ainda tenta esconder de forma aviltante suas próprias falhas, já que a transição tem emendas, sim; e, enfim, quando apresenta um sofisma com a pretensão de que ele seja aceito como verdade, a saber, a pretensa naturalidade da morte para o nascimento. Ao avocar para si uma arte que não possui, torna-se presunçoso; e o faz depois de, logo no primeiro parágrafo do livro, ter-se julgado superior a Moisés, ao menos na arte de compor as próprias memórias ${ }^{95}$. Logo, o parágrafo acima, longe de atestar sua competência, como pretendia o narrador, demonstra sua pouca habilidade, uma vez que suas artimanhas são desmascaradas, não por que alguém as denuncie, mas porque a incompetência é tal que é mostrada pelo seu discurso.

Observe: não é Brás Cubas, actante do enunciado, que, em um primeiro momento, é desqualificado, mas sim o narrador, actante da enunciação enunciada. $\mathrm{O}$ actante do enunciado só é afetado na medida em que é também o narrador e os elogios que recebe provém dele

\footnotetext{
${ }^{95}$ Obra Completa, vol. I, p.514 ).
} 
próprio. Recorde-se que o narrador de Iaiá Garcia também produzia um texto com junturas, mas ele ao menos era sóbrio, não as comentava e assim as fazia passar despercebidas, ou quase. Além disso, não fazia afirmações falsas e auxiliava, de fato, o leitor na leitura. Esses comentários talvez justifiquem uma citação um tanto longa de uma passagem em que Schwarz comenta os fazeres dos dois narradores:

[...] Nada o obriga [o narrador] a nos induzir um erro, a indicar como principal [o romance entre Jorge e Estela] uma linha que será secundária, a cortar uma ação em seu ponto interessante, para em seguida ainda the desmanchar o suspense etc. Digamos que ele [o narrador de Brás Cubas] assimila e transforma em regra subjetiva - e portanto um elemento formal - o momento de arbitrário que é parte de seu assunto, para infligi-lo ao leitor. Entretanto, há duas coisas em Iaiá Garcia que o arbitrário e o tempo não afetam [...] uma é a inquestionável autoridade do narrador. Este, portanto, pratica o arbitrário dentro da gravidade perfeita - uma pretensão que é o defeito capital do livro. [...] A segunda é a firmeza de Estela na segunda fase machadiana não haverá personagem puramente positiva nem as certezas dogmáticas a que esta se prende. $\mathrm{O}$ arbitrário do narrador [ em Memórias póstumas] estará assumido e posto em primeiro plano descarado enquanto a sua autoridade e a intenção de justificar se tornam fatores de derrisão. (1992: 147 - grifo meu)

Como se vê pelos comentários de Schwarz, o narrador de Iaiá Garcia não era assim tão diferente do de Memórias póstumas quanto se podia pensar. Segundo o crítico, também aquele narrador praticava suas arbitrariedades, porém, ao contrário de Brás Cubas, o fazia dentro da gravidade perfeita. A diferença entre os dois narradores - tal como ocorria com os personagens — não decorre apenas dos atributos morais de um (grave) e de outro (leviano), mas também da habilidade de que dispõem para conduzir sua narrativa. $O$ narrador de Memórias póstumas é desqualificado na medida em que sua tentativa de se justificar se torna um fator de derrisão, patrocinado pelo próprio enunciador, que esvazia sua autoridade. Desse modo, a instância da enunciação se mantém distante tanto da narrativa quanto da narração, fato que não ocorria até então, ou não ocorria desse modo. Isso não é pouca coisa e é fundamental para a economia e a coesão da narrativa, pois, num mundo em que houvesse uma instância julgadora, um destinador, ao abrigo de toda crítica, digamos, íntegro, estaria de alguma forma, salvo e teria alguma esperança.

Então... qual a utilidade dessas conclusões se se busca não o ethos do narrador, mas o do enunciador?

É que como não há acesso ao enunciador, senão por meio de seus prepostos instalados na narrativa, é preciso procurar na instalação do narrador marcas que conduzam àquele que o instalou. E o que se observa é que esse enunciador, ao contrário do narrador, é extremamente hábil para instalar um sujeito e um percurso narrativo absolutamente coerentes 
entre si, apesar da incoerência de superfície. Sim, Brás Cubas, actante do enunciado, é o sujeito da arbitrariedade, do querer inconstante e do não-dever. Não há regras ou normas que ele deva seguir, seja no trato consigo mesmo, como atesta sua veleidade, seja no trato com outros atores do enunciado, como Eugênia, D. Plácida, Prudêncio e outros. Por outro lado, seu modo de agir, enquanto actante da enunciação enunciada, na relação sua com o narratário, é idêntica, pois também é marcada pela ausência de deveres ou obrigações, como atesta o parágrafo citado. A habilidade desse enunciador é ainda demonstrada quando ele instaura dois percursos narrativos paralelos, conforme ficou apontado no capítulo que tratou das configurações narrativas: um é o percurso sem razão de ser da própria vida de Brás Cubas, que busca uma superioridade, qualquer que seja; outro, o da redação das memórias desse sujeito, que também segue à deriva. Percursos paralelos e extremamente harmônicos, que mostram a arbitrariedade e o paternalismo em ação e que fazem o narratário senti-los na própria pele. Passagens como a citada revelam ainda um enunciador dissimulado, que instala um narrador para afirmar o oposto do que ele pensa. Veja, Brás Cubas valoriza a ascensão social, mas na medida que essa busca é empreendida por um sujeito totalmente desqualificado, ela acaba por ser ridicularizada pela instância da enunciação. Contudo, não é apenas esse fazer que é criticado, pois como foi visto não é apenas o actante do enunciado que é desqualificado, mas o narrador que se apresenta como enunciador. Quer dizer, é o fazer literário, fazer do próprio enunciador que é satirizado.

Com exceção do sincretismo do narrador com os actantes do enunciado, o que se observa em Memórias póstumas é a repetição de procedimentos já vistos em obras anteriores: a adoção de uma debreagem enunciativa da enunciação e a instalação de um narrador que se apresenta como enunciador e que, ao interferir constantemente na narrativa, faz com que a narração prevaleça sobre o narrado. Certo, há ainda uma diferença em relação a outros romances: o fato de o narrador ser desqualificado pelo enunciador; contudo, conforme será visto na parte que trata dos níveis enunciativos, essa desqualificação também ocorre em obras anteriores, porém de outra forma. Enfim, até o momento, descobriu-se que o enunciador era frio, objetivo, desiludido, dissimulado. Agora, se percebe uma outra faceta, não inesperada: o senso de humor do enunciador, que ri de tudo, inclusive de um fazer que é o seu: a literatura. 


\section{Quincas Borba}

Em Quincas Borba, o narrador volta a não estar sincretizado com os actantes do enunciado e a ocupar-se apenas da narração - e de forma absolutamente explícita, diga-se de passagem. Por outro lado, as debreagens enunciativas da enunciação intensificam-se. Os comentários do narrador acerca da própria narração fazem com que sejam instaurados dois percursos narrativos paralelos, já observados em todos os romances anteriores: um, narrado pelo narrador, é constituído pelos programas executados pelos actantes do enunciado e analisado no capítulo sobre as configurações narrativas; outro, executado por ele próprio, que consiste na construção de um objeto de saber e na sua transmissão para o enunciatário; ou seja, a própria narração. Veja-se um exemplo já famoso, também citado por Fiorin (1996, p. 122). É a passagem, logo no início do romance, em que o narrador apresenta Quincas Borba, o filósofo:

ESTE Quincas Borba, se acaso me fizeste o favor de ler as Memórias póstumas de Brás Cubas, é aquele mesmo náufrago da existência, que ali aparece, mendigo, herdeiro inopinado, e inventor de uma filosofia. (Obra Completa, vol. I, p.644 - grifo meu )

Retomando o conceito de Metalepse de autor, proposto por Genette ${ }^{96}$, Fiorin considera que, nessa passagem, houve uma embreagem, pois o narrador apresenta-se como o enunciador, isto é, como o produtor físico do texto. É o que ele faz ao citar outro romance do "autor" Machado de Assis e, pelo uso do pronome me, sugerir que o livro Memórias póstumas de Brás Cubas também seria de sua autoria. Claro, o que ocorre, de fato, é apenas a neutralização da oposição entre enunciador e narrador, os quais, em passagens como essa, se querem amalgamados em um único ator, que, conforme o ponto de vista adotado, pode ser tanto Brás Cubas, quanto "Machado de Assis", não o real, claro, mas o que assina o Prólogo da terceira edição de Quincas Borba . Como quer que seja, essa passagem - uma dentre muitas instaura a atividade do narrador e tematiza a narrativa, a exemplo do que acontecerá ao longo do romance. De quebra, torna a imagem do enunciador mais e mais distante. Registre-se, porém, que essa não é a única vez em que o narrador apresenta-se como o próprio Brás Cubas; há uma outra, menos famosa e bem mais sutil. É quando, ao contar que Sofia não conseguia, por causa de seus ciúmes, dizer a Maria Benedita que Rubião era o noivo que

\footnotetext{
${ }^{96}$ Genette formula o conceito pela primeira vez em Figures III (Paris, Seuil, 1972) e o retoma com algumas modificações em Metalepse, Paris, Seuil, 2004.
} 
Palha escolhera para ela, o narrador dirige-se ao narratário e faz o seguinte comentário: $\underline{\text { Cế-lo- }}$ eis, pósteros? Sofia não pôde soltar o nome de Rubião. ${ }^{97}$ Ora, póstero é aquele que pertence às gerações futuras, que, no caso, vêm depois daquele que fala e que supõe-se, já morreu; caso contrário, os destinatários não poderiam ser pósteros em relação a ele. Daí conclui-se que o narrador de Quincas Borba, à semelhança do de Memórias póstumas, já era defunto quando narrou o romance. Mas não é apenas isso. Essa expressão remete inevitavelmente ao mesmo narrador Brás Cubas, que, aliás, a utilizara, tal e qual para narrar o dia que entrou em uma relojoaria e lá encontrara uma mulher que fora bonita, e não pouco bonita; mas a doença e uma velhice precoce haviam destruído-lhe a flor das graças. Em seguida, dirige-se ao leitor para revelar quem era a mulher e o faz nos seguintes termos: Crê-lo-eis, pósteros? Essa mulher era Marcela. ${ }^{98}$. Assim, Brás Cubas, enquanto narrador, insinua-se por todo romance querendo avocar para si a autoria da narrativa, valendo-se, talvez, de sua amizade com Quincas Borba e do fato de ser um dos poucos que conhecia seu real estado mental ${ }^{99}$

Não é apenas o uso das mesmas expressões ou a coincidência de episódios que faz pensar no mesmo narrador. A estruturação da narração é muito semelhante, repleta de interrupções que pouca, ou nenhuma, relação guardam com a narrativa, mas que são fundamentais para construir o percurso do narrador enquanto sujeito que constrói seu objeto de valor, como já acontecia nos outros romances. É o caso, por exemplo, do capítulo XLVI, que, ao descrever o diálogo de um mendigo com o céu, interrompe a narração dos remorsos de Rubião por ter assediado Sofia. Para se ter uma boa imagem do método de composição utilizado pelo narrador, da constante sobreposição da narração à narrativa, da utilização da debreagem enunciativa da enunciação no romance como um todo e, enfim, da semelhança entre os procedimentos de instalação deste narrador com o de romances anteriores, talvez, o melhor seja analisar três capítulos do romance. Mas tranqüilize-se, caro leitor; os capítulos, citados na integra, não consumirão duas dúzias de linhas e um número ainda menor de

\footnotetext{
${ }^{97}$ Obra Completa, vol. I, p. 710 - grifo meu.

${ }^{98}$ Idem, p.557 - grifo meu.

${ }^{99}$ Ver o capítulo XIII, em que o narrador faz questão de contar que o remetente da carta que comunicava a morte de Quincas Borba era Brás Cubas:

Então afinal o homem espichou a canela? disse ele, enquanto Rubião abria a carta, sorria à assinatura e lia: Brás Cubas. Era um simples bilhete:

O meu pobre amigo Quincas Borba faleceu ontem em minha casa, onde apareceu há tempos esfrangalhado e sórdido: frutos da doença. [...] (Obra Completa, vol. I, p. 653)
} 
minutos, aliás, linhas bem mais agradáveis do que estas a que estás acostumado. Aproveita, portanto.

\section{CAPÍTULO CXII}

AQUI é que eu quisera ter dado a este livro o método de tantos outros, - velhos todos em que a matéria do capítulo era posta no sumário: "De como aconteceu isto assim, e mais assim". Aí está Bernardim Ribeiro; aí estão outros livros gloriosos. Das línguas estranhas, sem querer subir a Cervantes nem a Rabelais, bastavam-me Fielding e Smollet, muitos capítulos dos quais só pelo sumário estão lidos. Pegai em Tom Jones, livro IV, cap. I, lede o título: Contendo cinco folhas de papel. É claro, é simples, não engana a ninguém; são cinco folhas, mais nada, quem não quer ler não lê, e quem quer lê, para os últimos é que o autor conclui obsequiosamente: "E agora, sem mais prefácio, vamos ao seguinte capítulo".

\section{CAPÍTULO CXIII}

SE tal fosse o método deste livro, eis aqui um título que explicaria tudo: "De como Rubião, satisfeito da emenda feita no artigo, tantas frases compôs e ruminou, que acabou por escrever todos os livros que lera".

Lá haverá leitor a quem só isso não bastasse. Naturalmente, quereria toda a análise da operação mental do nosso homem, sem advertir que, para tanto, não chegariam as cinco folhas de papel de Fielding. Há um abismo entre a primeira frase de que Rubião era co-autor até a autoria de todas as obras lidas por ele; é certo que o que mais lhe custou foi ir da frase ao primeiro livro; deste em diante a carreira fez-se rápida. Não importa; a análise seria ainda assim longa e fastiosa. O melhor de tudo é deixar só isto; durante alguns minutos, Rubião se teve por autor de muitas obras alheias.

\section{CAPÍTULO CXIV}

AO contrário, não sei se o capítulo que se segue poderia estar todo no título. (Obra Completa, vol. I, p. 738-9-grifos meus)

Os capítulos CXII, CXIII e CIV não acrescentam absolutamente nada à trama, não fazem andar a narrativa, não guardam qualquer relação com os programas narrativos dos sujeitos aí instalados, mas discutem o método empregado pelo pseudo-enunciador para compor seu romance, e é o percurso desse sujeito que está em jogo. A semelhança com o capítulo IX de Memórias póstumas, aquele da transição da morte para o nascimento, é tal que dispensa comentários. Nos dois casos, o tema da narrativa poderia ser algo como "venturas e desventuras de um narrador para compor sua narrativa", pois é apenas disso que se trata. Veja que esse modo de proceder já estava presente nos quatro primeiros romances de Machado, especialmente em Ressurreição e $A$ mão e a luva, porém, com intensidade e freqüência menores; trata-se, portanto, de uma alteração quantitativa e não qualitativa. Recorde-se: também naqueles, o narrador era apresentado não como alguém que realiza um fazer cognitivo, de transmissão do seu saber, mas como um sujeito que realiza um fazer pragmático de constituição de um objeto de valor, tal como acontece aqui. Ao lado da debreagem enunciativa da enunciação, ocorre a embreagem actancial, uma vez que o narrador apresenta- 
se como o próprio enunciador em sua qualidade específica de produtor de livros. A freqüência desse processo - a narração das hesitações do "autor", suas dúvidas de composição, seus erros e acertos, os comentários sobre outros sujeitos que realizaram percursos semelhantes - acaba por constituir o narrador como sujeito de um outro percurso que é a realização de uma narrativa no interior da qual são instalados sujeitos, os quais, por sua vez, têm seus próprios percursos. O narrador não é actante do enunciado segundo - o que relata o percurso de Rubião - , mas da narrativa primeira, que conta como o romance foi produzido, e, nesse ponto de vista, há, sim, sincretismo entre os dois actantes. Por isso, o narrador de Quincas Borba guarda suas semelhanças tanto com o narrador dos quatro primeiros romances quanto com o narrador dos quatro últimos. Além do estilo e da preocupação com os métodos a serem empregados, esse narrador guarda outras semelhanças com o de Memórias póstumas: o fato de não cumprir o que promete e de ludibriar seu pobre narratário. Afinal, ele interrompe a narrativa por três capítulos seguidos, nada acrescenta aos fatos narrados, nem constrói capítulos como os que eles diz que gostaria de construir. $\mathrm{Na}$ verdade, o que ele faz é exatamente o oposto do que se propõe a fazer: capítulos sem títulos e inúteis do ponto de vista da matéria narrada. Diz que está preocupado com a opinião do seu narratário, quando, na verdade, pouco se ocupa dele.

Todavia, como se sabe, não é o narrador que nos interessa, mas o enunciador. Assim, há que se registrar uma questão capital, já apontada anteriormente e que aqui vai só como lembrete: embora o narrador de Memórias póstumas ou de Quincas Borba tenha um temperamento diferente dos narradores dos romances que os antecederam, o ator da enunciação que se encontra em instância acima da deles parece claramente o mesmo, marcado por um mesmo proceder, que, em síntese, pode ser descrito como o uso abundante de metalepses de autor, no sentido utilizado por Genette e que será detalhado mais adiante. De fato, o enunciador manipula com extrema habilidade a relação causal que une o produtor de uma representação e a própria representação, mostrando como o narrativa trás em si as marcas de seu enunciador. Se o uso de figuras de linguagem define o ethos do orador, então, pode-se dizer que o uso de metalepses comuns em todas as obras de Machado, juntamente com a debreagem enunciativa da enunciação, contribui para a definição do ethos de um enunciador dissimulado, que não apenas se oculta sob diversas máscaras, mas que também é hábil para jogar com as instâncias narrativas e transgredir as fronteiras entre uma e outra 


\section{Dom Casmurro}

Nesse romance, o enunciador opta novamente por instalar um narrador em sincretismo com um dos actantes do enunciado, como já havia feito Memórias póstumas, e lhe confere uma alcunha: casmurro, adjetivo que não serve para caracterizar o actante do enunciado, sincretizado no mesmo ator, e sempre é mostrado como ingênuo, bem intencionado e sem maldades. O mesmo ator é chamado de Bentinho, quando executa os programas narrativos de ir para o seminário, namorar e casar com Capitu, ser amigo de Escobar etc., e atende por Bento Santiago ou Dom Casmurro, ao realizar o programa narrativo de relatar os mesmos episódios. Os dois fazeres não são estanques. Bentinho tornase casmurro em função dos fatos que narra e, talvez, seu projeto ao contá-los fosse justamente deixar essa condição. Aliás, veja-se que Bento Santiago é o único narrador explicitamente adjetivado de Machado, fato que convida ao breve exame do dicionário de Antônio Houaiss, para que se conheça algo mais a esse respeito:

Casmurro

Adjetivo e substantivo masculino

1) diz-se de ou indivíduo teimoso, obstinado, cabeçudo

2) diz-se de ou indivíduo fechado em si mesmo; ensimesmado, sorumbático

Substituindo, na primeira definição, os termos teimoso e obstinado pelas definições que lhes dá o mesmo dicionário, chega-se à seguinte formulação:

1b) diz se de ou indivíduo que não desiste facilmente, insistente (teimoso) [e que ] é defensor de uma opinião ou de um propósito, mesmo contrário à razão ou às ponderações (obstinado), cabeçudo

E substituindo, agora, os temos ensimesmado e sorumbático pelas definições do dicionário, obtém-se uma nova proposição para (2):

2B) diz-se de ou indivíduo fechado em si mesmo; voltado para dentro de si (ensimesmado), sombrio (que revela más intenções e/ou meios criminosos para conseguir algo) (sorumbático)

Assinalando o essencial de cada uma das definições, vê-se que casmurro na acepção (1) apresenta como traços semânticos principais a duratividade, a constância e a irracionalidade; já a acepção (2) é marcada por dois semas: a intransitividade, entendida como incapacidade on falta de desejo de transmitir algo a alguém, e a malevolência. As definições acima permitem, ainda, diferenciar o teimoso ou o obstinado do casmurro. Aqueles não têm os traços de malevolência ou de intransitividade que o caracterizam. Por outro lado, o casmurro 
se diferencia do indivíduo mau, pois este não tem as marcas de continuidade e intransitividade que definem aquele. Finalmente, o casmurro distancia-se do egoísta pelo fato deste último não se ver investido da malevolência (nos termos do casmurro) nem da duratividade. É de se notar que o próprio narrador não recomenda a consulta aos dicionários para saber o que significa casmurro, pois o termo não estaria sendo empregado no sentido que estes the dão, mas no que lhe pôs o vulgo, de homem calado e metido consigo mesmo ${ }^{100}$. Ora, as definições que os dicionários dão para a palavra casmurro são muito próximas do sentido com que ela é empregada no romance ${ }^{101}$ e indicam que o epíteto do narrador em nada contribui para dar credibilidade ao seu discurso, funcionando, antes, como um aviso para que seus leitores não se enganem quanto ao caráter daquele com quem estão lidando.

De fato todas, os atributos do casmurro são encontrados em Bento Santiago sem dificuldade. Diz o dicionário que a malevolência caracteriza o casmurro e Bento Santiago é de fato mau. Recorde-se o episódio em que ele quase envenena o filho ${ }^{102}$ ou o capítulo em que deseja que ele contraia lepra ${ }^{103}$. Outra das características do casmurro é a obstinação ou a teimosia e nada lhe tira da cabeça que Capitu o traiu, apesar de os elementos de que dispõe se limitarem ao olhar dela para o defunto no dia de seu enterro e à semelhança entre Ezequiel e Escobar - isso apesar de haver o antecedente da semelhança entre Capitu e a mãe de Sancha ${ }^{104}$, e de o próprio narrador reconhecer que Se fosse vivo José Dias, acharia nele [Ezequiel] a sua própria pesso $a^{105}$. A última característica do casmurro é a intransitividade, e Bento afirma que quase não sai de casa, tem poucos amigos e parece pouco permeável ao que acontece ao seu redor. $\mathrm{O}$ auge desse comportamento acontece na passagem em que afirma que no dia em que ficou sabendo da morte de Ezequiel jantou bem e foi ao teatro ${ }^{106}$.

Embora Bento Santiago seja diferente de Brás Cubas, na medida em que este (não obstante sua malevolência) é caracterizado fundamentalmente pela veleidade, um exame mais

\footnotetext{
${ }^{100}$ Obra Completa, vol. I, p. 809 - grifo meu.

${ }^{101}$ Segundo Houaiss, a palavra casmurro aparece pela primeira vez nos dicionários em 1881, na primeira edição do dicionário de Caldas Aulete. Como Dom Casmurro é de 1899, o termo era, então, recémnascido. Já o dicionário de Aurélio Buarque de Hollanda, cita justamente essa passagem do romance para abonar sua definição dessa palavra; alias, idêntica à de Houaiss.

${ }^{102}$ Idem, p. 937

${ }^{103}$ Idem, p. 943

${ }^{104}$ Ver o capítulo LXXXXIII - O retrato

${ }^{105}$ Obra Completa, vol. I, p. 943.

${ }^{106}$ Idem, p. 944
} 
detalhado revela que o enunciador se valeu, nos dois casos, de um procedimento bastante semelhante, pois os narradores dos dois romances são desqualificados pelo enunciador, pois seus ethé prestam um desserviço a si próprios, uma vez que leva o enunciatário a não-crer no que é dito. Há outros elementos que voltam a assinalar o parentesco, seja com Memórias póstumas, seja com todos os romances de Machado. O primeiro é o fato de o romance se constituir, como todos que o antecederam, por uma debreagem enunciativa da enunciação, na medida em que o narrador diz eu; o segundo é transformação da narração em tema da narrativa, o que, por sua vez, provoca o embaralhamento das instâncias enunciativas e dos respectivos actantes. É o que acontece quando Sancha, actante do enunciado, é instaurada como narratária e, ao mesmo tempo, como enunciatária:

\section{CAPÍTULO CXXIX / A D. SANCHA}

D. Sancha, peço-lhe que não leia este livro; ou, se o houver lido até aqui, abandone o resto. Basta fechá-lo; melhor será queimá-lo, para lhe não dar tentação e abri-lo outra vez. Se, apesar do aviso, quiser ir até o fim, a culpa é sua; não respondo pelo mal que receber. O que já lhe tiver feito, contando os gestos daquele sábado, esse acabou, uma vez que os acontecimentos, e eu com eles, desmentimos a minha ilusão; mas o que agora a alcançar, esse é indelével. Não, amiga minha, não leia mais. Vá envelhecendo, sem marido nem filha, que eu faço a mesma cousa, e é ainda o melhor que se pode fazer depois da mocidade. Um dia. iremos daqui até à porta do céu, onde nos encontraremos renovados, como as plantas novas, come piante novelle, [...] (Obra Completa, vol. I, p. 930-1 - grifos meus.)

Quem se dirige à Sancha não é mais Bentinho, marido da sua melhor amiga e actante do enunciado, mas o narrador, Bento Santiago, actante da enunciação enunciada. É um diálogo bem diferente do presente no capítulo anterior, quando ambos eram apenas interlocutores. Agora não, pois Sancha também passa, como Bentinho, a sincretizar actantes dos dois níveis. Ao dirigir-se a ela, o narrador a instauraria como narratária, porém, conforme demonstra o parágrafo acima, Sancha é instaurada como enunciatária, ou seja, como alguém que está "fora" da narrativa, conforme atestam as menções a este livro e à leitura que Sancha estaria fazendo naquele momento. É também anulada a oposição entre narração e narrativa, pois fatos dos dois mundos se misturariam. Por exemplo, o envelhecimento de Sancha sem marido nem filha pertenceria tanto ao mundo do narrado (casamento, maternidade e viuvez da personagem) quando da narração, pois seriam recebidos concomitantemente por Sancha e pelos demais "leitores". Conseqüências: aumento da credibilidade de Bento Santiago perante o narratário, uma vez que sua preocupação com Sancha lhe proporcionaria uma imagem de benevolente e reforçaria a impressão de que suas palavras são verdadeiras. Por outro lado, o enunciatário desse texto — não o construído por Bento, mas o verdadeiro — percebe que 
está diante de um enunciador extremamente hábil, que faz da criação literária e das estratégias para a criação de efeitos de verdade seus objetos de imitação. Atente-se para a semelhança $\operatorname{com} A$ mão e a lwva:lá, o enunciador fazia com que a campainha atuasse simultaneamente em duas instâncias e executasse programas narrativos distintos em cada uma delas. Em Helena, era Eugênia que podia encontrar-se com o leitor no teatro e, novamente, transitar de um a outro. Agora é Sancha que pode atravessar vários níveis enunciativos. Como se vê, em que pesem as diferenças de superfície, há um procedimento muito semelhante que caracteriza o fazer desse enunciador.

Veja-se agora um exemplo que está no capítulo seguinte ao citado e que contribui para fazer da elaboração do romance a narrativa primeira e dos fatos nele narrados - os programas executados por Bentinho - uma narrativa subordinada a esta e dependente dela. Depois de interromper o fluxo do texto para fazer o alerta acima à $D$. Sancha, Bento volta a narrar suas dificuldades conjugais, aliás, decorrentes das suas desconfianças. No parágrafo seguinte, interrompe novamente a narração para outro diálogo com o "leitor":

... Perdão, mas este capítulo devia ser precedido de outro, em que contasse um incidente, ocorrido poucas semanas antes, dous meses depois da partida de Sancha. Vou escrevê-lo; podia antepô-lo a este antes de mandar o livro ao prelo, mas custa muito alterar o número das páginas; vai assim mesmo, depois a narração seguirá direita até o fim. Demais, é curto. (Obra Completa, vol. I, p. 931)

Mais uma vez, o diálogo com o narratário acaba fazendo com que este assuma a posição do enunciatário, e o narrador, a do enunciador. E agora a conversa nada tem que ver com o narrador, pois trata-se de considerações de ordem, digamos, operacionais, como a numeração das páginas ${ }^{107}$. Nesse caso, não é apenas a narração que é narrada; a própria feitura do livro é discutida e contada com cesuras, diria Brás Cubas. A narração segue, assim, claudicando com emendas aqui e acolá, querendo criar um efeito de verdade, de que Bento Santiago é o autor do livro que o leitor lê, e a história é, portanto, verídica. Mas... efeito de verdade pra quem? Para o narratário inscrito no livro, que acreditaria nas artimanhas desse narrador, mas não para o enunciatário, que certamente não está preocupado com a sorte da leitora Sancha, mas extrai seu prazer justamente da dramatização de sua condição de leitor. $\mathrm{O}$ resultado final é a verossimilhança, não da traição de Capitu, mas da própria existência de Bento Santiago e de seu dilema. Se, por um lado, o episódio nada acrescenta ao drama de

\footnotetext{
${ }^{107}$ Assunto que o enunciador Machado de Assis conhecia bem, uma vez que seu primeiro emprego foi justamente na tipografia de seu amigo Paula Brito.
} 
Bentinho e Capitu, por outro, é um elemento importante no percurso do narrador, Bento Santiago, que, à semelhança de Brás Cubas e de outros narradores não nomeados, narra o processo de elaboração de sua narrativa.

Os percursos narrativos de Capitu e dos demais sujeitos está contido em um outro, o de Bento Santiago, cujo programa central é o de construção da própria narrativa, na qual estão investidos os valores buscados por ele — fato explicitado nos dois capítulos iniciais do livro, intitulados Do título e Do livro, que marcam, de forma inequívoca, que o percurso central e hierarquicamente primeiro do romance é a construção da mesma narrativa a que o narratário tem acesso. Trata-se de um processo diferente do existente, por exemplo, em Morte a crédito, de Louis-Ferdinand Céline, em que o narrador e personagem central, Ferdinand, também escreve um romance - a história de Gwendor, o Magnífico — cuja trama se desenrola paralelamente ao percurso narrativo do narrador, mas sem se confundir com o texto que o leitor $\hat{k}^{108}$.) Em todo os romances de Machado se observa um processo diferente, pois a narrativa a que o leitor tem acesso é a mesma que o narrador constrói no interior dessa narrativa primeira. A trama começa no momento em que tem início a elaboração do romance. Recordemos. No segundo capítulo, o narrador, Bento Santiago, conta que mandara construir no Engenho Novo a mesma casa em que vivera na Rua de Mata-Cavalos, inclusive com as pinturas das paredes, a fim de atar as duas pontas da vida ${ }^{109}$, mas que, apesar da semelhança entre os dois edifícios, não conseguira recompor seu passado:

[...]Depois, pensei em fazer uma "História dos Subúrbios" menos seca que as memórias do Padre Luís Gonçalves dos Santos relativas à cidade; era obra modesta, mas exigia documentos e datas como preliminares, tudo árido e longo. Foi então que os bustos pintados nas paredes entraram a falarme e a dizer-me que, uma vez que eles não alcançavam reconstituir-me os tempos idos, pegasse da pena e contasse alguns. Talvez a narração me desse a ilusão, e as sombras viessem perpassar ligeiras, como ao poeta, não o do trem, mas o do Fausto: Aí vindes outra vez, inquietas sombras?...

Fiquei tão alegre com esta idéia, que ainda agora me treme a pena na mão. Sim, Nero, Augusto, Massinissa, e tu, grande César, que me incitas a fazer os meus comentários, agradeço-vos o conselho, e vou deitar ao papel as reminiscências que me vierem vindo. Deste modo, viverei o que vivi, e assentarei a mão para alguma obra de maior tomo [...] (Obra Completa, p. 810-1)

No trecho acima, estão explicitados não só o momento em que o sujeito decide começar a elaboração do livro, mas também a manipulação que precedeu essa decisão, e,

\footnotetext{
${ }^{108}$ A primeira menção à história do "Rei Krogold" surge na página 22 e Ferdinand central faz a primeira "leitura" a seu primo, Gustin, na página 25. A partir daí, as leituras do romance irrompem no texto sem aviso prévio, ocasião em que são discutidos alguns aspectos relativos à composição, mas em um registro bem diferente do adotado por Machado.
}

${ }^{109}$ Obra Completa, vol. I p. 810. 
ainda seus destinadores-manipuladores: Nero, Augusto, Massinissa, César, incitam o sujeito a realizar um programa narrativo de construção do objeto de valor: deitar ao papel as reminiscências. A manipulação é por tentação e o prêmio, uma ilusão - cuja natureza não é esclarecida - que permitiria ao sujeito viver o que viveu, estando aí o valor investido no objeto. Como se não bastasse, em seguida há a citação do Fausto, que, apesar do contexto completamente distinto, sintetiza o percurso a ser realizado pelo sujeito. Tenha o leitor a paciência de ler uma citação do poema de Goethe um tanto longa, pois ela é fundamental para que se entenda quais os programas narrativos estão realmente em jogo no romance:

$1^{\mathrm{a}}$ parte

DEDICATÓRIA

Tornai, vós, trêmulas visões, que outrora Surgiram já à lânguida retina.

Tenta reter-vos minha musa agora? Inda minha alma a essa ilusão se inclina? À roda afluis! reinai, então, nesta hora Em que assomais do fumo e da neblina; Torna a fremir meu feito com o bafejo Que vos envolve em mágica o cortejo.

Trazei imagens de horas juvenis, Sombras queridas vagam no recinto; Amores, amizades, ressurgis Do olvido como um conto meio extinto; Renasce a dor, que em seus lamentos diz Da vida o estranho, errante labirinto. Evoca os bons que a sorte tem frustrado, E antes de mim, à luz arrebatado.

\author{
Meus novos cantos já não ouvirão \\ Os que ouviram os primeiros versos; \\ Desfeito, ah! se acha o grupo amigo, irmão, \\ Ecos de outrora estão no nada imersos. \\ Meu canto soa à ignota multidão, \\ Seu próprio aplauso ecoa em sons adversos, \\ E o mais, que a minha lira amara, erra, \\ Se vivo for, esparso sobre a terra. \\ E de um remoto anelo o grave encanto \\ Àquele reino de visões me acena; \\ Vibra, ora, em indecisos tons meu canto, \\ Qual da harpa eólia a murmurante pena; \\ Sinto um tremor, segue-se o pranto ao pranto, \\ A rígida alma abranda-se e serena; \\ O que possuo vejo ao longe, estranho, \\ E real me surge o que se foi antanho. . ${ }^{110}$
}

Apesar de os versos do Fausto - uma tragédia - falarem por si, não custa destacar que também o narrador de Dom Casmurro procurava fazer ressurgir horas juvenis, amores, amiz̨ades; também ele procurou evocar os bons que a sorte ou ele próprio frustrou e, por isso, seu grupo amigo também está desfeito, os ecos de outrora no nada estão imersos e também o canto de Bentinho vibra em tons indecisos. No entanto, não é verdade que o real surja como foi antanho para o narrador. Ou melhor, talvez surja como real aos olhos do narrador, sem que isso tire do leitor o direito de questioná-lo. Seja como for, a dedicatória do Fausto tem a clara função de servir como prólogo ao romance e explicitar que o que está em jogo não é um adultério, mas a narrativa elaborada por Bento, mediante a qual ele busca (re)viver o que viveu, ou

${ }^{110}$ Goethe, Johann Wolfgang. Fausto. Trad. Jenny Klabin Segall. $3{ }^{\text {a }}$ ed. Belo Horizonte / Rio de Janeiro: Villa Ricca, 1991, p. 27-8. 
desejaria ter vivido. Como o nível do narrado subordina-se ao da narração, os percursos narrativos dos actantes do narrado subordinam-se aos fazeres cognitivo e persuasivo do narrador (a narração) e não podem ser entendidos fora desse contexto. O breve exame do último parágrafo do romance talvez deixe as coisas mais claras:

[...]. O resto é saber se a Capitu da Praia da Glória já estava dentro da de Mata-cavalos, ou se esta foi mudada naquela por efeito de algum caso incidente. Jesus, filho de Sirach, se soubesse dos meus primeiros ciúmes, dir-me-ia, como no seu cap. IX, vers. 1: "Não tenhas ciúmes de tua mulher para que ela não se meta a enganar-te com a malícia que aprender de ti". Mas eu creio que não, e tu concordarás comigo; se te lembras bem da Capitu menina, hás de reconhecer que uma estava dentro da outra, como a fruta dentro da casca.

E bem, qualquer que seja a solução, uma cousa fica, e é a suma das sumas, ou o resto dos restos, a saber, que a minha primeira amiga e o meu maior amigo, tão extremosos ambos e tão queridos também, quis o destino que acabassem juntando-se e enganando-me... A terra lhes seja leve! Vamos à "História dos Subúrbios". (Obra Completa, vol. I p. 944 - grifos meus.)

Desaparecem todas as dúvidas do narrador e o veredicto é anunciado: Capitu e Escobar são mesmo traidores. Contudo, a sentença é questionável em razão da subjetividade das evidências apresentadas (fato que se reflete na impossibilidade de se saber se houve ou não um adultério), e também pelo processo contínuo de desqualificação a que é submetido o narrador. Por exemplo, Bentinho começar a desconfiar do envolvimento entre Capitu e Escobar exatamente depois de sentir-se, ele próprio, atraído por Sancha, mulher do amigo (capítulo CXVIII). Outras desqualificações resultam do próprio caráter de Bentinho, como acontece quando ele deseja matar o próprio filho, Ezequiel (cap. CXXXVI), ou quando janta bem e vai ao teatro (p. 944), como se nada houvesse ocorrido, ao saber da morte dele. Finalmente, deve-se lembrar que o próprio narrador afirma, lá no capítulo II, que sua narração tinha por finalidade, como não podia deixar de ter, a supressão de uma falta, de certa ilusão, então não esclarecida. Agora se sabe que essa ilusão consistia na sanção negativa daqueles que já estavam condenados.

Agora começam a surgir mais semelhanças entre esse enunciador e o dos demais romances, apesar das diferenças observadas. Juntamente com a debreagem enunciativa da enunciação, existem, mais uma vez, dois percursos correndo em paralelo: em um primeiro momento, é instalado um sujeito, Bento Santiago, que executa um único programa narrativo, a saber, a construção de uma narrativa no interior da qual instala diversos sujeitos (Bentinho, Capitu, Escobar e outros), cujos programas narrativos constituirão a narrativa segunda. As duas narrativas constroem o enunciado oferecido pelo enunciador "Machado de Assis", o qual coloca o enunciatário não apenas em conjunção com o saber que constitui a narrativa de 
Bento Santiago, relativa, como de costume, a um casamento movido por interesses outros, mas também com o percurso do narrador para construir seu texto; consequentemente, com um saber relativo à narração, à criação de efeitos de verdade. Como em Memórias póstumas, também em Dom Casmurro o narrador está sincretizado com um actante do enunciado, pois Bento Santiago narra para contar como foi traído pela mulher e pelo amigo. Conforme foi dito, sua narrativa é toda construída como uma peça de acusação, por meio da qual ele, pouco a pouco, apresenta a si mesmo como vítima, e a Capitu e Escobar como seus algozes, conforme fica claro no último parágrafo do romance. Paralelamente, o enunciador mostra Bento Santiago como um narrador ardiloso, que constrói efeitos de verdade para tornar sua tese verossímil e assim acaba por desqualificá-lo. Nesse momento, percebe-se que as fusões de instâncias enunciativas operadas ao longo do texto não são mero exercício de virtuosismo por parte do enunciador, mas procedimentos absolutamente necessários para a economia da trama, pois, sem eles, talvez fosse impossível conduzir os percursos em dois níveis ou discutir o processo de narração e a elaboração da narrativa. Enfim, operam-se dois movimentos simultâneos e antagônicos: a defesa de uma tese por um sujeito e, na instância acima, sua desqualificação no momento em que toma a palavra. Confirma-se, desse modo, o que foi dito há pouco: enunciador e narrador estão, de formas variadas, em franca oposição.

\section{Esaú e Jacó}

Já se sabe que a realização de embreagens actoriais é procedimento recorrente nos romances de Machado de Assis: em todos, o narrador é apresentado como enunciador e o narratário como enunciatário. Com Esaú e Jacó, não é diferente, mas, nesse romance, o processo ocorre em maior intensidade e se junta a outro, já assinalado por Fiorin (1996:11920): o eu torna-se ele.. Sabe-se que Aires, actante do enunciado, é o narrador do romance e, sendo assim, esperava-se que ele assumisse a narrativa e dissesse eu, como acontece no Memorial de Aires. No entanto, o narrador sempre trata o conselheiro, portanto, si mesmo, por ele, fato que anula, no modo do parecer, o sincretismo entre os actantes do enunciado e os da enunciação. Tal neutralização só não se efetiva plenamente por causa da informação fornecida por M. de A. na advertência, sobre a identidade do narrador, além de uma única deixa ao longo do texto. Consequentemente, Aires passa a ter seus papéis actanciais bem 
marcados, tal como ocorre, por sinal, com o narrador de Dom Casmurro, que, no plano do narrado, atende por Bentinho: e, no da narração, por Dom Casmurro.

Entretanto, mesmo que não houvesse a informação de M. de A., de que Aires é o narrador, a hipótese de que Esaú e Jacó é vazado em uma debreagem enunciva da enunciação não se sustentaria, pois, à semelhança de Ressurreição ou de Quincas Borba, a condução da narrativa é intensa, extensa e explicitamente marcada, fazendo surgir os dois percursos paralelos a que já nos referimos inúmeras vezes: um, o da construção da narrativa; outro, o dos programas narrativos contidos no interior da narrativa primeira. O processo fica mais complexo na medida em que a escrita do romance é vista de cima. Um exemplo talvez torne tudo mais claro. Ainda no começo do livro, o narrador apresenta o Conselheiro Aires como se este fosse outro indivíduo que não ele próprio. Em seguida, comenta a elaboração do diário mantido pelo conselheiro e que seria a fonte do romance:

Não cuides que [Aires] não era sincero, era-o. Quando não acertava de ter a mesma opinião, e valia a pena escrever a sua, escrevia-a. Usava também guardar por escrito as descobertas, observações, reflexões, críticas e anedotas, tendo para isso uma série de cadernos, a que dava o nome de Memorial. Naquela noite escreveu estas linhas:

"Noite em casa da família Santos, sem voltarete. Falou-se na cabocla do Castelo. Desconfio que Natividade ou a irmã quer consultá-la; não será decerto a meu respeito. " (Obra Completa, vol. I, p. 965 - grifo meu)

Em todo o texto, há apenas um ator, citado de diversas maneiras e sucessivamente associado a diversas instâncias narrativas. Inicialmente, repare que o narrador das linhas acima está quase implícito, manifestando-se apenas por meio do narratário, o qual é revelado

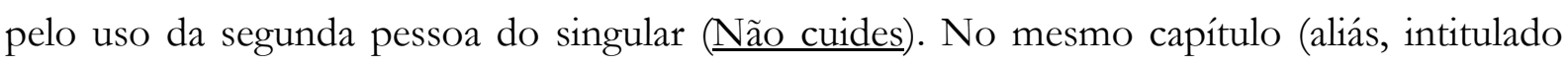
Esse Aires), o conselheiro, enquanto actante do enunciado, executa vários programas narrativos: apaixonar-se por Natividade, ser diplomata de carreira etc. Agora, veja que no trecho citado ocorre uma debreagem de segundo grau que instaura o mesmo Aires como narrador de segundo grau e responsável pela redação do Memorial, no interior do qual diz eu: (Naquela noite escreveu estas linhas: "[...]. Desconfio...). Repare: o sujeito de escreveu e de desconfio é o mesmo ator, Aires, porém, em instâncias narrativas diferentes: o sujeito de escreveu é o narrador; o de desconfio, o interlocutor; ambos sincretizados em Aires. A passagem acima faz menção ainda a outro texto que também seria de "autoria" de Aires (seu memorial), fato que reforça seu papel de enunciador, não apenas no Memorial de Aires, mas também de Esaú e Jacó, 
já que o romance seria oriundo do mesmo diário ${ }^{111}$. Finalmente, observe que a matéria narrada por Aires em seu diário, enquanto actante do enunciado de Esaú e Jacó, é relativa -se aos mesmos fatos que são narrados por Aires enquanto actante da enunciação enunciada, isto é, enquanto narrador de Esaú e Jacó. Os dois textos, o romance e memorial, discutiriam fatos envolvendo Natividade. O círculo assim se fecha sem que se possa definir com precisão a qual nível, afinal, pertence esse Aires, pois ele está em todos simultaneamente. Atente-se um instante para a Advertência. Lá se conta que o diário de lembranças que Aires escrevia era composto de seis cadernos e que o sétimo, e último, não fazia parte daqueles e nem era escrito na forma de diário. Todavia, agora que o memorial é citado em Esaú e Jacó e com o mesmo conteúdo, supõe-se que Esaú e Jacó é, na verdade, uma narrativa derivada do memorial, de um daqueles seis cadernos; trata-se, portanto, de certa forma, de uma narrativa segunda. O efeito final, como se pode imaginar, é a confirmação de que a elaboração do texto é o programa central do romance; e o conteúdo deste, um percurso secundário. Com isso, o enunciador vai se distanciando mais e mais do texto, tendendo - sempre no modo do parecer - ao desaparecimento; se o leitor permite o indesejado jogo de palavras.

Essa não é a única passagem que realça a dicotomia entre os dois Aires, o autor do memorial e actante do enunciado e o autor de Esaú e Jacó e actante da enunciação enunciada. Veja-se, por exemplo, aquela em que o conselheiro recorda a cantiga popular que ouvira, em Caracas, de uma atriz venezuelana, no momento em que se despedia dela. Ao final, o narrador cita um pequeno trecho da canção e justifica não citá-la na íntegra, afirmando que não podia dar a toada, mas Aires ainda a trazia de cor, e vinha a repeti-la consigo, vagarosamente, como ia andando ${ }^{112}$. Ora, se Aires e o narrador são a mesma pessoa, como pode o actante do enunciado conhecer a canção inteira e o narrador não? É que um Aires, o narrador, sofre as limitações do seu fazer de narrador, que o impossibilitam de transmitir a melodia, enquanto o outro Aires, o do enunciado, não sofre tais cerceamentos. Tal constatação remete a uma questão observada por Genette (2004: 106-9). Lembra o autor que o universo do narrador é irremediavelmente diferente do universo do personagem, ainda que se trate de narradores e personagens reais como os de uma autobiografia. O eu que narra é diferente do eu que vive, seus mundos não se confundem Assim, sob essa ótica, é indiferente que os dois Aires, o

\footnotetext{
${ }^{111}$ Observe-se que no momento da publicação de Esaú e Jacó não existia esse outro romance, que só surgiu seis anos mais tarde, fato que, no entanto, não altera as conclusões .

${ }^{112}$ Obra Completa, vol. I, p. 998.
} 
narrador e o personagem sejam ou não o mesmo indivíduo, pois eles pertencem a universos diferentes, ficcionais ambos, que, apesar da semelhança e da natureza ficcional comum, não se comunicam. É que o enunciador parece sempre preocupado em mostrar, por meio de seus jogos de espelhos e de efeitos de verdade, que o real é inacessível a qualquer texto, pois o en que conta não se confunde com o eu que vive. Começa-se, então, a perceber com mais nitidez as razões que levam o enunciador a - aparentemente - manter-se distante do texto: os efeitos de verdade só o são, também, na aparência. Expliquemos: quanto mais o narrador finge criar efeitos de verdade, construindo a ilusão de que Aires existiu mesmo, de que o leitor está mesmo acompanhando a feitura do texto que lê, mais o enunciador demonstra que, na verdade, o texto é um simulacro. Quanto mais o narrador tenta se aproximar do leitor real, mais se evidencia que ambos estão separados por uma barreira intransponível: a mesma linguagem que sopra a vida nesses seres de papel os impede de acessarem o real. Quer dizer, os efeitos de verdade são mostrados como o que são realmente: efeitos que buscam construir uma aparência de verdade, sem nunca conseguirem fazê-lo de fato, ou melhor, sem nunca conseguirem deixar de ser, aos olhos do leitor arguto, um efeito de verdade. Os textos, todos, de que tipos forem, sem exceção nenhuma, se revelam, então, na pena desse enunciador, construtores de falsas realidades que, enquanto tal, permanecem inacessíveis. Por isso, grande é a tentação de sugerir que, talvez, esse poeta concordasse com Platão, quando este afirma que os retóricos e poetas não conduzem a verdade e, por isso, devem mesmo ser banidos. De fato, talvez dissesse o enunciador em questão, nem os retóricos nem os poetas nos levam à verdade, mas..., acrescentaria ele, quem pode fazê-lo? Aliás, é possível uma construção, qualquer que seja, sem a intervenção da linguagem?

Cumpre deixar os devaneios e voltar à análise. E, talvez, o mais adequado seja deixar correr o texto até que, algumas linhas abaixo da citada, se encontrem outros dois espelhos postos um de frente para o outro e em cujas superfícies encontram-se apenas as imagens de Aires. É ele, o narrador, quem afirma:

Se Aires obedecesse ao seu gosto [de cantarolar a toada que ouviu da cantora e Caracas], e eu a ele, nem ele continuaria a andar, nem eu começaria este capítulo; ficaríamos no outro, sem nunca mais acabá-lo. (Obra Completa, vol. I, p. 998)

Como o en e o ele se referem ao mesmo indivíduo, o normal é que fosse escrito Se eu obedecesse ao men gosto, não continuaria a andar nem começaria..., mas Aires trata a si mesmo de ele, sem que deixe de haver sincronia entre o andar de um e o escrever de outro. Dizíamos ainda 
há pouco, que os universos são diferentes — e de fato são —, mas esse enunciador, que dizem ser um bruxo, amalgama os dois fazeres e obriga os sujeitos de instâncias diferentes, da enunciação e do enunciado, a, ainda que separados, seguirem o mesmo regime. E daí já não se sabe onde acaba uma instância e onde começa outra, pois o leitor acompanha o caminhar de um e o escrever de outro, naquela ambivalência de percursos sobre a qual tanto se tem insistido. Nem sempre, porém, os dois Aires aparecem assim cindidos e há pelo menos uma passagem em que as duas identidades voltam a ser uma. Está no capítulo LXV, que narra a noite de 15 de novembro. Natividade está angustiada, temendo que os filhos briguem ou se metam nalguma encrenca por conta da Proclamação da República. Aires, não contente em registrar o episódio, mostra, mais uma vez, como os universos separados podem se comunicar :

Paulo saiu, logo depois do jantar, prometendo vir cedo. A mãe, receosa de o ver metido em barulhos, não queria que ele saísse; mas outro receio fê-la consentir, e este era que os dois irmãos brigassem finalmente. Assim um medo vence a outro, e a gente acaba por dar o que negou. Não é menos certo que ela raciocinou alguns minutos antes de resolver, do mesmo modo que eu escrevi uma página antes da que vou escrever agora; mas ambos nós, Natividade e eu, acabamos por deixar que os atos se praticassem, sem oposição dela, nem comentário meu. (Obra Completa, vol. I, p. 1.033 - grifos meus)

Seguindo a lógica que tem prevalecido no livro, era esperado que o narrador escrevesse: mas ambos, Natividade e Aires, acabaram por... No entanto, ao utilizar o pronome de primeira pessoa, o narrador agora assume que é mesmo Aires, sem deixar margens para dúvidas. Observe-se que, quando afirma eu escrevi uma página antes da que vou escrever agora..., Aires refere-se a Esaú e Jacó e não ao memorial; é, portanto, ao actante da enunciação enunciada de Esaú e Jacó, ele próprio enquanto narrador, que ele se refere. Por outro lado, com o segundo eu (Natividade e eu), Aires refere a si próprio enquanto actante do enunciado enunciado, constituindo uma debreagem enunciativa do enunciado, uma vez que o narrador, conforme observa Fiorin (1996: 117), identifica-se com um dos actantes desse nível enunciativo. Nem tudo, porém, pode ser delimitado tão facilmente. Observe-se que, em seguida, o narrador afirma ambos nós, Natividade e eu, acabamos por deixar que os atos se praticassem. Em que termos, exatamente, Aires e Natividade deixaram que os atos em questão fossem praticados? Uma possibilidade é entender que Aires estava junto de Natividade (o que não está claro no texto) nesse momento e que ambos, depois de algum debate, teriam concordado com que Paulo saísse. O problema é que nada no romance indica que Aires tivesse essa autoridade. Outra possibilidade, mais interessante, é imaginar que Aires autorizou a saída de 
Paulo, não enquanto actante do enunciado, mas enquanto narrador, ou melhor, enunciador, que teria o poder de jogar com o destino dos actantes do enunciado. Essa hipótese ganha novos contornos com as últimas palavras do trecho acima, quando Aires complementa que as ações se praticaram sem comentário meu; isto é, sem um comentário do narrador. Mas do narrador de Esaú e Jacó ou do diário do conselheiro? Impossível saber, pois podem se referir tanto a um quanto a outro. Enfim, à medida em que avança a análise, a fusão de instâncias enunciativas e os malabarismos com as debreagens atingem um nível tal que se torna quase impossível discerni-las.

Para encerrar a análise de Esaú e Jacó, veja-se o capítulo XXVII, que atesta cabalmente a semelhança entre esse enunciador e o de Quincas Borba. Sim, a citação é longa como não convém a uma tese, mas, paciência; ao menos, é agradável de ser lida. Antes isso que nada:

\section{CAPÍTULO XXVII / DE UMA REFLEXÃO INTEMPESTIVA}

Eis aqui entra uma reflexão da leitora: "Mas se duas velhas gravuras os levam [Pedro e Paulo] a murro e sangue, contentar-se-ão eles com a sua esposa? Não quererão a mesma e única mulher?" O que a senhora deseja, amiga minha, é chegar já ao capítulo do amor ou dos amores, que é o seu interesse particular nos livros. Daí a habilidade da pergunta, como se dissesse: "Olhe que o senhor ainda nos não mostrou a dama ou damas que têm de ser amadas ou pleiteadas por estes dois jovens inimigos. Já estou cansada de saber que os rapazes não se dão ou se dão mal; é a segunda ou terceira vez que assisto às blandícias da mãe ou aos seus ralhos amigos. Vamos depressa ao amor, às duas, se não é uma só a pessoa..." Francamente eu não gosto de gente que venha adivinhando e compondo um livro que está sendo escrito com método. A insistência da leitora em falar de uma só mulher chega a ser impertinente. Suponha que eles deveras gostem de uma só pessoa; não parecerá que eu conto o que a leitora me lembrou, quando a verdade é que eu apenas escrevo o que sucedeu e pode ser confirmado por dezenas de testemunhas? Não. senhora minha, não pus a pena na mão, à espreita do que me vissem sugerindo. Se quer compor o livro, aqui tem a pena, aqui tem papel, aqui tem um admirador; mas, se quer ler somente, deixe-se estar quieta, vá de linha em linha; dou-lhe que boceje entre dois capítulos, mas espere o resto, tenha confiança no relator destas aventuras. (Obra Completa, vol. I, p. 983-3 - grifo meu)

Já se viu esse recurso, em tons variados, em $A$ mão e a lwva, Helena, Dom Casmurro... Agora, não são apenas os dois Aires que teimam em se unir, mas dois universos inteiros um ficcional e outro que não o seria — que fazem convergir os dois percursos a que se tem referido. Lembremo-nos de Aristóteles. Dizia o filósofo que o discurso devia fabricar suas próprias provas, inclusive os testemunhos que lhe aprouvesse. Veja agora o que faz o narrador: evoca dezenas de testemunhas para comprovar que conta somente o que suceden e que o narrado não sofre qualquer influência da leitora. Cínico, pois se sabe que, na verdade, não existem testemunhas, não existem leitoras, nada existe; cínico também porque, exatamente depois da reflexão intempestiva da leitora, o narrador apresenta os pais de Flora e ela própria, 
por quem os gêmeos vão se apaixonar, duas páginas depois (capítulo XXXI). Cínico, mas eficiente como meio para discutir a criação de efeitos de verdade, e mesmo a criação literária, pois esse é o grande espetáculo que está sendo encenado - e isso desde Ressurreição: a leitura do livro e o método empregado em sua composição.

No capítulo anterior, discutiu-se que as configurações narrativas de Esaú e Jacó eram um pouco distintas das dos demais romances. Agora, percebe-se que a instalação do narrador mantém, rigorosamente, o padrão adotado em obras anteriores: debreagem enunciativa da enunciação, busca da fusão de instâncias narrativas e instalação de dois percursos paralelos. Resta examinar uma questão: a autoridade do narrador. Viu-se que Bento Santiago, Brás Cubas e mesmo o narrador de Quincas Borba não eram lá muito dignos de crédito. E Aires? Sim, ele parece ter mais compostura; não comete os disparates de Brás Cubas nem as atrocidades de Bento Santiago. Contudo, como se acabou de ver acima, ele não é menos cínico do que esses senhores e, talvez, seja até mais ardiloso, na medida em que oculta sua identidade, provavelmente com o intuito de dar mais credibilidade aos fatos. Conclui-se, portanto, que mesmo no quesito autoridade, esse narrador não se distingue de seus pares.

\section{Memorial de Aires}

Embora o narrador de Memorial de Aires seja o mesmo de Esaú e Jacó, os dois romances diferem pelo fato de que, no primeiro, Aires assume explicitamente a narração, já que o romance seria parte de seu diário íntimo. Uma conseqüência desse fato é que a velha duplicidade de percursos, um relativo à busca por ascensão social e outro referente à construção de uma narrativa, torna-se ainda mais presente, pois, agora, são informadas até mesmo a data e a hora da produção de um determinado relato. Nessa perspectiva, o Memorial poderia ser resumido como a história de um velho diplomata aposentado que, nas horas vagas — quase todas —, registra em seu diário íntimo a vida de seus conhecidos, os quais, como de costume, têm de enfrentar o dilema de optar entre a ascensão social e as afeições íntimas buscadas por Félix.

Ao adotar a forma de um diário, o Memorial apresenta-se como um não-romance: ele não teria uma boa trama — sua história dessaborida, para lembrar o termo de José Paulo Paes, mal daria para passar o tempo da barca para Niterói — nem um público alvo, pois não teria sido escrito visando à publicação. Ao contrário dos outros romances, em que o narrador 
dirige-se ao leitor, aqui o narratário é o próprio papel, enfatizando-se justamente o fato de que ninguém teria acesso ao diário. Além disso, comparado, por exemplo, a $O$ amanuense Belmiro, romance de estréia de Cyro do Anjos, escrito cerca de três décadas mais tarde, o Memorial é mais radical, pois a forma de diário e sua escritura impõem-se com muito mais vigor na obra de Machado do que no Amanuense, que, diga-se de passagem, dialoga constantemente com o Memorial ${ }^{13}$, e cujo percurso central também é o da elaboração de um diário pelo sujeito. Por outro lado, a narrativa inscrita no diário está repleta de emendas e retificações; o texto parece emperrado, pouco coeso (como, aliás, já havia previsto o editor, M. de A.), com temas sendo retomados depois de encerrado o assunto e outros atravessando a narrativa. Vejam-se alguns exemplos: em 10 de janeiro, Aires cita uma conversa entre ele e Rita sobre o casamento de Fidélia e depois, rapidamente, relata o almoço que tiveram. Dois dias depois, em 12 de janeiro, retoma o assunto afirmando que $\mathrm{Na}$ conversa de anteontem com Rita esqueceu-me de dizer a parte relativa a minha mulher, que está enterrada em Viena ${ }^{114} \mathrm{Em} 5 \mathrm{de}$ janeiro, o diário começa com uma autocrítica: Relendo o que escrevi ontem, descubro que poderia ser ainda mais resumido, e principalmente não lhe por tantas lágrimas. ${ }^{115} \mathrm{Em} 23$ de maio, outra emenda: Les morts vont vite. Tão depressa enterrei o leiloeiro [assunto de 18 e 20 de maio] como o esqueci. Assim foi que, escrevendo o dia de ontem, deixei de dizer que no armazém do Fernandes achamos todos os objetos de mana Rita. ${ }^{116}$. Em 03 de agosto, Aires registrara o aniversário do ministério Ferraz, que o promovera a secretário de legação. A retificação vem em 10 do mesmo mês: Meu velho Aires trapalhão de minha alma, como é que tu comemoraste no dia 3 o ministério Ferraz, que é de 10? Hoje é que ele faria anos meu velho Aires Vês que é bom ires apontando tudo o que se passa; sem isso não te lembrarias nada ou trocarias tudo. ${ }^{117}$

Problemas de coesão e coerência, esquecimentos, incorreções de estilo, equívocos. É disso que tratam essas retificações, as quais pouco ou nada acrescentam à história do casal

\footnotetext{
${ }^{113}$ Veja-se, por exemplo, a bonita passagem em que o narrador, Belmiro, visita ao Rio de Janeiro e encontra-se com vários personagens de Machado:

Percorrendo a Rua Matacavalos, pensei com saudade naqueles cavalheiros que andavam de tílburi, jogavam voltarete e tinham, sobre o mundo pensamentos sutis. Divisei, a um canto, o vulto amável de Sofia e tive dó do Rubião. A meus ouvidos, mana Rita faz̧ia insinuações (Cale a boca, mana Rita...). Em certo bonde que me pareceu puxado por burricos tive a meu lado Dom Casmurro e lobriguei numa travessa dois vultos que deslizavam furtivos à luz. escassa dos lampiões: Capitu e Escobar. (p. 200).

${ }^{114}$ Obra Completa, vol. I, p. 1.099.

${ }^{115}$ Idem, p. 1.111

${ }^{116}$ Idem, p. 1.121

${ }^{117}$ Idem, p.1.138
} 
Aguiar, de Tristão e Fidélia, mas muito têm a dizer sobre o ato de narrar, sobre o modo de ser de Aires e, mesmo, sobre a íntima relação entre a constituição de uma individualidade e o ato de registrar o correr dos dias ${ }^{118}$. As passagens citadas, além de confirmar um texto "inacabado" (como havia sugerido o editor, M. de A.), mostram que os temas abordados subordinam-se ao ato de narrá-los, evidenciando - como é de praxe em Machado - a narração em detrimento da narrativa. Surgem, novamente, dois percursos paralelos: o relativo à elaboração do diário e os episódios envolvendo os conhecidos de Aires; o segundo subordinado ao primeiro. As constantes retificações de Aires evidenciam uma vez mais que ele registra não os fatos, mas o que eles lhe pareceram ser - é o caso dos inúmeros pareces do texto, lembrados por Bosi em Uma figura machadiana, os quais alteram profundamente a narrativa.

As emendas que Aires faz ao diário terminam por deixar o texto impreciso, indicando, além dos desenganos do diarista, que o texto pode conter informações equivocadas, como a relativa ao aniversário do Ministério Ferraz. Mais do que qualquer outra coisa é a precariedade dos registros de Aires que se destaca; o fato de o equívoco espreitar cada linha do diarista. A sobreposição de enganos e desenganos que percorrem o diário parecem querer alertar o leitor para um fato um tanto paradoxal: o diário, que não seria uma obra de ficção, mostra-se, ao longo da narrativa, infiel aos fatos, ou, pelo menos, não confiável. No entanto, ao explicitar que tal infidelidade é fruto dos desacertos - reais ou fingidos - de Aires, o romance transforma o "defeito" do diário em qualidade do próprio romance. Não seria verossímil que Aires, na posição que ocupa, pudesse ver seu mundo sem os óculos da ideologia de sua classe. Em Memórias póstumas, essa questão era colocada em termos diferentes, pois Brás Cubas era explicitamente não confiável, ou era sinceramente insincero, cuidando, ele próprio, de desestabilizar a própria narrativa. O narrador de Quincas Borba, que, em dado momento, apresenta-se como o próprio Brás Cubas, também não é lá muito digno de confiança e, constantemente, aponta ao leitor as próprias artimanhas, de maneira a deixá-lo de sobreaviso. Já Bentinho conseguiu enganar por mais tempo e, ainda hoje, parte da crítica literária dedica-se a esclarecer se Capitu o traiu ou não, esquecendo-se de

\footnotetext{
${ }^{118}$ Para uma discussão aprofundada sobre o papel dos diários íntimos e da escrita sobre si mesmo na sociedade burguesa do século XIX, ver O coração desvelado, de Peter Gay (São Paulo: Companhia das Letras, 1999, trad. Sérgio Bath). Em seu alentado estudo, Gay (op.cit.: 119) mostra que até o advento da psicanálise, no final da década de 1890, as autobiografias eram os melhores instrumentos de sondagem da vida introspectiva de que dispunham os vitorianos.
} 
verificar a pertinência da pergunta. De qualquer modo, depois de as suspeitas sobre o narrador atingirem o ápice em Memórias póstumas, parecem diminuir a cada romance, sem que se possa dizer que os respectivos narradores tenham-se tornado mais confiáveis. Aires seria aquele que logrou angariar um respeito maior: se em Esaú e Jacó era um narrador de mais compostura que seus antecessores, no Memorial parece ter atingido a perfeição da respeitabilidade.

Há, contudo, uma diferença capital entre Aires e Bento Santiago, ou mesmo entre o Memorial de Aires e os demais romances: o diário não teria sido escrito visando à publicação; aliás, nem seria um romance. Daí que embora o narrador e o narratário sejam instalados de forma explícita nesse romance — aliás, de forma mais intensa do que era nos romances anteriores —, sua actorialização é bem diferente: o narrador não é mais o "escritor" que luta para publicar sua obra e se fazer entendido, mas apenas alguém que, de forma despretensiosa, registra suas anotações. Em sintonia com tal proposta, o narratário também não é mais o leitor impaciente e ingênuo, mas o papel, a pena utilizada ou, mesmo, o próprio diário. Repare que isso se reflete nas instâncias narrativas que compõem o romance e que serão investigadas mais à frente. $\mathrm{O}$ destinatário da Advertência assinada por M.A é claramente o leitor inscrito, que ocupa a posição de narratário desse nível; enquanto o destinatário da narrativa de Aires é ele próprio ou, melhor, o papel, com quem dialoga com freqüência. Dessa forma, na medida em que o diário não teria um destinatário de verdade, ele não teria uma função comunicativa, como tinha o relato de Bento Santiago, e, por isso, ele seria, de certa forma, mais confiável: Aires não estaria se defendendo de nada nem atacando ninguém. Vejam-se alguns exemplos: no registro de 08.04.1888, a instauração do papel como destinatário acontece três vezes:

Papel, amigo papel, não recolhas tudo o que escrever esta pena vadia. Querendo servir-me acabarás desservindo-me, porque se acontecer que em me vá desta vida, sem tempo de e reduzir a cinzas os que te lerem depois da missa do sétimo dia, ou antes, ou ainda antes do enterro, podem cuidar que te confio cuidados de amor.

Não, papel. Quando sentires que insisto nessa nota, esquiva-te da minha mesa, e foge. [...]

Escuta, papel. O que naquela dama Fidélia me atrai é principalmente certa feição de espírito, algo parecido com o sorriso fugitivo, que já lhe vi algumas vezes. Quero estudá-la se tiver ocasião. Tempo sobra-me, mas tu sabes que ainda é pouco para mim mesmo, para o meu criado José e para ti, se tenho vagar e quê, - e pouco mais (Obra Completa, vol. I p 1.115-6)

Quatro dias depois, em 12.04.1888, após confessar que, se pudesse, diria mal de Fidélia, Aires acrescenta: 
Isto, sim, papel amigo, isto podes aceitar porque é a verdade íntima e pura e ninguém nos lê. Se alguém lesse achar-me-ia mau, e não se perde nada em parecer mau; ganha-se quase tanto como em sê-lo. (Obra Completa, vol. I p. 1.117)

Finalmente, em 16.06.1888, após narrar o diálogo que tivera na casa de Aguiar com um amigo da família, a respeito do provável casamento de Fidélia, o conselheiro afirma:

Já me parece que Fidélia acaba sem casar. Não é só aquela piedade conjugal que the perdura, é a tendência a cousas de ordem intelectual e artística, e pouco mais ou mais nada. Fique isto confiado a ti somente, papel amigo, a quem digo tudo o que penso e tudo o que não penso. (p. 1.127)

Esses trechos interessam não apenas por exemplificar a instauração do papel como narratário, mas, principalmente, por revelarem o objetivo visado por tal estratégia: ao ter como destinatário apenas o papel (o que equivale a ter apenas ele próprio nessa posição), Aires poderia ser absolutamente franco (como Brás Cubas teria sido, graças à sua condição de defunto), pois nada teria a esconder: não recolhas tudo / isto sim [...] podes aceitar / papel amigo, a quem digo tudo o que penso [...]. O conteúdo do memorial seria não só verdadeiro, mas secreto, à medida que o que registra são os pensamentos mais íntimos de seu autor. Nesse aspecto, o romance rompe, de forma radical, com os outros de Machado, e mesmo com Esaú e Jacó, pois, antes, a presença do leitor forçava o narrador a determinados recuos, a adotar ou não determinado tom etc. Isso já não ocorre agora, pois o leitor está absolutamente ausente, e o narrador, totalmente livre, não tendo nem mesmo a preocupação de pagar-lhe com um piparote caso não goste do romance. Diante dessas circunstâncias, o leitor é levado a crer que tem em mãos a verdade pura e sem fingimento, como gosta de afirmar o conselheiro. De outro modo: o narrador busca persuadir o leitor negando qualquer intenção de fazê-lo. O problema é que o enunciador consegue, nas entrelinhas, mostrar que a visão de Aires é parcial. Já se sabe que o Memorial de Aires é debreado de forma enunciativa e que o narrador está em sincretismo com os actantes do enunciado. Atente-se agora para uma diferença deste romance em relação a Memórias póstumas e Dom Casmurro que o torna próximo dos demais de Machado. Ao contrário de Brás Cubas e de Bentinho, Aires praticamente não tem outra função na trama que não a de escrever seu diário. Aliás, sua participação é ainda mais apagada do que era em Esaú e Jacó. Por outro lado, o conselheiro ganha todo destaque se for enfocada a narrativa primeira - do nosso ponto de vista, a principal —, relativa à elaboração do diário. É como se a narrador, claramente presente desde Ressurreição, agora ganhasse uma identidade, e como se o ato de narrar, que também sempre foi narrado, fosse agora dissecado, com a indicação, por exemplo, das datas e horas de composição e das idas e vindas que 
compõem esse fazer, conforme se viu quando se relatou os equívocos de Aires. Desse modo, percebe-se, também por esse ângulo, uma extrema coerência no fazer do enunciador, pois as mudanças no seu comportamento operam-se todas dentro de uma mesma lógica.

Observe-se, ainda, que o confronto entre a realidade e a sua narração, expresso nas retificações que Aires faz em seu diário, e nos seus diálogos com o papel, já habitava os primeiros romances, quando o narrador afirmava, como em $A$ mão e a luva, que, apesar de não ter dado a descrição literal das palavras de Estevão, sua narração era absolutamente fiel aos fatos. O mesmo se repetia em Helena, quando o narrador afirmava que havia omitido a história de toucador contada por Eugênia porque ela não era de interesse para a trama. Em Quincas Borba não é diferente, sendo que lá o narrador ganhava de forme muito sutil uma identidade, na passagem em que o narrador sugeria ser o próprio Brás Cubas. Em Dom Casmurro, esse processo se torna muito mais complexo e, praticamente, articula toda trama, que se alicerça, justamente, no acerto ou no erro da interpretação que Bento Santiago faz dos fatos narrados. O processo se repete em Memorial de Aires, com duas diferenças: agora é ainda mais extenso e é o próprio narrador quem descobre seus equívocos, ao menos no que toca a Fidélia e a Tristão, como se viu na análise anterior desse romance.. Por decisão ou por incompetência, Aires mostra-se, assim como Bento Santiago, um narrador pouco confiável: ele pode estar certo e pode não estar, mas como saber quando acontece uma coisa e quanto acontece outra?. Afinal, se ele se enganou em relação ao jovem casal que abandonou os velhos, porque não se teria enganado em outros assuntos?

Enfim, na instalação do narrador do Memorial de Aires observam-se algumas das recorrências buscadas neste trabalho que podem ser resumidas na instalação do programa de construção de um objeto de valor, a própria narrativa, portador de um saber com o qual o narratário será colocado em conjunção. Assim como nos romances anteriores, todos os procedimentos do enunciador, como a fusão de instâncias ou a instalação de actantes da enunciação enunciada são apenas decorrências desse princípio. A diferença do Memorial de Aires, se é que cabe o termo, é de grau: a escritura do diário absorve praticamente todo o texto, sobrando pouco espaço para a trama propriamente dita, que mais do que nunca se vê relegada ao segundo plano. 
O exame de todos os nove romances de Machado de Assis revelou outra coerência notável: todos, sem exceção, constituem uma macro debreagem enunciativa da enunciação, com um narrador que diz eu e que conduz de forma explicita a narrativa. É fato que, às vezes, tal condução é menos intensa, como em Iaiá Garcia, mas, mesmo nesse caso, não deixa de ser claramente marcada, conforme foi visto. Não contente em dizer eu, esse narrador se volta contra aquele que o instaurou e tenta, por todos os meios, em todos os romances, usurpar-lhe o lugar, assumindo um posto que não lhe pertence: o de enunciador. É o que faz quando se coloca como autor efetivo da obra, aquele que tomou da pena e redigiu o texto, que tem dúvidas quanto à composição do romance, que antecipa fatos e dialoga com o narratário, explica detalhes técnicos da impressão do livro, que faz as vezes de enunciatário e se indaga sobre os títulos a dar aos capítulos ou, ainda, recrimina-se pela organização do material que escreve. E não é só o narrador que se apresenta como enunciador e faz com que o narratário passe a enunciatário; os actantes do enunciado também podem se passar por actantes da enunciação enunciada, como ocorreu quando Sancha passou de interlocutora a narratáriaenunciatária, portanto, a actante da enunciação enunciada; é o que acontece também com a campainha de $A$ mão e a luva, que toca, chamando os actantes do enunciado para o almoço e despertando o narrador e o narratário para outro aspecto da narrativa.

Outro procedimento recorrente é fazer actantes da narrativa primeira passarem para a narrativa segunda ou vice versa, em um processo que Genette (2004) chama de metalepse de autor. E, de fato, o processo guarda inegáveis semelhanças com essa figura de linguagem. Fontanier (1997:128-9) define a metalepse como um recurso pelo qual “um poeta, um escritor é representado ou se representa como produə̨indo ele próprio aquilo que, na verdade, está apenas contando [...]. No calor do entusiasmo ou do sentimento abandona-se repentinamente o papel de narrador pelo de mestre ou de arbitrio soberano, de forma que em vez de simplesmente contar uma coisa que se faz on que é feita, determina-se ou ordena-se que ela se faça...”. A explicação não poderia ser mais clara; o narrador machadiano freqüentemente abandona seu papel de contador de histórias, substituindo-o pelo de mestre ou árbitro soberano. Ele deixa de narrar os fatos e passa a vivê-los, determinando que se produzam; é o que acontece, por exemplo, quando convida o leitor, em Iaiá Garcia, a entrar com ele um uma casa para conhecer os que lá vivem ou as coisas que lá se passaram. Nesses momentos, ele não apenas narra, mas determina que os fatos aconteçam aos olhos do leitor, o qual passa a ser, antes de mais nada, o expectador de um drama ao vivo. Como se sabe, a semiótica chama esse processo de embreagem actancial e entende que ele 
implica a neutralização da oposição entre os níveis enunciativos (Fiorin, 1996: 122-4); com os actantes passando de um nível a outro, como ocorre na obra de Machado de Assis

Ao conferir ao narrador o poder de fazer com que os fatos se produzam - e não apenas de narrá-los —, o enunciador faz com que a oposição entre realidade e representação da realidade também desapareça; afinal, a "realidade" desses textos não é a que é observada pelo narrador e posteriormente narrada; trata-se, antes, da "realidade" construída - e isso de forma explícita - por ele. Ao mesmo tempo em que age dessa maneira, o narrador assevera, sem cessar, sua sinceridade, alegando conhecer a verdade e que é o amor que tem por ela que o impede de alterar os fatos, mesmo se estes parecerem inverossímeis. Enquanto isso, o enunciador o desqualifica, exibe as marcas de sua imperícia, de forma explícita, como em Memórias póstumas; mais sutilmente, como em Dom Casmurro, ou de forma quase imperceptível, como em Memorial de Aires. Sim, o procedimento não foi inaugurado em Memórias póstumas; vem de muito antes, mas era realizado "de fora" da narrativa, por meio das advertências, como será estudado mais adiante.

Além disso, se, em algumas vezes, a associação entre o narrador e o enunciador é, digamos, possivel, ao menos para o leitor comum, ela é, em outros momentos, uma aberração. É o caso do defunto Brás Cubas, que não poderia ser o enunciador de Memórias póstumas nem de Quincas Borba. Mas veja que tampouco Aires poderia sê-lo, uma vez que não existe. Assim, os textos se fundam em uma contradição básica e uma mentira de princípio: aquele que diz eu não pode ser quem diz ser, porque a própria enunciação se encarrega de negá-lo. Desse modo, a representação da realidade se vê irremediavelmente fraturada, e o narrador, mesmo aquele dos primeiros romances, mostra-se pouco confiável, não apenas pelas suas idiossincrasias, mas também porque sua própria conduta é questionada.

Embora todo o processo de representação da realidade seja colocado em discussão, no ponto de partida - e de chegada — está o indivíduo. É sua identidade que, de pronto, é colocada em dúvida pelos fatos narrados, uma vez que o sujeito se constitui a partir dos valores com os quais está conjunto, como, aliás, explica a semiótica. Recorde-se, por exemplo, o diálogo entre Palha e Sofia sobre os assédios de Rubião, no qual a identidade de ambos passa a ser decorrente dos interesses em jogo. Rubião pode ou não ter sido inconveniente e Sofia e Palha podem ou não ter-se ofendido com seus atos; tudo vai depender dos interesses em jogo. E, naturalmente, a linguagem irá se adequar para descrever 
a situação de acordo com eles. Outro exemplo é o do par Bentinho-Capitu. Qual a identidade desses dois sujeitos? Observe-se que o que está em jogo não é a questão romanesca da traição, mas a identidade de Bentinho, que se mostra cindido: um é o Bentinho construído pelo narrado, o Bentinho vivido; outro é o construído pela narração, o Bentinho narrante. Qual dos dois é o verdadeiro? Ou melhor: será que a questão se coloca, uma vez que ambos são, ao fim e ao cabo, construção da linguagem? Não é diferente a questão que se coloca para Aires: o verdadeiro é o amável e cordato dos saraus ou o cáustico e ambíguo do diário?

Vê-se, agora, que o uso da metalepse é absolutamente coerente com os propósitos do enunciador. Sendo a linguagem o único meio de que dispõe o ator da enunciação para o exercício de seu fazer, e, ao mesmo tempo, desconfiando dela por princípio e dever de ofício, sua única saída é explicitar que nada é simplesmente narrado, mas reconstruído pela linguagem; ela não seria um vidro transparente, mas translúcido que deforma a mesma realidade a que permite o acesso. $\mathrm{O}$ universo instaurado por esse enunciador se mostra, então, dividido: um é o universo do narrador apresentado no momento em que constrói sua narrativa, que gosta de exibir o seu saber e sua pretensa perícia, e que não se deixa levar pelo gosto do leitor. É também aí que habitam o "leitor" e a "leitora", tão personagens quanto o narrador e que não conseguem — nas mais das vezes - acompanhar o seu fazer. Outro é o universo narrado por esse mesmo narrador, no qual habitam os sujeitos instalados por ele e que executam seus programas narrativos. O problema é que as fronteiras são porosas, de modo que habitantes de um universo passam para outro sem jamais deixar de pretender tragar o leitor, como fizera o mar com certo com nadador. O mar, nesse caso, mais bravio que aquele, é a própria linguagem que a todo o momento mostra que o narrador é também uma criação. $O$ enunciador também como que é arrastado por esse redemoinho linguageiro; mas, claro, não existe essa possibilidade, pois o eu que narra está totalmente separado do eu narrado. A esse respeito, recorde-se a célebre citação de Bakhtin (1993: 360):

Se eu narrar (escrever) um fato que acaba de acontecer comigo, já me encontro como narrador (ou escritor), fora do tempo-espaço onde o evento se realizou. É tão impossível a identificação absoluta do meu "eu" com o "eu" de que falo, como suspender a si mesmo pelos cabelos. O mundo representado, mesmo que seja realista e verídico, nunca pode ser cronotopicamente identificado com o mundo real representante, onde se encontra o autor-criador dessa imagem.

O interesse da metalepse, citadas várias vezes neste texto, está justamente no fato de ela investir contra essa divisão e evidenciar uma saudade de um eventual estado original, quem sabe, anterior à linguagem, em que os dois eus — o narrante e o narrado — viviam em 
comunhão. Genette (2004) demonstra que a impossibilidade de re-união dos dois universos é absoluta, ainda que o mundo do narrado pretenda pertencer ao mundo real tanto quanto o narrante. É o que o narratologista faz ao discutir a impossibilidade de confundir o Rousseau "real", isto é, o apresentado pelos livros de história e de filosofia, e que, dentre outras obras, escreveu suas memórias, e o Rousseau personagem dessas mesmas memórias - que, em larga medida, relatam acontecimentos "verídicos" e fazem deste último, um ser tão "real" quanto aquele dos livros de história. No entanto, ambos não se correspondem e habitam universos distintos, mesmo que os fatos narrados possam ser comprovados. É o que fica evidente nessa passagem:

[...] a redução progressiva da distância temporal entre o jovem e herói [Rosseau] e o necessariamente "menos jovem" enunciador de qualquer narrativa autodiagética não reduz em nada a diferença que separa essa duas funções que são viver — ainda que seja somente "ir dormir cedo" — e contar sua vida [...] Todo diarista pode experimentar essa diferença sabendo ao menos que sua vida "ativa" se interrompe no momento em que começa seu relatório diário e/ou seu exame de consciência. (Genette, op. cit.: 105)

Os dois universos, o do contado e o do vivido, também não se misturam quando ambos os universos são ficcionais. ${ }^{119}$ Voltando a Machado: um é Dom Casmurro; outro é Bentinho. Um conta; o outro, vive. O objetivo da narração é explícito: atar as duas pontas da vida e fazer o próprio narrador viver novamente o que já havia vivido. Ora, o romance é a demonstração cabal dessa impossibilidade, do fracasso do narrador. Independentemente do conteúdo de verdade das palavras de Bento Santiago, o fato é que ele não logrou reviver o que havia sido. Cria-se, assim, uma tensão permanente, jamais resolvida: de um lado, busca-se afirmar a identidade entre o universo narrado e o narrante; de outro à medida que tal fusão é buscada, evidencia-se mais e mais essa impossibilidade, que persiste mesmo quando os actantes do enunciado enunciado não estão sincretizados com os da enunciação enunciada, a exemplo dos quatro primeiros romances. Neles, o narrador não participa dos fatos narrados, mas, apesar disso, age como se estivesse presente à cena e participa ativamente da narração, comentando o que narra e mostrando como seu universo não é o dos fatos que ele narra; trata-se de um processo que, mais uma vez, causa a instabilidade dos dois universos, e, ao mesmo tempo, propõe sua fusão e os mostra como inconciliáveis.

\footnotetext{
${ }^{119}$ É o caso da narração feita por Ulisses, na Odisséia. Embora Ulisses seja um único ser, constituído de papel, o Ulisses que conta os episódios vividos na companhia de Polifemo não é o mesmo do Ulissses que relata esses episódios à corte de Alkinoos.
} 
Com base nos dados levantados até o momento, é preciso que agora seja delineado o ethos desse enunciador. No item anterior, viu-se que ele se mostra, em todos os seus enunciados, um indivíduo lúcido, frio, cético, que não acredita em ilusões ou romances e que instaura sujeitos que partem em busca de seus objetivos materiais sem se deixar levar por sentimentos. É o caso de Guiomar, de Helena, de Valéria, de Sofia, de Batista e Santos, de Tristão, e de tantos. Agora se vê que esse ceticismo é tal que atinge até mesmo a linguagem. Ela não serviria como elemento de representação da realidade, pois trai a missão que lhe foi conferida e, no lugar de representá-la, acaba por construir outra. Para fazer o enunciatário entrar em conjunção com esse saber, o enunciador instaura um sujeito que tem explicitamente o papel temático de narrador (isto é, de alguém que, por meio da linguagem, reconstrói o mundo para um terceiro), delegando a esse sujeito a instauração de um mundo onde os sujeitos executam programas narrativos de ascensão social. No entanto, enquanto seu delegado constrói esse mundo, esmerando-se por fazê-lo parecer o mais real possível, o enunciador o mostra como falso,ou melhor, como um simulacro. As constatações de há pouco confirmam e agudizam, por esse ângulo, o ceticismo do enunciador e constroem dele uma imagem aparentemente frágil, distante, enfraquecida pelos inúmeros prepostos de moral questionável que se interpõem entre ele e o enunciatário. Contudo, se, de fato, fosse assim, esse enunciador não teria o vigor que tem, não seria capaz de fazer seus enunciados atravessarem mapas e dicionários com grande vitalidade, há mais de um século. Desse modo, cumpre reconhecer que, até mesmo nesse momento, o jogo entre o ser e o parecer se faz valer. Na verdade, a identidade desse enunciador também se mostra uma incógnita, ou, pelo menos, de difícil apreensão e por isso diremos que ele é dissimulado e um exemplo seria sua aparente fraqueza: ela o é apenas na aparência. Na verdade, ele é rijo e seguro o suficiente para não temer ser ofuscado por seus narradores, pois detém com mão firme todos fios de sua trama. Enfim, a análise da instalação do narrador revela que, sob narradores tão diversos quanto Aires, Bento Santiago ou os narradores de Ressurreição e Iaiá Garcia, há um mesmo fazer e preocupações semelhantes, talvez a principal delas seja dissimular o pensamento daquele que lhes deu fôlego. 


\section{Delegação do saber}

0

observador, assim como o narrador, é um delegado do enunciador instalado no enunciado para aí exercer um fazer cognitivo: interpretar os fatos para que o narrador os relate ao leitor. O narrador irá, então, narrar de acordo com a perspectiva e o saber dos actantes cognitivos (observadores) instalados pelo enunciador no enunciado, de modo que o efeito de sentido produzido por toda a narrativa será resultado do fazer desses dois actantes: do observador, que vê, interpreta; e do narrador, que relata, da perspectiva daquele, o que foi visto. Compreensivelmente, é difícil de perceber a distinção entre um e outro fazer, pois, não raras vezes, observador e narrador estão sincretizados em único ator. Todavia, uma análise mais acurada mostra que o narrador geralmente adota uma determina perspectiva que corresponde ao ponto de vista de uma personagem. Claro, o saber do enunciador é uno e, certamente, superior ao dos actantes instalados no enunciado, mas não se tem acesso direto a ele; não é possível especular o que o enunciador sabe ou não, o que ele quis dizer com... Conhece-se, apenas, o que os actantes instalados no discurso sabem e é a oscilação, a distribuição desse saber que produz uma imagem da instância da enunciação, portanto, do seu ethos.

Lembrando que a função do narrador é falar e a do observador é ver e ouvir, e que o primeiro só pode narrar o que é sabido pelo segundo, Fiorin (1996: 107-11) propõe uma tipologia relativa à instalação do observador: ele pode ter uma focalização total ou parcial, podendo esta ser externa ou interna às personagens, ou a uma delas. No primeiro caso, o narrador poderá contar com uma perspectiva ampla sobre tudo o que se passa, e será dito que o narrador é onisciente. No segundo caso, o narrador não poderá saber tudo, ou, se souber, apresentará pontos cegos, falhos. É importante ver que embora o saber do narrador não se confunda em nenhum dos casos com o do enunciador, quando o foco é total, cria-se o efeito de sentido de que ambos detêm igual saber. No entanto, em termos práticos, isso seria não possível. Pense-se, por exemplo, no caso de uma matéria jornalística; é claro que a instância de enunciação (o jornalista que escreveu a matéria) não delega ao observador todo o seu 
saber, seja por questões políticas, de mercado ou, mesmo, prosaicas, como espaço disponível no jornal; ele terá, então, de fazer cortes para adequar o que ele sabe sobre o fato noticiado às condições do jornal em que trabalha. Já no caso de um foco parcial, a diferença entre o saber do narrador e do enunciador ficará evidente: haverá perguntas sem respostas ou com respostas múltiplas. Contudo, até em um narrador cujos observadores têm foco total pode ocorrer de ser explicitada essa diferença de saberes. É o caso do narrador que, mesmo onisciente, engana-se, faz juízos equivocados etc. Como se verá mais adiante, também nesses domínios Machado de Assis atuará com maestria.

Outro aspecto a ser observado é o do contraditório. Nesse caso, instalam-se no enunciado pontos de vista antagônicos sem que haja uma instância que os congregue. É o conto Dentro do bosque, de Yabu No Naka, adaptado para o cinema por Akira Kusorawa, que narra o suposto assassinato de um samurai e o estupro de sua mulher por um bandido. $\mathrm{O}$ texto é composto pelos depoimentos de um lenhador, um bonzo andarilho, um policial, uma velha, Tajoomaru (o assassino), a mulher do samurai e uma médium que recebe o espírito do samurai morto. O narrador primeiro apenas delega a voz a cada um desses interlocutores, os quais, de acordo com seu ponto de vista, narram ao juiz de instrução os fatos ocorridos. Assim, na versão do samurai assassinado, ele não fora morto pelo bandido, mas suicidara-se. Em seu depoimento, o assassino afirma que não estuprara a mulher, pois ela se oferecera a ele. Tajoomaru tampouco teria assassinado o samurai; antes, teria o derrotado em um duelo. Há, no conto, portanto, vários pontos de vista, vários observadores que têm um foco interno à narrativa e limitado aos acontecimentos presenciados. Desse modo, o narrador primeiro não exerce nenhum fazer cognitivo; e sua atividade restringe-se à delegação da voz a cada interlocutor, que passa a narrar os fatos de seu ponto de vista. Desse modo, o narrar e o observar são mostrados como atividades distintas, mas indissociáveis: a primeira é um fazer pragmático, de dar andamento aos fatos e comunicá-los ao enunciatário, organizar os turnos de fala; a segunda é um fazer cognitivo de interpretar os fatos narrados. Nesse caso, o observador está sincretizado com o interlocutor que expressa seu ponto de vista pela narração. O título em português, Dentro do bosque, já sugere que nenhuma informação exterior à cena do crime será trazida à luz, ou seja, que não há onisciência. São muitos os observadores, mas o narrador primeiro não adota nenhuma das perspectivas daqueles; na verdade, mostra que todas são necessariamente parciais. Se, por um lado,cada narrativa considerada isoladamente parece extremamente subjetiva, por outro, o conjunto delas adquire 
grande objetividade, dados que são ouvidas todas as testemunhas e considerados todos os pontos de vista. Como os pontos de vista são antagônicos e a verdade é uma só, sabe-se que alguém está mentindo, mas não se sabe quem: a morte do samurai resultou de um assassinato ou de um duelo? Houve estupro ou adultério? Evidencia-se, desse modo, que a instância da enunciação (que teria a resposta a esses questionamentos) não instalou no texto actantes dotados de competência cognitiva ampla, para saber tudo que se passou; nem epistêmica, que os permitisse distinguir o ser do parecer. Além disso, tal narrativa faz supor um enunciatário que não está interessado em histórias policiais, mas justamente nos efeitos verdade criados para persuadir o ouvinte — tal como na Siracusa dos antigos retóricos.

O enunciador pode, ainda, fazer com que o narrador adote um ponto de vista que não corresponde ao do ator com o qual está sincretizado. Veja-se o conto Tu és o homem, de Poe. Nele, o narrador conta a história do assassinato de um rico proprietário, seu conhecido. As investigações conduzidas por Carlito Goodfellow, homem de grande popularidade no local e melhor amigo do morto, fazem a culpa recair sobre o sobrinho da vítima, antigo desafeto do investigador. Durante toda a narrativa, percebe-se algo de errado, pois todos, inclusive o narrador, mostram-se muito ingênuos. Depois que o caso é dado por encerrado, com a condenação do sobrinho, o cadáver, aparece repentinamente e "acusa" Goodfellow pelo assassinato, proferindo a frase que dá nome ao conto. O narrador então explica que, há muito, começara a desconfiar de Carlito e que depois de se certificar de sua culpa, valera-se de um engenhoso artifício para incriminá-lo. Percebe-se, nesse momento, que, até então, o observador não estivera sincretizado com o narrador, que na verdade não era ingênuo, mas adotara o ponto de vista da comunidade local, crédula, que se deixava guiar pelo parecer para chegar ao ser. Apesar da diferença entre o ponto de vista do observador e o do narrador, não se nota, no conto de Poe, uma defasagem entre o saber do narrador e o do enunciador, pois ao final do conto nada deixa de ser esclarecido; cria-se, portanto, o efeito de que a instância da enunciação delegou todo seu saber ao narrador.

Nem sempre é assim e, muitas vezes, fica claro que o enunciador sabe mais que o narrador. Veja-se o famoso romance de Camus, O estrangeiro. Na segunda parte do romance, Meursault, que está preso por haver matado um árabe, não consegue entender porque seu advogado the pergunta se ele havia se emocionado no enterro da mãe, falecida algumas semanas antes d ele cometer o assassinato: 
Esta pergunta muito me espantou e parecia-me que não era capaz de a fazer a alguém. Não obstante respondi que perdera um pouco o hábito de me interrogar a mim mesmo e que estava difícil dar-lhe uma resposta. É claro que gostava da minha mãe, mas isso não queria dizer nada. Todos os seres saudáveis tinham, em certas ocasiões, desejado, mais ou menos, a morte das pessoas que amava. Aqui o advogado cortou-me a palavra e mostrou-se muito agitado. [...]

[o advogado] Pôs-se a pensar. Perguntou-me se se poderia dizer que, nesse dia, eu reprimira meus sentimentos naturais. Respondi: - Não, porque não é verdade. [...] Fiz lhe notar que essa história não tinha nenhuma relação com o meu caso, mas ele respondeu-me que se via bem que eu não conhecia a justiça de perto. (São Paulo: Abril Cultural, 1972, p. 85-6, Trad. Antônio Quadros).

O observador e o narrador estão sincretizados no mesmo ator do enunciado: Meursault, que, naturalmente, conhece todos os fatos relacionados a si próprio. Nesse caso, porém, está claro que a instância da enunciação, não delegou ao narrador um saber relativo a questões de conhecimento mais geral, como o funcionamento da justiça e o coração dos homens que veriam no fato de ele não externar seus sentimentos uma prova de sua culpabilidade. Daí sua não compreensão diante da agitação do seu advogado. Cria-se, desse modo, um fosso entre o saber da instância da enunciação (tanto enunciador quanto enunciatário) e o saber do narrador, e é na defasagem entre esses dois saberes que se estrutura boa parte do romance. Observe-se, ainda, que essa situação faz com que enunciação e enunciado passem a estar em oposição, não porque exista alguma ironia por parte do narrador(ao menos não na maior parte do romance), mas porque o sentido último da obra não está na nas palavras do narrador, mas na visão que delas é dada pela instância da enunciação.

Nos contos de Machado, observam-se várias estratégias e não seria possível examiná-las todas. Contudo, será importante fazer uma breve e parcial recordação para que fique marcada a oposição entre os procedimentos adotados nessas obras e os empregados nos romances. No conto Causa secreta, por exemplo, o narrador adota a perspectiva de Garcia, amigo de Fortunato, a partir da qual narra os fatos. A causa do título é secreta para ele, que não entende o modo de agir do sócio, mas não para Fortunato (é o nome do sócio), que, obviamente, conhece o motor da própria ação. Logo, se o narrador adotasse a perspectiva desse personagem, seria difícil fazer a causa do título permanecer secreta. Coerentemente à perspectiva adotada, a paixão de Garcia por Maria Luiza, esposa de Fortunato, é revelada aos poucos, à medida que ele adquire consciência desse sentimento, uma vez que a narrativa assume sempre o ponto de vista de Garcia. Por outro lado, mantendo a mesma perspectiva, Fortunato descobre a paixão do amigo por sua mulher apenas nos momentos finais do conto, quando Maria Luiza já está morta e Garcia aproxima-se do cadáver: 
Garcia tinha-se chegado ao cadáver, levantara o lenço e contemplara por alguns instantes a defunta. Depois, como se a morte espiritualizasse tudo, inclinou-se e beijou-a na testa. Foi nesse momento Fortunato que chegou à porta. Estacou assombrado; não podia ser o beijo da amizade, podia ser o epílogo de um livro adúltero. Não tinha ciúmes, note-se; a natureza compô-lo de maneira que lhe não deu ciúmes nem inveja, mas dera-lhe vaidade, que não é menos cativa ao ressentimento. Olhou assombrado, mordendo os beiços.

Entretanto, Garcia inclinou-se ainda para beijar outra vez o cadáver, mas então não pôde mais. O beijo rebentou em soluços e os olhos não puderam conter as lágrimas que vieram em borbotões, lágrimas de amor calado e irremediável desespero. Fortunato, à porta, onde ficara, saboreou tranqüilo essa explosão de dor moral que foi longa, muito longa, deliciosamente longa. (Obra Completa, vol. II, p. 519 - grifos meus)

É natural que Fortunato ficasse assombrado, pois desconhecia os sentimentos de Garcia. Ele chega a desconfiar de um adultério, ao passo que o leitor - que nem fica surpreso nem em dúvida — sabe que nada houvera, pois conhece os sentimentos e os atos de Garcia. Sabe tudo que ele sabia, uma vez que o narrador lhe contara e o informante do narrador não é outro senão o médico. Pelo mesmo motivo, o leitor desconhece o que Garcia desconhece, e a causa do modo de agir de Fortunato permanece secreta até os últimos momentos do conto. Para que a causa se revele, é preciso que o narrador adote o ponto de vista de outro observador, Fortunato, conforme fica indicado no segundo parágrafo do trecho citado acima. Agora, com base no observador sincretizado com Fortunato, o narrador não apenas conta o que esse personagem vê, mas, utilizando o discurso indireto livre, passa a contar o que ele sente, de modo a saborear com ele a explosão de dor moral que foi longa, muito longa, deliciosamente longa. A narração aproxima-se do fluxo de consciência, pois o leitor toma contato com o que sente Fortunato e com sua patologia, e não apenas com a descrição desses sentimentos. Naturalmente, o narrador sempre soube da psicopatia de Fortunato, e a causa de seu agir jamais lhe fora secreta, mas a revelou apenas ao final; caso contrário, não haveria como ou porquê manter o segredo. A mudança de foco não é, portanto, aleatória, pois cumpre uma função específica: mostrar ao leitor, sem realizar um juízo de valor, quais eram os impulsos de Fortunato; já o caráter, o ethos, de Fortunato é mostrado por ele próprio. A qualidade do conto deve muito a esse fantástico jogo de perspectivas: em quase todo o tempo, sobressai a de Garcia; nos momentos derradeiros, a de Fortunato.

Em $A$ causa secreta, adota-se, portanto, a focalização interna e variada dos fatos. Nem sempre é assim, pois o foco pode ser interno e fixo. É o que acontece em Singular ocorrência (Histórias sem data, 1884), conto constituído pelo diálogo entre os dois interlocutores. Um deles, que assume o papel de narrador segundo, conta ao outro a história de um amigo, Andrade, e sua amante. Amavam-se, mas, um dia, ela o trai com um desconhecido, sem que 
haja para isso qualquer explicação. Reconciliados, tudo volta ao normal, e Marocas, a amante, permanece fiel à Andrade mesmo após a morte deste, agindo como a mais recatada das viúvas. Veja-se o trecho em que o narrador descreve a um amigo que ouve sua narração o momento em que Andrade descobre a traição de Marocas:

[...] A cena que se seguiu foi breve, mas dramática. Não a soube inteiramente, porque o próprio Andrade é que me contou tudo, e, naturalmente, estava tão atordoado, que muita cousa lhe escapou. (Obra Completa, vol. II, p. 393 - grifo meu)

Observe: Andrade havia contado ao narrador que fora traído por Marocas (porém omite algumas informações); por sua vez, o narrador conta o que ouviu do próprio Andrade ao amigo que o escuta. Posteriormente, quando Andrade se reconcilia com Marocas, o próprio narrador está presente à cena e pode relatá-la integralmente a seu interlocutor:

[...] O Andrade nem me deu tempo de preparar nada; empurrou-me, e caíram, nos braços um do outro, Marocas chorou muito e perdeu os sentidos.

- Tudo se explicou?

- Cousa nenhuma, Nenhum deles tornou ao assunto; livres de um naufrágio, não queriam saber nada da tempestade que os meteu a pique. (Obra Completa, vol. II, p.395)

Claro, o enunciador que instalou aos interlocutores sabe tudo que se passou, mas não o observador. $\mathrm{Na}$ primeira citação acima, o observador sabe muito pouco, pois não presenciou os fatos; soube-os por um terceiro, Andrade, que devido a seu estado emocional não pôde fazer um relato detalhado: muita coisa lhe escapara. $\mathrm{Na}$ segunda citação, o observador, sincretizado com o narrador, estava presente à cena, mas não soube explicar as razões da traição ou da reconciliação, pois, novamente, as desconhecia. O conto ganha muito com uma perspectiva única, pois, se o observador fosse Andrade ou Marocas, a ocorrência teria de ser explicada e talvez perdesse parte de sua singularidade. Cria-se, ainda, duplo efeito de subjetividade: primeiro, porque é a visão parcial; de alguém que, ainda que indiretamente, foi afetado pelo episódio; depois, porque, além de não se ter a versão completa dos fatos, estes são dados de segunda mão, pois Andrade os relata ao narrador, que, por sua vez, contaos ao amigo. Ao final do conto, o interlocutor do narrador, o amigo que ouve seu relato, questiona a veracidade das palavras recebidas, fazendo nascer a dúvida: teria o narrador inventado tudo ou Andrade seria apenas um ingênuo que acreditou que Marocas realmente tivesse sido fiel? Será que o narrador desconheceria algum elemento da narrativa? Surgem várias possibilidades sem que possa optar por qualquer uma delas. Ao contrário do conto comentado anteriormente, neste os segredos não são revelados, a verdade não é esclarecida, e 
isso se deve justamente à natureza do observador, e não do narrador. Mais do que a fidelidade, o que parece estar em jogo aqui são o saber e o crer, o quais — parece que alguém já o disse - pertencerem a um único universo cognitivo. ${ }^{120}$

Se, em Causa Secreta, o enunciador instaura um observador que não está em sincretismo com o narrador e que tem uma focalização interna e parcial dos fatos, em Uns braços (Várias histórias, 1896), o processo é exatamente o oposto: o enunciador instaura um observador com visão total de tudo, que não se liga a nenhuma personagem e que está em sincretismo com o narrador. O conto narra a história de um adolescente, Inácio, escrevente do solicitador Borges, em cuja reside. Inácio deseja a esposa do patrão, D. Severina, que, muito vistosa, trazia nus os braços belos e cheios, em harmonia com a dona. Em dada ocasião, Inácio adormece e, em sonho, beija D. Severina. Nesse exato momento, ela aproxima-se dele, contemplá-o e, ao sentir-se também atraída por ele, beija-o nos lábios. O jovem não desperta, ignorando, portanto, os lábios de D. Severina. Recorde-se a cena, talvez uma das mais bonitas, dentre as muitas, da obra de Machado:

Que não possamos ver os sonhos uns dos outros! D. Severina ter-se-ia visto a si mesma na imaginação do rapaz; ter-se ia visto diante da rede risonha, e parada; depois inclinar-se, pegar-lhe nas mãos, levá-las ao peito cruzando ali os braços, famosos braços. [...] até que, inclinando-se, ainda mais, muito mais, abrochou os lábios e deixou-lhe um beijo na boca.

Aqui o sonho coincidiu com a realidade, e as mesmas bocas uniram na imaginação e fora dela. A diferença é que a visão não recuou e a pessoa real tão depressa cumprira o gesto, como fugiu até a porta vexada e medrosa. [...] Na verdade a criança tinha o sonho duro; nada lhe abria os olhos, nem os fracassos contíguos, nem os beijos de verdade. [...] (Obra Completa, vol. II, p.495-6)

O observador, sincretizado com o narrador, sabe tudo: dos sonhos de Inácio aos atos de Severina, passando pelos julgamentos que cada um faz de seus atos e desejos. Dessa vez, a beleza do conto (na verdade, parte dela) está no confronto dos dois saberes parciais dos actantes do enunciado — semelhantes no conteúdo, o beijo, e diferentes na essência, um é sonho; o outro, realidade — com o saber do narrador. Vê-se que o saber do observador é total e o narrador os utiliza para extrair do sonho e da realidade sua poesia. Por outro lado, não se detecta no conto uma distância entre o saber do enunciador e do narrador, uma vez que não há fatos não explicados, como em Singular Ocorrência, nem revelações feitas ao final do conto, como em $A$ causa secreta.

\footnotetext{
${ }^{120}$ Ver o estudo de Greimas Le savoir et le croire: un seul univers cognitif. In Du Sens II, p. 115-134.
} 
Três contos, três instaurações diferentes do observador, três maneiras diferentes de considerar o saber no texto. $\mathrm{O}$ que se tem até aqui não parece muito promissor, pois não se observam recorrências que permitam definir o ethos do enunciador pela forma como ele lida com o observador. Contudo, como se sabe, o objeto não é o enunciador dos contos, mas o dos romances e, por isso, ainda há esperança de encontrar as tão buscadas recorrências.

\section{Ressurreição}

Em Ressurreição, o narrador tem visão total dos fatos, pois o observador não está preso a nenhum dos personagens; paira acima de tudo e de todos: não há nada que desconheça, sendo o seu saber maior do que a soma dos conhecimentos de todas as personagens. Por exemplo, a declaração de amor de Felix a Lívia é acompanhada das seguintes observações do narrador:

\footnotetext{
A tarde estava realmente linda. Félix, entretanto, cuidava menos da tarde que da moça. Não queria perder o desejo de lhe dizer, como se fora verdade, que a amava loucamente. Encostada ao parapeito do terraço que dava para a chácara, a viúva simulava contemplar os esplendores do ocaso; na realidade, afiava o ouvido para escutar a confissão amorosa. (Obra Completa, vol. I, p. 138 - grifos meus)
}

O narrador descreve a cena e os diálogos. Como não é actante do enunciado, não poderia ter presenciado o acontecimento nem ter sabido do fato por um terceiro. Contudo, não apenas conhece aquele momento em detalhes, mas também os pensamentos das duas personagens, talvez, até, melhor que elas próprias. Conhece o que se passa na mente de Lívia, sabe que ela não contemplava o pôr-do-sol, como sua posição, encostada no parapeito, sugeria, mas que ela apenas simulava fazê-lo. Conhece também o coração de Félix melhor que ele, como dá a entender na frase: Não queria perder o desejo de lhe dizer, como se fora verdade, que a amava loucamente. O narrador sabe, portanto, que Félix não ama Lívia loucamente, embora ele próprio acreditasse nisso. Se o observador estivesse sincretizado com essa personagem, o narrador não poderia usar tal expressão, pois ela dá entender que Félix — ao contrário de Brás Cubas - de fato acreditava em seu amor, muito embora ele fosse falso. Alguns parágrafos à frente, no momento exato da declaração, o narrador afirma que o coração do médico, naquele instante ao menos, palpitava com o mesmo fervor que o de Lívia. Em outras palavras, ele sabe que a disposição passional de Félix é efêmera e pouco intensa, vicejando apenas naquele momento. Ora, só uma visão global, de um observador que tudo vê de cima, 
permitiria ao narrador conhecer a fundo a natureza dos sentimentos dos personagens. Nessa passagem, sobressai não apenas o saber geral do observador, mas, igualmente, a natureza do saber de que dispõe. Ao afirmar que, naquele instante, ao menos, o coração de Félix palpitava, o narrador lança uma dúvida sobre o saber de que ele próprio dispõe e que lhe é transmitido pelo observador. Quer dizer, ele julga o próprio saber e reconhece que tal saber, embora bastante extenso pode não ser completo ou totalmente correto.

Ao final do romance, naquela passagem em que o narrador julga o comportamento de todas as personagens e, explicitamente, o de Félix, pode-se observar outra ocorrência desse mesmo fazer. Revela-se nesse momento a presença de um saber de outro nível, não mais relativo ao fazer dos actantes do enunciado, mas ao fazer do próprio narrador. É a relação do narrador com a matéria narrada que se encontra em jogo. $\mathrm{O}$ mesmo acontece nos momentos (vistos no capítulo que trata da instalação do narrador) em que o narrador discute o casamento de Menezes com a filha do coronel e a autoria da carta que provocou o rompimento entre Lívia e Félix. Nesses casos, está em jogo não somente o saber do narrador sobre os fatos narrados, mas sobre a narração, sendo necessário, portanto, distinguir esses dois saberes: o relativo aos fatos ocorridos e o concernente ao julgamento feitos deles pelo narrador.

\section{A mão e a luva}

Em $A$ mão e a luva, o saber recebe um tratamento idêntico ao de Ressurreição. $\mathrm{O}$ observador está todo o tempo a par de tudo que se passa, inclusive na mente das personagens, muito embora, em alguns momentos, o foco esteja limitado a uma personagem. Veja-se a passagem em que Guiomar reflete sobre a carta que Jorge, sobrinho da baronesa, lhe enviara confessando seu amor. O narrador descreve os pensamentos e os receios de Guiomar como só ela poderia fazê-lo:

Paixão [o sentimento de Jorge] não era, - não o seria ao menos no sentido inteiro do vocábulo; mas alguma coisa menos, ou parecida com ela, e ainda assim verdadeira, via bem Guiomar que o poderia ser. Até que ponto chegaria entretanto o seu adorador, se ela o desatendesse logo; e dado o amor que a baronesa tinha ao sobrinho, até que ponto a recusa iria magoá-la? Guiomar varreu do espírito os receios que lhe nasciam de tais interrogações; mas sentiu-os primeiro, pesou-os antes de os arredar de si, o que revelará ao leitor em que proporção estavam nela combinados o sentimento e a razão, as tendências da alma e os cálculos da vida. (Obra Completa, vol. I, p. 233 - grifo meu) 
Além de conhecer os pensamentos da personagem, o narrador tem também a resposta para suas indagações. Sabe que Guiomar é guiada por considerações bem pouco românticas e, colocando-se como o próprio enunciador, chama a atenção do leitor para os habituais cálculos da vida realizados por ela. O discurso indireto livre reproduz o ponto de vista adotado por de Guiomar, a qual faz suposições sobre os sentimentos de Jorge e sobre as conseqüências que poderão advir se for rejeitado. $O$ narrador não conta tudo, porque o observador está preso a Guiomar, embora, a partir do trecho “Guiomar varreu...”, ele como que se solta da personagem e passa a vê-la de fora para dentro. Desaparece o discurso indireto livre e o narrador volta a assumir seus ares de enunciador, estabelecendo um diálogo com o leitor. Nos dois momentos, o observador sabe tudo, mas, na primeira parte, age como se olhasse o mundo pelos olhos de Guiomar e, com esses olhos, olhasse para dentro da personagem. Depois, aumentando a onisciência, passa a vê-la de cima, porém, sem se deter nela.

Outra demonstração da instalação é dada no fim do capítulo VIII e no começo do capítulo XI em que predomina um observador com visão total que transmite sucessivamente o que se passa com Estevão, Guiomar e a Baronesa, porém novamente sem se deter em nenhum deles. Inicialmente, veja-se o momento em que Estevão acaba de se declarar a Guiomar, que o ouve impaciente:

Tal é a transcrição, não literal, mas fiel, do que disse Estêvão durante esses dez minutos. As palavras caíam-lhe trêmulas e a voz saia-lhe sumida, em parte porque ele forcejava em a abafar, a fim de que o não ouvissem, em parte porque a comoção lhe comprimia a garganta. A dor era visivelmente sincera; a eloqüência vinha do coração.

Guiomar não ouvira tudo com a mesma expressão; a princípio um meio riso parecia desabrochar-lhe os lábios, mas não tardou que pelo rosto abaixo lhe caísse um véu mais compassivo e humano. Havia nela impaciência e ansiedade de acabar, de sair dali; era, sem dúvida, o receio de que a ausência se prolongasse de maneira que inspirasse suspeitas. Mas havia também comiseração e piedade. (Obra Completa, vol. I, p. 226-7 - grifo meu)

O observador não adota o ponto de vista de Guiomar ou de Estêvão, mas o de alguém que estaria presente a cena, muito embora os dois personagens estivessem sós. Ele comenta o próprio saber e atesta a qualidade das informações que transmite, afirmando que a transcrição do diálogo não era literal, mas fiel aos fatos. Quer dizer: suas informações não apenas parecem verdadeiras; elas o são; e ele pode dar-se plenamente por realizado, pois cumpriu sua tarefa de comunicar o que sabe. $\mathrm{O}$ enunciatário pode ficar tranqüilo; está diante de um narrador preciso, seguro, honesto, que, não contente em informar o que sabe, ainda explica tudo direitinho ao leitor, criando, assim, um inquestionável efeito de verdade, como 
indica a afirmação de que a transcrição é fiel, ainda que não seja literal. Trata-se, portanto, de um narrador que, apesar de suas pretensões usurpadoras, seria um fiel preposto do enunciador. No entanto, observe-se que a afirmação do narrador revela uma defasagem entre seu relato e os acontecimentos, ainda que tal defasagem, na visão dele, seja insignificante, dado que a transcrição, ainda que não literal, era fiel. Mais uma vez, o saber do enunciador evidentemente, capaz de dar uma transcrição literal dos fatos - distancia-se do saber do narrador. Mais do que um mero efeito de verdade, essa frase revela um enunciador desejoso mostrar que o seu saber não coincide com o do narrador e que o narrador não apenas narra, mas implica-se, em graus diferentes, na própria narrativa.

Pouco depois da passagem acima, a baronesa encontra os dois jovens e fica temerosa por não saber o que passara entre eles. É a oportunidade para o narrador mostrar novamente que conhece o íntimo da personagem, permitindo ao leitor contrapor os diferentes caracteres e confrontar o que cada um sente com o que demonstra sentir. Depois, como já fizera anteriormente, o narrador ensina o narratário a ler a passagem, mostrando-lhe a diferença de caracteres:

Não será preciso dizer a um leitor arguto e de boa vontade... Oh! sobretudo de boa vontade, porque é mister havê-la, e muita, para vir até aqui, e seguir até o fim, uma história, como esta, em que o autor mais se ocupa de desenhar um ou dois caracteres, e de expor alguns sentimentos humanos, que de outra qualquer coisa, porque outra coisa não se animaria a fazer; — não será preciso declarar ao leitor, dizia eu, que toda aquela jovialidade de Guiomar eram punhais que se lhe cravavam no peito ao nosso Estevão. [...] (Obra Completa, vol. I, p. 228 - grifos meu)

Ao comentar a própria narrativa, o narrador discute também o próprio saber e o do leitor e, ao apresentar-se como enunciador, deixa entrever uma defasagem entre seus saberes e os do enunciador verdadeiro e do enunciatário. O narrador tem em mente um narratário que gosta de tramas romanescas, que não se interessaria pela análise de caracteres e que precisaria usar de boa vontade para continuar a ler o romance. Já o enunciador tem em vista um enunciatário que se interessa não apenas pela análise dos caracteres, mas também pela discussão sobre a própria narração. $\mathrm{O}$ narrador ignora porque age da forma que age, mas não o enunciador, e, na passagem acima, evidencia a distância entre o seu saber e o delegado no tocante à narração e por esse viés a passagem revela, mais uma vez, a reflexão do narrador sobre o próprio fazer, sobre a narração, fato que obriga a pressupor, novamente, um observador que informa não sobre o fazer dos actantes do enunciado, mas da enunciação enunciada - o narrador e o narratário —, que têm uma avaliação equivocada do próprio 
fazer. Conforme foi dito no capítulo anterior, o narrador surge nesse momento, a exemplo dos actantes do enunciado, como sujeito de um fazer, cuja única peculiaridade é o fato de seu fazer consistir em uma narrativa. Em decorrência desse fato, embora o narrador disponha de um saber total sobre os fatos narrados, seu saber sobre o que faz é limitado. Convém insistir que o narrador não se equivoca quanto aos fatos que narra (ao menos, não há elementos para atestá-lo), mas sim quanto ao julgamento do próprio fazer e que a percepção desse fato implica a divisão dos observadores em duas espécies: aqueles ligados ao narrador e que transmitem um saber relacionado ao saber dos actantes do enunciado, e aqueles ligados à enunciação enunciada que observam o fazer do narrador e do narratário.

\title{
Helena
}

Em Helena, repete-se o processo já visto nos dois romances anteriores: o observador, em sincretismo com o narrador, tem uma visão geral de tudo e de todos os actantes do enunciado. É o que se vê logo no primeiro capítulo, na descrição do Dr. Camargo, único vilão, se tanto, da trama:

\begin{abstract}
Camargo era pouco simpático à primeira vista. Tinha as feições duras e frias, os olhos perscrutadores e sagazes, de uma sagacidade incômoda para quem encarava com eles, o que o não fazia atraente. Falava puro e seco. Seus sentimentos não vinham à flor do rosto, Tinha todos os visíveis sinais de um grande egoísta; contudo, posto que a morte do conselheiro não lhe arrancasse uma lágrima ou uma palavra de tristeza, é certo que a sentiu deveras. Além disso, amava sobre todas as coisas e pessoas uma criatura linda, - a linda Eugênia, como lhe chamava, - sua filha única e a flor de seus olhos; mas amava-a de um amor calado e recôndito. Era difícil saber se Camargo professava algumas opiniões políticas ou nutria sentimentos religiosos. Das primeiras, se as tinha, nunca deu manifestação prática; e no meio das lutas de que fora cheio o decênio anterior, conservara-se indiferente e neutral. Quanto aos sentimentos religiosos, a aferi-los pelas ações, ninguém os possuía mais puros. Era pontual do cumprimento dos deveres de bom católico. Mas só pontual; interiormente, era incrédulo. (Obra Completa, vol. I. p. 275 - grifos meus)
\end{abstract}

Fiel à tradição realista, o narrador se abstém de fazer juízos de valor. Um católico que fosse pontual no cumprimento dos deveres, mas incrédulo, poderia ser chamado de hipócrita e questionado sobre o que o leva a praticar tal pontualidade. O narrador, por sua vez, não dá fôlego a tais questionamentos, apesar suas informações os suscitem; apenas descreve o exterior da personagem e, em menor medida, seu interior. Não são levantadas dúvidas quanto às características de Camargo e seus sentimentos - ele sentiu deveras a morte do conselheiro - nem, tampouco, quanto ao saber do narrador, que se mostra seguro de si e das informações de que dispõe. Se não faz comentários a respeito do caráter de Camargo, claro fica o peso das aparências em sua conduta e a oposição entre elas, tanto para o bem 
quanto para o mal. A ausência de julgamentos cria ainda um efeito de objetividade e de clareza que tranqüiliza o enunciatário: a narração é conduzida por um narrador que não apenas tudo sabe, do interior e o do exterior das personagens, mas que é seguro, objetivo, reservado, dispensando o que poderia entediar o leitor. Seria uma espécie de narrador transparente, que não reflete ou refrata as imagens que recebe e as transmite sem desvios. Em outras palavras, não se percebem defasagens entre o seu saber e o saber daquele que o instalou, pois, se o narrador se engana, isso não é mostrado no texto.

Recorde-se, porém, que a oposição entre o saber do observador e do narrador é fundamental nesse romance. Como o leitor vem a descobrir apenas nos capítulos finais do livro, Helena não era filha do conselheiro Vale. Claro que o narrador conhecia a verdade, mas a relata apenas no momento em que o desenrolar da trama exige essa informação. É verdade que desde o momento em que começam os passeios de Helena em direção à casa de bandeira ąul, o leitor, habituado a romances, desconfia que lá reside algum mistério, mas o narrador oculta o fato do leitor até o momento em que a economia da trama exige a revelação, pois fazê-la antes acarretaria uma perda de tensão. Esse fato, central na trama, evidencia que, embora o narrador e o observador estejam sincretizados, o saber oscila ao longo do texto, justamente em função dos actantes cognitivos instalados.

A solidez do narrador não permitiria concluir que existe qualquer desnível entre o seu saber e do enunciador. Todavia, como se observou na passagem em que o narrador se equivoca quanto ao terceiro beijo de Camargo na filha, há sim um desnível entre o seu saber e o do narrador, ainda que muito mais tênue do que em outros romances. De igual modo, a omissão da historiazinha de toucador revela um actante cognitivo observando o fazer do narrador. Claro, são ocorrências pontuais, insuficientes para anular a imagem geral do narrador como "confiável", tal como indicado na passagem acima, mas apontam para um traço constante do enunciador: mostrar que o saber do narrador é incompleto. A resultante final desses dois processos indica um enunciador que enxerga a hipocrisia, uma vez que instaura atores com tal característica, e que domina o ofício de narrar e o exibe, de certa forma, como espetáculo. Ao mesmo tempo, mostra um narrador que não percebe ou não comunica sua existência - aliás, da mesma maneira que o narrador não assinalava o caráter mercantilista de Guiomar - e que é inseguro quanto à própria narração. As personagens são sempre enfocadas segundo um aspecto, digamos, positivo, e não são consideradas outras possibilidades. Lembrando os conceitos da semiótica tensiva, ao se considerar o campo 
perceptivo do narrador, observa-se uma grande profundidade da percepção; isto é, tanto o foco quanto a apreensão dos fatos narrados são tônicos. Por outro lado, com relação à própria narração, observa-se um menor profundor, pois o foco é menos intenso é a apreensão menos extensa. Além disso, os valores parecem filtrados pelo narrador, que só os vê de determinada ótica; isto é, passam apenas aqueles focados com mais intensidade. Assim, as atitudes de Guiomar ou Helena ou Camargo, por mais questionáveis que possam ser, não são enfocadas por esse ângulo, pois o narrador (e não o enunciador, nunca é demais lembrar) foca e apreende apenas um aspecto desse comportamento.

\section{Iaiá Garcia}

Nesse romance, começa a haver uma espécie de esvaziamento, ainda muito tênue, do saber do observador, que como que perde parte da onisciência de que até então dispunha. Ou melhor, não é que ele deixe de estar a par de tudo o que se passa, mas é que ele já não está tão certo do seu saber quanto antes, como em Helena. Na verdade, não é a extensão de saber do observador que muda, mas, de certa forma, a intensidade, a certeza. O preto se torna menos escuro, o branco já não é tão claro, e o narrador, antes tão peremptório, agora mostra sinais de dubiedade, vacila, seja porque mudou, seja porque a matéria narrada não mais permite a certeza. Nada comparável com o que está por vir, porém, não faltam nuanças que prenunciem a mudança. A cena em que Jorge não sabe se segue os conselhos da mãe e esquece Estela ou se obedece ao coração e insiste na reconciliação, talvez, ajude a compreender o que se passa:

Ora sentia-se odioso, ora ridículo. Quem se sente odioso pode ter no orgulho um refúgio; quem se sente ridículo acha no orgulho seu próprio flagelo.

— Tua mãe é quem tem razão, bradava uma voz interior; ias descer a uma aliança indigna de ti; e se não soubeste respeitar nem a tua pessoa nem o nome de teus pais, justo é que pagues o erro indo correr a sorte da guerra. A vida não é uma égloga virgiliana, é uma convenção natural, que se não aceita com restrições, nem se infringe sem penalidade. Há duas naturezas, e a natureza social é tão legítima e tão imperiosa como a outra. Não se contrariam, completam-se; são as duas metades do homem, e tu ias ceder à primeira, desrespeitando as leis necessárias da segunda.

- Quem tem razão és tu, dizia-lhe outra voz contrária, porque essa mulher vale mais que seu destino, e a lei do coração é anterior e superior às outras leis. Não ias descer; ias fazê-la subir; ias emendar o equívoco da fortuna; escuta a voz de Deus e deixa aos homens o que vem dos homens.

Jorge caminhava assim, levado de sensações contrárias, até que ouviu bater meia-noite e caminhou para casa, cansado e opresso. (Obra Completa, vol. I, p. 418) 
O observador continua conhecendo o interior das personagens, e, talvez, até mais que o de Helena. Seu foco continua total: nem interior nem exterior às personagens. No entanto, mudou o saber sobre o próprio saber. Jorge está cindido entre suas duas naturezas: a social e não-social. O dilema não é estranho a Machado; já foi vivido por Félix, Guiomar e Helena. Em todos os casos, o conflito foi resolvido sem maiores dificuldades. Estácio não vacila quando vê que tem de abandonar Helena, e Guiomar jamais pensaria em colher flores em sítios agrestes como nesse em que Jorge as procura. No entanto, o moço não consegue decidir-se e, depois de muito refletir, acaba cansado e opresso. De fato, a solução do dilema não se dará por suas mãos, mas pelas de Valéria, Estela e Iaiá. O observador transmite ao narrador os argumentos de uma e de outra das vozes (e não custa lembrar que uma delas reafirma o peso das questões sociais sobre os sentimentos) que povoam a mente do filho de Valéria, mas o narrador não opta por uma delas nem tenta uma síntese de ambas. Já não existe a segurança que caracterizava o narrador de $A$ mão e a luva ou de Ressurreição, o qual vaticinava sobre o que pensavam os personagens. A polifonia, ainda no plano do narrado, traz o fim da unicidade da personagem e parece assediar o narrador. Ele continua analítico, claro, sem ilusões e preocupado com o saber que transmite, mas já não tem aquela certeza de que dispunha até então: qual das vozes deve ser seguida? Recorde-se o final de Ressurreição em que Félix é claramente sancionado por ter feito a escolha errada em relação às duas naturezas e por ter optado pela intima, como dizia, então, o narrador. Lá, havia dúvidas quanto ao que era certo e errado; aqui, não há respostas. Começa, assim, a nascer o relativismo que permeará os romances seguintes de Machado.

À primeira vista, pode-se pensar que a ausência de um veredicto seria um reflexo de um menor saber do observador. Na verdade, é o contrário: o aumento do saber e a ampliação de suas perspectivas é que tornam difícil a obtenção de uma conclusão final. Conforme foi afirmado nos comentários sobre Helena, antes o narrador não conseguia penetrar as personagens a ponto de perceber suas incoerências; o campo de percepção era fechado e predominava a triagem dos valores. Agora, o campo começa a se abrir e valores opostos passam a ser percebidos por ele. Antes, os actantes cognitivos captavam uma única perspectiva dos fatos. Agora, com a ampliação do número desses actantes, aumentam as perspectivas e diminui a triagem. No entanto, o aumento de perspectivas ainda não atinge a reflexão sobre a narração. Se o saber do narrador a respeito dos actantes do enunciado aumentou, nada se pode afirmar sobre seu próprio fazer. Relacionado a esse fato está a não 
percepção de qualquer descompasso entre o saber do narrador e do enunciador, pois não há, no texto, qualquer outra voz, portanto qualquer outro observador, que o negue - nem mesmo em uma advertência, como ocorre nos demais romances de Machado. Todavia, a partir do próximo romance, a distância entre o saber do enunciador e do narrador começará a aumentar, ainda que nem sempre seja evidente.

\section{Memórias póstumas de Brás Cubas.}

Conforme ficou dito, esse romance traz uma novidade na obra de Machado: o narrador passa a estar sincretizado com o principal actante do enunciado, fazendo com que seu saber se limite ao desse actante. O mesmo ator desempenha diversos papéis temáticos, em especial, o de sujeito leviano que age de forma irrefletida, não dispõe de um saber-ser, de uma capacidade de julgamento sobre o próprio agir - o que contribui para distanciá-lo dos narradores que o precederam e torna mais explícita a defasagem entre o saber do narrador e o do enunciador. Essa novidade não significa que o ponto de vista da narração permaneça inalterado ao longo do texto, pois sua perspectiva se altera de acordo com as performances do sujeito com o qual está sincretizado. Esse fato já foi apontado por Fiorin (1996: 108), quando o autor comenta a mudança de opinião de Brás Cubas acerca de Marcela: o narrador sempre soube que ela era interesseira, mas o observador, sincretizado com a personagem, descobre isso aos poucos, à medida que envelhece. Outro exemplo é a divertida passagem do almoço no qual o pai de Brás comemora a derrota de Napoleão. Quem narra é Brás Cubas, defunto, mas a perspectiva e a interpretação do evento não são do adulto morto, mas da criança que observa e contrapõe sua demanda reprimida por doces à volúpia do pai, que se deleitava com as glosas ofertadas pelo Vilaça, exatamente como aquele Brás Cubas menino faria, se pudesse, com as compotas:

Quanto a mim, lá estava, solitário e deslembrado, a namorar uma certa compota da minha paixão. No fim de cada glosa ficava muito contente, esperando que fosse a última, mas não era, e a sobremesa continuava intacta. [...] Meu pai, à cabeceira, saboreava a goles extensos a alegria dos convivas, mirava-se todo nos carões alegres, nos pratos, nas flores, deliciava-se com a familiaridade travada entre os mais distantes espíritos, influxo de um bom jantar. Eu via isso, porque arrastava os olhos da compota para ele e dele para a compota, como a pedir-lhe que ma servisse; mas fazia-o em vão. Ele não via nada; via-se a si mesmo. E as glosas sucediam-se, como bátegas d'água, obrigando-me a recolher o desejo e o pedido. Pacientei quanto pude; e não pude muito. Pedi em voz baixa o doce; enfim, bradei, berrei, bati com os pés. Meu pai, que seria capaz de me dar o sol, se eu lho exigisse, chamou um escravo para me servir o doce; mas era tarde. A tia Emerenciana arrancara-me da cadeira e entregara-me a uma escrava, não obstante os meus gritos e repelões. (Obra Completa, vol. I, p. 530-1) 
De acordo com Greimas \& Courtés (1993: 321), para enunciar, o enunciador deve ter tanto uma competência sintagmática, que o habilite a produzir e organizar enunciados, quanto um saber-ser, que o capacite a sancionar o saber sobre os objetos e a garantir a qualidade desse saber. No exemplo acima, a instância da enunciação instalou, ao menos, três actantes cognitivos: o narrador, figurativizado no defunto, que dispões de uma competência sintagmática na medida em que organiza os programas narrativos do sujeito menino (querer doce, manipular o pai para obtê-lo, ser sancionado por tia Emerenciana); o actante observador, figurativizado no Brás-menino, que julga as glosas do Vilaça maçantes e os doces, irresistíveis (certamente Tia emerenciana teria outro julgamento) e, finalmente, outro actante cognitivo, sincretizado com o narrador, que julga o episódio sem importância e vê nele uma demonstração do que viria a ser o Brás-adulto. Veja que há três saberes diferentes: um relativo ao episódio ocorrido, a avaliação do mesmo episódio, e a competência para narrá-lo. Poderia haver ainda dois outros objetos de saber, aliás, bastante comuns em Machado: um referente à qualidade do saber transferido (por exemplo, quando o narrador afirma saber exatamente o que se passou ou atesta a própria sinceridade) e a avaliação acerca da própria narração (como acontece quando Brás Cubas comenta a passagem da narração da morte para o nascimento).

Em Memórias póstumas, o narrador, além de não saber mais tudo o que se passa a o seu redor, dado que está limitado à perspectiva de um único indivíduo, tem também o seu saber-ser reduzido, dado que sua capacidade de julgar os próprios fatos também é menor. Ele não pode mais, como podiam os que o antecederam, afirmar categoricamente o que se passa na mente das personagens nem que elas dão a entender o oposto do que pensam; agora, ele é capaz apenas de fazer conjecturas, e as faz, justamente, por saber que não sabe. E mesmo quando faz afirmações peremptórias, o enunciatário sempre fica na dúvida: será que é isso mesmo? afinal, o narrador não é onisciente. Basta que se imagine a descrição de Camargo, feita pelo narrador de Helena, agora na pena de Brás Cubas. Certamente muito menor seria a quantidade de informações diretas, mas maiores seriam os subentendidos que ele deixaria a cargo do enunciatário, pois tem que preencher os vazios de seu conhecimento com inferências e ao fazê-lo acarreta, inevitavelmente, muitas dúvidas, a maioria das quais permanece sem resposta. É o que acontece, por exemplo, na descrição de Cotrim. Um outro exemplo auxiliará a ver como as coisas funcionam: é a passagem em que Brás Cubas se reconcilia com a irmã e o marido, mais exatamente, o trecho em que o narrador conta, em 
discurso indireto livre, a reação do cunhado ao saber que ele partiria para o norte em companhia de Virgília e Lobo Neves:

[...] Que diacho podia eu achar no Norte? Pois não era na corte, em plena corte, que devia continuar a luzir, a meter num chinelo os rapazes do tempo? Que, na verdade, nenhum havia que se me comparasse; ele, Cotrim, acompanhava-me de longe, e, não obstante uma briga ridícula, teve sempre interesse, orgulho, vaidade nos meus triunfos. Ouvia o que se dizia a meu respeito, nas ruas e nas salas; era um concerto de louvores e admirações. E deixa-se isso para ir passar alguns meses na província, sem necessidade, sem motivo sério?

A menos que não fosse política...

- Justamente política, disse eu.

— Nem assim, replicou ele daí a um instante. — E depois de outro silêncio: — Seja como for,venha jantar hoje conosco.

— Certamente que vou; mas, amanhã ou depois, hão de vir jantar comigo.

— Não sei, não sei, objetou Sabina; casa de homem solteiro... Você precisa casar, mano. Também eu quero uma sobrinha, ouviu?

Cotrim reprimiu-a com um gesto, que não entendi bem. Não importa; a reconciliação de uma família vale bem um gesto enigmático. (Obra Completa, vol. I p. 591)

Um pouco antes do trecho acima, o narrador contara que Brás emocionara-se ao escutar o som de uma rabeca que ele e Sabina ouviam quando crianças enquanto a irmã permanecera de olhos secos. Depois, conta que lançara-se aos braços de Cotrim ao vê-lo entrar, mas que o cunhado ficara um pouco desconcertado com esse ato. Nos dois casos, o narrador, o próprio Brás Cubas, atribui as atitudes frias ao temperamento dos parentes. Seguem-se, então, os parágrafos acima, nos quais fica claro para o leitor que Cotrim exagera ao afirmar que Brás Cubas luશৃia na corte, que a briga por causa da herança (que quase acabou nos tribunais) fora ridícula e que sempre tivera orgulho, vaidade nos triunfos (quais???) de Brás Cubas. A desproporção dos termos empregados não deixa dúvidas de que Cotrim está sendo falso, mas o narrador não percebe, ou, se percebe, não conta. A cena é encerrada com um gesto enigmático que o marido de Sabina utiliza para reprimi-la quando ela sugere ao irmão ter uma filha. Brás percebe o gesto, considera-o enigmático, mas não atina com sua causa e limita-se a parodiar Henrique IV, afirmando que a reconciliação valia bem um gesto. Talvez Cotrim julgasse inconveniente que Brás Cubas tivesse filhos, pois isso reduziria sua parte nos bens que eventualmente fossem deixados por ele, mas não é possível afirmá-lo categoricamente, pois o narrador não sabe o que se passa na cabeça de ninguém, portanto, não pode transmiti-lo ao leitor. Assim, o que sobressai dessa passagem é que o enunciador (que saberia o porquê do gesto enigmático) não delegou ao narrador tudo o que sabia; guardou parte consigo ou delegou-o a outros actantes cognitivos. Naturalmente, o enunciador sempre sabe mais que o 
narrador, a diferença, no caso, é que essa defasagem é explicitada de forma que não acontecia em romances anteriores.

Até Memórias póstumas o observador estava sincretizado com o narrador, que não estava sincretizado com nenhum actante do enunciado, como ocorre em Memórias póstumas. Em compensação, agora o enunciador multiplicou o observador ao instalar vários actantes cognitivos ora sincretizados com o narrador; ora, não, como na passagem citada, em que o enunciatário percebe que há algo errado nas palavras de Cotrim, mas o narrador, não. O saber é distribuído para outros actantes cognitivos que expressam seus pontos de vista como que na surdina, uma vez que não lhes é dada voz. Daí a impressão de que o enunciador transmitiu um saber ao enunciatário, mas sem passar pelo narrador. Explique-se. A informação de que há algo de podre na cena acima chega até o leitor, mas não por Brás Cubas, que não se dá conta do que se passa. Ele sabe que Cotrim reprimiu Sabina com um gesto, mas não sabe o que isso significa, pois seu saber-ser, ou o saber que sanciona seu próprio saber sobre o mundo que o cerca, é insuficiente. Surge, assim, um discurso segundo que se apossa do narrador e o utiliza para transmitir suas idéias. No caso de Iaiá Garcia, em que Jorge fica dividido entre as vozes que ecoam em sua consciência, a polifonia é instaurada pelo narrador, que tem controle delas. Agora não, pois o narrador não se dá conta do que se passa.

A mesma questão pode ainda ser vista em termos de foco e apreensão. Sabe-se que a apreensão que esse narrador tem da realidade - entendida enquanto e extensão do conhecimento - é muito menor do que a de seus antecessores, pois ele está preso a um foco interno e a um dos atores do enunciado. Por outro lado, a passagem acima revela também que seu foco - entendido como a intensidade e a relação sensível com o saber disponível — é também muito tênue. As duas relações não precisariam ser, necessariamente, convergentes. O fato de o narrador apreender uma menor parcela da realidade, isto é, de não ser onisciente, não o impediria de ser um pouquinho mais perspicaz e de, por exemplo, ver que há segundas intenções nos gestos da irmã e do cunhado ou, ainda, de ver, em outro momento, o quanto o humanitismo de Quincas Borba era disparatado. Se ele não o faz, é porque seu foco, a intensidade da tensão que o une à realidade que ele observa, é muito tênue. Por sua vez, a atonia do foco do observador sincretizado com o narrador em relação ao seu objeto (os fatos narrados) permite que se manifestem outros pontos de vista, outras vozes, que apresentam uma outra versão para os mesmos fatos. 
É útil que se faça um contraponto entre a delegação do saber nesse romance e nos que o antecederam, pois isso será importante nas análises seguintes. Até Iaiá Garcia, inclusive, o saber era delegado a um observador com foco total que estava em sincronia com o narrador. Embora o enunciador sempre saiba mais que o narrador, em qualquer hipótese, buscava-se, até então, causar o efeito contrário (sempre esquecidas as advertências, como se verá a seguir), de que o narrador tinha pleno domínio de tudo. Desse modo, pode-se dizer que o foco e apreensão que aqueles narradores têm da realidade são tônicos, ainda que apresentassem oscilações. Agora há uma reviravolta total nesse quadro, pois, conforme citado, o narrador apreende uma extensão muito menor da realidade e, além disso, como indica seu saber-ser pífio, o seu foco com a realidade é também muito átono, o que explica o fato de ele saber muito menos. Por outro lado, no que concerne ao saber-fazer, as semelhanças entre esse romances e os anteriores é bem maior. Em todos os cinco romances examinados até agora, o narrador discute o seu saber-fazer, sua competência sintagmática. Em todos sobressai o fato de o enunciador saber mais que o narrador, na medida em que este visa a um destinatário distinto do que é visado por aquele; isto é, aquele tem em mente um leitor de obras romanescas, enquanto este um leitor mais sofisticado, que se deleita justamente com a reflexão sobre a atividade enunciativa.

\section{Quincas Borba}

Em Quincas Borba, o observador volta a ter uma visão total de tudo que se passa, sem que isso signifique que o leitor volte a ter todas as informações concernentes à trama. Sim, o observador, sempre sincretizado com o narrador, começa a penetrar no âmago de cada personagem já no belíssimo parágrafo de abertura do livro, que descreve Rubião das chinelas ao coração, com o perdão da rima. Mas, apesar das informações de que dispõe — ou, talvez, por causas delas —, as dúvidas do narrador são ainda maiores. É que o observador tudo vê e tudo sabe, mas o narrador pouco esclarece, o que leva a supor que nem sempre a sincronia com observador e narrador é total como acontecia anteriormente. Recorde-se o episódio em que Sofia passa o dia aborrecida, pensando em seus admiradores e brincando com a idéia do adultério com Carlos Maria. À noite, sonha que o matam. Desperta aos gritos, não só assustada, mas principalmente perturbada com o que o sonho e suas manifestações poderiam ter revelado de seus sentimentos. O marido pergunta o que se passa; a mulher mente, 
dizendo que sonhara com ele, Palha, que fica feliz por povoar o sonho da esposa e pelo desespero que ela teria sentido diante de sua morte. No dia seguinte, Sofia já esquecera o episódio. O narrador comenta:

ASSIM, pois, o que parecia vontade imperiosa reduzia-se a veleidade pura, e, com algumas horas de intervalo, todos os maus pensamentos se recolheram às suas alcovas. Se me perguntardes por algum remorso de Sofia, não sei que vos diga. Há uma escala de ressentimento e de reprovação. Não é só nas ações que a consciência passa gradualmente da novidade ao costume, e do temor à indiferença. Os simples pecados de pensamento são sujeitos a essa mesma alteração, e o uso de cuidar nas coisas afeiçoa tanto a elas, — que, afinal, o espírito não as estranha, nem as repele. E nestes casos há sempre um refúgio moral na isenção exterior, que é, por outros termos mais explicativos, o corpo sem mácula. (Obra Completa, vol. I p. 779).

O observador vigia, mas o narrador já não pune como antigamente. Conhece os desejos da personagem e os sabe lascivos, veleidosos, mas é incapaz de precisar e de classificar os sentimentos. Sofia teria remorsos? Ele já não sabe o que dizer; não porque lhe faltem elementos ou porque escasseie seu poder de análise. Ao contrário, é esse poder de análise, avultado, que lhe permite ver que há uma mescla de ressentimento e de reprovação, que a consciência passa gradualmente da novidade ao costume; do temor à indiferença... $\mathrm{O}$ que fazer, pois? Como julgar quem ou o que quer seja? $\mathrm{O}$ outro observador, aquele dos primeiros romances, também era arguto, também tinha o traçado preciso, bem definido, também era pouco feito a julgamentos, mas ao menos via as cores primárias e as definia bem. Este, talvez por sua extremada percepção, apenas vê nuanças e já não sabe definir bem onde começa e onde acaba cada cor; afinal, as tonalidades são tantas, e elas mudam conforme o ângulo. As categorias são sempre complexas, não porque o narrador ame as antíteses, mas porque a síntese não é mais possível. Nesse mundo de incertezas, não escapa ao observador o processo de cauterização contínuo que afeiçoa o homem a tudo com o que lida. Processo lento e ininterrupto que experimenta Sofia nas coisas mínimas, mas é destas que se nutre o observador, já que no seu mundo, como observou Bosi, não há mesmo grandes destinos a serem cumpridos. Dessa racionalização, dessa distração toda, surge então um corpo sem mácula; não porque ele tenha sido objeto da redenção cristã, mas porque a racionalização ou a veleidade ou o costume... ou a gente fina e amiga propiciou a redenção. Onde, portanto, a verdade? Onde os acusadores? Certamente, não com o narrador... Vê-se que o acesso a um observador com foco total não representou um retorno completo às origens e que o saber propiciado pelas múltiplas observações não redundou em um saber mais, digamos, definitivo, o qual permita tirar conclusões que antes pareciam tão ao alcance do narrador dos primeiros romances. 
Assim como os narradores dos primeiros romances, o narrador de Quincas Borba sabe tudo sobre o narrado, isto é, sobre os percursos realizados pelos actantes do enunciado, e também conhece tudo sobre a narração, o que inclui o narratário. A esse respeito, vale a pena lembrar outro exemplo famoso:

\section{CAPÍTULO CVI}

... OU, mais propriamente, capítulo em que o leitor, desorientado,— não pode combinar as tristezas de Sofia com a anedota do cocheiro. E pergunta confuso: - Então a entrevista da Rua da Harmonia, Sofia, Carlos Maria, esse chocalho de rimas sonoras e delinqüentes é tudo calúnia? Calúnia do leitor e do Rubião, não do pobre cocheiro, que não proferiu nomes, não chegou sequer a contar uma anedota verdadeira. É o que terias visto, se lesses com pausa. Sim, desgraçado, adverte bem que era inverossímil; que um homem, indo a uma aventura daquelas, fizesse parar o tílburi diante da casa pactuada. Seria pôr uma testemunha ao crime. Há entre o céu e a terra muitas mais ruas do que sonha a tua filosofia,- - ruas transversais, onde o tílburi podia ficar esperando.

- Bem; o cocheiro não soube compor, mas que interesse tinha em inventar a anedota?

Conduzira Rubião a uma casa, onde o nosso amigo ficou quase duas horas, sem o despedir; viu-o sair, entrar no tílburi, descer logo e vir a pé, ordenando-lhe que o acompanhasse. Concluiu que era ótimo freguês; mas, ainda assim não se lembrou de inventar nada. Passou, porém, uma senhora com um menino, - a da Rua da Saúde, - e Rubião quedou-se a olhar para ela com vistas de amor e melancolia. Aqui é que o cocheiro o teve por lascivo, além de pródigo, e encomendoulhe as suas prendas. Se falou em Rua da Harmonia foi por sugestão do bairro donde vinham; e, se disse que trouxera um moço da Rua dos Inválidos, é que naturalmente transportara de lá algum, na véspera, - talvez o próprio Carlos Maria, - ou porque lá morasse, ou porque lá tivesse a cocheira, - qualquer outra circunstância que lhe ajudou a invenção, como as reminiscências do dia servem de matéria aos sonhos da noite. Nem todos os cocheiros são imaginativos. Já é muito concertar farrapos da realidade.

Resta só a coincidência de morar na Rua da Harmonia uma das costureiras do luto. Aqui, sim, parece um propósito do acaso. Mas a culpa é da costureira; não lhe faltaria casa mais para o centro da cidade, se quisesse deixar a agulha e o marido. Ao contrário disso, ama-os sobre todas as coisas deste mundo. Não era razão, para que eu cortasse o episódio, ou interrompesse o livro. (Obra Completa, vol. I p. 732-3)

A passagem evidencia não somente o saber do narrador sobre os fatos que narra (a inexistência ou não de uma relação extraconjugal entre Sofia e Carlos Maria), mas também seu conhecimento sobre a recepção da narração; isto é, a leitura que o narratário (sempre apresentado como enunciatário) fez do capítulo LXXXIX, em que é narrada a anedota do cocheiro. Outra conseqüência da passagem acima é que o narratário se vê transformado em personagem de outra trama, não a que diz respeito a Rubião, mas a que é protagonizada pelo narrador e da qual ele é coadjuvante importante. As aventuras de Sofia revelam-se, assim, um pré-texto para que o enunciador discuta o que lhe interessa: a narração. Para que tudo isso ser possível, é preciso existirem observadores instalados no nível da narração, os quais comunicariam ao narrador fatos relacionados à própria narração, tal como as suposições do narratário. 
Em $A$ mão e a luva, o narrador também discutia o próprio fazer e a recepção que teria sua narrativa ao afirmar que é privilégio do romancista e do leitor saber o que as personagens imaginam. Tal discussão volta em Quincas Borba, porém, a partir de outra chave: agora, o saber do romancista mostra-se superior ao do leitor e este se vê nu em sua condição de sujeito manipulado, levado a crer naquilo que o narrador (posando de enunciador) deseja que ele creia. Claro, não é possível fazer tal discussão no nível do narrado; é preciso sair dele, tarefa que demanda a instauração do narratário no enunciado como interlocutor do narrador, e que ambos sejam apresentados como enunciador e enunciatário, pois é essa relação que está em jogo. Desse modo, os três níveis enunciativos fusionam-se para discutir o processo de narração, levando a um desdobramento do observador, cujo fazer cognitivo não se restringe mais aos fatos narrados, mas alcança a narração. Em outras palavras, o enunciador faz com que toda uma estrutura que estava a serviço do narrado passe a funcionar para a narração que assim é como que rebaixada, transformando-se no narrado.

Os exemplos citados revelam, mais uma vez, que o enunciador opta por instalar um observador com um foco bastante amplo, não somente em relação aos actantes do enunciado, mas também em relação aos actantes da enunciação enunciada; isto é, aos próprios narrador e o narratário. No entanto, um olhar mais atento revela que, embora esse narrador pudesse ser considerado onisciente, para usar os termos da crítica literária, o saber de que dispõe, ou que comunica, é menor do que em romances anteriores. Tome-se o exemplo do diálogo entre Sofia e Palha, já citado, no qual nenhuma palavra é dita a cerca das reais relações entre os dois cônjuges; ou, então, a passagem acima, na qual o narrador não consegue deslindar completamente a natureza dos sentimentos de Sofia. Nos dois casos, tal como acontecia em Memórias póstumas, o enunciatário consegue saber de coisas que não são comunicadas pelo narrador, fato que faz supor a existência de actantes cognitivos que, apesar de instados no enunciado, não estão em sincretismo com o enunciador. Veja: não há diferença entre a quantidade de saber de que dispunha, por exemplo, o narrador de Ressurreição e o de Quincas Borba, mas a intensidade do saber do segundo é menor, pois há coisas que lhe escapam, surgindo, assim, as lacunas em seu saber. 


\section{Dom Casmurro}

Em Dom Casmurro, o observador volta a ser estar sincretizado com um actante da narrativa, como em Memórias póstumas. No entanto, ao contrário de Brás Cubas, Bento Santiago não está morto, portanto do desdém dos finados, que não têm o que ganhar ou perder, mas deve defender seu ponto de vista, com a agravante de que pouco sabe sobre os fatos narrados. Entretanto, é jogando com as limitações do próprio saber que ele constrói sua argumentação. Assim, ora alega não saber a verdade sobre Capitu ou não ter a malícia dela; ora, pelas inferências que faz, mostra que sabe tudo, e usa esse saber para preencher informações relativas aos fatos que não observou. Aliás, Bento Santiago e o conselheiro Aires, de Memorial de Aires, são os narradores de Machado que menos sabem, ou melhor, que mostram ter o saber mais limitado acerca do que se passa à sua volta, e que se apresentam, de formas muito diferentes, como sujeitos desenganados. Em conseqüência do modo de agir de Bento Santiago e das informações de que não dispõe (por exemplo, uma prova material sobre o comportamento de Capitu), cria-se uma tensão entre o que o enunciatário gostaria de saber e o que sabe efetivamente, de forma que também ele se vê obrigado a repetir, em outro nível e de forma diferente, o raciocínio de Bentinho; isto é, preencher as lacunas do seu saber com inferências que podem ser mais ou menos acertadas. Observe: no plano da narrativa, o narrador manipula o narratário para querer saber a verdade, e, a julgar pelo final do livro, convence-o de que realmente fora vítima de uma traição. No plano da narração, porém, faltam elementos para que o enunciatário seja convencido do crime de Capitu, pois a argumentação do narrador é falha e faltam argumentos que permitam concordar ou discordar dele categoricamente. Isso faz com que o enunciatário, em um primeiro momento, ou em um determinado nível de leitura, oscile entre uma opinião e outra. Por conta disso, poder-se-ia pensar que, como a conjunção com o objeto de saber prometida pelo enunciador não se configura, o enunciatário, em um caso extremo, poderia sentir-se traído, já que teria sido manipulado para querer entrar em conjunção com um saber - a ocorrência ou não de um adultério —, mas termina a leitura sem saber o que se passou. Ocorre que isso só seria verdade se a traição de Capitu fosse de fato o objeto de saber em questão, mas entende-se que o saber em jogo é outro e que a trama relatada por Bento Santiago é apenas um meio um programa narrativo de uso, se preferirmos - para que o enunciatário entre em conjunção com o objeto de saber "verdadeiro". Expliquemos. De fato, o narratário é manipulado pelo 
narrador para decidir se houve ou não um adultério, e tudo leva a crer que o narrador atinge esse objetivo, pois o leitor inscrito no texto teria concordado com ele. No entanto, o saber que o enunciador quer transmitir está ligado, uma vez mais, à impossibilidade de alcançar a verdade, dado que ela é sempre uma construção da linguagem, portanto, naturalmente escorregadia e fugidia.

Lembrando o narrador de Quincas Borba, que há pouco afirmava que tudo é muito confuso, no mundo machadiano (o nosso), o corpo oscila da mácula à pureza em um átimo, de forma que nunca se sabe o que se passa, nunca se sabe quem é culpado e quem é inocente, se é que alguém é uma coisa ou outra. Não é a alegada traição de Capitu que está em jogo, mas justamente a impossibilidade de saber o que de fato se passou, já que, afinal, as duas possibilidades se mostram verossímeis. Assim como na velha Siracusa, onde vencia aquele que melhor soubesse construir seu discurso, no mundo de Machado o vencedor é o que melhor construir um efeito de verdade e, reconheça-se, Bento Santiago é exímio retórico; seu único defeito é ter sido instalado por um enunciador que, de forma sutil, se não chega a desmenti-lo, ao menos aponta as fissuras no seu discurso, as quais o mostram não exatamente como falso, mas como uma construção ardilosa, que pode ou não corresponder à verdade. E eis que se volta a um assunto caro a esse enunciador: a dicotomia entre verdade e verossimilhança, e o fato de só haver efeitos de verdade ou de mentira que causam a impressão de uma coisa ou outra.. O que interessa ao enunciador não é manipular o enunciatário para que este entre em conjunção com o saber sobre a existência ou não de um caso extraconjugal, típico das tramas romanescas, mas fazê-lo entrar em conjunção com uma espécie de nãosaber; talvez, convencê-lo de sua ignorância sobre tudo, a começar sobre si próprio, e, nesse aspecto, está uma das modernidades de Machado: a conclusão de que, não existe, verdade, mas verossimilhança $\mathrm{O}$ enunciatário, longe de se convencer sobre algo (por exemplo, sobre as misérias humanas, como aconteceria nos romances naturalistas), convence-se apenas de que nada sabe, de que muito pouco pode saber, pois seu ângulo de visão é necessariamente limitado e as verdades, muitas.

Mas o talvez seja mais prudente examinar um trecho do romance para verificar se essas afirmações se sustentam, e, para tanto, nada melhor do que o momento em que Bentinho passa a desconfiar explicitamente de Capitu, como acontece no enterro de Escobar:

[...] Muitos homens choravam também, as mulheres todas. Só Capitu, amparando a viúva, parecia vencer-se a si mesma. [...] A confusão era geral. No meio dela, Capitu olhou alguns 
instantes para o cadáver tão fixa, tão apaixonadamente fixa, que não admira lhe saltassem algumas lágrimas poucas e caladas...

As minhas cessaram logo. Fiquei a ver as dela; Capitu enxugou-as depressa, olhando a furto para a gente que estava na sala. Redobrou de carícias para a amiga, e quis levá-la; mas o cadáver parece que a retinha também. Momento houve em que os olhos de Capitu fitaram o defunto, quais os da viúva, sem o pranto nem palavras desta, mas grandes e abertos, como a vaga do mar lá fora, como se quisesse tragar também o nadador da manhã. (Obra Completa, vol. I, p. 927)

Para demonstrar que havia algo entre Capitu e Escobar, Bentinho se vale de suas próprias observações sobre quatro atos da mulher: o olhar fixo para o cadáver; as lágrimas poucas e caladas; o fato de tê-las enxugado depressa, olhando a furto para os presentes; e, por último, um segundo olhar para o defunto, com olhos grandes e abertos, como que querendo tragá-lo. De fato, isso nada prova, ainda mais porque muitos homens choravam, e as mulheres todas e uns e outras seriam menos próximos do morto do que Capitu. Não é a fragilidade dos argumentos de Bentinho ou o aspecto absolutamente subjetivo de suas observações (que não sobreviveriam em um tribunal) que interessam, nem as interpretações de natureza psicológica que o teriam levado a agir como agiu, mas o fato de o narrador não conseguir conhecer o íntimo de Capitu nem desvendar seus pensamentos, como fazia com tanta facilidade o narrador de Helena ou de $A$ mão e a luva. Todavia, tanto aos olhos de Bentinho quanto aos do narratário, a traição soa verossímil; afinal, também nada há que a negue.

Mas, afinal, o que é a verdade? Onde ela termina e onde começa a fabulação? Não apenas a voluntária, a urdida, mas aquela inconsciente, nascida do acaso e muito semelhante à verdade, já que ambas dependem de sua parenta, a verossimilhança. Recorde-se agora o episódio do cocheiro em Quincas Borba, lembrado há pouco. Na ocasião, Rubião e o narratário partiram de indícios e construíram uma tese (quase) verossímil, que, ao final, revelou-se falsa. Agora, Bento Santiago envereda pelo mesmo caminho, sem, contudo, dispor da voz do narrador que tudo esclarecia. As incertezas são, portanto, muito maiores. No caso presente, , porém, se o enunciatário não se enredar na discussão de uma ou de outra tese, nem nos argumentos para uma ou para outra, verificará que entrou sem querer num terreno pantanoso, em que a verdade ou a mentira são objetos de saber, como outros quaisquer, a serem construídos pelo sujeito, de acordo com os seus interesses e possibilidades. Foi esse o ensinamento, de certo modo teórico, do enunciador de Quincas Borba na passagem sobre o pretenso adultério de Sofia e Carlos Maria. Agora, ele parece mostrar na prática como se constroem as próprias verdades, essas moradas frágeis que têm o costume de desabar sobre a cabeça de seus moradores. 
E o que autoriza considerar os argumentos do narrador uma verdade construída? Dentre outros fatores, o fato de ela ser desmontada, não de toda, pelo enunciador que mostra não só sua fragilidade, mas também o fato de Bentinho poder estar sendo traído, sim, mas pelos seus próprios sentimentos, por sua própria concupiscência, como diz o texto bíblico ${ }^{121}$. A fragilidade decorre do fato de o enunciador mostrar que a desconfiança do adultério entre Capitu e Escobar surge na manhã seguinte à noite em que ele trocara olhares libidinosos (ou que ele assim julgara) com Sancha, mulher do amigo. O fato de esse mesmo ator acumular também o papel de responsável pela narração, leva ao questionamento do próprio conteúdo narrado, da autoridade desse narrador para afirmar o que afirma. Assim, existem várias teses possíveis: a de que Bentinho esteve certo nas duas ocasiões acerca dos olhares de Sancha e Capitu, que estava errado em ambas ou apenas em uma delas. A resultante final é a perda da confiança no narrador. Recordemos a passagem em que Bentinho se sente assediado por Sancha:

Sancha ergueu a cabeça e olhou para mim com tanto prazer que eu, graças às relações dela e Capitu, não se me daria beijá-la na testa. Entretanto, os olhos de Sancha não convidavam a expansões fraternais, pareciam quentes e intimativos, diziam outra cousa, e não tardou que se afastassem da janela, onde eu fiquei olhando para o mar, pensativo. A noite era clara.

Dali mesmo busquei os olhos de Sancha, ao pé do piano; encontrei-os em caminho. Pararam os quatro e ficaram diante uns dos outros, uns esperando que os outros passassem, mas nenhum passava. Tal se dá na rua entre dous teimosos. A cautela desligou-nos eu tornei a voltarme para fora. E assim posto entrei a cavar na memória se alguma vez olhara para ela com a mesma expressão, e fiquei incerto. Tive uma certeza só, é que um dia pensei nela, como se pensa na bela desconhecida que passa; mas então dar-se-ia que ela adivinhando...[...].

$[\ldots]$

A modéstia pedia então, como agora, que eu visse naquele gesto de Sancha uma sanção ao projeto do marido [de os dois casais viajarem juntos para a Europa] e um agradecimento. Assim devia ser. Mas o fluido particular que me correu todo o corpo desviou de mim a conclusão que deixo escrita. Senti ainda os dedos de Sancha entre os meus, apertando uns aos outros. Foi um instante de vertigem e de pecado. Passou depressa no relógio do tempo; quando cheguei o relógio ao ouvido, trabalhavam só os minutos da virtude e da razão. (Obra Completa, vol. I, p. 923-4)

Naquele momento, Bentinho estava certo das intenções de Sancha — e das suas... —, mas ao ver o desespero da viúva diante do caixão convence-se de que tudo não passara de vaidade sua e de que Sancha era amantíssima do marido Mais uma vez, o argumento é falho: quem não choraria diante do marido morto repentinamente, aliás, o choro poderia ser remorso. ${ }^{122} \mathrm{O}$ fato é que o olhar de Sancha para o defunto a redimira; o de Capitu a

\footnotetext{
${ }^{121}$ Está em Tiago 1:14.

${ }^{122}$ Veja como as coisas vão e vem, vem e vão, mas não em vão (como diria Oswald de Andrade), na obra de Machado: o argumento de Bento Santiago para afirmar que Sancha era amantíssima lembra o de Brás
} 
condenara. Argumentos pífios tanto para a condenação de uma quanto para a absolvição de outra. Como Bento Santiago pouco sabe, constrói para si um outro objeto de saber - um simulacro da realidade, diriam os semióticos —, no qual Bentinho figura como sujeito traído e a mulher e o amigo como traidores. Embora não se saiba se tal simulacro corresponde à realidade, sua função no texto é bastante clara: compensar a falta, cuja natureza também não é definida. O processo de construção desse simulacro é explicitado algumas páginas adiante:

[...] Tinha já comparado o gesto de Sancha na véspera e o desespero daquele dia; eram inconciliáveis. A viúva era realmente amantíssima. Assim se desvaneceu de todo a ilusão da minha vaidade. Não seria o mesmo caso de Capitu. Cuidei de recompor-lhe os olhos, a posição em que a vi, o ajuntamento de pessoas que devia naturalmente impor-lhe a dissimulação, se houvesse algo que dissimular. O que aqui vai por ordem lógica e dedutiva, tinha sido antes uma barafunda de idéias e sensações, graças aos solavancos do carro e às interrupções de José Dias. Agora, porém, raciocinava e evocava claro e bem. Concluí de mim para mim que era a antiga paixão que me ofuscava ainda e me fazia desvairar como sempre. (Obra Completa, vol. I, p. 929)

No trecho acima, observa-se a conjugação da ignorância de Bentinho com seu saber - a qual, supõe-se, o faz crer que Capitu realmente o traíra, descoberta que transforma sua maneira de ver o mundo. A verdade resultante das observações de Bentinho não é fruto da observação dos fatos (ainda que alguns sejam apresentados à guisa de prova), mas da sua construção pela linguagem e pela mente do sujeito. Para o enunciatário restam dúvidas prenhes de dúvidas: os fatos relatados se passaram tal e qual ele afirma ou o próprio Bentinho teria sido enganado pelos olhos do observador ciumento, pela antiga paixão que o ofuscava ainda e o fazia desvairar como sempre? Seria mera coincidência terem decorrido 24 horas entre o pretenso assédio de Sancha e os olhares de Capitu ou é o narrador que transfere à esposa o adultério que gostaria de ter praticado? Veja-se que, no capítulo seguinte ao citado, Bentinho para diante de um barbeiro e imagina que, se ele permanecesse mais tempo ali, a mulher deste também poderia namorá-lo ${ }^{123}$. Como, portanto, confiar em um narrador desse quilate? Fica impossível saber a verdade, pois, entre outros motivos, as observações deste observador, como reconhece ele próprio, podem não passar de um atordoamento provocado pela paixão. A questão da traição não pode ser, portanto, a mais relevante; é, antes, um meio para o enunciador mostrar que a mercantilização das relações, assunto há muito discutido por ele,

Cubas para provar que o Cotrim tinha sentimentos: a prova, dizia Brás Cubas na ocasião, é que Cotrim chorou diante da morte da filha:

A prova de que o Cotrim tinha sentimentos pios encontrava-se no seu amor aos filhos, e nadir que padeceu quando the morreu Sara, dali a alguns meses; prova irrefutável, acho eu e não unica. (Obra Completa, vol. I p. 620)

${ }^{123}$ Está no fim do fim do capítulo XXVII. 
traz consigo a impossibilidade de chegar a uma verdade qualquer, pois esta também flutua, como outras mercadorias, ao sabor das condições do momento e, principalmente, do sujeito. Observe que ainda que o narrador não seja totalmente desqualificado, como ocorria em Memórias póstuma; ele o é em parte e esse fato impede que se confie ou desconfie totalmente dele. Entretanto, se o narrador se desqualifica, o oposto ocorre com o enunciador que se mostra ainda mais competente, capaz de caminhar com segurança na zona nebulosa das incertezas. A conseqüência é a ruptura já mencionada entre narrador e agora adquire outros contornos.

Esse não é o primeiro relato das desconfianças de Bentinho, nem um caso isolado, mas contribui para a construção do arcabouço central da trama. Por exemplo, antes dessa passagem, o narrador já sugeria nas entrelinhas que havia algo de errado em seu casamento. Recordem-se os capítulos Embargos de terceiro e Dúvidas sobre dúvidas (CIII e CV), nos quais Bentinho vai sozinho ao teatro por que Capitu alegara estar com dor de cabeça. Ele volta para casa antes do esperado e encontra Escobar que lá tinha ido para tratar de um assunto considerado sem importância. Capitu já se sentia bem e o amigo vai logo embora. Bentinho fica desconfiado, de forma incompatível com a amizade que tinham. Ele relata o caso a Capitu que não lhe dá importância. Em seguida, conta à esposa que a mãe também mudara e parecia fria com ele e com a nora. Capitu reconhece a mudança, mas novamente considera o fato irrelevante. Bentinho não explicita suas desconfianças, a não ser pelo título do capítulo Dúvidas sobre dúvidas - e por dois subentendidos que levam o leitor a se perguntar por que o narrador disse o que disse. O primeiro é o fato de Bento Santiago intercalar entre os dois capítulos citados outro em que conta que Capitu quebrara um juramento de criança de jamais esquecer certa toada. Conclui afirmando que faltar ao compromisso é sempre uma infidelidade ${ }^{124}$, sem que o leitor consiga entender bem o que liga uma coisa a outra. Em seguida, começa a relatar o caso dos embargos de terceiros que teriam levado Escobar à sua casa:

\footnotetext{
Vamos agora aos embargos... E por que iremos aos embargos? Deus sabe o que custa escrevêlos, quanto mais contá-los. Da circunstancia nova que Escobar me trazia apenas digo o que lhe disse então, isto é, que não valia nada. (Obra Completa, vol.). I, p. 920
}

O narrador não conta porque custava escrevê-los, afinal, tudo indica tratar-se de um fato banal, aliás, tão banal que nem deveria ser relatado. O subentendido nunca explicitado é que a ida de Escobar à sua casa resultaria da relação adúltera que ele já manteria com

\footnotetext{
${ }^{124}$ Obra Completa, vol. I p. 920
} 
Capitu... Para melhor entendimento dessa passagem, recordem-se as três acepções oferecidas por Houaiss para a palavra embargo:

1. aquilo que impede, embaraça; empecilho, obstáculo, dificuldade;

2. qualquer um de vários institutos jurídicos com traço comum de impor obstáculo à pretensão do adversário na conquista de um direito;

3. retenção provisória, efetuada por um Estado, de navio mercante estrangeiro ancorado em porto de sua jurisdição.

Assim, o título embargos de terceiro pode referir-se ao assunto que levou Escobar à casa de Bentinho (acepção 2); pode ser o obstáculo que o terceiro, Bentinho, impôs às relações entre Escobar e Capitu (ou que Escobar impôs às relações entre Bentinho e Capitu - acepção 1); ou pode ser retenção provisória de Capitu por Escobar (acepção 3). Como de costume, qualquer alternativa pode ser verdadeira, justamente porque não se conhecem as reais intenções de Escobar nem se sabe o que se passou entre ele e Capitu durante a ausência de Bentinho. A ida de Escobar à casa do narrador, assim como os humores da mãe, teriam a mesma explicação: adultério. Claro, Bento Santiago não o afirma, mas dá a entender, construindo, assim, indícios que conferirão verossimilhança à hipótese da traição. Dir-se-ia que o narrador não dá ponto sem nó. Ou... ou será que é má vontade do leitor para com ele? Leitor que insiste em ver em todos os atos do narrador segundas intenções, da mesma maneira que Bentinho via em qualquer ato da esposa e do amigo indícios de fraude? Se Bento Santiago é desconfiado, então o enunciatário não o seria menos. Assim está instaurada a desconfiança generalizada, que atinge a relação do leitor com o narrador e mesmo consigo, já que passa a desconfiar de si mesmo: será que não estou exagerando?... Seja como for, a vitória é do enunciador: o conteúdo do livro é agora plasmado em sua forma. A desconfiança (que pode ser definida como um não-saber, na medida em que consiste em considerar algo como possivel, embora sem elementos que o comprovem), passa a permear todas as relações, inclusive as do enunciatário e do narrador. Nesse momento, o enunciador veria alcançado o objetivo de sua manipulação, pois o enunciatário passa a estar em conjunção com o saber proposto, que consiste, justamente, em um saber sobre o não-saber, processo que deve boa parte de sua eficiência ao fato de derivar das observações de um único actante, que, tal como o enunciatário, tem um foco único e limitado sobre tudo o que se passa e está sempre è mercê das dúvidas que a qualquer momento podem acometê-lo.

Antes de concluir esse tópico, talvez não seja ocioso recordar como a delegação do saber tem sido feita. Até Helena, o enunciador instalava um narrador que tudo sabia acerca 
dos fatos narrados e que, exceto pelas advertências, causava a impressão de saber tanto quanto o enunciador sobre a narrativa. Em Iaiá Garcia, o narrador continua gozando da onisciência, mas já apresenta alguma dificuldade em lidar com o que sabe. As dúvidas, porém, assolam apenas as personagens; a narração parece poupada disso. Em Memórias póstumas, ocorre uma mudança, pois o narrador tem seu saber duplamente esvaziado: não apenas não sabe mais o que se passa no íntimo dos demais actantes, mas seus julgamentos mostram-se também equivocados. Além disso, não revela tudo que sabe. Cria-se, desse modo, uma grande defasagem entre o narrador e o enunciador: há varias informações de que este dispõe, mas que não revela àquele. Depois, em Quincas Borba, acredita-se que a delegação do saber voltou a ocorrer nos moldes de anteriormente, pois o narrador sabe tudo sobre todos. Contudo, embora o narrador saiba mais, ele não esclarece vários pontos daquilo que narra, como a natureza dos sentimentos de Sofia, nem explicita os ilícitos praticados por Palha em relação à Rubião. Ou seja, volta a aumentar a extensão do conhecimento do narrador, mas não a intensidade e por isso suas conclusões são frágeis e, mesmo, contraditórias. Chega-se agora a Dom Casmurro em que o saber do narrador é ainda mais esvaziado. Como em Memórias póstumas, o saber está circunscrito a um indivíduo, e, além da extensão do saber ter-se reduzido, também sua intensidade é menor: o indivíduo sabe menos e vive cercado por dúvidas e hipóteses que jamais são confirmadas ou negadas, justamente porque não há elementos para tanto, sendo essa condição reveladora da presença de outros actantes cognitivos que expressam um ponto de vista que não é o do narrador, apesar de ele ser o único a ter VOz no texto. É o que acontece quando Bentinho não explica a questão dos embargos de terceiros nem se dá conta do quão estranho (para dizer o mínimo) é começar a duvidar da esposa 24 horas após entender que a mulher do amigo o assediou. Nesses casos, revelam-se observadores que observam a narração que são detentores de um saber que não é delegado ao narrador. Esse fato explica como o leitor consegue perceber que o saber do narrador é deficiente, que há incongruências em sua narrativa, sem que isso implique o enunciador. 


\section{Esaú e Jacó}

Esaú e Jacó é o único romance de Machado em que o narrador e o observador central não estão sincretizados, apesar do que se possa pensar em um primeiro momento. A dissociação pode ser percebida pelo fato de o narrador quase nunca dizer eu, apesar de, conforme foi visto, ser também um actante do enunciado. Ao narrar, como se diz, na terceira pessoa, o narrador acaba adotando uma perspectiva que não seria a de Aires, mas de um terceiro que tem vários informantes (observadores), sendo o conselheiro apenas um deles. Em alguns momentos, o narrador adquire ares de onisciência, pois sabe de coisas que ninguém jamais saberia, a menos que pudesse vasculhar tudo que se passa na mente de todas as personagens; em outras ocasiões, porém, fixa-se na perspectiva de Aires e tem seu saber circunscrito ao desse ator. Enfim, o observador desse romance ora se fixa em um actante do enunciado, ora é completamente exterior a todos os personagens, e tudo vê de cima, de uma perspectiva privilegiada, sem que se possa definir exatamente sua natureza. Para conhecer esse processo, o melhor é recorrer a um exemplo que destaca a cisão entre o narrador e o actante com o qual ele deveria estar sincretizado. Encontramo-lo no início do livro, justamente no capítulo já discutido anteriormente, em que o narrador apresenta Aires:

$$
\text { CAPÍTULO XII / ESSE AIRES }
$$

Esse Aires que aí aparece conserva ainda agora algumas das virtudes daquele tempo, e quase nenhum vício. Não atribuas tal estado a qualquer propósito. Nem creias que vai nisto um pouco de homenagem à modéstia da pessoa. Não, senhor, é verdade pura e natural efeito. Apesar dos quarenta anos, ou quarenta e dois, e talvez por isso mesmo, era um belo tipo de homem. Diplomata de carreira, chegara dias antes do Pacífico, com uma licença de seis meses.

Não me demoro em descrevê-lo. Imagina só que trazia o calo do ofício, o sorriso aprovador, a fala branda e cautelosa, o ar da ocasião, a expressão adequada, tudo tão bem distribuído que era um gosto ouvi-lo e vê-lo. Talvez a pele da cara rapada estivesse prestes a mostrar os primeiros sinais do tempo. Ainda assim o bigode, que era moço na cor e no apuro com que acabava em ponta fina e rija, daria um ar de frescura ao rosto, quando o meio século chegasse. O mesmo faria o cabelo, vagamente grisalho, apartado ao centro. No alto da cabeça havia um início de calva. Na botoeira uma flor eterna. (Obra Completa, vol. I, p. 964 - grifos meus)

O demonstrativo esse e o advérbio aí não deixam dúvidas quanto ao efeito de sentido que se quer causar: Aires estaria próximo do narratário e não do observador. Os dois pronomes oblíquos - me e lo, no segundo parágrafo — também não permitem a hesitação: o narrador não estaria sincretizado com Aires. No entanto, sabe-se, graças aos esclarecimentos de $\mathrm{M}$ de $\mathrm{A}$ na advertência, que isso não é verdade; portanto, o uso que o narrador faz da terceira pessoa para referir-se a Aires (portanto, a si próprio) deve ter outra 
explicação. E, de fato, embora o narrador seja realmente o conselheiro, o mesmo não pode ser dito do observador instalado no trecho acima, já que Aires é visto "de fora para dentro". Observe que a cisão entre narrador e observador não é indicada apenas pelos pronomes, mas também pelo efeito de distanciamento produzido pelas linhas acima, por um não-saber sobre a idade de Aires, que soaria estranho se o observador fosse ele próprio. Há também a descrição do conselheiro, toda ela feita de fora, em terceira pessoa, indicando, na verdade, uma embreagem; mais exatamente, um eu (Aires) que se apresenta como ele (narrador em terceira pessoa). Cria-se, assim, um efeito de objetividade que, entre outras coisas, impede que se considerem os dois parágrafos deselegantes, uma vez que a auto-louvação é extensa e explícita, como indica, por exemplo, a frase era um gosto ouvi-lo e vê-lo. Essa estratégia confere ainda alguma autoridade ao narrador, uma vez que juízos como esse não teriam nenhum valor se proferidos pelo próprio julgado. Assim, para que o narrador não seja considerado jactancioso e para que tenha algum crédito, é preciso que se esqueça que, afinal, ele e a personagem correspondem ao mesmo ator. E é fácil esquecê-lo, uma vez que a descrição acima é toda ela exterior a Aires, e, em nenhum momento, é relatado seu pensamento, tendose a impressão de que o conselheiro é, de fato, visto por alguém, e não que ele se vê a si próprio.

Em seguida, o narrador conta que Aires esteve enamorado de Natividade por algum tempo sem ser correspondido, e que, posteriormente, o marido dela, Santos, quis casá-lo com a cunhada. Recordemos:

Coincidência interessante: foi por esse tempo que Santos pensou em casá-lo [a Aires] com a cunhada, recentemente viúva. Esta parece que queria. Natividade opôs-se, nunca se soube por quê. Não eram ciúmes; invejas não creio que fossem. O simples desejo de o não ver entrar na família pela porta lateral é apenas uma figura, que vale qualquer das primeiras hipóteses negadas. O desgosto de cedê-lo a outra, ou tê-los felizes ao pé de si, não podia ser, posto que o coração seja o abismo dos abismos. Suponhamos que era com o fim de o punir por havê-la amado. (Obra Completa, vol. I p. 965 - grifos meus)

O narrador pouco sabe sobre o sentimento das personagens e limita-se a fazer conjecturas: parece que Natividade opôs-se... nunca se soube ... não creio... suponhamos... As razões que levaram Natividade a agir como agiu permanecem um segredo e tudo o que resta a esse narrador são conjecturas, pois, na passagem acima, o observador não está sincretizado com Aires, nem com Natividade nem com Santos. Repare que não há marcas de subjetividade na passagem acima, pois o conselheiro descreve a si próprio, e aos fatos que lhe afetaram, como um terceiro. Veja que na passagem acima se combinam dois elementos poucos comuns em 
Machado: de um lado, um efeito de objetividade; de outro, um saber não completo. O observador é exterior ao enunciado, teria uma visão de cima, mas isso não lhe garante a visão abrangente dos fatos. Observe ainda que ao conjugar uma narrativa em primeira pessoa com um observador externo, o enunciador revela que a objetividade, tal como a verdade, nada mais é que um efeito de sentido e, desse modo, mais uma vez mostra que a linguagem cria a realidade, não se contentando em apenas descrevê-la. Por outro lado, em outros momentos do romance, o observador não se mostra limitado a um ponto fixo, mas age como se tivesse uma visão total e ilimitada de tudo que se passa, como um típico narrador onisciente. Acompanhe-se o episódio em que Nóbrega, irmão das almas, ganha uma esmola de dois milréis de Natividade quando ela conhece do destino glorioso de seus filhos:

Sem rodeios, [Nóbrega] supôs que as duas senhoras vinham de alguma aventura amorosa, e deduziu isto de três fatos, que sou obrigado a enfileirar aqui para não deixar este homem sob a suspeita de caluniador gratuito. O primeiro foi a alegria delas, o segundo o valor da esmola, o terceiro o carro que as esperava a um canto, como se elas quisessem esconder do cocheiro o ponto dos namorados. Não concluas tu que ele tivesse sido cocheiro algum dia, e andasse a conduzir moças antes de servir às almas. Também não creias que fosse outrora rico e adúltero, aberto de mãos, quando vinha de dizer adeus às suas amigas. Ni cet excès d'honneur, ni cette indignité. Era um pobre diabo sem mais ofício que a devoção. Demais, não teria tido tempo; contava apenas vinte e sete anos.

$[\ldots]$

Na igreja, ao tirar a opa, depois de entregar a bacia ao sacristão, ouviu uma voz débil como de almas remotas que the perguntavam se os dois mil-réis... Os dois mil-réis, dizia outra voz menos débil, eram naturalmente dele, que, em primeiro lugar, também tinha alma, e, em segundo lugar, não recebera nunca tão grande esmola. Quem quer dar tanto vai à igreja ou compra uma vela, não põe assim uma nota na bacia das esmolas pequenas.

Se minto, não é de intenção. Em verdade, as palavras não saíram assim articuladas e claras, nem as débeis, nem as menos débeis; todas faziam uma zoeira aos ouvidos da consciência. Traduzi-as em língua falada, a fim de ser entendido das pessoas que me lêem; não sei como se poderia transcrever para o papel um rumor surdo e outro menos surdo, um atrás de outro e todos confusos para o fim, até que o segundo ficou só: "Não ... tirou a nota a ninguém... a dona é que a pôs na bacia por sua mão... também ele era alma"[...] (Obra Completa, vol. I, p. 952 - grifos meus)

Antes de cuidarmos do saber do observador, note-se que o primeiro parágrafo do trecho acima retoma uma questão que já havia surgido em Quincas Borba, que foi retomada em Dom Casmurro, e reaparece aqui: os desenganos provocados pelo parecer. Como o cocheiro que conduzia Rubião, Nóbrega, movido pelas aparências, também se equivoca quanto à natureza das atividades de Natividade e da irmã. Voltando ao observador, note-se que ele conhece todo o raciocínio da personagem. Primeiro, o narrador, Aires, dá ao leitor detalhes da cena apesar de não estar presente na ocasião e de não contar com um informante. Em seguida, conta as dúvidas de Nóbrega quanto à autenticidade da nota, relata as justificativas para a subtração da quantia. Enfim, acrescenta que uma eventual imprecisão seria decorrente 
de sua imperícia ou da dificuldade da matéria, e aí lembra, claro, o narrador de $A$ mão e a lwva, o qual tinha o cuidado de afirmar que, embora não fizesse a transcrição literal do pensamento de Estevão, sua narrativa era fiel aos fatos. Naturalmente, são fatos que Aires não poderia conhecer e que demandam a presença de um observador que não está sincretizado com esse ator e que, por isso mesmo, pode ver tudo de cima.

No entanto, o narrador faz pairar uma dúvida sobre o próprio saber quando afirma que, se mente, não o faz de forma intencional. Nesse momento, fica clara a defasagem entre o saber do enunciador, que evidentemente tudo sabe e não tem dúvidas acerca de nada, e o saber do narrador, que se mostra hesitante em muitas passagens como na acima e isso apesar do imenso saber de que dispõe e que o permite narrar os pensamentos de Nóbrega. Finalmente, o trecho citado, como aquele em que o narrador dialoga com uma leitora, discutido no capítulo sobre as configurações narrativas, revela a presença de outra espécie de actantes cognitivos, a saber, aqueles que não cuidam do narrado, mas da narração. Tudo isso é reforçado ao final da passagem, quando o narrador afirma que não sabe como se poderia transcrever para o papel um rumor surdo e outro menos surdo... Nesse momento, volta a ficar evidente não apenas a presença de observadores atentos à narração e a superioridade do saber do enunciador em relação ao do narrador, mas também o fato de a reflexão sobre o fazer literário dominar todo o romance.

Encerrando esta análise, observa-se que, nesse romance, o enunciador adota procedimentos ora semelhantes, ora distintos dos adotados em obras anteriores. É semelhante quando o enunciador explicita que sabe mais que o narrador e que o saber deste é, de formas variadas, pouco confiável. É diferente quando o observador e o narrador não estão mais sincretizados em um único actante. Certo, esse procedimento também ocorria, por exemplo, em Memórias póstumas, na passagem em que Brás Cubas se reconcilia com Sabina e Cotrim e não percebe a natureza dos sentimentos deles. Mas veja a diferença: naquele caso o narrador estava sincretizado com o observador, porém percebia-se também a presença de outros observadores que, como uma segunda voz relatavam o que não era percebido pelo narrador. Agora, porém, esse processo é explicitado se torna e dominante em todo o romance. Não se trata mais de algo de que o narrador não se dá conta, mas de uma completa segregação entre as duas funções: observar e narrar, fazendo com que o narrado seja muito menor que o observado. Isso não é novidade na obra de Machado, antes confirma o que já se observou inúmeras vezes: o ethos dissimulado do enunciador. 


\section{Memorial de Aires}

Como se sabe, o narrador do Memorial, conselheiro Aires, é o mesmo de Esaú e Jacó, mas o saber que Aires detém em cada romance é muito diferente, em função, justamente da relação do narrador com o observador. Viu-se que no romance discutido anteriormente não era possível definir o tipo observador, uma vez ele oscilava ao longo do texto: ora sincretizado com um actante do enunciado, ora não se fixando em ninguém, mas tendo uma visão ampla de cima, como um narrador onisciente. Isso não acontece no Memorial de Aires, que tem no conselheiro seu principal, mas não único, observador dos fatos narrados. O saber desse narrador é muito limitado, circunscrito aos fatos conhecidos pelo ator, fato que o aproxima mais de Bento Santiago do que do Aires de Esaú e Jacó, pois tal como acontece em Dom Casmurro, a estratégia adotada pelo enunciador permite observar um desvão entre a interpretação de Aires para os fatos que observa e outras interpretações igualmente possíveis e, talvez, mais acertadas. E, de fato, o final do romance nega muitas das conclusões do conselheiro, especialmente no que diz respeito ao casal Fidélia-Tristão. Outras não são negadas, mas há elementos suficientes para que o enunciatário discorde do conselheiro. $\mathrm{O}$ processo é tanto mais rico na medida em que, em muitos momentos, há um contraponto entre a interpretação de Aires e a de outro personagem, D. Cesária, cuja opinião, sempre oposta à dele, é, provavelmente, mais condizente com a realidade. Como não poderia deixar de ser, uma vez que o romance é um diário íntimo, o Memorial guarda todas as marcas dessa subjetividade e da limitação do indivíduo. Sem mais, veja-se por meio de um exemplo, extraído das primeiras linhas do romance, como ocorre a delegação do saber:

Nesse momento, a viúva descruzava as mãos, e fazia gesto de ir embora. Primeiramente espraiou os olhos, como a ver se estava só. Talvez quisesse beijar a sepultura, o próprio nome do marido, mas havia gente perto, sem contar dous coveiros que levavam um regador e uma enxada, e iam falando de um enterro daquela manhã. Falavam alto, e um escarnecia do outro, em voz grossa: "Eras capaz de levar um daqueles ao morro? Só se fossem quatro como tu". Tratavam de caixão pesado, naturalmente, mas eu voltei depressa a atenção para a viúva, que se afastava e caminhava lentamente, sem mais olhar para trás. Encoberto por um mausoléu, não a pude ver mais nem melhor que a princípio. (Obra Completa, vol. I p. 1.098 - grifos meus).

No parágrafo, não há certezas; apenas hipóteses. Grande é a distância entre esse narrador e o dos primeiros romances, o de Quincas Borba, e mesmo o de Esaú e Jacó, que em algumas ocasiões descrevia em detalhes o que alguém pensava, como no caso de Nóbrega. Diversos são os índices no texto, como o verbo parecer e o advérbio talvez, de que Aires é o sujeito do não-saber ou da dúvida; que indicam a possibilidade, mas não a certeza. Esse é o 
seu meio-ambiente: o dos meio-tons, da hesitação. O enunciador não delegou ao seu narrador tudo o que sabe, mas apenas um conhecimento muito limitado, que gera indagações, e não respostas. Muitos são indiciados, mas ninguém é acusado. Nem absolvido. No plano do narrado, a conjunção com o saber nunca se efetiva plenamente e sempre permanece em suspenso: talvez Fidélia quisesse beijar a sepultura; talvez não. Também no plano da narração, a conjunção não se verifica: qual a razão de Aires observar que coveiros discutiam sobre um caixão excessivamente pesado? Mera coincidência ou uma indicação, nas entrelinhas, do fato de a viuvez de Fidélia também ser um fardo difícil de suportar? Também o enunciatário fica sem resposta, e, assim, o enunciador, por meio de seus delegados, instaura a dúvida sem cessar; mostrando as diversas possibilidades dos fatos, mas não se definindo por nenhuma. Tal procedimento é realizado não apenas de forma direta, por meio das palavras que utiliza, mas também de forma indireta, mediante a alusão a fatos que sugerem uma outra interpretação daquilo que ele acaba de expor. São as inúmeras pontas aparentemente soltas do romance, as quais o enunciatário deve seguir ou não para tirar suas conclusões. Por sua conta e risco. Durante a narrativa, o narrador, em um procedimento semelhante ao de Bento Santiago, acaba arrastando o leitor para uma zona nebulosa, onde nada é certo, a começar pelas intenções do próprio diarista. Veja-se rapidamente a passagem em que Aires comenta a afirmação de D Cesária, segundo a qual Tristão preferia a política à Fidélia:

[...] Havia naquela palavra tal ou qual condenação do moço, mas só aparente; o sentido verdadeiro era o gosto de ver a dama preterida. [...] Ri-me naturalmente, negando ou calando. Dentro de mim achei que a opinião era injusta, mas talvez este meu conceito seja filho da afeição que vou tendo ao moço. Ela cresce-me, com a vista e a prática dos seus dotes, e naturalmente com a afeição e a confiança que me tem, ou parece ter. Seja o que for, a verdade é que não o defendi de todo, mas só em parte, e a graciosa dama apelou para o meu gosto, o equilíbrio do meu espírito, o longo conhecimento que tenho dos homens... Todas as grandes qualidades deste mundo. (Obra Completa, vol. I, p. 1.170 - grifos meus)

Talvez... parece... São bem escassas as certezas de Aires, inclusive no que diz respeito a seus próprios sentimentos. D. Cesária criticara Tristão e o fizera com veemência, segundo Aires. Ele atenua a ofensa propondo que o alvo seria Fidélia, mas, ao mesmo tempo, observando que sua avaliação poderia ser deturpada pela afeição que tinha ao rapaz, e resume: o fato é que não o defendi inteiramente. Veja que a dúvida do enunciatário é dupla: de um lado, não atina se D. Cesária tem ou não razão (embora o desfecho do romance sugira que sim); de outro, não descobre se Aires dá razão à velha senhora em alguma medida, pois tudo é muito fluido, incerto. Se antes, em Esaú e Jacó, o mesmo Aires era capaz de vasculhar o que se passava na mente de todos, agora é impotente para descobrir o que move seus próprios 
julgamentos. Recordem-se os primeiros romances plenos de certezas e julgamentos a respeito da conduta das personagens. Tudo agora esvanece; todas as possibilidades são válidas, mas nenhuma é certa: as observações sobre Tristão não permitem que se faça um quadro muito positivo dele, que ganha feições de um Brás Cubas um pouco mais civilizado. Assim, se Aires tem uma visão positiva do moço, isso se deve, em parte, como ele reconhece, às suas ligações pessoais e ao fato de haver entre eles a identidade da classe. Surge, mais uma vez, a dúvida tão assídua em Dom Casmurro: Bentinho nunca sabia se suas conclusões eram decorrentes de fatos ou se era sua paixão que o fazia vê-los do jeito que via. A mesma pergunta se faz Aires: como saber quem é Tristão, se as paixões estão sempre a corromper os fatos?

A ignorância de Aires acerca das motivações de Tristão e os indícios de que o conselheiro pode não ter a melhor a apreensão da realidade voltam a se manifestar em outra passagem, quando ele e o noivo de Fidélia estão em um café e o diplomata pergunta-lhe sobre as razões que teriam levado à doação da fazenda:

Tristão, a quem falei da doação de Santa-Pia, não me confiou os seus motivos secretos; disse-me só que Fidélia vai assinar o documento amanhã ou depois. Estávamos no Carceler tomando café. Ouvi-lhe também dizer que recebeu cartas de Lisboa, duas políticas; instam por ele. Quis saber se acudiria ao chamado, mas o gesto com que ele via subir o fumo do charuto parecia mirar tão-somente a noiva, o altar e a felicidade; não ousei passar adiante.(Obra Completa, vol. I p. $1.191)$

Tristão não explica a Aires as razões da venda da fazenda, mas o encadeamento do texto acima sugere que a alusão do moço às cartas que recebera de Lisboa fora feita à guisa de resposta, ainda que inconscientemente. Provavelmente, ele não sonhava com o altar, mas com a tribuna, e a felicidade sonhada não era a do matrimônio, mas a do mandato. A idéia ganha força com o desfecho da trama, quando Tristão abandona seus pais de estimação para acudir ao chamado das cartas. No trecho acima, o velho diplomata não vê a ligação entre os dois fatos, mas crê que Tristão mirava tão-somente a noiva, o altar e a felicidade. Mais uma vez, o final do romance mostrará que as preocupações o noivo de Fidélia eram de outra ordem, mais prática, e que Aires estava redondamente enganado em suas interpretações sentimentais. Ao final da mesma anotação, Aires registra com agudeza o fato de Tristão haver parado em um ourives para comprar alguma jóia. Para quem seria? Não há qualquer menção a ela no restante do diário. Poderia se tratar de um relógio para Aguiar, ou, quem sabe, de uma lembrança para uma amiga, como as que Brás Cubas costumava levar para Marcela. Como não há explicações, o fato apenas sugere, mais uma vez, que poderia haver uma outra 
narrativa, paralela à de Aires, que nunca foi narrada, e que o leitor recebe uma versão parcial e incompleta dos fatos, a do diplomata. Com isso não se pretende propor uma explicação para o que não é narrado ${ }^{125}$; trata-se apenas alertar para a existência de um desvão entre o diário e os fatos que teriam dado origem a ele e que revelaria a presença de outros observadores não sincretizados com Aires. Em termos mais técnicos: o enunciador não delegou ao seu narrador o saber necessário para uma correta interpretação dos fatos narrados, de modo que seus comentários soam ingênuos, piegas, mas... ingenuidade e pieguice do narrador e não do autor, que se mostra todo o tempo muito arguto com relação a tudo. Enfim, mais uma vez, observa-se uma defasagem entre o saber do enunciador e o do narrador.

Recordem-se, agora, os comentários de Aires a respeito de um diálogo que ele manteve com Tristão a respeito de política. Mais uma vez, surge a impressão de que o moço não era assim tão bom sujeito quanto pensa o conselheiro:

Outro assunto que nos prendeu também, menos que ela, foi a política, não a de cá nem a de lá, mas a de além e de outras línguas. Tristão assistiu à Comuna, em França, e parece ter temperamento conservador fora da Inglaterra; em Inglaterra é liberal; na Itália continua latino. Tudo se pega e se ajusta naquele espírito diverso. $\mathrm{O}$ que lhe notei bem é que em qualquer parte gosta da política. Vê-se que nasceu em terra dela e vive em terra dela. Também se vê que não conhece a política do ódio, nem saberá perseguir; em suma, um bom rapaz, não me canso de o escrever, nem o calaria agora que ele vai casar; todos os noivos são bons rapazes. (Obra Completa, vol. I, p. 1.188-9)

O narrador de Esaú e Jacó observava, com muita ironia, que o pai de Flora, Batista, era nulo de idéias e pronto para mudar de opinião ao sabor do vento ou do poder. Assim, passa de monarquista conservador a liberal e daí a republicano sem grandes dificuldades. Com Tristão parece não ser diferente, pois, como se vê pelo parágrafo acima, tudo se pega e se ajusta naquele espirito que gosta da política. No entanto, ao final, em oposição ao que diriam outros narradores machadianos, o conselheiro conclui que Tristão é um bom rapaz, mas faz uma ressalva que praticamente anula o elogio: todos os noivos são bons rapaz̧es. Tudo indica - $\mathrm{e}$ Aires não nega — que Tristão não diferia de tantos bacharéis e medalhões que habitavam o universo machadiano, mas o ponto de vista desse observador é outro e apenas o considera um bom rapaz. Mas se o narrador engana-se, voluntariamente ou não, se está pronto a

\footnotetext{
${ }^{125} \mathrm{O}$ entendimento deste trabalho é, portanto, diferente do de John GLEDSON. Em Fiçãa e História, o crítico inglês sugere que Fidélia e Tristão teriam mantido um relacionamento amoroso em Lisboa, quando ela ainda era casada com Noronha, e que o comportamento de ambos no Rio seria mero fingimento. Não é essa a questão que se coloca aqui. O objetivo é apenas assinalar que a visão de Aires é parcial e que o texto apresenta elementos para que se conclua que seus registros, por ignorância ou malícia do diarista, não corresponderiam à realidade, sem, contudo, afirmar - e entende-se que aí está a graça do romance - o que realmente teria ocorrido.
} 
apresentar atenuantes para os atos de seus amigos, o mesmo não se pode dizer do enunciador, que apresenta elementos suficientes para que o enunciatário não se engane junto com Aires. E eis que novamente narrador e enunciador estão em oposição, ainda que mais amigável.

Como ocorria em outros romances, a existência de um outro ponto de vista pressupõe a presença de outro observador que se opõe a Aires, e que abre a possibilidade de outra versão dos fatos. O processo não é inédito: já se fazia bem presente em Dom Casmurro, com a diferença de que agora ele se torna mais sutil e sofisticado. Viu-se que no nível narrativo as diferenças entre os romances são menores do que se pode pensar em um primeiro momento e que a grande diferença que parece existir entre eles decorre do julgamento do narrador a respeito dos fatos narrados. Guiomar não seria menos gananciosa que Sofia, mas o narrador não a mostrava desse modo. O mesmo raciocínio vale para Jorge e Brás Cubas, ambos ociosos e nulos, mas vistos de forma diferente pelo narrador. Pois bem, agora parece haver um retorno a esse narrador mais sereno, pois Aires sempre parece imbuído das maiores boa vontades para com todos. Contudo, o retorno é apenas aparente, pois, se, por um lado, Aires elogia, ou não critica, Tristão, por outro, fica clara a parcialidade do seu ponto de vista e o desejo explícito de procurar não saber. Para encerrar os comentários sobre o romance, recorde-se ainda passagem em que o diplomata afirma que, quando estava na ativa, era muito desconfiado, mas que se aposentou também da desconfiança e a deixava a cargo dos que ainda estavam em exercício. Bento Santiago é descrente de tudo e de todos, mas ainda buscava uma verdade — a dele —; já Aires renunciou até mesmo a essa busca.

[...] Creio nas afeições de Fidélia; chego a crer que as duas [por Noronha e Tristão] formam uma só, continuada.

Quando eu era do corpo diplomático efetivo não acreditava em tanta cousa junta, era inquieto e desconfiado; mas, se me aposentei foi justamente para crer na sinceridade dos outros. Que os efetivos desconfiem! (Obra Completa, vol. I, p. 1.191)

Em uma linha, Aires crê em afeições profundas e eternas; na seguinte, encarrega-se, ele próprio, de destruir ou abalar essa convicção, mas descrendo da própria dúvida: não vale a pena discordar. Pode até ser que Aires seja um desconfiado aposentado, porém, com um enunciado como esse, ele faz o enunciatário desconfiar de Fidélia, pois é como se afirmasse que nem ele próprio acredita em suas afirmações! Na verdade, Aires não seria ingênuo nem 
piegas, mas terrivelmente cético; tão cético que não vê mesmo utilidade em ser cético ou em debater na busca pela verdade, pois a sabe inacessível: que os efetivos desconfiem.

Bosi afirma que em Machado não há grandes destinos a serem cumpridos, apenas existências medíocres, cumpridas sem grandeza. Isso vale também para as vilanias. Não há grandes vilões nos romances; apenas os medíocres, se é que cabe a gradação, apequenando a existência. Mas se Aires vela os crimes de sua classe, o enunciador os desvela, sem, contudo, julgá-lo. Atente-se ainda para a fineza desse enunciador: ao invés de optar por um observador com foco total, que poderia contrapor várias interpretações de um mesmo fato, ele opta por vários observadores, com focos bastante limitados, cujas observações não coincidem com as do narrador, pois revelam outras vozes que se fazem ouvir como que em surdina, criando a polifonia do texto. Em $A$ mão e a luva, o observador relatava o que se passava na mente de cada uma das personagens e apontava as discordâncias relativas aos programas narrativos e contra-programas que executavam. No geral, porém, todas as vozes partilhavam a mesma visão de mundo, próxima da de Guiomar e da do narrador. As coisas se passam de outro modo agora, pois a visão de Aires não é mais única, soberana, uma vez que se abrem outras possibilidades, as quais, inclusive, questionam o narrador.

Nas passagens acima, fica evidente que o campo de visão de Aires é restrito e suas informações, poucas; ele sabe menos, ou tem menor poder de interpretação, que outros atores do enunciado, como D. Cesárea; ele não consegue desvendar o que pensam seus interlocutores, como acontece em relação a Tristão, fato que, paradoxalmente, parece ser, antes de qualquer coisa, uma decisão sua, quando afirma que se aposentou da desconfiança. Enfim, mais uma vez o enunciador optou por explicitar que o narrador sabe menos que ele, como havia feito em Memórias póstumas e Dom Casmurro. Como ocorre em todos os romances, a posição assumida pelo narrador é fragilizada ao longo do texto, o que evidencia que não apenas que o saber do narrador é incompleto, mas equivocado. No caso do Memorial de Aires, esse processo é, ao mesmo tempo, mais sutil e mais explícito que nos demais romances. É mais sutil, na medida em que Aires parece ser um narrador de mais compostura que seus antecessores; é mais explícito, quando se observa que Aires é o único narrador que afirma que seu engano é voluntário. 
Recordando as observações deste capítulo, nota-se que nos quatro primeiros romances e em Quincas Borba o enunciador instaura um observador que, em graus variados, tudo sabe das personagens e da trama. Nesses casos, pode-se dizer, como propõem Greimas \& Courtés (1993: 42), que ocorre uma debreagem cognitiva enunciva, pois o enunciador delega o saber aos sujeitos cognitivos, os observadores instalados ao longo da narrativa. No entanto, como será visto com mais clareza quando se discutir os níveis enunciativos de cada romance, o saber desses narradores, ditos oniscientes, é distinto do saber do enunciador, que possuiria outra visão sobre o narrado. Já em Memórias póstumas, Dom Casmurro e Memorial de Aires, em que o observador principal é sincretizado com um actante da enunciação enunciada, o saber do narrador oscila na medida em que varia o saber do ator com o qual está sincretizado. Nesses casos, ocorre uma debreagem cognitiva enunciativa, pois o enunciador delega o saber a um actante que diz eu. Claramente, o saber desses senhores também não se confunde com o do enunciador, que certamente teria as respostas para suas indagações. Em todos esses casos, o enunciatário desconfia que haveria um outro ponto de vista sobre os fatos narrados, como fica claro em muitas passagens dessas obras. Esaú e Jacó é um caso à parte, pois em alguns casos o observador está sincretizado com Aires, portanto, não pode saber tudo, e noutros (a maioria) não acompanha nenhum personagem e tem uma visão de cima, acerca de tudo que se passa, oscilação que faz com que, ao final, seu saber torne-se mais limitado que o do narrador de Quincas Borba. Essas observações indicariam, portanto, que não é possível depreender um ethos do enunciador tendo por base a delegação do saber, uma vez que as estratégias se alternam ao longo dos romances analisados.

Entende-se, entretanto, que tal impressão se deve ao fato de a constância na instalação do narrador ofuscar outro proceder mais revelador do fazer desse enunciador e do saber que ele delega aos actantes da enunciação enunciada. Trata-se do fato de que o narrador relata não apenas o fazer dos actantes do enunciado, seus programas narrativos, mas também os dos actantes da enunciação enunciada, isto é, dele próprio e do narratário. Tal constatação leva a pressupor a existência de um observador que exerce um fazer cognitivo específico: interpretar o fazer desses sujeitos e o processo de construção da narração. Veja que isso se coaduna às afirmações de vários estudiosos, tantas vezes comentadas, segundo as quais em Machado a narração adquire mais importância do que o narrado. Ora, para que isso seja possível é necessário que alguém observe o processo de narração. Por sua vez, esse fazer demanda a instalação de diversos observadores atentos à narração e que podem estar ou não 
sincretizados com o narrador. Nesse caso, não há exceção à regra: em todos os romances (ainda que em um menor grau em Helena e em Iaiá Garcia), o narrador comenta a própria narração e a leitura realizada pelo narratário, e se o faz é porque há observadores atentos ao fazer desse nível.

A análise do fazer dos narradores demanda a consideração da própria atividade de percepção da realidade e da maneira como os próprios observadores focam e apreendem o mundo que constitui a matéria prima da narração. Para tanto, os conceitos de campo de presença, foco e apreensão, tal como definidos pela semiótica tensiva ${ }^{126}$, serão de grande valia. Nos quatro primeiros romances de Machado, observa-se que o campo de presença do narrador, isto é, grosso modo, o domínio no qual se exerce sua atividade perceptiva é extenso e intenso: ele não apenas sabe tudo o que concerne à sua narrativa, mas também é capaz de fazer julgamentos a esse respeito. É o caso, por exemplo, de Ressurreição, em que o narrador não apenas conhece o íntimo dos personagens melhor do que elas próprias, mas também é capaz de tecer julgamentos sobre o seu fazer. Como o narrador não apenas sabe tudo, mas, além disso, não tem dúvidas a respeito desse saber, seu discurso não expressa outro ponto de vista além do dele: não há, portanto, espaço para outras interpretações. Curiosamente, esse saber hipertrofiado dispensa outras análises, já que os fatos estão bem colocados e demonstrados; são conhecidas sua natureza e composição, não há muito mais a descobrir, nem, portanto, a analisar. Relembre-se a cena em que Guiomar e Luís Alves trocam suas promessas: o narrador limita-se a mostrá-la, sem se deter em todas suas implicações; não haveria nada a ser dito que ele não já não tenha tido. A partir daí, a profundidade desse saber (entendida foco e apreensão conjugados) começa a apresentar um processo descendente, que, apesar de não acompanhar a ordem cronológica dos romances, atinge seu ponto mais átono no Memorial de Aires — ver gráfico na página 224 - , romance cujo narrador talvez seja o que dispõe de menos saber em toda obra de Machado. Consequentemente, como o foco se torna menos intenso, não há mais triagem do que deve ser apreendido, e o sujeito passa a ter que lidar com diversos valores, muitas vezes antagônicos, nascendo aí muitas contradições: a matéria narrada apresenta várias implicações e possibilidades de interpretação e o narrador já não consegue mais se decidir por uma ou por outra. É o caso do diálogo entre Virgília e Lobo

\footnotetext{
${ }^{126}$ Como não é possível, no espaço disponível, fazer uma resenha dessa teoria, remetemos o leitor pouco familiarizado a esses conceitos para os trabalhos de Zilberberg \& Fontanille (Tension et signification. Paris: Mardaga, 1998, p. 91-111) e de Fontanille (Sémiotique du discours. Limoges: Pulin, p. 64-72),
} 
Neves, os quais, à maneira de Guiomar e Luís Alves, mesclam juras de amor com propostas comerciais. No entanto, agora o tom é outro: se havia alguma seriedade da parte dos envolvidos, o mesmo não pode ser dito do narrador, que satiriza tal conduta. Como as cenas em $A$ mão e a luva e em Memórias póstumas são praticamente idênticas, a ausência de ironia no primeiro caso e sua presença no segundo só pode ser decorrente de uma transformação do olhar do narrador, a qual reflete uma mudança nos actantes cognitivos instalados no discurso. O saber não está mais concentrado no narrador, mas pulverizado entre vários actantes cognitivos, cada qual transmitindo sua perspectiva da cena. Por isso, apesar da polifonia, não é mais possível dar uma versão acabada dos fatos, e sobram pontos cegos, que não são esclarecidos pelos narradores (seja Brás Cubas, Bento Santiago ou Aires), e que indicam um déficit de saber a ser compensado: um saber que é virtual e precisa ser realizado. Como o narrador não tem respostas para as próprias perguntas, devido à atonia do foco e à diminuição de sua apreensão da realidade, seu fazer cognitivo nunca se realiza totalmente e o enunciatário nunca entra em plena conjunção com o saber sobre as intenções dos actantes do enunciado. Observe-se que isso ocorre mesmo no caso em que o narrador sabe tudo, como em Quincas Borba: apesar de onisciente, o narrador não consegue discernir claramente os sentimentos, não porque a quantidade de saber tenha diminuído, mas porque seu poder de julgamento, que supõe-se estar ligado ao foco, perdeu-se. Não se pode falar, portanto, em conjunção ou disjunção totais, mas em graus de junção, ou de conjunção, com o saber.

A análise da apreensão da realidade deve ainda ser dividida em dois aspectos, um relativo aos fatos narrados e outro relativo à narração, e considerar dois parâmetros: o saber do narrador em relação ao enunciador e o saber em relação aos actantes do enunciado. Vejase inicialmente o primeiro aspecto, o saber relativo à narração. Em todos os nove romances, o narrador sabe mais sobre a narração que os actantes do enunciado, que naturalmente, desconhecem a condução do texto, ainda que, em alguns momentos, sejam instalados como narratários, como é o caso de Sancha em Dom Casmurro, ou, ainda, que o narratário seja transformado em interlocutor e actante do enunciado, como em Quincas Borba O saber do narrador sobre a narração revela-se, ainda, em sete dos nove romances, muito inferior ao do enunciador, pois com freqüência ele mostra-se inseguro quanto à forma de conduzir a narração e a todo momento tem de explicar por que diz o que diz, justificar-se pela forma como conduz a narração; explicar os títulos que dá (ou não) aos capítulos, e assim sucessivamente. Evidentemente, a dúvida, a insegurança, a imperícia, são do narrador e não 
do enunciador. $\mathrm{O}$ narrador levanta tais questões porque tem em mente um narratário que tem pouco em comum (na verdade é quase uma antítese) com o enunciatário visado pelo enunciador. O narratário pede uma história romanesca, movimentada, com muitas peripécias. Já o enunciatário espera por uma discussão de outro nível, que reflita sobre o próprio fazer literário, sobre a criação de efeitos de verdade. Em miúdos, o narrador se engana não apenas quanto à forma de conduzir a narração, fato que indica que o enunciador sabe mais que ele, mas também em relação a esse fazer ${ }^{127}$. Certo, esse não é bem o caso do Memorial de Aires, cujo narrador mostra-se mais seguro, mais ponderado, e sequer dirige-se ao narratário (nesse caso, figurativizado no papel) para perguntar o que ele pensa e, muito menos, explicar porque narra como narra. No entanto, talvez o caso seja ainda mais grave, pois Aires "pensa" que escreve um diário, que tem como destinatário apenas o papel, quando o sujeito da enunciação sabe que se trata mesmo de um romance e que ele não é um diarista, mas um narrador. O seu engano quanto à narração é, portanto, ainda maior que o dos romances anteriores. Restam agora as duas exceções citadas, em que de fato o narrador mostra-se efetivamente mais seguro: Helena e Iaiá Garcia. Conforme foi visto, nesses romances o narrador não se justifica, pouco se dirige ao narratário e não se detecta nenhuma divergência entre o seu saber e o do enunciador. No entanto, como será visto no próximo capítulo, em Helena essa segurança é abalada pelas Advertências, o que faria de Iaiá Garcia a única exceção de fato.

Resta agora examinar o saber do narrador em relação ao narrado. Nesse caso, observa-se que nos quatro primeiros romances causa-se a impressão de que seu saber igualase ao do enunciador, pois não há nada que ateste o contrário e o leitor não tem de fazer conjecturas sobre o que o narrador quis dizer nem fica com dúvidas acerca de sua própria interpretação, se o narrador foi ou não irônico. Também por isso, a polifonia desses romances, no tocante ao narrador, é sensivelmente menor. Em Memórias póstumas, Dom Casmurro e Memorial de Aires, o narrador sabe claramente menos sobre a matéria narrada que o enunciador, que, por exemplo, poderia esclarecer se Bento Santiago foi ou não traído, sabe que os juízos de Brás Cubas são quase todos equivocados e, ao contrário de Aires, conhece as intenções de Fidélia e Tristão. Quincas Borba e Esaú e Jacó, não se enquadram nem em um grupo nem em outro. De um lado seus narradores sabem mais do que os narradores dos três

\footnotetext{
${ }^{127}$ Evidentemente, o enunciador sempre saberá mais que o narrador. O que se pretende, ao se contrapor o saber de um ao do outro, é que, em alguns romances, cria-se um efeito de sentido segundo o qual o saber de ambos se equivale; em outros, procura-se explicitar essa diferença.
} 
romances citados, já que seriam "oniscientes"; por outro, sabem muitos menos que os narradores das quatro primeiras obras de Machado. Em Esaú e Jacó, por exemplo, o narrador omite uma informação, relativa à sua identidade, que é revelada por outro actante, o editor M. de A.,.

O saber do narrador sobre a matéria narrada apresenta ainda outra configuração quando comparado com o saber dos actantes do enunciado. Nos quatro primeiros romances, em Quincas Borba e em Esaú e Jacó, o narrador sabe mais do que os actantes do enunciado no tocante ao narrado. Até Iaiá Garcia, esse saber é garantido pela onisciência, que corresponde tanto a um foco intenso quanto a uma percepção extensa; já em Quincas Borba e em Esaú e Jacó, esse saber é garantido apenas pela apreensão extensa, uma vez que o foco sofre uma perda de tonicidade significativa, não permitindo mais ao narrador ser tão categórico quanto antes. Por outro lado, em Memórias póstumas, Dom Casmurro e Memorial de Aires, o saber do narrador sobre o narrado equivale ao das demais personagens, e nada mais é do que a somatória das informações que recebe (sem saber, nas mais das vezes, se são verdadeiras ou não), aliada aos seus próprios conhecimentos. Naturalmente, como em Memórias póstumas e Dom Casmurro, o narrador narra depois que todos os fatos narrados se concluíram, causando a impressão de que ele saberia mais do que os demais. O que não é verdade, pois Brás Cubas, por exemplo, não tem capacidade de discernir as idéias de Quincas Borba, o filósofo, nem as intenções da irmã e do cunhado. Já Bento Santiago passa toda a narrativa tentando descobrir se foi ou não traído pelas pessoas que lhe eram mais próximas; e o conselheiro Aires enganase com o comportamento de Tristão e Fidélia tanto quanto o casal Aguiar ou Campos e, provavelmente, mais do D. Cesária, uma vez que ela parece conhecer o jovem casal melhor que ele próprio.

O saber do narrador em relação ao enunciador e em relação aos actantes do enunciado é apresentado no quadro a seguir. Na primeira coluna pode-se ver o saber do narrador sobre o narrado; na segunda, seu saber sobre a narração. Observa-se que de Ressurreição até Iaiá Garcia o enunciador cria o efeito de sentido de que o narrador sabe tanto quanto ele sobre o narrado e que a partir de Memórias póstumas cria-se o efeito oposto, de que o saber do narrador é inferior ao do enunciador. O saber do narrador em relação aos actantes do enunciado apresenta outra disposição: com exceção de Memórias póstumas, Dom Casmurro e Esaú e Jacó, o narrador sempre sabe mais que as personagens. Por outro lado, quando o saber em questão refere-se à narração, e tem como parâmetro o enunciador, a uniformidade é 
maior. Nesse caso, conforme citado, as exceções são Helena e Iaiá Garcia. Já em relação aos actantes do enunciado o saber do narrador sobre a narração é sempre superior. Faça-se ainda a ressalva de que o quadro abaixo fornece uma idéia um pouco distorcida do que foi discutido, pois, em todos os casos, há graus de variação não percebidos abaixo. Por exemplo, o saber de Aires em tanto em relação ao narrado quanto em relação à narração é muito inferior do que o dos demais narradores, fato não evidenciado abaixo.

\begin{tabular}{|c|c|c|}
\hline Romance & saber sobre o narrado & Saber sobre a narração \\
\hline Ressurreição & $S_{\text {enun }}=S_{\text {nar. }}>S_{\text {act. enun }}$ & $\mathrm{S}_{\text {enun }}>\mathrm{S}_{\text {nar. }}>\mathrm{S}_{\text {act. enun }}$ \\
\hline A mão e a luva & $S_{\text {enun }}=S_{\text {nar. }}>S_{\text {act. enun }}$ & $S_{\text {enun }}>S_{\text {nar. }}>S_{\text {act. enun }}$ \\
\hline Helena & $S_{\text {enun }}=S_{\text {nar. }}>S_{\text {act. enun }}$ & $S_{\text {enun. }}=S_{\text {nar. }}>S_{\text {act. enun }}$ \\
\hline Iaiá Garcia & $\mathrm{S}_{\text {enun }}=\mathrm{S}_{\text {nar. }}>\mathrm{S}_{\text {act. enun }}$ & $\mathrm{S}_{\text {enun }}=\mathrm{S}_{\text {nar. }}>\mathrm{S}_{\text {act. enun }}$ \\
\hline Memórias póstumas & $S_{\text {enun }}>S_{\text {nar. }}=S_{\text {act. enun }}$ & $S_{\text {enun. }}>S_{\text {nar. }}>S_{\text {act. enun }}$. \\
\hline Quincas Borba & $S_{\text {enun }}>S_{\text {nar. }}>S_{\text {act. enun }}$ & $S_{\text {enun }}>S_{\text {nar. }}>S_{\text {act. enun }}$. \\
\hline Dom Casmurro & $\mathrm{S}_{\text {enun }} \cdot>\mathrm{S}_{\text {nar. }}=\mathrm{S}_{\text {act. enun }}$ & $\mathrm{S}_{\text {enun }}>\mathrm{S}_{\text {nar. }}>\mathrm{S}_{\text {act. enun }}$ \\
\hline Esaú e Jacó & $\mathrm{S}_{\text {enun }}>\mathrm{S}_{\text {nar. }}>\mathrm{S}_{\text {act. enun }}$ & $\mathrm{S}_{\text {enun }}>\mathrm{S}_{\text {nar. }}>\mathrm{S}_{\text {act. enun }}$ \\
\hline Memorial de Aires & $\mathrm{S}_{\text {enun }}>\mathrm{S}_{\text {nar. }}=\mathrm{S}_{\text {act. enun }}$. & $\mathrm{S}_{\text {enun }}>\mathrm{S}_{\text {nar. }}>\mathrm{S}_{\text {act. enun }}$ \\
\hline
\end{tabular}

Onde:

$S_{\text {enun. }}=$ saber do enunciador, $S_{\text {nar. }}=$ Saber do narrador e $S_{\text {act. enun. }}=$ saber dos actantes do enunciado

A redução do saber do narrador, analisada em termos de tensividade, pode ainda ser vista no gráfico abaixo, que apresenta no eixo horizontal o foco, e no vertical, a apreensão .

Foco e apreensão do narrador nos romances de Machado de Assis

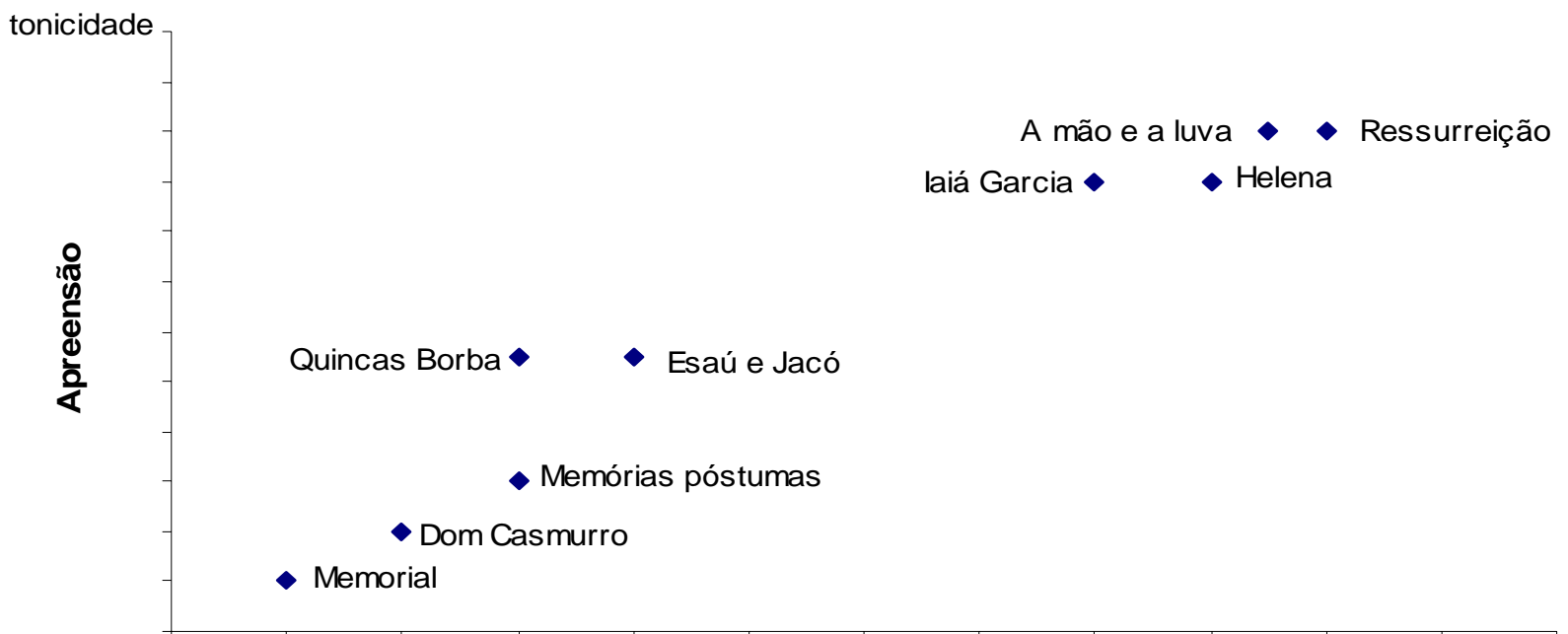


Como se pode observar, o foco e apreensão do narrador mantêm um comportamento convergente: o decréscimo de um leva ao decréscimo ou à estabilização do outro; porém, não na mesma proporção: por exemplo, a redução na extensidade da apreensão do narrador de Quincas Borba em relação ao de Iaiá Garcia é relativamente pequena, enquanto a perda de intensidade do foco é muito maior: embora os dois narradores sejam oniscientes, o foco do narrador de Quincas Borba é átono o que permite que outros actantes apresentem outra perspectiva dos fatos narrados, diferente da do narrador.

A redução do foco e da apreensão que o narrador tem da matéria narrada apresenta como contrapartida o aumento do número de observadores e, consequentemente, no nível discursivo, o aumento do número de vozes instaladas no enunciado. Recorde-se a cena em que Aires contempla Tristão, com o olhar perdido, fumando um charuto. Aires supõe que ele sonhava com o altar e a noiva, mas o desfecho da narrativa sugere, como ficou dito, que o devaneio tinha outra causa, mais prática: a tribuna e câmara em Lisboa. Outro narrador saberia exatamente o que Tristão pensa, mas a apreensão e o foco que Aires tem da realidade são menores. Contudo, há, ao longo texto, elementos que apontam para a possibilidade de engano de Aires, fato que marca a presença de outros observadores com outras perspectivas dos fatos; por exemplo, os que estão em sincretismo com D. Cesária ${ }^{128}$. Como não há apenas uma perspectiva, mas vários observadores sincretizados em um ator ou em vários atores, o sujeito se torna ele próprio dividido, dando origem a um mundo também difuso, cuja unidade é difícil de ser obtida. Observe-se, ainda, que a visão de um mundo fragmentado é compatível com um sujeito que tem um foco e uma apreensão átonos, conforme apontam Zilberberg e Fontanille (1998: 91-111). Trata-se, justamente, do mundo exibido pelos narradores a partir de Memórias póstumas.

Mas... essas considerações, juntamente com o gráfico acima, não confirmariam a existência de duas fases na obra de Machado; portanto, de dois ethos? Entende-se que não. Primeiro, porque as considerações feitas até o momento não indicam uma mudança nos valores instalados pelo enunciador no discurso e nem mesmo na relação fórica que o narrador mantém com eles. Tome-se o caso de Helena que tem sido considerada uma obra romântica pela crítica. Cabe perguntar: o que há de romântico ou de ingênuo em uma

\footnotetext{
${ }^{128}$ Com relação ao já citado episódio de Luís Alves e Guiomar, que, ao final de A mão e a luva, prometem auxiliar-se mutuamente para ascender socialmente, não se pode descartar a ironia, ainda que essa seja bem menos perceptível que em Memórias póstumas. Concordando com essa afirmação estaria o título da obra que também sugere essa possibilidade e a advertência, que será estudada no capítulo seguinte.
} 
narrativa sobre alguém que abandona o pai para receber a herança do amante da mãe e ainda se faz passar quem não é? De igual modo, em que medida a atitude de Guiomar difere da de Virgília e da de Sofia? Não são todas movidas pelo cálculo? E Félix, não é sancionado de forma negativa pelo narrador por ter buscado afeições íntimas? E será que Luís Alves, Estácio, Jorge, Brás Cubas, Pedro \& Paulo e Tristão são, de fato, tão diferentes quanto aparentam ser ou é a conduta do narrador que nos faz vê-los de formas distintas ${ }^{129}$ ? Será que a alegada diferença entre eles não decorre do fato de Jorge e Estácio serem apresentados por um narrador seguro de si enquanto os demais têm de se contentar com um narrador bisonho, claudicante, de espírito dobre? Aliás, atente-se para o fato de que nenhum narrador machadiano condena os medalhões que pululam em toda a obra. Aires não critica Tristão, Pedro ou Paulo; nem o narrador de Quincas Borba o faz em relação à Sofia; nem Brás Cubas ou Bento Santiago proferem qualquer autocrítica que seja digna do nome. O que acontece é que a tensão entre esses sujeitos e seus objetos (os acontecimento narrados) se tornou átona e permitiu que os pontos de vista de outros observadores instalados pelo enunciador manifestassem posições diferentes sobre os fatos. Esse processo implica, como já foi dito, a presença de observadores de um outro nível, os quais informam não mais sobre o fazer dos actantes do enunciado, mas o da enunciação enunciada. São actantes que, apesar de pertencerem ao mesmo nível do narrador, não têm expressão de voz, o que, contudo, não os impede de expressarem um ponto de vista da enunciação sobre os fatos narrados. Recorde-se a passagem de $A$ mão e a luva em que o narrador conta que é privilégio do romancista e do leitor ver no rosto dos personagens o que outros não podem ver. Talvez ela pudesse ser modificada para dizer que é privilégio do enunciador e do enunciatário ver aquilo que o narrador não pode ver, o que pressupõe a presença de um observador que observa o fazer do narrador, tanto ao narrar quanto ao tirar suas conclusões.

Em decorrência do aumento do número de actantes cognitivos, a polifonia dos textos aumenta. Inicialmente, não se observam muitas vozes presentes no discurso do narrador. Depois, a partir de Iaiá Garcia, os discursos começam a se mostrar polifônicos, mas

\footnotetext{
${ }^{129}$ Veja-se, por exemplo, o comentário de Schwarz (1992: 116) sobre Jorge:

"Jorge é boa pessoa, respeitoso e grave nas atitudes. Não impede que seja irresponsável, inconstante e nulo, - o gênero de cavalheiro estimável que Machado estudava e não ousava ainda qualificar e que já nas Memórias póstumas o narrador chamaria de "um compêndio de trivialidade e presunção"
}

Entende-se que a grande maioria dos jovens heróis machadianos (senão todos) são compêndios de trivialidade ou presunção, a diferença é que alguns têm esses atributos realçados e outros não. 
ainda no nível do enunciado, como no monólogo de Jorge e nas palavras que lhe são dirigidas por Procópio. Com Memórias póstumas, a polifonia invade o discurso do narrador, de modo que sempre se podem ouvir duas vozes, como no parágrafo em que Brás Cubas lamenta o fato de Eugênia ser bonita e coxa: há a voz do narrador e a de outro locutor que nega o que ele afirma e revela sua completa falta de caráter. A polifonia - responsável também pelo aprofundamento das análises presentes nos romances machadianos (aliás, notável desde as primeiras obras) - seria decorrente do aumento do número de observadores, o qual tem como contrapartida, no nível discursivo, o aumento do número de vozes que expressam os diferentes pontos vistas sobre a matéria narrada. Nasce, assim, uma análise muito mais arguta dos fatos expostos. Um indício pode ser visto, por exemplo, nas afirmações de Augusto Meyer. Em O homem subterrâneo ${ }^{130}$, o crítico comenta a volúpia pela análise do narrador machadiano e o amor da análise pela análise e os associa às diversas máscaras superpostas deste voluptuoso da acrobacia bumorística [com as quais] podemos compor uma cara sombria (p. 14). Ora, o que Meyer chama de máscaras superpostas do narrador machadiano, entendemos ser fruto dos diversos actantes cognitivos instalados que não permitam que se saiba exatamente qual o ponto de vista da instância da enunciação. Em todo o texto, o crítico aponta ainda os pontos em comum entre a obra de Machado e a de Dostoievski, autor cujos romances, conforme ensina Bakhtin em Problemas da poética de Dostoievski, são claramente polifônicos e nos quais a voz do "autor" se apaga sob as vozes de seus heróis.

As observações de Meyer lembram que outras questões abordadas nesse item também têm sido discutidas pela crítica literária, em uma outra abordagem, que é a sua. A lista é extensa e, por isso, a discussão se centrará em dois pontos principais, mais diretamente relacionados às afirmações acima. Em Ao vencedor as batatas, na conclusão do estudo dedicado a Iaiá Garcia, Roberto Schwarz afirma que a reviravolta na obra de Machado deu-se, em parte, pelo fato de o autor transformar em elementos centrais da trama personagens que antes eram apenas periféricos. É o caso, por exemplo, do mau-caratismo de Procópio, que se fará presente em Memórias póstumas, e da relação de Miss Oswald com a Baronesa em $A$ mão e a luva que se tornará central em Dom Casmurro com o José Dias. Schwarz mostra também que o comportamento cínico do narrador já se fazia presente em outra chave, por exemplo, em $A$ mão e a luva, e, pode-se acrescentar, em Helena. Pois bem, se esses elementos já estavam presentes na obra, o que os impedia de se manifestarem? Porque não são percebidos de

\footnotetext{
${ }^{130}$ In Machado de Assis. Rio de Janeiro: Livraria São José, 1958, p. 11-9
} 
pronto, como acontece com os últimos romances? Entende-se que é justamente o olhar do narrador que, então, focava outras questões como a ascensão social, filtrando demais aspectos que assim ficavam de escanteio. Com o maior enfraquecimento desse foco, aliado à uma menor diminuição da apreensão, esses elementos deixam de ser filtrados e passam a se tornar também centrais, dando origem a valores multifacetados, e não mais absolutos, como eram anteriormente. Daí a dificuldade, por exemplo, de saber a opinião de Aires acerca dos fatos que ele próprio narra.

O segundo aspecto está relacionado ao primeiro. A crítica machadiana tem também apontado para o fato de que a mudança na obra de Machado, de que resultaria a divisão de sua obra em duas fases, seria resultado de uma mudança do ponto de vista do narrador, que passaria a "narrar de cima", isto é, da perspectiva daqueles que já teriam ascendido socialmente. Talvez seja interessante propor uma outra visão do mesmo processo. De fato, a mudança na obra de Machado (sem que isso autorize uma divisão em duas fases) está relacionada, sim, a uma mudança na perspectiva do narrador, ocasionada pelo modo de percepção da realidade. Todavia, a topologia envolvida não é de natureza social, pois a ideologia dominante em todos os romances sempre foi a da classe dominante - basta que se lembre a sanção final de Félix, em Ressurreição; o discurso de Salvador, em Helena; ou o tom geral de $A$ mão e a luva, por exemplo. Desse modo, a razão da mudança está ligada à perda de tonicidade do campo perceptivo, que, conforme foi citado, reduz a percepção que o sujeito tem do mundo. A intimidade bumorística do narrador que se confessa praticante do arbítrio, para lembrar as palavras de Schwarz, não decorreria da ascensão social de Joaquim Maria Machado de Assis refletida no narrador (pois nada se sabe desse cidadão), mas resultaria da perda da tensão da relação deste com a matéria narrada, que permitiria o surgimento de visões que não são as da classe dominante, ou melhor, que lançam um olhar mordaz sobre o olhar da classe dominante. Em outras palavras, o narrador passa a saber menos; e não, mais.

A redução do saber do enunciador e o aumento da polifonia do texto não são processos que ocorrem de forma dissociada do surgimento do humor. Como ensina Bakhtin (1981: 169-71), a paródia sempre está relacionada a um confronto de vozes à possessão de um discurso por outro, e o uso do discurso possuído para fins que lhe seriam estranhos. A paródia sempre implica um discurso que tem por objeto não a realidade, mas outro discurso, 
aquele que é possuído ${ }^{131}$. Ora, todas as obras de Machado refletem esse esquema: são narrativas sobre a elaboração de narrativas que acabam por narrar algo como que de forma involuntária. Por exemplo, ao narrar sua vida, Brás Cubas narra sua própria estultice; e as memórias de Aires revelam também sua miopia. O texto final que o leitor tem em mãos se torna, desse modo, híbrido: é metade "obra" do narrador, metade "obra" de outras vozes nele instaladas. Trata-se de discursos que passam, então, a lutar. Como afirma Bakhtin, (1993. 390) trata-se de uma luta entre linguagens e entre estilos de linguagens [...] não de um diálogo do sujeito, nem de uma abstração semântica e sim do diálogo entre dois pontos de vista lingüistica que não se podem traduæiir reciprocamente.

Mas, afinal, o que tudo isso tem que ver com o ethos do enunciador, assunto principal e sempre esquecido por esta tese? As observações realizadas até agora mostram a unicidade do fazer do sujeito da enunciação - e cabe lembrar que o caso oposto criaria sérios obstáculos à definição de um ethos — e, de esse modo, também confirma as características encontradas anteriormente: o enunciador dessas obras é cético, frio, objetivo, dissimulado, característica que agora é confirmada na medida em que o enunciador dissimula seu pensamento por meio de narradores que dizem o oposto do que ele quer dizer, ou mesmo que não transmitem todos seu pensamento. Todavia, a paródia revela ainda outra face do enunciador: seu caráter zombeteiro, irreverente, que ele se vale do riso para propor uma outra ordem de tudo.

Contudo, essas observações talvez gerem um questionamento: em que medida são aplicáveis ao conjunto da obra de Machado? Afinal, se o tom jocoso de Memórias póstumas, Quincas Borba e Esaú e Jacó é relativamente evidente, o mesmo não pode ser afirmado a respeito dos demais romances. De fato, mas em todos eles observa-se o que é mais importante: a instalação de vozes que entram em conflito com a do narrador e que transformam o seu discurso em objeto de imitação. É isso que se espera demonstrar no capítulo seguinte.

${ }^{131}$ A respeito dos sonetos paródicos que abrem Dom Quixote, Bakhtin (1993) observa que não se pode relacioná-los ao gênero soneto, pois se trata, antes de mais nada, de um objeto de representação que assim, torna-se personagem da paródia. Em seguida, conclui: uma paródia pode representar e ridicularizar estas particularidades do soneto bem ou mal, de maneira muito profunda ou muito superficial. Mas, para nós, em qualquer caso, não se trata de um soneto e sim da imagem de um soneto (Bakhtin, Op. Cit.: 372). Entende-se, por razões a serem explicadas, que nos romances de Machado trata-se antes de ver na narração um objeto a ser imitado. 


\section{Niveis enunciativos}

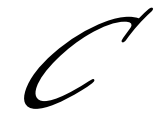

omo se sabe, a debreagem é a operação pela qual, ao enunciar, o sujeito projeta para fora de si as categorias semânticas relativas à pessoa, ao tempo e ao espaço da enunciação como um ele (não-eu), um então (não-agora) e um (lá, não-aqui). Conforme observam Greimas \& Courtés (1993: 79), no ato de linguagem se opera uma espécie de cisão que opõe, de um lado, a representação actancial, temporal e espacial da enunciação; e, de outro, mas de maneira implícita, o sujeito, o tempo e o espaço reais da enunciação, que sempre permanecem pressupostos ao texto. O enunciador continua, portanto, fora do enunciado, mas pode decidir pela projeção, no próprio enunciado, de uma simulação da enunciação que será, então, dita enunciada. Isso se faz pela inscrição, no texto, dos actantes (o eu e o tu), do tempo (o agora) e do local (o aqui) da enunciação. Naturalmente, o enunciador pode optar, pelo efeito oposto, de exclusão da enunciação do enunciado. Nesse caso, projetará no enunciado um ele, um então e um lá. Como se sabe, o processo não se esgota aí, pois tanto a enunciação enunciada quanto o enunciado enunciado podem dar origem a novas debreagens, realizando, assim, debreagens internas de $2^{\circ}, 3^{\circ}$, ou mesmo infinitos graus. Claro, não são os actantes instalados no discurso os responsáveis por tais projeções, mas o enunciador original, que se vale dos actantes já instalados para criar novos simulacros da atividade enunciativa, que assim é enunciada no texto. Com isso, criam-se vários efeitos; por exemplo, o de realidade, de que as coisas se passaram realmente como narrador, de que alguém de fato pronunciou as palavras que constam após o travessão, as quais teriam ido direto do produtor (o enunciador original) ao consumidor (o destinatário final) sem nenhuma intervenção.

Para este trabalho, o aspecto mais relevante do efeito de realidade criado não consiste na atestação da veracidade dos fatos, mas na simulação da própria atividade enunciativa, pois o conteúdo do enunciado como um todo passa a ser, em maior ou menor grau, a própria enunciação. Há outra conseqüência importante para os fins aqui desejados: ao enunciar a enunciação, o enunciador acaba por provocar um efeito de anulação da oposição entre os actantes do enunciado e os da enunciação, como se o eu enunciador fosse o mesmo eu 
projetado e como se não houvesse ninguém pressuposto no texto, e tudo estivesse lá. Para se ter uma idéia melhor de todos os fatos implicados no processo, examinem-se, brevemente, duas estrofes do belo poema Enquanto a chuva cai..., de Manuel Bandeira (1993: 67):

ENQUANTO A CHUVA CAI...

$[\ldots]$

A chuva cai. A chuva aumenta.

Cai, benfazeja, a bom cair!

Contenta as árvores! Contenta

As sementes que vão abrir!

Eu te bendigo, água que inundas!

Ó água amiga das raízes,

Que na mudez das terras fundas

Às vezes são tão infelizes.

[...]

Na primeira estrofe, não há nenhum eu instalado no texto; a instância da enunciação opta por se manter afastada do enunciado e nele instala apenas um sujeito, figurativizado na chuva, que exerce dois fazeres: cair e contentar outros sujeitos, estes, por sua vez, figurativizados em árvores e sementes. No entanto, na segunda estrofe, a enunciação passa a se projetar no enunciado, não apenas pela presença de um verbo discendi (bendizer), mas também pela explicitação do eu que estava pressuposto na estrofe anterior. Em seguida, o mesmo sujeito chuva, apesar de inanimado, é modalizado como detentor de afeto e, no mesmo processo, deixa de ser um ele para se transformar em tu (Ó água amiga das raízes), constituindo-se, assim, actante do diálogo que se estabelece com o $e \varkappa$. Desse modo, o objeto do poema deixa de ser apenas o cair da chuva e a inundação que ela provoca, e passa a ser, também, o diálogo que se estabelece entre a instância enunciação, agora enunciada, e a chuva, com a explicitação de sua atividade ilocutória (Eu te bendigo). É bom que fique claro que se trata "apenas" de um efeito de sentido, pois continua a haver um $e u$ pressuposto ao verso Eu te bendigo... e, mesmo que o poeta optasse por afirmar en digo que te bendigo, ainda assim continuaria a haver um pressuposto e, assim sucessivamente.

Contudo, deve-se atentar para uma diferença capital entre a debreagem de primeiro grau e as que se seguem a ela. Na primeira, o enunciador original, o produtor físico do enunciado, permanece pressuposto, ao passo que nas debreagens seguintes isso não acontece, pois seu enunciador, ou seja, seu "produtor físico", será um ator do nível imediatamente acima de onde foi debreado o discurso segundo. Assim, enquanto a primeira debreagem deve construir seu próprio sistema de referencialização, as demais já nascem referencializadas, na 
maior parte dos casos, pela debreagem anterior a ela, criando a ilusão de que o contexto de sua enunciação é o do nível anterior. É o que afirmam Greimas \& Courtés (1993: 80):

[...] cada debreagem interna produz um efeito de referencialização: um discurso de segundo grau, instalado no interior da narrativa, dá a impressão de que essa narrativa constitui a "situação real" do diálogo, e, inversamente, uma narrativa desenvolvida a partir de um diálogo inscrito no discurso, referencializa esse diálogo.

É essa questão que interessa mais de perto aqui: as múltiplas debreagens criam a impressão de deslocar o referente original e re-situar o discurso seguinte, provocando uma espécie de re-arranjo na enunciação como um todo. Embora o discurso citante e o citado tenham a mesma origem, e o enunciador real de ambos permaneça pressuposto, cria-se a ilusão de que o enunciador do discurso citado seria um ator do nível anterior.

Uma debreagem de segundo grau pode ter inúmeras funções, mas todas, de um jeito ou de outro, relacionadas às finalidades do discurso primeiro que a instaurou, que é, na verdade, sua razão se ser. Claro, nunca é demais lembrar que a enunciação original, física, do discurso como um todo permanece inalterada, mas, a cada debreagem, ela é substituída pela situação do discurso que a instaurou. A debreagem seguinte produz, portanto, um efeito de distanciamento em relação à enunciação da primeira, e, ao mesmo tempo, cria um novo referencial para a narrativa que virá. Veja-se, por exemplo, o início do conto Idéias do canário, de Papéis avulsos (1882):

Um homem dado a estudos de ornitologia, por nome Macedo, referiu a alguns amigos um caso tão extraordinário que ninguém lhe deu crédito. Alguns chegaram a supor que o Macedo virou o juízo, Eis aqui o resumo da narração.

No princípio do mês passado — disse ele [...] (Obra Completa, vol. II, p. 611)

O narrador primeiro, implícito, instaura um narrador segundo, Macedo, que conduz a narração. A narração de Macedo já nasce referencializada pela primeira que lhe servira de contexto: sabe-se que ela foi enunciada em uma roda de amigos, os quais não lhe deram crédito e alguns chegaram mesmo a pensar que seu enunciador perdera o juízo. Ao delegar a palavra a Macedo no parágrafo seguinte, o narrador primeiro distancia-se da narrativa desse narrador segundo e lava as mãos, pois já relatara as condições de recepção da narrativa: se o narratário acreditar na narração de Macedo, será por sua conta e risco. Note-se que o enunciador e a situação de enunciação do conto estão pressupostos e não se sabe em que condições ocorreram, mas o contexto da narrativa segunda, que começa com No princípio do mês passado..., é claramente identificado. Ou seja, a narração segunda ocorreu um mês antes da 
narração primeira, que aconteceu em data não identificada. A primeira conseqüência é que a narração segunda, de Macedo, perde parte de sua autonomia, pois já nasce configurada como extraordinária, no sentido negativo do termo. A segunda conseqüência é que o narrador primeiro torna-se mais distante, uma vez que o enunciatário não tem mais contato com ele, e sim com o interlocutor, Macedo, que assumiu, por delegação, a narração. Observe-se que a imagem do enunciador original também muda: ele não pode ser caracterizado como um enunciador de histórias fantásticas, mas como um enunciador que conta histórias em que há alguém que conta narrativas fantásticas; trata-se de um enunciador que constrói metáforas da atividade enunciativa.

Veja-se, agora, um exemplo bem diferente, o do conto Ponto de vista (Histórias da meianoite, 1873), todo ele composto de cartas trocadas entre Raquel e sua amiga, D. Luiza:

\author{
PONTO DE VISTA
}

I / A.D. LUÍZA P...., EM JUIZ DE FORA

Corte, 5 de outubro.

Não me dirá a quem entregou você as encomendas que lhe pedi? Na sua carta vem mal escrito o nome do portador, e até hoje nem sombra dele, quem quer que seja. Será o Luís?

Ouvi dizer que você vem para cá passar algum tempo; estimaria muito que assim fosse. Havia de gostar disso agora, apesar do calor, que tem sido forte. Hoje entretanto temos um dia excelente.

Ou então, no caso de não vir, estimaria muito eu ir para lá; [...] $[\ldots]$

Raquel

(Obra Completa, vol. II, p.240 - grifos meus)

O enunciador original do texto acima permanece pressuposto; tudo o que se sabe, pelo nome na capa do livro, é que se trata de certo Machado de Assis, cujo caráter não pode ser confundido com o do homem Joaquim Maria Machado de Assis. O narrador também permanece implícito e o conto dá a impressão de narrar-se a si mesmo, uma vez que é um interlocutor, Raquel, que assume o papel de "enunciador” do texto acima, e D. Luíza, sua interlocutora, o de "enunciatária". Sabe-se disso por conta indicação acima do primeiro parágrafo e da assinatura ao final do texto acima; a qual, juntamente com a diagramação, indica que se trata de uma carta. Esses mesmos índices permitem descobrir os actantes, o tempo e o espaço da enunciação da carta: os pronomes me e eu referem-se a Raquel e os pronomes você e the à D. Luíza. O advérbio cá indica o Rio de Janeiro, e o lá, Juiz de Fora, 
onde reside a destinatária da carta. Finalmente, os advérbios hoje e agora se referem ao dia 5 de outubro de um ano qualquer, sendo que o uso da palavra corte para indicar o Rio de Janeiro permite saber que a correspondência foi trocada em algum ano entre 1822 e 1889, período em que a cidade foi corte do Império Brasileiro. Mais adiante, o conto traz as cartas de D. Luíza a Raquel, havendo então a inversão dos dêiticos de pessoa e de espaço e alteração dos dêiticos relativos ao tempo. Em todo o conto, as únicas marcas do discurso primeiro são os títulos e a numeração dos capítulos, cada qual correspondendo a uma das cartas trocadas entre as missivistas. Os interlocutores assumem o lugar de enunciador e, assim, causam a impressão de que a situação de enunciação varia de acordo com cada carta, muito embora a enunciação real se mantenha estável, e seu contexto, desconhecido. Ou seja: a segunda debreagem deslocou todos os referentes da "enunciação" da carta e os deixou mais distantes da enunciação primeira. O enunciador verdadeiro é como que enfraquecido, uma vez que ele não seria mais o autor do conto, mas somente alguém que recolheu as cartas e as publicou. Evidentemente, não é assim que as coisas se passam de verdade; trata-se apenas de um efeito de sentido, mas é justamente esse fato que torna as múltiplas debreagens um instrumento importante na definição do caráter do enunciador que, não se deve esquecer, não pode ser confundido com o do sujeito real.

Outro caso é o do já citado conto O segredo do Bonzo, em que o narrador primeiro delega a voz a Fernão Mendes Pinto, que conduz toda a narrativa:

\section{O SEGREDO DO BONZO}

Capítulo inédito de Fernão Mendes Pinto

Atrás deixei narrado o que se passou nesta cidade Funchéu, capital do reino de Bungo, com o Padre-Mestre Francisco, e de como el-rei se houve [...]

Um dia andando a passeio com Diogo Meireles, nesta mesma cidade Funchéu, naquele ano de $1522[\ldots] \ldots$ (Obra Completa, vol. II, p.323)

Novamente, a participação do narrador primeiro limita-se ao título do conto e à explicação, na linha seguinte, de que se trata de um capítulo inédito de Fernão Mendes Pinto. As condições de produção do conto não são conhecidas, mas sabe-se que o eu, sujeito do verbo deixar, é Fernão; que o seu aqui é a cidade de Funchéu, como indica o demonstrativo esta; e que seu texto foi escrito muitos anos depois de 1522, como dá a entender o demonstrativo aquele. Após as duas linhas iniciais, é Fernão Mendes Pinto que conduz a 
narrativa, apresentando-se como o próprio enunciador. Como ficou dito acima, outros textos indicam que Fernão era tido por mentiroso contumaz, fato que desacredita sua narrativa, mas não o narrador primeiro, que surge como provável historiador, ou mesmo um erudito, uma vez que Fernão Mendes Pinto não é, ao menos atualmente, personagem muito conhecido. Assim, o mesmo fato que desabona a narrativa segunda - a personalidade de Fernão Mendes Pinto — valoriza a curtíssima narrativa primeira.

Naturalmente, o uso de múltiplas debreagens não é privilégio de Machado; a literatura está repleta delas, aliás, conforme foi visto quando se discutiu a instalação do narrador. $\mathrm{Na}$ ocasião (p. 132-3) , citou-se o exemplo de Cervantes, que no início da segunda parte do Dom Quixote instaura um narrador primeiro, não nomeado, que relata os problemas para a elaboração dessa parte do texto e depois delega a palavra para o narrador segundo. $\mathrm{O}$ procedimento já havia sido adotado no início do romance, quando o enunciador instaura o narrador primeiro, que se dirige ao leitor em termos que familiares:

Podes crer-me, desocupado leitor - e não preciso jurar - que eu quisera fosse este livro, como filho que é do entendimento, o mais formoso, galhardo e discreto que se pudera imaginar. Foi-me impossível, todavia, contrariar a ordem da natureza, já que nesta cada coisa engendra seu semelhante. [...] Mas eu, que, embora pareça o pai, sou padrasto de Dom Quixote, não quero deixar-me arrastar pela rotina nem suplicar-te quase com lágrimas nos olhos, como outros fazem, leitor caríssimo, que perdoes ou dissimules as faltas que neste filho meu vires[ ...](Cervantes, 1954, V. I, p. 101-2)

Cervantes instaura um narrador primeiro, que considera a si mesmo sem talento, o texto, sem qualidades, e o narratário, um desocupado. Findo o prólogo, o enunciador instaura diversos outros narradores que compõem "sonetos" em homenagem a Dom Quixote, a Sancho Pança e até mesmo ao cavalo do herói Rocinante. Depois, finalmente, instaura o narrador que contará a história de do cavaleiro andante. Há, portanto, três níveis enunciativos que precedem a trama central e que re-contextualizam a trama, a qual, tendo os narradores e narratários que tem, só pode ter um tom não sério. ${ }^{132}$

Veja-se agora o caso do conto $A$ estalagem das duas feiticeiras - um achado, de Joseph Conrad, pertencente à coletânea Dentro das marés. Nela, o narrador primeiro explica que o achado do título do conto deve-se ao fato de a narrativa ter sido encontrada em uma caixa de livros de

\footnotetext{
${ }^{132}$ E aí não custa lembrar a afirmação de que os sonetos que abrem Dom Quixote não louvam os homenageados, mas parodiam a forma poética "soneto", que, assim, se torna o verdadeiro objeto desses textos.
} 
segunda mão comprados em Londres numa rua que não existe mais, de um livreiro no último estágio de decadência. Em seguida, o narrador primeiro dá mais detalhes:

Uma confusão de páginas soltas no fundo da caixa instigou minha curiosidade. A caligrafia compacta, caprichada e regular não era atraente à primeira vista. Mas num certo lugar vi a declaração de que no a.D. 1813 aquele que escrevia tinha vinte e dois anos. Vinte e dois anos é uma idade interessante em que se fica facilmente inquieto e facilmente assustado, pois a faculdade de reflexão é fraca e o poder de imaginação forte. (Conrad,. Joseph. Dentro das marés. Trad. Julieta Cupertino. Rio de janeiro: Revan, 2004. p. 128 - grifos meus)

Inicialmente, o narrador primeiro deprecia a narrativa segunda ao sublinhar as condições em que teve acesso a ela; em seguida, lança dúvidas sobre o narrador segundo (aos vente e dois anos se fica facilmente assustado) e exime-se de qualquer responsabilidade sobre o conteúdo de seu achado. Depois, em outro momento, contextualiza situação da narração segunda: explica, então, que o narrador segundo contava com aproximadamente 60 anos quando escreveu sua narrativa (portanto, cerca de 40 anos depois ter vivenciado os fatos narrados por ele). Como o narrador primeiro adquiriu a caixa de livros no começo do século $\mathrm{XX}$, entende-se que se teriam passado cerca de 60 anos desde que da narrativa segunda foi escrita e quase um século desde a ocorrência dos fatos nela narrados. No entanto, o aspecto mais interessante está no fato de os dois narradores se alternarem. Assim, embora quem conduza a narrativa segunda seja o sujeito que vivenciou os fatos ali narrados, aqui e ali o narrador primeiro intervém com comentários ou esclarecimentos de natureza variada. É uma situação diferente da observada nos contos citados, pois o narrador primeiro não abandona definitivamente a narração; ele se reveza com o narrador segundo, propondo uma interpretação diferenciada dos fatos. É que acontece no trecho acima: o narrador primeiro já faz cair uma nuvem sobre a narrativa segunda ao afirmar que com 22 anos (idade do narrador quando vivenciou os fatos narrados) fica-se assustado facilmente. Enfim, há dois processos paralelos: a narrativa primeira, que relata o achado da caixa com livros e a leitura do seu conteúdo pelo narrador primeiro, e a narrativa segunda, contida nos manuscritos encontrados.

Em Recordações da casa dos mortos, Dostoievski adota um procedimento assemelhado. O narrador primeiro conta que, em uma cidade perdida da Sibéria, conhecera um expresidiário, que fora condenado por matar a esposa. Sabendo que se tratava de um homem instruído e, provavelmente, nobre, o narrador tenta, em vão, travar relações com ele para conhecer sua história. No entanto, apenas depois da morte de Alexandr Petrovich 
Goriantchikov (era o nome do ex-presidiário), o narrador consegue alguma informação sobre ele, ao obter acesso às suas anotações. Decide, então, publicá-las. Eis parte de seu relato:

[...] Enfim, descobri um caderno volumoso, coberto por uma caligrafia fina; estava, porém, inacabado, abandonado decerto por seu autor: era a narrativa dos seus dez anos de presídio. [...] Li-a, reli-a, e cheguei quase à conclusão de que havia sido redigida numa crise de loucura. Mas as notas sobre o presídio, aquelas "Cenas da Casa dos Mortos" como o próprio Alexandr Petrovich as intitula em certo trecho de seu manuscrito, não me pareceram falhas de interesse. O mundo dos descaídos, mundo absolutamente novo, até hoje impenetrável, a estranheza de certos fatos, algumas observações bizarras, cativaram-me a atenção e a curiosidade. Todavia, talvez eu me engane quanto ao valor da obra. Publico, pois, aqui alguns capítulos dessa narrativa: o público julgará... (Dostoievski, Fiodor M. Recordação da casa dos mortos. Trad. Raquel de Queiros. Rio de Janeiro: Livraria José Olympio Editora, 1962, p. 31).

Nesse caso sobressai a avaliação que o narrador primeiro faz do material encontrado: trata-se de uma narrativa sobre o mundo dos descaídos e faz uma ressalva quanto à qualidade do texto, pois afirma que talvez se engane quanto ao valor da obra. Depois dessa introdução, em que procura se afastar na narrativa segunda, é o narrador desta, Alexandr Petrovich Goriantchikov, quem assume a condução do texto até seu final, quando é posto em liberdade. Desse modo, o leitor praticamente se esquece do narrador primeiro que, ao contrário do que ocorre no conto de Conrad, não mais toma a palavra. A narrativa segunda passa, então, a ser a única existente, e o narrador primeiro, que delegara a palavra a Goriantchikov, desaparece completamente. Nesse caso — freqüente em Machado —, entre o ator da enunciação "Dostoievski" e o narrador, Goriantchikov, surge um terceiro, que faz as vezes de editor.

O procedimento pode ser mais radical e avançar sobre o processo de edição do livro, de forma a acentuar o efeito de que se trata realmente de um achado e de que o indivíduo que assina a obra é apenas seu editor. É o que acontece com outro romance, cujo narrador adota um procedimento também comum em Machado. Trata-se de $A$ Náusea, de Sartre, que é precedido por uma Nota dos editores:

\section{NOTA DOS EDITORES}

Esses cadernos foram encontrados entre os papéis de Antoine Roquentin. Publicamo-los sem nenhuma alteração.

A primeira página não está datada, mas temos boas razões para supor que ela antecede de algumas semanas o início do diário propriamente dito. Teria então sido escrita, o mais tardar, por volta do início de janeiro de $1932 .^{133}$

\footnotetext{
${ }^{133}$ Sartre, Jean Paulo. A náusea. . Trad. Rita Braga. Rio de janeiro: Nova Fronteira, 1983)
} 
Veja-se que o enunciador instaura um narrador primeiro — os editores -, que explica as condições em que o diário de Roquetin teria sido escrito e informa porque o primeiro registro não é datado - ele teria sido escrito dessa maneira pelo narrador segundo. Aliás, nesse primeiro registro são encontradas duas notas que explicam dois espaços em branco no texto; o primeiro seria devido a uma palavra ausente dos "originais" e o segundo, a uma palavra rasurada (p. 15). Na seqüência, os editores explicam que, na época em que escrevia o diário, Roquetin, que já havia viajado pela Europa, Ásia e África, pesquisava a vida do marquês de Rollebon, tema recorrente no diário. Naturalmente, a nota é tão parte do romance quanto os demais capítulos, mas a estratégia adotada pelo enunciador cria o efeito de que se tratam de coisas distintas: a nota acima seria a narração da publicação do diário e o diário relataria a pesquisa de Roquetin sobre o Marques de Rollebon. Além disso, o narrador primeiro (o editor) distancia-se das opiniões do narrador segundo, já que aquele não fez mais que reunir o texto e publicá-lo. Não se pode esquecer que a nota tem ainda o efeito de tornar o diário autêntico, embora nada afirme quanto ao teor de verdade do seu conteúdo.

Com esses exemplos, pretendeu-se mostrar que são muitas as possibilidades de instalar um discurso segundo e que os efeitos de sentido produzidos pelas múltiplas debreagens não se limitam aos efeitos de realidade ou de metaforização da enunciação, pois afetam, cada um à sua maneira, o sentido global do texto e a imagem do enunciador. No entanto, quando se atenta para os obras de Machado de Assis, o que se verifica é algo bastante diferente: dos nove romances do autor, apenas dois, Iaiá Garcia e Dom Casmurro, não contam com esse tipo de procedimento. Com relação às coletâneas de contos (não analisadas aqui), observa uma recorrência ainda maior: das oito coletâneas publicadas pelo autor, apenas a primeira, Contos Fluminenses (1872) não é precedida por um prefácio ou advertência assinados por M. A., M. de A. ou Machado de Assis. ${ }^{134}$ Denominaremos esse procedimento de macro-debreagens, pelo fato de ele consistir em uma debreagem de segundo grau, a qual instaura um narrador segundo que conduzirá a narrativa. Desse modo, com exceção dos romances citados, o que se chama de narrador é, na verdade, um narrador segundo instaurado pelo narrador primeiro, que assina M. de A ou M. A. São os enunciados desse narrador primeiro, que delega a palavra ao narrador

\footnotetext{
${ }^{134}$ Algumas das advertências dos romances de Machado de Assis surgiram apenas em edições posteriores, como é o caso de Quincas Borba, cuja advertência foi publicada apenas na terceira. Decidiu-se, porém, acolher todas, independentemente da edição em que passaram a compor o romance, pois considerou-se que elas definiam a versão final do texto, tal como desejava o autor. Nessa decisão, acompanhamos o procedimento adotado por Afrânio Coutinho na organização da Obra completa publicada pela Aguilar.
} 
segundo (Brás Cubas, Aires, ou alguém não nomeado) que serão analisados neste capítulo. Observe-se que é compreensível a tendência do leitor, (mormente o menos experiente), de associar M. de A. ou M. A. ${ }^{135}$ ao enunciador "de verdade", ao escritor Machado de Assis; porém, como se sabe, não é assim que tudo se passa, pois esse narrador primeiro é uma criação ficcional tanto quanto o narrador segundo. Caso contrário, ter-se-ia que acusar Machado de Assis de mentiroso por ter escrito que achou os manuscritos do Conselheiro Aires, quando se sabe que tal personagem nunca existiu.

O papel e a importância de textos, como os citados, são longamente discutidos por Genette em Semils, estudo no qual o narratologista define como paratexto qualquer texto ou fragmento de texto (títulos, dedicatórias, prefácios, epígrafes etc.) que acompanham a narrativa principal do romance. $\mathrm{O}$ autor alerta para a importância de levá-los em consideração, pois acredita que o paratexto é um discurso fundamentalmente heterônomo, auxiliar, voltado integralmente a outra coisa que constitui sua razãa de ser, e que é o próprio texto (p. 17). No restante de seu estudo, Genette mostra que o paratexto é parte tão importante da obra quanto o texto e mostra que sua leitura afeta sobremaneira a compreensão da trama "central", independentemente de o prefácio (que é o caso que nos interessa) ter surgido junto com a primeira edição do livro ou em edições posteriores. O autor chama ainda a atenção para o fato de não ser possível determinar a identidade de quem assina o prefácio, quer se trate de um homônimo ou de um heterônimo do "autor", pois, como requer qualquer obra de ficção, o prefácio pede para ser tomado ao pé da letra, e que o leitor renuncie a toda incredulidade, na verdade, a toda atitude hermenêutica e que considere [o destinador do prefácio] tal como ele se apresenta. (p.184) Quer dizer, deve-se aceitar que o destinador do prefácio é quem diz ser, porém, ao

\footnotetext{
135 Machado não inova ao assinar com suas iniciais introduções ou advertências. Também Vitor Hugo adota igual procedimento. . Segundo Halsall, (1995:388-394), toda sua obra (Bug-Jargal, Claude Gueux, O último dia de um condenado, O bomem que ri, Os miseráveis, Ham da Islândia, Notre-dame de Paris, Mil setecentos e noventa e três, e Trabalhadores do mar) está repleta de notas assinadas por V. H. Em Os miseráveis, por exemplo, as notas atingem a significativa soma de 945! Claro, em nenhum dos casos pode-se confundir V.H. com Vitor Hugo ou Machado de Assis com M. de A., mas os dois procedimentos têm em comum o fato de contribuírem para certo um efeito de verdade. Talvez as semelhanças terminem aí, pois V.H. solidariza-se com seus narradores, ou com o "aspecto moral" de suas obras, enquanto Machado de Assis procura afastar-se ou manter-se neutro em relação a elas. Registre-se, ainda, que o jogo de máscaras em Machado vem de longa data, do tempo em que ele sequer era conhecido. É o que indica o final da crônica de 11 de setembro de 1864, publicada no Diário do Rio de Janeiro:
}

"Mais algumas linhas, e vou escrever minhas iniciais.

Que querem dizer estas iniciais? perguntava-se em casa esta semana uma senhora, em quem a graça e o espirito realçam as mais belas qualidades do coração - segundo disse-me um amigo respondeu:

- M.A. quer dizer, primeiramente, 'Muito Abelhudo'- e depois, 'muito amável' "... 
mesmo tempo, sabendo que esse alguém não existe na realidade, pois se trata, apenas, na melhor das hipóteses, de um homônimo do autor. Sem prosseguir em um estudo classificatório tal como proposto por Genette ${ }^{136}$, gostaríamos de chamar a atenção para algo já apontado anteriormente: os prefácios instauram outro narrador, além do "autor", (independentemente, do nome que o assine ), o qual, a exemplo da nota dos editores de Sartre, muitas vezes apresentará informações certamente importantes para a compreensão do texto, mas não presentes na narrativa principal ${ }^{137}$.

Os exemplos citados poderiam servir de argumento contrário à utilização dos prefácios para definição do ethos, uma vez que essas primeiras debreagens são um procedimento bastante comum na literatura; portanto, seu uso por um escritor não poderia servir para identificá-lo. No entanto, conforme se pode ver a seguir, os textos prefaciais (para usar a denominação de Genette) de Machado têm, ao menos, três peculiaridades. A primeira, de menor importância, é o fato de serem sempre assinadas por M. de A. ou M. A., numa clara alusão ao ator da enunciação "Machado de Assis". A segunda é resultante do título: invariavelmente, os textos prefaciais recebem o nome de Advertência, fato que convida a mais uma investigação ao dicionário. Aurélio Buarque de Hollanda explica que advertir é chamar a atenção para, faz̧er reparar em, e apresenta como sinônimo o verbo prevenir, definido como dispor de maneira que se evite o dano ou o mal. Reunindo-se as duas definições, percebe-se que qualquer advertência visa a chamar a atenção do enunciatário para um fato qualquer, de modo que o enunciatário, analisando-o, atente para suas implicações evite um mal. Naturalmente, aquele que adverte surge como destinador que delega ao sujeito advertido um saber de que este não dispõe, mas que lhe é necessário. Juntamente com o saber, o destinador transmite ao destinatário um dever. examinar o que lhe é apresentado e agir de acordo com suas conclusões. Chega-se, assim, à terceira característica desses prefácios: o seu assunto. Via de regra, eles tratam menos do texto que se segue e mais do fazer que o gerou, ou do sujeito que os produziu, e, por esse motivo, considera-se necessária uma breve — brevíssima, diria o

\footnotetext{
${ }^{136}$ O Leitor interessado encontrará em Genette (1987, p. 164-98) um interessantíssimo estudo sobre a instância prefacial, nome escolhido pelo autor para agrupar todos os prefácios, posfácios e similares que rodeiam o texto central de um romance.

${ }^{137}$ Em Le pacte autobiographique, Philippe Lejeune (1996: 13-46) propõe que a questão da identidade do narrador seja investigada mediante a análise do contrato entre autor e leitor implicado na publicação da obra,o que determinaria o modo como a obra deveria ser lida e os efeitos de sentido criados. Tal enfoque, ainda que interessante, não é o adotado por este trabalho.
} 
José Dias — reflexão sobre o fazer do escritor, este considerado como enunciador que apresenta um papel temático específico: escrever livros.

O saber, o prazer, ou mesmo o status, prometidos pelo destinador-escritor a seu destinatário-leitor encontram-se investidos em um objeto-livro, fato que, naturalmente, pressupõe que o destinatário esteja previamente investido das modalidades do poder, para ser capaz de adquirir o livro, e do saber, que o capacita para a leitura e, portanto, para a fruição dos valores prometidos. ${ }^{138} \mathrm{O}$ enunciatário visado por essa enunciação é, portanto, aquele que já supriu suas necessidades básicas de alimento, abrigo, vestimenta etc. e, ainda, dispõe de um excedente para suprir a falta que lhe é instaurada por esse destinador. Realizada a manipulação, o enunciatário-leitor adquire e lê o livro, e recebe (ou não) o saber e sente o prazer que lhe haviam sido prometidos. Se o sujeito leitor é, em um primeiro momento, destinatário do enunciador, ele é também, quase simultaneamente, sujeito sancionador do seu destinador, na medida em que sanciona positiva ou negativamente o fazer daquele. Por sua vez, a mesma sanção, na forma de crítica literária ou de sucesso de vendas, manipula o enunciador para que este produza novo romance em nova tentativa de seduzir o leitor potencial, e assim sucessivamente.

A leitura de um livro pode ser vista ainda como um programa de uso realizado por um sujeito leitor que visa à realização de um programa de base: a obtenção de saber ou de prestígio. De fato, o simples fato de adquirir um livro e, eventualmente, de lê-lo, em um país em que a leitura é ainda considerada um privilégio, representa para o enunciatário um ato de promoção social como é a aquisição de determinados bens de consumo, pois o livro não se distingue das demais mercadorias. Bem de consumo relativamente caro, o livro funciona ainda como prova qualificante para o sujeito: se ele é leitor, então deve ter recursos e conhecimento para tanto: o leitor é aquele que quer, sabe e pode ler romances. É também aquele que deve lê-los como forma de distinção social.

Por outro lado, se o consumo de romances é para poucos, sua produção é privilégio (?) de um número ainda mais reduzido de sujeitos, uma vez que, para produzi-los são necessárias competências (tanto de natureza intelectual quanto material) ainda mais escassas

\footnotetext{
${ }^{138}$ Se atualmente são relativamente poucos os indivíduo que têm condições intelectuais e materiais de se tornarem leitores, na época de Machado a população "leitora" era ainda mais insignificante. Laurence Hallkewell (1985:147) explica que, naqueles dias, a grande maioria dos livros não chegava a ter 300 compradores por ano, e que, mesmo os livros de boa vendagem, raramente ultrapassavam os 800 exemplares anuais.
} 
do que a requerida para lê-los. O escritor é o sujeito que, tendo sido manipulado pelo destinador "sociedade", na falta de nome melhor, cumpriu sua parte no trato (ou considera que o fez) e, ao final, exige sua recompensa em termos de fama e de remuneração financeira. Mas, claro, esses não são os únicos personagens desse drama há, pelo menos, dois coadjuvantes de destaque: o editor e o crítico. O primeiro, destinador-qualificador do escritor, lhe dará o suporte material para realização de seu percurso, surgindo aí os inúmeros contratos e quebras de contratos que não competem a este trabalho ${ }^{139}$. Já o crítico atua como destinador judicador, pois é ele que confere ao escritor a prova, glorificante por excelência, que vai consagrá-lo ou não ${ }^{140}$. O romance surge, assim, como uma espécie de encruzilhada na qual se encontram o sujeito e seus destinadores, onde ele poderá obter o reconhecimento de seu talento ou da falta dele.

Esse drama, com todos seus personagens, está explicitamente encenado nas advertências dos romances de Machado, chamando a atenção do enunciatário para o fato de que, conforme discutido no capitulo referente às configurações, os romances contém um programa narrativo que antecede à trama central: trata-se de um sujeito executando o programa narrativo de redigir um livro, com suas diversas implicações. As advertências, de

\footnotetext{
${ }^{139}$.Nesse sentido, a situação de Machado de Assis era certamente diferenciada, como explica Hallewell,(1985:142):

A longa ligação de Garnier com Machado de Assis é prova de en esse editor era capaz de reconhecer real talento literário num escritor que não faz̧ia qualquer esforço para conquistar popularidade fácil e de que estava disposto a apóia-lo. Não que essa ligação tenha sido desvantajosa para qualquer dos dois: sua primeira manifestação, Crisálidas (1864), vendeu 800 exemplares em um ano e todos os trabalhos posteriores de Machado de Assis tiveram edições de mil ou mais exemplares: boas marcas se comparadas com as tiragens citadas por citadas por Werdet para os romances franceses, que eram de apenas 500 exemplares [...]. Os acordos financeiros, bastantes justos no início (\$150 por exemplar de Crisálidas, com 178 páginas e mais 43 exemplares grátis) tornaram-se indiscutivelmente generosos quando ficou patente que as vendas eram certas [...] Como ele conservou os direitos autorais, este foi um pagamento magnânimo seja qual for o padrão que se utilize [...].
}

${ }^{140}$ Duas críticas aos romances de Machado, publicadas logo após o surgimento dos livros a que se referem, esclarecem melhor o funcionamento desse drama. A primeira foi publicada no Novo Mundo de 23.12.1872:

Tudo, na Ressurreição, até seus mesmos defeitos, anima-nos a pedir que o autor prossiga nos seus estudos de "contrastes", como ele chama a estes, na sua modéstia. Para realcar a virtude, porém, é provável que ele se convença que não é necessário pintar tão viva e demoradamente certas cenas, que agora nos pesa ver num livrinho tão excelente como o seu. In. Guimarães, 2005: p.319.

A segunda foi publicada na Gazetinha de 2.2.1881 e tem por objeto Memórias póstumas:

Em suma, a nossa impressão final é a seguinte: - A obra do Sr. Machado de Assis é deficiente, senão falsa, no fundo, porque não enfrenta com o verdadeiro problema que se propôs a resolver e só filosofou sobre caracteres de uma vulgaridade perfeita; é deficiente, na fórmula, porque não bá nitidez, não bá desenho, mas bosquejos, não bá colorido, mas pinceladas ao acaso .

Apelamos para juizo mais competente. Op. Cit. P. 351-2 
um lado, e os diálogos do narrador com o leitor ou a leitora, de outro, ilustram o que Antonio Candido discute em Literatura e sociedade. Para o autor, a obra funciona como intermediária entre o escritor (que nos romances estudados corresponde ao narrador primeiro) e o público (o narratário). A resposta dos leitores à narrativa acabaria, desse modo, por constituir o escritor, como, aliás, sugere o constante diálogo de Bento Santiago com seus leitores. Recordemos as palavras de Candido:

Se a obra é mediadora entre o autor e o público, este é mediador entre o autor e a obra, na medida em que o autor só adquire plena consciência da obra quando ela lhe é mostrada através da reação de terceiros. [...] Sem o público, não haveria ponto de referência para o autor, cujo esforço se perderia caso não lhe correspondesse uma resposta, que é definição dele próprio. (Mello e Souza: 2000, p. 69).

Finalmente, as advertências, desse modo, confirmam o que já havia sido observado na análise da instalação do narrador: que a narrativa apresentada pelo narrador segundo se subordina ao percurso iniciado nas advertências. Elas são, enfim, um prólogo ao drama que será re-encenado nas páginas que se seguem a elas, não ao drama contido no enunciado central, mas resultante do fazer do narrador, ao qual se subordina o restante da trama.

\section{Ressurreição}

\section{ADVERTÊNCIA DA PRIMEIRA EDIÇÃO}

Não sei o que deva pensar deste livro; ignoro, sobretudo, o que pensará dele o leitor. A benevolência com que foi recebido um volume de contos e novelas, que há dous anos publiquei, me animou a escrevê-lo. É um ensaio. Vai despretensiosamente às mãos da crítica e do público, que o tratarão com a justiça que merecer.

A crítica desconfia sempre da modéstia dos prólogos, e tem razão. Geralmente são arrebiques de dama elegante, que se vê ou se crê bonita, e quer assim realçar as graças naturais. Eu fujo e benzo-me três vezes quando encaro alguns desses prefácios contritos e singelos, que trazem os olhos no pó da sua humildade, e o coração nos píncaros da sua ambição. Quem só lhes vê os olhos, e lhes diz verdade que amargue, arrisca-se a descair no conceito do autor, sem embargo da humildade que ele mesmo confessou e da justiça que pediu.

Ora pois, eu atrevo-me a dizer à boa e sisuda crítica, que este prólogo não se parece com esses prólogos. Venho apresentar-lhe um ensaio em gênero novo para mim, e desejo saber se alguma qualidade me chama para ele, ou se todas me faltam, - em cujo caso, como em outro campo já tenho trabalhado com alguma aprovação, a ele volverei cuidados e esforços. O que eu peço à crítica vem a ser - intenção benévola, mas expressão franca e justa. Aplausos, quando os não fundamenta o mérito, afagam certamente o espírito e dão algum verniz de celebridade; mas quem tem vontade de aprender e quer fazer cousa, prefere a lição que melhora ao ruído que lisonjeia.

No extremo verdor dos anos presumimos muito de nós, e nada, ou quase nada, nos parece escabroso ou impossível, mas o tempo, que é bom mestre, vem diminuir tamanha confiança, deixando-nos apenas a que é indispensável a todo o homem, e dissipando a outra, a confiança 
pérfida e cega. Com o tempo; adquire a reflexão o seu império e eu incluo no tempo a condição do estudo sem o qual o espírito fica em perpétua infância.

Dá-se então o contrário do que era dantes. Quanto mais versamos os modelos, penetramos as leis do gosto e da arte, compreendemos a extensão da responsabilidade, tanto mais se nos acanham as mãos e o espírito, posto que isso mesmo nos esperte a ambição, não já presunçosa, senão a refletida. Esta não é talvez a lei dos gênios, a quem a natureza deu o poder quase inconsciente das supremas audácias; mas é, penso eu, a lei das aptidões médias, a regra geral das inteligências mínimas.

Eu cheguei já a esse tempo. Grato às afáveis palavras com que juízes benévolos me têm animado, nem por isso deixo de hesitar, e muito. Cada dia que passa me faz conhecer melhor o agro destas tarefas literárias, - nobres e consoladoras, é certo, - mas difíceis quando as perfaz a consciência.

Minha idéia ao escrever este livro foi por em ação aquele pensamento de Shakeaspere

Our doubts are traitors,

And make us lose the good we oft might win

By fearing to attempt.

Não quis fazer romance de costumes; tentei o esboço de uma situação e o contraste de dois caracteres; com esses simples elementos busquei o interesse do livro. A Crítica decidirá se a obra corresponde ao intuito e sobretudo se o operário tem jeito para ela.

É o que lhe peco com o coração nas mãos.

M.A.

\section{ADVERTÊNCIA DA NOVA EDIÇÃO}

Este foi o meu primeiro romance. Escrito aí vão muitos anos. Dados em nova edição, não lhe altero composição nem o estilo, apenas troco dois ou três vocábulos, e faço tais ou quais correções de ortografia. Como outros que vieram depois, e alguns contos e novelas de então, pertence à primeira fase de minha vida literária.

1905

M. de A.

(Obra Completa, vol. I, p. 116)

A narrativa de Ressurreição, tal como a temos hoje, é precedida por dois textos de dois outros narradores: um contemporâneo à publicação do romance e outro de trinta e três anos depois. O sujeito do primeiro apresenta-se como o sujeito do fazer e da espera. Conta que fora manipulado já duas vezes: na primeira, provavelmente por tentação, produziu um volume de contos e novelas e foi sancionado de forma positiva pelo destinador, que tem seu papel judicador explicitado ao ser chamado de juiz ${ }^{141}$. Na ocasião, a sanção cognitiva positiva encorajou-o a produzir o novo volume, funcionando, também, como uma nova manipulação, agora por sedução, que o levou a produzir nova obra. O sujeito explicita que está em busca

${ }^{141}$ Segundo a bibliografia de Machado de Assis, da Editora Nova Aguilar, Machado publicara, antes de Ressurreição, o livro Contos Fluminenses, também em 1872. Anteriormente a essas obras, Machado só havia publicado coletâneas de poesias e algumas peças de teatro. 
de nova sanção positiva, a qual, se obtida, funcionará tanto como prova glorificante em relação ao percurso já realizado, quanto como prova qualificante para que realize novos esforços (programa de uso) e produza nova obra, em um processo contínuo de manipulação.

Ele opta por explicitar a relação que mantém com o seu destinador, como se jogasse às claras. No entanto, na busca por uma sanção positiva, o sujeito também manipula o destinador, porém negando que o esteja fazendo na medida em que afirma que este prólogo não se parece com esses prólogos. O sujeito critica a falsa humildade de outros prólogos, mas o dele não é diferente, pois sua humildade, falsa ou verdadeira, também tenta seduzir seu destinador. Apesar de ter em mente as provas glorificante e qualificante citadas, ele pouco comenta o produto do seu fazer; apenas afirma que não quis fazer romance de costumes; que tentou o esboço de uma situação e o contraste de dois caracteres. Em compensação, fala muito de si. Mostra-se portador de uma ambição refletida, diz que é grato pelas sanções positivas que já recebera, que é detentor de uma aptidão média e que considera a tarefa literária nobre, consoladora e difícil, se feita conscienciosamente. Quer dizer, além de afirmar que cumpriu o contrato, realizando a obra que lhe fora confiada, apresenta-se como sujeito que comunga do mesmo universo de valores do seu destinador, que é o da justa medida, do bom-tom, dos bons costumes. Longe de buscar uma argumentação objetiva, seu discurso é subjetivo, em todos os sentidos da expressão. Termina afirmando que está com o coração nas mãos, o que conflita com o primeiro parágrafo em que dizia que a obra ia despretensiosamente às mãos da crítica. Para harmonizá-las é preciso que se separe o romance do fazer que o gerou. A obra é, sim, na visão do sujeito, despretensiosa, modesta, mas realizada com o coração nas mãos, isso é, de forma aflita, temerosa quanto aos resultados. Mais uma vez, o que está em jogo não é o objeto, mas o sujeito, que procura investir-se dos valores que julga serem os do destinador, valorizado pela sedução, pelo fato de o sujeito reconhecer nele o saber para sancioná-lo cognitiva (achar que ele tem talento) e pragmaticamente (comprar o livro).

A ênfase dada pelo sujeito a seu fazer, em detrimento do objeto, indica que ele visa não a mostrar que o objeto construído está investido dos valores desejados pelo destinador, mas para apresentar-se como detentor do saber esperado, ainda que o produto desse saber o romance — não o ateste. Viu-se que o sujeito apresenta-se modalizado pelo dever e pelo querer, quando denomina seu próprio fazer de tarefa. ${ }^{142}$ Sabe-se também que ele já está em

\footnotetext{
${ }^{142}$ Houaiss define tarefa como qualquer trabalho, manual ou intelectual, que se faz por obrigação ou voluntariamente; ou seja, movido por um dever ou um querer.
} 
conjunção com o objeto de valor pretendido (a publicação de um romance). Contudo, faltalhe a validação do destinador que indique que de fato ele é detentor do saber / poder buscado. Atente-se para a inversão: o saber e o poder não são, nesse caso, condições para a conjunção com o objeto desejado, mas o objeto é como que um pretexto que o sujeito procure a conjunção com essas modalidades, fato que se reflete no conteúdo de romance. Nas análises anteriores, viu-se, com insistência, que o fazer narrativo, isto é, a narração, sobrepunha-se ao objeto, isto é, ao narrado. Eram os comentários do narrador sobre a própria narração que faziam a narrativa de Félix cair em segundo plano e criavam outra, cujo protagonista é o próprio narrador em sua busca para elaborar o romance. Ora, a advertência acima pouco fala do romance; em compensação, discute bastante o drama do "romancista", aliás como acontece ao longo da narrativa, quando o narrador explica porque disse ou não isso ou aquilo, atesta o próprio saber, enfim, mostra que como autor tem privilégios que não estão ao alcance do leitor: não só o saber sobre os fatos narrados, mas o domínio de uma técnica que o leitor desconhece — na verdade, os dois saberes que se discutiu no capítulo anterior. Isso leva o narrador a certos excessos, como acontece em Memórias póstumas quando Brás Cubas enaltece seus defeitos acreditando que são qualidades. Assim, a narrativa contida na advertência coaduna-se ao percurso do narrador e revela a razão de ser dos seus comentários: não são mero exercício de metalinguagem ou de virtuosismo, mas a discussão do fazer literário e a busca pela conjunção com o saber necessário a essa atividade, da mesma forma que os actantes do enunciado visavam ao poder.

Em 1905, com a nova edição de Ressurreição, é publicada nova advertência, sem que a primeira fosse omitida. Agora, o narrador limita-se a reafirmar que o romance fora sua primeira produção, que lá se vão muitos anos e que o texto permanece praticamente inalterado. Dessa vez não há nenhuma palavra sobre o seu fazer, sobre a busca de uma sanção positiva e nem sobre o conteúdo do romance. Este sujeito não se apresenta mais como o da espera, na medida em que sanção já ocorreu (e foi positiva) e que não se encontra mais na posição de inferioridade em relação ao destinador. Não lhe interessa (ou se interessa não afirma) o que pensam seus juízes. Seu discurso aproxima-se mais de um discurso programador ou meramente informativo, não havendo, portanto, razão para a tensão que caracterizava a primeira advertência. A menção ao tempo decorrido entre o momento então atual e primeira edição do romance, aliada à referência a primeira fase de sua obra, sugerem certo distanciamento do sujeito em relação ao texto e mesmo do fazer que o gerou. Não se pode 
afirmar, com base na segunda advertência, que seus valores tenham mudado, mas que a relação do sujeito com seu objeto, a narrativa, tornou-se menos intensa, e a apreensão, menos tônica, para lembrar os termos da semiótica tensiva. Mudou também a relação da advertência com a matéria narrada. A primeira advertência antecipava o drama do narrador e, de certa forma, teorizava o que ele praticava. Agora, ao contrário, o tom geral da advertência sugere, embora não se possa afirmar categoricamente, certo distanciamento em relação à matéria narrada, ainda que de forma mais branda do que a verificada em outros romances. A insistência em opor iniciação e maturidade (foi meu primeiro romance); passado e presente (ai vão muito anos) e, enfim, em mostrar que houve mudança em seu fazer (pertence à primeira fase de minha carreira), indicam, claramente, um desnível entre o saber do narrador da segunda advertência, o da primeira, e o do romance, sendo razoável supor que a enunciação identifique-se mais com o narrador mais experiente e oponha-se ao inexperiente.

Em síntese, o enunciador projeta três narradores, todos dizendo "eu” e afirmando-se como "autores" do romance: inicialmente, o da advertência da primeira edição; depois, o da narrativa; enfim, o da última advertência.. O narrador primeiro não deixa dúvidas: a narrativa é mesmo uma ficção; não exatamente um romance de costumes, mas o "esboço de uma situação" e, desse modo, torna ineficazes os efeitos de verdade produzidos pelo narrador segundo. Cria-se, assim, uma contradição entre ambos, da qual resulta a evidência, agora, por outro ângulo, da narração em detrimento do narrado. O terceiro narrador não opera nenhuma debreagem, mas distancia-se dos demais narradores ao mostrar um saber superior ao deles e ao propor-se a julgá-los. Cria-se desse modo, um texto polifônico e a imagem de um sujeito que, ao contrário de Aires, ama as polêmicas, pois elas pululam em seus romances.

\section{A mão e a luva}

ADVERTÊNCIA DE 1874

Esta novela, sujeita às urgências da publicação diária, saiu das mãos do autor capítulo a capítulo sendo natural que a narração e o estilo padecessem com esse método de composição um pouco fora dos hábitos do autor. Se a escrevera em outras condições dera-lhe desenvolvimento maior, e algum colorido mais aos caracteres, que aí ficam esboçados. Convém dizer que o desenho de tais caracteres, - o de Guiomar, sobretudo, - foi o meu objeto principal, senão exclusivo, servindo-me à ação apenas de tela em que lancei os contornos dos perfis. Incompletos, embora, terão eles saído naturais e verdadeiros?

Mas talvez estou eu a dar proporções muito graves a outra coisa de tão pequeno tomo. O que aí vai são umas poucas páginas que o leitor esgotará de um trago, se elas lhe aguçarem a curiosidade 
ou se lhe sobrar alguma hora que absolutamente não possa empregar em outra cousa. — mais bela ou mais útil.

M. de A.

\section{ADVERTÊNCIA DE 1907}

Aos trinta e tantos anos decorridos do aparecimento desta novela à reimpressão que ora se faz parece que explicam as diferenças de composição e de maneira do autor. Se este não lhe daria agora a mesma feição, é certo que lha deu outrora, e, ao cabo, tudo pode servir a definir a mesma pessoa.

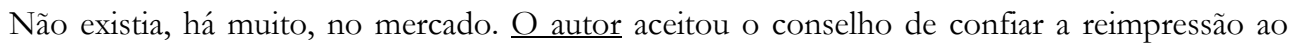
editor dos outros livros seus. Não lhe alterou nada; apenas emendou erros tipográficos, fez correções de ortografia e eliminou cerca de quinze linhas. Vai como saiu em 1874.

M. de A.

(Obra Completa, vol. I, p. 198 - grifos meus)

Tal como Ressurreição, A mão e a luva também apresenta duas advertências separadas por 30 anos e uma mudança razoável de ponto de vista. A primeira discute menos o fazer do sujeito que a de Ressurreição: conta apenas que o romance fora originariamente publicado diariamente, capítulo a capítulo, o que teria impedido o autor de desenvolver mais o texto. A razão de ser de tal comentário parece clara: ele visaria a fazer com que o destinador considerasse as vicissitudes da produção no momento do julgamento. Mais uma vez, é a narração, e não o narrado, que se destaca. No primeiro período, ocorre ainda uma embreagem na medida em que o eu projeta-se como em ele - o autor -, o mesmo ocorrendo com o tu, projetado como o leitor. Em seguida, a partir do terceiro período, quando o assunto desloca-se da narração para o narrado, o enunciador projeta-se como um eu, anulando o efeito de objetividade até então criado e substituindo-o por um efeito de subjetividade, como se criasse um vínculo indissolúvel entre esse en e seu texto $\mathrm{O}$ sujeito então explica que Guiomar é do jeito que é porque interessava ao autor fazer um esboço de caracteres, traçar contornos, perfis, e não, digamos, personalidades densas. Desse modo, entende-se que os programas narrativos executados pelos atores visam a definir esses caracteres. Mais uma vez, os objetos surgem como um pretexto para que o sujeito adquira modalidades. Chega-se, assim, a um tema caro à semiótica, que é o fato de os sujeitos definirem-se em função dos objetos com os quais entram - ou buscam entrar — em conjunção. Isso também vale para o enunciador, com a diferença de que o objeto com o qual ele busca a conjunção é o próprio enunciado, tanto que para a semiótica ele definido como 
ator da enunciação, aliás, esse é o ethos que sobressai, o de um sujeito cujo papel temático é enunciar, ou, se preferirmos, escrever.

Ainda que de forma menos explícita, permanece a condição de sujeito que busca a sanção positiva e procura influenciar o fazer interpretativo do destinador: afirma que gostaria de ter dado maior colorido aos caracteres, mas que as condições de produção o obrigaram a um esboço, e, nesse momento, reafirma a preocupação com um tema que era também o objeto do narrador da advertência de Ressurreição: ele volta a explicitar sua atividade de romancista e algumas questões técnicas relativas a esse fazer, tal como fará ao longo do romance, havendo concordância entre esse narrador e o do romance propriamente dito. Enfim, o sujeito busca, novamente, a sanção positiva do destinador que ateste que ele detém o saber desejado, e daí a importância de indicar os contra-programas que o teriam impedido de mostrar todo o saber de que dispõe. Contudo, se tais argumentos são reveladores da tensão do sujeito, em seguida, busca-se a distensão a partir da afirmação de que estaria dando proporções muito graves a outra coisa de tão pequeno tomo. O narrador da advertência de Ressurreição afirmava que o fazer literário era tarefa nobre, consoladora e difícil, já este parece não ser tão peremptório a esse respeito, ou se o é, prefere não afirmar; afinal, o leitor poderia facilmente empregar seu tempo em uma tarefa mais bela e útil. Se a leitura de romances é assim, não haveria porque sua escritura ser diferente.

A relação entre as duas advertências de $A$ mão e a luva é muito semelhante à das advertências de Ressurreição. Nos dois casos, observa-se certa comunhão de valores entre o narrador da primeira advertência e o da narrativa, e certo distanciamento do narrador da segunda advertência em relação aos outros dois. No caso de $A$ mão e a luva, tal distanciamento é explícito, na medida em que, em 1907, ele afirma que se não daria ao romance a mesma feição, é certo que tha deu outrora.... Quer dizer, esse narrador não compactua com o narrador do romance, mas reconhece - e concordamos integralmente com ele - que, ao cabo, tudo pode servir a definir a mesma pessoa, fato que explica a manutenção de ambas as advertências. Cabe a pergunta: porque não daria a mesma feição? Porque o seu saber hoje é outro, tanto no que se refere à composição quanto ao saber sobre os fatos narrados. A distância do sujeito da segunda advertência em relação ao romance pode ainda ser vista pelo fato de o enunciador projetar-se apenas como um ele - o autor -, o que o permite distanciar-se da obra sem ter de fazer uma autocrítica explícita, como, por exemplo, quando afirma que não daria a mesma feição ao romance. 
O primeiro narrador de $A$ mão e a luva parece concordar com o primeiro narrador de Ressurreição si o mesmo valendo para os narradores das segundas advertências. Parece haver, portanto, entre a redação da primeira e da segunda advertência de cada romance uma significativa mudança de ponto de vista, fato confirmado quando o enunciador evoca, novamente, o tempo passado para explicar as diferenças de composição e de maneira do autor. Tal asserção, porém, não corrobora a idéia das duas fases; antes, confirma a unicidade da obra. Viu-se que a partir de Memórias póstumas há uma discordância e um distanciamento do enunciador em relação ao narrador do romance. O que se vê agora nessas advertências é o mesmo processo, em termos diferentes, pois o narrador das segundas advertências - que assina M. de A. e também se apresenta como enunciador - marca claramente a distância, ainda que de forma elegante, em relação aos seus narradores. Se o enunciador concordasse inteiramente com a narrativa, então não haveria porque afirmar que o escreveria de outra forma se pudesse. Por outro lado, se discorda da narrativa, então poderia simplesmente ter omitido a primeira advertência, como fez com algumas linhas desse e de outros romances, e mantido a segunda. Ao que parece, porém, a estratégia do enunciador - absolutamente coerente com o conjunto da obra - era permitir ao narrador expressar-se livremente, sem deixar de assinalar, sempre, sua oposição a ele, de uma maneira ou de outra, sempre. E essa tem sido a regra em todos os romances de Machado, com a única exceção de Iaiá Garcia, que não conta com advertência nem exibe uma oposição do enunciador em relação ao narrador.

Em síntese, a estrutura de $A$ mão e a luva repete a de Ressurreição a partir da realização de três debreagens enunciativas e da instalação de três eus: o primeiro delega a palavra ao segundo, que conduz a narração, enquanto o terceiro sanciona, de forma mais ou menos negativa, o fazer dos dois. Daí resulta a evidência do caráter ficcional da narrativa - e os artifícios do narrador segundo para criar efeitos de verdade. Por mais que o narrador afirme que tudo se passou como ele narra e os fatos são a verdade pura, o leitor já foi avisado pelo narrador primeiro de que se trata apenas de um esboço de caracteres, ou seja, é mesmo tudo mentira. Diante da instalação de tantos sujeitos, o enunciador da obra como um todo — isto é, do enunciado contido entre as duas capas — se torna quase uma miragem: ora está próximo, ora muito distante, sendo seu posicionamento em relação ao narrado de difícil apreensão. 


\section{Helena}

\section{ADVERTÊNCIA}

Esta nova edição de Helena sai com várias emendas de linguagem e outras, que não alteram a feição do livro. Ele é o mesmo da data em que o compus e imprimi, diverso do que o tempo me fez depois, correspondendo assim ao capítulo da história do meu espírito, naquele ano de 1876.

Não me culpeis pelo que lhe achardes romanesco. Dos que então fiz, este me era particularmente prezado. Agora mesmo, que há tanto me fui a outras e diferentes páginas, ouço um eco remoto ao reler estas, eco de mocidade e fé ingênua. É claro que, em nenhum caso, lhes tiraria a feição passada; cada obra pertence ao seu tempo.

M. de A.

(Obra Completa, vol. I p 272. - grifos meus)

A primeira edição de Helena não contava, ao que se saiba, com advertência de espécie alguma, sugerindo que ou o sujeito já não buscava tão intensamente a sanção do destinador, ou o fazia por outros meios. Seja como for, o narrador da única advertência de Helena, escrita muitos anos depois da publicação do livro, conforme indica o demonstrativo aquele, também se distancia explicitamente do narrador do romance. Afirma que atualmente é diferente de então, chega mesmo a pedir ao narratário que não o culpe pelo tom romancesco no livro e justifica-se dizendo que este lhe era prezado, usando o imperfeito e dando a entender que a afeição já não é a mesma. Ora, são palavras bem pouco estimulantes para um leitor desavisado. Grande é a distância daquele narrador de Ressurreição que, com o coração nas mãos, pedia a benevolência da crítica e do público. Este afirma ainda que a vida o levou a outras e diferentes páginas, apesar de ainda ouvir um eco de fé ingênua a qual, nem era preciso dizer, não possui mais. Apesar disso, não tiraria do romance a feição recebida, pois o texto corresponde a um capitulo da história do seu espirito. Desse modo, o narrador da advertência explicita o seu percurso pessoal e o caracteriza pela busca da conjunção com a modalidade do saber, ou melhor, do saber-saber, já que a ingenuidade, conforme ficou dito acima, caracteriza-se, em primeiro lugar, pelo não saber acerca do próprio saber. Poder-se-ia argumentar que a advertência não fazia parte do projeto original do livro, mas, nesse caso, ter-se-ia que fazer a mesma objeção ao prólogo e ao Ao leitor de Memórias póstumas, por exemplo, ou à Advertência de Esaú e Jacó, textos fundamentais para a compreensão do romance que antecedem. No caso de Memórias póstumas, recorde-se que prólogo só foi incorporado ao romance na segunda edição e que o Ao leitor não constava da publicação original do livro nas páginas de $O$ Globo. Ora, 
ambos têm sido incorporados pela crítica como partes constitutivas do romance. Por que, então, dar outro tratamento à Helena ou $A$ mão e a luva e Ressurreição ?143

A advertência de Helena encontra as demais na medida em que nada explica acerca da obra: o autor não esclarece se se trata de um romance de aventuras ou se buscou, como nos anteriores, fazer um esboço de caracteres. Não conta se o romance foi publicado em capítulos ou se teve boa acolhida. Novamente, é o fazer do sujeito, enquanto produtor de textos literários, que se destaca. O objeto é discutido, mas não pelo seu conteúdo e sim pela sua natureza específica de texto literário. O diálogo com o narratário, na posição de enunciatário, também retorna no pedido não me culpeis... e revela a real natureza do enunciatário visado pelo enunciador. Não é o leitor de aventuras amorosas, como tantas vezes dá a entender o narrador machadiano, mas sim o leitor que não aprecia esse tipo de literatura. Assim, descobre-se que o enunciatário de Helena é o mesmo visado pelos outros romances da dita fase madura de Machado de Assis. Ora, sendo o enunciatário o mesmo, não há como o enunciador ser outro. No caso de Helena, há também dois narradores: além daquele que conduz a narrativa, há um outro que sanciona, de forma mais negativa que positiva, o fazer deste e, novamente, desmascara os efeitos de verdade criado e assim revela os verdadeiros interesses do enunciatário.

Todavia, a grande importância desses paratextos, para lembrar o termo cunhado por Genette, advém do fato de eles instalarem diferentes níveis enunciativos, portanto diferentes narradores, e, assim, privilegiar pontos de vista distintos que podem concordar ou não entre si e com o do narrador. No caso de Helena, parece claro que o narrador da advertência discorda do narrador do romance e que, provavelmente, tem a mesma visão de mundo que o enunciador - ao menos, não há elementos no texto para que se ateste o contrário. O que isso revela do ethos do enunciador desses romances? Que ele, provavelmente, ama o debate; afinal, em três romances, ele instaura, por três vezes, a polêmica entre seus narradores.

\footnotetext{
${ }^{143}$ Observe-se que a dedicatória do Fausto, citada mais acima, foi incorporada por Goethe ao romance apenas por volta de 1797 — sete anos após as a primeira publicação da Primeira parte —, quando o autor retomou a obra, atendendo a diversos pedidos de seu amigo, o poeta Frieddrich Schiller. Ver o prefácio Erwin Theodor n GOETHE
} 


\author{
AO VERME \\ QUE \\ PRIMEIRO ROEU AS FRIAS CARNES \\ DO MEU CADÁVER \\ DEDICO \\ COMO SAUDOSA LEMBRANÇA \\ ESTAS \\ MEMÓRIAS PÓSTUMAS
}

PRÓLOGO DA TERCEIRA EDIÇÃO

A primeira edição destas Memórias póstumas de Brás Cubas foi feita aos pedaços na Revista Brasileira, pelos anos de 1880. Postas mais tarde em livro corrigi o texto em vários lugares. Agora que tive de o rever para a terceira edição emendei ainda algumas coisas e suprimi duas ou três dúzias de linhas. Assim composta, saí novamente à luz esta obra que alguma benevolência parece ter encontrado no público.

Capistrano de Abreu, noticiando a publicação do livro perguntava: "As Memórias póstumas de Brás Cubas são um romance?" Macedo Soares, em carta que me escreveu por esse tempo recordava amigamente as Viagens na Minha Terra. Ao primeiro respondia já o defunto Brás Cubas (como leitor viu e verá no prólogo dele que vai adiante) que sim e que não que era romance para uns e não para o era para outros. Quanto ao segundo, assim se explicou o finado: "trata-se de um obra difusa, na qual eu, Brás Cubas, se adotei a forma livre de um Sterne ou de um Xavier de Maistre, não sei se lhe meti algumas rabugens de pessimismo". Toda essa gente viajou: Xavier de Maistre à roda do quarto, Garrette na terra dele, Sterne na terra dos outros. De Brás Cubas se pode talvez dizer que viajou à roda da vida.

O que faz do meu Brás Cubas um autor particular é o que ele chama "rabugens de pessimismo". Há na alma deste livro, por mais risonho que pareça um sentimento amargo e áspero, que está longe de vir dos seus modelos. É taça que pode ter lavores de igual escola, mas leva outro vinho. Não digo mais para não entrar na crítica de um defunto que se pintou a si e a outros conforme lhe pareceu melhor e mais certo.

Machado de Assis.

\section{Ao leitor}

Que Stendhal confessasse haver escrito um de seus livros para cem leitores, coisa é que admira e consterna. O que não admira, nem provavelmente consternará, é se este outro livro não tiver os cem leitores de Stendhal, nem cinqüenta, nem vinte, e quando muito, dez.. Dez? Talvez cinco. Trata-se, na verdade, de uma obra difusa, na qual eu, Brás Cubas, se adotei a forma livre de um Sterne, ou de um Xavier de Maistre, não sei se lhe meti algumas rabugens de pessimismo. Pode ser. Obra de finado. Escrevia-a com a pena da galhofa e a tinta da melancolia, e não é difícil antever o que poderá sair desse conúbio. Acresce que a gente grave achará no livro umas aparências de puro romance, ao passo que a gente frívola não achará nele o seu romance usual; eilo aí fica privado da estima dos graves e do amor dos frívolos, que são as duas colunas máximas da opinião.

Mas eu ainda espero angariar as simpatias da opinião, e o primeiro remédio é fugir a um prólogo explícito e longo. O melhor prólogo é o que contém menos coisas, ou o que as diz de um jeito obscuro e truncado. Conseguintemente, evito contar o processo extraordinário que empreguei na composição destas Memórias, trabalhadas cá no outro mundo. Seria curioso, mas nimiamente extenso, e aliás desnecessário ao entendimento da obra. A obra em si mesma é tudo: se te agradar, fino leitor, pago-me da tarefa; se te não agradar, pago-te com um piparote, e adeus.

Brás Cubas 
Memórias póstumas não conta com nenhuma advertência. Em compensação, tem uma dedicatória, um prólogo e um ao leitor que pode ser tanto uma advertência quanto um segundo prólogo. Antes de analisar a dedicatória, vejam-se as definições de Houaiss para esse substantivo:

1. Inscrição afetuosa que marca um presente ou lembrança, como livro, retrato etc.; dedicação.

2. Mensagem escrita por autor, intérprete, ator etc., em livro [...] ou outro objeto artístico ou literário, e destinada a quem o adquiriu ou recebeu graciosamente

Uma dedicatória comporta uma pequena estrutura narrativa composta de um sujeito doador, um donatário e um objeto artístico no qual está inscrito o valor modal do afeto, que pode ser traduzido como um querer-fazer o bem a outrem, estando o benefício relacionado ao objeto de arte doado, de fato ou simbolicamente. O sujeito doador é caracterizado pelo querer-bem e pelo papel temático de artista; o donatário, pelo saber (ele tem os conhecimentos necessários para apreciar, ainda que não compreenda, um objeto artístico) e pelo papel temático de consumidor de obras de arte. Doador e donatário estão, portanto, ligados pela arte e pelo afeto, o qual pode remeter a um percurso narrativo anterior, quando os papéis estariam invertidos e o doador de agora seria o beneficiário de então devido a alguma atitude do donatário atual para com ele.

A dedicatória de Memórias póstumas, porém, é inusitada, para dizer o mínimo. O doador é figurativizado como um defunto, portanto, alguém que não se encontra conjunto com nenhuma modalidade, e o donatário, em um verme, caracterizado, é verdade, como consumidor, mas consumidor de matérias orgânicas em decomposição que, obviamente não poderia ser caracterizado pelo saber. Assim, o primeiro não poderia doar nem exercer o papel de artista e nem o segundo o de consumidor de obras de arte, sendo essa a primeira de uma série de afrontas à realidade. No mais, a dedicatória mantém sua estrutura clássica, uma vez que o afeto parece unir doador e donatário, ainda que de uma maneira perversa: o benefício do verme teria sido comer as carnes do autor e o deste de servir-lhe de alimento. Além disso, em que pese a falta de correspondência com a realidade, o defunto apresenta-se como o autor do livro que o leitor têm em mãos, muito embora seja apenas seu narrador. Enfim, a dedicatória leva por água abaixo qualquer pretensão de verdade e mostra-se, evidentemente, uma falsa dedicatória. Seu objetivo não é, certamente, dedicar o livro a quem quer que seja, mas mostrar o quadro de valores desse sujeito, que se assemelha aos dos vermes. E, claro, é a literatura e seus prólogos que se vêem rebaixados a um negócio entre cadáveres e vermes; 
sendo, portanto, grande a distância em relação àquele sujeito que considerava o fazer literário uma tarefa nobre e consoladora.

Subindo um nível enunciativo e pensando no enunciador de fato, observa-se que, com a dedicatória, logo abaixo do título do romance, o enunciador instaura um contrato claro com seu enunciatário: não se está em busca de um efeito de verdade, mas de um efeito de mentira; X não deve ser interpretado como X, está claro. Defuntos não escrevem e vermes não lêem; logo, o narrador mente. Não se busca representar a realidade, mas rir-se dela. Rir dos prólogos sérios, das dedicatórias afetuosas, rir da própria literatura, de modo a recriá-la no ato de sua destruição. $\mathrm{Na}$ verdade, o prólogo parece estar roendo as carnes de um modelo literário, ingênuo, como dizia o narrador do outro prefácio, que cria na possibilidade de representação da realidade, corroendo as carnes de um texto que pudesse ser fiel aos fatos. Finalmente, ao instaurar um defunto autor que dedica sua obra a um verme, o enunciador distancia-se uma vez mais desse sujeito e de sua narrativa. Volta-se, assim, a um procedimento análogo ao visto anteriormente, porém, de outra forma, pois, tal como ocorria nos prólogos anteriores, o drama encenado nessa advertência envolve, de um lado, um produtor de textos de ficção; e, de outro, o consumidor desses mesmos textos. A diferença fica por conta da figurativização empregada: lá, os actantes encarnavam em indivíduos da mais completa normalidade; agora, em defuntos e vermes. Ainda em conformidade com que se apurou em Ressurreição e $A$ mão e a luva, esse narrador primeiro está em plena concordância com o narrador da narrativa central. Como se vê, até o momento há mais semelhanças do que diferenças entre as advertências de Memórias póstumas e a dos romances citados.

Logo em seguida, o leitor depara com um prólogo que também lembra as advertências já estudadas. Inicialmente, discutem-se questões relativas à publicação do romance em jornais e em livro. Em seguida, o mesmo sujeito comenta cartas que teria recebido de leitores "de verdade", na medida em que sua existência é atestada por outros textos considerados não ficcionais. Cria-se, assim, um efeito oposto ao anterior: de verdade pura e simples, de respeito às normas do bom senso e da sã literatura. No entanto, essa tranqüilidade é abalada no segundo parágrafo, quando o enunciador delega a palavra ao mesmo defunto, autor do prólogo acima, e, desse modo, coloca-se no mesmo nível dele, como se ambos — "autor de verdade" e defunto-autor - convivessem pacificamente. Finalmente, o sujeito que assina Machado de Assis comenta o fazer do defunto, mas nega-se a criticá-lo, como se este fosse um outro autor e não um delegado seu. Machado de Assis oscila: 
ora é o produtor físico de Memórias póstumas, ora é apenas um intermediário entre o autor, Brás Cubas, e os leitores, portanto, uma espécie de editor. Não há solidariedade nem desavença explícita entre esse Machado de Assis e o autor Brás Cubas, apenas uma divergência sutil de opiniões expressa pela atitude de galhofa do último que sempre ri de tudo (e, no mais, não tem qualquer credibilidade), e o tom amargo e áspero que primeiro vê no livro. Finalmente, não há qualquer indício de que o sujeito Machado de Assis busque influir na sanção realizada pelo enunciatário-destinatário. Não justifica seu fazer nem comenta a obra, aliás nega-se a criticá-la.

Encerrando a abertura do livro, há o texto endereçado Ao leitor assinado por Brás Cubas, que se apresenta, também, como autor do livro. O texto começa mais ou menos bem comportado, com o sujeito comparando sua obra à de Stendhal e explicando o modo de composição de uma forma que lembra as advertências dos romances anteriores. No entanto, a coisa não demora a descambar quando ele afirma que se trata de uma obra de finado, escrita no outro mundo, para, em seguida, afirmar, como não houvesse dito nada demais, que quer ganhar as simpatias da opinião, de um jeito bem parecido ao dos narradores das outras advertências. Afirma, como aqueles, sua aversão a prefácios longos, dizendo que, por esse motivo, não narrará a narração processo (certamente) extraordinário empregado na composição de suas Memórias. O leitor até pensa que tem no que se segurar quando o texto termina de forma abrupta, desrespeitosa, com o narrador afirmando, numa atitude impensável anteriormente, que se o livro não agradá-lo, azar o dele, dando início ao tom desrespeitoso que vai dominar todo o romance.

Os três textos citados que antecedem o romance revelam uma estrutura bem semelhante à de Ressurreição, A mão e a luva e, em menor grau, Helena: o enunciador delega a palavra a um narrador primeiro, da dedicatória, supostamente Brás Cubas; depois, a um narrador segundo, que assina Machado de Assis e delega a palavra ao narrador terceiro, o qual assina Brás Cubas, que, finalmente, delega a palavra ao narrador do romance, o mesmo Brás Cubas. A diferença fica por conta da dedicatória, inexistente nos romances anteriores. A relação entre cada sujeito e o romance já é um pouco diferente: o primeiro, o terceiro e o quarto narradores concordam entre si, mas o segundo afasta-se de todos, porém, com menos intensidade do que visto anteriormente. Ao final, sobressai o fato de o romance conter, como os anteriores, vários níveis enunciativos e, assim, também por essa via, a narração se destaca em relação ao narrado. Todos os sujeitos têm o seu papel temático explicitado: Brás Cubas é 
o defunto autor; o sujeito Machado de Assis quer fazer crer que é o escritor (já de renome) Joaquim Maria Machado de Assis; os demais personagens citados, como Capistrano de Abreu, têm sua condição de leitores destacada. Nem mesmo o fazer do leitor passa despercebido: Se a obra não te agradar, fino leitor...

Desse modo, confirma-se que, anteriormente à narração dos programas narrativos de Brás Cubas, há um outro drama sendo encenado: o do sujeito que escreve e, assim, constrói seu objeto de valor. A estrutura do drama está completa: no papel de destinador manipulador, a crítica, especializada ou não; no de sujeito do fazer e da espera, o narrador segundo, que tem em Brás Cubas uma espécie de anti-sujeito; e, no papel de destinador judicador, o leitor. Essa é a primeira estrutura debreada que não se confunde com a das memórias de Brás Cubas. Claro, nenhum leitor minimamente competente iria se sentirofendido pelo piparote de Brás Cubas, pois sabe que Brás Cubas não é o “autor" e que o alvo do piparote não é ele, mas o narratário. As memórias do defunto surgem assim como um prétexto, um programa de uso, se preferirmos, para que o sujeito obtenha o que realmente quer: a sanção positiva do seu público. Observe-se, agora, que, no nível narrativo, a estrutura é praticamente idêntica à de Ressurreição de $A$ mão e a luva. A recorrência de uma determinada estratégia de debreagem parece, assim, desenhar o ethos do enunciador.

O fato de quatro dos cinco romances de Machado apresentarem diversos níveis narrativos confirma não só a dissimulação desse narrador, já que ele se oculta sob várias máscaras, mas também o seu gosto pela polêmica, ou, pelo menos, pelo debate (o que ocorre nesses textos). O que as advertências de Memórias póstumas trazem de novo (na verdade, já era prenunciado pelas análises anteriores) é o profundo senso de humor desse narrador, seus gosto pela paródia, pela sátira e, mesmo, pelo grotesco; ele não poupa nem a si mesmo, já que nada é mais satirizado nessas advertências do que seu próprio fazer, seu papel temático de escritor. Certo, o grotesco de Machado não é o da Idade Média, está mais próximo de Swift, de Voltaire e Sterne, mas, mesmo assim, cumpre funções semelhantes, pois o grotesco de Machado, como o desses escritores

[...] ilumina a ousadia da invenção, permite associar elementos heterogêneos, aproximar o que está distante, ajuda a liberar-se do ponto de vista dominante sobre o mundo, de todas as convenções e de elementos banais e habituais, comumente admitidos; permite olhar o universo com novos olhos, compreender até que ponto é relativo tudo o que existe e, portanto, compreender a possibilidade de uma ordem totalmente diferente do mundo. (Bakhtin, 1999:30). 
É esse ethos, digamos, satírico que emerge dessas advertências, com todas as implicações citadas por Bakhtin. A questão é que, para que esse humor possa ser incorporado ao ethos do enunciador, é preciso que ele volte a manifestar-se. Aguardemos.

\title{
Quincas Borba
}

\author{
PRÓLOGO DA TERCEIRA EDIÇÃO
}

\begin{abstract}
A segunda edição deste livro acabou mais depressa que a primeira. Aqui sai ele em terceira, sem outra alteração além da emenda de alguns erros tipográficos, tais e tão poucos que, ainda conservados, não encobririam o sentido.

Um amigo e confrade ilustre tem teimado comigo para que dê a este livro o seguimento de outro. "Com as Memórias póstumas de Brás Cubas, donde este proveio, fará você uma trilogia e a Sofia de Quincas Borba ocupará exclusivamente a terceira parte." Algum tempo cuidei que podia ser, mas relendo agora estas páginas conclui que não. A Sofia está aqui toda. Continuá-la seria repeti-la, e acaso repetir o mesmo seria pecado. Creio que foi assim que me tacharam este e alguns outros dos livros que vim compondo pelo tempo afora nos silêncio da minha vida. Vozes houve, generosas e fortes, que então me defenderam; já lhes agradeci em particular; agora o faço cordial e publicamente.
\end{abstract}

1899

M. de A.

O narrador primeiro de Quincas Borba, M. de A., apresenta-se também como o autor do romance e comenta, como nos outros romances, as diferenças entre essa edição e as anteriores. Inicialmente, revela que o romance já fora sancionado positivamente pelo destinador em termos pragmáticos (a segunda edição esgotara-se mais rápido que a primeira) e em termos cognitivos (os comentários dos amigos), apesar de ter havido também sanções negativas do anti-destinador. Assim, esse narrador volta a se apresentar como sujeito investido do papel temático de escritor e que faz da própria narrativa o objeto de sua discussão. O drama encenado não é diferente, portanto, dos anteriores. Contudo, não há, como acontecia nos outros casos, um distanciamento desse narrador em relação ao do romance; há, na verdade, até mesmo certa solidariedade, decorrente, talvez, das críticas recebidas. No entanto, a despeito de todos os efeitos de verdade criados pelo narrador de Quincas Borba, a advertência o revela como ser de papel, ficção e, assim, o coloca a nu. Desse modo, a Advertência de Quincas Borba se opõe simetricamente à de Helena: lá, faltava quem se solidarizasse com o narrador; aqui, não há quem se oponha a ele.

A peculiaridade deste narrador é ele revelar-se alvo de críticas; ele não as responde, mas agradece aos que o fizeram por ele. Sabe-se, assim, que houve sanções negativas ao seu 
fazer e que elas, de alguma forma, foram consideradas (uma das justificativas para não acolher as sugestões recebidas é que isso seria dar razão aos críticos). Assim, reencontra-se o narrador de Ressurreição, o qual também explicitava seu papel actancial de sujeito do fazer, fato que faz pressupor uma manipulação anterior e uma sanção de alguma espécie; porém, diferentemente daquele, este enunciador não está mais com o coração nas mãos. Outro ponto de reencontro com os narradores das advertências é o fato de o percurso desse sujeito, enquanto construtor de objetos de saber, ser explicitado. Se a existência do sujeito, portanto sua identidade, é indissociável do objeto com o qual se relaciona, então, encontra-se, uma vez mais, a marca desse enunciador, a qual não se altera ao longo do tempo, ainda que apresente matizes diferenciados.

Enfim, a cada nova obra, confirma-se a predileção do enunciador por instaurar em seus romances múltiplos níveis enunciativos, o que implica a instauração de diversas vozes que expressam seus pontos de vista. Confirma-se, assim, a imagem de um enunciador que se oculta sob várias vozes e que aprecia o debate.

Esaú e Jacó

\section{ADVERTÊNCIA}

Quando o conselheiro Aires faleceu, acharam-se-lhe na secretária sete cadernos manuscritos, rijamente encapados em papelão. Cada um dos primeiros seis tinha o seu número de ordem, por algarismos romanos, I, II, III, IV, V, VI, escritos a tinta encarnada. O sétimo trazia este título: Último.

A razão desta designação especial não se compreendeu então nem depois. Sim, era o último dos sete cadernos, com a particularidade de ser o mais grosso, mas não fazia parte do Memorial, diário de lembranças que o conselheiro escrevia desde muitos anos e era a matéria dos seis. Não trazia a mesma ordem de datas, com indicação da hora e do minuto, como usava neles. Era uma narrativa; e, posto figure aqui o próprio Aires, com o seu nome e título de conselho, e, por alusão, algumas aventuras, nem assim deixava de ser a narrativa estranha à matéria dos seis cadernos. Último por quê?

A hipótese de que o desejo do finado fosse imprimir este caderno em seguida aos outros, não é natural, salvo se queria obrigar à leitura dos seis, em que tratava de si, antes que lhe conhecessem esta outra história, escrita com um pensamento interior e único, através das páginas diversas. Nesse caso, era a vaidade do homem que falava, mas a vaidade não fazia parte dos seus defeitos. Quando fizesse, valia a pena satisfazê-la? Ele não representou papel eminente neste mundo; percorreu a carreira diplomática, e aposentou-se.

Nos lazeres do ofício, escreveu o Memorial, que, aparado das páginas mortas ou escuras, apenas daria (e talvez de) para matar o tempo da barca de Petrópolis. Tal foi a razão de se publicar somente a narrativa. Quanto ao título, foram lembrados vários, em que o assunto se pudesse resumir, Ab ovo, por exemplo, apesar do latim; venceu, porém, a idéia de lhe dar estes dois nomes que o próprio Aires citou uma vez: 
A advertência de Esaú e Jacó apresenta a peculiaridade de não ser assinada. Além disso, toda ela é vazada de forma enunciva; não há marcas de pessoa e o enunciador opta pelo pronome se e pelo uso voz passiva, de forma a aumentar a indeterminação do sujeito e apagar todas as marcas de pessoa, como se a advertência se enunciasse por si mesma. Por outro lado, se o leitor já leu o Memorial de Aires, sabe que quem assina essa advertência é o mesmo $M$. de A. daquele romance, muito embora não se manifeste. Ao proceder dessa forma, o narrador da advertência imita o procedimento do conselheiro Aires, pois, como se sabe, é ele quem narra Esaú e Jacó, muito embora quase nunca diga eu, nem mesmo quando se refere a si próprio.

Em que pesem as semelhanças de procedimentos, o narrador das advertências distancia-se do romance ao apresentar-se simplesmente como o sujeito que encontrou os cadernos do velho conselheiro após sua morte, atribuiu-lhes um título e os publicou. Desse modo, deixa de ter o papel temático de escritor e passa a ter o de editor. Ele não é mais responsável pelo texto e pouco sabe sobre ele: ignora-se a razão do título dos cadernos do qual foi tirado o romance, a razão do registro das memórias e nem mesmo se era desejo do conselheiro publicá-las. O editor também não esclarece qual o interesse da publicação, uma vez que sua utilidade seria apenas matar o tempo da travessia entre o Rio e Niterói. Finalmente, não fica claro se as tais páginas mortas e obscuras do diário foram eliminadas. A única informação relevante dessa advertência é o fato de ela desmascarar o narrador ao informar que ele era o próprio Aires, que, ao que parece, preferia manter-se incógnito. Como quer que seja, cria-se aqui um simulacro completo do fazer literário, trazendo para primeiro plano as perguntas: porque escreve o homem? Porque publica? E, também, a questão da identidade do sujeito.

Um leitor mais ingênuo poderia levar a sério essa advertência; afinal, ao contrário do que ocorria em Memórias póstumas, tanto sua forma quanto seu conteúdo procuram causar um efeito de verdade, segundo o qual Aires existiu e o $e u$ da advertência é, de fato, apenas o editor - efeito que será intensificado anos depois com a publicação de Memorial de Aires. Por outro lado, um leitor mais habituado não se deixará levar pela advertência, pois sabe que esse é um procedimento não incomum na literatura, empregado para causar um efeito de verdade e, assim, aumentar o interesse pela leitura. No entanto, esse mesmo leitor experimentado talvez entendesse que o autor das advertências de Ressurreição e Quincas Borba, por exemplo, era de fato o escritor Machado de Assis. E o que autorizaria tal distinção? Na verdade, nada. Pois 
nada garante que o escritor Machado de Assis tenha recebido os conselhos citados na advertência de Quincas Borba. Pode tê-los recebido ou não. Na verdade, não importa, pois isso está fora do texto. O relevante é que o romance que se conhece hoje comporta duas instâncias narrativas: uma primeira que narra a origem do livro e que instaura uma segunda, a qual conduz a narrativa. Os sujeitos de ambas apresentam-se, em momentos e formas diversas, como enunciadores, muito embora sejam narradores. Assim, todas as advertências se igualam e todas constituem um intermediário entre o enunciador - que continua pressuposto ao texto - e o narrador dos romances. Esse atravessador intermedeia a relação e afasta os envolvidos, sendo a forma como ocorre tal afastamento que muda. Às vezes, esse narrador primeiro opta por criticar, ainda que veladamente, o romance ou seu narrador em outras ocasiões, o distanciamento ocorre pela instauração de um narrador completamente desqualificado, como o de Memórias póstumas, com o qual não seria possível compactuar. Finalmente, o distanciamento pode se dar, como aqui, simplesmente pelo fato desse narrador afirmar que não escreveu o livro, logo, não pode responder pelo que estiver contido nele.

Observe-se, porém, que o sujeito da advertência não se distancia de seus antecessores se for considerado que, como os demais, ele surge como aquele que tornou possível a publicação dos escritos de Aires. Esse era o papel implícito dos sujeitos das advertências anteriores e que agora é explicitado. Em essência, o percurso narrativo não se alterou: é sempre o mesmo sujeito que constrói o mesmo objeto - a narrativa — para nele investir os seus valores. Pode-se dizer, portanto, que a constância observada no plano do narrado, observada no capítulo dedicado às configurações narrativas, repete-se no plano da narração, evidentemente, com outra estrutura. Lá, era o sujeito que partia em busca da conjunção com o objeto ascensão social. Aqui, é o sujeito que, por meio da construção de uma narrativa, busca a conjunção com um objeto como reconhecimento artístico. O resultado final é aquele ao qual já se habituou: a confirmação do ethos do enunciador como alguém que se oculta sob diversas máscaras e que, com isso, reflete sobre o próprio fazer. 


\section{Memorial de Aires}

Em Lisboa, sobre lo mar, Marcas novas mandey lavrar... Cantiga de Joham Zorro
Para veer meu amigo

Que talhou preyto comigo,

Alá vou, madre.

Para veer meu amado Que mig'a preyto talhado, Alá vou, madre.

Cantiga d'el-rei Dom Denis.

\section{ADVERTÊNCIA}

Quem me leu Esaú e Jacó talvez reconheça estas palavras do prefácio: "Nos lazeres do ofício escrevia o Memorial, que, apesar das páginas mortas ou escuras, apenas daria (e talvez dê) para matar o tempo da barca de Petrópolis.”.

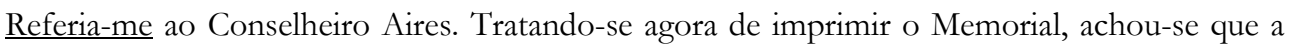
parte relativa a uns dous anos (1888-1889), se for decotada de algumas circunstâncias, anedotas, descrições e reflexões, - pode dar uma narração seguida, que talvez interesse, apesar da forma de diário que tem. Não houve pachorra de a redigir à maneira daquela outra, — nem pachorra, nem habilidade. Vai como estava, mas desbastada e estreita, conservando só o que liga o mesmo assunto. O resto aparecerá um dia, se aparecer algum dia.

M.de A

A advertência de Memorial de Aires compõe com a de Esaú e Jacó, aliás, citada de forma explícita, uma terceira narrativa que antecede as outras duas contidas nos dois romances. Trata-se de um sujeito, M. de A., editor ou homem de letras, que, após a morte do conselheiro, dedica-se a vasculhar sua secretaria, ler seus cadernos de anotações e publicar aqueles que lhe parecem mais interessantes. Inicialmente, publica o último, e, depois, o material relativo aos anos de 1888 e 1889, contidos nos outros seis cadernos. A natureza das relações entre M. de A. e Aires são desconhecidas, mas sabe-se que aquele conhecia o conselheiro a ponto de afirmar, em Esaú e Jacó, que a vaidade não fazia parte de seus defeitos (informação que poderia ser questionada, tendo-se em vista algumas passagens do mesmo romance), mas não a ponto de descobrir a razão de ser das anotações do velho diplomata e mesmo se ele desejaria vê-las publicadas. $\mathrm{M}$ de $\mathrm{A}$. não presta um grande serviço à divulgação da obra do conselheiro ao afirmar, por duas vezes, que, apesar das páginas mortas ou escuras, [o diário de Aires] apenas daria (e talvez dê) para matar o tempo da barca de Petrópolis. Não se trata, portanto, de registros históricos ou políticos, como seria de se esperar, dada a carreira diplomática do diarista, nem de reflexões filosóficas ou mesmo de uma narrativa empolgante: mero passa-tempo, segundo M. de A., e não dos mais duradouros. No caso do Memorial, o editor informa ainda que não houve pachorra de a redigir à maneira daquela outra (Esaú e Jacô), nem pachorra, nem habilidade - e que o texto vai como estava, apenas mais desbastado. Em 
outras palavras, trata-se de obra de escasso interesse redigida sem habilidade. O descaso é tal que, se fosse para tomar a advertência ao pé da letra, não haveria como evitar a pergunta: bom, mas se esses são os predicados do texto, então porque publicá-lo?

Esaú e Jacó e o Memorial de Aires encerram outra narrativa, também comum aos dois romances: a história de José Marcondes da Costa Aires, que chega ao Brasil em 9 de janeiro de 1887, após mais de 30 anos de carreira diplomática, a maior parte foi vivida no exterior. Aposentado, viúvo, sem filhos, e contando com cerca de 65 anos, Aires não tem outra atividade além de visitar os amigos, com os quais sempre evita entrar em polêmica, e registrar suas vidas em seus cadernos. É apenas nesse momento que os dois romances divergem: como se sabe, Esaú e Jacó relata a história dos gêmeos, enquanto o Memorial de Aires, a de Tristão Fidélia e o Casal Aguiar. Os dois romances poderiam ser reunidos em um único: a história de um editor que encontra os cadernos de um diplomata que registra em seu diário íntimo a vida de seus conhecidos; no primeiro, um triângulo amoroso; no segundo, as desilusões de um casal de velhos diante de um casal de jovens. As duas narrativas pertencem, portanto, ao terceiro nível enunciativo de cada um dos romances. As conseqüências dessas múltiplas debreagens já são sabidas: distanciamento do enunciador em relação ao narrador da narrativa central e, considerando todas as instâncias narrativas, substituição da imitação da realidade pela imitação do ato de narrar, ou a imitação da imitação da realidade. O processo é comum a todos os romances de Machado, e atinge o ápice no Memorial de Aires, na medida em que o conselheiro quase não tem outro papel na trama que o de registrar suas memórias, e que tal registro é sempre acompanhado das condições de sua elaboração, configurando, de forma explícita e extensa, uma outra narrativa. A idéia de que o romance seria um retorno às convenções esbarra, dentre outros, exatamente neste ponto: Aires é, explicitamente, o segundo narrador em cena; está subordinado a um outro narrador que habilmente se oculta nas entrelinhas dos registros do conselheiro, tornando-se quase invisível. De certa forma, vale a explicação sugerida na análise de Helena: de fato, o olhar lançado por Aires para a realidade registrada em seu diário é romancesco (basta que se recorde os termos com que o conselheiro descreve Tristão quando este está fumando ou maneira como se refere à Fidélia), mas ocorre que é esse olhar que está sendo imitado e não a realidade vista pelos olhos dele. Daí a importância de se registrar que Aires não é o único narrador em cena e a trama envolvendo Fidélia e Tristão é a terceira narrada no livro. Sob esse aspecto, pode-se aplicar ao Memorial o que Bakhtin (Bakhtin, 1981: 45) dizia a respeito de Dostoievski: 
O autor reserva efetivamente ao seu herói a última palavra. É precisamente desta, ou melhor, da tendência a ela que o autor necessita para o plano do herói. Ele não constrói a personagem com palavras estranhas a ela, com definições neutras, ele não constrói um caráter, um tipo, um temperamento nem, em geral, uma imagem objetiva do herói; constrói precisamente a palavra do herói sobre si mesmo e sobre o seu mundo.

É exatamente isso que Machado faz: constrói precisamente a palavra do herói, Aires, sobre si mesmo e sobre o seu mundo, com as palavras, as idéias e o ponto de vista do herói e, acrescente-se, da classe social a que pertence. Mas, claro, não significa que o enunciador concorde com o herói ou que essa representação valha por si mesma; na verdade, é essa a visão de mundo que lhe interessa estudar. Não se pode afirmar que no Memorial de Aires enunciação e enunciado estejam em oposição nos mesmos termos em que estavam, por exemplo, em Memórias póstumas, mas, também nesse romance, a enunciação deixa claro tanto a parcialidade do ponto de vista de seu narrador quanto a provável existência de outras visões sobre tudo; por exemplo, a de D. Cesária. A oposição se daria também pelo fato de Aires equivocar-se, intencionalmente ou não, a respeito de vários aspectos, especialmente ,no que diz respeito à conduta de Tristão e Fidélia, uma vez que até a véspera da partida de casal para Portugal, ele acredita que os dois permaneceriam ao lado dos Aguiar e que a viagem seria temporária, pois é isto que ambos sustentam. Apenas com a notícia da partida, o conselheiro descobre que se enganara quanto ao caráter dos dois jovens. Ora, engano do narrador, mas não do enunciador, pois não faltam, ao longo do texto, indícios de que as coisas não eram assim tão róseas quanto pintava o diplomata. Em outras palavras, ao enunciador não importa (ou não principalmente) imitar o mundo de Aires, mas imitar o olhar de Aires sobre seu mundo. Como se vê, sempre estamos às voltas com uma imitação, digamos, de segundo grau. À semelhança de Dom Casmurro, sobrepõem-se aqui duas narrativas: uma explicitada pelo narrador e outra que só pode ser lida nas entrelinhas e que revela que enunciação e enunciado não concordam plenamente, ou que seus pontos de vista podem ser diferentes. Enfim, as advertências lançam as bases para que se estabeleçam dois pontos de vista sobre o mesmo objeto e que, em torno da narrativa, desenvolva-se uma polêmica velada (para lembrar os termos de Bakhtin) entre o narrador da trama central e outros narradores instalados pelo enunciador.

A advertência do Memorial de Aires difere da de Esaú e Jacó pelo fato de vir assinada por M. de A, o mesmo que já havia assinado advertências anteriores, as quais eram dadas como reais, como a de Quincas Borba ou de Ressurreição. Ora, essa também almeja tal 
julgamento e faz de tudo para causar um efeito de verdade, inclusive com a menção a um livro que realmente existiu, de autoria de alguém cujas iniciais são as mesmas do remetente dessa advertência. Não há no texto, portanto, qualquer elemento que autorize um tratamento diferenciado para uma ou para outra, e todas devem ser entendidas como parte do romance e do jogo que, a todo momento, propõe a fusão de instâncias narrativas e a substituição do conceito de verdade pelo de eficiência: todas as advertências são verdadeiras porque se apresentam como tal. Esse é seu grande legado: ensinar que tudo é artifício, ou melhor, uma construção discursiva. Como na velha Siracusa, ganha quem souber causar o melhor efeito de verdade. Ao vencedor...

Para encerrar este tópico, observe-se que a advertência do Memorial de Aires é precedida de trechos de duas cantigas que lhe servem de epígrafe e que fazem referência não ao processo de narração, como acontece frequentemente, mas à narrativa de Aires. A segunda cantiga fala de alguém que parte para encontrar seu amigo e seu amado, enquanto a primeira, de certa forma, sinaliza o processo oposto, ao falar de alguém que estabelece elos com Lisboa. Ora, os dois percursos são realizados por Tristão; primeiro, quando parte de Lisboa para rever seus amigos e acaba encontrando sua amada (ou aquela que ele apresenta como tal), depois, porque, ao mesmo tempo, fixa marcas em Lisboa com sua carreira política. Certamente, uma epígrafe dessa natureza em um texto que se pretende um diário íntimo não deixa de soar estranha, ainda mais porque é o único caso na obra enunciador. Tal ocorrência, juntamente com a associação entre a trama narrada por Aires e a tragédia Tristão e Isolda, propiciada pelo nome do protagonista, acabam por comprometer o efeito de verdade criado e restabelecer o processo que tanto se tem apontado: de um lado, a construção de efeitos de verdade; de outro, a demolição desses mesmos efeitos.

$\cos \cos 20$

Analisando-se as onze advertências e prefácios contidos em sete romances de Machado, observa-se, na maior parte delas, um distanciamento em relação ao narrador do romance. Em Ressurreição, A mão e a luva e Memórias póstumas, o enunciador instaura dois sujeitos em tempos distintos: um que mantém uma relação não conflituosa com o narrador - e que marca nitidamente sua preocupação com relação à sanção — e outro que se afasta dele em graus variados e mostra-se pouco preocupado com o julgamento que vier a receber. 
Em Helena, ocorre uma crítica, pode-se dizer, especializada do romance, acompanhada de um pedido de desculpas do narrador primeiro pelo que o leitor achar de romancesco no livro; nesse caso, falta quem se solidarize com o narrador. Algo parecido acontece em Esaú e Jacó e no Memorial de Aires; em ambos, o afastamento do narrador das advertências em relação ao dos romances talvez seja ainda maior, uma vez que o editor se exime da narrativa, afirma desconhecer a razão da manutenção do diário, e realça que sua identidade é diferente da do narrador - o que não ocorria em Helena. Conclui-se que a advertência busca chamar a atenção não apenas para o conteúdo dos diários, mas principalmente para sua escritura. Mais uma vez, ao lado dos percursos dos sujeitos instalados no enunciado, passa a se destacar o percurso do sujeito que produz o diário. Já em Quincas Borba não se observa qualquer antagonismo entre o narrador da advertência e o da narrativa central. Enfim, ponto comum entre todas as advertências é que o fazer literário do sujeito surge como um percurso narrativo tão ou mais importante que a trama central do romance.

A divergência entre o narrador das advertências e o dos romances também corrobora o que foi afirmado no capítulo anterior; isto é, que há uma defasagem entre os saberes de que um e outro dispõem. Por exemplo, quando o narrador primeiro de $A$ mão e a luva afirma que não daria a mesma feição ao livro, conclui-se que disporia de um saber sobre a narração superior ao do narrador segundo, o que faz supor que esse narrador pertence a um nível narrativo hierarquicamente superior, pois pode julgar o fazer de outro. O mesmo acontece na advertência de Esaú e Jacó, quando o sujeito revela que o narrador do romance é Aires. Embora não se possa afirmar que esse sujeito tenha um saber maior que o conselheiro, é certo que ele é portador de uma informação exterior ao romance, não fornecida pelo narrador e relativa tanto ao enunciado, pois Aires é actante desse nível, quanto à narração, uma vez que Aires é o narrador. Conclui-se, daí, que o enunciador não distribuiu seu saber de forma igualitária entre seus narradores, mas conferiu ao primeiro um saber-ser, isto é uma capacidade de julgamento acerca do próprio saber (ou do de outrem), a qual estava ausente no narrador segundo. Finalmente, o fato de o primeiro narrador — hierarquicamente superior e dotado de uma maior saber — discordar do segundo sugeriria uma oposição entre o narrador do romance e o enunciador, instigada ainda mais pelo caráter em geral pouco confiável daquele.

O outro ponto de convergência dessas advertências é o mais óbvio de todos: o simples fato de elas existirem acarreta a criação de uma espécie de degrau enunciativo, ou 
seja, da realização de uma debreagem primeira que precede a instauração do narrador responsável pela condução da narrativa. Essa primeira debreagem é sempre feita de forma enunciativa, de modo a reforçar a idéia de que aquele que fala não é o narrador, mas o produtor físico do texto, efeito intensificado pela assinatura (M. de A. ou M. A.), em uma óbvia menção ao escritor Machado de Assis, que, certamente, não pode ser associado ao en que aí fala. Desse modo, as instâncias enunciativas acabam por se fundir, provocando uma grande vertigem, pois nunca se sabe com qual nível se está lidando. A exceção, que acaba por confirmar a regra, é Esaú e Jacó, cuja advertência é debreada de forma enunciva, sendo também a única que não é assinada. Ora, sabe-se que o narrador do romance, Aires, é um actante do enunciado que nunca diz eu, nem mesmo quando descreve seus próprios sentimentos. Conclusão: nada impede que Aires adote esse comportamento também na advertência e que nela se refira a si próprio na terceira pessoa. O fato de ele já estar morto não representa um obstáculo intransponível, um vez que ele não seria o primeiro narrador defunto da obra de Machado. Contudo, o objetivo dessas observações não é fazer elucubrações acerca da autoria dessas advertências, mas, apenas, mostrar que elas têm um papel muito claro na obra de Machado: desestabilizar a narração e re-situar a narrativa, conforme foi comentado no início deste capítulo. Desse modo, Esaú e Jacó, por exemplo, deixa de ser a história de dois irmãos que estão em eterna disputa e passa a ser a história de um conselheiro que registrava em seus cadernos a vida de dois irmãos, Pedro e Paulo. De igual modo, Ressurreição deixa de ser a história de Félix e Lívia e passa a ser a história de um jovem escritor que se apresenta para a crítica em um ensaio em gênero novo para ele e que deseja saber se tem alguma qualidade ou se todas lhe faltam, como é afirmado na introdução.

A narrativa primeira está assim colocada: é o sujeito que tenta executar a contento o percurso para o qual foi manipulado, o qual consiste em criar um objeto literário em que esteja investido o valor de "qualidade", ou seja, como imitar bem a realidade, questão que, por sua vez, remete a outra, relativa às próprias condições de apropriação dessa realidade para que ela possa ser imitada. E cá estamos, de novo, às voltas com as questões que tanto atormentaram os narradores machadianos, que desde Ressurreição preocupam-se em mostrar ao narratário que sabem como tudo se passou e são hábeis em narrá-lo. Recorde-se o capítulo de Quincas Borba em que o narrador diverte-se à custa do leitor, mostrando como o enganara a respeito das aventuras entre Sofia e Carlos Maria; ou o dilema central de Dom Casmurro, que não é outro senão a correta apreensão da realidade. Finalmente, não se deve esquecer que o 
conselheiro Aires, com toda sua vivência diplomática, cometeu um erro crasso ao julgar as intenções de Tristão e Fidélia. No centro da impossibilidade definir a realidade, está o próprio sujeito, cuja identidade permanece inacessível, seja porque está morto, como em Memórias póstumas; seja porque é um alienado, como o Rubião de Quincas Borba, que não consegue identificar quem são seus amigos; seja porque vive atormentado por duplos, como a Flora de Esaú e Jacó; ou, simplesmente, porque a identidade, como já ensinava o velho Jacobina de $O$ Espelho (Papéis avulsos, 1882), é definida pela alma exterior e esta deve ser adquirida, como tudo em uma sociedade capitalista.

Em síntese, o enunciador instaura um narrador primeiro (o das advertências) que se faz passar pelo próprio enunciador, quase como um laranja, como se diz hoje em dia, que discute o fazer literário, os percalços por que passou para imitar a realidade. Por sua vez, esse laranja instaura um narrador segundo que constrói sua imitação da realidade, aquela que diz respeito à ascensão social — mas isso, sem deixar de lado o fazer literário. Dessas múltiplas debreagens surge, num primeiro momento, um ethos de sinceridade, de alguém que joga às claras, afinal, por meio de seus prepostos, o enunciador abriria seu coração e contaria seus dilemas. Todavia, não se pode esquecer que o narrador primeiro não é o enunciador e não se confunde com ele, pois o enunciador permanece oculto atrás de diversas máscaras. Percebese, então, que a sinceridade é, na verdade, dissimulação, tão bem construída que parece sinceridade. Sim, pois a assinatura $M$. de A., presente em quase todas as advertências, poderia levar o leitor ingênuo a pensar que o $e u$ desses textos é mesmo Joaquim Maria Machado de Assis, quando se sabe que não é ele, que não pode ser ele, pois Aires nunca existiu e nunca seus cadernos foram encontrados. Assim, a semelhança é mero simulacro para enganar os incautos; dissimulação, portanto. Ora, não é outra a função das referências “autobiográficas" em Memorial de Aires. Recorde-se o episódio da abolição da escravatura em que Aires se recusa a participar de um cortejo comemorativo, a ser estudado no capítulo seguinte. Sabe-se que o episódio aconteceu com o escritor Machado de Assis, mas que este, ao contrário do conselheiro, aceitou o convite. Logo, a referência não é autobiográfica, apenas parece sê-lo. A dissimulação encobriria, na verdade, um cínico dissimulado, se é que o oxímoro é possível. Em que medida isso invalidaria as observações sobre as advertências? Em nada; ao contrário, apenas confirma que todas são fabulação, como o restante do romance.

Contudo, as advertências parecem também oferecer um problema para este trabalho. Lá atrás se afirmou que nenhum dos percursos narrativos centrais dos romances de Machado 
poderia ser considerado romântico. No entanto, o narrador primeiro, chamado aqui de laranja, procura eximir-se do que o leitor achar de romanesco em Helena - e está claro que o adjetivo é empregado em seu sentido pejorativo, de trama exageradamente sentimental, idealista - e, além disso, se não houvesse algo de reprovável nessas narrativas, ao menos na visão desse narrador primeiro, não haveria porque ele procurar distanciar-se delas, como também acontece em Ressurreição e $A$ mão e a luva. Inicialmente, deve-se observar que esse distanciamento ocorre em todos os romances, mesmo naqueles que não seriam considerados românticos. Em seguida, é preciso distinguir os fatos do julgamento que deles é feito pelo narrador. Viu-se que os heróis machadianos, ou os percursos por eles realizados, não diferiam de forma significativa de romance a romance, e que, na verdade, eram diferenciados pelo olhar do narrador, ou melhor, por sua competência para torná-los mais ou menos respeitáveis. O narrador de Helena conseguia construir uma boa imagem do Dr. Camargo; já Brás Cubas (intencionalmente ou não) não logra fazê-lo em relação a Cotrim; o narrador de Iaiá Garcia traça um perfil positivo de Jorge, apesar dos pesares, enquanto Aires fracassa ao tentar a mesma empreitada em relação a Tristão. O que se propõe é que o narrador segundo lança, de fato, um olhar positivo (ou não negativo) sobre suas narrativas; um olhar, diria o narrador primeiro, romanesco, que não é acompanhado pela instância da enunciação. Reveja-se a cena em que Aires vê Tristão fumando e olhando o vazio. O conselheiro, em uma atitude que bem poderia ser chamada de romanesca, considera que ele sonha com o altar, mas o desfecho do romance mostra que estava redondamente enganado; portanto, a instância da enunciação não partilhava esse ponto de vista.

Enfim, as advertências confirmam o que foi afirmado quando se discutiu a delegação de saber: em todos os romances o discurso do narrador, a narrativa segunda, é que é o objeto imitado. Dessa situação, nasce a polifonia, que tem seu eixo central no diálogo entre os narradores instalados no texto, ou entre o narrador que conduz a narrativa e as demais vozes instaladas. O diálogo, conflituoso, tanto pode se estabelecer nas advertências quanto no corpo da narrativa, sendo que esses procedimentos podem andar juntos ou separados. Em Memórias póstumas e Memorial de Aires, por exemplo, a oposição surge nos dois momentos; já em Helena, está apenas na advertência; e, em Dom Casmurro e Quincas Borba, apenas no texto. O que muda é apenas a forma pela qual o enunciador afasta-se de seus narradores e, por isso, nenhum dos percursos dos romances pode ser chamado de romanesco, ficando evidente, de um jeito ou de outro, a oposição entre enunciação e enunciado. A única exceção seria 
justamente Iaiá Garcia, em que, de fato, não se nota tal oposição. Aliás, veja que Iaiá é outra exceção que confirma a regra. Sendo a função da advertência marcar a oposição em entre a enunciação e o enunciado e não havendo neste romance uma oposição (ao menos não tão claramente marcada), não haveria porque construir uma advertência ao leitor. Afinal, advertilo do quê? A outra exceção, Dom Casmurro, decorre, em nosso entendimento, de uma impossibilidade, pois o romance se estrutura no delicado equilíbrio entre a confiança e a desconfiança em relação ao narrador; logo, qualquer manifestação do enunciador em relação a seu preposto, colocaria em risco esse equilíbrio.

Enfim, as advertências presentes nos romances de Machado - e agora se percebe o quanto fazem jus ao nome - parecem compor com as narrativas uma harmonia admirável, e apontar para um único sujeito da enunciação, um único ethos. Além de confirmar sua dissimulação, a análise dos vários níveis enunciativos caracteriza o enunciador como alguém que tem gosto pela polêmica, sempre instalada de forma sutil, como não poderia deixar de ser tendo em vista seu jeito dissimulado. As advertências revelam que esse enunciador, em vez de optar por uma versão única dos fatos, prefere debate, o confronto de opiniões, e, assim, deixa que seus narradores apresentem livremente seu ponto de vista sobre o mundo - a palavra do herói, como diria Bakhtin. Ao mesmo tempo, porém, aponta a possibilidade de tudo ser diferente, de haver uma outra via. Precisa-se, assim, a imagem de contestador a que se referiu anteriormente. $\mathrm{O}$ enunciador não contesta uma verdade por que tenha outra a propor; o faz simplesmente, sem apontar a possibilidade de outra que ele também nunca defende. É o que ele faz com maestria no Memorial de Aires: o conselheiro tem sua visão; D. Cesária, a dela; nenhuma é endossada ou negada, e a apresentação de ambas concede ao enunciatário várias visões da realidade, ensinando-lhe que tudo sempre pode ser de outro modo. É desse modo que seu ceticismo não se opõe ao seu jeito contestador irreverente: o fato de contestar algo não significa sua opção por outra possibilidade.

A seguir se verá que esse ceticismo é bem mais arraigado do que se pode pensar em um primeiro momento. 


\section{Contrato enunciativo}

omo qualquer ato comunicativo, a produção de um romance implica o
estabelecimento de uma relação entre um sujeito destinador/enunciador e outro sujeito destinatário/enunciatário. Como se sabe, a relação é intermediada por um objeto de saber, no caso em análise, o próprio romance. Essa relação implica ainda um acordo ou, para usar o termo semiótico, um contrato, que irá impor aos dois sujeitos determinado comportamento: o enunciador deverá entregar o objeto contratado e o enunciatário será levado a um estado de espera em relação ao objeto. Posteriormente, durante e após a fruição do romance, o destinatário sancionará o fazer do enunciador em termos de crítica, especializada ou não. A realização perfeita do contrato implica, como se vê, a transformação das competências modais do sujeito da enunciação: o enunciatário passará a estar em conjunção com um dado saber de que não dispunha até então; e o enunciador será sancionado como sujeito competente, em diversos graus e maneiras diferenciados. Os contratos analisados têm ainda a peculiaridade de sancionarem programas narrativos no interior de um determinado discurso e, por esse motivo, são chamados de contratos enunciativos. Neste caso, em princípio, o destinador-enunciador exerce um dizer verdadeiro, que tem como contrapartida um crer verdadeiro por parte do destinatário-enunciatário, que irá aderir ou não ao discurso recebido, atribuindo-lhe um estatuto de verdade ou de mentira. ${ }^{144}$

Uma das cláusulas mais importantes do contrato estabelecido entre os dois sujeitos diz respeito à verossimilhança e ao conteúdo de verdade do objeto de saber transferido. De acordo com Greimas (1983: 103), a verossimilhança pode ser definida como uma apreciação que o discurso projeta de si mesmo tendo como base certa concepção de realidade, a qual varia conforme a sociedade. O mesmo autor acrescenta ainda que "O discurso verossímil não é apenas uma representação 'correta' da realidade sociocultural, mas também um simulacro montado para fazer parecer verdadeiro e que, desse modo, pertence à classe dos discursos persuasivos" (op. cit.: 423). О conceito de verossimilhança é, portanto, sócio-cultural: o que hoje é verossímil poderá não

\footnotetext{
${ }^{144}$ Ver Greimas \& Courtés, 1993: p. 146.
} 
sê-lo amanhã ou não para todos os indivíduos e nem se aplica para todos os discursos. Por exemplo, não cabe falar em verossimilhança de uma lei, de uma teoria científica ou mesmo de uma piada. Espera-se que esta faça rir, pouco importando se é verossímil ou não. Por outro lado, a verossimilhança não se aplica apenas a textos literários ou ditos ficcionais; diz respeito também àqueles passíveis de serem tidos por verdadeiros ou falsos como, por exemplo, testemunhos, depoimentos, notícias e relatos cotidianos. No caso do romance, o enunciatário espera que o objeto recebido seja verossímil, pois essa cláusula está implícita no contrato entre as partes e será fundamental na sua sanção. Se o enunciatário receber um romance que ele considera inverossímil, isso certamente irá pesar negativamente na sanção que fará do enunciador.

A esse respeito, recordem-se os comentários de Machado de Assis sobre o Primo Basílio, de Eça de Queiroz. A principal crítica do escritor brasileiro refere-se ao fato de não haver relação lógica entre o adultério de Luíza e Basílio e o desfecho da trama, decorrente de um fato fortuito: a descoberta, pela criada Juliana, das cartas trocadas entre os dois amantes. Relembre-se, inicialmente, a resposta de Machado às críticas recebidas por seu primeiro artigo:

[...] Releiam-me; lá verão que, depois de analisar o caráter de Luíza, de mostrar que ela cai sem repulsa nem vontade, que nenhum amor nem ódio a abala, que o adultério é ali uma simples aventura passageira, chego à conclusão de que, com tais caracteres como Luíza e Basílio, uma vez separados os dois, e regressando o marido, não há meio de continuar o romance, porque os heróis e a ação não dão mais nada de si, e erro de Luíza seria um simples parênteses no período conjugal. Voltariam todos ao primeiro capítulo: Luíza tornava a pegar no Diário de Notícias, naquela sala de jantar tão bem descrita pelo autor; Jorge ia escrever os seus relatórios, os freqüentadores da casa continuariam a ir a li encher os serões. Que acontecimento, logicamente deduzido da situação moral dos personagens, podia vir continuar uma ação extinta? Evidentemente, nenhum. Remorsos? Não há probabilidade deles; porque ao enunciar-se a volta do marido, Luíza não obstante o extravio das cartas, esquece todas as inquietações, "sob uma sensação de desejo que a inunda". Tirai o extravio das cartas, a casa de Jorge passa a ser uma nesga do paraíso; sem essa circunstância, inteiramente casual, acabaria o romance. Ora a substituição do acessório pelo principal, ação transplantada dos caracteres e dos sentimentos para o incidente, para o fortuito, eis o que me pareceu incongruente e contrário às leis da arte. (Obra Completa, vol. III p. 910 itálicos do autor; grifos meus).

Machado reprova em Eça o fato de os caracteres de Luíza e Basílio não permitirem o desenlace que a trama teve, uma vez que, com suas caracteres, as personagens não poderiam sentir remorsos nem, portanto, conferir à trama a densidade dramática que seria desejável. Segundo Machado, para que o adultério levasse à morte, Eça teve de recorrer a um expediente fortuito, de certa forma alheio à trama, fazendo com que essa perdesse parte de sua força, isto é, de sua capacidade de imitar a realidade. O deslize é tão mais grave na medida 
em que a escola a que se filiava o autor, o realismo, tinha como princípio a imitação precisa e imparcial da realidade. Machado não nega o talento do autor, nem as virtudes do romance, mas aponta para a ausência de uma relação lógica entre as partes que o constituem, incongruência que faz o trama perder parte de sua verossimilhança, um dos itens implícitos do contrato estabelecido entre o enunciado e o enunciatário. Enfim, Machado reprova em Eça o fato de o autor ter substituído uma questão secundária - o encontro fortuito das cartas por Juliana — pelo principal, a lógica que deveria por si só levar ao desfecho "natural" da trama. A infração dessa cláusula leva o enunciatário, no caso, Machado, a sancionar negativamente o enunciador, Eça. Veja-se agora a crítica propriamente dita, em que o brasileiro cobra do português maior obediência às regras do realismo e aponta a fragilidade da relação entre causa e efeito:

[...] Se escreveis uma hipótese, dai a hipótese lógica, humana, verdadeira. Sabemos todos que é aflitivo o espetáculo de uma grande dor física; e, não obstante, é máxima corrente em arte, que semelhante espetáculo, no teatro, não comove a ninguém; ali vale somente a dor moral. Ora bem; aplicai esta máxima ao vosso realismo, e sobretudo proporcionai o efeito à causa. E não exijais a minha comoção a troco de um equívoco. (Obra Completa, vol. III p. 907)

Como se pode observar, Machado questiona justamente a inverossimilhança do Primo Basílio quando fala em falta de congruência ou de ausência de relação entre causa e efeito. Registre-se que, no mesmo texto, Machado faz vários elogios ao romance, discordando daqueles que haviam criticado a linguagem adotada e mostrando que essa era necessária à economia da obra, até mesmo para atender aos princípios da escola a que se filiava o autor. Não é tampouco a questão veridictória (a ocorrência ou não dos fatos narrados) que importa ao crítico, mas justamente, (como dizia Aristóteles na Poética), o fato de a imitação ter ocorrido de forma não artística, ou como diz Machado, de o romance ter violado as leis da arte.

A segunda cláusula presente no contrato enunciativo diz respeito ao caráter veridictório do saber transferido. Conforme explicam Greimas \& Courtés (1993: 420), não se trata da adequação ou não a um referente externo ao discurso, mas do efeito de realidade nele construído, o qual pode afirmar-se a si mesmo como real ou fictício. Mais uma vez, essa cláusula não está presente em todos os contratos. Por exemplo, um romance pode se apresentar como real, como Madame Bovary, ou ficcional, como Macunaíma; o importante não é, portanto, a existência de um referente "real", mas a verossimilhança. Um texto que se intitula conto de fadas ou fiç̧ão científica se apresenta como não verdadeiro, pois o efeito que 
procura causar é de que se discutem fatos imaginados, não necessariamente ocorridos, sem que isso represente perda de verossimilhança nem uma menor capacidade do enunciador de tratar da realidade. As fábulas de Esopo e La Fontaine são um bom exemplo. Já uma notícia de jornal, por exemplo, busca, necessariamente, o efeito de que é o fiel retrato da realidade, de que se adequa perfeitamente ao "referente externo" e o leitor não espera outra coisa. Desse modo, as evidências de que um jornal mentiu acarretam uma quebra de confiança entre ele e seus leitores, que podem repercutir até mesmo na esfera jurídica, como aconteceu anos atrás quando se descobriu que um dos mais renomados jornalistas do The New York Times forjava suas entrevistas. Por outro lado, em certos países, alguns jornais têm o costume de estampar manchetes mentirosas no dia primeiro abril; porém, nesse caso, o contrato muda: admite-se que nesse dia os jornais publiquem notícias falsas que assim são recebidas pelos leitores, pois todos sabem que primeiro de abril é o dia da mentira, portanto, que nesse data os jornais podem dar-se ao luxo de mentir, ou melhor, de apresentar falsas notícias. Vê-se, claramente, que há uma cláusula no contrato entre enunciador e enunciatário, autorizando que não se fale a verdade em um dia específico, e só nele. Esse era o caso, também, do já extinto Planeta Diário, publicação que parodiava os jornais ditos sérios e as notícias ditas verdadeiras. O mais interessante é que isso era feito com vários recursos utilizados pelos jornais para causar o efeito de verdade, como aspas, fotografia, entrevistas com personalidades etc., Ficou célebre uma manchete que dizia: Maluf entrega-se à polícia. Em seguida, havia uma foto desse político e, abaixo dela, dizeres como Maluf desabafa: "Cansei dessa vida". Ao proceder dessa forma, o jornal não apenas satiriza o personagem tido por desonesto, mas também os procedimentos utilizados pelos jornais para causar a impressão de verdade. Claro, ninguém poderia processar o jornal por falsidade ideológica, pois era consenso que as notícias publicadas apenas pareciam, mas não eram, verdadeiras.

Observe-se, ainda, que tal questão não se limita aos textos escritos. É famoso o episódio ocorrido na União Soviética após a ascensão de Stalin. O sucessor de Lênin procurou apagar de quase todas as fotografias a imagem de seu rival, Trotski. Como em quase todas as imagens da época, viam-se apenas Lênin e Stalin, supunha-se que Trotsky jamais houvesse estado presente em tais ocasiões. Apenas após o relatório de Kruschov, em meados da década de 1950, e mais recentemente com o fim da União Soviética, é que se soube que as fotografias haviam sido adulterada e que Trotsky de fato estivera junto a Lênin e Stalin naquelas ocasiões. Descobriu-se, então, que, tais fotografias eram uma mentira; pareciam ser 
verdadeiras, mas não o eram, pois a imagem que continham não correspondia à realidade a que elas se referiam, ao tal "referente externo". No entanto, essas fotografias cumpriram seu papel na época: construir uma versão da realidade, segundo a qual Stalin foi, durante todo o tempo, o mais próximo, senão o único, a auxiliar de Lênin. Hoje, a nova versão das mesmas fotografias também cumpre seu papel, o de confirmar outra verdade, a saber, que Stalin foi um ditador e usou de todos os meios para eliminar seus oponentes, contando para tanto com a ajuda de Lavrenti Pavlovitch Beria, chefe da NKVD (nome do então serviço secreto soviético), condenado à morte e executado poucos meses após o falecimento de Stalin, e tido como o responsável por tais montagens.

Um texto, porém, nem sempre se apresenta verdadeiro ou falso, como os citados. Por exemplo, o filme Pra frente Brasil, de Roberto Farias (1982), citado também por Barros, conta a história de um homem inocente que é preso, torturado e morto pelas forças de repressão, durante a ditadura militar no Brasil. Ao final do filme, surgem na tela dizeres como: "Essa é uma obra de fiç̧ão, qualquer semelhança com fatos ou pessoas reais é mera coincidência". Diante de tal frase, a platéia nos cinemas ria, percebendo a ironia. A frase não vinha em letras pequenas ao final dos créditos, como estamos habituados, mas em letras garrafais, juntamente com cenas que mostram a vitória da seleção brasileira na década de 70, imagem copiosamente usada pela ditadura militar para promover o Brasil e, especialmente, a si própria. Normalmente, essa frase viria ratificar o contrato implícito nas obras de ficção e eximir o produtor de eventuais complicações legais: tudo o que foi visto era mesmo mentira — isto é, parecia ser, mas não era. No entanto, os dizeres exibidos em momento e forma inesperados, aliados ao próprio enredo do filme e ao momento vivido pelo país, de abertura política, produzem um efeito de ironia, que inverte o sentido original da frase: o que passa a ser ficcional (portanto, mentiroso) não são os episódios narrados no filme, mas sim a própria afirmação de que esses episódios seriam ficcionais. Dessa forma, a enunciação do filme retoma um dos procedimentos da censura, que consistia, justamente, em afirmar que nada do que se noticiava sobre a repressão era verdadeiro. A frase acaba contribuindo para a imitação da realidade e para causar um efeito de sentido de que tudo o que foi narrado,a o contrário do sue sugere a célebre frase, aconteceu de fato. Nunca é demais enfatizar que não se está discutindo uma questão moral, relativa a dizer ou não a verdade; trata-se dos efeitos de sentido presentes no texto, os quais levam o enunciatário a deduzir que o enunciador fala ou não a verdade. $\mathrm{O}$ conto de fadas e os filmes de ficção científica criam efeitos que levam o 
enunciatário a crer que nada do que é narrado aconteceu de fato, mas que poderia vir a ocorrer em determinadas condições: em um mundo mágico, no futuro, num passado remoto, em outra galáxia etc.... As notícias dos jornais e os documentos da antiga União Soviética tinham o objetivo oposto, isto é, fazer crer. Já o filme de Roberto Farias é interessante, pois se observa uma polifonia característica: há uma voz que diz que tudo aquilo é ficção (não existiu) e outra que diz que, na verdade, tudo aconteceu sim. Os documentos de Stalin são uma mentira; não são verdadeiros, apesar de pareceram. O filme é um segredo: é verdadeiro, apesar de não parecer.

O fato de, em alguns casos, o contrato enunciativo estipular que se fale a mentira, e, em outros casos, que se diga a verdade, traz implicações para as relações entre enunciação e enunciado. Assim, no primeiro caso, o discurso é construído mediante um desacordo entre a enunciação enunciada e o enunciado enunciado, resultante de um antagonismo entre as avaliações que remetem à enunciação e aquelas que dizem respeito ao enunciado. É o caso do filme citado, em que o enunciado afirma que os fatos narrados são falsos, mas a instância da enunciação afirma que eles são, sim, verdadeiros, contando, para isso, com a argúcia do enunciatário, que sabe que os fatos descritos realmente ocorreram. É também esse o caso dos jornais que durante os anos de repressão política publicavam receitas de bolo na primeira página. Ora, o contrato enunciativo em questão estipula que na primeira página dos jornais só devem ser publicadas notícias que o enunciador e o enunciatário consideram importantes e que receitas culinárias não pertencem a essa categoria. Logo, se o jornal-enunciador, conhecedor dessas regras, as viola com a instauração de um enunciado não condizente com elas, então, o enunciatário, que também conhece as mesmas regras e confia que o enunciador não irá desrespeitá-las sem um bom motivo, passa a procurar razões para tal contravenção; nesse processo, irá atinar com o sentido real da receita, que não é o de ensinar a fazer um bolo, mas fazer saber que a notícia importante foi censurada. Se, por um lado, essa estratégia não permite que a notícia censurada chegue a o conhecimento do enunciatário, por outro, permite que este descubra que existe um segredo: o que não parece ser uma censura (pois não há as célebres palavras “censurado”), é, na verdade, uma censura, pois a receita é uma falsa receita: ela parece ser uma receita, mas é, na verdade, um protesto contra a censura. Mais uma vez, para que essa estratégia funcione é preciso que enunciador e enunciatário partilhem o mesmo conjunto de regras (não se publicam receitas na primeira página), um mesmo saber (a 
existência de uma censura) e um mesmo conjunto de valores que faz o enunciatário confiar no enunciador ao supor que este não violaria uma regra sem um bom motivo.

No caso da literatura, um romance que procure efeitos de sentido de verdade apresentará, nas mais das vezes, uma concordância entre enunciador e narrador. No outro caso, quando o efeito almejado for o de mentira, narrador e enunciador estarão em oposição. $\mathrm{Na}$ verdade, trata-se de um contínuo; em um extremo, estarão os casos em que o narrador não é, por motivos vários, confiável, no outro, um narrador acima de qualquer suspeita. Entre eles, haverá aqueles narradores, mais ou menos hábeis, que cometam maiores ou menores deslizes, que permitirão ou não constatar a incompatibilidade entre enunciador e narrador. Veja-se, por exemplo, o conto Sereníssima república (Papéis avulsos, 1882). Nele, o narrador, cônego Vargas, esforça-se por fazer sua teoria de que as aranhas têm um regímen social parecer crível e, para tanto, instaura inúmeras marcas de veridicção em seu discurso. Vejam-se algumas:

Minha descoberta não é recente; data do fim do ano de 1876. Não a divulguei então, — a não ser o Globo, interessante diário desta capital, não a divulgaria ainda agora, - por uma razão que achará fácil entrada no vosso espírito. Esta obra de que venho falar-vos carece de retoques últimos, de verificações e experiências complementares. Mas o Globo noticiou que um sábio inglês descobriu a linguagem fônica dos insetos, e cita o estudo feito com as moscas [...]

Senhores, vou assombrar-vos, como teria assombrado a Aristóteles, se lhe perguntasse: Credes que se possa dar regímen social às aranhas? Aristóteles responderia negativamente, como vós todos, porque é impossível crer que jamais se chegasse a organizar socialmente esse articulado arisco, solitário, apenas disposto ao trabalho, e dificilmente ao amor. Pois bem, esse impossível, filo eu.

Ouço um riso, no meio do sussurro de curiosidade. Senhores, cumpre vencer os preconceitos. A aranha parece-vos inferior, justamente porque não a conheceis. [...] (Obra Completa, vol. II p.340).

O narrador esforça-se por fazer seu discurso parecer verdadeiro, recorrendo à inscrição de marcas de veridicção, tais como a explicação de que só divulgou suas descobertas depois de verificá-las, a exemplo do que faria qualquer cientista responsável, que só se decide pela divulgação depois que outra descoberta tão fantástica quanto a sua tenha sido publicada por um jornal respeitado e conhecido pelo enunciatário. Depois, durante todo o conto, faz menção às datas de suas descobertas e ao resultado obtido com as experiências realizadas, como se tratasse realmente de um experimento científico. Além disso, procura construir o ethos de alguém culto, por exemplo, ao mencionar a invenção do balão pelo Pe. Bartolomeu de Gusmão (não mencionada na trecho acima) e citar Aristóteles. Finalmente, aparenta ter 
certo espírito científico ao reconhecer que sua descoberta ainda requer alguns experimentos e solicitar que sejam abandonados os preconceitos, sentimento não condizente com a ciência.

No entanto, enquanto o narrador esforça-se por fazer crer, o enunciador trabalha com o objetivo oposto, de desacreditá-lo. O caráter completamente absurdo da sua teoria é suficiente para tornar inócuos seus esforços: alguém que acreditasse na organização política das aranhas não poderia mesmo ser levado a sério. $O$ enunciatário entende, então, que a questão central do conto não pode ser, claro, a vida social das aranhas, mas que a dita teoria é um pretexto para que o enunciador discuta o que realmente lhe interessa e, para tanto, ele instaura no texto um narrador que não é digno de crédito. $O$ enunciatário passa então a procurar outras possibilidades de leitura, por exemplo (para ficar numa leitura mais superficial), o conto ser uma alegoria dos casuísmos da legislação eleitoral no Brasil do II Império. Enfim, o fato de enunciação e enunciado estarem em desacordo obriga o enunciatário a buscar uma interpretação que recoloque as coisas em seus devidos lugares, de forma a restabelecer seu contrato original com o enunciador, tal como fazia o leitor do jornal ao deparar com receitas na primeira página. O resultado é tal que embora o texto pareça mentiroso, o enunciador não é tomado por mentiroso, pois o enunciatário sabe que ele mente apenas no modo do parecer.

Observe-se que aí estão contidas duas estratégias distintas a serem adotadas pelo sujeito do fazer persuasivo, o qual pode tanto fazer com que manifestação (parecer) e essência (ser) concordem quanto optar por fazer com que se contradigam. No primeiro caso, partindo do parecer (ou não-parecer), ele fará o enunciatário chegar ao ser (ou não ser). No segundo, partindo do parecer, ele fará com que o sujeito chegue ao não ser — descobrindo, portanto, que algo é mentira — , ou então, partindo do não-parecer, fará o enunciatário concluir pelo ser, portanto, que está diante de um segredo. No primeiro caso, cria-se um efeito de franqueza, de sinceridade; no segundo, de dissimulação. De igual modo, o enunciador que construir enunciados em concordância com a enunciação será considerado sincero; no caso oposto, dissimulado.

Uma última questão relativa ao contrato enunciativo diz respeito ao conceito de linguagem implicado. Conforme explica Fiorin (2005: 141), há, pelo menos, três atitudes diante da linguagem, cada qual tendo repercussões sobre a estratégia adotada para representar o mundo. De acordo com a primeira, a linguagem está no lugar de um referente externo a ela; 
conseqüentemente, a arte reflete ou imita a realidade. Um exemplo desse contrato é o realismo ou o naturalismo de Eça de Queiroz, autor que almeja à objetividade acima de tudo. As descrições devem ser, portanto, precisas, e o sujeito deve apagar-se e deixar que a realidade (natural, social etc.) fale por si só. A segunda atitude entende que o mundo não é compreensível sem a atividade humana. É o sujeito que, de certa forma, constrói um mundo; são suas impressões, seus sentimentos, que importam e não a realidade em si mesma, a qual, sem o homem, não é nada. É o caso do romantismo, que centra não centra a representação na realidade propriamente, mas na visão que o sujeito tem dela. É o caso de muito contos de Poe, em que fica patente que o que é narrado não é a "realidade", mas a visão dela que tem o indivíduo. Longe de apagar-se, o sujeito vem para o primeiro plano, a partir do qual a imitação é feita. A terceira atitude é a que entende que a relação do homem com o mundo não se dá de forma direta, pois é intermediada pela linguagem. Como afirma Fiorin, segundo tal modelo, o mundo não existe sem a linguagem e esta não depende daquele; na verdade, ela o cria inúmeras vezes, de acordo com a instância da enunciação. Se, por um lado, a linguagem deixa de representar o mundo, por outro, o sujeito deixa de ter acesso à realidade senão pela linguagem. Essa questão é bem freqüente nos quadros do pintor belga René Magritte, que, em diversas de suas obras discute, justamente, a impossibilidade de o homem interagir com o mundo sem a intermediação da linguagem. ${ }^{145}$ Fiorin denomina esse contrato enunciativo de contrato semiótico, pois nele

[...] Tem-se consciência de que a ordem da linguagem e a ordem do mundo não são perfeitamente homólogas. Por isso, a linguagem não é a representação transparente de uma realidade, mas é a criação de diferentes realidades, de diversos pontos de vistas sobre o real. Mostra-nos, por conseguinte, a relatividade da verdade, a possibilidade de que a realidade seja outra. Nada há fixo, imutável, verdadeiro. A verossimilhança, nesse tipo de contrato, é uma construção interna a obra e não uma adequação ao referente como pretende o contrato enunciativo objetivante. (Fiorin, 2005: 145).

Esse é precisamente o caso de Machado de Assis: nada é fixo, imutável, verdadeiro, pois há sempre vários pontos de vista sobre tudo, sendo a ordem da linguagem determinante sobre o mundo. Por isso, o fato de a narração dominar o narrado não é mero exercício metalingüístico ou virtuosismo, mas o cumprimento cabal desse contrato. Ao explicitar que está narrando, o sujeito também explicita que está (re) construindo o mundo e a si próprio.

\footnotetext{
${ }^{145}$ É, por exemplo, o caso da série La condition humaine (1933, 1935), d e várias outras obras em que o pintor investiga justamente a semiose, como os quadros La trabison des images (1952), Ceci c'est un morceau de fromage (1963) e Ceci n'est pas une pomme (1964).
} 
Não cabe falar em verdade, se ela é uma criação do discurso, nem que narrador mente ou não, pois ele não imita a realidade, mas a constrói, ou, se preferirmos, imita um discurso sobre a realidade. Por isso, oscila em vários momentos: em uma linha, afirma que apenas narra o que de fato se passou; na seguinte, explicita que é o narrador de um romance e que está se valendo de estratégias para criar efeitos de verdade. O resultado é que o enunciatário acaba por perder aquela mesma fé ingênua a que se referia o narrador da segunda advertência de Ressurreição, pois descobre que não existe verdade ou mentira, mas apenas efeitos de. Tratase, de algo, bem familiar a estes dias — os nossos — em que uma fotografa, um filme, uma gravação não bastam mais para provar a autenticidade do que quer que seja e que um oxímoro como realidade virtual tornou-se uma banalidade. É que como lembra Greimas em Du sens II, o conceito de verdade foi substituído pelo de eficácia: é verdadeiro o discurso que consegue se afirmar como verdadeiro.

Nas páginas seguintes, será analisado o comportamento das diversas cláusulas do contrato enunciativo na obras de Machado. Contudo, o primeiro item, relativo à verossimilhança, não será discutido, pois se entende que a crítica literária tem-se dedicado a mostrar que toda a obra de Machado é verossímil. Resta examinar, portanto, duas questões: se o contrato firmado com o enunciatário procura causar efeitos de verdade e definir qual a concepção de linguagem que está implícita em seus romances.

\section{Ressurreição}

Em Ressurreição, o enunciador busca criar um efeito de realidade, isto é, de que as coisas realmente se passaram tal como narrado. A compostura do narrador vai na mesma direção e sugere que enunciação e enunciado estariam, portanto, de acordo, desde que ressalvada a segunda advertência do livro. Prevalece um tom de franqueza, de que tudo é dito às claras sem meias palavras, o que só faz sentido se os fatos narrados realmente ocorreram. É o caso, por exemplo, quando o narrador sanciona cada uma das personagens ao final do romance. Não haveria dúvidas ou dificuldades: todos são o que parecem ser e o narrador mostra isso claramente. Examine-se, contudo, o trecho relativo a Raquel e Meneses:

Ligeiros e felizes foram eles [os anos] para Raquel e Meneses, que eu tenho a honra de apresentar ao leitor, casado, e amantes ainda hoje. A piedade os uniu; a união os fez amados e venturosos.

A pouco e pouco, o primeiro amor de Raquel [Félix] se foi apagando, e o coração da moça não achou melhor convalescença que desposar o enfermeiro. (Obra Completa, vol. I, p. 194 - grifo meu) 
O narrador, que tudo sabe, tudo afirma às claras: Raquel parece amar Meneses e ser feliz, e de fato o ama e é feliz, não havendo, portanto, motivo para o leitor duvidar do julgamento do narrador. O fato de ele sentir-se honrado ao apresentá-los ao leitor sugere ainda que o casal é mesmo de carne e osso, pois ninguém apresentaria seres de ficção. Mais uma vez, enunciatário e actantes do enunciado são colocados no mesmo mundo e rompe-se a fronteira entre ficção e realidade; ou melhor, não se rompe nada, pois o narrador conta uma história verídica. Não há segredos ou mentiras e nada é dissimulado. O mesmo ocorre com Lívia, que, depois de desiludir-se com Félix, termina seus dias triste e solitária:

[...] A solidão seria o remate final da vida [de Lívia], e, como a olhos profanos não seria dado devassar o sagrado recinto, lá a deixaríamos sozinha e quite, aprendendo a amar a Deus e esquecer os homens.

Mas o romance é secular, e os heróis que precisam de solidão são obrigados a buscá-la no meio do tumulto. Lívia soube isolar-se na sociedade. (Obra Completa, vol. I, p. 194-5 - grifo meu)

Para Lívia, não há possibilidade de dissimulação, pois o sujeito sempre pode ser devassado por olhos profanos. Como não é possível dissimular, resta a alternativa de esconderse. O narrador, além de nada ocultar de seu leitor, não crê na possibilidade de que algo possa ser ocultado. Ou seja, a franqueza e a ausência de dissimulação perpassam não apenas a narração, mas também o narrado.

Resta agora examinar a segunda cláusula do contrato, a relativa à concepção de linguagem implicada no romance. E aí vem a surpresa: embora vigore um desejo de criar efeitos de realidade, esse desejo é anulado pela conduta do narrador que a todo momento lembra o leitor de que tudo é, afinal, fabulação. Sim, desgraçado - diria o narrador de Quincas Borba - repara que Livia, Félix, Raquel, Meneses são todos minhas criações e como eu próprio sou cria da linguagem, todos, eu à frente, somos seus filhos. Lívia deve isolar-se em sociedade não por conta de uma lei ligada à biologia, à raça, ao meio social ou sua origem, como afirmaria um narrador naturalista, mas porque o romance é secular; isto é, moderno e boje em dia, continuaria o narrador, as moças não vão mais para os conventos, soaria inverossimil, mas ficam em casa ao abrigo de olhares e leitores indiscretos. São as leis da representação que se impõem aos personagens e não as da natureza. E por quê? Porque o mundo e o sujeito não existem sem a linguagem; é ela que constrói tanto um quanto outro. Sim, o narrador cria efeitos de verdade, mas os cria afirmando que o está fazendo e, assim, os anula: efeitos de verdade não são mais mostrados como verdade, mas como efeitos que visam a provocar essa impressão. Tudo não passa de um cenário (dirá o nosso conselheiro daqui a pouco) em cujo lado voltado para platéia há um 
belo jardim, mas, do outro, não há senão lona velha. Note: a apresentação de Raquel e Menezes executa dois movimentos ao mesmo tempo: se a apresentação dá a entender que eles existem, a referência ao leitor lembra que se trata de seres de papel. Se a solidão de Lívia, resultante do desenlace de sua relação com Felix, obedece às leis da arte como diria certo crítico, por outro, o narrador torna tais leis ineficazes ao afirmar que o romance é secular. Lívia não tem o fim que tem porque é assim que aconteceria na realidade, mas porque é essa a convenção literária atual. Não existe a possibilidade de o mundo se impor ao sujeito por si mesmo, pois o mundo é construção da linguagem, e os sujeitos, pelo menos os de papel, também devem obedecer às suas leis.

Assim, no romance de estréia de Machado, as duas cláusulas vigentes no contrato enunciativo estipulam que se diz a verdade (" $\mathrm{x}$ " deve ser interpretado como " $\mathrm{x}$ "); por outro lado, a realidade não deve ser vista como uma construção da realidade, e daí relatividade que parece impregnar todas as obras do autor.

\section{A mão e a luva}

Em $A$ mão e a luva, vigoram as mesmas cláusulas existentes no contrato anteriormente firmado entre esse enunciador e seu enunciatário: por um lado, parece não haver segredos ou dissimulações por parte do narrador ou das personagens, tudo é mesmo verdade; por outro, esse mesmo narrador lembra o leitor que tudo é representação. Os parágrafos a seguir, extraídos do início do romance, quando Estevão conta a Luís Alves que ama Guiomar, mas que fora rejeitado por ela, ilustram bem esse fato:

[...] Achavam-se os dois no corredor da casa de Luís Alves, à rua da Constituição, — que então se chamava dos Ciganos; - então, isto é, em 1853, uma bagatela de vinte anos que lá vão, levando talvez consigo as ilusões do leitor, e deixando-lhe em troca (usurários!) uma triste, crua e desconsolada experiência.

\section{$[\ldots]$}

Ali mesmo lhe confiou Estevão tudo o que havia, e que o leitor saberá daqui a pouco, caso não aborreça estas historias de amor, velhas como Adão, e eternas como o céu. Os dois amigos demoraram-se ainda algum tempo no corredor, um a insistir com o outro para que subisse, o outro a teimar que queria ir morrer, tão tenazes ambos, que não haveria meio de os vencer, se a Luís não ocorresse uma transação.

— Pois sim, disse ele, convenho em que deves morrer, mas há de ser amanhã. [...] Nestas últimas horas que tens de viver na terra dar-me-ás uma lição de amor, que eu te pagarei com outra de filosofia. (Obra Completa, vol. I, p. 199 - grifos meus) 
A cena é clássica do romantismo: o jovem apaixonado deseja morrer após ser rejeitado pela amada. Algumas linhas adiante, o narrador esclarecerá que o amor de Estevão por Guiomar era um amor um pouco estouvado e cego, mas sincero e puro, como parece ser (e é) pura e sincera a amizade que existe ente ele e Luís. As relações ambíguas entre Sofia, Palha e Rubião, ou entre Escobar e Bentinho, não têm lugar aqui. Tudo é como parecer ser. Não há segredos ou mentiras e os sentimentos são o que são, ainda que Luís Alves não leve o amigo a sério e que o comércio permeie todas as relações. Os dois amigos defendem tenazmente suas posições, até que ocorre a Luís uma transação para dissuadir o amigo, fato que já indica o poder do comércio, prática que se tornará corrente e explícita - e não dissimulada — nas relações entre Guiomar e Luís. Os efeitos de realidade são realçados com menção ao nome da rua onde se passa a cena, no tempo do enunciado - Rua dos Ciganos - e ao nome que ela tem agora, no tempo da enunciação - Rua da Constituição. Enunciação e enunciado parecem caminhar juntos: há efeitos de realidade para ancorar o narrado, e, também, para ancorar a narração. Não há, portanto, motivos para o enunciatário duvidar da intenção do narrador de criar um efeito de verdade.

Por outro lado, ao mesmo tempo, o narrador não deixa de apresentar-se como um contador de histórias que irá narrar uma dessas de amor, velha como a de Adão e Eva. Observe que o conteúdo do narrado depende do desenrolar da narração, pois o leitor saberá do conteúdo do diálogo entre os dois amigos se não se aborrecer da história. Ou seja, o narrador explicita que a narração é fruto da relação que vier a se estabelecer entre ele (que posa de enunciador) e o narratário (que posa de enunciatário). Certo, desde Benveniste se sabe que o sujeito da enunciação não é único, mas envolve, pelo menos, enunciador e enunciatário; a novidade está no fato de essa questão ser explicitada, o que, de um lado, reforça a idéia de que a narração é o conteúdo da narrativa, e, de outro, destrói os efeitos de verdade criados. Na verdade, o narrador não está imitando a realidade; está imitando a imitação da realidade. Do mesmo modo, a história do Gênesis não é mais sagrada, mas uma história como outra qualquer, pois só o que existe são narrativas que constroem a sua realidade. Esse é o contrato firmado por esse enunciador com seu enunciatário: não o de lhe mostrar a realidade como ela é, tal como pretendiam fazer realistas, tampouco de mostrar o ponto de vista e os sentimentos de um sujeito, mas mostrar a realidade construída pela linguagem, explicitando que, tal como no relato bíblico da criação, o mundo é criado na medida em que é enunciado. 


\section{Helena}

Em Helena, há uma primeira e tênue mudança em relação aos romances anteriores. O engano e a dissimulação estão explicitados na própria narrativa, estruturada sobre o jogo das modalidades veridictórias: inicialmente, a existência de Helena é um segredo (ninguém sabia de sua existência); em seguida, com a revelação de sua história, surge a mentira, pois ela parece, mas não é, irmã de Estácio. Quando a verdade é enfim descoberta, Helena morre, sugerindo que, mesmo nesse romance, tido por açucarado, não há lugar para verdade. Ao mesmo tempo, os sentimentos entre os pseudo-irmãos segue outro percurso: inicialmente, trata-se de uma afeição fraternal, depois, transforma-se, no modo de segredo, em uma relação incestuosa, e, finalmente, revela-se um falso incesto, já que não há ligação consangüínea entre eles. O narrador já não joga tão às claras como antes, uma vez que, conforme se viu, oculta parte do que sabe, atendendo a necessidades de diversas ordens. Contudo, a busca pela criação de um efeito de verdade em toda a narrativa continua a prevalecer. Os segredos, mentiras e falsidades da narrativa não comprometem a verdade da narração. Vejam dois momentos em que esse jogo se mostra com mais clareza. O primeiro está na passagem em que Helena mostra ao Padre Melchior a carta que recebera de Estácio:

Melchior franziu a testa; a fisionomia, de ordinário meiga, tornou-se severa, como a consciência dele. O padre tinha uma das mãos de Helena entre as suas; deixou-a insensivelmente cair. Entre os dois estabeleceu-se um silêncio que os acabrunhava e que não ousavam romper; como subjugados por um mistério, receavam cada um deles que o outro lho lesse na fronte; instintivamente desviaram os olhos.

Melchior foi o primeiro que voltou a si. A reflexão corrigiu a espontaneidade, e o padre reassumiu o gesto usual, com essa dissimulação que é um dever, quando a sinceridade é um perigo. (Obra Completa, vol. I, p. 336 - grifos meus)

O padre lê as cartas que Helena e Estácio trocaram e percebe que nelas há mais do que parece, fato que já era de conhecimento de Helena. Cria-se então entre ambos uma situação de dissimulação, que, segundo o narrador, era um dever, ao passo que a sinceridade era um risco. Todavia, o segredo que Melchior e Helena escondem um do outro não é o mesmo, pois o padre, ignorando a real situação da protagonista, teme pelo incesto, enquanto Helena o sabe impossível, apesar do sentimento entre ela e Estácio ser de natureza sensual. Para Melchior, o que está em jogo é a preservação da família; para Helena, a manutenção do espólio, e ela, como Guiomar, prefere o inventário à paixão. Contudo, na atitude do narrador não há dissimulação; o leitor, por menos que esteja habituado à leitura de romances, 
desconfia que algo há de surgir, e suas expectativas não são frustradas. Assim, se o engano e a dissimulação surgem como um elemento central na trama, e a linguagem um elemento essencial desse processo, visto que a revelação do amor entre os protagonistas se dá por meio da palavra, ainda que de forma involuntária. No entanto, a relação entre narrador e o leitor paira acima disso. A dissimulação pode até ser um dever de sociedade, como sugere o narrador, mas isso não vale para sua relação com o leitor, que, aliás, é pacífica como a firmada entre o enunciador e narrador, dado que - esquecendo a advertência — não há nada que oponha um ao outro.

Veja-se agora esta passagem, já ao final do romance, quando a real situação de Helena é descoberta e não haveria mais empecilhos à união dela com Estácio:

entre em que o engano volta a ocupar o centro da discussão, envolvendo, dessa vez, apenas o indivíduo em sua relação consigo mesmo. É quando o Padre revela a Estácio os próprios sentimentos deste para com a irmã:

A princípio foi esse olhar um simples encontro; mas, dentro de alguns instantes, era alguma coisa mais. Era a primeira revelação, tácita, mas consciente, do sentimento que os ligava. Nenhum deles procurara esse contato de suas almas, mas nenhum fugiu. $\underline{\mathrm{O} \text { que eles disseram um ao outro, }}$ com os simples olhos, não se escreve no papel, não se pode repetir ao ouvido; confissão misteriosa e secreta, feita de um a outro coração, que só ao céu cabia ouvir, porque não eram vozes da terra, nem para a terra as diziam eles. As mãos, de impulso próprio, uniram-se como os olhares; nenhuma vergonha, nenhum receio, nenhuma consideração deteve essa fusão de duas criaturas nascidas para formar uma existência única. (Obra Completa, vol. I p. 386 - grifo meu)

No texto acima o narrador sugere que haveria realidades que não estariam ao alcance da linguagem, vozes que não seriam da terra que ela não saberia reproduzir. Trata-se, de certa forma, do processo oposto ao verificado em outras ocasiões, quando ficava claro que muito do narrado era mera construção linguageira. Em que pese essa diferença, o que se verifica é o rompimento da isonomia entre a linguagem e seu "referente", pois haveria casos em que tal relação não seria possível. Desse modo, o narrado passa a se mostrar a reprodução possivel ou conveniente do real. O enunciador, por meio do seu narrador, parece descrer uma vez mais do projeto realista, da possibilidade de reprodução da realidade tal e qual pela linguagem. É verdade, busca-se ao longo do romance um efeito de realidade, segundo o qual as coisas, de fato, aconteceram, e o saber do narrador é importante para tranqüilizar o narrador de que ele não se engana. Contudo, mas há elementos que desestabilizam esse processo e fazem pensar de outro modo. Inicialmente, recorde-se que na Advertência a oposição entre narrador e enunciador é explicitada. Em seguida, há a questão da linguagem, como apontada acima, que 
não é a primeira, pois o episódio da historiazinha de toucador de Eugênia, também colocava em questão as relações entre linguagem e referente. Naquele caso, o narrador não reproduzia a conversa porque tal reprodução não seria conveniente para a narração; neste, ele não o faz por uma impossibilidade. Lá ficou claro que a narrativa não é imitação da realidade, mas sim construção da linguagem. Aqui, evidencia-se mais uma vez que a linguagem e a realidade não se misturam e isso justamente apesar do próprio narrador propor o contrário. Considerados esses aspectos, os efeitos de verdade construídos pelo narrador - como a descrição pormenorizada da reação do padre Melchior à carta de Estácio — perdem sua eficiência, pois fica explicitado, ao mesmo tempo, que o leitor está lendo um romance, portanto, tudo é fingimento.

\section{Iaiá Garcia}

Em Iaiá Garcia, estão ausentes algumas práticas que caracterizam o enunciador, como a oposição entre enunciação e enunciado ou entre enunciador e narrador, e a ausência de um narrador primeiro que delegue a palavra ao narrador condutor da narrativa. Isso poderia sugerir que vigora um contrato diferente entre enunciador e enunciatário, porém, a permanência da mesma configuração narrativa e da debreagem enunciativa da enunciação, e a preocupação com os efeitos de realidade e verdade, voltam a lembrar a permanência de um mesmo ethos do enunciador. É verdade, a concepção de linguagem como criadora de universos se faz presente de forma apenas embrionária, mas é suficiente para mostrar que essa cláusula está em vigor. Em Iaiá, essa concepção de linguagem continua restrita ao plano do enunciado, não tendo, ainda, atingido a enunciação enunciada. É o que pode ser observado no diálogo em que Procópio confessa a Jorge seu amor por Iaiá, insinuando, ao mesmo tempo, que o moço estaria interessado por Estela:

Procópio Dias [...] balbuciou a confissão plena de seus sentimentos, mas com um ar de envergonhado, meio sincero e meio fingido, e tão a ponto e natural, que era difícil saber onde acabava a sinceridade e onde começava a simulação. Animou-se a pouco e pouco; e não the escondeu nada. Confessou que a filha de Luís Garcia lhe transtornara de todo o espírito e que ele estava resoluto aos maiores sacrifícios para obter-lhe a mão. (Obra Completa, vol. I, p. 458)

Afinal, Procópio Dias era sincero ou não? O próprio narrador parece não saber e confessa que era difícil saber onde acabava a sinceridade e onde comeşava a simulação. O dilema do narrador será o mesmo do leitor em todos os romances seguintes: em que medida Brás 
Cubas, Bento Santiago e Aires são sinceros? O leitor atento dirá que não são exatamente nem uma coisa nem outra, ou que às vezes são sinceros e outras não, sendo difícil saber onde acaba a sinceridade e onde começa a simulação. O pensamento de Procópio pouco difere do de Brás Cubas; a diferença é que aqui ele é discutido pelo narrador, enquanto lá é praticado por ele. O que começou com Jorge, isto é, a dúvida sincera a respeito dos próprios sentimentos e motivações, transforma-se na dissimulação de Procópio e esta não cessará mais de crescer. O diálogo entre Jorge e Procópio é revelador de que a linguagem começa a surgir como única realidade. Tudo o que os dois interlocutores têm um do outro são palavras sobre cuja veracidade quase nada pode ser dito. Aliás, o leitor sabe que as suspeitas de Procópio eram duplamente fundadas; primeiro, porque havia, sim, interesse de Jorge por Estela (mais ou menos correspondido) e, depois, porque havia, também, interesse dele por Iaiá, correspondido de forma mais ou menos sincera. Se Procópio dissimula, Jorge mente. Os dois lembram a afirmação de Greimas de que o tipo de comunicação social sobre o qual repousa a coesão social parece como a história do malandro e do bobo. O primeiro engana o segundo, mas depois deixa enganar-se por ele. Um mesmo ator hábil para enganar o outro, continua Greimas, mostra-se desarmado diante do discurso deste, pronto para crer no que lhe é apresentado. O enunciador de Iaiá mostra que nesse contexto não se espera do sujeito que ele produza um discurso verdadeiro, mas um discurso que produza o efeito de sentido de "verdade" "146. Procópio não se ilude com a indignação de Jorge nem se ofende com suas negativas, apenas revela ao filho de Valéria seus próprios pensamentos, aqueles que o moço não queria admitir. É o que se observa na seqüência do diálogo, quando Procópio diz a Jorge que estimaria que ele tivesse um relacionamento extraconjugal com Estela, a essa altura já casada Luis Garcia:

Jorge não disse nada; olhou somente para o interlocutor, com um ar de estupefação, a que o outro sorriu benevolamente. Fez-se uma curta pausa. Procópio Dias rompeu enfim o silêncio:

- Talvez estimasse [que Estácio se envolvesse com Estela], sem deixar de indignar-me depois; isto é, a indignação no momento seria abafada pelo interesse. Atenda-me, doutor; sejamos justos com a natureza humana. Virtudes inteiriças são invenções de poetas. Não me fazia bom cabelo que o senhor gostasse da outra [Estela], e menos ainda que ela lhe correspondesse, porque, em suma, ambicionando entrar na família, não desejaria que a família tivesse a menor mácula. Esta é a realidade. Mas, eu amo, doutor; e por mais ridícula que pareça esta confissão, por mais grosseira que seja a minha casca, a verdade é que amo a enteada apaixonadamente: é o meu pensamento de todos os dias. Ora, dado que o senhor amasse a outra, qual era o primeiro movimento do meu coração? Ligá-los ao meu interesse. Desde que entre os dous houvesse um segredo, e que esse segredo fosse descoberto ou suspeitado por mim, o senhor e ela eram os meus melhores aliados, e a resistência daquela menina, e a vontade do pai, tudo cedia em meu favor. (Obra Completa, vol. I, p. 458-9)

${ }^{146}$ Du Sens II, p. 109 
Procópio não só descrê da indignação de Jorge diante do adultério, como, em seguida, afirma que virtudes inteiriças, como aquelas de Estácio em Helena, são invenções de poetas. O que prevalece é o interesse ou, como diria Guiomar, o cálculo. Alerte-se para a diferença: em $A$ mão e a luva, o interesse era legítimo, ou melhor, legitimado pelo narrador; aqui, o interesse se mostra o artífice de toda moral, sendo digno o que for justificado por ele. Não há, portanto, ato moral ou imoral, mas atos mais ou menos eficientes, isto é, justificados por sua eficácia: aos olhos de Procópio, o adultério em si mesmo não é moral ou imoral, tudo vai depender da relação que existir entre esse ato e seus interesses. Se forem compatíveis, por que não? É o utilitarismo de Stuart Mill que funda - ou consagra - a sociedade capitalista. E eis que se chega a uma conclusão semelhante à de Greimas (1983: 111): o conceito de moral ou de verdade foi substituído pelo de eficácia; é verdade o que conseguir causar a impressão de verdade. Assim, o tom anti-romântico, que domina todos os romances de Machado, associado à sobreposição da narração sobre o narrado (não permitindo ao leitor esquecer que está diante de um simulacro), decorre não da revelação de uma verdade oculta sob camadas de hipocrisia, como queriam realistas e naturalistas, mas da constatação de que não há verdade alguma a ser revelada, pois tudo é uma construção da linguagem. O curioso é que, ao mesmo tempo em que o narrador faz tal "denúncia", encarrega-se ele próprio de afirmar que não inventa nada, pois apenas relata o que de fato teria acontecido: a verdade pura dos fatos. Não se trata de contradição, mas de cinismo mesmo; de reproduzir, mais do que revelar, um dado comportamento, ou, se preferirmos um ethos.

\section{Memórias póstumas}

O contrato mudou radicalmente: não se busca mais causar um efeito de sentido de verdade ou de realidade. O enunciatário não pode mais levar nada ao pé da letra, mas entender que " $\mathrm{X}$ " agora quer dizer "não-X". Primeiro, porque, logo de início, a instalação de um narrador defunto destrói qualquer pretensão de verdade; depois, porque, ao longo do romance, Brás Cubas demonstra não ter qualquer moral, assumindo pontos de vista que não poderiam ser endossados pela enunciação. Logo, o efeito buscado agora é de mentira. $\mathrm{Na}$ passagem reproduzida abaixo, por exemplo, a oposição entre enunciação e enunciado está colocada, porém não porque seja um defunto que narre ou porque a narração se sobreponha ao narrado, mas porque as palavras do narrador não podem ser assumidas pelo enunciador 
em virtude de seu aspecto moral. Logo, "X" deve ser interpretado como "não-X" e a voz do enunciado é negada pela enunciação. A citação é longa, agastante, como são muitas idéias de Brás Cubas, mas necessária para evidenciar que o enunciador não tem mais a pretensão de criar efeitos de verdade e isso não apenas porque o caráter ficcional do narrador é explicitado, mas também porque as posições assumidas por ele são admissíveis. A passagem é aquela em que Brás Cubas faz considerações sobre Eugênia, alcunhada por ele a flor da moita, em referência à sua origem bastarda:

O pior é que era coxa. Uns olhos tão lúcidos, uma boca tão fresca, uma compostura tão senhoril; e coxa! Esse contraste faria suspeitar que a natureza é às vezes um imenso escárnio. Por que bonita, se coxa? por que coxa, se bonita? Tal era a pergunta que eu vinha fazendo a mim mesmo ao voltar para casa, de noite, sem atinar com a solução do enigma [...]

[...] Manhãs bonitas, frescas, convidativas; lá embaixo a família a chamar-me, e a noiva, e o parlamento, e eu sem acudir a coisa nenhuma, enlevado ao pé da minha Vênus Manca. Enlevado é uma maneira de realçar o estilo; não havia enlevo, mas gosto, uma certa satisfação física e moral.Queria-lhe, é verdade; ao pé dessa criatura tão singela, filha espúria e coxa, feita de amor e desprezo, ao pé dela sentia-me bem, e ela creio que ainda se sentia melhor, ao pé de mim. E isto na Tijuca. Uma simples égloga. Dona Eusébia vigiava-nos, mas pouco; temperava a necessidade com a conveniência. A filha, nessa primeira explosão da natureza, entregava-me a alma em flor.

[...] Pobre Eugênia! Se tu soubesses que idéias me vagavam pela mente fora naquela ocasião! Tu, trêmula de comoção, com os braços nos meus ombros, a contemplar em mim o teu bem-vindo esposo, e eu com os olhos em 1814, na moita, no Vilaça, e a suspeitar que não podias mentir ao teu sangue, à tua origem. (Obra Completa, vol. I, p. 554-5. - grifos meus)

O desprezo e o cinismo de Brás Cubas não conhecem limites. Para ele, o único valor de Eugênia (e a ironia do nome é cruel), ou melhor, sua utilidade, é satisfazê-lo física e moralmente. Como bom capitalista que é, deve maximizar os ganhos e minimizar os custos, portanto, considera um desperdício, um capricho da natureza, uma mulher bonita ser manca, pois a beleza seria desperdiçada pela deficiência. Pouco eficiente, portanto. Como todas as relações são mercantis, o bem-estar que ele proporcionaria a Eugênia deve ser pago e ela o faz honestamente, como boa devedora que era. Claro, não é mesmo para levá-lo a sério, mas nunca é demais lembrar que a mercantilização das relações já estava colocada em $A$ mão e a luva e mesmo em Helena, como fica claro na exposição de Salvador a Estácio. Lembre-se, ainda, que o Sr. Antunes, de Iaiá Garcia, recrimina a filha por ter perdido a oportunidade de fazer um bom negócio ao não ceder às investidas de Jorge e que ele não titubeia quando tem de optar entre a companhia dela e a proteção dele. Assim, nada do que Brás Cubas afirma é novidade. A surpresa fica por conta da desfaçatez com que ele trata Eugênia. Veja: D. Eusébia tempera a necessidade (vigiar o casal) com a conveniência (casá-los), e Procópio de Iaiá Garcia não pensava de maneira diferente, pois, para o comerciante, o interesse (sempre ele) 
abafava a indignação, como ele explica a Jorge na passagem vista ainda agora. A mudança deve ser buscada, portanto, não nos actantes do enunciado, mas nos da enunciação enunciada, isto é, no narrador. Em Iaiá Garcia, o ponto de vista de Procópio ficava restrito a ele, e, se o narrador não o criticava, também não endossava suas idéias, o que, por sua vez, fazia com que a relação entre enunciação e enunciado fosse mais pacífica. Agora não, pois o enunciador não pode compactuar com esse discurso e, por isso, o contrato tem de mudar: enunciação e enunciado estão agora em franca oposição; a primeira negando o segundo. Assim, o enunciador não deseja, não pode, não deve, ser interpretado de forma literal e o narrador não transmite mais as idéias dele, mas o contrário. Note que não há porque pensar que Brás Cubas seja irônico ou que pense de forma diferente do que dão a entender suas palavras; na verdade, elas espelham seus atos. O contrato muda porque suas palavras, as do narrador, não podem mais ser assumidas pelo enunciador. Não há mais meios de ambos concordarem. Tais fatos, já observados em análises anteriores, agora se mostram com todas as cores e com uma intensidade não vista. Nos romances anteriores, a oposição estava circunscrita às advertências; agora, perpassa todo o texto.

Contudo, a segunda cláusula do contrato (a relativa ao conceito de linguagem) mantém-se inalterada em relação aos demais romances, ainda que atinja proporções muito maiores. As advertências desse romance, discutidas no item anterior, assim como os comentários a propósito do narrador, não deixam dúvidas quanto ao fato de a linguagem ocupar a posição central no romance, e de o enunciador destruir qualquer ilusão da verdade, mostrando que a narrativa é uma construção linguageira e não a imitação da realidade. A instalação de um defunto como narrador não deixa dúvidas de que o objetivo não é mais criar a imitar a realidade, mas criar uma outra realidade por meio da linguagem. A seqüência do trecho citado mostra o quanto os dois universos - o real e o ficcional - estão amalgamados:

\section{CAPÍTULO XXXIV}

A uma alma sensível

Há aí, entre as cinco ou dez pessoas que me lêem, há aí uma alma sensível, que está decerto um tanto agastada com o capítulo anterior, começa a tremer pela sorte de Eugênia, e talvez...,sim, talvez, lá no fundo de si mesma, me chame cínico. Eu cínico, alma sensível? Pela coxa de Diana! Esta injúria merecia ser lavada com sangue, se o sangue lavasse alguma coisa nesse mundo. Não, alma sensível, eu não sou cínico, eu fui homem; meu cérebro foi um tablado em que se deram peças de todo gênero, o drama sacro, o austero, o piegas, a comédia louçã, a desgrenhada farsa, os autos, as bufonerias, um pandemônio, alma sensível, uma barafunda de coisas e pessoas, em que podias ver tudo, desde a rosa de Smirna até a arruda do teu quintal,desde o magnífico leito de Cleópatra até o recanto da praia em que o mendigo tirita o seu sono. Cruzavam-se nele pensamentos de vária casta e feição. Não havia ali a atmosfera somente da águia e do beija-flor; 
havia também a da lesma e do sapo. Retira, pois, a expressão, alma sensível, castiga os nervos, limpa os óculos, - que isso às vezes é dos óculos, - e acabemos de uma vez com esta flor da moita. (Obra Completa, vol. I, p. 554-5)

O narrador se apresenta uma vez mais como aquele que efetivamente tomou a pena e escreveu as linhas que o leitor lê; desse modo, a desfaçatez que estava restrita ao nível do enunciado, isto é dirigida para Eugênia, sobe para a instância da enunciação enunciada, isto é, o narratário. Embora o leitor "real" seja de fato um dos que lêem Brás Cubas, não é a ele que se refere a expressão alma sensível, mas a outro indivíduo, de papel, sobre quem o narrador (também de papel), tripudia, rindo do seu moralismo ao afirmar que seus valores talvez não fossem tão diferentes dos do leitor. Ele recusa a acusação de cinismo sendo ainda mais cínico. Veja, por exemplo, o trecho em que investe contra a tradição judaico-cristã afirmando que o sangue nada lava no mundo, para, em seguida, afirmar que foi homem como qualquer outro e teve os sentimentos que todos teriam; logo, não seria cínico, mas franco, e os outros, como o leitor que o lê, é que seriam hipócritas. Para realçar a farsa de todos, ele afirma que $o$ drama sacro, o austero, o piegas, a comédia louçã, a desgrenhada farsa, os autos, as bufonarias... e a arruda do quintal habitavam sua mente de homem, e, claro, a do leitor. Desse modo, esses substantivos deixam de ser gêneros dramáticos e passam a ser comportamentos sociais construídos pela linguagem, assim como a moral seria uma construção discursiva. Não haveria, portanto, realidade além da linguagem, mas apenas realidades, todas linguageiras. Não caberia falar em verdade ou em mentira, pois ambas pressupõem uma realidade à qual o discurso se referiria. O que se vê é que essa realidade exterior à linguagem não existe, ou melhor, não passa de outra realidade construída pela linguagem. Como se percebe, o ceticismo do enunciador é bem mais profundo do que o verificado quando se discutiu as configurações narrativas.

\section{Quincas Borba}

Um exame cuidadoso revelará que a oposição entre enunciação e enunciado existente em Memórias póstumas se manifesta de outra forma em Quincas Borba. Ao mesmo tempo em que o narrador esforça-se para afirmar que o narrado de fato aconteceu, a narração como um todo é mostrada como fabulação, como poiesis. É o que ocorre no capítulo XVI, já citado, em que o narrador mostra como o leitor se enganara ao supor uma relação adúltera entre Sofia e Carlos Maria; ou ainda nos capítulos CXII a CXV, em que o narrador afirma que gostaria de poder seguir o método de Cervantes ou Rabelais - e os exemplos, claro, não 
são aleatórios. Agora, o distanciamento entre enunciação e enunciado não decorre das posições morais do narrador, mas do fato de a enunciação afirmar a todo instante que o narrado é puro artifício e que seu delegado mente quanto diz que apenas relata o que se passou. No mesmo movimento, mostra como é fácil construir ilusões de verdade. A mentira não está, portanto, no conteúdo narrado, mas na narração; isto é, no comportamento adotado pelo narrador durante o ato de narrar. É o que ocorre, por exemplo, quando o narrador jura ou apenas dá a entender que fala a verdade. Recorde-se um desses momentos, aquele quando Palha e Camacho são apresentados um ao outro na casa de Rubião:

Palha e Camacho olharam um para o outro... Oh! esse olhar foi como um bilhete de visita trocado entre as duas consciências. (Obra Completa, vol. I, p. 692 - grifo meu).

Em princípio, a interjeição acima só poderia ser proferida por alguém que tivesse presenciado a troca de olhares entre Palha e Camacho e que fosse profundamente tocado por ela, o que faz supor que a cena teria ocorrido de fato. Mas é preciso ver que, claro, a interjeição demonstra a ironia do narrador em relação à própria cena que acaba de narrar, pois denota uma emoção que não seria compatível com uma troca de olhares, supõe-se, nada amistosa e que nada teve de dramática. Algumas linhas abaixo, o narrador volta a dar entender que estava presente ao jurar que Rubião não tinha vontade de ir a Minas, apesar das suas palavras:

[...]Entretanto, [Rubião] ainda insistiu por poucos dias de viagem, e, para ser exato, devo jurar que o fez sem desejo de que lhe aceitassem a proposta

Recursos como o juramento têm a finalidade de criar efeitos de verdade, uma vez que o jurador dá seu testemunho pessoal. Mas, na situação acima, ainda mais após o ob do narrador, não se pode levar o juramento a sério, pois o narrador não participou de nada, não colheu testemunhos, não pode, portanto, jurar sobre o que não sabe e, menos ainda, sobre algo sabidamente ficcional. Em outras palavras, um juramento só faz sentido se tiver como objeto um fato cuja existência é possível, ao passo que aqui tudo é claramente apresentado como ficção. O resultado final é que, no tocante à linguagem, prevalece o contrato semiótico, pois, como os efeitos de verdades pretendidos pelo narrador são anulados pela enunciação enunciada, o que se destaca é a força da linguagem que ergue e destrói coisas belas, como diria o poeta. Veja que, em razão de seus juramentos, o narrador se implica no narrado como se o tivesse vivido e esse é um dos motivos pelos quais não se pode considerar Quincas Borba uma narrativa em terceira pessoa, mas, antes, a narração em primeira pessoa de fatos que não 
envolveram diretamente o narrador. O resultado é, mais uma vez, uma aporia: de um lado um narrador que jura que fala a verdade; de outro, um enunciador que o desmente.

Todavia, há passagens mais explícitas nesse romance que talvez seja um dos que mais reflitam sobre a linguagem. Avancemos até o final do livro, quando Rubião já ensandeceu e passa a se valer de procedimentos semelhantes aos do narrador para criar efeitos de verdade. Em um desses momentos, o ex-mestre-escola é tão convincente que chega mesmo a confundir Sofia, que sabia que nada do que ele afirma era verdade. A passagem está entre os capítulos CXLIX e CVXIV, naquela cena em que Rubião toma a carruagem com a mulher do Palha e manda o cocheiro seguir a esmo pela cidade. Durante o longo trajeto, ele relata à Sofia um encontro não ocorrido entre eles e o faz com tal verossimilhança, com requintes tais, que ela quase acredita em suas palavras, apesar de sabêlas falsas:

- A mim lembra-me, como se fosse ontem. Tu chegaste de carro, não era este; era um carro de praça, uma caleça. Desceste medrosa, com o véu pela cara; tremias como varas verdes... Mas os meus braços te ampararam... O sol daquele dia devia ter parado, como quando obedeceu a Josué... E contudo, minha flor, aquelas horas foram compridas como diabo, não sei por que; a rigor, deviam ser curtas. Era talvez porque a nossa paixão não acabava mais, não acabou, nem há de acabar nunca... Em compensação, não vimos mais o sol; ia caindo para o outro lado das montanhas quando a minha Sofia, ainda medrosa, saiu para a rua, e pegou de outra caleça. Outra ou a mesma? Creio que foi a mesma. Não imaginas como fiquei; parecia tonto, beijei tudo em que havias tocado; cheguei a beijar a soleira da porta. Creio que já te contei isso. A soleira da porta. E estive quase a ir de rastos, beijar os degraus da escada... Não o fiz, recolhi-me, fechei-me para que se não perdesse o teu cheiro; violeta, se bem me recordo...

Não, não era possível que o intuito de Rubião fosse fazer crer ao cocheiro uma aventura mentirosa. A voz era tão sumida que Sofia mal podia escutá-la; mas, se lhe custava a entender as palavras, não chegava a compreender o sentido delas. A que vinha aquela história não sucedida? Quem quer que a ouvisse, aceitaria tudo por verdade, tal era a nota sincera, a meiguice dos termos e a verossimilhança dos pormenores. E ele continuou suspirando as belas reminiscências... (Obra Completa, vol. I, p. 772 - grifo meu)

Repare nos detalhes: o modelo do carro, o véu de Sofia, os movimentos dos braços, os odores... até mesmo alguma indecisão, tudo atestando que o tal encontro realmente ocorrera, pois tais detalhes criam efeitos de realidade. Crédulo, Rubião acredita em sua narração a ponto desta acabar por funcionar como realidade para ele próprio e fazer Sofia temer que outros o ouvissem e cressem nele, tal a verossimilhança dos detalhes. O episódio desnuda uma vez mais os procedimentos do narrador, mostrando-os todos como farsa, como urdidura; aliás, tema recorrente em Quincas Borba. Mata-se, assim, na raiz, a pretensão do realismo de retratar fielmente a realidade, inclusive com a discussão precisa dos pormenores. O enunciador desmonta os mais sofisticados procedimentos dos realistas e os exibe em sua 
essência: são apenas efeitos de verdade, aliás, bastante freqüentes, pois comparecem aos discursos dos políticos, sussurram nos colóquios dos namorados, animam as conversas de botequim, tranqüilizam os sonhos dos alienados e... tecem as linhas dos narradores. Tal como o mágico que tem seus ardis revelados à frente da platéia, o narrador também tem suas estratégias expostas pela loucura de Rubião, fiel espelho, que (quase) faz as artimanhas do narrador perderem toda eficácia. Sim, quase, porque depois de contar o segredo do truque, ele volta a realizá-lo e todos voltam a crer que ele é, de fato, um bruxo. Ao final da passagem, os papéis se invertem: é Sofia que passa a se valer de procedimentos da mesma natureza para fazer, de forma quase desesperada, todos crerem que nada houvera, o que, curiosamente, é verdade. Dessa vez, quem fica aturdido é o próprio Rubião:

Rubião ergueu as cortinas, e o lacaio veio abrir a portinhola. Sofia, para tirar toda a suspeita a este, pediu novamente ao Rubião que fosse com ela à casa do marido; disse-lhe que este precisava falar-lhe, com urgência. Rubião olhou um pouco espantado para ela, para o lacaio e para a rua; e respondeu que não, que iria depois. (Obra Completa, vol. I, p. 774 - grifo meu)

Todo o romance é assentado nesses jogos de construção de verdades e mentiras em que a verdade "de verdade" é a maior de todas as fantasias. O cocheiro, que poderia crer nas declarações de Rubião agora acreditaria que nada ocorreu e ficaria sem saber onde está a verdade, pois tudo o que resta é a verossimilhança. Mas há ainda um terceiro elemento nesse episódio a apontar para os artifícios do enunciador, desta vez decorrente de um sofisticado trabalho de intertextualidade, que também visa a mostrar que a cena é puro romance, que dialoga com outro romance. E não com qualquer romance, mas com aquele que é considerado o romance realista por excelência. Referimo-nos, claro, a Madame Bovary, mais especificamente, ao primeiro capítulo da terceira parte, quando Emma vai a Rouen encontrarse com Leon, seu segundo amante, no início da relação entre eles. A heroína estava disposta a romper o relacionamento, mas, após um rápido encontro na igreja, Leon a convence a entrar em um fiacre. Sob as ordens do amante, o carro vaga durante horas por toda a cidade e pelos arredores mais fechado que uma urna e agitando-se mais que um navio ${ }^{147}$, para espanto dos transeuntes. Compare-se agora o final dessa passagem Madame Bovary com o trecho acima e veja que Sofia é mais dissimulada que Emma:

${ }^{147}$ Flaubert, Gustave. Madame Bovary. Paris: GF Flammarion, 1986, p. 318. 
Depois, por volta das seis horas, o carro parou em uma ruela do bairro de Beauvoisine, uma mulher [Emma] desceu portando um véu e seguiu sem desviar a cabeça. ${ }^{148}$

Em vez de desviar a cabeça, como faz a personagem de Flaubert, em um gesto pouco eficaz, Sofia optou por simular outro diálogo entre ela e Rubião, demonstrando, assim, maior domínio dos mecanismos usados para criar efeitos de verdade. Agora se entende um pouco melhor o desvario de Rubião que teria nascido (quem sabe?) da leitura de Madame Bovary. Em sua mente, talvez ele fosse Leon, e Sofia, Emma. Assim, a ficção retoma uma vez mais o lugar da realidade; ou melhor, ambas se neutralizam, pois apresentam como uma construção discursiva.

As observações permitem confirmar o perfil desse enunciador tal como esboçado até o momento. Ao instalar um actante da enunciação enunciada, o narrador, que exprime um pensamento diferente, senão oposto, ao seu, cria um efeito de dissimulação; afinal, não transmite as idéias de forma direta, mas de um jeito obliquo e dissimulado, como diria o José Dias. Por exemplo, enquanto o narrador afirma que não fabula nada, o enunciador aponta para o fato de toda a narração ser uma construção que nada tem de real. Mas, se é assim, a dissimulação desse enunciador resulta, em última instância, em grande sinceridade (ou seria cinismo?), ao impedir que o leitor se iluda com o que lê. Na verdade, é cinismo mesmo, pois não há outro modo de caracterizar alguém que assume de forma impávida a própria dissimulação e continua a empregá-la mesmo depois de desmascarado.

Retomem-se agora as passagens citadas e veja que em todas elas o discurso é apresentado não como referência a uma realidade exterior que ele reproduz ou evoca, mas como local de instalação de inscrição da verdade ou da falsidade que basta por si só e é resultante de um acordo tácito entre enunciador e enunciatário; sejam eles narrador e narratário, tal como na passagem que tratava dos comensais de Rubião, sejam dois actantes do enunciado, como Rubião e Sofia. Ora, o que o enunciador mostra na prática foi teorizado pela semiótica, com extrema clareza, cerca de cem anos depois: a verdade e a mentira não devem ser buscadas fora do discurso, mas no seu interior:

[...]O discurso é esse lugar frágil onde se inscrevem e se lêem a verdade e a falsidade, a mentira e o segredo; esses modos da veridicção resultam da dupla contribuição do enunciador e do enunciatário. Suas diferentes posições não se fixam senão sob a forma de um equilíbrio mais ou menos estável que provém de um acordo implícito entre os dois actantes da estrutura da

\footnotetext{
${ }^{148} \mathrm{Id}$. Ib.
} 
comunicação. É essa entente tácita que é designada sob o nome de contrato de veridicção. (Greimas, 1983: 105).

\section{Dom Casmurro}

Em Dom Casmurro não há aquela oposição explícita entre enunciação e enunciado, ou entre narrador e enunciador, que se observava em Memórias póstumas - o que não significa que ela não exista ou mesmo que seja menor. Na verdade, a situação é mais complexa. Antes, o leitor, ao menos, tinha a tranqüilidade de jamais poder levar Brás Cubas a sério, pois era clara a oposição entre ele e a instância da enunciação. Não havia dúvidas quando ao contrato: os enunciados estavam sempre invertidos e, para conhecer o pensamento do enunciador, talvez bastasse inverter as palavras do narrador. Bento Santiago não pode ser tratado da mesma forma, pois ele é narrador mais sofisticado, que faz afirmações não menos terríveis que as de Brás Cubas, mas as faz de outro modo, digamos, mais dissimulado. Um indício banal da seriedade com que Bento Santiago tem sido tratado é a eterna polêmica a respeito da existência ou não do adultério de Capitu. $\mathrm{Na}$ verdade, a polêmica se sustenta apenas se for admitido que o narrador é sincero, que tem as dúvidas que diz ter. E mesmo tal questionamento deve enfrentar um terreno difícil, pois a subjetividade presente em toda a narrativa e o temperamento do narrador já tornam essa questão um tanto ociosa. Ainda que Bento Santiago seja sincero, que seu relato seja honesto, nada disso torna sua narrativa mais confiável; afinal, como se sabe, nenhuma narrativa em primeira pessoa é isenta. Ele pode estar sendo sincero, sem que isso signifique que seus juízos sejam acertados. Finalmente, nada permite concluir que Bento seja portador das idéias da enunciação. Desse modo, chega-se a uma primeira cláusula do contrato enunciativo firmado entre o enunciador e seu enunciatário: não se busca criar um efeito de verdade, ainda que o narrador trabalhe com esse objetivo, nem, como ocorria em Memórias póstumas, de mentira, mas justamente mostrar a relatividade de uma e de outra.

Chega-se, assim, a uma das grandes questões desse romance, vizinha à travada em Quincas Borba. Lá, a todo o momento, o enunciador mostrava a linguagem como grande artífice da realidade; tratava-se, portanto, não de imitá-la, mas de construí-la. Agora, a mesma questão é vista sobre outro enfoque: o da impossibilidade de se chegar à verdade, não apenas à verdade do outro, mas à nossa própria, pois o indivíduo que surge desse romance está irremediavelmente cindido, é incapaz de confiar em si próprio, em suas impressões, e tem de 
levar essa dúvida consigo. Sísifo, o rei da cidade de Corinto, foi condenado pelos deuses a passar a eternidade no inferno empurrado uma enorme rocha que, ao atingir o cume da montanha, rolava até a base, obrigando-o a empurrá-la novamente e, assim, infinitamente. Pois bem, parece que o enunciador condena Bento Santiago, e com ele o leitor, a buscar a todo tempo a verdade, mas quando está prestes a encontrá-la, ela rola montanha abaixo, após mostrar-se sempre uma construção do próprio sujeito que a constrói. Observa-se, assim, um duplo movimento em Dom Casmurro: primeiro, o narrador constrói a verdade; em seguida, o enunciador a faz rolar ladeira abaixo, mostrando-a, já que se está a falar de mitos gregos, como uma quimera linguageira.

Voltemos ao romance.

O narrador passa todo o livro tentando convencer o narratário de que fala a verdade. Claro está, portanto, que o contrato, ao menos nesse nível, visa a construir um efeito de verdade. Por exemplo, para convencer o leitor de que é sincero e que o livro é verdade pura, Bento confessa que, quando rezava pela mãe, às vezes distraia-se com um tique-tique e que não emendava uma oração na outra ${ }^{149}$. Em outra ocasião, trata o leitor de leitor de minhas entranhas $^{150}$, ao confessar que teve ciúmes de Capitu quando José Dias insinuara que ela poderia andar de namoros com a peralta da vizinhança. Contudo, talvez o momento mais interessante para os propósitos deste trabalho seja aquele em Bentinho cita Montaigne para atestar sua sinceridade:

\section{CAPÍTULO LXVIII / ADIEMOS A VIRTUDE}

Poucos teriam animo de confessar aquele meu pensamento da Rua de Mata-cavalos [o de que se sua mãe morresse escaparia ao seminário]. Eu confessarei tudo o que importar à minha história. Montaigne escreveu de si: ce ne sont pas mes gestes que j'écris; c'est moi, mon essence Ora, há só um modo de escrever a própria essência, é contá-la toda, o bem e o mal. Tal faço eu, à medida que me vai lembrando e convidando à construção ou reconstrução de mim mesmo. Por exemplo, agora que contei um pecado, diria com muito gosto alguma bela ação contemporânea, se me lembrasse, mas não me lembra; fica transferida a melhor oportunidade. (Obra Completa, vol. I, p. 880)

Aí está a prova de que Bentinho busca a verdade, doa a quem doer, como se usa dizer em Brasília: está pronto a confessar que desejara a morte da mãe; tudo para que o leitor conheça a sua essência. É difícil pensar em maior prova de apego à verdade. E não se pode negar que, de um jeito ou de outro, Bentinho escreveu sua essência: as inúmeras vezes que se

\footnotetext{
${ }^{149}$ Obra Completa, vol. I, p. 870

${ }^{150}$ Idem, p. 874
} 
mostra fraco diante de Capitu ou da mãe, que narra seus ciúmes, que confessa o quase assassinato do filho, que confidencia o seu relacionamento com a mulher e tantas outras ocasiões traçam, de fato, sua essência. No entanto, no mesmo momento que faz esta afirmação, cita Montaigne, famoso justamente por misturar ficção e realidade, ou melhor, por fazer de si mesmo um personagem de seus ensaios. Confrade de Bakhtin, Montaigne parece querer forçar a identificação do eu narrado com o eu narrante, ao mesmo tempo em que, como o filósofo russo, atesta essa impossibilidade. Atente agora para o fato de que, após citar Montaigne dizer que não escreve seus gestos, mas sua essência, Bentinho afirma que o faz à medida que se vai lembrando e convidando à construção ou reconstrução de si mesmo. ${ }^{151}$ Quer dizer, a essência que Bentinho e Montaigne contam não é a essência real do indivíduo ontologicamente tomado, mas a essência do indivíduo construído no e pelo discurso; em outras palavras, a essência, o ethos do ator da enunciação. É esse sujeito que é construído no e pelo texto. Talvez se possa rever um pouco o que foi considerado como a razão de ser da narrativa de Bento. Pode ser que ela vise a acusar Capitu, mas pode ser também que à maneira de Jó Joaquim, do conto Desenredo, Bento Santiago busque se reconstruir a si e a seu mundo pela linguagem, aliás, como ele próprio afirma no trecho acima. O que a réplica da casa de Mata-Cavalos não logrou fazer, isto é, reviver o que ele viveu, ele obteria mediante a linguagem. Assim, ao mesmo tempo em que o narrador afirma falar a verdade, o enunciador mostra, nas entrelinhas do discurso de seu delegado, que a verdade em questão é a construída pelo texto, e, mais do que isso, que talvez não exista outra, como aliás ensina, de Guimarães Rosa em Desenredo. ${ }^{152}$

Qual é, portanto, o contrato entre o enunciador do romance e seu enunciatário? Não é propriamente um contrato polêmico em que $\mathrm{X}$ quer dizer não-X, mas um contrato em que essa questão não se coloca, pois sabe que é a linguagem que faz "X" parecer verdadeiro ou não. Não cabe afirmar que Bentinho mente ou fala a verdade, mas apenas que constrói a sua

\footnotetext{
${ }^{151}$ Está no Essais, livro II, capítulo VI. Vale a pena ler todo o capítulo, pois nele Montaigne discute justamente a construção do $e n$ e da personalidade pelo discurso, como fazem os pintores que fazem seus auto-retratos. Algumas linhas antes do trecho citado por Machado, Montaigne escreve: "Pretendem que eu dê testemunho de mim por obras e atitudes e não de maneira direta, por palavras. Eu pinto principalmente meus pensamentos, matéria informe, que não pode ser manifestada por atos." (Les Essais, Livre II, p 379 ).

${ }^{152}$ Recorde-se o belíssimo trecho de Desenredo, em que o narrador conta como Jô Joaquim obteve a total redenção da sua amada (Livíria, Rivília, Irlívia ou Vilírua):
}

O ponto está em que o soube, de tal arte: por antipesquisas, acronologia, miúda conversinhas escudadas remendados testemunhos. Jô Joaquim, genial, operava o passado — plástico e contraditório rascunho. Criava nova, transformada realidade, mas ialta. Mais Certa? In. Tutaméia, p. 40. 
verdade e isso é o que o enunciador mostra. Mas observe: se o narrador diz que fala a verdade e o enunciador diz que ele apenas fabula, então, ambos estão novamente em oposição, ainda que de forma mais sutil do que a observada anteriormente. A oposição é mostrada de forma oblíqua e dissimulada, para lembrar de novo o José Dias, pois não está colocada com todas as letras; se soa ingênuo afirmar que Bentinho é vítima de Capitu, não soaria diferente a versão oposta, segundo a qual ele é seu algoz. Em miúdos: é preciso ter lupa para ver o que está em jogo, pois o enunciador nunca diz nada às claras — característica que atingirá o ápice em Memorial de Aires. Veja-se que não se está distante do contrato firmado pelo enunciador desde os primeiros romances, pois, também naqueles, o narrador dizia a todo o momento que estava fabulando. A diferença é que essa fabulação é agora negada pelo narrador, que adquire o estilo dos confessionários.

Relembre-se ainda a passagem em que Bentinho despede-se de Escobar sob a janela de Capitu. Ela, que até então não o conhecia, pergunta ao namorado quem era o amigo. Os comentários do narrador durante e após o diálogo não deixam dúvida de que sua narrativa não se afasta do drama teatral:

-Que amigo é esse tamanho? perguntou alguém de uma janela ao pé.

Não é preciso dizer que era Capitu. São cousas que se adivinham na vida, como nos livros, sejam romances, sejam histórias verdadeiras. Era Capitu, que nos espreitara desde algum tempo, por dentro da veneziana, e agora abrira inteiramente a janela, e aparecera. Viu as nossas despedidas tão rasgadas e afetuosas, e quis saber quem era que me merecia tanto.

—É o Escobar, disse eu indo pôr-me embaixo da janela, a olhar para cima.

\section{CAPÍTULO LX / UMA REFORMA DRAMÁTICA}

Nem eu, nem tu, nem ela, nem qualquer outra pessoa desta história poderia responder mais, tão certo é que o destino, como todos os dramaturgos, não anuncia as peripécias nem o desfecho. Eles chegam a seu tempo, até que o pano cai, apagam-se as luzes, e os espectadores vão dormir. Nesse gênero há porventura alguma cousa que reformar, e eu proporia, como ensaio, que as peças começassem pelo fim. (Obra Completa, vol. I p. 883-4 - grifos meus)

Afinal, o que esse narrador narra é verdade ou não? Uma vez mais o narrador compara o que narra a uma peça de ficção e o destino a um dramaturgo, como já fizera Brás Cubas no trecho citado anteriormente. Desse modo, por outro caminho, assemelha-se ao narrador de Jacques le fataliste que afirmava ao leitor que podia fazer o que bem entendia com as personagens, pois detinha o controle de tudo. Bento também aponta para o fato de que se advinham as coisas tanto na ficção quanto na realidade, pois tudo tem um comportamento semelhante. No entanto, no mesmo momento, ele faz o oposto: ao contrário do destino, 
anuncia as peripécias futuras, pois seus comentários não têm outra finalidade que a de chamar atenção do leitor para o papel que Escobar desempenhará na trama. Outra coisa: a reforma dramática que o narrador diz que defenderia em um ensaio, ele próprio a pratica, afinal, ele começou sua narrativa pelo final, quando já era um Casmurro, e depois volta ao princípio de tudo. Solidifica-se, assim, o ethos que se vai construindo desse enunciador e que deve ser examinado com cuidado: de um lado, como se afirmou, ele se mostra dissimulado, na medida em que instaura narradores com discursos opostos aos seus; paralelamente, suas narrativas não pretendem ser nenhuma uma fotografia da realidade com pretensões de cientificidade nem a descrição do ponto de vista de um indivíduo, mas mostrar que é filha da linguagem e que a realidade seria um discurso como os demais. Todavia, a consideração desse aspecto atenua, senão modifica, o comentário sobre a dissimulação do enunciador. Veja, o realismo tinha a aspiração de imitar a realidade tal e qual; o romantismo queria expressar o ponto de vista de um indivíduo sobre o mundo, como se esse sujeito de fato existisse. Já esse enunciador, antes do advento do marxismo e da psicanálise, revela a impossibilidade tanto da proposta do realismo quanto da do romantismo, ao mostrar que tanto o sujeito quanto a realidade que o cerca são criação da linguagem — e Bento Santiago explicita o fato ao afirmar que constrói a si mesmo na medida em que escreve.

\section{Esaú e Jacó}

O conselheiro Aires é sem dúvida um narrador de mais compostura que seus antecessores. Não desrespeita o leitor como Brás Cubas nem tem sobre si as suspeitas que pesam sobre Bento Santiago. Não se pode dizer, portanto, que os enunciados devam ser invertidos antes de serem interpretados - pelo menos não em grande escala. No entanto, uma vez mais o efeito de realidade pretendido pelo narrador é quebrado em outra instância. Viu-se anteriormente que Aires conhece coisas que não poderia conhecer, como o pensamento de Nóbrega ou detalhes de situações que não presenciou. Isso não se deve, certamente, a uma falha de composição, uma vez que a informação sobre a identidade do narrador é dada à parte do romance, na advertência, como se chamasse a atenção para o fato, e, ainda por cima, por um terceiro, que faz questão de distinguir-se do narrador e que não pode ser associado ao autor. Assim, a identidade impossível do narrador é, pode-se dizer, proposital, faz parte da trama e aponta para a oposição entre enunciação e enunciado, não 
porque o narrador assuma posições moralmente questionáveis, mas porque todo seu esforço para convencer é desmontado pelo enunciador, que revela o seu fazer como pura fabulação.

Não é apenas por essa via — cuja ocorrência em outros romances já foi apontada que o contrato entre enunciador e enunciatário se assemelha aos anteriores. Também a concepção de linguagem é a mesma: em Esaú e Jacó, firma-se um contrato semiótico; isto é, a realidade, nem objetiva nem subjetiva, é uma criação da linguagem. Aliás, essa questão é reposta no romance com uma clareza que talvez não seja encontrada em nenhum dos outros. Referimo-nos à bela passagem em que o narrador compara a própria narrativa a uma peça de teatro e sugere que o leitor aguarde a evolução dos acontecimentos como se estivesse no auditório, no intervalo da espetáculo. Ocorre que, por meio de sua metáfora, ele acaba discutindo os efeitos de verdade criados pelo teatro e, claro, por ele próprio:

Enquanto os meses passam, faze de conta que estás no teatro, entre um ato e outro, conversando. Lá dentro preparam a cena, e os artistas mudam de roupa. Não vás lá; deixa que a dama, no camarim, ria com os seus amigos o que chorou cá fora com os espectadores. Quanto ao jardim que se está fazendo, não te exponhas a vê-lo pelas costas; é pura lona velha sem pintura, porque só a parte do espectador é que tem verdes e flores. Deixa-te estar cá fora no camarote desta senhora. Examina-lhe os olhos; têm ainda as lágrimas que lhe arrancou a dama da peça. Fala-lhe da peça e dos artistas. Que é obscura. Que não sabem os papéis. Ou então que é tudo sublime. Depois percorre os camarotes com o binóculo, distribui justiça, chama belas às belas e feias às feias, e não te esqueças de contar anedotas que desfeiem as belas, e virtudes que componham as feias. As virtudes devem ser grandes e as anedotas engraçadas. Também as há banais, mas a mesma banalidade na boca de um bom narrador faz-se rara e preciosa. E verás como as lágrimas secam inteiramente, e a realidade substitui a ficção. Falo por imagem; sabes que tudo aqui é verdade pura e sem choro. (Obra Completa, vol. I p. 1.003)

Não vás lá... não te exponhas a ver o jardim pelas costas; é pura lona velha sem pintura. Veja, o jardim convence, apesar de ser lona; a dama, que acabara de chorar com os expectadores, agora ri com seus amigos atores, os quais não são mais personagens; mas o riso dela não proíbe o choro do expectador. Além de separar as realidades do palco e de fora dele, o narrador convida novamente à fusão delas ao reconhecer o valor encenação e observar que não existem anedotas banais ou preciosas, pois tudo depende dos lábios de um narrador, que, se habilidoso, é capaz de fazer a realidade substituir a ficção apesar de o expectador saber que o jardim é lona velha e o leitor não ignorar que tem entre as mãos um texto ficcional; logo, lona velha. Mas... mas se o leitor dá ouvidos à lona velha, então ela talvez seja verdadeira... A fusão das duas vidas separadas pelo palco é explicitamente afirmada ao final do parágrafo, quando Aires afirma que fala por imagem e que o narratário sabe que tudo o que ele diz é verdade pura. Ora, o enunciatário sabe que nada do que o narrador diz é verdade e o enunciador sabe que o enunciatário sabe. Assim, uma afirmação como essa só pode ser 
reveladora do cinismo do enunciador ... e de sua preocupação com o fato de a linguagem apresentar-se como criadora de realidades. Observe que a revelação da identidade do narrador por M. de A. já havia criado um descompasso entre a pessoa do narrador, actante do enunciado como os demais, e narração. Trata-se de um narrador onisciente que não poderia sê-lo. Erro do enunciador? Certamente, não. É verdade, é uma afronta à verossimilhança, mas visa a mostrar que o romance também é ficção, lona velha pintada de jardim, e não realidade; portanto, nada é verdade, apenas efeito de verdade, apesar dos esforços do narrador.

Volte-se, agora, a Memórias póstumas. Brás Cubas revelava as artimanhas de que se valia para criar efeitos de verdade para Eugênia. Agora, o conselheiro Aires faz o mesmo para mostrar como cria os efeitos de realidade para seu leitor, que então fica a se perguntar, mas, então, é tudo mesmo mentira? Então o narrador é cínico e mentiroso? . Sim, desgraçado, diria de novo o narrador de Quincas Borba, é tudo mentira, on verdade, pouco importa; tudo depende da habilidade daquele que conta a anedota, de como ele se vale da linguagem para construir sua identidade e mesmo a realidade. O que estou a te dizerer é algo que os semioticistas te dirão décadas mais tarde: em vez de ficares discutindo o que é verdade ou não, é melhor pensares, caro leitor, se o discurso é eficiente ou não. Esse é o contrato, explícito, entre enunciador e enunciatário; não se trata de mostrar como as coisas acontecem de uma maneira objetiva, imparcial, científica; nem de apresentar o ponto de vista de um sujeito, apesar de os fatos serem narrados em primeira pessoa, mas de revelar realidades construídas pela linguagem. São dois fazeres: o do narrador, que pinta a lona de verde e a faz florida, e o do enunciador, que vira a parte não pintada para o leitor, e, ao mesmo tempo o avisa para ficar onde está, deixando que a linguagem construa suas realidade. Afinal, conclui o enunciador, é ela a grande dama do meu, do teu, drama.

\section{Memorial de Aires}

Conforme foi visto, o diário de Aires está repleto de equívocos e de ocasiões em que o diarista engana-se em relação aos juízos que faz vários fatos e pessoas, de forma que, por mais bem intencionado que possa ser, suas avaliações merecem cautela, pois outros julgamentos, como o de D. Cesárea, podem ser mais acertados. A credibilidade de Aires fica um pouco mais arranhada quando sua atividade profissional é vista de fora e surgem outros depoimentos que sugerem que seu mundo não seria exatamente como ele pinta, assemelhado 
ao de Teócrito, e que sua carreira talvez o tivesse levado a atitudes não tão respeitáveis quanto a imagem construída faz crer. Uma breve recordação de alguns fatos que antecederam a abolição da escravidão talvez ajude a compreender a posição do conselheiro:

Desde que foi votada a lei de 28 de setembro de 1871, o Governo Brasileiro tratou de fazer acreditar ao mundo que a escravidão havia acabado no Brasil. Uma propaganda voltada para ele começou a espalhar que os escravos iam sendo gradualmente libertados em proporção considerável e que os filhos das escravas nasciam completamente livres. A mortalidade dos escravos é um detalhe que nunca aparece nessas estatísticas falsificadas, cuja idéia é que a mentira no exterior habilita o Governo a não fazer nada no país e deixar os escravos entregues à sua própria sorte.

[...] os crimes contra escravos, o número de africanos ainda em cativeiro, a caçada de negros fugidos, os preços flutuantes da carne humana, a educação dos ingênuos na escravidão, o aspecto mesmíssimo dos ergástulos rurais: tudo o que é indecoroso, humilhante, triste para o Governo, é cuidadosamente suprimido. (Nabuco, 1988: 77).

$\mathrm{Na}$ Europa, a propaganda oficial do governo brasileiro dava conta que milhares de contos de réis eram destinados à libertação dos escravos, quando, na verdade, bem pouca coisa havia mudado com a Lei do Ventre Livre e, menos ainda, em virtude da ação da oficial. Como as condições dos escravos continuavam absolutamente desumanas e a mortalidade infantil entre eles era absurdamente alta, a Lei do Ventre Livre não teve efeito prático algum, mas alimentou a propaganda externa, na qual a diplomacia desempenhava um papel fundamental. Obviamente, não se pode considerar que todos os diplomatas ou servidores públicos de alto escalão do Império estivessem a serviço da escravidão. Nabuco de Araújo, ministro da justiça entre 1853 e 1866, teria sido exemplo de homem público que lutou contra ela. Contudo, a crer no testemunho de seu filho, Joaquim Nabuco, a militância abolicionista se oporia, em alguma medida, ao exercício da diplomacia. É o que ele deixa subentendido em Minha Formação:

Como quer que seja, tenho daquele cargo, de adido de legação, único que exerci, a mais reconhecida e afetuosa lembrança. Nunca mais teria eu podido aceitar outro; com efeito, pouco depois entrava para a Câmara e dava-se a minha incompatibilidade de abolicionista militante com o sistema político da escravidão... (Nabuco, 1981: 81)

Joaquim Nabuco, amigo de Machado, contemporâneo de Aires e diplomata como ele, provavelmente discordaria das opiniões do conselheiro. Inicialmente, porque para ele o Brasil estava muitíssimo longe de ser um mundo repleto de felicidade, pelo menos para a imensa maioria das pessoas que aqui viviam e, segundo, porque a diplomacia brasileira tinha muito pouco do que se orgulhar: entre 1831 e 1850, fora instrumento de uma séria disputa com a Inglaterra para manter o tráfego negreiro e, após essa data, viu-se transformada em 
instrumento de propaganda cuja missão era convencer o mundo de que não havia mais escravos no Brasil ${ }^{153}$; os poucos remanescentes estariam tão felizes que prefeririam continuar na mesma situação (talvez porque trabalhassem para Fidélia...). Mas deixemos que o próprio conselheiro explique seu ponto de vista. Por exemplo, no registro de 19 de abril, realizado após Santa-Pia decidir que ele próprio daria a alforria a seus escravos para atestar seu direito de propriedade, e que a aprovação da abolição já é certa, Aires conta as dificuldades que enfrentou nos Estados Unidos quando aquele país aboliu a escravidão e fez do nosso o único do ocidente em que ainda havia escravos ${ }^{154}$ :

Ainda me lembra do que ia lá fora, a nosso respeito, por ocasião da famosa proclamação de Lincoln "Eu, Abraão Lincoln, presidente dos Estados Unidos da América ..." Mais de um jornal fez alusão nominal ao Brasil, dizendo que restava agora mais que um povo cristão e último imitasse aquele e acabasse também com os seus escravos. Espero que hoje nos louvem... (p. 1.117)

Aires confirma o depoimento de Nabuco, e conta, por experiência própria, o que significava representar a última nação cujo governo comercializava seres humanos de forma oficial. Repare que seu desejo de que o país fosse louvado por deixar de praticar (com muito atraso) um crime, revela uma ingenuidade, pouco compatível, para dizer o mínimo, com um homem da sua vivência. Além disso, se Aires se opunha à escravidão, tal oposição não era tão acirrada que o impedisse de executar cabalmente suas atribuições. Veja-se seu comentário sobre a abolição no próprio 13 de maio:

Enfim lei. Nunca fui, nem o cargo me consentia ser propagandista da abolição, mas

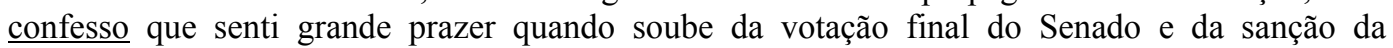
Regente. (p. 1.118 - grifo meu)

Novamente Aires confirma Nabuco sobre a oposição entre sua carreira diplomática e a luta pela abolição. Segundo suas próprias palavras, Aires nunca fora propagandista da

${ }^{153}$ Entre 1830 (quando teve início a pressão da Inglaterra para que o Brasil acabasse com o tráfego) e 1888, período que coincide em parte com a atuação de Aires, a diplomacia brasileira atuou de forma ativa para proteger o interesse dos escravocratas. O depoimento é dado por Nabuco de Araújo, pai de Joaquim Nabuco:

De 1831 até 1850 o Governo Brasileiro achou-se, com efeito, empenhado com o inglês em uma luta diplomática do mais triste caráter para nós, por não podermos executar os nossos tratados e as nossas leis. (Nabuco, 1988: 77)

${ }^{154} \mathrm{Na}$ verdade, após sua abolição nos Estados Unidos a escravidão perdurou em Cuba, então colônia, até 1880, quando, na seqüência da "Guerra dos dez Anos", foi suprimida após várias agitações. Logo, ao tornar-se independente, em 1895, e proclamar a República, Cuba há muito havia abandonado a escravidão. Assim, a posição do Império Brasileira em 1888 era realmente delicada. Ora, Aires era funcionário graduado desse império. 
abolição, mas o que isso significa em linguagem diplomática? Talvez que fosse indiferente a ela, o que, considerando-se o assunto, é algo questionável, de novo, para dizer o mínimo. Registre-se também sua obediência ao cargo que não o consentia ser partidário da abolição, embora muitos diplomatas o fossem ou, como no caso de Nabuco, abandonassem a carreira para poder sê-lo. Finalmente, é o caso de perguntar por que ele confessa ter sentido grande prazer na abolição; o estranho não seria que ele confessasse o oposto, que era contrário a ela? Sem esquecer que Santa-Pia alforriara seus escravos apenas para reafirmar seu direito de propriedade e que o Barão também sentiu certo praz̧er na abolição, sem fosse movido por qualquer sentimento humanitário e sem que isso impedisse Aires de julgá-lo positivamente. Assim, é possível pensar que talvez o diplomata ficasse pouco à vontade em seu meio para expressar tal opinião ou que ainda não tivesse assimilado a aposentadoria e se sentisse, ou quisesse sentir-se, na obrigação de representar o país escravocrata. Afinal, no seu meio ninguém se opunha verdadeiramente à escravidão e Campos, por exemplo, não aprovara sequer a alforria promovida por Santa-Pia. Repare ainda que, para Aires, ser contrário ou a favorável à escravidão não parece ser algo relevante e que o diplomata dá a entender que acha razoável que os deveres profissionais venham antes de questões morais, embora nem todos pensassem da mesma forma, como foi o caso de Nabuco, aliás, vale repetir, grande amigo do escritor Machado de Assis. De qualquer modo, os trechos citados revelam uma outra imagem do conselheiro, não tão correta quanto a pretendida por parte da crítica, nem tão distante da de outros narradores machadianos. Apenas mais refinada.

No entanto, como se sabe, não é objetivo deste trabalho discutir as posições morais de Aires, mas apenas mostrar que elas não são ingênuas e comprometem a imagem de bom velhinho que o conselheiro construiu para si. Como já foi dito anteriormente, volta-se a uma situação semelhante à dos primeiros romances, em que o narrador traçava uma imagem romanesca do que via, ao passo que o enunciador desautorizava o mesmo julgamento. A diferença agora, é que a oposição entre as duas visões, extremamente sutil, pois embora algumas posições de Aires não sejam aceitáveis (como a relativa a escravidão), ele não as expõe com faziam outros narradores machadianos. Ao contrário de Brás Cubas ou Bentinho, Aires é narrador de grande habilidade, como o dos primeiros romances. No entanto, a oposição entre ele e o enunciador que o instaurou narrador não advém apenas da advertência ou da posição diante da escravidão, mas de pequenos, quase imperceptíveis, deslizes de Aires. A situação se torna mais complexa — e, de certa forma, cínica — quando se observa que, ao 
mesmo tempo que instaura um narrador ao qual se opõe, o enunciador procura a todo custo associa-lo ao escritor Machado de Assis. É o que acontece quando reproduz no corpo do romance, trechos de crônicas da coluna A semana, do jornal Gazeta de Notícias, que também seriam publicadas pelo mesmo enunciador. Examinem-se dois exemplos:

$$
\text { registro de } 24.06 .1888
$$

Ontem conversei com a senhora do Aguiar acerca das antigas noites de S. João, Santo Antônio e S. Pedro, e mais as suas sortes e fogueiras. D. Carmo pegou do assunto para tratar ainda do filho postiço. Leve o diabo tal filho. A filha postiça é que há de estar a esta hora mui triste no casarão da fazenda, onde certamente passou as antigas noites de S. João de donzela esperançada e crédula. [...].

Também eu tirei sortes outrora. Com pouco se fingia de Destino, - um livro, um rimador de quadras e um par de dados. "Se há de desposar a pessoa a quem ama", dizia o título da página, por exemplo: deitavam-se os dados, os números eram cinco e dois, sete: ia-se à quadra sétima, e lia-se. Suponhamos que se lia.. Vá, risco a quadra que cheguei a escrever aqui. Geralmente era engraçada, - pelo menos, mas também troçava com a pessoa que consultava o Destino. Todos riam, criam deveras; em todo caso passavam-se as horas até chegar o sono. E ali vinha este velho camareiro da humanidade, que os pagãos chamaram Morfeu, e que a pagãos e cristãos e até a incréus fecha os olhos com seus eternos dedos de chumbo. Agora, meu sono amigo, só tu virás daqui a uma ou duas horas, sem livros de sorte nem dados. Quando muito trarás sonhos, e já não serão os mesmos de outro tempo. (p. 1.129)

\section{crônica de 26.06.1893}

Não posso aprender sequer a acender pistolas e tirar sortes de S. João. São talentos desaprendidos. Meu bom S. João, companheiro do romantismo, da idade em flor, e de várias relíquias que os santos de outra idade levaram consigo. Vejo as moças e os moços em volta da mesa, livro de sortes aberto, dados no copo, copo na mão, e o leitor do livro lendo o título da página: "Se alguém lhe ama em segredo." A moça deitava os dados: cinco e dois. O leitor corria ao número 7 , onde se dizia por verso que sim, que havia uma pessoa, um moço que, por sinal, estava com fome. "É o Rangel! Bradava um gracioso; tragam o chá, que o Rangel está com fome.” E riam os moços e moças, e continuavam o copo, os dados, as quadras, o leitor do livro, o Rangel, o gracioso, até que todos iam dormir os seus sonos desambiciosos, sem querer saber da fusão, nem de encampação, nem de tratados literários, nem de jóias, nem de Cleópatras, nem de nada. (Gledson, 1996: 259)

Como se vê, os dois textos são muito parecidos e as diferenças, desprezíveis. A explicação estaria no fato de o cronista e o diplomata serem a mesma pessoa ou terem vivenciado as mesmas situações, ainda que não da mesma maneira, e terem as mesmas opiniões e sentimentos sobre esses fatos, o que não é verdade, como se verá a seguir. Em todo caso, o fim é o mesmo: convencer o leitor de que o conselheiro é sincero e Aires seria o pseudônimo do escritor Machado de Assis. Veja-se agora um segundo exemplo, mais interessante:

\section{Registro de 13.05.1888}

[...] Estava eu na Rua do Ouvidor, onde a agitação era grande e a alegria geral.

Um conhecido meu, homem de imprensa, achando-me ali, ofereceu-me lugar no carro, que estava na Rua Nova, e ia enfileirar no cortejo organizado para rodear o paço da cidade, e fazer ovação à Regente. Estive quase, quase a aceitar, tal era o meu atordoamento, mas os meus hábitos quietos, os costumes diplomáticos, a própria índole e a idade me retiveram melhor que

\section{Crônica de 14.05.1893}

Houve sol, e grande sol, naquele domingo de 1888, em que o Senado votou a lei, que a regente sancionou, e todos saímos à rua. Sim, também eu saí à rua, eu, o mais encolhido dos caramujos, também eu entrei no préstito, em carruagem aberta, se 
as rédeas do cocheiro aos cavalos do carro, e recusei. Recusei com pena. Deixei-os ir, a ele e aos outros que se ajuntaram e partiram da Rua Primeiro de Março. Disseram-me depois que os manifestantes erguiam-se nos carros, que iam abertos, e faziam também todos os ministros. Se eu lá fosse, provavelmente faria o mesmo e ainda agora não me teria entendido... Não, não faria nada; meteria a cara entre os joelhos. ( p. 1.118) me fazem favor, hóspede de um gordo amigo ausente; todos respiravam felicidade, tudo era delírio. Verdadeiramente, foi o único dia de delírio público que me lembra ter visto. (Gledson, op. cit;: 258)

A descrição, detalhada, do cortejo é basicamente a mesma nos dois textos e em ambos o narrador que fora convidado por um homem de imprensa para acompanhar o préstito (o gordo ausente da crônica era, com certeza, Ferreira de Araújo, editor de $A$ Gazeta de Notícias ). Contudo, a diferença é significativa: em conformidade com a posição de quem confessa ter sentido prazer com a abolição, Aires recusou o convite para festejá-la, mas o cronista o aceitou, também de forma coerente com a posição adotada em várias crônicas. Desse modo revela-se, mais uma vez que o narrador mantém uma relação conflituosa com a enunciação, não por ter participado ou não do cortejo, mas porque são expostas suas estratégias para criar efeitos de verdade. Curiosamente, Augusto Meyer entendeu que a "verdade" estava com Aires (que ele entende ser o próprio Machado), pois, em seu entendimento, o temperamento do escritor nunca lhe permitiria participar de tais festejos:

O Outro, o que "foi na onda", não passa de um fantasma em carne e osso, leviano e crédulo. [...] $\mathrm{Na}$ versão literária do fato, está a sua atitude sincera, ele tenta justificar-se, corrigindo a realidade[...] Diga-se, em resumo, que [Machado] não foi [ao cortejo] e não se entende. (Meyer: 1958: 47)

Assim, pelo menos para Meyer, a estratégia de fundir narrador e enunciador deu certo, e não foram poucos os que entenderam que Aires expressava o pensamento de Machado $^{155}$. É compreensível: tanto o diplomata quanto o cronista esforçaram-se por parecer verdadeiros aos olhos do leitor e, para tanto, lançam mão de acontecimentos que teriam vivenciado para com eles "corrigir a realidade", como diria Meyer, e assim convencer seu destinatário. A existência do cortejo, a presença de Araújo e outros fatos são utilizados por Aires e pelo cronista para convencer o leitor. Em outras palavras, são mecanismos, criados para estabelecer efeitos de verdade, que são desmascarados no próprio momento de sua

\footnotetext{
${ }^{155}$ Em História concisa da literatura brasileira, por exemplo, BosI considera que D. Carmo seria uma espécie de projeção de D. Carolina, esposa de Machado.
} 
utilização. Qualquer semelhança com os métodos utilizados por Bentinho não é mera coincidência ${ }^{156}$.

O interesse das comparações e da citação dos comentários da crítica não está em verificar como e se Machado utilizava as crônicas como rascunho para seus romances, nem em especular sobre a participação do escritor em manifestações cívicas, mas sim em observar como, ao embaralhar ficção e realidade, o enunciador mostra que a única verdade é a do texto. O procedimento é velho conhecido: de um lado, criar efeitos de verdade que beiram à perfeição (é o que faz Rubião com Sofia e é a forma como procede Aires); de outro, desmontar esses efeitos ao instalar aqui e ali elementos que rompem com essa pretensa isonomia entre linguagem e referente externo e exibem tudo como artifício da enunciação. Retomando uma idéia esquecida lá em cima, deve-se observar que o romance realiza dois movimentos opostos: primeiro, apresenta-se autêntico, solidamente ancorado na realidade (como atestam as semelhanças do Memorial com as crônicas) e com um narrador absolutamente confiável; depois, por meio das inúmeras retificações de Aires, dos julgamentos equivocados e das diferenças em relação ao que teria de fato ocorrido, expõe a precariedade da narração. Compare-se, mais uma vez, a narrativa de Aires com a de Brás Cubas: as memórias do defunto poderiam ser verossímeis, mas jamais seriam verdadeiras. Bentinho avança significativamente nas duas modalidades, mas não consegue convencer plenamente, enquanto Aires atinge a perfeição. Esse jogo de efeitos faz com que a trama talvez pudesse receber o seguinte subtítulo: instruções para criação de um texto verossímil e que seja aceito como verdadeiro...

O exame das posições adotadas por Aires em relação è escravidão e o confronto do romance com as crônicas mostra um sofisticado trabalho do enunciador. Tanto na narração quanto no narrado, criam-se efeitos de verdade e, no entanto, não se pode afirmar que, no romance como um todo, enunciação e enunciado estejam de acordo, pois as afirmações de

\footnotetext{
${ }^{156}$ Lembrando que a Gazeta de Notícias era francamente abolicionista e que, na prática, Machado não era apenas redator do jornal, mas um associado, Raimundo Magalhães Jr. não se deixa levar pelas artimanhas dos narradores da crônica e do Memorial. Distinguindo o diplomata do escritor, o crítico propõe a seguinte interpretação:

Por que havia de atribuir a este [Aires], exatamente, o que se passou com ele próprio? Machado, nessa passagem, dá noticia de um conhecido de Aires, "bomem de imprensa", que lá se foi de carro. Por que não reconbecer esse homem de imprensa o próprio Machado? Afinal, ninguém melhor do que ele conhecia Aires... E por que havia de negar no derradeiro livro um ato que era público e não podia envergonbá-lo? Machado não o nega. Antes o confirma, numa crônica de A Semana, de 14.05.1893, em que escreve: "Houve sol [...]"(Magalhães, 1971: 120)
} 
Aires devem sempre (ou quase) ser invertidas para serem corretamente compreendidas: $\mathrm{X}$ deve ser interpretado como não-X. Aprofundando a análise, tal posicionamento revela que, para o enunciador, a linguagem não é reprodução fiel da realidade, mas criadora dela. Assim, diria ele, tudo o que se pode afirmar é que há discursos que produzem a verdade e outros que não o fazem. Desse modo, a concepção que o enunciador tem do discurso adquire feições bem próximas das descritas por Greimas: lugar frágil onde se inscrevem e se lêem a verdade e a falsidade, a mentira e o segredo; esses modos da veridiç̧ão resultam da dupla contribuição do enunciador e do enunciatário. Como se sabe, essa concepção de linguagem está presente em todas as obras de Machado, desde Ressurreição. No Memorial de Aires, porém, ela apresenta a peculiaridade de em alguns momentos ser extremamente sutil e de noutros ser explicitada, quase de forma didática. É o que acontece na passagem em que D. Carmo conta a Aires que Tristão insinuara à Fidélia a doação de sua fazenda para os escravos libertos:

Eles que a trabalhem para si. Não foi bem assim que [Tristão] lhe falou; pôs-lhe uma nota voluntariamente seca, em maneira que lhe apagasse a cor generosa da lembrança. Assim o interpretou a própria Fidélia, que o referiu a D. Carmo, que mo contou, acrescentando:

— Tristão é capaz da intenção e do disfarce, mas eu também acho possível que o principal motivo fosse arredar qualquer suspeita de interesse no casamento. Seja o que for, parece que assim se fará.

- E andam críticos a contender sobre romantismos e naturalismos!

Parece que D. Carmo não me achou graça à exclamação, e eu mesmo não the acho graça nem sentido. (Obra Completa, vol. I, p. 1.191 - grifos meus)

Sobrepõem-se diversas interpretações de um mesmo fato: românticos diriam que Tristão fez a sugestão por generosidade ou idealismo (embora não houvesse qualquer indício de que alguém lá fosse abolicionista e o pai de Fidélia fosse francamente contrário a idéia); já naturalistas, como D. Cesária, tenderiam a ver em Tristão apenas o interesse. Uma terceira possibilidade seria a de que a fazenda, que já não valia nada, seria um empecilho ao estabelecimento definitivo do casal em Lisboa; daí a necessidade de vendê-la. Essa possibilidade não aventada pelo narrador, mas se mostra a mais provável, dado o desenlace da trama. Aires descarta tanto a interpretação romântica quando a naturalista, não por considerá-las inverossímeis, mas justamente por entender que a verdade é sempre uma construção da linguagem. Não há uma realidade objetiva, tampouco um indivíduo autônomo, mas a construção de realidades pela linguagem. Aliás, é o que faz Tristão, ao pôr em sua fala uma nota seca, que Fidélia interpreta como uma estratégia para esconder seus sentimentos. A discussão que parece interessar ao enunciador não é sobre romantismos ou naturalismos, nos 
quais não crê, nem sobre o comportamento conjugal de Capitu ou ainda a causa da rivalidade entre os irmãos Pedro e Paulo. Nada disso interessa a esse enunciador que não acredita em propósitos, como não crê que a realidade possa ser representada. A questão é a impossibilidade do julgamento, e não se o veredicto é (ou não) correto. É que, como sempre, o enunciador pensa o discurso como o lugar instável, frágil, onde se inscrevem a verdade e a mentira, o segredo e a falsidade. Nessa medida, o Memorial de Aires é muito mais cético e duro do que os romances que o antecederam, e a discussão sobre a construção da narrativa se mostra ela própria questionada. A cobra comeu-se: esse enunciador, que há muito era caracterizado pelo seu ceticismo, agora quase descrê de seu próprio enunciado. O saber com o qual ele deseja colocar o enunciatário em conjunção refere-se, justamente, à impossibilidade de conjunção com um saber que se pretenda "verdadeiro".

\section{$\cos \cos 20$}

A análise dos contratos celebrados entre enunciador e enunciatário por meio dos romances comentados pede a consideração de dois aspectos: a criação (ou não) de um efeito de verdade ou realidade e a concepção de linguagem presente nessas obras. O primeiro deve ser desdobrado em dois, como foi feito quando se discutiu a delegação do saber: o efeito produzido no tocante ao narrado e no tocante à narração.

Com relação ao narrado, observe-se, inicialmente, que todos os narradores, sem exceção, procuram criar efeitos de realidade, segundo os quais o que narram realmente aconteceu. Examine-se o caso que parece mais problemático, Memórias póstumas: O problema não está no que Brás Cubas narra, afinal, nada do que afirma é inverossímil ou impossível e, reconheça-se, o narrador sempre tem a preocupação de comprovar o que narra; as indicações de locais, datas e nomes do mundo "real" têm a função de situar a narrativa no mundo do leitor. O que soa falso, ficcional, não é, portanto, o conteúdo, o narrado, mas o fato de o narrador ser um defunto e narrar de além tumulo. Pode-se pensar, entre outros, em contos como A sereníssima república (História sem data, 1884), que narra fatos que teriam se passado em uma república de aranhas; Conto Alexandrino (Papéis avulsos, 1882), que relata as experiências impossíveis realizadas por dois filósofos alexandrinos, Stroibus e Pítias; ou mesmo Lágrimas de Xerxes (Páginas recolhidas, 1899), conto que supõe um outro diálogo entre Romeu e Julieta. Nesses casos, é claro que nada do que é narrado poderia de fato ter ocorrido, pois são 
histórias absurdas, sobre episódios impossíveis por motivos variados, portanto, neles o narrador não busca causar um efeito de realidade, mas de ficção. Certo, em $A$ sereníssima república, é evidente a menção aos casuísmos eleitorais do Brasil e qualquer leitor reconhece a semelhança entre as duas repúblicas. No entanto, a intenção do narrador é mostrar uma situação absurda - uma república de aranhas — e, assim, salientar o absurdo brasileiro. A realidade não deixa de ser imitada, mas, para tanto, ele se vale de um efeito de ficção. Veja que no caso de Lágrimas de Xerxes a situação é exatamente oposta à de Memórias póstumas na medida em que a narração é plenamente possível, afinal, o narrador inicia o conto com a seguinte afirmação: Suponhamos (tudo é supor) que Julieta e Romen, antes que o Frei Lourenço os casasse travam com ele este diálogo curioso... ${ }^{157}$ : Quer dizer, o narrador assume que sua narrativa é apenas uma suposição, baseada em uma outra versão, para outro texto ficcional; não há, portanto, pretensão de causar efeitos de realidade. Já nos romances, conforme citado, o narrador, ainda que absurdo, sempre procura criar efeitos de verdade de modo que $\mathrm{X}$ deve ser lido como $\mathrm{X}$.

Esse efeito de realidade é, no entanto, desestabilizado quando se atenta não mais para a possibilidade da ocorrência de um fato, mas para as posições assumidas pelo narrador, fato que fica mais evidente em Memórias póstumas e Quincas Borba. Nesses casos, o enunciador busca, ao mesmo tempo, causar um efeito de realidade e mostrar enunciação e enunciado em conflito. Por exemplo, no episódio envolvendo Brás Cubas e Eugênia, não são apenas os fatos em si mesmos que causam repulsa, mas a forma como são narrados, sobretudo, o cinismo de Brás Cubas e sua atitude de colocar-se acima de tudo e de todos. Veja-se agora que, em Quincas Borba, não é a troca de olhares entre os comensais de Rubião que soa falsa, mas o testemunho e a apreciação da cena feita pelo narrador que não são compatíveis com o que se passa ou mesmo com a narração em terceira pessoa. Desse modo, mais uma vez, não é o narrado que causa estranhamento, mas a posição do narrador em relação a ele. Examine-se, ainda, o Memorial de Aires, romance onde tudo transcorre na mais absoluta normalidade e o narrador é um exemplo de boas maneiras. Dessa vez, a desconfiança não decorre não do que Aires conta, mas da posição equivocada, excessivamente crédula ou otimista, diante daquilo que narra, a qual leva o enunciatário a crer que há algo de errado diante de tanta bondade. Recorde-se, uma vez mais, o que foi descoberto em Helena ou Iaiá Garcia, no capítulo que tratou dos níveis narrativos. Lá, o conflito entre enunciação e enunciado (pois é disso que se trata nos casos analisados) não era manifestada por uma posição explicitamente absurda do

\footnotetext{
${ }^{157}$ Obra Completa, vol. II p. 615
} 
narrador, porque a instância da enunciação se valia das advertências para manifestar sua oposição ao narrador, como se o fizesse de fora do romance. Atente-se, agora, para Dom Casmurro. A oposição se manifesta na medida em que o narrador, de um modo diferente do de Aires, tropeça em vários momentos e no mais importante deles, ao reunir provas sobre o adultério. Em todos esses casos, o enunciatário é levado a concluir que, a despeito do efeito de realidade criados, enunciação e enunciado estão em oposição. Dom casmurro ilustra bem o caso. A bisonhice de Bento Santiago na condução da narração não afeta exatamente a verossimilhança dos fatos que narra, mas faz com que a posição assumida pelo narrador — a de que o comportamento de Capitu apresentaria indícios de adultério - se mostre, no mínimo, questionável e, desse modo, volta a sinalizar para uma oposição entre enunciação e enunciado. O único romance em que tal oposição não se verifica é Iaiá Garcia; não se pode afirmar que o enunciador se oponha ao narrador nem de forma exterior à narrativa, pois o romance não contém advertências, nem internamente, já que não se nota por parte do narrador qualquer atitude em relação ao narrado que justificasse afirmar que exista uma oposição em relação ao enunciador.

Quando se enfocam os efeitos de realidade em relação à narração, a situação se torna mais diversificada. Em um extremo, está Memórias póstumas, que, conforme foi comentado acima, instaura um narrador impossível; logo, a narração em si mesma é absurda. No extremo oposto, está o Memorial de Aires, cuja preocupação com a construção de verdade no tocante a narração leva o enunciador ao extremo de informar a data e a hora que cada registro teria sido feito e de haver anotações que têm apenas a finalidade de corrigir erros contidos em registros anteriores, como aquela em que Aires percebe que havia se equivocado quanto ao aniversário do ministério Ferraz. Claro que o engano é apenas do narrador e não do enunciador, portanto, o objetivo do registro equivocado seria, dentre outros, conferir verossimilhança ao diário, pois seria pouco crível que um diarista nunca se equivocasse. Entre Memórias póstumas e o Memorial, se posicionariam as demais obras, em um contínuo difícil de ser estabelecido, dado que cada obra diferencia-se das demais apenas por nuanças. Assim, sem pretender uma maior precisão, ao lado de Memórias póstumas poder-se-ia colocar Esaú e Jacó, na medida em que um narrador onisciente que diz eu e é actante do enunciado, como Aires, também seria impossível. De novo, o que soa irreal não é o narrado, mas a narração. Quincas Borba viria em seguida, se for considerado que não se pode levar a sério um narrador que se perde em discussões sobre o título a ser dado aos capítulos de sua narrativa ou que se 
apresenta como defunto, (já que pode-se entender que Quincas Borba também foi narrado por Brás Cubas). Ao lado do Memorial, pode-se enfileirar Helena e Iaiá García, romances em que não há nada que desabone a narração. Mais ou menos eqüidistante dos dois extremos, mas, talvez, mais próximos do Memorial de Aires, e não necessariamente nessa ordem, encontraríamos Dom Casmurro, A mão e a luva e Ressurreição. A dúvida fica por conta de sinais contraditórios construídos nos dois últimos romances. De um lado, a narração é conduzida dentro da mais absoluta normalidade, porém, há momentos, justamente quando o narrador se dirige ao narratário, em que essa normalidade é quebrada, fazendo com que o enunciatário se dê conta de que tudo é, afinal, fingimento.

É preciso que se examine também a concepção de linguagem que permeia todos os romances de Machado, mais uma vez, sem exceção. Não se trata de uma concepção, positivista, segundo a qual a linguagem é uma representação fiel da realidade, nem de uma perspectiva subjetiva, que privilegia o olhar do indivíduo; trata-se, antes, do entendimento de que entre o mundo e o sujeito e mesmo entre o sujeito e ele próprio há sempre a intervenção da linguagem refratando sua percepção. Desse modo, tanto o mundo quanto o sujeito resultam de uma construção linguageira, de existência precária, instável. Observe que essa perspectiva é absolutamente coerente com o fato, citado no item anterior, de que esses romances não imitam a realidade, mas um discurso sobre a realidade. Ora, sendo a posição do enunciador a de que a linguagem se sobrepõe entre o sujeito e o mundo, não haveria como imitar um ou outro; tudo o que resta, é imitar o discurso do sujeito sobre a realidade ou sobre ele mesmo, como fazem todos os narradores machadianos. Isso já se mostrava presente em Ressurreição, quando o narrador afirmava, a respeito do destino de Lívia, que o romance era secular, motivo pelo qual ela fica em casa em vez de se refugiar em um convento. Essa preocupação volta em Quincas Borba, na passagem em que Rubião, valendo-se da linguagem, cria um fato inexistente a ponto de confundir Sofia, que sabia que nada havia ocorrido. $O$ mesmo acontece ainda quando o narrador de $A$ mão e a luva afirma que é privilégio do escritor e do leitor saber o que se passa na mente das personagens, deixando claro, portanto, que elas e seu mundo são seres de papel. O tema é retomado, em outra chave, quando Bento Santiago afirma que constrói a si mesmo quando escreve, mostrando a sobreposição da linguagem e da realidade, e citando, como exemplo, Montaigne, outro adepto da mesma teoria. Esses momentos deixam claro que não se imita a realidade nem os sentimentos de um indivíduo, mas trabalha-se a linguagem em funcionamento. Talvez o romance que mais explicite esse 
processo seja Esaú e Jacó, especialmente na passagem citada neste capítulo. Por meio da alusão a uma peça de teatro, o narrador mostra, de uma maneira diferente, mas análoga à utilizada em Quincas Borba, os artifícios para a construção da realidade e lembra que o cenário que parece real não passa de lona velha, que suas afirmações tão convincentes, as tramas tão bem urdidas, seriam apenas construções da linguagem, um amontoado de morfemas, nada mais. É um processo um tanto esquizofrênico, se é que cabe o termo, por que de um lado propõe uma aproximação do narratário e, de outro, impõe um distanciamento, já que mostra que também essa aproximação é lona velha, ou seja, fruto da linguagem, pois o narratário com quem se propõe a aproximação não tem existência real. Isso explica também porque, ao longo deste trabalho, afirmava-se que, em alguns momentos, o enunciador parecia distante, e noutros que ele parecia próximo do enunciatário. É que os dois movimentos, de mesmo sentido, mas de direção opostas, estão sempre presentes na obra do autor.

Contudo, é preciso deixar claro que a atitude do enunciador apenas reproduz o relacionamento entre linguagem e realidade observado no mundo do enunciador, que, ao reproduzi-lo, apenas transpõe para uma chave, digamos, artística, algo que ocorria diariamente em cada esquina. Tome-se o exemplo da escravidão, já discutido. $O$ escravo estava presente em toda a sociedade brasileira, fazendo parte do cotidiano dos brasileiros. De acordo com Nabuco (1981:95), um só exemplar, ao acaso, de qualquer dos grandes órgãos de imprensa bastaria para conservar para sempre as feições e os caracteres da escravidão. No entanto, apesar disso, a escravidão fora quase totalmente banida das leis nacionais, da mesma forma que estava excluída das preocupações do Conselheiro e seu grupo, que parecem morar em outro país. Mas não são apenas eles, pois a Constituição do Império vigente na época sequer mencionava a palavra escravo e quem a lesse jamais suporia que o país que ela constituía era escravocrata. Examinem-se, como exemplo, alguns artigos da Constituição Política do Império do Brasil, de 25 de março de 1824:

\section{Título II}

\section{DOS CIDADÃOS BRASILEIROS}

$[\ldots]$

Art. $6 .^{\circ}-$ São cidadãos brasileiros:

$\left.1 .^{\circ}\right)$ Os que no Brasil tiverem nascido, quer sejam ingênuos ou libertos ainda que o pai seja estrangeiro, uma vez que este não resida por serviço de sua nação. (Barreto, 1971, p. 6) 


\section{TíTULO VIII}

\section{DAS DISPOSIÇÕES GERAIS E GARANTIAS DOS DIREITOS CIVIS, E POLÍTICOS DOS CIDADÃOS BRASILEIROS.}

Art. 179 - A inviolabilidade dos direitos civis e políticos dos cidadãos brasileiros, que têm por base a liberdade, a segurança individual e a propriedade, é garantida pela Constituição do Império, pela maneira seguinte:

$[\ldots]$

10) À exceção de flagrante delito, a prisão não pode ser executada senão por ordem escrita da autoridade legítima. Se esta for arbitrária, o juiz que a deu e quem a tiver requerido serão punidos, com as penas que a lei determinar.

$[\ldots]$

13) A lei será igual para todos, quer proteja, quer castiga, e recompensará em proporção dos merecimentos de cada um

$[\ldots]$

18) Organizar-se à quanto antes um código civil e criminal, fundado nas sólidas bases da justiça e equidade.

19) Desde já ficam abolidos açoites, a tortura, a marca de ferro quente, e todas as mais penas cruéis. (idem, p.41-42 - grifos meus)

O Art. 6. ${ }^{\circ}$, habilmente, não explica quem não é cidadão. Assim, supõe-se, erroneamente, que para sê-lo basta ter nascido em solo brasileiro, de pais que não estavam a serviço de outra nação. A lei de 07 de novembro de 1831, que declarava que todos os escravos que entrassem no território brasileiro a partir daquela data seriam livres, juntamente com o termo ingênuo, referindo-se a escravos alforriados, contribui para o entendimento de que, na pior das hipóteses, houvera, no passado,escravos nesse país, e que esses já teriam sido libertados, e gozando de plena cidadania. Segundo a Constituição, os direitos civis baseiam-se na liberdade, na segurança individual e na propriedade (nessa ordem); não podem ocorrer prisões arbitrárias; a lei é igual para todos; açoites e torturas são abolidos. Uma vez que não há qualquer restrição, supõe-se (mais uma vez erroneamente) que tais dispositivos aplicam-se a todos os indivíduos, e não apenas aos cidadãos brasileiros; portanto, nenhuma das práticas da escravidão poderia ser tolerada, mesmo se a vítima não fosse um brasileiro. Mais espantoso é o fato de que o código civil, citado no inciso 18 , tenha sido elaborado trinta anos depois sem que fosse sequer mencionada a questão da escravidão. A justificativa do autor, registrada por Nabuco, merece ser conhecida:

“Cumpre advertir, dizia o autor da Consolidação, que não há um só lugar no nosso texto [o código civil], onde se trate de escravos. Temos, é verdade, a escravidão entre nós; mas se esse mal é uma exceção que lamentamos, condenada a extinguir-se em época mais ou menos remota, façamos também uma exceção, um capítulo avulso na reforma das nossas Leis civis; não as maculemos com disposições vergonhosas, que não podem servir para a posteridade; fique o estado de liberdade sem o seu correlativo odioso. As leis concernentes à escravidão (que não são muitas) 
serão pois classificadas à parte, e formarão nosso Código Negro.” (Nabuco, 1988: 97 - grifos meus)

Seria engraçado, se não fosse sério. A escravidão é uma exceção que vigora de norte a sul do país, estava estampada em qualquer atividade produtiva (e mesmo fora dela) e era tão lamentada que ainda se passariam outros 33 anos para que fosse extinta. Veja que o texto mostra a absoluta independência entre uma realidade objetiva - a participação da escravidão em todas as esferas nacionais - e os textos legais que deveriam regulamentar a mesma realidade. Teixeira de Freitas teme macular as leis civis, com disposições vergonhosas, como se a realidade, em tese muito mais real que os textos legais, já não estivesse imunda pelas práticas igualmente vergonhosas. Mais: propõe que fique o estado de liberdade sem o seu correlativo odioso, como se a supressão de dispositivos relativos a escravidão fizesse com que passasse a vigorar um estado de liberdade.

Nesse mundo, em que o texto e a realidade a que ele se refere não guardam correspondência, nem mesmo no Direito; em que a escravidão, base sobre a qual se articula toda a economia do país e todas as relações sociais, sequer é mencionada na Constituição e nos principais dispositivos legais; a atitude de Aires é mais do que esperada, é natural. Por esses motivos, Aires pode dizer tranquilamente a Santos, como se fosse a coisa mais corriqueira do mundo, que, com a Proclamação da República, nada mudaria no país, exceto a constituição. Explica-se, desse modo, porque o país escravocrata de constituição liberal pôde tranqüilamente conceber um defunto-autor e porque o fato de M. de A. assinar a advertência não quer dizer nada. A denúncia desse estado de coisas não poderia ser feita senão de forma "involuntária”, como parece suceder quando Aires finge não se dar conta do quão irreal é o mundo descrito por ele no diário, ou quando Teixeira de Freitas explica porque excluíra do Código Civil os dispositivos relativos à escravidão e assim acaba por delatar o que pretendia ocultar. Ambos terminam por revelar um mundo em que as relações são apenas um simulacro, e a linguagem é usada como vassoura que varre tudo para debaixo do tapete. Aires e seus amigos representam, portanto, uma rara oportunidade de flagrar a varredura em funcionamento.

As análises apresentadas ao longo deste capítulo parecem, portanto, confirmar que o contrato em questão não prevê a entrega de um objeto que imite a realidade nem que expresse uma individualidade, mas a discussão do processo de construção de simulacros da realidade, mostrando linguagem em funcionamento; ou seja, o processo de construção do 
sentido, portanto de realidades e indivíduos. Muito mais do que um gosto metalingüístico, ou um exercício de virtuosismo, esse fazer revela um enunciador tremendamente cético e coerente. Seu ceticismo não decorre de uma visão pessimista da realidade, que a nega e prega mudanças, mas de algo mais visceral, que nega a própria apreensão da realidade, pois ela sempre será parcial, fruto do olhar de um indivíduo sobre o mundo, ele próprio já comprometido pela linguagem. Em tais condições, uma proposta de reforma do mundo ou das instituições já nasceria viciada. Daí a opção pela destruição pura simples, ou melhor, pela desconstrução, realizada com força, mas com delicadeza. Daí também a coerência de instalar um narrador que, romance após romance, mostra o que mantém o homem vivo, quais são os valores vigentes, o que realmente interessa. Sem desconsiderar, ao mesmo tempo, a instalação de um outro narrador, em outro nível, que mostra que esse discurso, entre mil aspas, de denúncia, é mostrado como uma narrativa: não é sério; é simples urdidura ou, se preferirmos, não é a realidade, mas um discurso sobre a realidade; pode ser correto, mas não pode ser. Aí está a coerência do enunciador e, do ponto de vista deste trabalho, o ceticismo entranhado do narrador desencadeia toda uma série de procedimentos que se tem visto. 
ncerrada a análise das cinco variáveis eleitas para este estudo, é preciso reuni-las e
verificar o que elas têm a dizer do ethos do enunciador. É isso que será feito ao longo do presente capítulo. Ao final, em um quadro sintético, são apresentadas as principais conclusões obtidas durante a análise de cada uma das variáveis estudadas ${ }^{158}$.

No capítulo dedicado às configurações narrativas, viu-se que o enunciador instaura um narrador que instala um sujeito, figurativizado em um homem ou mulher jovem, que busca adquirir um objeto de valor descritivo, o prestigio ou a ascensão social. Viu-se que a busca se dá, em termos topológicos, no Rio de Janeiro e, em termos cronológicos, na segunda metade do século XIX. Nas mais das vezes, o papel de destinador manipulador é exercido pela família (via casamento ou herança) e o de destinador judicador, do qual o narrador é fiel proposto, pela sociedade. Aprofundando um pouco mais a análise, concluiu-se que, no nível fundamental, estava jogo uma categoria também topológica, definida como superioridade $\mathrm{x}$ inferioridade. Em todos os casos, na perspectiva do narrador, a dêixis eufórica era a superioridade / proeminência e a disfórica, inferioridade / mediocridade. Naturalmente, a sintaxe fundamental variava de acordo com o romance havendo aqueles, como Ressurreição e Memórias Póstumas, em que o movimento é descendente: o sujeito sai da mediocridade e chega à inferioridade. Em outros, como em A mão e a Luva e Esaú e Jacó, o movimento é ascendente. Finalmente, há o caso de Quincas Borba, em que se observam vários percursos realizados ao mesmo tempo, como ascensão do casal Palha e a ascensão e queda de Rubião.

Abordando a mesma questão por outro ângulo, concluiu-se que não há lugar, em nenhum dos nove romances de Machado de Assis, para o devaneio ou para ideais, mas apenas, e tão somente, para o cálculo e o interesse. Não é um mundo de poetas, mas de estrategistas, e talvez um bom representante da gente Assis seja Guiomar, caracterizada pela fria eleição do espírito, a qual rege não apenas ela, mas a maior parte dos heróis machadianos,

${ }^{158}$ Como ficou dito no início deste trabalho, as análises das cinco variáveis se recobrem em grande medida. Se, por um lado, isso pode tornar a leitura maçante, por outro, é útil para mostrar que determinada conclusão é confirmada por mais de uma variável. 
todos heróis sem nenhum (ou muito pouco) caráter e, por isso mesmo, vitoriosos, se é que cabe o adjetivo. O narrador de $A$ mão e a luva conta que a heroína amava as flores, queria-as belas e viçosas, mas em vaso de Sèvres. Quer dizer, não se trata de alguém sem sentimentos, mas de alguém que os mantém sob controle. Uma consulta ao dicionário de Houaiss indicará que sentimento é a disposição emocional complexa da pessoa, predominantemente inata e afetiva, com referência a um dado objeto, e que controle é $o$ ato [...] de exercer poder, autoridade (sobre algo ou alguém), manter sobre dominio próprio, dominar. Supondo ainda que o sentimento — ou disposição emocional com referência a algo ou alguém — implique, em maior ou menor grau, determinado querer, pode-se concluir que controlar sentimentos significa, em termos modais, estar investido de um poder-não-querer. É exatamente o caso de Guiomar, que ama as flores, mas domina seu querer na medida em que pode não querê-las, caso isso signifique buscá-las em sítios agrestes. É também a situação de Estela, que ama Jorge, porém coloca esse sentimento em segundo plano, tendo em vista sua condição social. Também Sofia é freqüentada por desejos vários, mas sabe subordiná-los a seus objetivos últimos (ou primeiros). Não é diferente o comportamento do casal Fidélia e Tristão, que amam os velhos pais de estimação, porém, não o suficiente para trocá-los pelo prestígio na ex-metrópole. Por outro lado, Estevão, Brás Cubas, Rubião o casal Aguiar são incapazes de subjugar seus sentimentos ou de não subordiná-los a interesses de ordem mais prática, e, por isso, são sancionados negativamente: o primeiro é enviado para um exílio em solo pátrio; os dois intermediários, Brás e Rubião, para a campa, sendo que este faz escala no sanatório; e os dois velhos acabam olhando o vazio, com saudade de si mesmos, na bonita e amarga descrição do narrador.

Ora, a insistência com que os romances discutem essa questão, valorizando — ao menos no plano do enunciado - a fria eleição do espírito e o poder-não-querer em detrimento do querer (ou, alternativamente, privilegiando o dever, pois a rejeição de um querer implica em alguma medida a subordinação a um dever) contribui para que o enunciador apresente um ethos de alguém mais afeito a equações que a fábulas, alguém não desprovido de emoções e de paixões, mas capaz de colocá-las nos seus devidos lugares. E, de fato, salvo a de Rubião, que dispensa comentários e é, antes de mais nada, resultado de seu estado mental, não há paixões desenfreadas nesses romances, apenas aquelas devidamente subordinadas a interesses muito bem definidos. Chegou-se assim à primeira definição do ethos do enunciador: o de alguém frio, objetivo, que não acredita em romances. Se há alguma novidade nessa conclusão, ela talvez decorra do caminho percorrido para obtê-la e do fato de 
ela caracterizar a obra do enunciador como um todo sem dar margens a qualquer distinção e, desse modo, acabar por caracterizar o ator da enunciação. Não custa repetir: quando se diz que o enunciador é frio, calculista, não se pretende, de forma alguma, fazer qualquer inferência sobre a personalidade de Joaquim Maria — que não é, nem de longe, objeto deste estudo -, mas mostrar que o conjunto da obra do ator da enunciação Machado de Assis constrói a imagem, o ethos, de seu enunciador como alguém que tem essas características. Observe-se ainda que alguns dos primeiros críticos de Machado, seus contemporâneos, apontavam para um fato semelhante, mas aí, nas mais das vezes, atribuindo-o a Joaquim Maria ${ }^{159}$. Por exemplo, ao comentar Ressurreição, romance de estréia de Machado, Carlos Ferreira, em artigo do Correio do Brazil, de 15.05.1872 afirma que o escritor trabalha mais com a inteligência do que com o coração e que as paixões violentas parecem-lhe frouxamente descritas. Já a respeito de $A$ mão e a lwva, um crítico que assina Araucarius comenta nO Novo mundo, de Nova Iorque, em 22.2.1875, que em Machado fracos são os caracteres, a urdidura despida de interesse comovente, a ação fria [...] Na mesma linha, Urbano Duarte, da revista Phenix Litterária, sugere a Machado, a propósito de Iaiá Garcia, que apimente um pouco mais o bico de sua pena afim de que seus romances não morram linfáticos. José Veríssimo, como sempre, destoa da crítica modorrenta de seu tempo, que tanto desgosto deve ter trazido ao escritor. Ao comentar o surgimento de Dom Casmurro, o crítico aponta com maestria as mesmas características observadas por esta análise, tendo o cuidado de não atribuí-la ao cidadão Machado de Assis, mas à imagem construída no discurso. Vale a pena ler um trecho um pouco maior:

Na obra do Sr. Machado de Assis, a emoção é por via de regra, não sei se não poderia dizer sempre, de ordem intelectual. Falece-lhe ou esconde-a ciosamente - e, talvez, seja esta a hipótese verdadeira - a emoção sentimental. Advirto que não quero fazer a psicologia do senhor Machado de Assis; e os meus conceitos, certos ou falsos, do escritor derivam-se apenas do estudo da sua obra. É notável que vindo do romantismo, nada lhe haja ficado do seu sentimentalismo romântico, e que ao contrário, toda a sentimentalidade, talvez com horror da pieguice em que ela descambou finalmente naquela escola, lhe repugne. In Guimarães, Hélio. Os leitores de Machado de Assis, p. 410 - grifos meus.

Veríssimo tem o cuidado de explicitar que não se interessa pela psicologia do senhor Machado de Assis, mas — diríamos nós, carregando um pouco nas tintas - pelo ethos do enunciador construído nesses romances, o qual se caracteriza por considerar a emoção

${ }^{159}$ Devemos as citações a seguir ao notável trabalho de Hélio de Seixas Guimarães, que em Os leitores de Machado de Assis (2005: 293-483) fez extenso levantamento das críticas recebidas pelos romances de Machado na ocasião de sua publicação. Deve-se também ao autor a identificação dos pseudônimos que assinam essas críticas. 
disfórica e a razão eufórica. Tal característica se reflete na instalação de sujeitos com objetivos bem concretos e práticos: a ascensão social ou mesmo a acumulação de capital.

$\cos \cos 20$

No capítulo dedicado à instalação do narrador, observou-se que, em todos os romances de Machado, havia um outro percurso anterior ao narrado pelo narrador: o do sujeito que constrói sua narrativa para, por meio dela, entrar em conjunção com os valores almejados. Os noves romances estão alicerçados em uma primeira debreagem enunciativa da enunciação: inicialmente, o enunciador instala um eu no enunciado que narra suas peripécias para construir a narrativa, a qual contém o percurso realizado de formas diferenciadas por um sujeito em busca de ascensão social. Viu-se que não há na obra romanesca de Machado a chamada narrativa em terceira pessoa, pois, mesmo o narrador de Iaiá Garcia, o mais discreto de todos, não deixa de intervir na narrativa, chamando atenção para si e, principalmente, para o seu fazer, discutindo-o profundamente, mostrando as alegrias e tristezas de seu fazer. No tocante ao narrador, a única variação observada ao longo de todos os romances decorre do fato de que em Memórias Póstumas, Dom Casmurro, Esaú e Jacó e Memorial de Aires, ele está sincretizado com um actante do enunciado e nos demais não. Em todos os nove romances, porém, o narrador é mostrado como sujeito que executa um percurso narrativo bastante específico: a construção de um objeto no qual investe os valores desejados. Naturalmente, a ênfase não é a mesma em todos as obras: em um extremo poder-se-ia situar Iaiá Garcia e Helena, e, no outro, Memorial de Aires, romance em que Aires não tem outro papel que o de escrevente de suas memórias.

Em um primeiro momento, pode-se pensar que tal percurso estaria muito distante do referente à aquisição de prestígio social, e que a conciliação de ambos seria impossível, resultando em uma fraca coerência desses romances. É uma idéia equivocada por vários motivos e uma nova consulta ao dicionário, mais precisamente ao verbete prestígio, contribuirá para ver que as coisas não são tão díspares quanto parecem à primeira vista:

Prestígio (substantivo masculino)

1 ilusão dos sentidos, produzida por artifícios ou artes mágicas; prestidigitação.

2 [...]

3 grande influência exercida por pessoa ou coisa sobre outra(s) pessoa(s)

$4 \quad[\ldots]$

$5 \quad[\ldots]$ 
6 valor sociocultural positivo atribuído a uma coisa, a um indivíduo ou a um grupo, que faz com que estes se imponham aos demais, os quais adotam uma atitude de subordinação.

Comentou-se à saciedade que em todos os romances de Machado, sem exceção, os actantes instalados no enunciado estavam em busca do prestígio social (tal como o substantivo é definido por Houaiss no item 6 acima), pois todos procuravam por um valor sociocultural (dinheiro, casamento, fama, carreira...) que lhes permitisse se impor aos demais ou, ao menos, deixar de estar subordinados a eles. Contudo, observe-se que prestígio também se refere (e é sua primeira acepção) à ilusão dos sentidos, produzida por artifícios, e que o dicionário francês Le Petit Robert acrescenta que prestígio, em francês (e a definição vale para o português), é o fato que causa grande impacto na imaginação, que seduz, que causa admiração. Ora, todos os narradores machadianos mostram-se empenhados, ainda que muitas vezes de forma pouco hábil, em seduzir o narratário, iludindo-lhe os sentidos, causando admiração, assombro, e mostrando-se preocupados em exibir sua arte aos seus leitores e, assim, cativá-los. Alguns o fazem com mais habilidade, como o narrador de Helena ou o Aires de Memorial de Aires, outros com menos, como Brás Cubas, mas todos buscam tal efeito. Nunca é demais repetir que a bisonhice do narrador é proposital, fruto de uma decisão do enunciador. Atente-se agora para a terceira acepção do dicionário de Houaiss, que define prestígio como influência exercida por uma pessoa ou coisa sobre outra pessoa, portanto uma situação na qual um sujeito S1 procura atingir uma condição tal que ele passe a transferir seus valores modais a outro sujeito S2, transferência que não é outra coisa senão a própria influência. Em outras palavras, S1 procura obter condições para que se possa impor como destinador de S2. Nos romances de Machado, os papéis de S1 e S2 são desempenhados tanto por actantes do enunciado (como Guiomar em relação a Luís Alves, Tristão em relação a Aires etc.) quanto por atores da enunciação enunciada, isto é, o narrador em relação ao narratário. Nos dois casos, está em jogo a obtenção de prestígio, tendo em vista os valores nos quais tal prestígio é figurativizado: em um caso, bens materiais; noutro, a própria narrativa.

Todavia, a análise da instauração do narrador trouxe outras lições, talvez mais interessantes. Inicialmente, viu-se que o enunciador parecia distante, apagado, frágil, uma vez que o narrador usurpava-lhe a posição e buscava causar a ilusão de que era ele o próprio o autor do livro. A esse respeito, recordem-se os comentários de Bento Santiago sobre a impressão do livro e a numeração das páginas. No entanto, como se sabe, o narrador e o enunciador não se confundem e têm seus papéis muito bem demarcados, sendo a aparente 
fraqueza e distância do segundo, indícios não apenas de sua força e habilidade, mas também de seu jeito dissimulado, como o de alguém que age nos bastidores, que fala nas entrelinhas. É um agir todo especial, que busca a todo instante subverter as regras da linguagem, não só quando o enunciador se oculta atrás do narrador para se passar por enunciador, mas também quando procura instalar actantes de um nível em outro, como ele fez, por exemplo, com Sancha em Dom Casmurro. Nos dois casos, trata-se de um sujeito que procura disfarçar a ordem das coisas ou ao menos embaralhá-las. Por aí se observa outra simetria curiosa: enquanto, no nível do enunciado, atores como Helena ou Sofia dissimulam seus sentimentos ou sua identidade, no nível da enunciação, o enunciador procura subverter as leis da linguagem, como faz em Ressurreição ou no Memorial de Aires, e também dissimular sua identidade. Se os narradores são dissimulados, o enunciador não é outra coisa, mostrando que a dissimulação não é uma característica incidental nos romances machadianos, mas um elemento estruturador da trama e da relação entre o narrador e o narratário. Nova consulta aos dicionários, no verbete dissimular, talvez permita ver em mais detalhes o que significa esse adjetivo. Para o Houaiss, ser dissimulado é:

esconder os próprios sentimentos, intenções, desejos etc.

ocultar, disfarçar (idade, erro, defeito etc.)

suavizar o resultado de (algo)

aparentar o contrário do que de fato ocorre; fingir, simular

agir com dissimulação, com reserva, com discrição

colocar(-se) de modo que não seja visto; ocultar(-se), esconder(-se)

e para o Aurélio é

1. Ocultar ou encobrir com astúcia; disfarçar:

2. Não dar a perceber; calar:

3. Fingir, simular:

4. Atenuar o efeito de; tornar pouco sensível ou notável.

Apesar das nuanças de cada uma das acepções acima, é possível depreender em todas uma mesma pequena seqüência narrativa, na qual um sujeito S1 coloca um sujeito S2 em disjunção com um objeto de saber concernente à conjunção de S3 (sincretizado com S1) com determinado(s) saber(es). Em outras palavras, um sujeito esconde de outro alguma informação relativa a si próprio, visando à execução de um outro programa narrativo de base. Esquematizando, temos: 


\section{$\mathrm{S} 1 \rightarrow \mathrm{S} 2 \cap \mathrm{O} 1(\mathrm{~S} 3 \cup \mathrm{O} 2)$}

Onde:

$\mathrm{S} 1$ = sujeito do fazer dissimulador

$\mathrm{S} 2$ = sujeito que sofre a dissimulação

$\mathrm{O} 1$ = saber que S1 oculta de S2

S3 = sujeito, cuja identidade modal deve ser mantida em segredo, nas mais das vezes, sincretizado com S1

$\mathrm{O} 2$ = identidade modal de S3

Examine-se a seqüência acima por meio de alguns exemplos. Brás Cubas (S1) oculta de Eugênia (S2) suas reais intenções (O1): portanto, a coloca em disjunção sobre sua própria (isto é, de Brás Cubas, agora S3) conjunção com determinadas modalidades (o objeto de saber - O2): querer enganá-la. Outro exemplo é o de Capitu, na passagem em que o pai a surpreende e a Bentinho desenhando seus nomes em um muro. Segundo o narrador, Capitu dissimulara com maestria tanto o ato que praticavam quando o que sentiam, portanto, Capitu (S1) coloca Pádua (S2) em disjunção com um determinado saber relativo a ela própria (S3). Um último exemplo é o de Aires, que, ao ser convidado por Tristão para ser seu padrinho de casamento, dissimula seu enfado. Examinem-se agora as definições do Aurélio para dissimulado. Lá, pode-se ver que dissimular é encobrir com astúcia; portanto, a dissimulação demanda alguma competência específica, ainda que com variações. O mesmo dicionário acrescenta ainda que dissimular pode ser simplesmente tornar pouco sensível ou notável, características que, certamente, não se aplicam a Brás Cubas, mas que, como veremos daqui a instantes, aplicam-se bem ao enunciador. Ao apresentar o narrador como enunciador, esse enunciador (S1) oculta do enunciatário (S2) sua própria identidade (O1). A dissimulação não se limita à identidade dos actantes e abrange também as idéias defendidas por um e por outro, como acontece quando, além de fazer o narrador se passar por enunciador, o enunciador coloca na boca de seu delegado idéias opostas às que ele realmente defende (O2). Em todos os casos, ele oculta do enunciatário seus pensamentos, ou mesmo sua real identidade, portanto, dissimula.

Por outro lado, a relação entre narrador e narratário parece ser exatamente oposta à existente entre enunciador e enunciatário: o primeiro procura mostrar-se sempre extremamente sincero para com o segundo, aliás, uma sinceridade tal que, não raro, beira à 
indelicadeza. Recorde-se brevemente o que diz Antônio Houaiss a respeito do adjetivo sincero

1. que se exprime sem artifício nem intenção de enganar ou de disfarçar o seu pensamento ou sentimento.

2. que é dito ou feito de modo franco, isento de dissimulação.

E também a explicação do dicionário francês Le Petit Robert

1. é aquele que está disposto a reconhecer a verdade e a tornar conhecido o que pensa e sente realmente, sem consentir a enganar-se a si próprio nem aos outros.

Como se vê, o sincero e o dissimulado são simetricamente opostos, mas têm mais em comum do que se pode imaginar em um primeiro momento. Nos dois casos está em jogo um saber relativo aos pensamentos ou sentimentos daquele que enuncia; a diferença é que o dissimulado oculta esse saber do enunciatário, enquanto o sincero o revela voluntariamente. Em tese, é isso que Bentinho faz quando chama o narratário de leitor das minhas entranhas e diz que lhe conta absolutamente tudo. É também o que faz Brás Cubas, que afirmava que não recuaria diante de nada, ou ainda de Aires, que dizia fazer do papel um confessionário. Todos buscam atestar a própria sinceridade por meio da revelação de um saber que lhes seria inconveniente. O raciocínio é simples: ao revelarem fatos constrangedores sobre si próprios, estariam atestando sua própria sinceridade e, desse modo, fariam com que o narratário acreditasse nas histórias que contam. No entanto, como se sabe, essa sinceridade é questionável, na medida em que a instância da enunciação se encarrega de espalhar aqui e ali indícios de que o narrador não é assim tão sincero quanto parece. Para ficar no caso mais óbvio, basta pensar que o narrador não é quem diz ser, logo não tem os problemas que afirma ter, como os de composição ou de impressão do livro. Sob essa ótica, a sinceridade do narrador se transforma em cinismo. E cinismo nos dois sentidos que lhe dá o Houaiss: enquanto substantivo, na medida em que o texto é uma afronta ostensiva às convenções $e$ conveniências morais e sócias; e enquanto adjetivo, como fingimento, descaramento.

O cinismo contamina o enunciador, se for lembrado que o narrador nada mais é que um preposto seu. Além disso, o cinismo e a dissimulação não advêm apenas das posições morais assumidas, mas também, talvez principalmente, do fato de o enunciador propor descaradamente aquilo que não é verdade. É o que acontece quando Aires afirma que não vale a pena ver o cenário da peça, pois ele não passaria de lona velha e, ao final, afirma que se expressa por metáfora, pois tudo o que diz é a verdade pura sem fingimento. Ora, nada é verdade e tudo é fingimento, a começar pelo próprio Aires. Se o enunciador nega o óbvio, 
não há outro modo de caracterizá-lo: ora é dissimulado, ora é cínico, atributo que, como se verá na conclusão, é de grande importância para este trabalho.

$\cos \cos 2 \cos 20$

A discussão acerca da delegação do saber revelou a necessidade de considerar tal delegação em dois planos: o do narrado, que concerne aos programas narrativos executados pelos actantes do enunciado, e o da narração, que diz respeito aos actantes da enunciação enunciada, o narrador e o narratário. Embora o saber do enunciador seja sempre superior ao do narrador, uma vez que este é instalado por aquele, a superioridade, em alguns casos, é explicitada. Isso ocorre quando o narrador age sem discernimento, como na ocasião em que Brás Cubas ignora as reais intenções de Sabina ou Marcela, ou mesmo quando Aires se equivoca a respeito de Tristão e Fidélia - e isso apesar de ser alertado por outro actante, D. Cesárea. Viu-se também que, apesar de os narradores de Quincas Borba e Esaú e Jacó serem oniscientes, fica patente que seu saber é inferior ao do enunciador, pois há pontos cegos em sua narrativa, aspectos que não conseguem captar ou questões que são incapazes de deslindar. Nos quatro primeiros romances não há nada disso, pois o efeito de sentido causado é o de que o saber do narrador equivale ao do enunciador. Por essa razão, esse poderia ser um critério a ser utilizado para justificar a divisão da obra de Machado em duas fases. Contudo, proceder desse modo seria desprezar os outros aspectos analisados, os quais apontam justamente para uma unidade admirável. Por exemplo, se for enfocada a delegação do saber no tocante à narração, o quadro é completamente outro: em sete dos nove romances, o enunciador explicita que sabe mais sobre a narração que o narrador, como fica evidente nas vezes em que pressupõe um narratário que nada tem em comum com o enunciatário. Agora, os únicos romances que destoam são Iaiá Garcia e, em menor grau, Helena. O quadro também é diferente quando se compara o saber do narrador em relação ao dos actantes do enunciado. Nesse caso, quem destoa do grupo é Memórias Póstumas, Dom Casmurro e Memorial de Aires, que apresentam narradores cujo saber sobre o narrado é igual ou inferior ao dos actantes do enunciado.

No mesmo capítulo observou-se que o foco e a apreensão que o narrador tem da realidade apresentam, em linhas gerais, um movimento de atonia crescente entre Ressurreição e Memorial de Aires, fato que reflete o esvaziamento de seu saber. Seguindo uma linha 
descendente, a cada romance aumentam os pontos cegos, o narrador sabe menos, engana-se com mais freqüência, faz julgamentos mais equivocados. Registre-se, porém, que tal movimento não coincide com uma ordem cronológica, pois a apreensão e o foco que Aires de Esaú e Jacó tem da realidade são maiores que, por exemplo, os de Brás Cubas. Conforme foi discutido, quanto mais se reduzem os procedimentos de triagem do saber, menos o narrador pode ser peremptório acerca do que narra, e os valores do universo passam a predominar, multiplicando-se, com eles, os pontos de vista. Surge daí uma visão embaralhada da realidade que não permite ao sujeito afirmar claramente a identidade de nada. Tudo pode ser de um jeito, mas pode ser de outro. Tristão pode ser um arrivista, mas pode não ser; Capitu pode ter traído... ou não.

Claro, esse movimento não alcança o enunciador, que sempre demonstra uma percepção arguta da realidade e uma habilidade manifestada, justamente, pela instauração de um narrador incompetente, não só para conduzir uma narrativa (afinal, o narrador de Quincas Borba sequer sabe como nomear seus capítulos), mas também para defender seus pontos de vista (como Bentinho, que comete a extravagância de narrar a paixão de Capitu por Escobar logo depois de assediar sua deste, Sancha) e para avaliar corretamente os personagens que compõem o seu drama, como acontece com Aires. A esse respeito vale recordar que os heróis-sem-nenhum-caráter que povoam o mundo machadiano apresentam as mesmas características, do primeiro ao último romance e que é o narrador quem sofre uma transformação radical, ao tornar-se mais e mais canhestro. É ele que faz Brás Cubas parecer tão inferior a Jorge, quando, na verdade, talvez sejam farinha do mesmo saco. Nesse momento, o que é eufórico no plano do enunciado, como o percurso de ascensão social executado por vários actantes, torna-se disfórico no plano da enunciação enunciada. Ou melhor, o que é disforizado é o olhar positivo que o narrador lança sobre esse fazer. A sanção positiva que o narrador lança sobre o fazer dos actantes do enunciado se torna disfórica quando se atenta para a estatura moral do narrador. A discordância do enunciador em relação ao seu delegado não é explícita, mas, discreta, sutil, na verdade, dissimulada, para lembrar os termos do item anterior. Talvez, nesse aspecto, a única exceção dentre os romances seja, justamente, Memórias Póstumas em que a oposição entre enunciador e narrador é evidente.

Viu-se também que a defasagem entre os saberes do enunciador e do narrador implica a instalação de vários actantes cognitivos que transmitem outros pontos de vista sobre o narrado. No nível discursivo, esses múltiplos actantes cognitivos dão origem a 
diversas vozes, que mostram a realidade sob diferentes perspectivas, nenhuma delas forte o suficiente para prevalecer sobre as demais. Recorde-se o caso de Bento Santiago. É impossível saber se ele é ingênuo ou maquiavélico, pois há elementos no texto que corroboram tanto uma hipótese quanto a outra. O processo torna-se ainda mais complexo na medida em que não há apenas observadores que observam o fazer dos actantes no enunciado; há também observadores que observam o fazer do narrador na construção do texto e o transmitem como uma segunda voz abafada, ou, se preferirmos, como uma presença potencial. Instalados em um nível hierárquico acima do narrador - ao menos, acima do narrador segundo, que conduz os romances —, esses observadores seriam portadores do ponto de vista da instância da enunciação acerca do fazer do próprio narrador e aí se observa, novamente, a defasagem entre o saber do enunciador e o saber do narrador no tocante à narração. Aquele sabe exatamente para quem enuncia, enquanto o segundo ilude-se supondo um narratário que nada tem que ver com o enunciatário. O fato é que em todos os romances surge um princípio que, conforme explica Bakhtin ${ }^{160}$, estava presente no riso da Idade Média: a existência de duas verdades; uma oficial, séria, e outra popular, cômica; dois pontos de vista: o do narrador e o do enunciador, um o avesso do outro. Nada fica incólume sob a pena do enunciador, que zomba de tudo e de todos. Surge, desse modo, o riso que escarnece do comportamento sério de tudo, como pode ser visto no olhar que Aires lança sobre a Proclamação da República e outros eventos que se seguiram. Naturalmente, o riso em Machado é muito diferente, corrosivo, amargo, mas, ainda assim, é riso e guarda um parentesco indelével com o riso da idade média: seu caráter libertador, seu poder de relativizar tudo, pois sempre há uma outra versão sobre o mesmo fato, uma outra verdade. Veja que não é mera coincidência o fato de que, à medida que aumenta polifonia dos romances de Machado, cresce, com ela, o riso.

O menor saber do narrador, responsável por sua pouca habilidade, aliado à profusão de actantes cognitivos instalados pelo enunciador, é responsável pela polifonia que brota das páginas dos romances de Machado e dá vazão à sátira, à corrosão que primeiro desgasta o próprio narrador e os seus valores e, em seguida, todo o seu mundo, atingindo mesmo a literatura. E daí se observa o quanto o enunciador é irreverente, zombeteiro; vê-se que, para

\footnotetext{
${ }^{160}$ Para uma breve e muito interessante discussão a respeito do riso, ver $A$ cultura popular na Idade Média e no Renascimento, especialmente o capítulo primeiro, Rabelais e a história do riso. Bakhtin, Mikhail. São Paulo: Hicitec,1999, p. 125-70.
} 
ele, não há nada que seja sagrado, que ele não poupa ninguém. Inicialmente, havia-se concluído que o enunciador era frio, objetivo, pouco afeito a devaneios. Depois, que era dissimulado, cínico. Chega-se, agora, pelo riso, a novos componentes desse ethos; trata-se de alguém mordaz, que o é em dois dos sentidos que o dicionário dá para o adjetivo: o de alguém que agride ou corrói; cáustico, corrosivo, sarcástico e que é excessivamente rigoroso no modo de criticar ou enxergar as coisas. Observe-se, ainda, que sendo o rigor, segundo o mesmo dicionário, um fenômeno de grande intensidade, conclui-se, usando a metalinguagem da semiótica tensiva, que o mordaz é aquele que apresenta um foco excessivamente intenso, justamente uma das principais características desse enunciador e que o opõe ao narrador, possuídos, conforme foi visto, de um foco átono. O enunciador é também irreverente e zombeteiro na medida em que menospreza, ridiculariza tudo e todos, a começar pela morte e por qualquer drama humano, passando por tudo que possa ser sério, como a política e as instituições até chegar à literatura. ${ }^{161}$

$\cos \cos 2 \cos 20$

Quando se discutiu a questão dos níveis discursivos, verificou-se um constante conflito entre o enunciador e o narrador, que não apenas confirmou a dissimulação do primeiro, mas também revelou uma outra faceta sua: a de um indivíduo não autoritário, que não impõe seus pontos de vista, mas respeita posicionamentos opostos ao seu, se é que ele tem algum. Trata-se de alguém que privilegia o contraditório, a polêmica, já que se vale da polifonia para instaurar o debate em todos os seus romances.

Além disso, o conteúdo das advertências revelou uma reflexão do enunciador sobre seu próprio fazer. Como se viu, as advertências funcionam como prólogo, sim, mas não ao drama encenado — as histórias de Félix, Guiomar, Helena, Bentinho, Rubião, Aires etc. —, e sim ao drama do narrador, mostrado como sujeito cujo percurso narrativo consiste em construir sua narrativa - fato, no mais, percebido quando os comentários sobre o narrar adquirem tanta importância quanto o narrado. As advertências explicitaram diversos aspectos desse fazer, tais como: a preocupação com a recepção do romance, a dúvida quanto ao

\footnotetext{
${ }^{161}$ Infelizmente, não há mais espaço neste trabalho para uma discussão sobre o riso na obra de Machado. Todavia, um breve comentário acerca das crônicas pode ser encontrado em Estratégias e máscaras de um fingidor: a crônica de Machado de Assis. Cruz, Dilson Ferreira da. São Paulo: Nakin / Humanitas, 2002, p. 16892.
} 
tratamento mais adequado a ser dado às histórias narradas, a oposição entre um romance de costumes e um romance repleto de peripécias, a reação do leitor, e várias outras questões que são retomadas ao longo dos romances mediante a instauração do narratário e o embaralhamento das instâncias narrativas. Recorde-se agora o que ficou dito no terceiro capítulo, acerca da dupla manipulação a que se viam submetidos os escritores brasileiros. De um lado, a questão nacional; de outro, o molde francês. Na ocasião, foi dito, sem que a afirmação fosse justificada, que esse drama não era estranho a Machado. Agora, talvez se compreenda porque, na medida em que as advertências, articuladas aos comentários do narrador, exibem bem o problema. Por meio delas, e do narrador nelas instaurado, o enunciador propõe a mesma discussão: ora o narrador justifica-se por não ter feito o que a crítica considerava ser a discussão da realidade nacional - é o que acontece quando, em Ressurreição e $A$ mão e a luva, explica porque não fez um romance de costumes — , ora satiriza o molde europeu, como no prefácio de Memórias Póstumas. Conforme foi citado, Antonio Candido alertava para o fato de que, no início da literatura nacional, dois objetivos se impunham aos artistas: a representação da realidade nacional e a obediência ao modelo europeu. Na opinião do crítico, a tentativa de conciliação desses objetivos gerava quase sempre um duo desafinado, uma obra claudicante entre um propósito e outro. Agora, vê-se que, independentemente do grau de afinação dos romances nacionais, o problema não passava despercebido por Machado, que o transforma em matéria literária - e é nessa condição que a questão é trazida para o romance. O dilema vivido pelos escritores nacionais é, em certa medida, encenado pelo narrador que se vê cerceado pela leitora que lhe pede algo que não pode dar. O leitor inscrito deseja um romance que reproduza os modelos europeus — e os críticos da época não pensavam de forma diferente - enquanto o narrador, que estaria preocupado com a reprodução pura e simples da realidade nacional, em tese, muito mais sem graça que o molde importado, sempre afirma que seu fazer e sua preocupação são outros. Nasce daí um narrador que também é desajeitado, que não sabe bem como adequar a massa à forma, que hesita, que tem de justificar-se a todo instante pelas escolhas realizadas, que sente grande necessidade de ter o narratário ao pé de si... Já o enunciador não padece desses males, pois, embora ciente da pressão do molde europeu e da crítica, não se preocupa com a adequação da imitação ao objeto imitado (coisa na qual não acredita) nem com a obediência ao modelo europeu, que ele sempre satiriza. Na verdade, embora o fazer literário seja discutido em seus romances, o seu objetivo é discutir a própria questão da representação 
da realidade, daí seu diálogo com autores que apresentaram a mesma preocupação, como Montaigne, Cervantes e outros. O que está em questão não é a literatura nacional, embora, evidentemente, ela não possa ficar alheia à discussão, mas a possibilidade de uma representação "fiel" da realidade. Ao instalar um sujeito que procura construir seu texto, Machado acaba imitando o processo de imitação da realidade, prática que não estava restrita aos artistas, uma vez que envolvia toda a realidade nacional, pois, como aponta Schwarz, os modelos econômicos e políticos implantados não passavam, muitas vezes, de um simulacro precário do molde europeu. Paradoxalmente, a imitação da imitação (única alternativa para quem não crê que a realidade possa ser representada de forma objetiva) acaba se mostrando a melhor forma de captar a realidade nacional, também ela constituída quase exclusivamente de simulacros.

A importância das advertências não se resume, porém, à reflexão sobre as possibilidades de representação da realidade; elas têm papel importante ao re-situar a narrativa central, chamando a atenção do enunciatário para o fato de que ela está subordinada a uma narrativa primeira e de que entre o narrador e o enunciador estabelece-se uma oposição, ou, ao menos, um distanciamento. A importância das advertências torna-se ainda mais evidente quando se atenta para a definição que os dicionários dão para o verbo advertir:

Houaiss: atentar ou fazer atentar em; dar-se conta de; observar, reparar.

Aurélio: $\quad$ chamar a atenção para fazer com que repare.

Le Petit Robert: informar (alguém) de qualquer coisa a afim de que se tome cuidado, de que sua atenção seja despertada.

Entende-se que a função das advertências machadianas é exatamente a descrita acima: chamar a atenção do enunciatário para que ele repare em algo, para que tome cuidado com o que está em jogo. O cuidado em questão diz respeito, primeiro, à existência de dois degraus enunciativos e, em seguida, à oposição existente entre eles, a qual impede que o sentido último do texto esgote-se no narrador e obriga o enunciatário a considerar o intenso diálogo que se estabelece entre as instâncias narrativas que constituem o romance. Por meio das advertências, o enunciador executa dois movimentos: inicialmente, instaura dois níveis enunciativos em conflito; depois, chama a atenção do enunciatário para tal conflito ou, mais exatamente, para o fato de que não endossa as opiniões de seu narrador ou, ao menos, as mantém sob suspeita. É o que acontece em Ressurreição quando o narrador primeiro afirma que a obra pertence à primeira fase de sua vida literária, ou quando afirma, em $A$ mão e a luva, que 
daria outra feição ao romance se fosse escrevê-lo novamente, ou, ainda, em Helena, quando se desculpa pelo que houver de romanesco no romance. A estratégia muda em Memórias póstumas, mas, obviamente, não se pode afirmar que a enunciação endosse uma dedicatória ao primeiro verme que roeu as frias carnes do pretenso autor. Em Esaú e Jacó, o afastamento é mais discreto, porém o editor, M. de A., não faz boa propaganda da obra ao terminar sem explicar porque se decidiu por sua publicação. Chega-se agora ao Memorial de Aires e sua advertência, esta também bem pouco estimulante: nada se fala da obra e afirma-se que seu único interesse seria matar o tempo na travessia entre o Rio e Niterói. Nos dois casos, fica evidente o distanciamento entre o narrador dos romances e o sujeito das advertências. Enfim, dos sete romances que contém advertências, apenas em Quincas Borba não se observa tal distanciamento, mas, mesmo nesse caso, a narrativa é mostrada como construção linguageira, apesar de o narrador, como lhe é peculiar, jurar que tal e tal cena aconteceram exatamente como ele as descreve.

Reunindo-se agora tudo o que foi revelado pelas advertências, pode-se acrescentar mais um elemento à definição do ethos do enunciador. $\mathrm{O}$ confronto dos textos inaugurais dos romances com a trama propriamente dita revela uma polêmica mais ou menos velada. De fato, os valores ou a posição defendidos pelo narrador segundo são contestados de forma mais ou menos aberta pelo narrador primeiro. A oposição é mostrada de outras formas; no interior dos romances, por exemplo, quando o narrador assume posições absurdas. Ocorre que aí a oposição se dá pela ironia, como já se percebeu. Surge assim um enunciador contestador que instaura a polêmica bem nos termos pospostos por Bakhtin (1981), pois, como ocorre com as polêmicas veladas, o discurso do narrador primeiro é construído de maneira que, além de resguardar seu próprio sentido objetivo, ele pode atacar polemicamente o discurso do outro (o narrador) sobre o mesmo assunto e afirmação do outro sobre o mesmo objeto (Bakhtin, op.cit.: 169). Bakhtin acrescenta ainda que, na polêmica velada, ao lado do sentido objetivo do discurso (o objeto em discussão), surge outro sentido, que é voltado justamente para o discurso do outro, origem da polêmica (idem: 170). Enfim, se, na questão do saber, viu-se que o enunciador privilegiava o embate de pontos de vista antagônicos do qual ele extraia o riso; percebe-se, agora, que a polêmica acontece também mediante a instauração de pontos de vista antagônicos associados a níveis enunciativos distintos. 
O exame do contrato enunciativo implícito nos romances revelou um duplo acordo: no nível do narrado, busca-se criar um efeito de verdade ou de realidade, de que tudo o que é narrado de fato ocorreu, de que a narrativa se passa em locais freqüentados ou conhecidos pelo leitor. Por outro lado, no nível da narração, cria-se o efeito oposto, de que se trata de uma falsa narração, ou melhor, de que o sentido último da narração não é aquele explicitado no texto, pois muitas das atitudes do narrador seriam incompatíveis com quem se propõe a realizar tal tarefa. A conjugação de um efeito de verdade, em um nível, com um efeito, digamos, de falsidade, no outro, tem como resultante, em linhas gerais, a oposição entre a enunciação e o enunciado. Na essência, a oposição se dá pelo fato de que, enquanto o narrador se esforça por causar efeitos de verdade, o enunciador mostra que, por mais verossímeis que possam ser tais efeitos, eles não passam exatamente disso, de efeitos de verdade, de simulacros construídos pela linguagem, e não da verdade "de verdade", que permanece fora do alcance da linguagem. Em termos práticos, essa oposição se mostra de varias maneiras: pela instalação de um narrador impossível, como Brás Cubas ou o Aires de Esaú e Jacó; pelo comportamento pouco respeitoso do narrador para com o leitor, como em Quincas Borba; por meio de um narrador contraditório, que constantemente afirma que o narrado é ficção enquanto garante que narra a verdade pura dos fatos, como acontece em Ressurreição e $A$ mão e a luva; mediante a instalação de um narrador que emite conceitos equivocados sobre o que narra, como Aires no Memorial; pela utilização de um narrador pouco confiável, que apresenta uma versão parcial dos fatos (para dizer o menos) como Bento Santiago, ou, finalmente, pela simples instalação de um outro narrador que manifesta seu descontentamento com a forma como a narrativa é conduzida, como em Helena. Naturalmente, encontram-se vários desses procedimentos em cada um dos romances.

Atente-se agora para outra implicação que resulta da combinação dos dois processos. A narrativa relatada pelo narrador segundo, absolutamente normal e mesmo, sob certos aspectos, banal, conjugada à narração de seu processo de elaboração (tumultuado, dadas as características do enunciador) permite ao enunciador realizar um corte longitudinal do próprio fazer, e mostrar não só o resultado da superfície, a narrativa, mas também como se chegou a ele. E aí acontece algo que lembra a anedota envolvendo leis e salsichas: quando se sabe como são feitas, nunca mais se quer vê-las pela frente. O enunciador disseca a construção de efeitos de verdade e faz com que a representação tenha suas entranhas expostas; entranhas que, nesse caso, correspondem ao fato de que o uso da linguagem jamais 
implica uma postura passiva, de simples reprodução da realidade, pois ela sempre acarreta a reconstrução daquilo a que se refere, tema, aliás, recorrente nos quadros de Magritte. Contudo, ao contrário do que acontece com leis e salsichas, saber como a verdade é construída não nos afasta do texto, mas o torna mais fascinante, ainda que o preço a pagar seja uma não pequena dose de desilusão. Os recursos empregados nessa (des)construção especialmente a instalação de um narrador pouco confiável e a fusão de instâncias enunciativas - acabam por mostrar a narrativa como uma construção de linguagem e não como a adequação a um referente externo. Além disso, todos os efeitos de verdade ou de realidade construídos pelo narrador segundo são colocados a nu e exibidos como o que de fato são: efeitos, o que, por sua vez, revela que o enunciador não considera a possibilidade de uma verdade exterior ao discurso, mas que cada discurso constrói a sua própria versão dos fatos. De outro modo: a apreensão da realidade sofre necessariamente a intervenção da linguagem, que inevitavelmente deforma o mundo a que dá acesso. Daí a importância desse jogo duplo: de um lado, criar efeitos de verdade; de outro, denunciar que o leitor não lida com a "verdade", mas com estratégias concebidas com o fim explícito de fazer-crer. Conclui-se que esse enunciador não crê em sinceridade ou falsidade, categorias que ele considera ociosas ou de pouca valia, mas prefere falar em discursos mais ou menos eficazes, mais ou menos hábeis. É isso o que mostra por meio de Rubião, que constrói um discurso extremamente eficaz, apesar de não se fundar sobre a realidade. Chega-se, assim, a mais um componente do ethos desse enunciador: o ceticismo. E aí vale a pena consultar o dicionário de Houaiss a respeito do que vem a ser ceticismo:

\section{Ceticismo. Substantivo masculino}

1 Rubrica: filosofia.

Doutrina segundo a qual o espírito humano não pode atingir nenhuma certeza a respeito da verdade, o que resulta em um procedimento intelectual de dúvida permanente e na abdicação, por inata incapacidade, de uma compreensão metafísica, religiosa ou absoluta do real.

O cético não é, necessariamente, o descrente, mas aquele que não pode ter certeza acerca de nada, que abdica (o que pressupõe um ato consciente) a uma compreensão absoluta do real e duvida permanentemente, posicionamento que caracteriza uma ligação átona, tanto em termos extensivos quanto intensivos, entre ele e qualquer objeto de saber. E a razão desse comportamento vem justamente da convicção de que entre o real e a apreensão dessa realidade está a linguagem em suas múltiplas semióticas: o sentido conferido ao mundo não é o resultante da sua apreensão pela visão, audição etc., mas o que emerge da interposição da 
linguagem e por isso a retórica é o meio propício deste sujeito, pois a velha ciência, como ensinava Cícero, também não lida com certezas, embora as cobice, mas faz da dúvida sua razão de ser e sua matéria prima. O que ela almeja não é a verdade, mas o consenso, ainda que este venha a ser obtido em bases bastante precárias. O final de Dom Casmurro é um bom exemplo. Bento Santiago afirma que na criança com quem brincava na infância já estava a mulher que o trairia, e acrescenta: $t u$ [o narratário] concordarás comigo se te lembrares bem da Capitu menina, hás de reconhecer que uma estava dentro da outra, como a fruta dentro da casca. Logo, supõe-se um consenso: o narrador teria convencido o narratário de sua verdade. Não é outra verdade a buscada pela retórica, e, para o cético, assim seriam todas as verdades: parciais, subjetivas, efêmeras, precárias, relativas...

Contudo, o ceticismo não é a única característica do enunciador revelada pelo contrato enunciativo firmado pelo enunciador. Como se viu, trata-se de um contrato misto, que ora prevê a verdade ora a mentira, sem que fique muito claro quando é que está valendo uma cláusula ou outra. Por exemplo, em um momento, quando o narrador chama o leitor de leitor de minhas entranhas, ele estaria sendo extremamente sincero, pois estaria revelando fatos que não precisaria revelar e que deporiam contra ele próprio. Entretanto, pouco depois, afirma explicitamente que constrói e reconstrói a si mesmo quando escreve, deixando claro sua parcialidade no que escreve e não escreve. Numa linha, diz que narra a verdade pura dos fatos; na seguinte, afirma que é privilégio do romancista e do leitor saber o que se passa na mente das personagens. Instaura um narrador onisciente que é também actante do enunciado, ou um narrador que é defunto. Mais uma vez, a situação é bem exemplificada naquela passagem em que Aires, ao comentar o cenário da peça de teatro, mostra que o jardim florido não passa de lona velha e que o choro da atriz é pura encenação, para depois afirmar que sua narrativa é a verdade pura sem fingimento. Ora, sabe-se que não há diferença entre a lona velha que serve de jardim e o texto do narrador: ambos são efeitos de verdade. No entanto, depois de confirmar esse fato, na verdade, de chamar a atenção do leitor para ele, o narrador volta a afirmar que seu texto não é fingimento, mas a verdade pura e simples. Note que esse não é um procedimento isolado, pois se trata de uma constante em toda a obra romanesca de Machado: de um lado, a demonstração de que não existe reprodução fiel da realidade; de outro, a atestação a cada instante de que o leitor lê a transcrição do que teria ocorrido. Entende-se que tal comportamento caracteriza exatamente o cínico, ao menos, na definição que lhe é dada pelo dicionário francês Le Petit Robert. Examinemo-la: 
Uso corrente: Aquele que exprime abertamente e sem reservas sentimentos ou opiniões que chocam o sentimento moral ou o senso comum, frequentemente com uma intenção de provocação.

Ora, o enunciador não faz outra coisa ao longo de sua obra. A afronta não diz respeito apenas à moral, como acontece quando Brás Cubas se dirige a uma alma sensível, que poderia se ofender com a forma como se refere a Eugênia; atinge também os postulados das ciências da linguagem, como no momento em que instaura um narrador que assina M. de A., forçando uma identificação com o escritor Machado de Assis, e ao, mesmo tempo, fazendo referências a Aires, como se ele realmente existisse. Conforme será visto na conclusão, o cinismo do enunciador não é uma de suas características entre outras, mas o princípio que rege seu comportamento, especialmente se o termo for considerado não em sua versão, digamos, vulgar, mas se for relembrada sua origem filosófica.

$\cos \cos \cos s$

O comportamento das variáveis examinadas em todos os romances encontra-se resumido no quadro a seguir, o qual apresenta também o traço do ethos revelado em cada capítulo. Duas ressalvas devem ser feitas. A primeira é que a sucinta descrição do comportamento de cada variável em cada romance, tal como apresentada no quadro, pode dar a impressão de que a situação é exatamente idêntica em cada romance, o que não é verdade. Por exemplo, embora, em muitos casos, o saber do narrador se mostre superior ao dos actantes do enunciado, tal superioridade não se manifesta da mesma maneira, nem nos mesmos termos, em todos os romances e nem tem as mesmas características. De igual forma, a oposição entre enunciação e enunciado também não ocorre sempre nos mesmos termos. A segunda ressalva diz respeito ao traço do ethos detectado em cada linha. Na verdade, o exame de cada variável revela mais de um aspecto do ethos, porém optou-se por identificar aquele que mais se sobressai em dada variável ou na qual se mostra mais nitidamente. Por exemplo, o caráter dissimulado do enunciador pode ser observado na análise do contrato enunciativo ou das instâncias enunciativas, mas entendeu-se que ele se mostra mais claramente na instalação do narrador e por isso ele é mencionado apenas na linha correspondente a essa variável. 


\section{Síntese dos ethé revelados de acordo com a variável analisada}

\begin{tabular}{|c|c|c|c|c|c|c|c|c|c|c|}
\hline Romance & Ressurreição & A mão e a luva & Helena & Iaiá Garcia & $\begin{array}{l}\text { Memórias } \\
\text { póstumas }\end{array}$ & Quincas Borba & Dom Casmurro & Esaú e Jacó & $\begin{array}{l}\text { Memorial de } \\
\text { Aires }\end{array}$ & Ethos \\
\hline $\begin{array}{c}\text { Configurações } \\
\text { discursivas }\end{array}$ & $\begin{array}{l}\text { PN1: aquisição de } \\
\text { prestígio social }\end{array}$ & $\begin{array}{l}\text { PN1: aquisição de } \\
\text { prestígio social }\end{array}$ & $\begin{array}{l}\text { PN1: aquisição de } \\
\text { prestígio social }\end{array}$ & $\begin{array}{l}\text { PN1: aquisição de } \\
\text { prestígio social }\end{array}$ & $\begin{array}{l}\text { PN1: aquisição de } \\
\text { prestígio social }\end{array}$ & $\begin{array}{l}\text { PN1: aquisição de } \\
\text { prestígio social }\end{array}$ & $\begin{array}{l}\text { PN1: aquisição de } \\
\text { prestígio social }\end{array}$ & $\begin{array}{l}\text { PN1: aquisição de } \\
\text { prestígio social }\end{array}$ & $\begin{array}{l}\text { PN1: aquisição de } \\
\text { prestígio social }\end{array}$ & $\begin{array}{l}\text { objetivo, frio, } \\
\text { racional }\end{array}$ \\
\hline \multirow{3}{*}{$\begin{array}{c}\text { Instalação do } \\
\text { narrador }\end{array}$} & $\begin{array}{l}\text { Debr. enunciativa } \\
\text { da Eção. }\end{array}$ & $\begin{array}{l}\text { Debr. enunciativa } \\
\text { da Eção.. }\end{array}$ & $\begin{array}{l}\text { Debr. enunciativa } \\
\text { da Eção. }\end{array}$ & $\begin{array}{l}\text { Debr. enunciativa } \\
\text { da Eção. }\end{array}$ & $\begin{array}{l}\text { Debr. enunciativa } \\
\text { da Eção. }\end{array}$ & $\begin{array}{l}\text { Debr. enunciativa } \\
\text { da Eção. }\end{array}$ & $\begin{array}{l}\text { Debr. enunciativa } \\
\text { da Eção. }\end{array}$ & $\begin{array}{l}\text { Debr. enunciativa } \\
\text { da Eção. }\end{array}$ & $\begin{array}{l}\text { Debr. enunciativa } \\
\text { da Eção. }\end{array}$ & \multirow{3}{*}{$\begin{array}{l}\text { dissimulado, } \\
\text { distante, }\end{array}$} \\
\hline & $\begin{array}{l}\text { Ndor } \neq \text { actante } \\
\text { do Edo. }\end{array}$ & $\begin{array}{l}\text { Ndor } \neq \text { actante } \\
\text { do Edo }\end{array}$ & $\begin{array}{l}\text { Ndor } \neq \text { actante } \\
\text { do Edo. }\end{array}$ & $\begin{array}{l}\text { Ndor } \neq \text { actante } \\
\text { do Edo. }\end{array}$ & $\begin{array}{c}\text { Ndor }=\text { actante do } \\
\text { Edo. }\end{array}$ & $\begin{array}{l}\text { Ndor } \neq \text { actante } \\
\text { do Edo. }\end{array}$ & $\begin{array}{c}\text { Ndor }=\text { actante do } \\
\text { Edo. }\end{array}$ & $\begin{array}{c}\text { Ndor }=\text { actante do } \\
\text { Edo.: }\end{array}$ & $\begin{array}{c}\text { Ndor }=\text { actante do } \\
\text { Edo. }\end{array}$ & \\
\hline & $\begin{array}{l}\text { PN2: Construção } \\
\text { da narrativa }\end{array}$ & $\begin{array}{l}\text { PN2: Construção } \\
\text { da narrativa }\end{array}$ & $\begin{array}{l}\text { PN2: Construção } \\
\text { da narrativa }\end{array}$ & $\begin{array}{l}\text { PN2: Construção } \\
\text { da narrativa }\end{array}$ & $\begin{array}{l}\text { PN2: Construção } \\
\text { da narrativa }\end{array}$ & $\begin{array}{l}\text { PN2: Construção } \\
\text { da narrativa }\end{array}$ & $\begin{array}{l}\text { PN2: Construção } \\
\text { da narrativa }\end{array}$ & $\begin{array}{l}\text { PN2Construção } \\
\text { da narrativa }\end{array}$ & $\begin{array}{l}\text { PN2: Construção } \\
\text { da narrativa }\end{array}$ & \\
\hline \multirow{2}{*}{$\begin{array}{cc}\begin{array}{c}\text { Delegação } \\
\text { do saber }\end{array} & \text { Nção }\end{array}$} & $\mathrm{SE}=\mathrm{SN}>\mathrm{SAE}$ & $\mathrm{SE}=\mathrm{SN}>\mathrm{SAE}$ & $\mathrm{SE}=\mathrm{SN}>\mathrm{SAE}$ & $\mathrm{SE}=\mathrm{SN}>\mathrm{SAE}$ & $\mathrm{SE}>\mathrm{SN}=\mathrm{SAE}$ & $\mathrm{SE}>\mathrm{SN}>\mathrm{SAE}$ & $\mathrm{SE}>\mathrm{SN}=\mathrm{SAE}$ & $\mathrm{SE}>\mathrm{SN}>\mathrm{SAE}$ & $\mathrm{SE}>\mathrm{SN}=\mathrm{SAE}$ & \multirow{2}{*}{ mordaz, irônico } \\
\hline & $\mathrm{SE}>\mathrm{SN}>\mathrm{SAE}$ & $\mathrm{SE}>\mathrm{SN}>\mathrm{SAE}$ & $\mathrm{SE}=\mathrm{SN}>\mathrm{SAE}$ & $\mathrm{SE}=\mathrm{SN}>\mathrm{SAE}$ & $\mathrm{SE}>\mathrm{SN}>\mathrm{SAE}$ & $\mathrm{SE}>\mathrm{SN}>\mathrm{SAE}$ & $. \mathrm{SE}>\mathrm{SN}>\mathrm{SAE}$ & $\mathrm{SE}>\mathrm{SN}>\mathrm{SAE}$ & $\mathrm{SE}>\mathrm{SN}>\mathrm{SAE}$ & \\
\hline $\begin{array}{l}\text { Instâncias } \\
\text { enunciativas }\end{array}$ & $\begin{array}{l}\text { Duas instâncias } \\
\text { em oposição }\end{array}$ & $\begin{array}{l}\text { Duas instâncias } \\
\text { em oposição }\end{array}$ & $\begin{array}{l}\text { Duas instâncias } \\
\text { em oposição }\end{array}$ & Uma instância & $\begin{array}{l}\text { Duas instâncias } \\
\text { em oposição }\end{array}$ & $\begin{array}{l}\text { Duas instâncias } \\
\text { em concordância }\end{array}$ & .Uma instância & $\begin{array}{l}\text { Duas instâncias } \\
\text { em oposição }\end{array}$ & $\begin{array}{l}\text { Duas instâncias } \\
\text { em oposição }\end{array}$ & $\begin{array}{l}\text { contestador, } \\
\text { polêmico }\end{array}$ \\
\hline \multirow{3}{*}{$\begin{array}{l}\text { Contrato } \\
\text { enunciativo }\end{array}$} & $\begin{array}{l}\text { Efeito de verdade } \\
\text { no narrado }\end{array}$ & $\begin{array}{l}\text { Efeito de verdade } \\
\text { no narrado }\end{array}$ & $\begin{array}{l}\text { Efeito de verdade } \\
\text { no narrado }\end{array}$ & $\begin{array}{l}\text { Efeito de verdade } \\
\text { no narrado }\end{array}$ & $\begin{array}{l}\text { Efeito de verdade } \\
\text { no narrado }\end{array}$ & $\begin{array}{l}\text { Efeito de verdade } \\
\text { no narrado }\end{array}$ & $\begin{array}{l}\text { Efeito de verdade } \\
\text { no narrado }\end{array}$ & $\begin{array}{l}\text { Efeito de verdade } \\
\text { no narrado }\end{array}$ & $\begin{array}{l}\text { Efeito de verdade } \\
\text { no narrado }\end{array}$ & \multirow{3}{*}{$\begin{array}{l}\text { cético, } \\
\text { cínico }\end{array}$} \\
\hline & $\begin{array}{l}\text { Edor discorda do } \\
\text { Ndor no narrado } \\
\text { e na narração. }\end{array}$ & $\begin{array}{l}\text { Edor discorda do } \\
\text { Ndor no narrado } \\
\text { e na narração. }\end{array}$ & $\begin{array}{l}\text { Edor discorda do } \\
\text { Ndor no narrado. }\end{array}$ & $\begin{array}{l}\text { Não se observa } \\
\text { desacordo entre } \\
\text { Edor e narrador }\end{array}$ & $\begin{array}{l}\text { Edor discorda do } \\
\text { Ndor no narrado } \\
\text { e na narração. }\end{array}$ & $\begin{array}{c}\text { Edor discorda do } \\
\text { Ndor no narrado } \\
\text { e na narração. }\end{array}$ & $\begin{array}{l}\text { Edor discorda do } \\
\text { Ndor no narrado } \\
\text { e na narração. }\end{array}$ & $\begin{array}{l}\text { Edor discorda do } \\
\text { Ndor no narrado } \\
\text { e na narração. }\end{array}$ & $\begin{array}{l}\text { Edor discorda do } \\
\text { Ndor no narrado } \\
\text { e na narração. }\end{array}$ & \\
\hline & $\begin{array}{l}\text { Linguagem } \neq \\
\text { realidade }\end{array}$ & $\begin{array}{l}\text { Linguagem } \neq \\
\text { realidade }\end{array}$ & $\begin{array}{l}\text { Linguagem } \neq \\
\text { realidade }\end{array}$ & $\begin{array}{l}\text { Linguagem } \neq \\
\text { realidade }\end{array}$ & $\begin{array}{l}\text { Linguagem } \neq \\
\text { realidade }\end{array}$ & $\begin{array}{l}\text { Linguagem } \neq \\
\text { realidade }\end{array}$ & $\begin{array}{l}\text { Linguagem } \neq \\
\text { realidade }\end{array}$ & $\begin{array}{l}\text { Linguagem } \\
\text { realidade }\end{array}$ & $\begin{array}{l}\text { Linguagem } \\
\text { realidade }\end{array}$ & \\
\hline
\end{tabular}

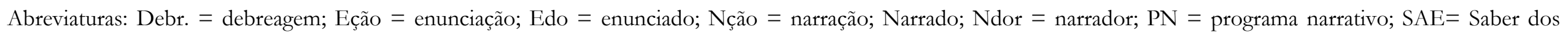
actantes do enunciador; $\mathrm{SE}=$ saber do enunciador, $\mathrm{SN}$ saber do narrador, 


\section{Conclusão}

$N$

a apresentação do número 137 da revista Langages, citada no início deste trabalho, Pierre Bordron e Jacques Fontanille situam a retórica no domínio do imanente, do que não está garantido por uma verdade divina, mas deve ser argumentado a partir de premissas prováveis (p.4). E, de fato, desde seus primórdios, a retórica lida com a ausência, com a falta de melhores alternativas. É a quem se recorre quando não há opções mais eficazes, seja a apresentação de evidências materiais daquilo que se argumenta, seja o uso da violência. Foi a força que permitiu aos invasores de Siracusa tomar as terras de seus antigos moradores e a impossibilidade de usá-la, aliada à inexistência de títulos de propriedade, que fez com que tudo tivesse que ser discutido na praça, por meio de outro instrumento: a palavra. Em outro campo, é a falta de evidencia material que levou Bento Santiago a desenvolver toda uma argumentação para tentar provar a ocorrência de um adultério.

No entanto, a falta de provas materiais dá à retórica a possibilidade (e a liberdade) de tratar do que pode ou poderia ser de outro modo, como ensinava Cícero. Daí, como explica Isócrates, a importância da criatividade, da elegância do dizer e de saber lidar com as paixões que movem o auditório. É assim que nasce o conflito permanente que alimenta a retórica e que consiste na oposição constante entre duas espécies de grandezas: as que estão ausentes da cena enunciativa por qualquer motivo, e as que são construídas no e pelo discurso para compensar a falta das primeiras. É por isso, como ensina Aristóteles, que o fazer do retórico não consiste (ou não de forma preponderante) em apresentar provas daquilo que se afirma já que sua escassez é condição de existência para a retórica —, mas em inventá-las por meio do discurso, o logos, e, por isso, o auditório e o orador têm tanta importância quanto aquilo que é dito, pois ambos - um pelo seu caráter, o ethos, e o outro pelas paixões que apresenta, o pathos - participam ativamente da construção das evidências que serão apresentadas.

No início deste trabalho viu-se que essa discussão estava bem presente nos diálogos de Platão. O filósofo criticava a retórica e seus mestres justamente por não apresentarem provas daquilo que afirmavam e por distorcerem a realidade - crítica, aliás, esperada, uma 
vez que, ao inventar provas, o retórico acaba por recriar a realidade. O embate envolvia, em última instância, a verdade e a verossimilhança, sendo o apego da retórica a esta última a causa de algumas das críticas mais contundentes de Platão; por exemplo, a que ele faz aos retóricos por terem ensinado que a verossimilhança vale mais do que a verdade e por fazerem pela força de suas palavras, [...] parecer grande o que é pequeno e pequeno o que é grande, e dar às coisas novas um ar de antiguidade, às coisas antigas um ar de novidade. (Fedro, 266e-267c). Aí se vê novamente o conflito entre o que está presente (o fato de algo ser pequeno ou novo) e aquilo que, apesar de ausente, é convocado pelo discurso e transformado pela força das palavras(ganhando aparência de grandiosidade ou de antiguidade). Repare que Platão não nega a força das palavras, e é justamente essa força, o fato de a linguagem não apenas descrever o mundo, mas ser capaz de criá-lo novamente, que o faz rejeitar a retórica e propor uma linguagem nua, desprovida de ornamentos e que se aproxime o mais possível da lógica.

O conflito é também o elemento que aglutina todas as características do enunciador machadiano dos romances e que faz pensar na dimensão retórica do discurso desses textos, tal como propõem Bordron e Fontanille no texto citado ${ }^{162}$. Entende-se que todos os traços do caráter desse enunciador repousam também sobre uma dualidade e uma tensão permanentes: o dissimulado joga com as intenções que revela e com as que esconde, havendo, portanto, um conflito entre o que deve ser exposto e o que deve ser ocultado, envolvendo duas grandezas que lutam para se manifestar. O jogo realizado pelo irônico é semelhante. Nesse caso, o elemento revelado ou disfarçado não diz respeito à identidade do sujeito ou às suas ações, como acontece com o dissimulado, mas ao conteúdo de seus enunciados: dois sentidos passam, então, a lutar no interior do enunciado, cada qual buscando prevalecer sobre o outro, enquanto a instância da enunciação joga com graus distintos de assunção do próprio discurso. Evidentemente, o polêmico e o contestador também têm predileção pelo embate de opostos, agora, porém, travado em campo aberto, envolvendo uma disputa entre, pelo menos, dois conceitos, duas possibilidades, assumidos

${ }^{162}$ Os autores sugerem que todo discurso comporta uma dimensão retórica da enunciação, a qual envolveria quatro aspectos, aqui resumidos rapidamente: i) coexistência no discurso de grandezas opostas que lutam para sobrepujar uma a outra e assim serem manifestadas; ii) o fato de uma das grandezas estar presente e ser evidente enquanto a outra é concebida pelo discurso; iii) o fato de a instancia da enunciação assumir, em graus de existência distintos, as grandezas em jogo, o que permite falar em níveis de assunção e de presença e dá origem a um discurso polifônico, seja de forma não explícita, como no caso da ironia, seja de modo explícito, como acontece quando cada ator assume um ponto de vista distinto; iv) a existência de um conjunto de um sistema de valores com alguns elementos euforizados pela instância da enunciação e outros disforizados. In Langages, $\mathrm{n}^{\circ}$. 137, p. 6-11. 
por atores distintos, que lutam pela supremacia de seu ponto de vista. Finalmente, o cético e o cínico mostram um embate mais preciso: para simplificar, entre a viabilidade das leis e convenções sociais ou entre elas e os instintos humanos. Em todos os casos, tal como acontece com a retórica, a disputa envolve tanto grandezas que são percebidas ou assumidas de forma explícita quanto outras, construídas pelo discurso e assumidas mais ou menos enfaticamente. $\mathrm{O}$ conflito que serve de combustível para a retórica é também a energia que move o texto machadiano; espécie de reação em cadeia em que o núcleo do átomo bombardeado é sempre o mesmo e cuja energia não é convertida em calor, mas em sentido. Em comum a todos os atributos do enunciador está a dualidade, o duplo, composto de entidades que, por um lado, são antagônicas, posto que defendem opiniões opostas, mas da mesma natureza, dado que se interessam pelas mesmas questões, porém com pontos de vista antagônicos. Não por acaso, Esaú e Jacó ilustra bem o processo.

Contudo, resta examinar uma das características do enunciador que não envolve, em si mesma, nenhuma espécie de conflito. Trata-se do primeiro traço do seu ethos observado: a objetividade, a frieza, o cálculo, os quais estavam intimamente ligados aos valores buscados pelos sujeitos instalados no enunciado (o prestígio ou a ascensão social) e ao fato de tal busca sobrepujar qualquer outra preocupação que possam ter, chegando, mesmo, a constituir-se em sua razão de ser, espécie de programa de base central do indivíduo. De fato, todos os romances apresentam sujeitos que perseguem a conjunção com valores descritivos que expressam prestígio social, e que subordinam todos os demais valores e programas à busca por tal conjunção. Diferentemente do que ocorre com as demais características do ethos, não se pode afirmar que a objetividade demonstrada pelo enunciador ao instalar tais programas e tais sujeitos implique algum conflito, digamos interno, como ocorre com o dissimulado. No entanto, o conflito volta a existir quando se observa que a busca por esses valores, euforizada no plano do narrado, é disforizada no plano da narração na medida em que a instância da enunciação instala um narrador grosseiro como Brás Cubas, mal intencionado como Bento Santiago ou míope (para dizer o menos) como Aires. Caso o narrador seja competente, como o de Helena ou de Iaiá Garcia o enunciador trata de instalar no texto outro narrador que se encarrega de criticá-lo. Em outras palavras, enquanto o narrador fia sua trama de sujeitos que tudo fazem para ascender socialmente, a instância da enunciação desfia o mesmo tecido, não durante a noite, como certas gregas, mas em plena luz do dia, desafiando o destinatário, em uma atitude bastante cínica, uma vez que os dois fazeres são contínuos e explícitos e, 
certamente, acabam por demolir de forma acintosa muitas das crenças do enunciatário. Ora, a demolição dos valores que fundam a sociedade é tarefa a que se dedicam os cínicos, ao menos na sua acepção filosófica, os quais ridicularizam todas as convenções e se levantavam contra todos os valores, especialmente os que fundam a civilização, tais como o trabalho, a família a pátria o casamento, a soberania política. Como observa Fontanille (1993: 59), a militância dos cínicos não se restringia à moral e aos costumes, mas era ampla e alcançava mesmo o simulacro sobre o qual repousa a semiose, pois, se o objeto de sua crítica é as convenções que estruturam a sociedade, a maior de todas as convenções, a língua, não podia ficar de fora. Ao final, as próprias condições para a obtenção do conhecimento são questionadas, em um procedimento que, mais uma vez, lembra muito o fazer do enunciador que estudamos. No entanto, há ainda outras implicações que nos conduzem ainda para mais perto do enunciador:

A crítica dos valores [realizada pelos cínicos] conduz à crítica das valências que os fundam; a crítica das valências conduza à crítica do elo social que os garante: o cínico deve aprender a não ter expectativas ou esperanças, a não confiar em nada ou em ninguém. O cinismo não é, portanto, apenas o estado daquele que não crê em nada, mas o fazer daquele que tripudia sobre a confiança, um fazer não-crer, uma dissuasão desesperada.

Essa dissuasão é mais freqüentemente do tipo veridictório: a análise e a perversão dos sistemas de valores é veridictória na medida em que desmascara o ser, desnuda o real, dissipa as ilusões da linguagem da vida social e da civilização. (Fontanille: op.cit.: 61-2 - grifos meus)

Ora, nada é mais corriqueiro para os narradores machadianos do que o ato de tripudiar sobre a confiança alheia. Antes de demolir o que quer que seja, é a confiança no que quer seja que é abatida. Antes de questionar o valor do que quer que seja, é a própria noção de valor que é questionada, ou, como dizem os semióticos, a valência. A partir daí, o enunciador destrói muitos dos valores que fundam a sociedade moderna. A mais evidente, a busca de prestígio social ou por acumulação de capital, é mostrada como uma quimera, apesar de ser reconhecida como elemento que realmente move o mundo; as relações pessoais, sejam conjugais, familiares, de amizade ou de consideração são todas descartadas e mostradas como moeda de troca, cujo valor, como sempre ocorre com as moedas, oscila ao sabor da conjuntura; a demolição não poupa sequer o fazer artístico do enunciador, uma vez que é destruída qualquer pretensão de que a realidade possa ser representada objetivamente: tudo é fabulação, construção linguageira. Todos esses fatores poderiam caracterizar o cético, não fosse o fato de o enunciador fazer de seu processo exterminador uma militância: quer dizer, ele não se contenta em afirmar que não crê nisso ou naquilo, mas mostra sua descrença 
mediante as atitudes que adota; em vez de pregar que não existe verdade, ele instaura narradores vis, que não cansam de asseverar a própria idoneidade para, depois de ganhar a confiança do leitor, escarnecer dele e de sua ingenuidade. Como bom cínico, ele tripudia sobre sua confiança. Para lembrar as palavras de Fontanille (idem: 59), o cínico (e o nosso enunciador representa bem a classe) é um verdadeiro militante anti-axiológico, que se propõe a fazer tábua rasa, que se aplica a minar toda axiologia que tenha a menor relação com uma coerção social.

Alguns indícios do comportamento cínico do enunciador já se mostravam quando se discutiu a delegação do saber. $\mathrm{Na}$ ocasião, concluiu-se que o objeto de saber com o qual o enunciador colocava o enunciatário em conjunção consistia em um saber sobre a própria ignorância. Agora, esse aspecto se torna um pouco mais preciso: como acontece com os atos de todo cínico, o fazer do enunciador consiste em um fazer-não-crer: não-crer nos valores estruturadores da sociedade, buscados incessantemente pelos sujeitos instalados no enunciador; não-crer na possibilidade de uma representação objetiva da realidade ou do indivíduo; não-crer na existência de uma verdade que seja exterior ao discurso que a constrói; não-crer nas relações pessoais, comportamento que se coaduna à conduta do cínico tal como Fontanille a descreve nos parágrafos citados. Trata-se de negar tudo, inclusive o próprio fazer literário, porém não com propósitos moralizadores, mas visando a negação pela negação, pois o fazer do enunciador não gera uma crítica social ou aos costumes como poderia ocorrer em romances naturalistas ou realistas; promove, antes, a destruição pura e simples, inclusive da própria denúncia, uma vez que a própria linguagem é colocada sob suspeita. Paradoxalmente, na medida em que sua crítica não propõe nenhuma atitude restauradora, ela acaba por ser mais radical; não apenas rejeita o aqui e agora, mas nega qualquer possibilidade de mudança.

Como indica a citação do texto de Fontanille, o cínico não apenas recusa os sistemas de valores vigentes, mas nega a própria noção de valor, o valor do valor, ou propõe que a valência de tudo seja igual a zero. Como se sabe, o conceito de valência nasce na química para explicar o poder de atração que um átomo exerce sobre outros átomos ou que o núcleo do ato exerce sobre os elétrons que o orbitam. Transposto para a semiótica, o conceito diz respeito à tonicidade da ligação entre um sujeito (fonte) a um alvo (objeto), tonicidade que se decompõe em intensidade, ou a energia dessa ligação, e a extensidade ou a percepção da morfologia que o sujeito tem do objeto. Como para o cínico, a valência de tudo é igual a zero, ele não se sente atraído ou repelido por nada, fato que não o impedia de entrar em conjunção com objetos não desejados para evitar que no futuro não viesse a sentir-se atraído por eles e, 
desse modo, se visse privado da extrema liberdade que é não desejar. Assim, o cínico deveria satisfazer suas necessidades, quaisquer fossem, antes mesmo que nascessem, como uma precaução para que não viesse a sofrer em função de um desejo que não pudesse ser satisfeito, ou cuja necessidade de satisfação viesse a se constituir em um empecilho para sua liberdade. O cínico era, enfim, aquele em relação ao qual nenhum objeto exerce qualquer poder de atração; aquele em relação a quem a tonicidade de tudo é nula, para o qual o valor não tem valor, e, por isso, sente-se livre, inclusive para violar as regras. Note-se que por aí se pode explicar o fato de o narrador de Memórias póstumas ser um defunto: os mortos são os únicos cujo desdém é absoluto, incomensurável, justamente porque nada mais tem valor para eles; nada os atrai nem é atraído por eles, salvo, naturalmente, os vermes. Daí a valência zero, daí o cinismo sem limites.

O gráfico apresentado na página 224 mostrava que a intensidade e a extensidade da apreensão da realidade pelo narrador decrescem de Ressurreição ao Memorial de Aires, enquanto a percepção do enunciador mostrava-se constante e tônica, tanto no que diz respeito à intensidade quanto no que se refere à extensão, assertiva que parece contrariar as afirmações de agora. $\mathrm{Na}$ verdade, entende-se que não há contradição, pois a crítica aos valores, e à sociedade como um todo, inerente ao comportamento do cínico, é, de fato, reveladora de uma percepção tônica da realidade, a qual, em um segundo momento, gera o riso, a ironia, a caricatura, e outras atitudes que são tão familiares aos romances, e mesmo à obra de Machado como um todo. Contudo, essa arguta percepção, segundo a qual todos os valores são, afinal, contrafação, e que leva ao comportamento transviado, só é possível porque nada prende o cínico, nada o atrai, ele não está sujeito à manipulação de espécie alguma, justamente porque nada tem valor para ele, nada é eufórico ou disfórico. Ora, como se sabe, sem um sistema de valores comuns, não há manipulação possível. Assim, a profunda relação que une o cínico a um objeto de saber específico que, na falta de nome melhor, denominamos de crítica do homem, é, ao mesmo tempo, causa e conseqüência de seu desligamento dos objetos descritivos.

No início deste trabalho afirmou-se que o ethos era uma espécie de fiador do discurso, imagem que é simultaneamente construída pelo discurso e testemunha da veracidade do que é afirmado. No entanto, ao final das análises realizadas, chegou-se a uma espécie de anti-ethos; afinal, quem confiaria em alguém que se mostra dissimulado, irônico, polêmico, cético, cínico...? Ninguém, certamente. Mas, então, isso não seria um indício de que 
haveria algo de errado com as análises ou com a definição do ethos adotada? Entendemos que não. Um enunciador que demolisse todos os valores, mas se mostrasse confiável, indicaria que há, afinal, alguns valores remanescentes. É verdade, a mensagem de um enunciador não confiável, mesmo que se referindo à não confiabilidade dos indivíduos, não teria nenhum crédito, e cairia no mesmo problema, porém do lado oposto (é a célebre aporia contida na frase "todo cretense é mentiroso"). Como resolver o problema? É justamente aí que se mostra o vigor do conceito de ethos e o engenho do enunciador. Ninguém nos romances de Machado afirma que não existe verdade ou prega abertamente a destruição dos valores, mas a exibição da condição humana, mostrada - e não asseverada - de forma incessante de romance a romance, não permite outra conclusão. O processo começa com Ressurreição e Félix, seu herói pusilânime; continua em $A$ mão e a luva com Guiomar, cuja única pretensão é mudar sua condição social e que, para tanto, está disposta a tudo; modus operandi que não difere em substância do de Helena, que troca o afeto paterno pela herança do amante da mãe em um ambiente similar ao de Iaiá Garcia, com Procópio e Jorge, que aparentam diferença, porém, mais concordam que discordam; sem contar com a própria Iaiá, discípula fiel de Guiomar. A coisa prossegue com Brás Cubas, que dispensa comentários, e se intensifica com Quincas Borba e o casal Palha, que não deixa dúvidas ao que veio. Chega-se a Dom Casmurro e seu narrador que não titubeia ao contar que quase matou o próprio filho, desejou que ele contraísse lepra e que, ao saber de sua morte, come bem e vai ao teatro, talvez em companhia dos gêmeos-sem-propósitos, Pedro e Paulo, frutos da mesma cepa: ociosos, fúteis, vaidosos não têm outra preocupação que subir, subir, subir, como lembra a cabocla do castelo, preferencialmente pisando no outro. O ciclo se encerra com o casal Tristão e Fidélia, que não hesitam em abandonar seus pais de estimação sem ao menos avisar-lhes; isso sem contar com o excelente Barão Santa-Pia, o qual, com a ironia do nome, não deixa escapar uma oportunidade para atestar seu direito de propriedade sobre outros seres humanos. Certo, nada disso permite atribuir ao enunciador - que não se confunde com o autor de carne e o osso, não custa repetir pela vez derradeira - as características que lhe atribuímos, mas o problema é que o leitor não passa incólume por esses senhores e sente na própria pele o que significa conviver com os sujeitos instaurados pelo enunciador e ser objeto do mesmo tratamento que dispensam a seus pares. Como bom cínico que é, o enunciador não apenas prega a nulidade dos valores, mas os esvazia à nossa frente e, depois, afirma como certa mulher:

Grandes lascivos, espera-vos a voluptuosidade do nada. 


\section{Bibliografia}

Akutagawa, Ryonosuke. Dentro do Bosque In Contos. São Paulo: Centro de Estudos NipoBrasileiros e Japan Foundation, s/d, p.81-91

AlCoforado, Maria. Cartas portuguesas. Porto Alegre: L\& PM Editores, 2000.

Amossy, Ruth. A noção de ethos da retórica à análise do discurso. Trad. Dilson Ferreira da Cruz. In Amossy, Ruth. Imagens de si no discurso. Trad. Dilson Ferreira da Cruz, Fabiana Komesu e Sírio Possenti. São Paulo: Contexto, 2004.

. O ethos na intersecção das disciplinas: retórica, pragmática, sociologia dos campos. Trad. Dilson Ferreira da Cruz. In Amossy, Ruth. Imagens de si no discurso. Trad. Dilson Ferreira da Cruz, Fabiana Komesu e Sírio Possenti. São Paulo: Contexto, 2004.

Andrade, Mário. Macunaíma o herói sem nenhum caráter. Paris: Association Archives de la Littérature latino-américaine; Brasília: CNPq, 1988.

Aristoteles. Rhétorique. Paris : Livre de poche, 1991.Trad. C. E. Ruelle.

. Poética. Trad. Baby Abrão. In. Os pensadores - Aristóteles. São Paulo: Nova Cultural, 1999.

ASSIS, Joaquim Maria Machado de. Obra completa. Rio de Janeiro: Nova Aguilar, 1997, 3 vol.

BAKHTin, Mikhail. A cultura popular na idade média e no renascimento. O contexto de François Rabelais. 2. ed. Trad. Yara Frateschi. São Paulo: Hucitec, 1999.

. Problemas da poética de Dostoiévski. 3. ed. Rio de Janeiro: Forense-Universitária, 1981.

Questões de literatura e estética. (A teoria do romance). Trad. Aurora Fornoni Bernardini et al. 3 ed. São Paulo: Editora da Unesp / Hucitec, 1993.

BAndeIRA, Manuel. Estrela da vida inteira. 25 ed. Rio de Janeiro: Nova Fronteira, 1993.

BARreto, Carlos Eduardo. Constituições do Brasil. São Paulo: Saraiva, 1971.

BArreto, Lima. Triste fim de Policarpo Quaresma. 14 ed. São Paulo: Ática, 1995.

Barros, Diana Luz Pessoa de. De l'ambiguité de certains textes, In Voies livres n. 31. Lion: março de 1990.

. La cohérence textuelle. In PARret, H. e Ruprecht, H.G. Exigences et perspectives de la sémiotique. Recueil d'himmages pour A.J. Greimas. Amsterdã : John Benjamins, 1985. 
. Teoria do discurso - fundamentos semióticos. São Paulo: Atual, 1988.

BARTHeS, Roland. L'aventure sémiologique. Paris: Seuil, 1985.

Benveniste, Emile. Problèmes de linguistique générale, 2. Paris : Gallimard, 1974.

BERTRAND, Denis. Enthymème et textualisation. In Langages n. 137, p. 29 - 45. Março de 2000. . Précis de Sémiotique littéraire. Paris : Nathan, 2000

Bordron, Jean-François et FOnTANILle, Jacques Présentation. In Langages n. 137, p. 3 - 15 março de 2000.

Borges, Jorge Luis. Obras completas. Trad. Alexandre Eulálio, Carlos Nejar et al. São Paulo: Globo, 2001.

Bosi, Afredo. O enigma do olhar. São Paulo: Ática, 1999.

BORDIEU, Pierre. L'économie des échanges linguistiques. In Langue française No. 34, mai 1977.

Camus, Albert. A peste. Trad. Valery Rumjanek. Rio de Janeiro: Record, s/d. . O estrangeiro. Trad, Antônio Quadro. São Paulo: Abril Cultural, 1972.

CÉLINE. Louis-Ferdinand. Mort à crédit. Paris: Gallimard, 1952.

Cervantes Saavedra. Miguel de. Dom Quixote V vol. Trad. Almir de Andrade e Milton Amado 2 ed. Rio de Janeiro: Livraria José Olympio Editora, 1954.

Charaudeau, Patrick. Discurso político. Trad. Dilson Ferreira da Cruz e Fabiana Komesu. São Paulo: Contexto, 2006.

CONRAD. Joseph. Dentro das marés. Trad. Julieta Cupertino. Rio de Janeiro: Revan, 2004.

Constituição Federal - atualizada até 31.12.2001 7 ed. São Paulo: Editora Revista dos Tribunais: 2002.

Coquet, Jean-Claude. La quête du Sens. Paris: Presse Universitaire de France, 1997.

Cruz, Dilson Ferreira da. Estratégias e máscaras de um fingidor - a crônica de Machado de Assis. São Paulo: Humanitas / Nankin, 2002.

DAsCAL, Marcelo. O ethos na argumentação. Trad. Sírio Possenti. In Amossy, Ruth. Imagens de si no discurso. Trad. Dilson Ferreira da Cruz, Fabiana Komesu e Sírio Possenti. São Paulo: Contexto, 2004.

DisCINI, Norma. O estilo nos textos. São Paulo: Contexto, 2003.

DostolÉvski, Fiódor Mikháilovitch. Recordação da casa dos mortos. Trad. Raquel de Queiroz. Rio de Janeiro: Livraria José Olympio Editora, 1962.

Ducrot, Oswald. O dizer e o dito. Campinas: Pontes, 1988. 
EGGS, Ekkehard. Ethos aristotélico, convicção e pragmática moderna. Trad. Dilson Ferreira da Cruz. In Amossy, Ruth. Imagens de si no discurso. Trad. Dilson Ferreira da Cruz, Fabiana Komesu e Sírio Possenti. São Paulo: Contexto, 2004.

FACIOLI, Valentin. Um defunto estrambótico. São Paulo: Nankin, 2002.

FAORO Raimundo. A pirâmide e o trapézịo. São Paulo: Companhia Editora Nacional, 1974.

FAusto, Boris. História do Brasil. São Paulo: Edusp / FDE, 1994.

Ferreira, Aurélio Buarque de Hollanda. Novo dicionário da língua portuguesa. 1 ed. Rio de janeiro: Nova Fronteira, s.d.

FIORIN, José Luiz. As Astúcias da enunciação. As categorias de pessoa, espaço e tempo. São Paulo: Ática, 1996.

- O corpo nos estudos as semiótica francesa. In Corpo e sentido. Silva, Inácio Assis, São Paulo: Unesp, 1996.

. O contrato de veridicção no romance. Perfiles Semióticos Revista de Estudios Semiolingüísticos, Mérida, v. 1, p. 137-152, 2004.

. O ethos do enunciador. In Razões e sensibilidades. Cortina, Arnaldo e Marchezan, Renata Coelho (org.) Araraquara: Laboratório Editorial/ FCL/UNESP. São Paulo: Cultura Acadêmica Editora, 2004.

FlauberT, Gustave. Madame Bovary. Paris: Flammarion, 1986.

FOnTANiLle, Jacques. Le cynisme, du sensible au risible. In Bertrand, Denis et al. (org) L'Humour Européen. Lubin- Sèvres: Université Marie Curie-Sklodowska / Centre International d'Etudes Pédagogiques, 1993 . Le savoir partagé. Paris-Amsterdan: Hadès-Benjamins, 1987. . Sémiotique du discours. Presse Universitaire de Limoges, 1998.

FontAniLLE, Jacques e Zilberberg, Claude. Tension et signification. Liège: Largada, 1998.

Fontanier, Pierre. Les figures du discours. Paris: Flammarion, 1977

GAY, Peter. O coração desvelado: a experiência burguesa da Rainha Vitória a Freud. Trad. Sérgio Bath. São Paulo, Companhia das Letras, 1999.

Geninasca, Jacques. La parole Littéraire. Paris : Presse Universitaire Française, 1997

Genette, Gérard.. Fiction et diction. Paris: Seuil, 2004. . Metallepse. Paris: Seuil, 2004. . Senil. Paris: Seuil, 1987.

Gledson, John. A semana. São Paulo, Hucitec, 1996. 
. Bons dias! São Paulo: Hucitec, 1992.

- John. Machado de Assis: fiç̧ão e história Rio de Janeiro: Paz e Terra, 1986.

GoETHE, Johann Wolfgang von. Fausto. Trad. Jenny Klabin Segall. Belo Horizonte - Rio de janeiro: Villa Rica, 1991.

Gomes, Eugênio. Machado de Assis. Rio de Janeiro: Livraria São José, 1958.

- Testamento estético de Machado de Assis. In ASSIS, Joaquim Maria Machado de Obra completa. Rio de Janeiro: Nova Aguilar, 1997, 3 vol.

Greimas, Algirdas Julian. Du sens II. Paris: Seuil, 1983. . Maupassant, la sémiotique du texte: exercices pratiques. Paris: Seuil, 1976. . Sémantique structurale. Paris: Presse Universitaire de France, 1986. . Sémiotique des passions. Paris: Seuil. 1991. . Sémiotique et sciences sociales. Paris: Seuil. 1976.

.. e Courtés, Joseph. Sémiotique, dictionnaire raisonné de la théorie du langage I. Paris: Hachette, 1979 .

Guidin, Márcia Lígia. Armário de vidro: a velhice em Machado de Assis. São Paulo, Nova Alexandria, 2000.

Guimarães, Hélio Seixas. Os leitores de Machado de Assis. São Paulo: Nankin / Edusp, 2004

Halleweld, Laurence. O Livro no Brasil. (sua história). Trad. Maria da Penha Villalobos e Lólio Lourenço de Oliveira. São Paulo: T. A. Queiroz, 1985

HalsalL, Albert W. Victor Hugo ou l'art de convaincre. Le récit hugolien: rhétorique, argumentation, persuasion. Montreal, ed. Balzac, L'Univers des discours, 1995.

. L'Art de convaincre. Le récit pragmatique rbétorique, idéologie, propagande. Toronto, Paratexte, 1988.

HARKOT-DE-La-TAILlE, Elizabeth. Ethos e persuasão em "Dentro do Bosque", de Ryonosuke Akutagawa, comunicação apresentada no Mini-ENAPOL de Semiótica, 15/09/2005.

Henault, Anne. L' histoire de la sémiotique. Paris: Presse Universitaire de France, 1992.

HouaIss, Antonio. Dicionário Honaiss da lingua portuguesa. Rio de Janeiro: Objetiva, 2001.

Isocrates. Discours. Paris: Société d'édition Les Belles Lettres, 1929.

JAKOBSON, Roman. Lingüistica e comunicação. Trad. Izidoro Blikstein. São Paulo: Cultrix, 1992.

LANDOWSKI, Eric. En deçà ou delà des stratégies: la présence contagieuse. In Oliveira, Ana Cláudia de e Marroni, Fabiane Villela (Org.). VII Caderno de discussão do centro de pesquisas sociossemióticas.. São Paulo: Editora CPS, 2001 
. Viagem às nascentes do sentido. In Corpo e sentido. Silva, Inácio Assis, São Paulo: Unesp, 1996,

Lejuene, Philippe. Le Pacte Autobiographique. Paris: Seuil, 1996.

LOPES, Edward. Metáfora: da Retórica à Semiótica. São Paulo: atual, 1986.

Lotman, I. M. Sobre o problema da tipologia da cultura. Trad. Lucy Seki. In Schnaiderman, Bóris (org.). Semiótica Russa. São Paulo: Perspectiva, 1979.

Magalhães JR., Raimundo. Machado de Assis desconhecido. São Paulo: Lisa, 1971.

Maingueneau, Dominique. Pragmática para o discurso literário. São Paulo: Martins Fontes, 1996. . Genèse du discours. Liége: Mardaga, 1984.

_. Novas tendências em análise do discurso. 3. ed. Campinas: Pontes, 1997.

. O contexto da obra literária. São Paulo: Martins Fontes, 1995.

. Ethos, cenografia e incorporação Trad. Sírio Possenti. In Amossy, Ruth. Imagens de si no discurso. Trad. Dilson Ferreira da Cruz, Fabiana Komesu e Sírio Possenti. São Paulo: Contexto, 2004.

Maingueneau, Dominique e Charaudeau, Patrick Dicionário de análise do discurso. Trad. Fabiana Komesu, Sírio Possenti, Maria do Rosário Gregolin, Dilson Ferreira da Cruz et al. São Paulo: Contexto, 2004.

Mello e Souza, Antonio Candido de. Esquema de Machado de Assis. In Vários escritos. São Paulo: Duas Cidades, 1995, 3 a ed. . Formação da literatura brasileira. 7 ed. Belo Horizonte / Rio de Janeiro: Itatiaia, 1993.

MeYer, Augusto. Machado de Assis. Rio de Janeiro: São José, 1958.

MEYER, Michel. L'bistoire de la rhétorique des grecs à nos jours. Paris: Le livre de Poche, 1999 .Questions de rhétorique. Paris: Le livre de Poche, 1993.

Montaigne, Michel Eyquem de Essais. Paris : Presse Universitaire de France, 1988.

NABuco, Joaquim. Minha Formação. Brasília: Editora da Universidade de Brasília, 1981 . O Abolicionismo. Petrópolis: Vozes, 1988.

PAES, José Paulo. Gregos e Baianos. São Paulo: Brasiliense, 1985;

Passos, Gilberto Pinheiro. As sugestões do conselheiro: o intertexto francês em Esaú e Jacó e Memorial de Aires. Tese de livre docência apresentada na Universidade de São Paulo, 1993

PereIRA, Lúcia Miguel. História da literatura brasileira Rio de Janeiro: Livraria José Olympio Editora, 1950. 
. Machado de Assis (Estudo Crítico e Biográfico). 6 Ed. Belo Horizonte, Itatiaia.

Peterline, Ariovaldo. A retórica na tradição latina. In Retóricas de ontem e de hoje. MoscA, Lineide do Lago Salvador (org.). São Paulo: Humanitas Editora / FFLCH/USP, 1997.

Platẽo. Cratyle. In Platon. Paris: Garnier Frères, 1967

. Górgias. In Platon. Paris: Garnier Frères, 1967

. Phédre. In Platon. Paris: Garnier Frères, 1964

. Protagoras. In Platon. Paris: Garnier Frères, 1967

PoE, Edgar Allan. Obra Completa. Rio de Janeiro: Nova Aguilar, 1965.

ReBOul, Oliver. Introdução à retórica. São Paulo: Martins Fontes, 2000.

Ricoeur, Paul. La métaphore vive. Paris: Seuil, 1975.

.. Soi meme comme un autre. Paris: Seuil, 1990.

RoBert, Paul. Le nouvean Petit Robert. Paris: Dictionnaires Le Robert, 1993

SARTRE, Jean Paul. A náusea. Trad. Rita Braga. Rio de Janeiro: Nova Fronteira, 1983.

Savioli, Francisco Platão e FIorin, José Luiz. Para entender o texto 11 ed. São Paulo: Ática, 1995.

SILVEIRA, Francisco Maciel. Literatura barroca: literatura portuguesa. São Paulo: Global, 1987

SCHWARZ, Roberto. Ao vencedor as batatas. 4. ed. São Paulo: Livraria Duas Cidades, 1992.

. Um mestre na periferia do capitalismo. São Paulo: Livraria Duas Cidades, 1992, 2a. ed.

VIALA Alain. A eloqüência galante: uma problemática da adesão. Trad. Fabiana Komesu. In Ruth. Imagens de si no discurso. Trad. Dilson Ferreira da Cruz, Fabiana Komesu e Sírio Possenti. São Paulo: Contexto, 2004.

Vieira, Pe. Antônio. Sermões. Porto: Lello \& Irmão — Editores, 1959, XV vol.

Weber, Max. A ética protestante e o espirito capitalista. Trad. M. Irene de Q. F. Szmrecsányi e Tamás J. M. K. Smerecsányi. São Paulo: Pioneira, 1967. 


\section{A}

AKUTAgawa, RYONOSUKE $\cdot 345,348$

ALENCAR, JOSÉ DE $\cdot 65,68,122$

AMOSSY, RUTH $\cdot 16,37,44,45,345,346,347,349$

ANDRADE, MÁRIO · 128, 182, 183, 204, 345, 346

ANJOS, CYRO DOS $\cdot 168$

ARISTÓTELES · VI, I, 4, 5, 13, 14, 16, 17, 18, 19, 20, 21, 22, $23,24,25,26,27,28,29,30,31,33,34,36,37,39,41$, $43,44,48,57,71,72,82,166,273,277,338,343,345$ ASSIS, JOAQUIM MARIA MACHADO DE $\cdot$ I, II, III, IV, 1, 2, 3 , $27,29,41,42,43,59,60,62,63,64,65,66,68,70,74$, $77,78,79,80,81,82,83,84,85,86,89,92,93,94,97$, $100,102,105,107,108,111,112,114,117,121,122$, $123,125,130,131,133,135,136,137,139,141,146$, $150,152,153,154,156,157,158,160,161,168,169$, $171,173,174,176,179,181,184,192,193,194,201$, 202, 204, 209, 211, 212, 218, 219, 220, 222, 223, 225, $226,227,228,229,233,235,237,238,239,240,241$, $242,244,250,252,253,255,256,257,260,263,264$, $265,267,268,270,272,273,279,280,282,288,298$, $303,305,306,307,308,309,313,318,320,321,322$, $326,328,329,330,335,336,343,344,345,346,348$, 349,350

AzEVEDo, Aluísio · 59, 123

\section{B}

BAKHTIN, MiKHAIL $\cdot 68,175,227,228,257,258,263,264$, $270,298,328,332,345$

BANDEIRA, MANUEL $\cdot 61,231,345$

BARRETO, CARLOS EDUARDO $\cdot 109,314,345$

BARRETO, LIMA 109

BARros, Diana LuZ PESSOA DE $\cdot$ III, 275, 345

BARTHES, ROLAND · I, III, 6, 20, 21, 25, 31, 32, 45, 48, 57, 346

BenVENisTe, EMILE $\cdot 46,283,346$

BERTRAND, DENIS · III, 24, 70, 73, 74, 346, 347

BordRON, JeAn-FranÇOIS · 23, 26, 338, 339, 346

BORGES, JORGE LUIS · 133, 134, 184, 346

BOSI, AFREDO $\cdot 1,67,169,198,218,307,346$

BOURDIEU, PIERRE $\cdot 37$

\section{C}

CALVINO, JoÃo $\cdot 34,35,36$

CAMUS, ALBERT $\cdot 127,180,346$

CÉLINE, LOUIS-FERDINAND $\cdot 158,346$

Cervantes SaAvedra, Miguel DE $\cdot 129,130,152,235$, $291,331,346$
Cícero · VI, 4, 19, 30, 31, 32, 33, 39, 55, 335, 338

CONRAD, JOSEPH $\cdot 76,235,236,237,346$

CoQuet, JeAn-Claude $\cdot 55,346$

CÓRAX $\cdot 5,6,7$

COURTÉS, JOSEPH · 2, 22, 28, 46, 51, 61, 70, 73, 74, 80, 81, $82,105,125,194,219,230,232,271,273,348$

\section{D}

DaScal, MARCELO $\cdot 346$

DISCINI, NORMA $\cdot$ III, 62, 64, 122, 346

DostoievsKi, FoÓdor MiKHÁILOVITCH · 345, 346

DUCROT, OSWALD · I, II, III, 55, 57, 58, 346

$\bar{E}$

EGGS, EKKEHARD $\cdot 37,45,347$

ERASMO DE ROTERDÃ $\cdot 32,35$

ESOPO $\cdot 274$

$\bar{F}$

FACIOLI, VALENTIN $\cdot$ III, 1, 347

FARIAS $\cdot 275$

FARIAS XE "FARIAS", ROBERTO $\cdot 275$

FAUSTO, BORIS $\cdot 158,159,252,347,348$

Ferreira, Aurélio BuARQue de Hollanda · 34, 38, 45 , $307,320,329,345,346,347,349,350$

FIORIN, JOSÉ LUIZ · III, 45, 48, 59, 74, 122, 125, 150, 161, $165,174,178,193,278,279,347,350$

FLAUBERT, GUSTAVE $\cdot 294,295,347$

FONTANIER, PIERRE $\cdot 173,347$

FONTANILLE, JACQUES · 23, 26, 220, 225, 338, 339, 341, $342,346,347$

FREITAS, TEIXEIRA DE $\cdot 316$

G

GAy, PETER $\cdot 169$

GENETTE GÉRARD · 72, 150, 153, 163, 173, 176, 239, 240, 252,347

GENICASCA, JACQUES $\cdot 32,347$

GLEDSON, JOHN $\cdot 77,107,216,306,347$

GOETHE, JOHANN WOLFGANG VON $\cdot 159,252,348$

GOMES, CARLOS $\cdot 68,348$

GOMES, EUGÊNIO $\cdot 68,348$

GONÇALVES DiAS $\cdot 68$

GÓRGIAS · 7, 8, 9, 10, 11, 12, 13, 14, 22, 23, 350 
Greimas, ALGIRDAS JULIAN · I, III, 6, 56, 69, 73, 287, 296, 348

GUIDIN, MÁRCIA LÍGIA $\cdot 348$

Guimarães, HÉlio SEIXAS · 47, 66, 80, 123, 242, 298, 320,348

\section{$\boldsymbol{H}$}

HaLlewell, LAURENCE $\cdot 242,348$

Halsall, AlBert W · 72, 77, 239, 348

HARKOT-DE-LA-TAILLE, ELIZABETH $\cdot 348$

HÉNAULT, ANNE $\cdot 348$

HouAiss, ANTONIO $\cdot 34,87,97,104,120,154,155,207$, $245,254,319,322,323,325,331,334,348$

\section{$\boldsymbol{J}$}

JAKOBSON, ROMAN $\cdot 348$

$\boldsymbol{L}$

LA FONTAINE, JEAN DE $\cdot 32,55,274$

LANDOWSKI, ERIC $\cdot 31,348$

LEJUENE, PHILIPPE $\cdot 349$

LÊNIN, WLADIMIR, ILLITCH $\cdot 274$

LÍSIAS $\cdot 9,22$

LOPES, EDWARD $\cdot 349$

LOTMAN, I M $\cdot 61,63,64,349$

LUTERO, MARTINHO $\cdot 32,33,34,35,36$

\section{M}

Macedo, JoAquim MANUEL DE. · 65, 112, 232, 253

MAGRITTE, RENÉ · 279, 334

MaInGUeNEAU, DominiQue $\cdot 55,56,58,59,71,349$

MARIA AlCOFORADO $\cdot 60,345$

MAURÍ́CIO PD. JOSÉ $\cdot 68$

MEIRELES, Vitor $\cdot 68,234$

Mello e Souza, Antonio CANDido de $\cdot 64,65,66,112$, $121,134,243,330,349$

Meyer, Augusto $\cdot 227,307$

MEYER, MiCHEL · 19, 30, 31, 33, 227, 307, 349

Montaigne, Michel EyQuem DE · 297, 298, 313, 331, 349

\section{$N$}

NABUCO, JoAQuim · 68, 113, 303, 304, 305, 314, 315, 316 , 349

NePOMUCENO ALBERTO $\cdot 68$

$\boldsymbol{P}$

PAes, José PAUlo $\cdot 114,167,349$

PAssos, Gilberto PinHeiro · 349
Paulo, Apóstolo 31, 34, 38

Pereira, Lúcia Miguel $\cdot 1,108,349$

Pessoa, Fernando $\cdot$ III, 62, 73, 345

Pinto, Fernão MENDES $\cdot 127,234$

Platão · VI, 4, 5, 8, 9, 10, 11, 12, 13, 14, 15, 16, 17, 19, 20 , $21,23,24,25,27,28,30,31,34,40,164,338,350$

Poe, Edgar Allan · 68, 76, 180, 279, 350

$\boldsymbol{Q}$

QueIROZ, EÇA DE $\cdot 68,122,272,279$

QUINTILANO $\cdot 16,24,30,32,33$

QUINTILIANO · VI, 16, 24, 30, 32, 33

$\boldsymbol{R}$

Reboul, Oliver $\cdot 350$

RENAN $\cdot 68$

Ricoeur, PAUL $\cdot 5,18,19,29,46,350$

RoBert, PAUL $\cdot 322,325,331,335,350$

RosSEAU, JEAN-JACQUeS $\cdot 176$

$S$

SARTRe, JeAn PAUL $\cdot 237,240,350$

SAVIOLI, FRANCISCO $\cdot 48,350$

SCHWARZ, ROBERTO · 41, 91, 93, 94, 148, 225, 227, 228 , 331,350

SÓCRATES $\cdot 8,9,10,11,12,13,14,15,22,23,25,29,35$

STALIN, JOSEPH $\cdot 274,276$

STERNE, LAURENCE $\cdot 253,257$

SWIFT, JONATHAN $\cdot 257$

$\bar{T}$

TísIAS $\cdot 5,6,7,12,19$

TROTSKY, LEON $\cdot 274$

$\bar{V}$

VERÍSSIMO, JOSÈ $\cdot 68,320$

VERNE, JÚLIO $\cdot 75$

VIALA, ALAIN $\cdot 350$

VIERA, PE. ANTONIO $\cdot 36,68,350$

\section{W}

WEBER, MAX $\cdot 34,350$

$\bar{Z}$

ZiLBerberG, Claude $\cdot 220,225,347$ 